INSTITUTO DE PESQUISAS ENERGÉTICAS E NUCLEARES Autarquia associada à Universidade de São Paulo

\author{
NÊUTRONS, RADIAÇÃO E ARQUEOLOGIA: \\ ESTUDO DE CASO MULTIANALÍTICO DE CERÂMICAS \\ DA TRADIÇÃO BORDA INCISA NA AMAZÔNIA CENTRAL
}

ROBERTO HAZENFRATZ-MARKS

Tese apresentada como parte dos Requisitos para obtenção do Grau de Doutor em Ciências na área de Tecnologia Nuclear - Aplicações

Orientador:

Prof. Dr. Casimiro Sepúlveda Munita 


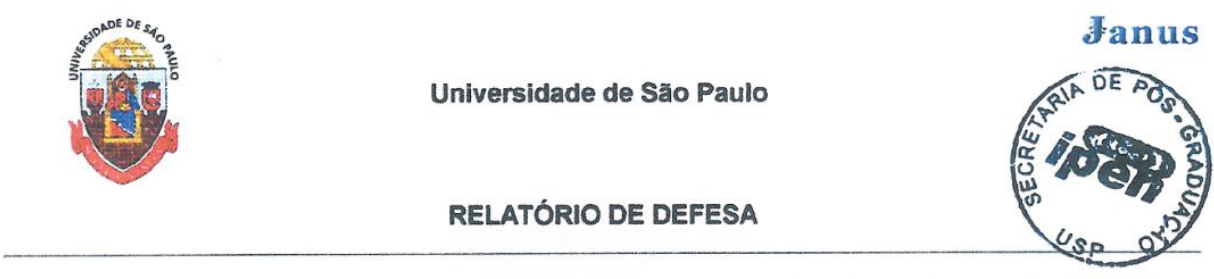

Aluno: 85131 - $5123330-1 /$ Página 1 de 1

Relatório de defesa pública de Tese do(a) Senhor(a) Roberto Hazenfratz-Marks no Programa: Tecnologia Nuclear, do(a) Instituto de Pesquisas Energéticas e Nucleares da Universidade de São Paulo.

Aos 09 dias do mês de maio de 2014, no(a) Aud. Dr. Rui Ribeiro Franco realizou-se a Defesa da Tese do(a) Senhor(a) Roberto Hazenfratz-Marks, apresentada para a obtenção do título de Doutor intitulada:

"Nêutrons, radiação e arqueologia: estudo de caso multianalítico de cerâmicas da tradição borda incisa na Amazônia Central"

Após declarada aberta a sessão, o(a) $\mathrm{Sr}($ a) Presidente passa a palavra ao candidato para exposiçẫo e a seguir aos examinadores para as devidas arguições que se desenvolvem nos termos regimentais. Em seguida, a Comissão Julgadora proclama o resultado:

\begin{tabular}{|c|c|c|c|}
\hline Nome dos Participantes da Banca & Função & Sigla da CPG & Resultado \\
\hline Eduardo Goes Neves & Titular & MAE-USP & APROVADO \\
\hline Lucia Pereira Barroso & Titular & IME - USP & \\
\hline Paulo Sergio Cardoso da Silva & Titular & IPEN & \\
\hline Sonia Hatsue Tatumi & Titular & UNIFESP - Externo & Hiproundo \\
\hline
\end{tabular}

Resultado Final: Aprorade

Parecer da Comissão Julgadora *

Eu, Ana Claudia Martinelli Feher

ivis

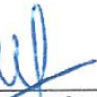

, lavrei a presente ata, que assino juntamente com os(as) Senhores(as). São Paulo, aos 09 dias do mês de maio de 2014
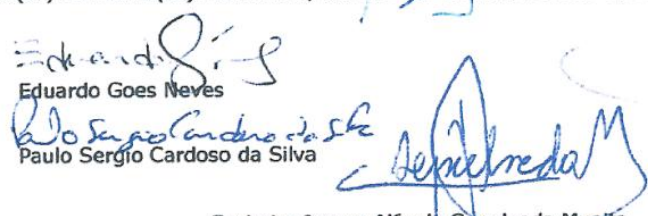

C c cuiceso Lucia Pereiza Barroso, Sonia Hatsue Tatumi

Casimiro Jayme Alfredo Sepulveda Murita Presidente da Comissäb Julgadora

* obs: Se $o$ candidato for reprovado por algum dos membros, o preenchimento do parecer é obrigatório.

A defesa foi homologada pela Comissão de Pós-Graduação em $12 / 05 / 14$ e, portanto, o(a) aluno(a) faz jus ao título de Doutor em Ciências obtido no Programa Tecnologia Nuclear - Áréa de concentração: Tecnologia Nuclear Aplicações.

$$
\frac{\text { ACle/urci, ca cis. }}{\text { Presidente dá Comissão de Pós-Graduação }}
$$


À minha família. 


\section{AGRADECIMENTOS}

A lista de agradecimentos é longa e, provavelmente, cometerei injustiças ao omitir nomes que de uma forma ou outra, sutil ou não, contribuíram para esta tese, seja com uma ideia, uma conversa, uma sugestão, ou por simplesmente existirem... Mas tentarei!

Começo agradecendo à minha família, que respeitou as minhas escolhas desde a graduação, e entendeu que eu não pretendia trilhar um caminho convencional. Sou grato pelos valores passados, e pelas diferenças que me fizeram entender que cada ser é único, independentemente da proximidade e origem, e que isso deve ser respeitado.

Agradeço ao Prof. Dr. Casimiro Sepúlveda Munita, por aceitar ser meu orientador, acreditar no meu trabalho e por ter entendido que eu procuro de trabalhar de forma independente, o que, de forma alguma, quer dizer trabalhar de maneira isolada.

Ao Prof. Dr. Eduardo Góes Neves, do MAE-USP, pela elaboração conjunta do projeto, pelo fornecimento de amostras e pelas várias críticas e sugestões para o direcionamento do trabalho. Ao Guilherme Zdonek Mongeló e Eduardo Kazuo Tamanaha, por ajudar na seleção das amostras e coleta de informações arqueológicas.

Agradeço ao CNPq, CAPES e FAPESP (Processo 10/07659-0) pelo auxílio financeiro para a condução desta pesquisa e estágio de Doutorado nos EUA.

Agradeço Dr. Paulo Oliveira, estatístico cujas discussões, sugestões e análises foram essenciais para a conscientização do que era necessário estudar e do que poderia ser feito.

À Prof. Dra. Sônia Hatsue Tatumi, agradeço por ter cedido as instalações de seu antigo laboratório de difração de raios X, na FATEC; e por ter cedido as instalações de seu atual laboratório de datação por luminescência opticamente estimulada, na UNIFESP.

Ao Dr. Nilo Cano, pela disponibilidade em ajudar nos experimentos de ressonância paramagnética eletrônica, e pela discussão dos resultados.

Ao Dr. Juan Mittani, pela ajuda nos experimentos de datação por luminescência opticamente estimulada, e pela sugestão de mudança de técnica quando tivemos problemas com a datação por termoluminescência, devido à quantidade de amostra.

Agradeço ao Dr. Michael Glascock, do Missouri University Research Reactor, por sua orientação durante meu estágio realizado em seu laboratório, nos EUA, no qual 
pude aprender mais sobre análise estatística multivariada, arqueometria e análise por ativação com nêutrons.

Ao Diego Giglioti Tudela, pela ajuda nos experimentos de difração de raios X, preparação de amostras para datação e tentativas com datação termoluminescente. Mas, acima disso, pela amizade e companheirismo, e por momentos de boas risadas em nossa sala.

Agradeço ao Dr. Junhua Guo e Dra. Chen Song pelas análises no Departamento de Geologia da Universidade do Missouri, onde pude aprender muito sobre a análise de minerais argilosos e interpretação de difratogramas de raios $\mathrm{X}$.

À Kelly Plaça Nunes, pelas discussões, ideias e ajuda com problemas burocráticos enquanto eu não estava no Brasil. Além disso, pela amizade e companheirismo, e por momentos de boas risadas.

À dona Grinaura, por manter a sala sempre limpinha, impecável, e pelos momentos de conversa para quebrar um pouco a rotina.

À Tassiane Matsubara, pela amizade desde o início do Doutorado em 2009. Sua presença e amizade foram essenciais para que a pós-graduação fosse um momento especial na minha vida. E como esquecer as risadas, mesmo em momentos inoportunos, e os interesses comuns por arte? Espero levar sua amizade para sempre!

À Priscila Vallinoto, pela amizade desde o início do seu mestrado, no final de 2010. Sua presença veio somar, trazendo alegria, irreverência e muito companheirismo e cumplicidade. Foi uma das pessoas mais especiais que conheci neste processo. E um brinde à tia Penha! Espero levar sua amizade para sempre!

Aos amigos incríveis do teatro: Rodrigo Amorim Gonçalo, Patrícia Trevisan, Maristela Racy Kheirallah, Milton Miyamoto, Bruno Cerqueira, Iuri Odainai, Thiago Fontes Menezes, Paula Carvalho e Fábul Henrique. Conhecemo-nos durante esta minha trajetória de Doutorado, paralelamente, enquanto estudávamos no Macunaíma. A amizade e presença de vocês durante este período foi essencial para que a vida fosse mais leve e divertida. Que nossa amizade e amor pela arte dure para sempre!

À Amanda Bravim, pela amizade, confiança e pelos bons papos nos cafés.

A Guilherme Guimarães, Ed Paiva, Fábio Sussa, Thalita Pinheiro Sanches, Daniele Seo, Mychelle Rosa, Bianca Geraldo, Elaine Wirney, Edson Moreira, Rita de Cássia Andre, Liliane, Rogério Baria Ribeiro, Cristina Zampieri, Guilherme Soares Zahn e Regina Beck pela amizade e por muitos momentos engraçados. 
"O senhor... Mire veja: o mais importante e bonito, do mundo, é isto: que as pessoas não estão sempre iguais, ainda não foram terminadas - mas que elas vão sempre mudando."

Riobaldo em Grande Sertão: Veredas João Guimarães Rosa 


\title{
NÊUTRONS, RADIAÇÃO E ARQUEOLOGIA: ESTUDO DE CASO MULTIANALÍTICO DE CERÂMICAS DA TRADIÇÃO BORDA INCISA NA AMAZÔNIA CENTRAL
}

\author{
Roberto Hazenfratz-Marks
}

\section{RESUMO}

Este trabalho é um estudo arqueométrico interdisciplinar envolvendo material cerâmico arqueológico da Amazônia Central, proveniente de dois sítios de grandes dimensões, Lago Grande e Osvaldo, na região de confluência dos rios Negro e Solimões. Procurou-se testar a hipótese de uma rede de trocas entre os antigos habitantes desses sítios, focando em trocas materiais e/ou tecnológicas. Essa hipótese tem implicações para teorias de ocupação da Amazônia Central pré-colonial que procuram relativizar o papel das dificuldades ambientais da floresta tropical como fator limitante para a emergência da complexidade social na região. A caracterização físico-química de fragmentos cerâmicos e argilas próximas aos sítios foi realizada por meio de: análise por ativação com nêutrons instrumental (INAA) para determinação da composição química elementar; espectroscopia de ressonância paramagnética eletrônica (EPR) para determinação da temperatura de queima; difração de raios X (XRD) para determinação da composição mineralógica; e datação de cerâmicas por luminescência opticamente estimulada (OSL). Estudos mostraram que a área dos sítios foi ocupada por culturas produtoras das fases cerâmicas Manacapuru e Paredão, da Tradição Borda Incisa, em torno dos séculos V-X d.C. e VIIXII d.C., respectivamente. Os resultados de INAA foram analisados por métodos estatísticos multivariados, que possibilitaram definir dois grupos químicos de cerâmicas para cada sítio, para os quais não se observaram variações significativas na temperatura de queima e composição mineralógica. A partir do cruzamento com dados arqueológicos, a superposição entre pares de grupos foi interpretada como correlata da existência de uma rede de trocas pretérita, embora não tenha sido possível definir se ela teria ocorrido apenas entre Lago Grande e Osvaldo. Pelo contrário, sugeriu-se, pela comparação de dois grupos químicos de cerâmicas, que Lago Grande participava de uma rede mais extensa de trocas.

Palavras-chave: Arqueometria; Amazônia Central; Cerâmica arqueológica; Tradição Borda Incisa, Análise por ativação com nêutrons; Análise estatística multivariada. 


\title{
NEUTRONS, RADIATION AND ARCHAEOLOGY: \\ A MULTIANALYTICAL CASE STUDY OF INCISED RIM TRADITION CERAMICS IN CENTRAL AMAZON
}

\author{
Roberto Hazenfratz-Marks
}

\begin{abstract}
This thesis is an interdisciplinary archaeometric study involving archaeological ceramic material from two large archaeological sites in Central Amazon, namely Lago Grande and Osvaldo, on the confluence region of Negro and Solimões rivers. It was tested a hypothesis about the existence of an exchange network between the former inhabitants of those sites, focusing on material and/or technological exchange. That hypothesis has implications for archaeological theories of human occupation of the pre-colonial Central Amazon, which try to relativise the role of ecological difficulties of the tropical forest as a limiting factor for the emergence of social complexity in the region. The physical-chemical characterization of potsherds and clay samples near the sites was carried out by: instrumental neutron activation analysis (INAA) to determine the elemental chemical composition; electron paramagnetic resonance (EPR) to determine the firing temperature; X-ray diffraction (XRD) to determine the mineralogical composition; and dating by optically stimulated luminescence (OSL). Previous studies showed that Osvaldo and Lago Grande were occupied by people which produced pottery classified in the Manacapuru and Paredão phases, subclasses of the Incised Rim Tradition, around the $5-10^{\text {th }}$ and $7-12^{\text {th }}$ centuries $\mathrm{BC}$, respectively. INAA results were analyzed by multivariate statistical methods, whereby two chemical groups of pottery were defined for each archaeological site. Significant variation in firing temperatures and mineralogical composition were not identified for such groups. By integration of the results with archaeological data, the superposition between pairs of chemical groups was interpreted as a correlate of an ancient exchange network, although it was not possible to define if it existed exclusively between Lago Grande and Osvaldo. On the contrary, it was suggested that Lago Grande participated in a more extensive exchange network by comparison of two chemical groups.
\end{abstract}

Keywords: Archaeometry; Central Amazon; Archaeological pottery; Incised Rim Tradition; Neutron activation analysis; Multivariate statistical analysis. 


\section{SUMÁRIO}

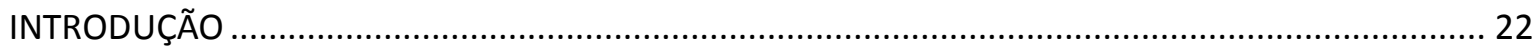

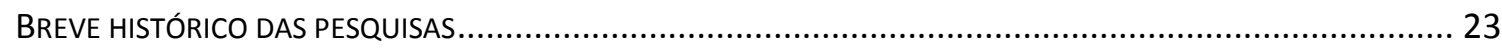

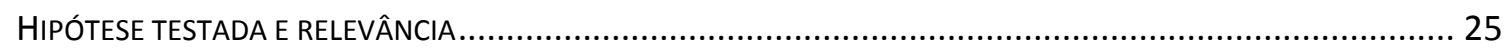

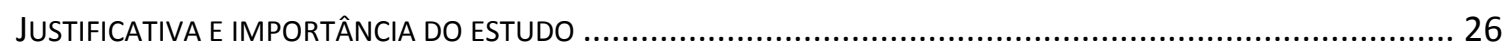

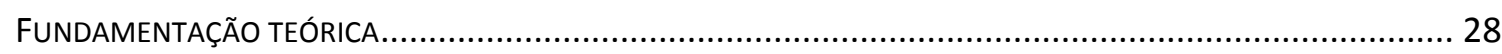

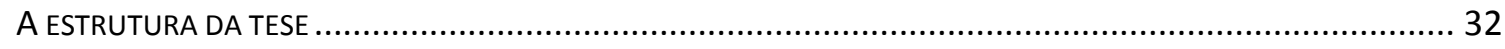

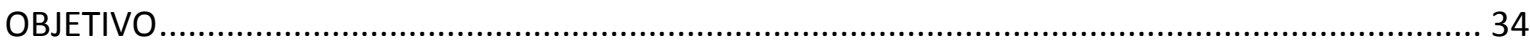

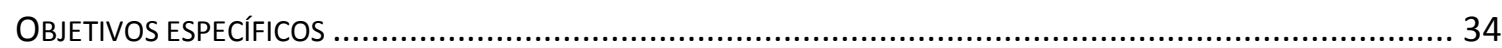

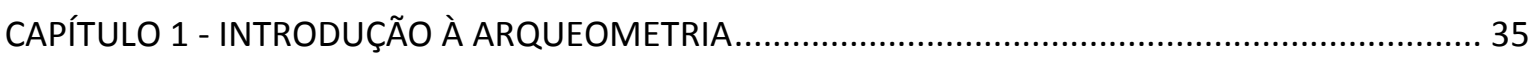

1.1. BREVE HISTÓRICO DE DESENVOLVIMENTOS CIENTíFICOS QUE INFLUENCIARAM A ARQUEOMETRIA ............. 36

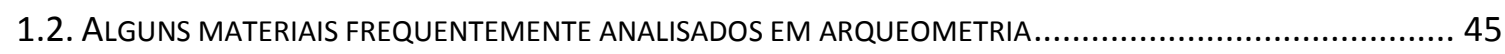

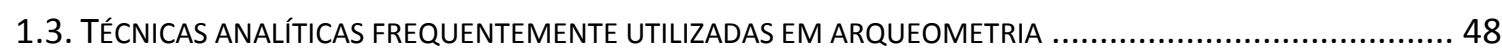

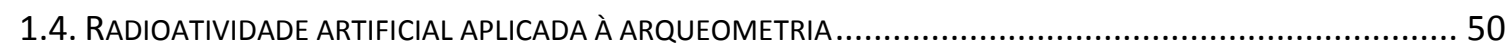

1.5. CARACTERIZAÇÃO QUÍMICA ELEMENTAR DE MATERIAIS ARQUEOLÓGICOS ........................................... 51

CAPÍTULO 2 - ÁREA DE ESTUDO E CONTEXTO ARQUEOLÓGICO DA AMAZÔNIA CENTRAL ............... 55

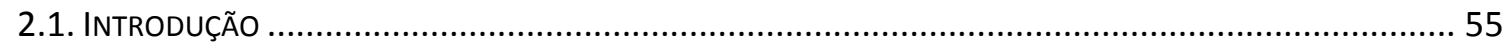

2.2. QUESTÕES GERAIS SOBRE ARQUEOLOGIA AMAZÔNICA - AMAZÔNIA CENTRAL.................................... 57

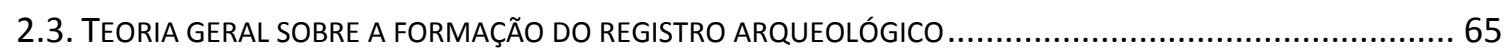

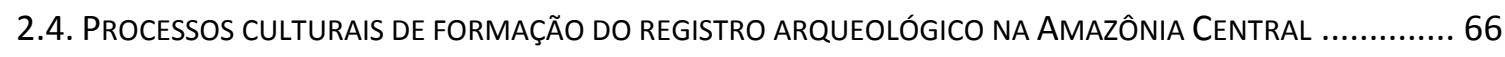

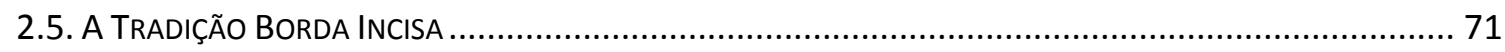

2.6. Processos naturais de formação do Registro arqueolóGICo na AMAZÔNIA CENTRAL.................. 73

2.7. ÁREA DE ESTUDO: SÍtIOS ARQUEOLÓGICOS LAGO GRANDE E OSVALDO .............................................. 77

CAPÍTULO 3 - MATERIAIS CERÂMICOS - FUNDAMENTOS E APLICAÇÕES EM ARQUEOLOGIA......... 84

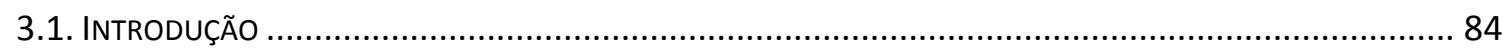

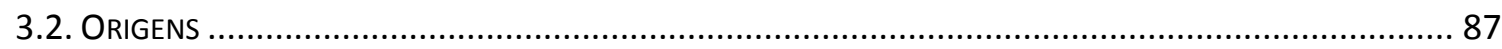

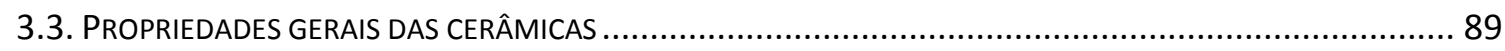

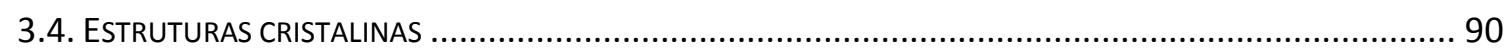

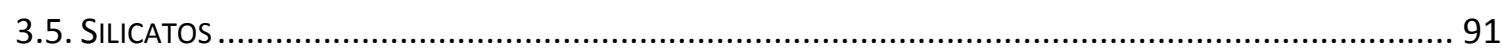

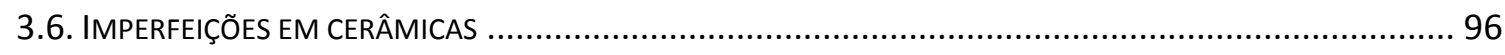

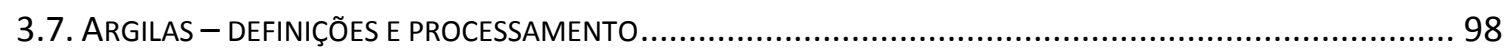

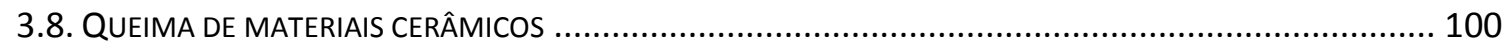

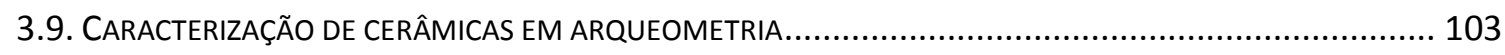

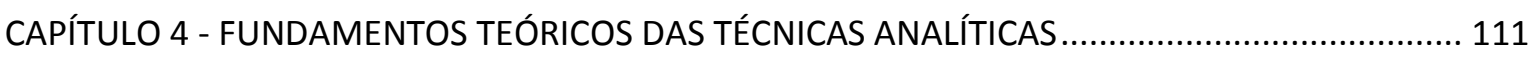

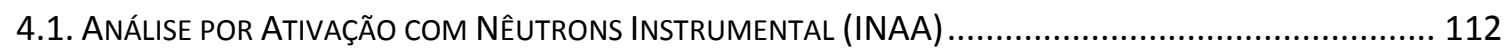

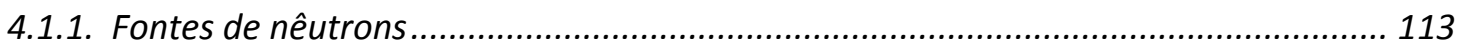

4.1.2. Reatores nucleares como fonte de nêutrons............................................................. 114 
4.1.3. Princípios gerais de análise por ativação com nêutrons........................................... 116

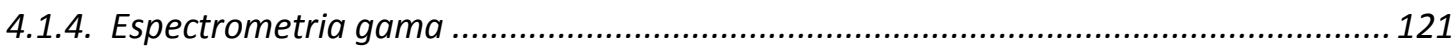

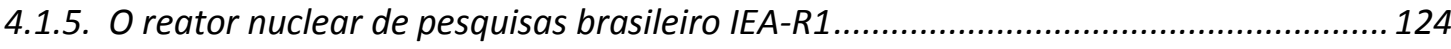

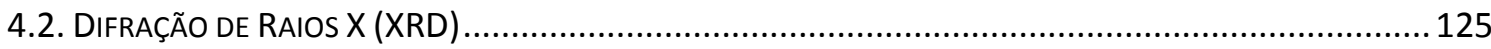

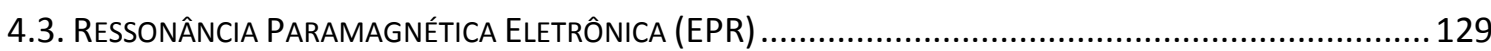

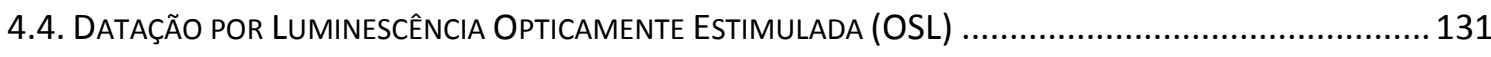

CAPÍTULO 5 - FUNDAMENTOS TEÓRICOS DOS MÉTODOS ESTATÍSTICOS......................................... 137

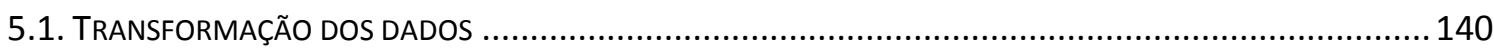

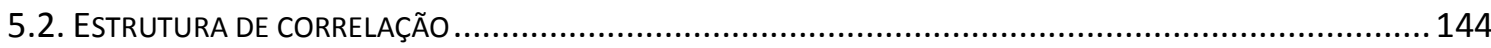

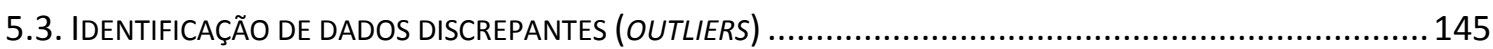

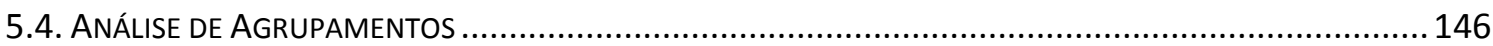

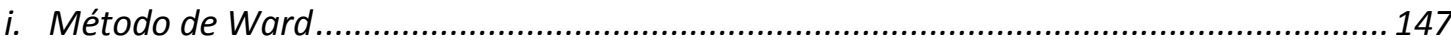

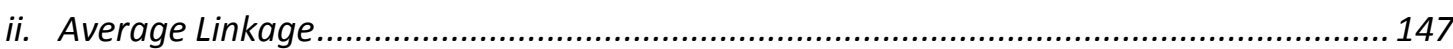

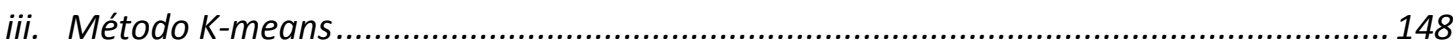

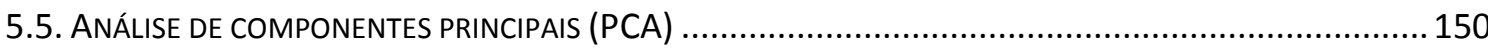

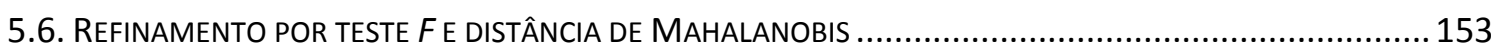

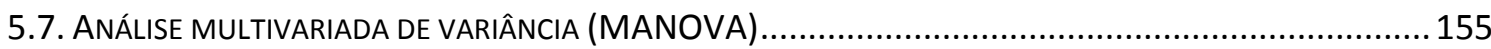

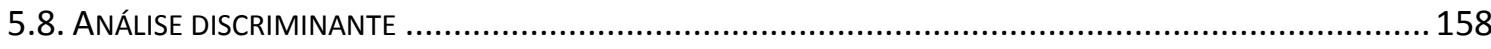

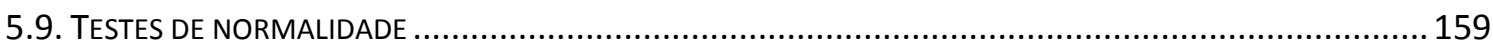

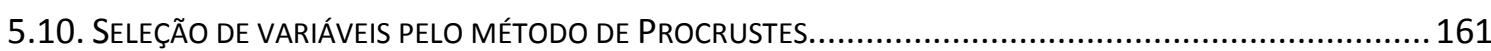

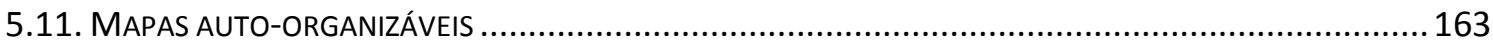

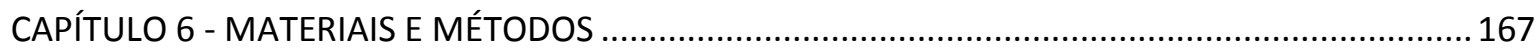

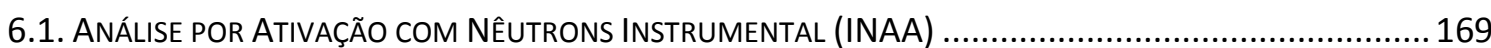

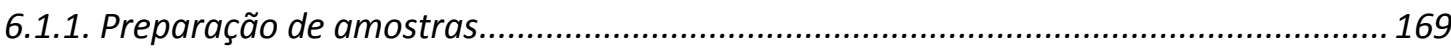

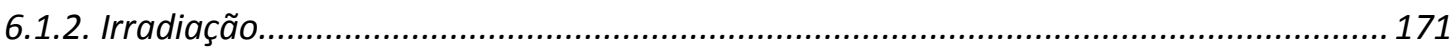

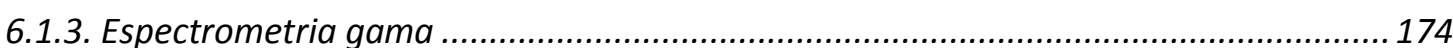

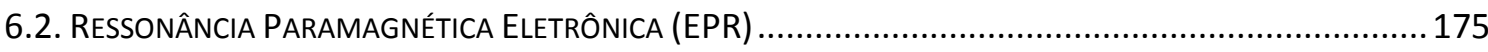

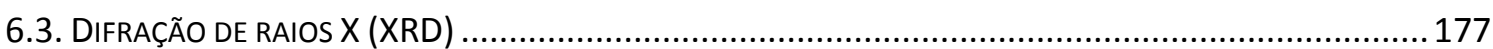

6.4. DATAÇÃO POR LUMINESCÊNCIA OPTICAMENTE ESTIMULADA (OSL) .............................................. 178

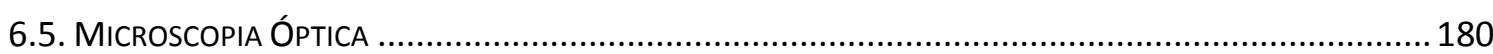

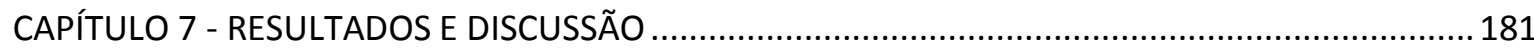

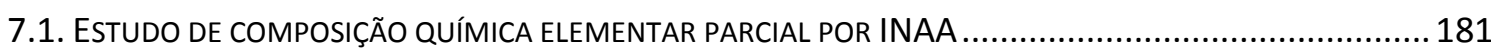

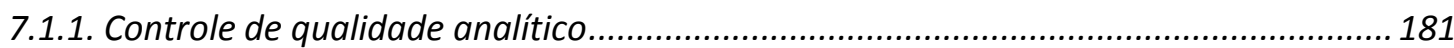

7.1.2. Medidas de INAA dos fragmentos cerâmicos arqueológicos ....................................... 195

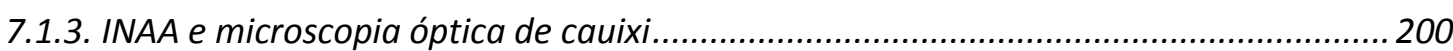

7.1.4. Seleção dos elementos químicos para as análises multivariadas ...............................203

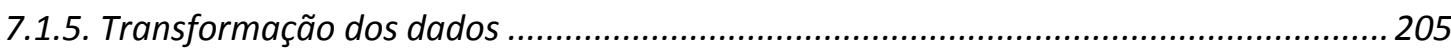

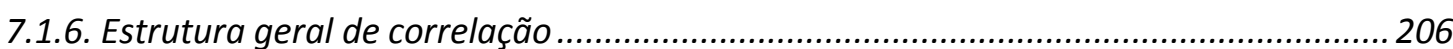

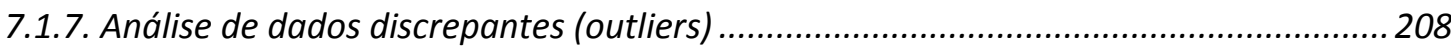

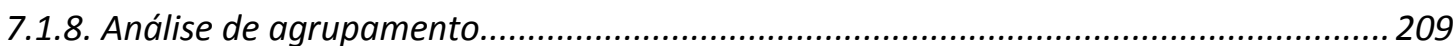

7.1.9. Análise de componentes principais (PCA) com transformação $\log _{10} \ldots \ldots \ldots \ldots \ldots \ldots \ldots \ldots . . . . . . . . . . . . . . .214$

7.1.10. PCA com transformação de dados em razão logarítmica aditiva (alr)....................... 231 
7.1.11. Comparação preliminar entre as transformações de dados $\log _{10}$ e alr 239

7.1.12. Estudo de agrupamento e PCA por sítio arqueológico............................................. 241

7.1.13. Análise comparativa entre Lago Grande e Osvaldo............................................... 257

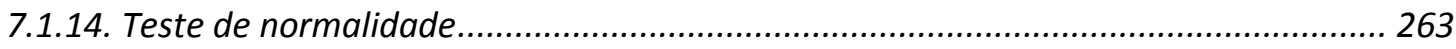

7.1.15. Teste de homogeneidade das matrizes de covariância ............................................ 265

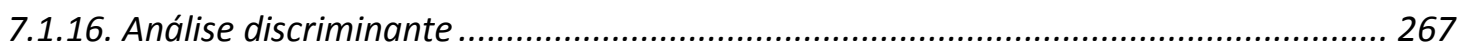

7.1.17. Seleção do conjunto mínimo de variáveis pelo método Procrustes ........................... 270

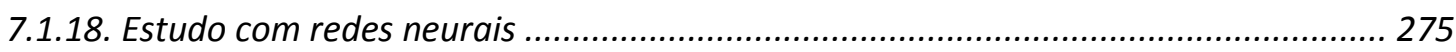

7.1.19. O significado arqueológico dos grupos químicos definidos ..................................... 283

7.1.20. Comparação entre os Cenários 3 e 5 e implicações arqueológicas............................ 285

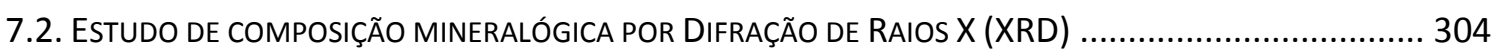

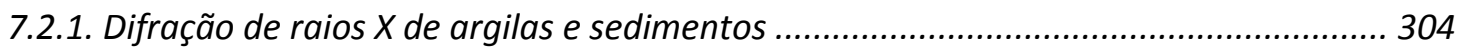

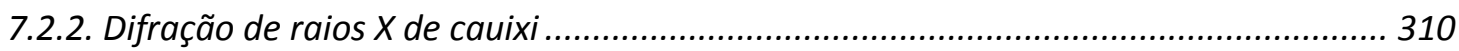

7.2.3. Difração de raios $X$ de fragmentos cerâmicos arqueológicos ..................................... 311

7.3. DeterminaÇÃO DA TEMPERATURA dE QUEIMA POR RESSONÂNCIA PARAMAGNÉtICA ELETRÔNICA (EPR)

7.3. DETERMINAÇÃO DA TEMPERATURA dE QUEIMA POR RESSONÂNCIA PARAMAGNÉTICA ELETRÔNICA (EPR)

7.4. DATAÇÃO POR LUMINESCÊNCIA OPTICAMENTE ESTIMULADA (OSL) .............................................. 325

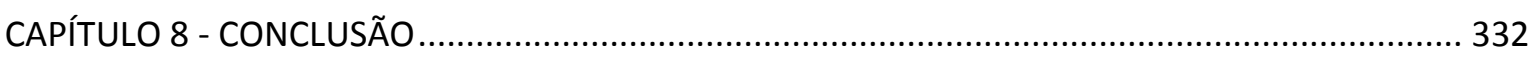

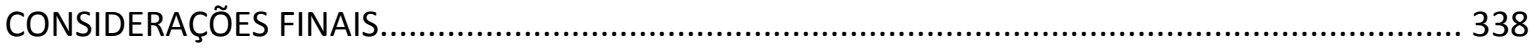

Apêndice A - Concentrações elementares no material de referência IAEA-Soil-7 por INAA.

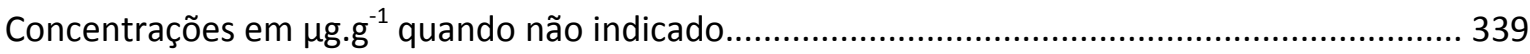

Apêndice B - Informações arqueológicas e concentrações elementares nos fragmentos cerâmicos de Lago Grande e Osvaldo por INAA. Concentrações em $\mu g, g^{-1}$ quando não indicado.................. 344

Apêndice C - Cartas de Controle para o material de referência IAEA-Soil-7 ................................... 374

Apêndice D - Controle de qualidade analítico pelo teste de proficiência adaptado da IAEA-

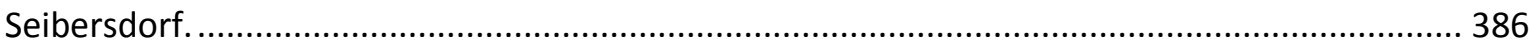

Apêndice E - Microscopia óptica ilustrando a presença de espículas biogênicas da esponja de água

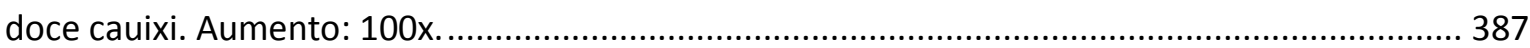

Apêndice F - Dendrogramas das análises de agrupamento............................................................. 390

Apêndice G - Rotina para teste de Shenton-Bowman para normalidade multivariada em Scilab.

Apêndice H - Comparação PCA preliminar entre os sítios arqueológicos Lago Grande, Osvaldo,

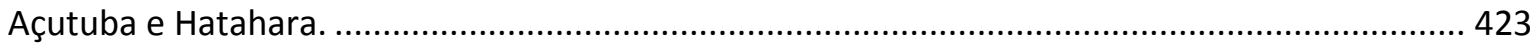

Apêndice I - Curvas de EPR para determinação da temperatura de queima.................................. 425

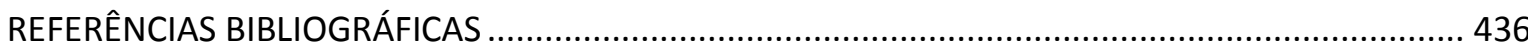




\section{Lista de Figuras}

Figura 2.1 - Fotografia de cauixi in natura. O ramo no canto inferior direito corresponde ao ramo de ligação. Fonte: Jensen et al. (2011).

Figura 2.2 - A região de confluência dos rios Negros e Solimões na Amazônia Central, indicando os dois sítios estudados. Fontes: Ezilon maps e Portocarrero (2006)............................................... 78

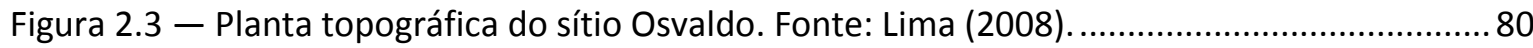

Figura 2.4 - Planta topográfica do sítio Lago Grande. Fonte: Lima (2008)................................... 81

Figura 3.1 - Objetos comuns fabricados com materiais cerâmicos: xícara de chá chinesa, tijolo de construção, azulejo e vaso de vidro. Fonte: Callister (2007)........................................................ 86

Figura 3.2 - Vênus de Vestonice, uma estatueta de terracota de 25.000 anos, com aproximadamente $10 \mathrm{~cm}$ de altura, encontrada em 1920, na República Tcheca, por Dolní Vestonice. Acredita-se tratar de um amuleto da fertilidade. Fonte: www.portaldarte.com.br...... 88 Figura 3.3 - Esquema ilustrativo das posições tetraédricas e octraédricas para cátions. As esferas azuis e vermelhas representam ânions. Fonte: Callister (2007). ................................................. 91 Figura 3.4 - Unidades tetraédricas de SiO44 - . Fonte: Callister (2007) .........................................92 Figura 3.5 - Cinco estruturas para íons silicato, formados a partir de tetraedros de SiO44-. Fonte: Callister (2007).

Figura 3.6 - Representação de uma lâmina de silicato bidimensional com unidade estrutural $\left(\mathrm{Si}_{2} \mathrm{O}_{5}\right)^{2-}$. Fonte: Callister (2007).

Figura 3.7 - Estrutura da caulinita $\mathrm{Al}_{2}(\mathrm{OH})_{4}\left(\mathrm{Si}_{2} \mathrm{O}_{5}\right)$. Esse tipo de argila é composto por lâminas de $\left(\mathrm{Si}_{2} \mathrm{O}_{5}\right)^{2-}$, unidas por lâminas positivamente carregadas de octaedros de $\mathrm{Al} 2(\mathrm{OH}) 42+$, formando camadas duplas, empilhadas de forma paralela, formando pequenas placas planas, aproximadamente hexagonais, com menos de $1 \mu \mathrm{m}$ de diâmetro, em geral. As moléculas polares de água são facilmente absorvidas entre a parte superior das lâminas positivas e pela parte inferior das lâminas de silicato. Fontes: Barsoum (2003) e Callister (2007). ...................................95 Figura 3.8 - Estrutura da mica. Nesta estrutura, íons de alumínio substituem um quarto dos átomos de silício nas camadas, o que faz necessário que íons, como o $\mathrm{K}^{+}$, liguem-se entre as camadas tetraédricas, de forma a torná-las eletricamente neutras por meio de ligações iônicas que são mais fortes que as ligações entre as camadas dos filossilicatos. Dessa forma, a mica não absorve água tão facilmente quanto as argilas. Fonte: Barsoum (2003) .........................................96 Figura 3.9 - Esquema ilustrativo dos defeitos pontuais e impurezas em estruturas cristalinas de materiais cerâmicos. Fonte: Adaptado de Callister (2007) ............................................................. 97

Figura 4.1 - Espectro eletromagnético. Fonte: Sociedade Brasileira de Física............................... 111

Figura 4.2 - Espectro típico de nêutrons em reatores nucleares de fissão................................... 115

Figura 4.3 - Esquema ilustrando os processos nucleares que ocorrem pela interação de um nêutron incidente com um núcleo-alvo em análise por ativação com nêutrons.

Figura 4.4 - Espectro gama típico de uma amostra de cerâmica arqueológica obtida no Laboratório de Análise por Ativação Neutrônica do IPEN - CNEN/SP............................................123 Figura 4.5 - Espalhamento de raios $X$ por planos cristalinos. $O$ ângulo de espalhamento $\theta$ depende apenas da distância interplanar $d$, porém a intensidade de difração dependerá da natureza célula unitária, ou estrutura cristalina. Assim, as estruturas (b) e (c) espalharão raios $X$ no mesmo ângulo $\theta$, porém com intensidades diferentes. Adaptado de Barsoum (2003). 
Figura 4.6 - Esquema simplificado do princípio de EPR. Fonte: Adaptado de Bartoll \& Tani (1998).

Figura 4.7 - Acúmulo de dose alfa, beta e gama nos grãos de quartzo e feldspato ao longo do tempo.

Figura 5.1 - Exemplo de dendrograma obtido em uma análise de agrupamentos. As cores dos diferentes segmentos representam cada um dos quatro grupos definidos no estudo. 147 Figura 5.2 - Exemplo de gráfico obtido por PCA no software Statistica, indicando a presença de dois grupos de amostras pela projeção dos dados nas duas primeiras componentes principais, que explicaram, neste caso, cerca de $73 \%$ da variância do sistema. 152

Figura 5.3 - Diagrama ilustrativo do método Procrustes para seleção de variáveis. 163 Figura 5.4 - Representação gráfica de um mapa auto-organizável, na qual os neurônios são representados por colunas verticais. A superfície da estrutura corresponde ao mapa visualizado graficamente após a aplicação do método. Fonte: Adaptado de Tanevska et al. (2007).. 164 Figura 6.1 - Exemplos de amostras dos sítios arqueológicos Lago Grande e Osvaldo para análise. 168

Figura 6.2 - Remoção de superfície lateral e incisão de broca para obtenção de pó de fragmentos cerâmicos arqueológicos dos sítios Lago Grande e Osvaldo. 170

Figura 6.3 - Acondicionamento do pó obtido na preparação de amostras para INAA. 170 Figura 6.4 - Pesagem de amostra de cerâmica arqueológica para irradiação com nêutrons térmicos. 171

Figura 6.5 - Soldagem dos invólucros de polietileno sob papel celofane. 172 Figura 6.6 - Montagem de "coelho" contendo amostras para irradiação com nêutrons térmicos. 173

Figura 6.7 - Acondicionamento de cápsulas de polietileno, contendo as amostras irradiadas, no trilho do trocador automático para espectrometria gama. 174 Figura 6.8 - Chegada da tubulação pneumática do trocador automático ao espectrômetro gama. 175

Figura 7.1 - Exemplo de carta de controle para as determinações de concentração do elemento químico Hf por INAA no material de referência IAEA-Soil-7. As demais cartas encontram-se no Apêndice $C$. 186 Figura 7.2 - Variação percentual das concentrações elementares nos fragmentos cerâmicos dos sítios Lago Grande e Osvaldo em relação às concentrações médias dos mesmos elementos nas argilas queimadas do sítio Osvaldo. 198 Figura 7.3 - Variação percentual das concentrações elementares de $\mathrm{Na}$ e Co nos fragmentos cerâmicos dos sítios Lago Grande e Osvaldo em relação às concentrações médias desses elementos nas argilas queimadas do sítio Osvaldo. 198 Figura 7.4 - Microscopia óptica (100x) das amostras CSQN109 (esquerda) e CSQN130 (direita) ilustrando a presença de espículas de sílica biogênica, provenientes do cauixi, esponja de água doce considerada o principal antiplástico utilizado nas cerâmicas dos sítios Lago Grande e Osvaldo. 200

Figura 7.5 - Distribuição de frequências de valores de concentração não determinados por INAA para a base de dados de Lago Grande e Osvaldo. 204 Figura 7.6 - Escores nas duas primeiras componentes principais dos dados do Cenário 1 para os sítios Lago Grande e Osvaldo. As elipses representam a região de confiança de $95 \%$. 216 
Figura 7.7 - Escores na primeira e terceira componentes principais dos dados do Cenário 1 para os sítios Lago Grande e Osvaldo. As elipses representam a região de confiança de $95 \%$. .............217 Figura 7.8 - Escores nas duas primeiras componentes principais dos dados do Cenário 1, sem o $\mathrm{Na}$, para os sítios Lago Grande e Osvaldo. As elipses representam a região de confiança de $95 \%$.

Figura 7.9 - Escores na primeira e terceira componentes principais dos dados do Cenário 1, sem o $\mathrm{Na}$, para os sítios Lago Grande e Osvaldo. As elipses representam a região de confiança de $95 \%$.

Figura 7.10 - Escores nas duas primeiras componentes principais dos dados do Cenário 2 para os sítios Lago Grande e Osvaldo. As elipses representam a região de confiança de $95 \%$................... 227 Figura 7.11 - Escores na primeira e terceira componentes principais dos dados do Cenário 2 para os sítios Lago Grande e Osvaldo. As elipses representam a região de confiança de $95 \%$. .............227 Figura 7.12 - Escores nas duas primeiras componentes principais dos dados do Cenário 3 para os sítios Lago Grande e Osvaldo. As elipses representam a região de confiança de $95 \%$.....................229 Figura 7.13 - Escores na primeira e terceira componentes principais dos dados do Cenário 3 para os sítios Lago Grande e Osvaldo. As elipses representam a região de confiança de $95 \%$. .............230 Figura 7.14 - Escores nas duas primeiras componentes principais dos dados do Cenário 4 para os sítios Lago Grande e Osvaldo. As elipses representam a região de confiança de 95\%...................235 Figura 7.15 - Escores na primeira e terceira componentes principais dos dados do Cenário 4 para os sítios Lago Grande e Osvaldo. As elipses representam a região de confiança de $95 \%$. .............235 Figura 7.16 - Escores nas duas primeiras componentes principais dos dados do Cenário 5 para os sítios Lago Grande e Osvaldo. As elipses representam a região de confiança de $95 \%$....................237 Figura 7.17 - Escores na primeira e terceira componentes principais dos dados do Cenário 5 para os sítios Lago Grande e Osvaldo. As elipses representam a região de confiança de $95 \%$. .............238 Figura 7.18 - Escores nas duas primeiras componentes principais dos dados do Cenário 3 para o sítio Lago Grande. As elipses representam a região de confiança de $95 \%$. ....................................243 Figura 7.19 - Escores na primeira e terceira componentes principais dos dados do Cenário 3 para o sítio Lago Grande. As elipses representam a região de confiança de $95 \%$. .................................243 Figura 7.20 - Escores nas duas primeiras componentes principais dos dados do Cenário 3 para o sítio Lago Grande com grupos químicos refinados utilizando-se distância de Mahalanobis e distribuição F. As elipses representam a região de confiança de $95 \%$. 244 Figura 7.21 - Escores na primeira e terceira componentes principais dos dados do Cenário 3 para o sítio Lago Grande com grupos químicos refinados utilizando-se distância de Mahalanobis e distribuição F. As elipses representam a região de confiança de $95 \%$. 245 Figura 7.22 - Escores nas duas primeiras componentes principais dos dados do Cenário 5 para o sítio Lago Grande. As elipses representam a região de confiança de $95 \%$. .....................................247 Figura 7.23 - Escores na primeira e terceira componentes principais dos dados do Cenário 5 para o sítio Lago Grande. As elipses representam a região de confiança de $95 \%$.

Figura 7.24 - Escores nas duas primeiras componentes principais dos dados do Cenário 5 para o sítio Lago Grande com grupos químicos refinados utilizando-se distância de Mahalanobis e distribuição F. As elipses representam a região de confiança de $95 \%$. 249 Figura 7.25 - Escores na primeira e terceira componentes principais dos dados do Cenário 5 para o sítio Lago Grande com grupos químicos refinados utilizando-se distância de Mahalanobis e distribuição F. As elipses representam a região de confiança de $95 \%$. 249 
Figura 7.26 - Escores nas duas primeiras componentes principais dos dados do Cenário 3 para o sítio Osvaldo. As elipses representam a região de confiança de $95 \%$.

Figura 7.27 - Escores na primeira e terceira componentes principais dos dados do Cenário 3 para o sítio Osvaldo. As elipses representam a região de confiança de $95 \%$.

Figura 7.28 - Escores nas duas primeiras componentes principais dos dados do Cenário $\mathbf{3}$ para o sítio Osvaldo com grupos químicos refinados utilizando-se distância de Mahalanobis e distribuição F. As elipses representam a região de confiança de $95 \%$. 252 Figura 7.29 - Escores na primeira e terceira componentes principais dos dados do Cenário 3 para o sítio Osvaldo com grupos químicos refinados utilizando-se distância de Mahalanobis e distribuição F. As elipses representam a região de confiança de $95 \%$. 253 Figura 7.30 - Escores nas duas primeiras componentes principais dos dados do Cenário 5 para o sítio Osvaldo. As elipses representam a região de confiança de $95 \%$. 255 Figura 7.31 - Escores na primeira e terceira componentes principais dos dados do Cenário 5 para o sítio Osvaldo. As elipses representam a região de confiança de $95 \%$. 255 Figura 7.32 - Escores nas duas primeiras componentes principais dos dados do Cenário 5 para o sítio Osvaldo com grupos químicos refinados utilizando-se distância de Mahalanobis e distribuição F. As elipses representam a região de confiança de $95 \%$. 256 Figura 7.33 - Escores na primeira e terceira componentes principais dos dados do Cenário 5 para o sítio Osvaldo com grupos químicos refinados utilizando-se distância de Mahalanobis e distribuição F. As elipses representam a região de confiança de $95 \%$.

Figura 7.34 - Escores nas duas primeiras componentes principais dos dados do Cenário 3 para os dois grupos químicos de Lago Grande e Osvaldo. As elipses representam a região de confiança de 95\%. 258

Figura 7.35 - Escores na primeira e terceira componentes principais dos dados do Cenário 3 para os dois grupos químicos de Lago Grande e Osvaldo. As elipses representam a região de confiança de $95 \%$....... 258

Figura 7.36 - Escores nas duas primeiras componentes principais dos dados do Cenário 5 para os dois grupos químicos de Lago Grande e Osvaldo. As elipses representam a região de confiança de 95\%.

Figura 7.37 - Escores na primeira e terceira componentes principais dos dados do Cenário 5 para os dois grupos químicos de Lago Grande e Osvaldo. As elipses representam a região de confiança de $95 \%$. 261

Figura 7.38 - Projeção $\mathrm{CD} 2 \times \mathrm{CD} 1$ da análise discriminante canônica a partir dos grupos químicos de Lago Grande e Osvaldo, definidos para o Cenário 3. As elipses representam a região de confiança de $95 \%$ 267

Figura 7.39 - Projeção CD3xCD1 da análise discriminante canônica a partir dos grupos químicos de Lago Grande e Osvaldo, definidos para o Cenário 3. As elipses representam a região de confiança de $95 \%$. 268

Figura 7.40 - Projeção CD2xCD1 da análise discriminante canônica a partir dos grupos químicos elementares de Lago Grande e Osvaldo, definidos para o Cenário 5. As elipses representam a região de confiança de $95 \%$. 269

Figura 7.41 - Projeção CD3xCD1 da análise discriminante canônica a partir dos grupos químicos elementares de Lago Grande e Osvaldo, definidos para o Cenário 5. As elipses representam a região de confiança de $95 \%$. 269 
Figura 7.42 - PCA comparativo (PC2xPC1) para a base de dados dos sítios Lago Grande e Osvaldo com nove elementos (acima, Cenário 3) e os cinco elementos (abaixo) selecionados pelo método Procrustes. 272

Figura 7.43 - PCA comparativo (PC2xPC1) para a base de dados dos sítios Lago Grande e Osvaldo com oito razões elementares (acima, Cenário 5) e as quatro razões (abaixo) selecionadas pelo método Procrustes.

Figura 7.44 - Mapa de Kohonen para os grupos químicos de Lago Grande definidos no Cenário 3. Nomenclatura: $\mathrm{g} 1$ = grupo $\mathrm{A} ; \mathrm{g} 2$ = grupo $\mathrm{B}$

Figura 7.45 - Mapa de Kohonen para os grupos químicos de Osvaldo definidos no Cenário 3. Nomenclatura: $\mathrm{g} 1$ = grupo $\mathrm{A} ; \mathrm{g} 2$ = grupo $\mathrm{B}$. .278

Figura 7.46 - Mapa de Kohonen para os grupos químicos de Lago Grande e Osvaldo definidos no Cenário 3. Nomenclatura: g1 = grupo A de Lago Grande; g2 = grupo B de Lago Grande; g3 = grupo A de Osvaldo; g4 = grupo $B$ de Osvaldo. 279

Figura 7.47 - Mapa de Kohonen para os grupos químicos de Lago Grande definidos no Cenário 5. Nomenclatura: $\mathrm{g} 1$ = grupo $\mathrm{A} ; \mathrm{g} 2$ = grupo $\mathrm{B}$. 280

Figura 7.48 - Mapa de Kohonen para os grupos químicos de Osvaldo definidos no Cenário 5. Nomenclatura: g1 = grupo A; g2 = grupo B. 281 Figura 7.49 - Mapa de Kohonen para os grupos químicos de Lago Grande e Osvaldo definidos no Cenário 5. Nomenclatura: g1 = grupo A de Lago Grande; g2 = grupo B de Lago Grande; g3 = grupo A de Osvaldo; $\mathrm{g} 4$ = grupo $B$ de Osvaldo. 282 Figura 7.50 - Histograma de classificação de amostras Manacapuru de Lago Grande (LG) e Osvaldo (Osv) em grupos químicos definidos no Cenário $3\left(\log _{10}\right)$ e Cenário 5 (alr)...................... 288 Figura 7.51 - Histograma de classificação de amostras Paredão de Lago Grande (LG) e Osvaldo (Osv) em grupos químicos definidos no Cenário $3\left(\log _{10}\right)$ e Cenário 5 (alr). 289 Figura 7.52 - Histograma de classificação de amostras dos grupos químicos de cerâmicas de Lago Grande a partir do Cenário $3\left(\log _{10}\right)$ e Cenário 5 (alr) segundo a estratigrafia...............................296 Figura 7.53 - Histograma de classificação de amostras dos grupos químicos de cerâmicas de Osvaldo a partir do Cenário $3\left(\log _{10}\right)$ e Cenário 5 (alr) segundo a estratigrafia...............................296 Figura 7.54 - Histograma de classificação de amostras das unidades de escavação U1, U3 e U4 de Lago Grande em grupos químicos de cerâmicas, definidos a partir do Cenário $3\left(\log _{10}\right)$ e Cenário 5 (alr). 298

Figura 7.55 - Histograma de classificação de amostras da unidade de escavação S710 E1966 e de tradagem de Osvaldo em grupos químicos de cerâmicas, definidos a partir do Cenário $3\left(\log _{10}\right)$ e Cenário 5 (alr). 298

Figura 7.56 - Escores nas duas primeiras componentes principais dos dados do Cenário 5 para as argilas projetadas contra os dois grupos químicos de Lago Grande e Osvaldo. As elipses representam a região de confiança de $95 \%$. 302 Figura 7.57 - Escores na primeira e terceira componentes principais dos dados do Cenário 5 para as argilas projetadas contra os dois grupos químicos de Lago Grande e Osvaldo. As elipses representam a região de confiança de $95 \%$. 302 Figura 7.58 - Difratograma de fração argilosa das amostras de argilas CSQN83 (superior),

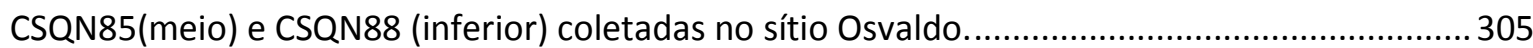
Figura 7.59 - Difratograma da amostra de sedimento CSQE148 de região próxima à confluência dos rios Negro e Solimões 306 
Figura 7.60 - Difratograma da amostra de sedimento CSQE156 de região próxima à confluência dos rios Negro e Solimões.

Figura 7.61 - Difratograma da amostra de sedimento CSQE167 de região próxima à confluência dos rios Negro e Solimões. 308

Figura 7.62 - Difratograma da amostra de sedimento CSQE197 de região próxima à confluência dos rios Negro e Solimões. 309

Figura 7.63 - Difratograma de cauixi 1, coletado na região de confluência dos rios Negro e Solimões.

Figura 7.64 - Difratograma de cauixi 2, coletado na região de confluência dos rios Negro e Solimões. 310

Figura 7.65 - Difratograma de fragmentos cerâmicos arqueológicos do sítio Lago Grande.. 312

Figura 7.66 - Difratograma de fragmentos cerâmicos arqueológicos do sítio Osvaldo. 314

Figura 7.67 - Difratograma de fragmentos cerâmicos arqueológicos de Lago Grande e Osvaldo, e comparação com radiação de fundo (padrão em vermelho).

Figura 7.68 - Espectro de EPR para banda $X$ (esquerda) em temperatura ambiente e fator espectroscópico experimental $g$ em função da temperatura de aquecimento (direita) para determinação da temperatura de queima da amostra CSQN61. 320 Figura 7.69 - Curvas de crescimento das amostras de Lago Grande e Osvaldo para datação por OSL. 


\section{Lista de Tabelas}

Tabela 2.1 - Cronologia cerâmica para a Amazônia Central baseada em datação por ${ }^{14}$ C. Fonte:

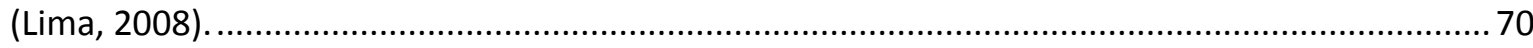

Tabela 3.1 - Percentual de caráter iônico das ligações interatômicas em alguns materiais cerâmicos. Fonte: Callister (2007). ........................................................................................ 85

Tabela 3.2 - Abundância de minerais na crosta terrestre. Fonte: Carter \& Norton (2007)............86

Tabela 3.3 - Abundância dos elementos químicos na crosta terrestre. Fonte: Lutgens \& Tarbuck (2000).

Tabela 3.4 -Principais transformações físico-químicas em argilas silicatadas durante o processo de queima. As faixas de temperatura são aproximadas. Fontes: (Rice, 1987; Artioli, 2010)............. 102

Tabela 4.1 - Classificação dos nêutrons segundo sua energia. Fonte: Terremoto (2004)..........113 Tabela 4.2 - Características nucleares dos radioisótopos utilizados. Fontes: Banco de dados Genie 2000 e NNDC-EUA $\left(1 \mathrm{~b}=10^{-24} \mathrm{~cm}^{2}\right)$

Tabela 6.1 - Amostras de cerâmica arqueológica selecionadas para EPR. ..............................176

Tabela 6.2 - Amostras de cerâmica arqueológica selecionadas para XRD...............................177

Tabela 6.3 - Amostras de cerâmica arqueológica selecionadas para datação por OSL...............179

Tabela 7.1 - Resultados de INAA para o material de referência IAEA-Soil-7. As unidades estão em $\mu \mathrm{g} \cdot \mathrm{g}^{-1}$, quando não indicadas.

184

Tabela 7.2 - Parâmetros descritivos da base de dados de concentrações elementares em fragmentos cerâmicos arqueológicos dos sítios Lago Grande e Osvaldo e argilas queimadas (concentrações em $\mu \mathrm{g} / \mathrm{g}$, a menos que seja indicado). 196

Tabela 7.3 - Resultados de INAA para a esponja de água doce (cauixi) usada como antiplástico principal nas cerâmicas arqueológicas dos sítios Lago Grande e Osvaldo. 202

Tabela 7.4 - Estrutura geral de correlação para as variáveis do Cenário 1, referente aos coeficientes de correlação de Pearson para a base de dados de Lago Grande e Osvaldo com

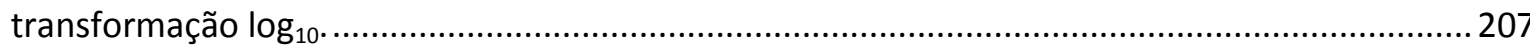

Tabela 7.5 - Dados discrepantes na base de dados dos sítios Osvaldo e Lago Grande...............208 Tabela 7.6 - Análise comparativa de três métodos de agrupamento: Average Linkage, Ward e Kmeans para uma base de dados de 127 amostras de Lago Grande e Osvaldo. 210 Tabela 7.7 - Coeficientes de ponderação e variância das quatro primeiras componentes principais para o Cenário 1 com dados de Lago Grande e Osvaldo.

Tabela 7.8 - Coeficientes de ponderação e variância das quatro primeiras componentes principais para o Cenário 1, sem o $\mathrm{Na}$, com dados de Lago Grande e Osvaldo. 218 Tabela 7.9 - Coeficientes de ponderação e variância das quatro primeiras componentes principais para o Cenário 2, com dados de Lago Grande e Osvaldo.

226

Tabela 7.10 - Coeficientes de ponderação e variância das quatro primeiras componentes principais para o Cenário 3, com dados de Lago Grande e Osvaldo. 229 Tabela 7.11 - Matriz de variação dos elementos químicos do Cenário 1 para os dados de Lago Grande e Osvaldo.

Tabela 7.12 - Coeficientes de ponderação e variância das quatro primeiras componentes principais para o Cenário 4, com dados de Lago Grande e Osvaldo. 
Tabela 7.13 - Coeficientes de ponderação e variância das quatro primeiras componentes principais para o Cenário 5, com dados de Lago Grande e Osvaldo.....

Tabela 7.14 - Coeficientes de ponderação e variância das quatro primeiras componentes principais para o Cenário 3, apenas com as amostras de Lago Grande.

Tabela 7.15 - Coeficientes de ponderação e variância das quatro primeiras componentes principais para o Cenário 5, apenas com as amostras de Lago Grande.

Tabela 7.16 - Coeficientes de ponderação e variância das quatro primeiras componentes principais para o Cenário 3, apenas com as amostras de Osvaldo.

Tabela 7.17 - Coeficientes de ponderação e variância das quatro primeiras componentes principais para o Cenário 5, apenas com as amostras de Osvaldo.

Tabela 7.18 - Concentrações médias em $\mu \mathrm{g} \cdot \mathrm{g}^{-1}$ dos elementos nos grupos químicos de cerâmicas de Lago Grande e Osvaldo, com transformação $\log _{10}$ (Cenário 3).

Tabela 7.19 - Concentrações médias de razões elementares para os grupos químicos de cerâmicas de Lago Grande e Osvaldo, com transformação alr (Cenário 5)

Tabela 7.20 - Valores de $p$ dos testes de normalidade univariada de Anderson-Darling para os grupos químicos do Cenário $3(\alpha=0,05)$.

Tabela 7.21 - Valores de $p$ dos testes de normalidade univariada de Anderson-Darling para os grupos químicos do Cenário $5(\alpha=0,05)$. 264

Tabela 7.22 - Testes de normalidade multivariada de Shenton-Bowman e Shapiro-Wilk para os grupos químicos do Cenário $3(\alpha=0,05)$. 264

Tabela 7.23 - Testes de normalidade multivariada de Shenton-Bowman e Shapiro-Wilk para os grupos químicos do Cenário $5(\alpha=0,05)$. 265

Tabela 7.24 - Teste de homogeneidade das matrizes de covariância para os grupos químicos do Cenário $3(\alpha=0,05)$. 266

Tabela 7.25 - Teste de homogeneidade das matrizes de covariância para os grupos químicos do Cenário $5(\alpha=0,05)$. 266

Tabela 7.26 - Seleção de variáveis pelo método Procrustes para o Cenário 3, com os dados combinados de Lago Grande e Osvaldo.

Tabela 7.27 - Seleção de variáveis pelo método Procrustes para o Cenário 5, com os dados combinados de Lago Grande e Osvaldo. 273 Tabela 7.28 - Análise multivariada de variância (MANOVA) para os grupos químicos de cerâmicas determinados por análise de agrupamentos e PCA para Lago Grande e Osvaldo. Nível de significância $\alpha=0,05$. 285

Tabela 7.29 - Classificação das amostras nos grupos químicos do Cenário 3 e Cenário 5 segundo a fase cerâmica, para os sítios Lago Grande e Osvaldo. 288 Tabela 7.30 - Classificação das amostras nos grupos químicos do Cenário 3 e Cenário 5 segundo estratigrafia, para os sítios Lago Grande e Osvaldo 295 Tabela 7.31 - Classificação das amostras nos grupos químicos do Cenário 3 e Cenário 5 segundo a unidade de escavação, para os sítios Lago Grande e Osvaldo. Tabela 7.32 - Classificação das amostras nos grupos químicos do Cenário 3 e Cenário 5 segundo o tipo de objeto cerâmico, para os sítios Lago Grande e Osvaldo. 300 Tabela 7.33 - Distâncias interplanares de reflexões basais características de minerais argilosos. Fonte: Adaptado de Albers et al. (2002). 304 Tabela 7.34 - Classificação das amostras de Lago Grande analisadas por XRD em grupos químicos, presença de feldspatos e concentrações de $\mathrm{Na}$ e K por INAA. 
Tabela 7.35 - Classificação das amostras de Osvaldo analisadas por XRD em grupos químicos, presença de feldspatos e concentrações de $\mathrm{Na}$ e K por INAA. ...................................................... 315

Tabela 7.36 - Resultados de temperatura de queima por EPR para os fragmentos cerâmicos de

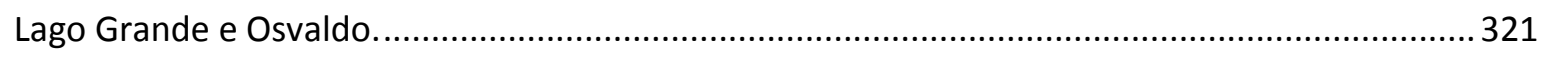

Tabela 7.37 - Concentrações dos elementos químicos U, Th e K nos fragmentos cerâmicos e argilas próximas aos sítios Lago Grande e Osvaldo, para cálculo das componentes beta e gama da taxa de dose anual. 327

Tabela 7.38 - Componentes beta e gama das taxas anuais de dose para os fragmentos cerâmicos de Lago Grande e Osvaldo. 328

Tabela 7.39 - Cálculo da taxa anual de radiação cósmica para os sítios Lago Grande e Osvaldo. 328 Tabela 7.40 - Datações por OSL de fragmentos cerâmicos dos sítios Lago Grande e Osvaldo. As idades de ${ }^{14} \mathrm{C}$ para comparação foram retiradas de Lima (2008) 329

Tabela 7.41 - Teste $t$ para idades de fragmentos cerâmicos de Lago Grande e Osvaldo obtidas por OSL. Nível de significância $\alpha=0,05$. 330 


\section{Lista de Siglas}

EPR: Ressonância paramagnética eletrônica.

INAA: Análise por ativação com nêutrons instrumental.

IPEN: Instituto de Pesquisas Energéticas e Nucleares.

MAE-USP: Museu de Arqueologia e Etnologia da Universidade de São Paulo.

OSL: Luminescência opticamente estimulada

PCA: Análise de componentes principais.

XRD: Difração de raios X.

\section{Lista de Cenários}

Cenário 1: Os 14 elementos químicos As, K, La, Lu, Na, Yb, Ce, Cr, Cs, Eu, Fe, Hf, Sc e Th com transformação logarítmica $\log _{10}$.

Cenário 2: Os 12 elementos $\mathrm{As}, \mathrm{La}, \mathrm{Lu}, \mathrm{Yb}, \mathrm{Ce}, \mathrm{Cr}, \mathrm{Cs}, \mathrm{Eu}, \mathrm{Fe}, \mathrm{Hf}, \mathrm{Sc}$ e Th com transformação logarítmica $\log _{10}$.

Cenário 3: Os 9 elementos $\mathrm{La}, \mathrm{Lu}, \mathrm{Yb}, \mathrm{Ce}, \mathrm{Cr}, \mathrm{Eu}, \mathrm{Fe}, \mathrm{Sc}$ e Th com transformação logarítmica $\log _{10}$.

Cenário 4: Os 12 elementos $\mathrm{As}, \mathrm{La}, \mathrm{Lu}, \mathrm{Yb}, \mathrm{Ce}, \mathrm{Cr}, \mathrm{Cs}, \mathrm{Eu}, \mathrm{Fe}, \mathrm{Hf}, \mathrm{Sc}$ e Th com transformação em razão logarítmica aditiva (alr).

Cenário 5: Os 9 elementos $\mathrm{La}, \mathrm{Lu}, \mathrm{Yb}, \mathrm{Ce}, \mathrm{Cr}, \mathrm{Eu}, \mathrm{Fe}, \mathrm{Sc}$ e Th com transformação em razão logarítmica aditiva (alr). 


\section{INTRODUÇÃO}

Um dos principais objetivos da arqueologia é o estudo de grupos humanos pretéritos por meio de seu vestígio material. Pela impossibilidade de se observar o comportamento humano dessas sociedades diretamente e, muitas vezes, pela falta de registros escritos acerca das mesmas, o estudo de seus vestígios materiais torna-se essencial (Pollard \& Heron, 1996).

A arqueologia contemporânea é caracterizada pela diversidade de objetivos de pesquisa e abordagens metodológicas. Não obstante, as diferentes linhas de pensamento estão engajadas no mesmo objetivo geral: o entendimento de grupos humanos do passado, e suas relações, por meio de sua cultura material, ou registro arqueológico (Jones, 2004). Nesse contexto, é possível entender a interação da arqueologia com as ciências exatas, como a física, a química, as ciências biológicas e da Terra, com o objetivo de maximizar a obtenção de informações úteis à comunidade arqueológica, em sua tarefa de elaborar modelos, testes de hipóteses e teorias acerca das atividades humanas pretéritas (Pollard \& Heron, 1996).

A área de estudo que abrange este trabalho é a Arqueometria, um campo multi e interdisciplinar que integra uma série abordagens físicas, químicas e biológicas, como a análise química elementar, datação, análise de DNA, paleobotânica, arqueometalurgia e ciências da conservação à Arqueologia. A caracterização físico-química de materiais arqueológicos é frequentemente empregada para tratar de questões referentes à origem da matéria-prima, tecnologia de fabricação de objetos e existência de interconexões entre grupos humanos na forma, por exemplo, de rotas de comércio (Pavia, 2006). Um dos principais focos da arqueometria desde a década de 1950 tem sido o estudo de cerâmicas que, por sua resistência a diferentes condições ambientais, são encontradas em quantidades significativas na maioria dos sítios datando desde o período Neolítico, e por isso se tornaram centrais em estudos arqueológicos.

Este trabalho é um estudo interdisciplinar envolvendo a aplicação de quatro técnicas analíticas físicas a material cerâmico arqueológico da Amazônia Central, proveniente dos sítios Lago Grande e Osvaldo, na região de confluência dos rios Negro e Solimões. As técnicas analíticas utilizadas com esse objetivo foram a análise por ativação com nêutrons 
instrumental, a difração de raios $X$, a ressonância paramagnética eletrônica e a datação por luminescência opticamente estimulada para o estudo de fragmentos cerâmicos arqueológicos escavados durante o Programa Amazônia Central (PAC).

No contexto brasileiro, o trabalho dos arqueólogos no estudo da arqueologia amazônica promove uma espécie de resgate da história antiga dos povos indígenas dessas regiões, um trabalho de suma importância se reconhecermos que alguns dos processos de ocupação no presente são guiados, em certo grau, por processos que guiavam a ocupação humana pré-colonial. Essa problemática deveria ser considerada quando da elaboração de políticas públicas para a proteção desses povos e de seu legado, responsáveis pelo verdadeiro início da história do Brasil (Neves, 2006; Heckenberger \& Neves, 2009).

\section{Breve histórico das pesquisas}

Em torno de 6400 a.C., a produção cerâmica já era uma arte muito bem desenvolvida, e data desse milênio a explosão na utilização de materiais cerâmicos na Ásia, Orientes Próximo e Médio, e na Europa. Esse fato resultou de uma mudança no estilo de vida, necessidades e crenças dos povos antigos, com o advento dos processos de sedentarismo, agricultura e criação de gado (Boch \& Nièpce, 2007).

Acredita-se que o aparecimento da cerâmica no Novo Mundo ocorreu posteriormente em relação ao Velho Mundo, embora datações futuras possam questionar essa observação. O advento das cerâmicas revolucionou a dieta ao fornecer um meio para que a fervura e o cozimento fossem introduzidos no preparo da comida, além de fornecer um meio adequado ao armazenamento de bens perecíveis e às artes esculturais (Leute, 1987).

Há uma linha teórica que associa o aparecimento dos primeiros recipientes cerâmicos ao complexo tecnológico Neolítico, compreendendo um conjunto de ferramentas e recipientes para a preparação de comida e armazenamento, relacionado a mudanças no estilo de vida dos seres humanos pelo mundo inteiro, no fim do Período Paleolítico e no período posterior. Foram mudanças dramáticas que ocorreram, como o aparecimento da prática de produção de comida, em vez da coleta, e assentamentos na forma de aldeias, em vez de acampamentos temporários. Embora não tenha havido, necessariamente, uma relação causal 
entre o aparecimento da agricultura e a produção de cerâmica, observa-se uma tendência à produção dessa última majoritariamente por sociedades sedentárias (Rice, 1987, p. 9).

Até recentemente, a pesquisa arqueológica na América do Sul esteve fortemente focada nas culturas andinas, embora a arqueologia amazônica possua uma história centenária (Moraes, 2006; Neves, 2006). Pesquisas recentes têm questionado os estereótipos populares, e até mesmo científicos, que enxergam a Amazônia como um lugar de uniformidade cultural e ecológica, com assentamentos pequenos e dispersos de grupos indígenas vivendo em uma selva tropical virgem. Há inúmeras evidências de que sociedades pré- e pós-colombianas produziram impactos importantes na fauna, flora, hidrologia e constituição dos solos (Heckenberger \& Neves, 2009).

No final do século XV, a bacia amazônica era ocupada densamente por diferentes povos indígenas. A partir de meados do século XVI até início do XVII, com o estabelecimento dos primeiros europeus na Amazônia, há registros escritos sobre a existência de grandes aldeias, algumas delas ocupadas por milhares de pessoas, conectadas por estradas e integradas em amplas redes regionais de comércio e em federações políticas de alcance regional. Segundo relatos, esses assentamentos ao longo dos rios poderiam ser tão extensos que seria necessário viajar alguns quilômetros para percorrer toda sua extensão (Neves, 2008). Acreditase que tais referências tenham desaparecido do registro histórico a partir do século XVIII, em função da diminuição e dispersão populacional ocasionadas pela colonização europeia, na forma de doenças, guerra e escravidão (Machado, 2006; Moraes, 2006; Heckenberger \& Neves, 2009).

Mesmo sabendo que exageros possam ter ocorrido em suas descrições (para justificar o financiamento das expedições), os relatos dos primeiros viajantes sobre a abundância de recursos e a existência de organizações sociais complexas na Amazônia contrastam com a realidade etnográfica atual, marcada por ocupações esparsas com baixa densidade demográfica e baseadas em estruturas de idade e gênero. Essa dicotomia foi responsável, em grande parte, pelas divergências interpretativas em relação ao passado dos grupos que habitaram a região (Machado, 2006; Moraes, 2006), de forma que os estudos atuais sobre a ocupação da Amazônia pré-colonial apoiam-se sobre um amplo debate quanto às formas de organização social e padrões de mobilidade dessas populações (Myers, 1992; Meggers, 1996; Machado, 2006). 
O modelo "padrão" propõe a ideia de cultura como resposta a problemas ambientais (determinismo ambiental), defendendo que as antigas ocupações pré-coloniais da Amazônia seriam caracterizadas pela baixa densidade demográfica e formas de organização social baseadas em estrutura de idade e gênero, de forma análoga às comunidades atuais, caracterizando um quadro de continuidade histórica. Assim, seria improvável a existência de organizações humanas complexas na floresta tropical, devido a limitações naturais que estimulariam uma elevada mobilidade entre seus habitantes, impossibilitando o crescimento demográfico e impedindo o desenvolvimento de organizações humanas sociopoliticamente estratificadas (Meggers, 1996; Machado, 2006; Portocarrero, 2006).

Por outro lado, uma das perspectivas “críticas" argumenta sobre a existência de grandes adensamentos populacionais no período pré-colonial, denominados cacicados, que seriam uma forma de organização social baseada no estabelecimento de uma hierarquia de alcance regional, a partir de um centro de poder, formando sociedades complexas que contrastariam com o cenário atual observado para os grupos indígenas da Amazônia. Essa linha de pensamento procura relativizar o papel das dificuldades ambientais como fator limitante para a emergência da complexidade social (Machado, 2006). A ruptura histórica marcada pelo desaparecimento dessas sociedades complexas estaria relacionada ao contato com os europeus.

Em 1995, teve início o Projeto Amazônia Central (PAC), coordenado pelo Prof. Dr. Eduardo Góes Neves, do Museu de Arqueologia e Etnologia da Universidade de São Paulo (MAE-USP), em parceria com a Universidade Federal do Amazonas. Esse projeto tem o objetivo principal de entender a forma e o tamanho dos assentamentos na região, estudando a densidade do registro arqueológico e a duração das ocupações. As amostras utilizadas neste trabalho foram escavadas no âmbito desse projeto

\section{Hipótese testada e relevância}

Esta tese de doutoramento é o primeiro estudo arqueométrico com material cerâmico arqueológico da Amazônia Central, proveniente dos sítios Lago Grande e Osvaldo, que visa testar se a potencial definição e comparação de grupos químicos de cerâmicas desses dois sítios de grandes dimensões, assim como características tecnológicas evidenciadas em sua 
microestrutura e temperatura de queima, poderiam indicar a existência de uma rede de trocas entre os antigos habitantes dos sítios, focando em trocas materiais e/ou tecnológicas potenciais.

Essa hipótese já havia sido levantada em estudos anteriores (Mongeló, 2011) pelo fato de ter sido encontrado material cerâmico exógeno e contemporâneo de fases cerâmicas distintas às dominantes nos dois sítios. Assim, procurou-se testar se potenciais redes de troca entre os mesmos, pertencentes a um contexto mais geral e complexo de esferas de interação (Lima, 2008), poderiam explicar esses padrões. Essas possíveis redes de troca entre os dois sítios poderiam ser correlatas de um contexto mais abrangente, relacionado a um possível sistema regional de interação na região, já observado em regiões periféricas da Amazônia, mas ainda pouco estudado na Amazônia Central (Mongeló, 2011). Longe de pressupor um teste definitivo para tais modelos, o objetivo principal é o de fornecer material adicional para as discussões arqueológicas por meio de novas informações geradas pela análise do registro arqueológico de Lago Grande e Osvaldo, considerados como um microcosmo da Amazônia Central.

\section{Justificativa e importância do estudo}

A Amazônia continua sendo vista por muitos como uma das últimas fronteiras inexploradas do planeta, um exemplo de natureza virgem, livre da ação humana desde o início dos tempos. A arqueologia mostra que esse pensamento é enganoso. No exame de mapas de distribuição de terras indígenas na Amazônia contemporânea, nota-se que a ocorrência de sítios arqueológicos, correlatos de ocupações humanas pretéritas, é mais ampla (Neves, 2006).

Neste trabalho, os sítios arqueológicos Lago Grande e Osvaldo foram escolhidos para o estudo devido ao intensivo trabalho de escavação realizado nos mesmos; proximidade geográfica $(\approx 9 \mathrm{~km})$; única fase cerâmica produzida in situ; por representarem um microcosmo da Amazônia Central (Portocarrero, 2006); contemporaneidade; e por haver bibliografia de referência bem fundamentada (Donatti, 2003; Moraes, 2006; Portocarrero, 2006, Lima, 2008; Mongeló, 2011). Um dos aspectos importantes relacionados a esses sítios é que eles apresentaram evidências de grandes assentamentos humanos fora de áreas de várzea. Essa constatação é evidenciada, entre outros fatores, pela presença e extensão de terra preta 
antropogênica, um indício de povos vivendo em grandes aldeias de ocupação contínua, com a prática de agricultura e pesca. Esse fato levou os arqueólogos a questionarem se a alta produtividade do solo de regiões de várzea seria realmente uma condição necessária para o sedentarismo e crescimento populacional (Portocarrero, 2006).

Dentro da visão de Meggers (1996), ligada ao determinismo ecológico para a interpretação da história de ocupação da região amazônica, os grandes sítios localizados nas regiões de várzea seriam resultado de múltiplas reocupações, e não de uma variação de tamanho dos assentamentos. Contudo, há atualmente claras evidências de assentamentos grandes e permanentes tanto em ambientes de várzea, como de terra firme, contrariando os pressupostos do modelo padrão advogado por Betty Meggers (Heckenberger et al., 1999). Dessa maneira, o estudo dos sítios Lago Grande e Osvaldo está inserido no contexto geral da questão da ocupação amazônica pré-colonial, com implicações que questionariam os pressupostos do determinismo ambiental.

Este trabalho procura justificar a interdisciplinaridade advogada para a arqueometria (Dunnel, 1993; Pollard \& Heron, 1996), correlacionando, dentro dos limites analíticos e de seu escopo, os resultados arqueométricos ao contexto arqueológico da região.

Deve-se salientar que a caracterização química e outros métodos físicos não são panaceias. Essas análises irão gerar informações significativas na medida em que são projetadas contra um robusto contexto analítico e arqueológico de conhecimento. Dessa forma, poderão suprir a comunidade arqueológica com dados robustos para teste de hipóteses na forma de afirmações probabilísticas. Poderão, também, sugerir relações inesperadas entre os artefatos arqueológicos, estimulando a geração de novas hipóteses para a interpretação do registro (Harbottle, 1982a).

A arqueologia da Amazônia ainda é escassamente conhecida, mas pesquisas e desenvolvimentos recentes têm mudado a forma pela qual vemos a região, por meio de evidências de histórias indígenas dinâmicas e diversas, vida sedentária e complexidade social, desafiando estereótipos de aldeias primitivas pequenas e dispersas vivendo em uma floresta intocada (Heckenberger \& Neves, 2009). Essas descobertas relativizariam o papel de limitações ambientas inerentes à floresta tropical como fatores limitantes do aparecimento de sociedades sedentárias e de crescimento demográfico entre as populações ameríndias (Heckenberger et al., 1999). 


\section{Fundamentação teórica}

Em muitas regiões do planeta, fragmentos de vasos cerâmicos quebrados são o tipo de artefato mais comum encontrado em sítios arqueológicos, devido à sua resistência na maioria dos solos. Além de sua abundância e alta resistência a intempéries, as cerâmicas possuem várias características macroscópicas (como decoração, cor, forma e função) que as tornam indicadores culturais e cronológicos na arqueologia (Velde \& Druc, 1999). A cerâmica não é, normalmente, um artigo exótico e de luxo, como ouro ou jade, restrito apenas a residências e tumbas de altos estratos sociais. Embora haja certos tipos de cerâmicas associadas às elites, a uso cerimonial ou fúnebre, a cerâmica é uma classe de artefato essencialmente não restrita. Ela serviu - e serve - a funções ordinárias como o cozimento, armazenamento e higiene para todos os membros da sociedade, sendo encontrada em grande variedade no registro arqueológico (Rice, 1987, p. 25).

Além disso, suas características microscópicas, como composição química elementar, podem ser utilizadas na abordagem de problemas referentes à sua origem. Em suma, as cerâmicas podem ser consideradas como um registro que, combinadas ou não com outras evidências, são capazes de revelar diversos aspectos referentes a uma cultura préhistórica, incluindo o local provável de sua manufatura, origem das matérias-primas, métodos de produção, comércio, entre outros (Glascock \& Neff, 2003; Heimann, 2010). A combinação de análise estilístico-tipológica e outros estudos arqueológicos com análises arqueométricas tem sido de grande importância para o entendimento do modo de vida de grupos humanos ancestrais (Pollard, 2008).

A ideia básica implícita na caracterização química de cerâmicas arqueológicas é a de que as concentrações elementares, principalmente dos elementos em nível traço, de cada cerâmica são indicativas da matéria-prima utilizada em sua fabricação, as argilas e antiplásticos, as quais poderiam ser identificadas pela sua variabilidade geoquímica, como enunciado no postulado de proveniência (Weigand et al., 1977, p. 24):

"(...) namely that there exist differences in chemical composition between different natural sources that exceed, in some recognisable way, the differences observed within a given source." 
Dessa forma, seria possível identificar grupos de artefatos similares e realizar estudos de proveniência, procedimento frequentemente denominado como determinação da assinatura química da cerâmica (Martini, 2003; Munita, 2005; Speakman \& Glascock, 2007). Uma das técnicas mais utilizadas com esse objetivo é a análise por ativação com nêutrons (Dias \& Prudêncio, 2007; Tite, 2008).

No entanto, com algumas exceções, é improvável que alguém identifique a origem de objetos e suas matérias-primas de maneira inequívoca. A proveniência de cerâmicas, de maneira absoluta, é difícil em virtude da variabilidade da própria fonte e influências antrópicas, desde a fabricação (misturando fontes diferentes de argila) até o uso final, além de possíveis efeitos diagenéticos (Pollard et al., 2007).

Do ponto de vista prático, há duas abordagens para estudos de proveniência (Glascock \& Neff, 2003). A primeira abordagem refere-se à caracterização de fontes conhecidas de matérias-primas e o entendimento da variabilidade química entre elas. A seguir, os artefatos analisados são atribuídos a determinadas fontes de acordo com a semelhança entre seus perfis composicionais. Nessa abordagem, há a possibilidade de existir fontes não conhecidas que não foram caracterizadas.

Na segunda abordagem, adotada neste trabalho, artefatos de origem desconhecida são amostrados e analisados. A seguir, métodos estatísticos multivariados, como métodos de reconhecimento de padrões, são aplicados para agrupar as amostras por sua composição química, de forma que os grupos formados tenham algum significado arqueológico e/ou geoquímico. Então, a interpretação arqueológica pode ser realizada pela atribuição dessas amostras a uma origem ou grupo (que pode ser um grupo cultural) específico.

As técnicas selecionadas neste trabalho têm sido utilizadas frequentemente em trabalhos de arqueometria (ver descrição das técnicas nos Capítulos 1 e 3). Os fatores que devem ser considerados na escolha do método analítico utilizado incluem adequabilidade para a matriz analisada; sensibilidade; precisão; exatidão e efeito da análise na amostra (destruição total, parcial ou técnica absolutamente instrumental); análise superficial, interna ou representativa de toda a amostra; e local de análise (em laboratório ou em campo).

Os resultados de caracterização química são frequentemente analisados para identificar grupos de artefatos similares por meio da aplicação de técnicas estatísticas 
multivariadas (Baxter et al., 2008). Essas técnicas são essenciais em arqueometria, tendo em vista o grande número de variáveis geradas, como a concentração de múltiplos elementos químicos. No hiperespaço composicional das concentrações elementares, um grupo seria caracterizado pela localização de seu centroide e estrutura de correlação entre essas concentrações (Glascock, 1992). Variações nas concentrações elementares podem ter origem natural (variabilidade geoquímica natural em uma determinada fonte, ou entre diferentes fontes de matéria-prima), ou origem cultural (padrões diferentes na escolha e mistura de matérias-primas). Ambos são fatores importantes na interpretação dos dados em estudos arqueométricos.

Do ponto de vista analítico, há várias vantagens operacionais em se utilizar a ativação com nêutrons. A capacidade de penetração dos nêutrons na matéria, devido à inexistência de carga elétrica líquida, permite estudar a composição média da amostra, e não apenas de sua superfície. Um dos fatores limitantes e críticos deste projeto é a quantidade de analito disponível. Define-se como analito, neste trabalho, o pó de cerâmicas arqueológicas obtido para análise. A análise por ativação com nêutrons representa uma escolha adequada, pois com uma massa em torno de 100 mg é possível obter resultados satisfatórios. Além disso, é parcialmente destrutiva, pois apesar de remover uma alíquota dos fragmentos, a decoração superficial e a forma dos mesmos são preservadas. Assim, esses fragmentos podem ser utilizados em outros estudos arqueológicos, minimizando o problema de destruição de amostras (Harbottle, 1982a).

Por fim, pode-se citar a disponibilidade de um reator nuclear de pesquisas, o IEAR1, do Instituto de Pesquisas Energéticas e Nucleares (IPEN - CNEN/SP), como fator na escolha da técnica. Em localidades onde não há disponibilidade de um reator, as opções de técnicas analíticas podem estar limitadas à espectrometria de massa por plasma induzido e técnicas de fluorescência de raios $\mathrm{X}$, por exemplo.

Neste trabalho, dá-se menos ênfase à classificação arqueológica apriorística, e parte-se de uma ênfase maior em aspectos matemáticos na definição e discriminação dos grupos químicos de cerâmicas (Bishop et al., 1982; Harbottle, 1982a). A partir desses grupos então definidos, parte-se para a exploração de possíveis correlações arqueológicas, em termos de sítio de proveniência, fase cerâmica, estratigrafia e unidade de escavação. 
Outra limitação de estudos arqueométricos, como este trabalho, refere-se ao tipo de amostra analisada. Tipicamente, as amostras desses estudos estão longe de serem amostras ideais do ponto de vista analítico, pois costumam ser pequenas, fragmentárias, potencialmente modificadas e/ou contaminadas durante o contexto deposicional, ou até mesmo durante a prática de escavação. Esses fatores fazem da caracterização química e mineralógica em arqueometria um campo desafiador, longe de uma aplicação rotineira de química analítica, tendo paralelos com a ciência forense (Pollard \& Heron, 1996). 


\section{A estrutura da tese}

O Capítulo 1 trata da área do conhecimento na qual está inserido este trabalho, a Arqueometria. Conta com um breve histórico contextualizando os primeiros trabalhos de aplicação de análises físicas e químicas a materiais arqueológicos, citando alguns tipos de materiais e técnicas analíticas frequentemente utilizadas. Um foco especial é dado à caracterização química elementar e à utilização da radioatividade artificial para fins analíticos nessa área do conhecimento.

O Capítulo 2 trata da área de estudo, discorrendo brevemente sobre a Amazônia e sua arqueologia, focando em questões que afetam a ocupação humana pré-colonial da Amazônia Central. A seguir, o viés discursivo passa ao entendimento das questões arqueológicas da região por meio da discussão de processos culturais e naturais que condicionaram a formação de seu registro arqueológico. Fala-se um pouco mais especificamente sobre a Tradição Borda Incisa, da qual o material cerâmico dos sítios Lago Grande e Osvaldo fazem parte, e finaliza-se com a descrição dos sítios estudados e a relevância de sua escolha.

O Capítulo 3 discorre sobre os fundamentos da matriz física de maior interesse neste trabalho, a cerâmica. É proposto um breve histórico e são citadas propriedades gerais desses materiais. A seguir, parte-se para o entendimento microscópico dessa matriz, pela caracterização de sua microestrutura e imperfeições do retículo cristalino. O capítulo segue abordando as argilas e seu processamento, como o importante processo de queima, citando-se alguns processos físico-químicos de relevância associados. O capítulo é finalizado com uma discussão sobre aplicações de análise físico-química de cerâmicas em arqueologia.

O Capítulo 4 discorre sobre os fundamentos e equacionamentos essenciais ao entendimento das técnicas analíticas utilizadas. Dá-se um foco especial à análise por ativação com nêutrons, a técnica-mestra deste trabalho, citando-se algumas de suas vantagens e desvantagens, e princípios gerais dessa modalidade de ativação utilizando reatores nucleares de pesquisa como fonte de nêutrons. Cita-se algumas características do reator nuclear de pesquisas brasileiro IEA-R1, a fonte neutrônica utilizada nas análises. A seguir, discorre-se sobre a difração de raios X, para a caracterização microestrutural de materiais; a ressonância 
paramagnética eletrônica, para determinação da temperatura de queima de cerâmicas; e, finalmente, sobre a datação por luminescência opticamente estimulada.

O Capítulo 5 discorre sobre os fundamentos teóricos dos métodos estatísticos multivariados empregados. Inicialmente, são tratadas as duas transformações de dados utilizadas, a transformação logarítmica decimal $\left(\log _{10}\right)$ e racional (alr), cuja comparação neste trabalho foi uma das principais responsáveis pela definição dos cenários de análise e interpretação do ponto de vista arqueológico. A seguir, são tratados a estrutura de correlação, identificação de dados discrepantes, análise de agrupamentos, análise de componentes principais, refinamento dos agrupamentos, análise multivariada de variância, análise discriminante, testes de normalidade, seleção de variáveis e mapas auto-organizáveis, uma aplicação de inteligência artificial.

O Capítulo 6 discorre sobre a metodologia empregada na aplicação de cada técnica analítica, bem como a amostragem e os materiais necessários para a obtenção dos resultados.

O Capítulo 7 discorre sobre o tratamento estatístico dos resultados experimentais obtidos pela aplicação de cada uma das quatro técnicas analíticas, buscando correlações arqueológicas sempre que possível, no intuito de responder à hipótese geradora desta tese de doutoramento.

Finalmente, o Capítulo 8 trata da conclusão deste estudo, retomando os principais resultados e pontos discutidos para formar um quadro integrado das respostas encontradas para a hipótese geradora desta tese e outras questões pertinentes. Também discute brevemente as limitações do trabalho, propondo novos caminhos e estudos progressivamente integrados dos sítios estudados na região, para investigação de pontenciais redes de troca em escala regional na Amazônia Central. 


\section{OBJETIVO}

O objetivo deste trabalho é contribuir à discussão dos modelos de ocupação da Amazônia Central antes do contato com os europeus, pela comparação do material cerâmico arqueológico de dois sítios de grandes dimensões na região, para os quais foi levantada a hipótese de uma rede de trocas. A existência dessa e de outras redes, dentro de um contexto mais amplo de esfera de interações, tem implicações para a discussão da emergência da complexidade social na floresta tropical amazônica, questionando modelos baseados no determinismo ambiental.

\section{Objetivos específicos}

Para prosseguir ao teste da hipótese levantada, foram aplicadas quatro técnicas analíticas físicas com os seguintes objetivos:

- Análise por ativação com nêutrons instrumental (INAA): determinação da composição química elementar das amostras, visando à possível formação de grupos químicos de cerâmicas.

口 Difração de raios X (XRD): determinação da estrutura mineralógica das cerâmicas para correlação com os grupos químicos formados, identificando possíveis diferenciações nas matérias-primas.

口 Ressonância paramagnética eletrônica (EPR): determinação da temperatura de queima de algumas cerâmicas para detectar possíveis diferenciações tecnológicas no processo de queima, e possível correlação com grupos químicos.

口 Datação por luminescência opticamente estimulada (OSL): para verificação e confirmação da contemporaneidade dos sítios, e comparação com cronologia de referência na literatura. 


\section{CAPítulo 1}

\section{INTRODUÇÃO À ARQUEOMETRIA}

Um dos principais objetivos da arqueologia é o estudo das atividades de grupos humanos pretéritos por meio de seu vestígio material. Pela impossibilidade de se observar o comportamento humano dessas sociedades diretamente e, muitas vezes, pela falta de registros escritos acerca das mesmas, o estudo do registro arqueológico torna-se essencial. Nesse contexto, é possível entender a interação da arqueologia com as ciências exatas, como a física, a química, as ciências biológicas e da Terra, com o objetivo de maximizar a obtenção de informações úteis à comunidade arqueológica, em sua tarefa de elaborar modelos, testes de hipóteses e teorias acerca das atividades humanas pretéritas (Pollard \& Heron, 1996).

Uma das aplicações mais recorrentes desde o início das análises físico-químicas de artefatos arqueológicos é o rastreamento de movimentos migratórios de populações em períodos pré-históricos, com base na composição química característica de objetos transportados com esses povos (Harbottle, 1982).

De acordo com Tite (apud Pollard \& Heron, p. 2, 1996), uma possível classificação dos vários estudos interdisciplinares em arqueologia pode ser feita da seguinte forma:

- Estudos de datação por métodos físicos e químicos, fornecendo cronologias absolutas e relativas;

- Estudos de artefatos que abordam questões de proveniência, tecnologia de fabricação de objetos e uso;

- Estudos ambientais para o tratamento de questões referentes a paisagens pretéritas, clima, flora, fauna, dieta, nutrição, saúde e patologia dos indivíduos;

口 Métodos matemáticos para tratamento, análise e modelagem de dados, como a estatística multivariada; 
- Sensoriamento remoto para a localização e caracterização de possíveis pontos de escavação, pela identificação de objetos enterrados, por exemplo;

- Ciências de conservação que estudam os processos de deterioração, e o desenvolvimento de métodos para a conservação do registro arqueológico, e obras de arte em geral.

As análises arqueométricas podem ser não destrutivas, parcialmente destrutivas (semidestrutivas), ou totalmente destrutivas (Harbottle, 1982a; Pollard et al., 2007). A escolha da melhor abordagem deve ser feita de acordo com interesses e limitações de museus, institutos e pesquisadores, no intuito de delimitar a metodologia mais adequada para se atingir um ponto ótimo entre a obtenção de informações analiticamente úteis e a preservação do patrimônio cultural.

\subsection{Breve histórico de desenvolvimentos científicos que influenciaram a Arqueometria}

Os primeiros trabalhos sobre aplicação de análises químicas a materiais arqueológicos do qual se tem conhecimento são o trabalho de Johann Friedrich Gmelin (17481804), em 1783, versando sobre a história da mineração dos povos germânicos; e o de George Pearson (1751-1828), em 1796, sobre objetos metálicos arqueológicos (arqueometalurgia), com experimentos e observações acerca de aços produzidos em Mumbai (Rehren \& Pernicka, 2008).

Outro pioneiro na análise química de objetos arqueológicos foi Martin Heinrich Klaproth (1743-1817). Além de suas contribuições significativas à química analítica e mineralógica, ele determinou a composição química aproximada de algumas moedas gregas e romanas, feitas de ligas de cobre, além de alguns objetos metálicos e peças de vidros romanos. Também foi um dos pioneiros no desenvolvimento da gravimetria e descobriu alguns elementos químicos. Com sua análise de materiais antigos, Klaproth foi o primeiro a delinear estratégias quantitativas para a análise de ligas de cobre e vidros (Harbottle, 1982a; Pollard \& Heron, 1996).

Em torno de 1800, análises químicas de vidros, pigmentos e ligas metálicas utilizadas em armas e moedas começaram a ser realizadas mais frequentemente. Humphry 
Davy (1778-1829), por exemplo, investigou em 1815 um pote com resíduos de pigmentos, que pertencia originalmente a um pintor da Roma Imperial. No mesmo ano, Davy publicou um artigo sobre a análise de pigmentos antigos encontrados em Pompeia e Roma. Também há evidências, em um relatório de 1867, de que Michael Faraday (1791-1867) estudou um esmalte aplicado em cerâmica romana, no qual a presença de chumbo forneceu as primeiras evidências do uso sistemático de esmalte com esse elemento na Antiguidade (Leute, 1987; Pollard \& Heron, 1996).

Além de contribuições significativas à química moderna durante a primeira metade do século XIX, Jöns Jacob Berzelius (1779-1848) estudou a composição de bronzes antigos. Já August Kekulé (1829-1896) analisou uma amostra de alcatrão de madeira, formada parcialmente por compostos aromáticos, ou anéis de benzeno, cuja estrutura seria proposta pelo cientista em 1865 (Pollard \& Heron, 1996).

Até o início do século XIX, as técnicas analíticas físico-químicas foram aplicadas a objetos de origem arqueológica de forma esporádica e não sistematizada. Na direção de uma maior integração entre as pesquisas das ciências naturais e arqueologia, pode-se citar o trabalho de Carl Goebel (1794-1851), um professor de química na Universidade de Dorpat, durante a década de 1840. Ele foi o primeiro pesquisador, segundo registros históricos, a sugerir explicitamente que a química poderia ser útil à arqueologia e estudo da pré-história. Um de seus principais trabalhos consistiu em analisar inúmeros objetos de latão, escavados nas províncias bálticas da Rússia, cuja composição química foi comparada com artefatos de ligas de cobre provenientes da Grécia, Roma e Europa pré-histórica. Ele concluiu que a origem dos artefatos era, provavelmente, romana; ou pelo menos que os metalurgistas dessas peças tinham conhecimento sobre as técnicas romanas de fabricação de metais. Sua análise envolveu um número estatisticamente significativo de objetos similares, e estabeleceu propriedades químicas de grupos de objetos, em vez de basear sua análise em apenas uma amostra. Goebel estava interessado também na interpretação de seus resultados do ponto de vista arqueológico e histórico, e foi, dessa forma, a primeira pessoa a sugerir explicitamente que a análise química de artefatos antigos poderia ser de utilidade à arqueologia. Ele publicou os resultados na forma de um boletim de 38 páginas, considerado um dos clássicos da química arqueológica. Assim, as análises científicas em arqueometria progrediam para além da mera 
geração de dados analíticos para amostras individuais (Goebel, 1842; Harbottle, 1982; Pollard \& Heron, 1996).

Na década de 1850, o pesquisador austríaco Jan Erazim Wocel (1803-1871) sugeriu que as correlações de composição química poderiam ser utilizadas na determinação da proveniência e identificação das fontes de material arqueológico, podendo até mesmo fornecer datas relativas para sua manufatura e utilização (Pollard \& Heron, 1996).

O aparecimento dos primeiros apêndices de análises químicas e sua citação em relatórios de grandes escavações representa o início de colaborações significativas entre arqueólogos e químicos. Um exemplo de relatório refere-se à análise de quatro bronzes assírios e uma amostra de vidro na publicação de Austen Henry Layard, intitulada "Discoveries in the Ruins of Nineveh and Babylon", publicada em 1853, referente a uma expedição realizada para a curadoria do Museu Britânico (Layard, 1853; Pollard \& Heron, 1996).

O trabalho de Otto Helm (1826-1902), um farmacêutico polonês, para identificar a origem de âmbares por volta do final do século XIX representa uma das primeiras aplicações sistemáticas das ciências naturais à arqueologia. Era um trabalho abrangente com um problema arqueológico específico a ser tratado: a determinação da origem geográfica de 2000 contas de âmbar escavadas em Micenas, por Schliemann (Pollard \& Heron, 1996).

Damour, um mineralogista francês, analisou a origem de vários machados de pedra encontrados em monumentos celtas. Também analisou machados de outros materiais, como jade, ágata e jaspe de diferentes localidades. Ele analisou ainda quatro fontes diferentes de obsidianas e seis artefatos desse material, entre eles uma máscara da América Central (Harbottle, 1982a).

Além das diversas realizações desses cientistas, inúmeros trabalhos de outros pesquisadores foram realizados durante o século XIX, de forma que, em torno do final do mesmo século, havia um conjunto de resultados analíticos disponíveis, e os componentes químicos principais dos materiais citados eram bem conhecidos (Leute, 1987; Pollard \& Heron, 1996).

Outro marco do início da utilização de técnicas físicas pode ser definido em 1896, quando Roentgen usou os recém-descobertos raios X (1895) para estudar a absorção em pigmentos de chumbo em um quadro de Duerer, além de outras obras, já reconhecendo que 
essas análises poderiam ser úteis na identificação de obras falsificadas. Nesse mesmo ano, o pesquisador italiano Folgheraiter media momentos magnéticos em cerâmicas etruscas (Leute, 1987).

Em torno do final do século XIX, as escavações arqueológicas tornaram-se mais sistemáticas, e os resultados de análises químicas tornaram-se mais comuns em relatórios e novas sugestões de trabalhos começaram a ser feitas. O crescente número de artefatos encontrados trouxe uma ênfase crescente à questão da restauração e conservação. O pioneiro nessa área foi Friedrich Rathgen, que desenvolveu procedimentos para a conservação de relíquias, a partir de um laboratório estabelecido no Staatliche Museen zu Berlin (Pollard \& Heron, 1996).

Estudos de datação representam um campo de estudo importante para balizar teorias arqueológicas. A técnica de datação mais antiga é a datação por arqueomagnetismo, cujo pioneiro foi Thellier, em 1936. Na década de 1940, outras técnicas como datação por ${ }^{14} \mathrm{C}$, datação por potássio-argônio (K-Ar) e também métodos baseados na análise de flúor e nitrogênio foram introduzidos. O desenvolvimento da datação por ${ }^{14} \mathrm{C}$ ocorreu em 1949 , por Willard Libby (Pollard \& Heron, 1996), permitindo que sítios pudessem ser datados em relação aos demais e que sequências culturais pudessem ser estabelecidas. A datação por termoluminescência foi proposta em 1953, mas procedimentos precisos de medida foram desenvolvidos apenas em torno de 1970. Em 1962, a datação por traço de fissão foi introduzida e, em 1967, foi a vez da datação por ressonância de spin eletrônico (Leute, 1987).

Em 1896, Henri Becquerel (1852-1908) descobriu acidentalmente a radioatividade natural. Em fevereiro daquele ano, Becquerel pretendia realizar um experimento para confirmar sua teoria sobre a fosforescência, e guardou uma placa fotográfica envolvida em papel preto junto com um mineral de urânio. Depois de alguns dias, quando foi recuperar a placa, ele verificou uma imagem formada por radiação na mesma, mais intensa do que o esperado. Sua descoberta daria início à era nuclear no mundo (Munita, 2005).

Marie e Pierre Curie entraram na história da radioatividade por influência desse mesmo cientista. Por sugestão de seu professor Becquerel, Marie Sklodowska Curie (18671934), escolheu como tema de seu doutorado a identificação de uma impureza desconhecida em um minério de urânio, a pechblenda, analisada previamente pelo próprio Becquerel e cuja radioatividade detectada era maior que a do urânio puro. Ela e seu marido, o físico Pierre 
Curie (1859-1906), conseguiram isolar dois novos elementos da pechblenda que eram mais radioativos que o urânio: o polônio (em homenagem à Polônia, terra natal de Marie Curie), 60 vezes mais radioativo que o urânio, e o rádio, 400 vezes mais radioativo. $\mathrm{O}$ anúncio da descoberta desses dois elementos ocorreu em 1898 e, em 1903, o casal Curie dividiu com Becquerel o Prêmio Nobel de Física (Munita, 2005).

Em 1934, Irène Curie (1897-1956), filha do casal Curie, e seu marido Frédéric Joliot (1900-1958), descobriram a radioatividade artificial. Eles mostraram que as partículas expelidas por núcleos de elementos naturalmente radioativos (as partículas alfa, identificadas por Rutherford) poderiam ser utilizadas para bombardear e induzir a radioatividade em elementos naturalmente não radioativos (ex.: ${ }^{27} \mathrm{Al}+{ }^{4} \mathrm{He} \rightarrow{ }^{30} \mathrm{P}+{ }^{1} \mathrm{n}$ ). Assim, pela produção dos atualmente denominados radioisótopos artificiais, o casal ganhou o Nobel de Química em 1935 (Munita, 2005).

Em 1936, George Hevesy e Hilde Levy submeteram sais de terras raras a uma fonte natural de nêutrons, feita de $\mathrm{Ra}(\mathrm{Be})$. Eles verificaram que muitos elementos tornaram-se altamente radioativos pelo bombardeamento com nêutrons, e que os mesmos decaíam com cinéticas distintas. A partir dessa descoberta, eles verificaram o potencial para a identificação de elementos químicos presentes nas amostras pela medição das diferentes radioatividades, induzida por bombardeamento com nêutrons, e meias-vidas características dos diferentes elementos determinados (Ehmann \& Vance, 1991; Glascock \& Neff, 2003).

Muitas das técnicas analíticas de caracterização utilizadas em arqueometria são consequências adicionais de programas de pesquisas desenvolvidos por agências governamentais durante a Segunda Guerra Mundial e o período subsequente, a Guerra Fria, com o financiamento de inúmeros programas nucleares e espaciais. Com relação às ciências nucleares, muitos reatores de pesquisas foram instalados em laboratórios nacionais e universidades pelo mundo, com o intuito de desenvolver aplicações nucleares à pesquisa científica que não fossem relacionadas à área militar (Pollard et al., 2007; Price \& Burton, 2012). A construção de diversos reatores na década de 1950 e 1960 com fluxos de nêutrons suficientemente altos permitiu uma sensibilidade adequada em análise por ativação com nêutrons aplicada a problemas analíticos reais (Glascock \& Neff, 2003).

O primeiro relatório sobre análise de materiais arqueológicos utilizando análise por ativação neutrônica apareceu em 1957 (Sayre e Dodson, 1957). O trabalho dos dois 
pesquisadores foi sugerido por J. Robert Oppenheimer, diretor do projeto Manhattan, durante a Segunda Guerra Mundial, e diretor do Instituto de Estudos Avançados na Universidade de Princeton. Em 1954, ele discutiu com Richard W. Dodson, diretor do departamento de química do Brookhaven National Laboratory, sobre a possibilidade de se utilizar a análise por ativação com nêutrons para a análise química de cerâmicas arqueológicas com o propósito de se determinar sua proveniência (Pollard et al., 2007). Um dos arqueólogos então interessados no novo projeto foi o professor H. A. Thompson, do Institute and Homer Comfort of Haverford College.

Em 1955, o nome de E. V. Sayre foi sugerido por Dodson para encarregar-se do novo projeto de pesquisa. Nos testes experimentais iniciais, Sayre analisou estátuas gregas de terracota por meio da análise por ativação com nêutrons no reator à base de grafite de Brookhaven.

Os resultados dos experimentos com análise por ativação com nêutrons em cerâmicas foram apresentados a arqueólogos, químicos e outros cientistas em uma reunião no Princeton Center for Advanced Studies, em março de 1956, dirigida por Oppenheimer (Speakman \& Glascock, 2007). A pesquisa foi publicada no ano subsequente (Sayre e Dodson, 1957). Os resultados foram considerados promissores e novas pesquisas foram encorajadas (Harbottle \& Holmes, 2007).

Os estudos que integram as análises físico-químicas do registro arqueológico foram classificados em um mesmo campo de estudos que recebeu a denominação de Arqueometria, termo cunhado a partir de 1958, quando surgiu em Oxford um periódico com este nome (Martini, 2003; Speakman \& Glascock, 2007). Entre as contribuições ao primeiro volume desse periódico, é possível destacar a apresentação dos dados do primeiro levantamento geomagnético internacional por Aitken, em 1958, e o segundo relatório de análise de material arqueológico utilizando análise por ativação com nêutrons por Emeleus, no mesmo ano (apud Pollard et al., 2007). Dessa forma, o termo Arqueometria surgiu como a sistematização de uma área interdisciplinar de estudos que liga as ciências exatas à conservação, restauração e estudo do patrimônio cultural.

Até antes da segunda metade do século XX, a análise química elementar era realizada, principalmente, por diversos métodos químicos de via úmida, associadas a técnicas colorimétricas e espectrográficas, que consumiam muito tempo de análise, restringindo-as à 
determinação de elementos cujas concentrações fossem superiores a 1\%. Muitas técnicas analíticas de caracterização química, como métodos de determinação de elementos em níveis de concentração de até ng.g ${ }^{-1}$, ou mesmo inferiores, alcançou seu estado de implementação, tal como conhecemos hoje, apenas na década de 1950. Embora os princípios envolvidos nesses métodos, como a espectroscopia, sejam mais antigos, a instrumentação necessária tornou-se comercialmente disponível quando consumidores de peso, como a indústria de semicondutores, articularam suas necessidades. O advento da eletrônica e o desenvolvimento dos computadores também tiveram papel importante na implementação dessas técnicas, por facilitarem a coleta e tratamento de grandes quantidades de dados (Leute, 1987).

Estavam, então, estabelecidas as condições para análises químicas multiementares precisas, com a combinação de técnicas analíticas adequadas, principalmente análise por ativação com nêutrons, e tecnologia apropriada para fins de detecção e espectrometria. Essas análises multielementares abriram as portas para estudos de proveniência, sendo o perfil de concentrações elementares um novo atributo na distinção entre materiais arqueológicos e fontes de matéria-prima. Na segunda metade do século XX, muitos elementos podiam ser medidos, em níveis de até ppb $\left(10^{-9} \mathrm{~g} \cdot \mathrm{g}^{-1}\right)$, e a necessidade de uma quantidade cada vez menor de massa, da ordem de miligramas, tornou a análise elementar uma rotina em muitas investigações arqueológicas (Price \& Burton, 2012).

Durante as décadas de 1950 e 1960, viu-se o aparecimento da denominada Nova Arqueologia, na qual ocorreu um esforço explícito por parte dos arqueólogos em enfatizar o potencial do registro arqueológico em explicar o passado humano, em vez de apenas descrevêlo. Esse pensamento evoluiu de tal forma a considerar que todo o comportamento humano poderia ser enquadrado em leis que tratavam de fenômenos culturais. Dessa forma, a identificação de padrões no registro arqueológico e cultura material poderia ser utilizada na exploração de correlatos comportamentais, independentemente do tempo e espaço. Evidências de contatos entre os povos, por meio da troca de artefatos e materiais naturais (e, consequentemente, a transmissão de ideias) foram vistos como fatores importantes, aos quais as análises provenientes das ciências naturais poderiam contribuir na análise de mudanças em sistemas econômicos e sociais. Esse crescente interesse na distribuição de materiais iniciou uma era prolífica na arqueometria, com a utilização de inúmeras técnicas para a caracterização química de materiais, como obsidianas, cerâmicas, metais, vidros e materiais orgânicos. Além 
disso, os bancos de dados robustos gerados pela aplicação dessas técnicas poderiam então ser tratados estatisticamente por meio de computadores (Pollard \& Heron, 1996).

Um dos objetivos principais na caracterização de materiais arqueológicos é determinar a origem do material do qual são feitos, como mármores, obsidianas, âmbar, cerâmicas, entre outros. Assim, por exemplo, tendo a origem sido identificada com sucesso, ela pode ser plotada em um mapa e conectada a outros sítios onde objetos da mesma origem foram encontrados, permitindo o estabelecimento de rotas de comércio. Antes do advento de métodos físico-químicos de caracterização, esse procedimento só era possível de ser realizado com artefatos de estilo muito específico, como ânforas de vinho do Mediterrâneo, por exemplo. Com as técnicas de caracterização discutidas aqui, esses estudos puderam ser estendidos a materiais cujo estilo fosse menos diagnóstico arqueologicamente, ou até mesmo a matérias-primas (Leute, 1987).

Em geral, arqueólogos e diretores de museus e coleções particulares, não apreciam a ideia de fornecer amostras grandes, diagnósticas e quase integralmente preservadas para estudos arqueométricos de caracterização por métodos que exijam queima, dissolução, e outros procedimentos destrutivos na preparação de amostras para análise. Dessa forma, técnicas não destrutivas, ou instrumentais, e que exijam uma quantidade pequena de material amostrado são desejáveis (Leute, 1987).

No Brasil, como marco nos estudos arqueométricos, podem-se citar os trabalhos do final da década de 1960, de Shigueo Watanabe, atualmente pesquisador do Instituto de Física da Universidade de São Paulo, e que foi o introdutor da datação por termoluminescência no Brasil. Seu grupo de pesquisa analisou fragmentos de vasos cerâmicos e urnas funerárias encontradas no interior paulista. Atualmente, para citar alguns exemplos, há grupos trabalhando com arqueometria na Universidade Estadual de Campinas, Universidade Estadual de Londrina, Universidade Federal do Piauí, Universidade Estadual do Rio de Janeiro, Universidade Federal do Rio de Janeiro, Universidade Federal de São Paulo (liderado por Sônia Tatumi), Universidade de São Paulo e Universidade Federal do Sergipe.

No Instituto de Pesquisas Energéticas e Nucleares, em São Paulo, os primeiros trabalhos sobre arqueometria datam do final da década de 1990, sobre a aplicação de análise por ativação com nêutrons em cerâmicas brasileiras, realizados por Casimiro Munita (Munita 
et al., 2000). Em 1998, nascia o Grupo de Estudos Arqueométricos desse instituto, no intuito de designar os pesquisadores e alunos envolvidos em pesquisas em arqueometria.

Para se ter uma ideia da quantidade de material arqueológico analisado, pode-se citar um exemplo com cerâmicas arqueológicas nos EUA: de 1988 a 2004, mais de 25.000 amostras de argilas e cerâmicas arqueológicas do mundo todo foram analisadas por análise por ativação com nêutrons instrumental pelo Archaeometry Laboratory at Missouri University Research Reactor (MURR), um dos laboratórios mais conceituados na área, e ainda ativo no ano de publicação desta tese (Glascock et al., 2004).

Entre o final da década de 1980 e década de 1990, houve o descomissionamento de alguns reatores nucleares e a aposentadoria de pesquisadores de destaque na área, responsáveis pela condução de projetos importantes, como os do Brookhaven National Laboratory, Lawrence Berkeley Laboratory, Universidade de Toronto e Universidade Hebraica de Jersualém. Contudo, a demanda internacional por ativação com nêutrons não diminuiu e, felizmente, os programas remanescentes conseguiram aumentar sua capacidade de análise para atender a demanda crescente (Glascock \& Neff, 2003). A análise por ativação com nêutrons tem sido uma importante ferramenta para pesquisas de proveniência de materiais arqueológicos desde a década de 1960. Contudo há de ser reconhecido que a quantidade de reatores nucleares de pesquisa disponíveis tem diminuído, devido, principalmente, à visibilidade da energia nuclear e afins perante a sociedade. Em consequência disso, outras técnicas analíticas têm sido aplicadas para atender a demanda, como a técnica de ICP-MS (Glascock et al. 2004).

Cerâmicas arqueológicas de tempos anteriores ao contato com o homem europeu no "Novo Mundo" têm sido um dos pontos principais de pesquisa arqueológica nas Américas. Alguns países latino-americanos (como Chile, Argentina e Peru) possuem instalações nucleares que possibilitam a aplicação da tecnologia nuclear em vários campos, como a arqueometria. Um exemplo de sucesso da combinação da perícia analítica desses países e interesses comuns de pesquisa foi a criação do Co-ordinated Research Project $(C R P)$ on Nuclear Analytical Techniques in Archaeological Investigations, organizada pela IAEA, tendo como países participantes Brasil, Peru, Chile, Argentina, Cuba, México, EUA e Áustria. O primeiro encontro de coordenação de pesquisa (Research Co-ordination Meeting - RCM) do CRP ocorreu em junho de 1997 no Smithsonian Institution, em Washington, DC, EUA. Nesse 
encontro, foram introduzidos o projeto conceitual e planos de trabalho preliminares. A ênfase foi dada para uma estreita colaboração entre cientistas analíticos das ciências exatas e arqueólogos, desde a definição do problema, seleção de sítios para amostragem e interpretação dos resultados analíticos por meio de análise estatística multivariada. Também se deu especial importância à validação das técnicas analíticas utilizando-se diversos materiais de referência. Em abril de 1999, um segundo encontro RCM foi realizado em Cuzco, Peru, para apresentação e discussão de resultados preliminares de projetos individuais e para o refinamento dos métodos utilizados. O último $R C M$ foi realizado em Santiago, Chile, em novembro de 2000. Nesse encontro foi revelada a extensa quantidade de informação obtida pelos grupos de pesquisa participantes durante o CRP, o qual é descrito no relatório TRS416 - Nuclear Analytical Techniques in Archaeological Investigations (2003). Os resultados demonstraram o grande potencial da combinação de análise nuclear e pesquisa arqueológica.

A arqueometria, em seu desenvolvimento e aprimoramento, exigiu uma cooperação interdisciplinar entre cientistas de diferentes áreas, que possuíam pouco conhecimento sobre os métodos e paradigmas de pensamento do outro (Harbottle and Holmes, 2007). Atualmente, a arqueometria é um campo de pesquisa que envolve aspectos de química analítica, espectroscopia, química orgânica, eletroquímica, física, ciências da conservação, museologia, antropologia, história, história da arte, arqueologia, entre outros campos (Vandenabeele, 2007).

\subsection{Alguns materiais frequentemente analisados em arqueometria}

Os principais materiais analisados em arqueometria são cerâmicas, obsidianas, vidros, pinturas, objetos metálicos, turquesas, jades, pigmentos, resinas fósseis, entre outros. Os objetivos principais em análises físicas e químicas de materiais arqueológicos são a determinação da fonte de matéria-prima, ou proveniência, estabelecimento de rotas de comércio, estudo da tecnologia de produção, datação de artefatos e determinação da autenticidade de peças, como esculturas, vasos cerâmicos e pinturas (Leute, 1987). Alguns desses materiais mais estudados são discriminados a seguir. 
Cerâmicas

Estes materiais serão descritos em mais detalhes no Capítulo 3. As principais pesquisas arqueométricas com cerâmicas envolvem estudos de proveniência, caracterização de parâmetros de produção por análise microestrutural a partir de técnicas como difração de raios X e análises petrográficas (Leute, 1987; Martini, 2003; Munita, 2005; Speakman e Glascock, 2007)

Obsidianas

Obsidiana é um vidro natural produzido quando a lava vulcânica resfria rapidamente, passando pela temperatura de transição vítrea, sem que haja tempo suficiente para o crescimento de cristais. Esse material contém certos elementos em nível micro e traço, que formam domínios magnéticos dentro do vidro. A velocidade dos processos de resfriamento, a composição química da lava, o conteúdo de impurezas magnéticas e variações locais do campo geomagnético influenciam propriedades como o tamanho, forma e qualidade das inclusões magnéticas, as quais tornam uma obsidiana suficientemente característica de uma região (Carter et al., 2012; Leute, 1987). Foram materiais muito utilizados para a produção de lâminas, raspadores e pontas de projéteis (Harbottle, 1982). Esses materiais, por permanecerem virtualmente inalterados ao longo do tempo, do ponto de vista químico, são os materiais ideais para estudos de proveniência. Estudos de caracterização química e proveniência podem ser realizados por INAA, XRF, PIXE-PIGME, SEM-EDS, espectroscopia Raman, entre outros.

Objetos metálicos

Objetos metálicos são analisados em arqueometria com o objetivo de se entender a metalurgia dos povos antigos, desde a extração do minério, passando pela fusão, forjamento, têmpera e demais processos associados que o artesão tinha em mente. As ferramentas para a análise desses materiais geralmente compreendem microscopia óptica, microscopia eletrônica de varredura (MEV), difração de raios X e métodos de análise química (Leute, 1987). 
Vidros

Artefatos de vidro são feitos a partir de alguns silicatos amorfos. A fusão e solidificação desses materiais não são instantâneas, como em materiais cristalinos, mas progressiva, de um estado líquido até outro estado altamente viscoso. O controle da viscosidade apropriada torna possível a modelagem desses objetos. Há registros da produção de material vítreo datando desde o quarto milênio a.C., e pequenos objetos vítreos desde o terceiro milênio a.C. Contudo, o início da produção em quantidades significativas data de 1500 a.C., aproximadamente, sendo que os primeiros vidros foram produzidos na Mesopotâmia e/ou Egito. Os desenvolvimentos tecnológicos e a crescente disponibilidade de vidros, em torno do séc. I d.C. permitiu novos usos para o material, como uso doméstico em louças, construção de janelas, e decoração com pigmentos ou mosaicos. Vidros antigos são normalmente uma mistura de sílica (areia), sais alcalinos e óxido de cálcio. Estudos de proveniência e de tecnologia de produção desses materiais são frequentes em arqueometria (Robinet \& Eremin, 2012).

Pigmentos

A cor é um dos aspectos mais importantes na apreciação estética de objetos produzidos pelos seres humanos. Os pigmentos têm sido utilizados na decoração de cerâmicas, azulejos, tecidos, esculturas e, obviamente, em pinturas. Os pigmentos utilizados em pinturas estão em constante desenvolvimento desde a Antiguidade. Para grande parte dos pigmentos, é possível saber quando foi introduzido de forma precisa. Em estudos de autenticidade, por exemplo, é possível fazer uma comparação entre o tempo em que o pigmento surgiu e a data alegada para a origem da obra de arte, como uma pintura. Ferramentas de análise costumam ser as análises físicas de caracterização de microestrutura, como a análise de difração de raios $\mathrm{X}$; métodos visuais de iluminação com luz polarizada, infravermelho e ultravioleta; cromatografia; espectroscopia Raman; datação pela análise de pigmentos com uma data de aparecimento bem estabelecida; e métodos de determinação elementar, como XRF, e razões isotópicas (principalmente para pigmentos inorgânicos) (Leute, 1987; Vandenabeele \& Edwards, 2012). Para camadas finas de pintura em quadros, métodos não destrutivos são 
mandatórios, como a análise de fluorescência de raios X com dispositivos portáteis. Também é possível estudar mudanças na estrutura química dos pigmentos, causadas por degradação, por exemplo (Vandenabeele \& Edwards, 2012). A análise científica de objetos de arte, como as pinturas, tem se tornado progressivamente mais importante devido às necessidades dos campos da arte, história da arte e ciências de conservação, no sentido de se entender a evolução cultural dos materiais utilizados, e os processos de degradação dos materiais, no intuito de se planejar estratégias de conservação (Koulompi et al., 2012).

\subsection{Técnicas analíticas frequentemente utilizadas em arqueometria}

A pesquisa em arqueometria requer, frequentemente, o desenvolvimento, adaptação e otimização de técnicas analíticas altamente sensíveis, visando a sua aplicação ao estudo de objetos arqueológicos e artísticos. Atualmente, um grande conjunto de técnicas está disponível, requerendo do pesquisador o conhecimento das vantagens, desvantagens e adequações de cada técnica. Além disso, sólidos conhecimentos de física e química são essenciais, tendo em vista que muitas vezes os artefatos tornados objetos de pesquisa são únicos e não podem ser danificados, como peças de exposição dos acervos dos museus (Vandenabeele, 2007). A destruição do objeto também deve ser evitada, do ponto de vista analítico, pois permite que diferentes técnicas sejam aplicadas ao mesmo objeto em abordagens multianalíticas, como a do presente trabalho.

Em Arqueometria, alguns dos métodos físico-químicos utilizados com maior frequência são descritos a seguir. Uma lista completa de técnicas analíticas para vários tipos de materiais e problemas arqueológicos pode ser encontrada em Malainey (2011):

口 INAA - Análise por ativação com nêutrons instrumental: utilizada para caracterizar a composição química elementar de um material (Speakman \& Glascock, 2007). Este método analítico vem sendo utilizado pelo Grupo de Estudos Arqueométricos do Laboratório de Análise por Ativação Neutrônica (LAN) do IPEN desde 1998 (Munita et al., 2003).

- ICP-MS - Espectrometria de massa por plasma indutivamente acoplado: utilizada em análise química multielementar (Golitko et al., 2012). 
口 ICP-AES - Espectrometria de emissão atômica por plasma indutivamente acoplado: utilizado em análise química multielementar (Wells, 2004).

口 PIXE - emissão de raios $\mathrm{X}$ induzida por prótons: utilizada na caracterização de elementos químicos presentes em uma amostra (Lesigyarski et al., 2013).

- XRF - Fluorescência de raios X: utilizada na caracterização da composição química elementar (Malainey, 2011).

- AAS/AES - Espectroscopia de absorção e de emissão atômica: utilizada na análise química elementar de amostras. É uma técnica em que a amostra é triturada e diluída em meio aquoso para ser analisada (Genga et al., 2008).

- UV/vis - Espectroscopia de absorção/reflexão na região do ultravioleta-vísivel: é uma técnica útil para se determinar pigmentos utilizados na produção de cerâmicas (Vandenabeele et al., 2008).

- SEM - Microscopia eletrônica de varredura: utilizada na análise morfológica e mineralógica de materiais. Pode ser acoplada a detectores de fluorescência de raios X para análise química. (Mazzocchin et al., 2008).

- Análise Petrográfica: utilizada para o estudo da composição mineralógica de materiais líticos e cerâmicos. (Malainey, 2011)

- Microscopia óptica: microscopia óptica convencional, microscopia petrográfica, a partir de luz polarizada para identificar e caracterizar minerais em argilas e pigmentos; microscopia metalúrgica, a partir de luz refletida para o estudo da composição química e dos efeitos dos processos tecnológicos em metais. Análises preliminares da microestrutura (Leute, 1987; Malainey, 2011).

口 EPR - Espectroscopia de ressonância paramagnética eletrônica: é uma técnica que pode ser utilizada para a determinação da temperatura de queima de um material cerâmico (Polikreti et al., 2004; Mangueira et al., 2011).

- XRD - Difração de raios X: possibilita a análise da estrutura mineralógica de um material (Dias \& Prudêncio, 2007; Malainey, 2011).

Espectroscopia Mössbauer: utilizada para se obter informações sobre a condição de queima das cerâmicas. Por esta técnica, através da medição da absorção de ressonância nuclear sem recuo, é possível caracterizar o estado de oxidação e a vizinhança 
magnética do ferro, duas propriedades a partir das quais as condições de queima podem ser deduzidas (Zhang et al., 2005).

- Análises mecânicas: Para analisar parâmetros de performance dos materiais, no estudo de sua tecnologia de produção (Yonekuraa \& Suzukic, 2009).

口 Datação por termoluminescência: técnica utilizada para se obter a idade da última queima de materiais cerâmicos (Wintle, 2008).

口 Datação por ${ }^{14} \mathrm{C}$ : Utilizada para datar vestígios de matéria orgânica de plantas e animais de até 60.000 anos (Malainey, 2011).

- Datação geomagnética: utilizada para datação de artefatos pela variação na magnetização de materiais, gerada pela variação na direção e intensidade do campo magnético terrestre ao longo do tempo (Malainey, 2011).

- Caracterização de microalgas fossilizadas: utilizada em análise de cerâmicas, para a correlação com prováveis fontes de argila (Kligmann \& Calderari, 2012).

口 Datação Ar-Ar e Ar-K (Malainey, 2011).

口 Datação por traço de fissão (Malainey, 2011).

- Espectroscopia Raman (Malainey, 2011).

- Espectroscopia de ressonância nuclear magnética (Malainey, 2011).

口 Análises de DNA (Malainey, 2011).

\subsection{Radioatividade artificial aplicada à arqueometria}

Em química analítica, trabalha-se frequentemente com fenômenos que envolvem as camadas eletrônicas. Contudo, se há interesse na determinação de elementos, em vez dos compostos, o estudo dos núcleos atômicos torna-se conveniente, por ser virtualmente independente dos demais átomos ligantes na formação do composto. Assim, determinação de elementos-traço baseados em fenômenos nucleares são uma prática recorrente em aplicações arqueométricas.

Os nuclídeos (átomos especificados pela constituição de seu núcleo: Z, N e estado energético) de ocorrência natural são estáveis ou de decaimento muito lento, frequentemente não resultando em intensidades de contagem suficientemente altas para caracterização por espectrometria gama. Assim, faz-se necessária a irradiação das amostras, com partículas como 
nêutrons ou prótons, de forma a torná-las suficientemente radioativas para fins espectrométricos (Leute, 1987).

A ativação implica na geração de núcleos em estados excitados, que passarão por processos de decaimento com emissão de raios gama que são de interesse analítico. Em arqueometria, isso é feito, geralmente, pela irradiação com nêutrons, na técnica de análise por ativação com nêutrons (em inglês, NAA), embora ativação com outras partículas também seja possível (Leute, 1987). A NAA é aplicada extensivamente em estudos de proveniência de materiais inorgânicos, como líticos, cerâmica e vidros, pela determinação simultânea de elementos em nível macro, micro e traço (Malainey, 2011).

\subsection{Caracterização química elementar de materiais arqueológicos}

A análise elementar de materiais envolve a caracterização de sua composição para determinar a presença e quantidade de vários elementos químicos. É uma parte fundamental da química arqueológica, considerada um subcampo da arqueometria. A análise elementar pode ser mais bem situada e entendida pelo desenvolvimento de sua própria história. Entender, materialmente, do que é feito o mundo, sempre representou um dos maiores esforços intelectuais da Humanidade. No mundo ocidental, houve diferentes linhas filosóficas sobre a constituição do mundo material, desde Aristóteles, que assumia todas as substâncias existentes como uma mistura dos quatro elementos (terra, água, ar e fogo), passando por outros filósofos, como Demócrito, Leucipo e Epicuro, que identificaram o átomo como uma parte indivisível da matéria. A prova da existência do átomo tal como a conhecemos atualmente só seria realizada muito tempo depois. Parte dos fundamentos da ciência moderna e a investigação sistemática dos elementos iniciou-se no mundo árabe, no século IX, por Jabir ibn Hayyan (c.721-c.815), um dos pais da química, nascido na Pérsia. Ele iniciou a descrição sistemática dos elementos básicos e estabeleceu os rudimentos da estrutura da tabela periódica pela distinção de metais e não metais em sua classificação (Price \& Burton, 2012).

A tabela periódica representou uma organização sistemática de 66 elementos químicos conhecidos em 1869, pelo cientista russo Dmitri Mendeleiev (1834-1907). Ele organizou os elementos por massa e outras propriedades, e previu a existência de novos elementos em sua tabela, baseada em padrões repetitivos observados, ou comportamento 
periódico dos elementos. Essa tabela possui agora mais de 100 elementos químicos, e novos continuam a ser descobertos, embora apenas 90 sejam de ocorrência natural e de potencial interesse arqueológico (Price \& Burton, 2012).

Os processos estelares são responsáveis pela abundância relativa dos elementos, sendo os elementos mais leves, como carbono, oxigênio, nitrogênio, sódio, alumínio e silício mais abundantes em ordens de grandeza, em relação aos elementos produzidos em eventos cósmicos extremos, como as supernovas (ex.: ouro, platina e urânio). Quando supernovas ocorrem, no final da existência de uma estrela, essa explosão dispersa pelo espaço os elementos criados durante os processos nucleares estelares. Essa explosão também ejeta partículas subatômicas, que podem interagir com os elementos formados anteriormente por fusão nuclear, criando a maior parte dos elementos da tabela periódica mais pesados que o ferro (Price \& Burton, 2012).

Elementos mais abundantes e leves, como silício, oxigênio e alumínio, juntamente com frações menores de sódio, potássio, cálcio e magnésio e ferro compreendem a maior parte dos materiais geológicos. Sendo assim, a análise desses elementos é útil na identificação desses materiais. Normalmente, os elementos mais pesados e mais raros não são os constituintes majoritários dos materiais arqueológicos mais comuns (com exceção para artefatos de ouro e outros metais preciosos, por exemplo). Esses elementos mais pesados costumam ocorrer em níveis de traço. Sua quantidade nos vários materiais pode variar significativamente sem alterar substancialmente sua natureza. Dessa forma, apesar de não serem normalmente úteis na identificação básica de um material, podem ser utilizados para encontrar diferenças mais sutis entre amostras diferentes do mesmo material. Esses elementos são muito importantes em arqueometria para caracterizar artefatos de diferentes regiões (estudos de proveniência), embora a geografia não seja a única causa da variação dos elementos-traço (ex.: estrôncio e bário podem variar nos ossos, devido à dieta; urânio e terras raras podem ser afetados pela contaminação do ambiente deposicional) (Price \& Burton, 2012).

Em materiais inorgânicos, como cerâmicas arqueológicas, a caracterização para a definição da origem e de rotas de comércio é baseada na determinação de elementos-traço. Os elementos macroconstituintes não são tão significantes nesse sentido, pois eles apenas definem qual o tipo de material. Já os elementos em níveis micro e traço, cujas concentrações relativas 
variam de porcentagem $\left(10^{-2} \mathrm{~g} \cdot \mathrm{g}^{-1}\right)$ até ppm $\left(10^{-6} \mathrm{~g} \cdot \mathrm{g}^{-1}\right)$ ou ppb $\left(10^{-9} \mathrm{~g} \cdot \mathrm{g}^{-1}\right)$, são considerados os elementos diagnósticos e característicos de uma determinada pasta cerâmica. Além disso, como não é apenas um elemento em nível micro ou traço que caracteriza adequadamente um material, mas sim um conjunto dos mesmos, a análise multielementar torna-se mandatória (Leute, 1987; Mommsen, 2004).

Uma extensão da análise de elementos-traço é a chamada análise isotópica por espectrometria de massa, na qual são caracterizadas razões isotópicas. Um exemplo de aplicação é a determinação de impurezas de chumbo em vidro ou moedas de prata, na qual se caracterizam as razões isotópicas dos quatro isótopos de chumbo $\left({ }^{204} \mathrm{~Pb}:{ }^{206} \mathrm{~Pb}:{ }^{207} \mathrm{~Pb}:{ }^{208} \mathrm{~Pb}\right)$. Durante a formação geológica do minério, a difusão e demais processos físicos característicos que ocorrem são sensíveis à massa atômica. Dessa forma, minérios de origens diferentes exibirão razões isotópicas distintas (Leute, 1987).

A caracterização físico-química de materiais arqueológicos é frequentemente empregada na abordagem de questões referentes à origem da matéria-prima, tecnologia de fabricação de objetos e existência de interconexões entre grupos humanos (Pavia, 2006). Um dos principais focos da arqueometria desde a década de 1950 tem sido o estudo de cerâmicas que, por sua resistência a diferentes condições ambientais, são encontradas em quantidades significativas na maioria dos sítios datando desde o período Neolítico, e por isso tornaram-se centrais em estudos arqueológicos.

Um estudo de arqueometria, como área interdisciplinar que é, deve integrar os resultados ao contexto arqueológico dos objetos de estudo. Bishop, do Center for Materials Research and Education of the Smithsonian Institution já havia alertado enfaticamente para a necessidade da abordagem interdisciplinar, e encorajou cientistas envolvidos com arqueometria a irem além de meras interpretações fenomenológicas, utilizando a imaginação em vez de uma abordagem meramente descritiva (IAEA, 2003). Essa visão também é defendida por outros pesquisadores (Dunnel, 1993; Pollard \& Heron, 1996).

Um problema crítico na interpretação de estudos analíticos de materiais arqueológicos é a tendência de se "ler o presente no passado", em relação à percepção dos artesãos em relação ao que estavam realizando por meio da escolha de uma sequência particular de produção, e como as pessoas que utilizavam os artefatos significavam suas propriedades. Os estudos etnoarqueológicos frequentemente expõem nossa sociedade a uma 
forma nova de se pensar sobre o mundo material, lembrando-nos que os objetos são utilizados para criar e expressar relações sociais; e que mitos, ritos a tabus podem estar associados à produção, distribuição e uso dos mesmos (Tite, 2009).

Embora trabalhos arqueométricos estejam dentro de uma linha que contempla, de modo geral, a nova arqueologia, é importante ressaltar que durante a década de 1980, a contribuição de análises das ciências físicas e biológicas para o estudo do passado humano passou por um crescente escrutínio, reflexo de uma postura mais crítica em relação à ciência, de modo geral. Surgiram abordagens metodológicas denominadas de pós-processuais, que enfatizaram o papel do relativismo e do subjetivismo na interpretação arqueológica, assim como ressaltaram os papéis ideológicos e simbólicos da cultura material de maneira mais ampla do que era feito anteriormente. Assim, a contribuição das ciências naturais seria mais limitada nesse tipo de pesquisa (Pollard \& Heron, 1996). 


\section{CAPítulo 2}

\section{ÁREA DE ESTUDO E CONTEXTO ARQUEOLÓGICO DA AMAZÔNIA CENTRAL}

\subsection{Introdução}

A Amazônia ocupa mais de $40 \%$ do território nacional, sendo que seu rio principal, o rio Amazonas, é responsável por quase $20 \%$ de toda a água doce despejada mundialmente por rios nos oceanos e mares. A bacia amazônica cobre uma área de aproximadamente sete milhões de quilômetros quadrados. Nessa região, há grande variação sazonal no regime de chuvas e nível dos rios. O período de cheia do rio Amazonas é de novembro a julho, e seu nível diminui entre julho e outubro. Os sedimentos superficiais das planícies de inundação são expostos nos períodos secos, quando ficam isolados das águas do rio. As estações de cheia e de seca têm consequências importantes para a organização das sociedades amazônicas, pois afeta suas atividades de subsistência, como a pesca (Viers et al., 2005; Neves, 2006; Heckenberger \& Neves, 2009).

Em geral, os solos amazônicos são pobres em nutrientes, com exceção de algumas áreas, como as planícies de rios de "águas brancas", como o Solimões. A baixa fertilidade do solo pode ser explicada pelo contexto geológico da região. A bacia amazônica está localizada sobre áreas geologicamente antigas e, sob as condições extremas dos climas tropicais, os solos são constantemente expostos a ciclos de chuvas torrenciais e evaporação intensa, causando a lixiviação dos mesmos, que se tornam ácidos e incapazes de manter seus nutrientes. $\mathrm{O}$ desenvolvimento da floresta, a despeito da fertilidade do solo, é explicado pela reciclagem eficiente da biomassa produzida, que é decomposta e reabsorvida por meio de fungos associados às raízes das plantas, na forma de associações mutualísticas denominadas micorrizas. Assim, em áreas desmatadas, a floresta costuma demorar a se recompor, pois o desmatamento interrompe a reciclagem de nutrientes, empobrecendo o solo e expondo-o às chuvas, que acabam por levar os nutrientes restantes. 
Em uma floresta madura, como as áreas amazônicas sem desmatamento recente, a maior parte da biomassa costuma estar localizada na copa das árvores, em vez do solo. Esse padrão é importante no entendimento da ocupação amazônica, já que ele dificulta a ocorrência de espécies de animais formadoras de bandos vivendo na superfície do chão, para fins de caça. Animais como pacas, antas e capivaras costumam ser solitários e apresentam comportamento territorial de difícil previsão. Assim, uma alternativa encontrada por várias sociedades amazônicas foi o desenvolvimento da pesca, já que os animais aquáticos da região são uma fonte mais previsível e abundante de alimento. Esse contexto pode explicar porque sítios arqueológicos localizados junto aos grandes rios costumam ser maiores e apresentar maior densidade de registro arqueológico que outros (Neves, 2006).

A grande biodiversidade da Amazônia afetou e afeta de forma significativa o processo de ocupação humana dessa região (Heckenberger \& Neves, 2009). Além disso, a natureza sempre foi fonte de inúmeras referências para as sociedades indígenas, como pode ser observado na identificação dos ricos padrões de decoração cerâmica utilizados por diversas populações da Amazônia pré-colonial, por exemplo. Essas inúmeras referências moldaram a forma como indivíduos e sociedades dessa região construíram narrativas sobre si mesmos e seu papel no universo (Neves, 1999; Neves, 2006).

A sociodiversidade também é outra característica notável da Amazônia, tornada latente ao se considerar a quantidade de línguas indígenas identificadas na região. Na bacia amazônica, são faladas línguas de, no mínimo, quatro grandes famílias: Arawak, Carib, Gê e Tupi-Guarani. Além disso, foram identificadas famílias menores e línguas isoladas. A diversidade social e cultural amazônica manifesta-se também nas diferentes ideologias de seus grupos moradores (Heckenberger \& Neves, 2009).

Diante desse contexto, torna-se inviável considerar um único padrão de organização social e política para as sociedades amazônicas pré-coloniais. A variabilidade geográfica dentro da bacia amazônica e a diversidade são fatores-chave para o entendimento da arqueologia dessa região. Dessa forma, a visão tradicional da Amazônia como um grande ecossistema homogêneo, na forma de um inferno verde ou paraíso perdido, ocupada por grupos também homogêneos, deveria ser abandonada (Neves, 2006; Heckenberger \& Neves, 2009). 
Parte dos problemas referentes à condução e discussão de estratégias voltadas à ocupação e ao desenvolvimento sustentável da Amazônia está ligada ao desconhecimento e desinteresse em relação à sua história milenar de ocupação humana. Os povos indígenas que ainda ocupam a região - apesar dos processos de redução demográfica, deslocamento geográfico e mudança cultural - têm como ancestrais os povos que viviam na Amazônia antes do início da colonização europeia. Dessa forma, o trabalho dos arqueólogos no estudo da arqueologia amazônica promove uma espécie de resgate da história antiga dos povos indígenas dessas regiões, um trabalho de suma importância se reconhecermos que alguns dos processos de ocupação no presente são guiados, em certo grau, por processos que guiavam a ocupação humana pré-colonial. Essa problemática deveria ser considerada quando da elaboração de políticas públicas visando a proteção desses povos e do seu legado, responsáveis pelo verdadeiro início da história do Brasil (Heckenberger \& Neves, 2009).

\subsection{Questões gerais sobre arqueologia amazônica - Amazônia Central}

Até recentemente, a pesquisa arqueológica na América do Sul esteve fortemente focada nas culturas andinas, embora a arqueologia amazônica possua uma história centenária, iniciada por pesquisadores brasileiros e estrangeiros na segunda metade do século XIX a partir, principalmente, do Museu Nacional (RJ) e o Museu Paraense Emilio Goeldi (Moraes, 2006; Neves, 2006). A Amazônia continua sendo vista por muitos como uma das últimas fronteiras inexploradas do planeta, um exemplo de natureza virgem, livre da ação humana desde o início dos tempos. A arqueologia mostra que esse pensamento é enganoso. No exame de mapas de distribuição de terras indígenas na Amazônia contemporânea, nota-se que a ocorrência de sítios arqueológicos, correlatos de ocupações humanas pretéritas, é mais ampla (Neves, 2006). A maior parte das terras indígenas de grandes dimensões está, atualmente, localizada longe da calha principal dos rios Amazonas e Solimões, em áreas como a bacia do alto rio Negro e do alto rio Xingu.

Pesquisas recentes têm questionado os estereótipos populares, e até mesmo científicos, que enxergam a Amazônia como um lugar de uniformidade cultural e ecológica, com assentamentos pequenos e dispersos de grupos indígenas vivendo em uma selva tropical virgem. Há inúmeras evidências de que sociedades pré- e pós-colombianas produziram 
impactos importantes na fauna, flora, hidrologia e constituição dos solos (Heckenberger \& Neves, 2009).

No final do século XV, a bacia amazônica era ocupada densamente por diferentes povos indígenas. A partir de meados do século XVI até início do XVII, com o estabelecimento dos primeiros europeus na Amazônia, há registros escritos sobre a existência de grandes aldeias, algumas delas ocupadas por milhares de pessoas, conectadas por estradas e integradas em amplas redes regionais de comércio e em federações políticas de alcance regional. Segundo relatos, esses assentamentos ao longo dos rios poderiam ser tão extensos que seria necessário viajar alguns quilômetros para percorrer toda sua extensão (Neves, 2008). Acreditase que tais referências tenham desaparecido do registro histórico a partir do século XVIII, em função da diminuição e dispersão populacional ocasionadas pela colonização europeia, sentida na forma de doenças, guerra e escravidão (Machado, 2006; Moraes, 2006; Neves, 2006; Heckenberger \& Neves, 2009).

Mesmo sabendo que exageros possam ter ocorrido em suas descrições (para justificar o financiamento das expedições), os relatos dos primeiros viajantes sobre a abundância de recursos e a existência de organizações sociais complexas na Amazônia contrastam com a realidade etnográfica atual, marcada por ocupações esparsas com baixa densidade demográfica e baseadas em estruturas de idade e gênero. Essa dicotomia foi responsável, em grande parte, pelas divergências interpretativas em relação ao passado dos grupos que habitaram a região (Machado, 2006; Moraes, 2006), de forma que os estudos atuais sobre a ocupação da Amazônia pré-colonial apoiam-se sobre um amplo debate quanto às formas de organização social e padrões de mobilidade dessas populações (Myers, 1992; Meggers, 1996; Machado, 2006). A seguir são apresentadas, de forma simplificada, duas dentre as principais linhas de pensamento referidas. É importante salientar que essas linhas não são estanques, sendo comuns propostas interpretativas intermediárias, ou mesmo variações das mesmas (Machado, 2006).

O modelo "padrão" propõe a ideia de cultura como resposta a problemas ambientais (determinismo ambiental), defendendo que as antigas ocupações pré-coloniais da Amazônia seriam caracterizadas pela baixa densidade demográfica e formas de organização social baseadas em estrutura de idade e gênero, de forma análoga às comunidades atuais, caracterizando um quadro de continuidade histórica. Esse modelo considera o 
desenvolvimento de sociedades humanas como uma resposta direta a problemas ambientais, com o objetivo de garantir sua sobrevivência. Assim, essa linha de pensamento julga ser improvável a existência de organizações humanas complexas na floresta tropical, devido a limitações naturais que estimulariam uma elevada mobilidade entre seus habitantes, impossibilitando o crescimento demográfico e impedindo o desenvolvimento de organizações humanas sociopoliticamente estratificadas (Meggers, 1996; Machado, 2006; Portocarrero, 2006).

Por outro lado, uma das perspectivas "críticas" argumenta sobre a existência de grandes adensamentos populacionais no período pré-colonial, denominados cacicados, que seriam uma forma de organização social baseada no estabelecimento de uma hierarquia de alcance regional, a partir de um centro de poder, formando sociedades complexas que contrastariam com o cenário atual observado para os grupos indígenas contemporâneos da Amazônia. Essa linha de pensamento procura relativizar o papel das dificuldades ambientais como fator limitante para a emergência de sociedades complexas (Machado, 2006). A combinação de pesca, caça e coleta em áreas de várzea poderia complementar formas alternativas de agricultura, como a coivara, garantindo assim a subsistência de grandes grupos humanos. Pela visão de Denevan (1996 apud Lima, 2008, p. 18), a imprevisibilidade do regime de cheia das várzeas teria sido superada pelos povos antigos por meio da exploração integrada dos recursos de várzea e de terra firme. O padrão de assentamento encontrado na área de pesquisa do PAC (Projeto Amazônia Central) corrobora o modelo do uso do espaço proposto por Denevan.

A ruptura histórica marcada pelo desaparecimento dessas sociedades complexas estaria relacionada ao contato com os europeus, que trouxeram doenças, guerra e escravidão aos povos indígenas (Machado, 2006; Portocarrero, 2006). Dessa forma, a baixa densidade demográfica desses povos observada atualmente na Amazônia seria, provavelmente, mais resultado de contingências do processo colonial, além do ciclo da borracha na região, do que de alguma inaptidão determinada ecologicamente (Machado, 2006; Neves, 2006).

Em 1995, teve início o Projeto Amazônia Central (PAC), com o objetivo principal de entender a forma e o tamanho dos assentamentos na região, estudando a densidade do registro arqueológico e a duração das ocupações. O PAC também realizou um refinamento da cronologia da área de confluência dos rios Negro e Solimões com mais de cem datações por 
${ }^{14} \mathrm{C}$, fazendo com que a região de confluência seja, no momento da redação deste trabalho, a região mais bem datada da Amazônia. Uma das premissas desse projeto era de que o centro de origem cultural sul-americano teria que ser buscado nas proximidades de Manaus. Assim, problemas específicos de pesquisa nessa região amostral são válidos para a construção e teste de modelos interpretativos para toda a Amazônia. As principais questões estudadas são (Moraes, 2006):

1. Emergência de cacicados pré-coloniais;

2. Assentamentos sedentários, densos e de longa duração;

3. Distribuição linguística nas terras baixas da América do Sul;

4. Cronologias de ocupação.

Sabe-se que havia uma preferência por assentamentos próximos a cursos d'água. Com relação à fertilidade das terras, seria de se esperar que a maioria dos sítios encontrados estivesse nas proximidades do rio Solimões, e não do rio Negro, devido à maior disponibilidade de recursos nas proximidades das águas brancas, em comparação com as águas pretas. Contudo, observou-se que há uma semelhança de ocupação entre as duas áreas (Lima, 2008). Uma das explicações levantadas reside na localização desses sítios no baixo curso dos rios, já próxima à confluência, de modo que o acesso aos recursos de cada um deles seria facilitado. A outra explicação reside na presença de cursos d'água que interpolam a calha dos rios maiores, como é o caso do rio Ariaú, que em determinadas épocas do ano, carrega água e sedimentos do rio Solimões até o rio Negro.

Lima concluiu (2008, p. 352) que a análise preliminar dos padrões de uso do espaço e inserção na paisagem dos sítios arqueológicos na área de confluência dos rios Negro e Solimões poderia ser sintetizada em três tendências:

a. Sítios implantados juntos aos grandes rios, independente de serem de águas brancas ou pretas, tendem a ser maiores e a apresentar sequências de ocupação longas e aparentemente mais contínuas. 
b. Os sítios de interflúvio em lagos aparecem em maior quantidade e são também de grande porte, mas sua sequência de ocupação é mais restrita que a dos sítios do contexto anterior.

c. Os sítios de interflúvio em igarapés não relacionado a formações lacustres são menos frequentes, menores e menos densos, com sequências curtas e aparentemente descontínuas.

A partir do contexto anterior, duas hipóteses foram levantadas. A primeira diz respeito a um possível processo de adensamento populacional, que levou a uma exploração mais sistemática de outros nichos nos quais as maiores populações não estavam instaladas, já que os sítios à beira dos grandes rios não deixaram de ser ocupados em nenhum momento. A segunda hipótese é relacionada à facilidade de comunicação, por meio dos canais e furos existentes na região, que viabilizaria o estabelecimento de uma rede onde circulariam pessoas, ideias, objetos e, principalmente, informações. Dessa forma, outros fatores, que não apenas a disponibilidade imediata de recursos, influenciariam a configuração espacial dos assentamentos, fornecendo um elemento de tensão para a dicotomia várzea versus terra firme, que não seria o único elemento explicativo satisfatório para a Amazônia Central.

$\mathrm{O}$ início da produção cerâmica, do aparecimento das terras pretas de índio (definida adiante) e da origem e adoção da agricultura na floresta tropical são fenômenos que marcaram o início do chamado Período Formativo no norte da América do Sul. Segundo Lathrap (1970 apud Moraes, 2006), todos os sistemas agrícolas da América do Sul seriam derivados de um sistema antigo de cultivo de mandioca desenvolvido nas várzeas da Amazônia. Acredita-se que a domesticação da mandioca ocorreu por volta do ano 5000 a.C. As cerâmicas mais antigas das Américas foram identificadas por Anna Roosevelt nos anos 1980, e teriam entre 7 mil e 11 mil anos de idade (Moraes, 2006). Roosevelt acreditava na existência de cacicados autóctones, que combinavam o cultivo do milho com outras atividades de subsistência. Já Carneiro e Denevan (apud. Moraes, 2006) acreditavam que a utilização de recursos aquáticos seria suficiente para manter o padrão de complexidade do tipo cacicado, e que ainda as populações antigas poderiam utilizar uma combinação desses recursos com o cultivo de mandioca, em terra firme. 
No registro arqueológico da região, as evidências mais antigas de ocupação dessa área por grupos ceramistas e horticultores remontam aos últimos séculos antes da Era Cristã, e aparecem em vários pontos da Amazônia Central em sítios arqueológicos multicomponenciais. Geralmente, estão a mais de um metro abaixo da superfície e são pouco densas, evidenciando um uso não intenso do solo e discretas alterações na paisagem, ou matrizes de solo relacionadas, sejam elas arenosas (espodossolos) ou argilosas (latossolos). Materiais dessa fase arqueológica, cujo nome convencionou-se chamar de Açutuba, foram encontrados em sítios como Açutuba, Hatahara, Lago Grande e Osvaldo (Lima et al. 2006; Lima, 2008).

Com relação à utilização do espaço, o gradual aumento demográfico observado na Amazônia Central, demonstrado pelo tamanho, densidade e quantidade de sítios, estimularia uma exploração mais intensiva dos recursos disponíveis e uma ampliação dos nichos ambientais ocupados. Os sítios passariam a possuir usos e funções específicas, que não somente a de sítio-habitação. A esse processo estão associadas as cerâmicas e os contextos da fase cerâmica Manacapuru. Um exemplo da utilização específica de um sítio é sugerido pelo contexto arqueológico encontrado no sítio Nossa Senhora do Perpétuo Socorro, no qual foram encontradas estruturas para o cozimento de cerâmica, junto com uma centena de estruturas de combustão, cuja formação de terra preta foi sugerida como uma atividade deliberadamente praticada no sítio (Lima, 2008, p. 363).

Ainda relacionado ao crescimento demográfico, existe a questão da intensificação no uso do solo, demonstrada pelo rápido processo de formação de terra preta antropogênica. É no contexto da fase Manacapuru que se observaram os primeiros assentamentos vinculados a essas matrizes antrópicas. Mais densas e profundas, essas terras pretas passariam a se formar na mesma intensidade tanto em solos arenosos (como o dos sítios Açutuba e Cachoeira), quanto em solos argilosos (como o do sítio Osvaldo). A densidade do registro passa a ser superior a das ocupações da fase Açutuba e a tecnologia da indústria cerâmica seria muito semelhante em todos os sítios estudados.

Nos sítios maiores e mais densos relacionados à fase Manacapuru, pode ser observada uma série de elementos comuns à fase posterior, Paredão, como a identificação de assentamentos em formato circular ou elipsoidal, que evidenciam uma diferença de uso do espaço e uma modificação mais intensa da paisagem, interpretados como a materialização de uma cosmovisão que distinguiria e beneficiaria espaços público-rituais, uma característica de 
povos Arawak (Fausto, 2005). A presença da fase Manacapuru em sítios cujo registro é unicomponencial, facilitou a identificação da disposição espacial dos assentamentos, relacionada à forma de utilização do espaço por parte dos povos produtores dessa cerâmica.

Na Amazônia Central, as fases Açutuba, Manacapuru e Paredão estão inseridas num macrocomplexo cerâmico denominado Tradição Borda Incisa, encontrada primeiramente ao longo do rio Orinoco. Atualmente, sua distribuição vai desde a bacia desse rio até o Alto Xingu. As cerâmicas desse macrocomplexo dividem características gerais como bordas largas; presença de decorações plásticas (incisões), geralmente na superfície das abas; presença de engobo vermelho; entre outros.

Acredita-se que os povos representados pela Tradição Borda Incisa tenham descido em direção ao sul, até a região da Amazônia Central, numa dispersão conhecida como Diáspora Arawak, com início estimado entre 500 a.C. a 500 d.C. e origem no noroeste amazônico (Portocarrero, 2006). Os povos Arawak eram considerados como os "fenícios das florestas", podendo navegar por grandes distâncias.

Em torno dos séculos IX, $\mathrm{X}$ e os seguintes, a quantidade de sítios e a densidade do registro são ainda maiores, e a terra preta antropogênica é mais escura. Datam dessa época as evidências mais claras de assentamentos circulares, e os nichos de interflúvio encontravam-se largamente ocupados. Além disto, são observados sinais de construção de montículos artificiais, como os montículos funerários, reforçando a ideia de uso específico do espaço. A partir desse último dado do registro, é possível aventar a necessidade de uma grande mobilização de mão-de-obra, implicando em uma divisão social de trabalho. Outra evidência de tal mobilização se dá na ocorrência de grandes valas defensivas junto ao limite de grandes sítios arqueológicos, como Lago Grande e Açutuba, servindo para se lançar um olhar sobre as possíveis convivências pacíficas ou conflituosas entre os diferentes grupos.

Um ponto estudado nas pesquisas é acerca do tipo de relação entre os povos Arawak e de outras etnias. Em geral, acredita-se que tentavam estabelecer relações pacíficas com outros povos. Contudo, a partir dos séculos XI e XII, começaram a aparecer cerâmicas da fase Guarita. Essa fase é associada aos povos Tupi e, nessa mesma época, houve o aparecimento de valas defensivas, como a unidade 5 do sítio Lago Grande, um dos sítios estudados neste trabalho (Donatti, 2003). 
O contexto anteriormente descrito, a partir da análise do registro arqueológico, evidencia um adensamento populacional relacionado à fase Paredão, que pode ser considerada como o ápice da ocupação da Tradição Borda Incisa na Amazônia Central (Lima, 2008). Partindo-se da hipótese da existência de uma rede de interações de longo alcance atuante na região, modificações na cultura material das fases da Tradição Borda Incisa refletiriam uma série de contingências históricas, tanto locais como regionais, experimentadas pelos povos que habitavam a Amazônia Central.

Dentro da visão de Meggers (1996), ligada ao determinismo ecológico para a interpretação da história de ocupação da região amazônica, os grandes sítios localizados nas regiões de várzea seriam resultado de múltiplas reocupações, e não de uma variação de tamanho dos assentamentos. Lathrap, de outro modo, interpreta os grandes sítios como correlatos arqueológicos de grandes aldeias onde teriam vivido populações com padrões de organização social mais hierarquizado (1970a apud Lima, 2008). Contudo, há atualmente claras evidências de assentamentos grandes e permanentes tanto em ambientes de várzea, como de terra firme, contrariando os pressupostos do modelo padrão advogado por Betty Meggers (Heckenberger et al., 1999).

Uma hipótese interpretativa recorrente na discussão arqueológica atual acerca dos padrões de ocupação pré-colonial é defendida e testada por Lima (2008) em sua tese. Ela propõe que as fases cerâmicas relacionadas à Tradição Borda Incisa representam um desenvolvimento cultural, sociopolítico e econômico de sociedades vivendo dentro de um mesmo sistema macrorregional. A autora propõe que a ocupação da Amazônia Central foi agenciada por grupos culturais integrados através de um complexo sistema sociopolítico, que extrapolou fronteiras étnicas, linguísticas e ambientais. A materialização desse sistema se daria pela tradição cerâmica da Borda Incisa e teria se desenrolado ao longo dos séculos I ao XII d.C. A autora ainda denomina o sistema como esfera de interações, na qual existe uma padronização de um sistema de comunicação, expresso através da cultura material e das formas de organizar o espaço.

Mais detalhes sobre o modelo padrão para a ocupação da Amazônia pré-colonial e algumas críticas podem ser encontrados em Heckenberger et al. (1999), Neves (1999), Donatti (2003), Machado (2006), Moraes (2006), Neves (2006), Neves \& Petersen (2006), Portocarrero (2006), Lima (2008), Heckenberger \& Neves (2009) e Silva (2009). 
A arqueologia da Amazônia ainda é escassamente conhecida, mas pesquisas e desenvolvimentos recentes têm mudado a forma pela qual vemos a região, por meio de evidências de histórias indígenas dinâmicas e diversas (incluindo caminhos alternativos para a domesticação de plantas e animais), vida sedentária e complexidade social, desafiando estereótipos de aldeias primitivas pequenas e dispersas vivendo em uma floresta intocada. (Heckenberger \& Neves, 2009). Essas descobertas relativizariam o papel de limitações ambientais inerentes à floresta tropical como fatores limitadores do aparecimento de sociedades sedentárias e de crescimento demográfico entre as populações ameríndias (Heckenberger et al., 1999).

\subsection{Teoria geral sobre a formação do registro arqueológico}

O registro arqueológico pode ser entendido como formado por objetos culturalmente depositados e que não fazem mais parte de uma sociedade existente (Schiffer, 1987a). Esses objetos podem ser artefatos cerâmicos, líticos, construções, monumentos e até resíduos orgânicos provenientes de atividades humanas, como a preparação de alimentos. Desde sua produção, uso e possível modificação dos materiais até o evento da coleta em escavações arqueológicas, o registro arqueológico é alterado por uma série de processos físicos, químicos e biológicos, inclusive os que podem ocorrer durante o contexto deposicional do registro, após o descarte. Assim, o registro arqueológico é fragmentário em sua natureza, pois uma parte relevante de evidências pode ter sido perdida ou alterada significativamente, tornando a interpretação do registro um desafio considerável (Pollard \& Heron, 1996).

Uma série de discussões sobre interpretação em arqueologia, estimuladas pelas colocações de Walter Taylor no que se refere a uma maior necessidade de atenção ao "contexto" e "semelhanças", suscitou inúmeras reflexões acerca da natureza do registro arqueológico. Uma maneira recorrente de visualizá-lo é como um palimpsesto de atividades ocorridas em episódios distintos durante um longo período de tempo (Binford, 1981). Binford ainda enfatiza que nossas observações do registro arqueológico devem estar ligadas ao entendimento do contexto cultural, para que inferências confiáveis acerca do passado sejam realizadas. Na visão do autor, isso é possível porque os padrões no registro arqueológico 
representariam alguns dos determinantes organizacionais básicos da rotina de um grupo humano do passado.

Ao tratar do registro arqueológico, Schiffer (1987a) define dois contextos associados. O primeiro é o contexto sistêmico, que se refere aos artefatos no período de sua participação em sistemas comportamentais. O contexto arqueológico, por sua vez, diz respeito aos artefatos que interagem somente com o ambiente natural, como aqueles encontrados nas escavações. É interessante notar que um objeto pode transitar entre o contexto sistêmico e arqueológico de maneira cíclica, por reocupações de assentamentos, por exemplo.

Os processos que dão origem ao registro arqueológico são chamados de processos de formação. Eles podem ser de dois tipos básicos: os culturais e os não culturais, ou naturais. Os processos culturais de formação são aqueles em que a agência de transformação é o comportamento humano. São responsáveis por manter os objetos dentro do contexto sistêmico, pelo depósito, e consequente formação do contexto arqueológico, assim como qualquer transformação cultural do registro subsequente ao seu descarte. Por sua vez, os processos não culturais são aqueles originados a partir de fenômenos do ambiente natural. Eles agem sobre os objetos em todo o tempo, tanto no contexto sistêmico como no contexto arqueológico, e são responsáveis pelo que degrada e pelo que é preservado; pelo colapso de estruturas e acumulação de sedimentos; por uma série de distúrbios no registro, desde terremotos até caminhos feitos por minhocas; e pela geração de evidências, ou ecofatos, relevantes para estudos paleoambientais (Schiffer, 1987a).

Schiffer (1972) também listou algumas referências que evidenciam que uma das hipóteses mais importantes feitas pelos arqueólogos é que o padrão espacial do registro arqueológico reflete o padrão espacial de atividades realizadas no passado e, consequentemente, aspectos culturais de um grupo. Segundo o autor, a cultura é vista como um sistema comportamental composto por subsistemas inter-relacionados e autorregulados, que processam matéria, energia e informação (Schiffer, 1972).

\subsection{Processos culturais de formação do registro arqueológico na Amazônia Central}

Os objetos materiais possuídos por um grupo humano estão relacionados à sua tecnologia de domínio, que compreende não apenas os artefatos em si, mas também os conhecimentos necessários para criá-los e utilizá-los. Arqueólogos tradicionalmente tratam a 66 
variabilidade da cultura material por meio de categorias estilísticas e funcionais. O termo função, para um artefato, pode ser entendido além de sua função utilitária, ou tecnofunção. Além dessa última, pode-se falar em função social e função ideológica. Todas essas três funções influenciam no design de um artefato, e devem ser consideradas ao se tentar explicar a variabilidade técnica e sua mudança ao longo do tempo (Skibo, 1992). Essas três funções representariam vetores de processos culturais de formação do registro arqueológico, podendo ser estudadas e inferidas a partir da pesquisa desse registro.

As particularidades da produção de artefatos cerâmicos influenciam na variabilidade do registro arqueológico. Pode-se enumerar, para fins didáticos e não estanques, as diversas etapas envolvidas na tecnologia de produção cerâmica:

1. Seleção, coleta e preparo das argilas;

2. Processo de fabricação do objeto cerâmico (moldagem, roletagem, modelagem etc.);

3. Secagem e queima;

4. Acabamento e tratamentos decorativos (técnicas e motivos);

5. Evidências de utilização, reutilização e descarte.

Um vaso cerâmico pode ser estudado de uma série de maneiras. Sua argila queimada pode ser analisada para fornecer uma data para o vaso, o qual, por sua vez, pode fornecer uma datação para o local onde foi encontrado. Também podem ser realizados testes para encontrar a fonte da argila utilizada na sua manufatura e, potencialmente, fornecer evidências sobre a amplitude do território e contatos do grupo detentor daquela tecnologia cerâmica. A decoração pictórica na superfície do vaso pode auxiliar na correlação e classificação de estilos decorativos (tipologia), assim como pode nos contar algo sobre as crenças de um povo, particularmente se o vaso contiver representação de deuses ou outras figuras mitológicas. Ainda, a forma do vaso e qualquer vestígio orgânico encontrado no mesmo, podem fornecer informações acerca do uso do pote (ex.: um utensílio para cozimento de alimentos), além de deixar dicas sobre a dieta daquele povo (Renfrew \& Bahn, 2007, p. $38)$.

Dessa forma, e por meio de outras análises feitas nas cerâmicas pelos arqueólogos, é possível visualizar todo um exercício classificatório da variabilidade do registro como uma 
tentativa de se entender a formação do contexto arqueológico, a partir das quatro dimensões da variabilidade artefatual propostas por Schiffer (Schiffer, 1987b): formal, quantitativa, espacial e relacional. Como exemplo, podemos citar, dentro da dimensão formal, as várias tipologias cerâmicas propostas historicamente na arqueologia amazônica (Donatti, 2003; Lima, 2008).

A partir da aceitação da premissa da Diáspora Arawak, podemos enumerar alguns elementos de sua tessitura cultural, ou ethos, comuns a diversos grupos pertencentes a este tronco, persistentes em longa duração: aldeias circulares, xamanismo, hierarquia social, espaços públicos político-rituais bem definidos, participação em sistemas multiétnicos e multilínguisticos, extensas redes pacíficas de troca em escala regional, horticultura elaborada e sedentarismo (Fausto, 2005; Lima, 2008). Podemos interpretar estas características como processos culturais que condicionaram parte do contexto arqueológico na Amazônia Central, em relação as suas relações de heterogeneidade e homogeneidade, bem como padrões de ocorrência.

Schiffer (1987b) propõe a forma como um parâmetro de avaliação da variabilidade do registro. Para entender o papel que este parâmetro pode ter no contexto em questão, basta lembrar que entender os significados da variabilidade formal é importante para se compreender os usos a que se destinavam os objetos depois de prontos. Por meio da análise das cerâmicas da Amazônia Central, foi possível constatar que determinadas categorias de objetos com finalidade cotidiana estão vinculados a uma grande variabilidade em termos de processos de fabricação e escolha de matéria-prima, mas não de sua morfologia, cujas mudanças são pequenas com o passar das gerações (Lima, 2008).

Em relação ao padrão de descarte, o momento em que um artefato passa do contexto sistêmico para o contexto arqueológico, Schiffer (1972) definiu dois tipos de refugo. Refugo primário seria o material descartado no próprio local de uso, e refugo secundário, o material descartado em um lugar distinto do local de utilização. Há ainda o refugo de fato, que é o refugo deixado quando do abandono de um assentamento, e a questão da reutilização do refugo, já apontada no esquema proposto pelo autor (idem, p. 158).

No contexto amazônico, a reutilização do refugo está refletida nos montículos encontrados em vários sítios de ocupação Paredão, como Lago Grande, os quais são responsáveis por grande parte do material escavado e onde muitos fragmentos cerâmicos são encontrados. Uma questão ligada aos montículos é que eles eram formados a partir de 
cerâmicas com material do entorno, originalmente mais antigo. A consequência disso é que se obtinha uma estratigrafia invertida, não condizente com as ocupações sequenciais ao longo do tempo, fazendo com que a afiliação cultural e a posição cronoestilística fossem muito debatidas dentro da arqueologia amazônica (Lima, 2008, p. 38). Foi ainda verificado que os montículos estão normalmente associados a unidades habitacionais, e sua disposição sugeriria um padrão de assentamento circular em sítios Paredão.

Podemos relacionar hipoteticamente a reutilização do refugo como impulsionada, em parte, pela necessidade em se dar um fim ao refugo secundário, de lixeiras, que se acumularia com maior intensidade em períodos de crescimento demográfico. Este fato seria consistente com um princípio geral sobre a ocorrência de refugo secundário, como lembra Schiffer (1972, p. 162):

“(...) with increasing site population (or perhaps site size) and increasing intensity of occupation, there will be a decreasing correspondence between the use and discard locations for all elements used in activities and discarded at a site."

Na região da Amazônia Central, a presença de montículos artificiais é um traço cultural das ocupações Paredão, num momento em que a região foi mais densamente povoada. A presença desses montículos sugere a reutilização de cerâmicas em um uso para os quais não tinham sido originalmente criadas, caracterizando um exemplo de reutilização de artefatos após seu descarte (Lima, 2008).

O contexto sistêmico que se procura entender na região da Amazônia Central é conhecido em grande parte apenas por processos de inferência, embora haja trabalhos etnoarqueológicos que procuram entender objetos ainda interativos com povos daquela região. Desde a década de 1970, esses trabalhos têm sido realizados com diferentes temas, problemas, objetivos e perspectivas teóricas, ampliando as possibilidades de interpretação do registro arqueológico, bem como contribuindo na crítica e na revisão dos paradigmas tradicionais utilizados na explicação do modo de vida das populações amazônicas (Silva, 2009).

Os polêmicos conceitos de fase e tradição são utilizados historicamente pela arqueologia brasileira na interpretação da variabilidade cerâmica arqueológica. Fase cerâmica foi definida, por Willey \& Phillips (1958 apud Lima, 2008), como "unidade arqueológica que 
possui traços suficientemente característicos para distingui-la de outras unidades (...) de uma localidade ou região cronologicamente limitada a intervalos de tempo relativamente breves". Já tradição seria a "a persistência em tempo e espaço (amplos) de um conjunto de traços que caracterizam a tecnologia cerâmica.". Thomas \& Ehrich (1969 apud Lima, 2008) afirmam que tais ferramentas metodológicas podem ajudar no estabelecimento de padrões que definiriam grupos humanos compartilhando elementos culturais, na forma de origens comuns ou contatos entre comunidades ou regiões.

Cerâmicas têm sido classificadas em grupos, ou fases, na Amazônia Central desde 1968, pelo arqueólogo alemão Peter Hilbert (Lima, 2008). Hilbert dividiu o material cerâmico em três fases, estabelecendo, a partir dessa seriação, uma cronologia dos grupos humanos que habitaram a região no período pré-colonial. Estudos posteriores, compreendendo mais de cem datações radiocarbônicas, estabeleceram uma cronologia atual para a região (Tabela 2.1).

Tabela 2.1 - Cronologia cerâmica para a Amazônia Central baseada em datação por ${ }^{14}$ C. Fonte: (Lima, 2008).

\begin{tabular}{c|c}
\hline Fase Cerâmica & Período \\
\hline Açutuba & III a.C - III d.C. \\
Manacapuru & VI d.C. - X d.C. \\
Paredão & VIII d.C. - XI d.C. \\
Guarita & IX d.C. - XVI d.C. \\
\hline
\end{tabular}

As fases cerâmicas foram historicamente estabelecidas com base na decoração, forma do vaso e, principalmente, pelo tipo de aditivo antiplástico utilizado. Na Amazônia Central era comum selecionar argilas de diversas fontes, limpá-las, misturá-las e adicionar antiplástico à pasta argilosa obtida. Essas fases têm o potencial de funcionar como “impressões digitais" de comunidades pré-coloniais (Moraes, 2006), embora ainda seja muito discutível a conexão entre fases cerâmicas e grupos étnicos ou famílias linguísticas (Mongeló, 2011). 


\subsection{A Tradição Borda Incisa}

As duas fases discutidas e analisadas neste trabalho, Manacapuru e Paredão, pertencentes ao macrocomplexo cerâmico Tradição Borda Incisa, são caracterizadas pela utilização de cauixi como tempero, uma esponja de água doce, e um dos antiplásticos mais recorrentes na região. O cauixi foi uma escolha cultural característica dessa tradição cerâmica e serviu como base para as tipologias realizadas nas décadas de 50 e 70 na Amazônia (Lima, 2008). A alta estabilidade térmica e as baixas taxas de aquecimento das espículas de sílica dessa esponja explicariam o sucesso na aplicação desse antiplástico nas pastas cerâmicas na planície amazônica durante o período pré-colombiano (Keding et al., 2010).

As cerâmicas da Tradição Borda Incisa são caracterizadas por bordas largas com topo achatado, decoração na superfície das bordas na forma de incisões. Além disso, em alguns casos, há pintura ou engobo vermelho decorando o interior ou o exterior dos vasos. Essa tradição engloba fases definidas por Hilbert (1968 apud Lima 2008) e outras fases cerâmicas nas bacias dos rios Amazonas e Orinoco.

O cauixi (Fig. 2.1) é encontrado em ambientes relacionados às águas pretas (rio Negro, lagos e pequenos igarapés). A sua coleta só é possível em uma época do ano, quando as águas baixam. Apesar da sazonalidade da oferta, seu uso é generalizado nas cerâmicas da Tradição Borda Incisa. Aparece, também, na composição das cerâmicas encontradas em sítios de água branca, como é o caso do Hatahara, indicando que, além do evidente armazenamento, havia também o transporte desse antiplástico (Lima 2008).

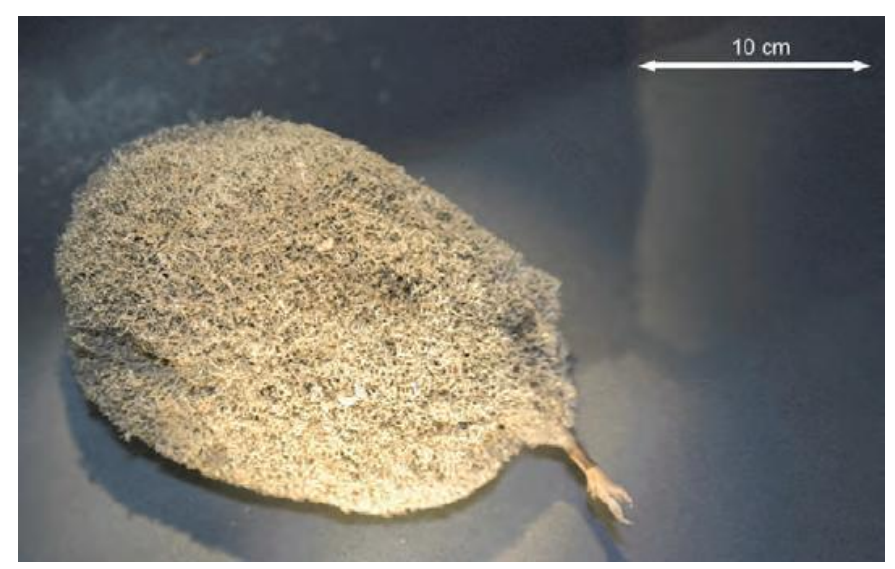

Figura 2.1 - Fotografia de cauixi in natura. O ramo no canto inferior direito corresponde ao ramo de ligação. Fonte: Jensen et al. (2011). 
O cauixi pode ser visto como um parâmetro para estudar a variabilidade do registro arqueológico. Apesar de poder ser considerado um elemento padronizador de toda a tecnologia cerâmica da Tradição Borda Incisa, importantes variações no seu uso foram observadas (Lima, 2008). Como exemplo, podem-se citar o tamanho e a orientação das espículas, que variam internamente às fases, de acordo com suas pastas e formas (Portocarrero, 2006). Dessa forma, a presença e modo de ocorrência do cauixi são parâmetros que trazem simultaneamente elementos homogeneizadores e diferenciais na classificação artefatual do registro arqueológico da Amazônia Central. As diferenças citadas seriam consequência das particularidades do processo produtivo. Contudo, as espículas da esponja aparecem em padrões semelhantes em materiais cronologicamente contíguos, mas em sítios diferentes. Essa afinidade entre seus processos produtivos sugere uma possível interação entre assentamentos (Lima, 2008, p. 282). Desta forma, a rede de interações formada envolveria uma troca de informações tecnológicas, que em última instância afetaria a variabilidade do registro, no sentido de permitir a identificação de um padrão na utilização do antiplástico.

É importante ressaltar que a vinculação entre cultura material e grupo étnico nem sempre pode ser realizada. Lima (2008), por exemplo, trata as fases Açutuba, Manacapuru e Paredão como detentoras de elementos tecnológicos e contextuais, cuja divisão em fases distintas tornou-se necessária. As fases cerâmicas são vistas como entidades independentes, podendo ser relacionadas de forma descritiva, distribucional e genética, na qual uma fase daria origem à outra localmente e sob influências regionais, por meio de mudanças de caráter cultural, político e socioeconômico de sociedades vivendo dentro de um mesmo sistema macrorregional. De qualquer forma, a região da Amazônia Central configura-se como um complexo mosaico cultural, no qual há uma fluidez entre as fases estudadas, a despeito de tentativas normativas e sequenciais ao se propor uma cronologia para a Amazônia (Lima, 2008).

As cerâmicas pertencentes à fase Manacapuru apresentam grande variabilidade formal, porém sempre com bordas expandidas; cauixi como antiplástico característico; decoração rebuscada, na forma de figuras abstratas zoomorfas e antropomorfas em incisões de todos os tipos; e engobo.

A fase Paredão é caracterizada por cerâmicas com variabilidade formal menor, em relação à fase Manacapuru, sendo característicos os grandes vasos com alça (fruteiras), cuias, 
grandes urnas funerárias e panelas sem decoração; a decoração é mais rara, aparecendo geralmente sob a forma de pintura vermelha com motivos geométricos em espiral e em linhas gregas e apêndices antropomórficos nas urnas; o antiplástico característico também é o cauixi. As cerâmicas dessa fase são geralmente muito finas, bem queimadas e acabadas. A essa fase estão associados correlatos de expansão demográfica na Amazônia Central, com o aparecimento de montículos. Há linhas interpretativas que consideram a fase arqueológica Paredão como uma manifestação de mudanças dentro da fase Manacapuru (Moraes, 2006).

Na cronologia disponível para as ocupações pré-coloniais na Amazônia, um pico populacional é observado em torno dos séculos XI e XII, concomitante a uma diminuição gradual da variabilidade formal e decorativa dos artefatos. (Lima, 2008, p. 395). Essa diminuição na variabilidade do registro poderia ser indicativa de uma necessidade maior de produção de cerâmica utilitária no contexto da fase Paredão. (Lima, 2008, p. 276).

\subsection{Processos naturais de formação do registro arqueológico na Amazônia Central}

Parte da crosta terrestre consiste de um mosaico de depósitos de várias idades, superfícies erodidas, e terras com distribuições previsíveis. Os vestígios arqueológicos, considerados depósitos após o seu uso num contexto sistêmico, estão sujeitos aos mesmos processos naturais de enterro, intemperismo e erosão que afetam a preservação e distribuição de depósitos de origem não cultural. Esses processos naturais podem preservar, alterar ou destruir o contexto deposicional original, sendo que o contexto ambiental observado no momento de uma escavação não é, necessariamente, correlato do contexto ambiental antigo (Bettis III, 1992).

Apesar de os primeiros habitantes da Amazônia terem, provavelmente, utilizado uma série de matérias-primas diferentes para produzir seus artefatos e organizar seus modos de vida, as condições normalmente desfavoráveis à preservação de materiais orgânicos fez com que restassem quase que apenas instrumentos de pedra lascada e polida e refugos de sua produção, como as lascas (Neves, 2006).

A preservação de uma grande quantidade de material cerâmico e o fato de ser encontrado em muitos sítios arqueológicos estão ligados ao potencial de conservação obtido a partir da queima da argila. Se bem queimadas, as cerâmicas são virtualmente indestrutíveis. 
Desta forma, não é de surpreender o fato de que para períodos posteriores à introdução das cerâmicas na América do Sul (em torno de 7000 a.C., segundo Renfrew \& Bahn [2007], embora ainda não haja um consenso [Neves, 2006]), esses materiais tenham sido a principal fonte de evidências. Os atributos físicos que podem ser estudados a partir da análise cerâmica são, por exemplo, a forma, a decoração superficial, o conteúdo mineral e mesmo resíduos orgânicos deixados dentro dela. É importante dizer que solos ácidos podem danificar a superfície das cerâmicas, e argilas porosas ou mal queimadas podem se fragilizar em ambientes úmidos. Apesar da alta frequiência com que cerâmicas são encontradas nos sítios arqueológicos, outros objetos como ferramentas de madeira ou cestos, podem ter igualado, ou mesmo superado, em abundância e importância os artefatos cerâmicos (Renfrew \& Bahn, 2007).

Com relação aos materiais orgânicos, sua conservação no registro arqueológico é determinada pelo material circundante e pelo clima (local e regional). Os climas tropicais são os mais destrutivos, com sua combinação de chuvas abundantes, solos ácidos, altas temperaturas, alta umidade, erosão e a abundância de vegetação e insetos. Florestas tropicais podem enterrar sítios rapidamente, com suas raízes que podem destruir construções de alvenaria e outros materiais, enquanto chuvas torrenciais gradualmente destroem pinturas e rebocos, assim como promove o rápido decaimento de objetos ou construções de madeira (Renfrew \& Bahn, 2007, p.47-48).

Uma exceção às condições de conservação acima mencionadas refere-se à presença de montículos, cuja função poderia ser funerária ou habitacional, provavelmente para evitar o empoçamento de água na parte interna da habitação durante o período de chuvas (Moraes, 2006, p. 169). Os materiais construtivos eram compostos por terra preta antropogênica e cerâmicas, os quais funcionavam como uma cobertura que encapsulava o seu conteúdo, fazendo com que permanecesse em estado de ótima conservação, fato contrastante com o resto dos solos amazônicos (Lima, 2008, p. 112). Desta forma, a função funerária de alguns montículos pôde ser identificada por uma série de sepultamentos humanos preservados. Adicionalmente, foram encontrados vários ossos de animais em ótimas condições de conservação. Em contextos arqueológicos, a matéria orgânica preservada possui potencial para datação de sítios (Renfrew \& Bahn, 2007, p. 96-128). 
Aqui cabe uma distinção entre artefatos e ecofatos. Artefatos são objetos feitos ou modificados por seres humanos, como ferramentas líticas, cerâmicas e armas metálicas. Artefatos têm potencial analítico para fornecer evidências esclarecedoras de várias questões arqueológicas importantes, muito além das tecnológicas. Ecofatos, por sua vez, seriam vestígios orgânicos e também vestígios ambientais, como esqueletos, ossos de animais e vestígios de plantas, bem como solos e sedimentos. Os ecofatos também podem lançar uma luz sobre atividades humanas do passado, como a dieta das pessoas e as condições ambientais sob as quais elas viviam (Renfrew \& Bahn, 2007, p.38).

Um exemplo do potencial analítico dos ecofatos é dado a seguir. A domesticação de plantas é uma condição fundamental para a emergência da agricultura (Neves, 2006). Os centros de domesticação podem ser identificados a partir dos vestígios paleobotânicos encontrados em sítios arqueológicos. Dentro da Amazônia, há uma área específica que pode ter sido um importante centro de domesticação: a bacia do alto Madeira e seus afluentes, no atual estado de Rondônia. A partir de evidências botânicas e genéticas, essa região foi identificada como o centro de domesticação da mandioca e da pupunha, duas das mais importantes plantas cultivadas na Amazônia atualmente. Talvez, não por acaso, essa seja uma das poucas áreas onde há evidências claras de ocupação humana contínua durante todo o Holoceno (idem)

A presença de solo ao longo do registro arqueológico indicaria a passagem de algum período de tempo sob condições de relativa estabilidade da paisagem. Além disto, uma camada de solo isolada numa sequência estratigráfica denotaria um hiato entre eventos deposicionais. Processos deposicionais lentos durante ocupações múltiplas de um sítio arqueológico resultariam num registro que seria uma mistura de conjuntos artefatuais dessas múltiplas ocupações (Holliday, 1992). A formação de solo em um sítio arqueológico pode influenciar profundamente a natureza do registro. Longos períodos de tempo podem ser representados pela superfície de terra, de forma que registros de uma longa ocupação podem estar comprimidos em zonas de apenas poucos centímetros.

Além da importância dos solos naturais na formação do registro arqueológico na Amazônia Central, não se pode deixar de citar a ocorrência das terras pretas de índio, um tipo de solo antropogênico, e uma das principais evidências associadas à existência de grandes assentamentos na região. Os primeiros teóricos haviam considerado esses solos como 
desenvolvidos a partir de antigos depósitos de cinzas vulcânicas ou material orgânico acumulado no fundo de lagos, e os artefatos encontrados seriam devido às ocupações indígenas da área, atraídas pela fertilidade natural do solo. Atualmente, no entanto, a maioria dos pesquisadores acredita que as terras pretas são, de fato, depósitos culturais criados pelo acúmulo de lixo disposto nas proximidades de áreas de habitação. A ocorrência destas terras na Amazônia tem servido para balizar teorias acerca de padrões de assentamento pré-coloniais, densidade de população e desenvolvimento cultural dos povos que habitaram a região (Woods \& McCann, 1999).

As alterações nas cerâmicas, resultantes de processos físicos e químicos podem causar adição, depleção ou modificação de um material. Exemplos de modificações relacionadas ao uso podem ser: depósitos de carbono (a partir de comida queimada ou fuligem de um forno), resíduos orgânicos, e abrasão (relacionada a requisições mecânicas na utilização de um pote, e também a outras fontes não mecânicas, como erosão salina ou rachaduras de origem térmica). Essas modificações, ainda que de origem natural, ocorrem no contexto sistêmico de utilização das cerâmicas. Alterações pós-deposicionais incluem: queima não intencional (a partir de incêndios, por exemplo), incorporação de matéria orgânica do solo, abrasão fluvial e quebra (Skibo, 1992). No caso da Amazônia, ainda são importantes os processos de bioturbação, em função da intensa dinâmica da floresta no que diz respeito ao ciclo da matéria orgânica, e que podem gerar inversões estratigráficas nos depósitos.

Cabe aqui um exemplo de influência de eventos pós-deposicionais na interpretação do registro arqueológico. Na região entre a Amazônia Central e baixo Amazonas, encontra-se uma fase cerâmica denominada Itacoatiara, composta de cerâmicas similares às fases Açutuba e Manacapuru. Essa fase foi alvo de intensos debates, pois as cerâmicas foram encontradas em um sítio multicomponencial sobre materiais relativos à fase Guarita. A posição estratigráfica, bem como outros fatores, levou Hilbert a classificá-las como pertencentes ao complexo mais recente, pertencente à Tradição Incisa e Ponteada. No entanto, não há cerâmicas dessa fase na Amazônia Central e Lathrap, entre outras coisas, defendeu que a fase Itacoatiara seria associada à Tradição Barrancóide (ou Tradição Borda Incisa), de ocorrência mais antiga. Perturbações estratigráficas durante o processo de urbanização da região, bem como processos erosivos transformaram a topografia da margem do rio Amazonas e, provavelmente, 
contribuíram para as conjunturas conflitantes propostas para essa fase cerâmica (Lima, 2008, p. 367).

\section{7. Área de estudo: sítios arqueológicos Lago Grande e Osvaldo}

Neste trabalho, os sítios arqueológicos Lago Grande e Osvaldo foram escolhidos para tratar de questões arqueológicas e arqueométricas devido ao intensivo trabalho de escavação realizado nos mesmos; proximidade geográfica $(\approx 9 \mathrm{~km})$; unicomponencialidade do material cerâmico; por representarem um microcosmo da Amazônia Central (Portocarrero, 2003); contemporaneidade; e por haver bibliografia de referência bem fundamentada (Donatti, 2003; Moraes, 2006; Portocarrero, 2006, Lima, 2008; Mongeló, 2011). Um dos aspectos importantes relacionados a esses sítios é que eles apresentaram evidências de grandes assentamentos humanos fora de áreas de várzea. Essa constatação é evidenciada, entre outros fatores, pela presença e extensão de terra preta, como indício de povos vivendo em grandes aldeias de ocupação contínua, com a prática de agricultura e pesca. Esse fato levou os arqueólogos a questionarem se a alta produtividade do solo de regiões de várzea seria realmente uma condição necessária para o sedentarismo e crescimento populacional, como proposto em modelos baseados na dicotomia várzea vs. terra firme (Portocarrero, 2006). Dessa maneira, o estudo desses sítios estaria inserido no contexto geral da questão da ocupação amazônica pré-colonial.

Os sítios Lago Grande e Osvaldo situam-se na região de confluência dos rios Negro e Solimões (Fig. 2.2), no município de Iranduba, AM (Fig. 2.2). O rio Solimões é um rio de "águas brancas”, devido à sua coloração barrenta, segundo uma tipologia clássica proposta no século XIX. Ele possui amplas áreas de várzea, e seu aspecto denso e barrento deve-se aos sedimentos que traz desde sua nascente nos Andes centrais, no território peruano. Os Andes são uma formação geológica recente, sendo que suas montanhas sofrem um processo erosivo intenso, devido às variações sazonais de temperatura e regime de chuvas, justificando a carga sedimentar do Solimões, rica em nutrientes, fertilizando anualmente suas planícies de inundação (Donatti, 2003; Neves, 2006). 


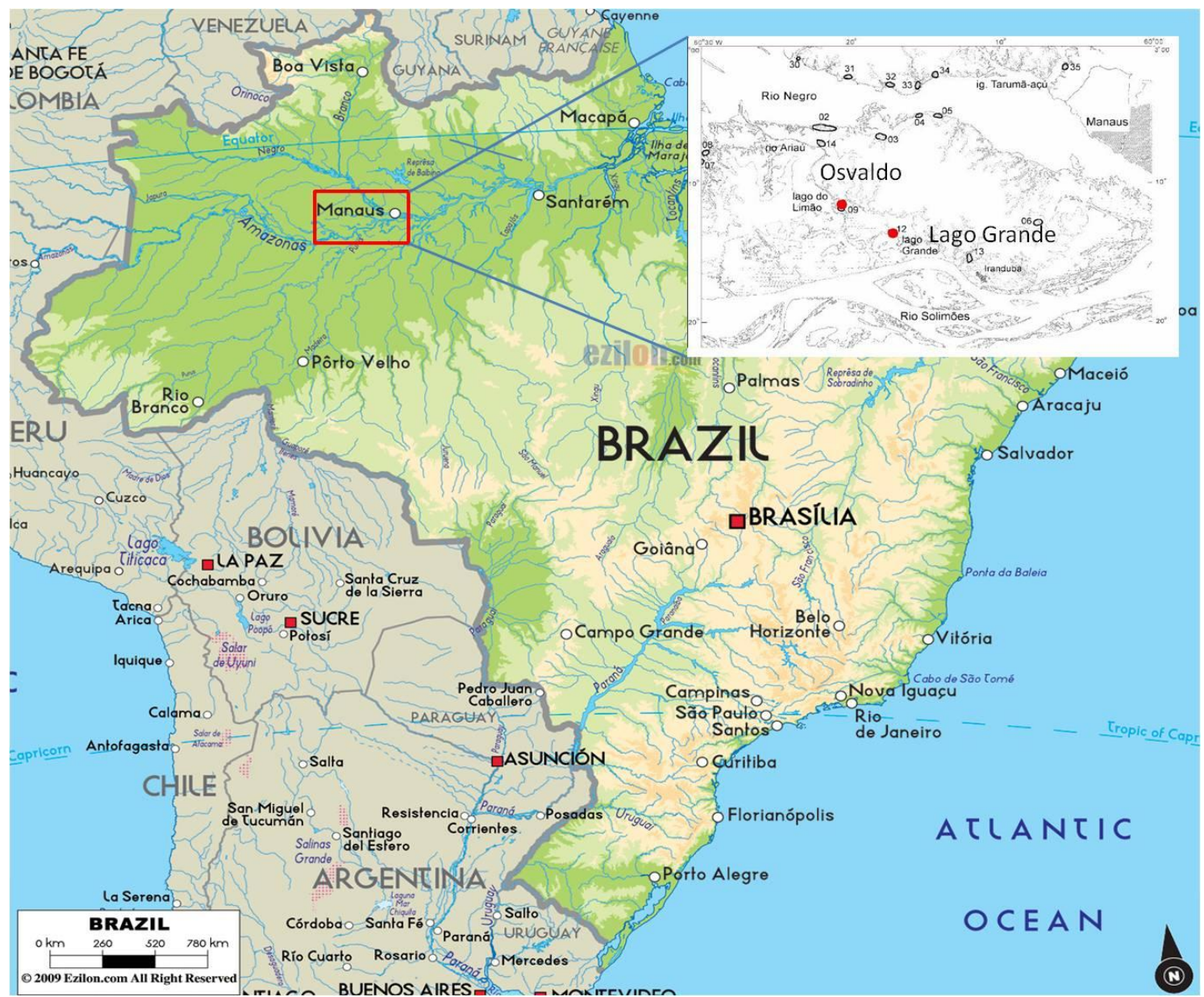

Figura 2.2 - A região de confluência dos rios Negros e Solimões na Amazônia Central, indicando os dois sítios estudados. Fontes: Ezilon maps e Portocarrero (2006).

O rio Negro é um rio de "águas pretas", segundo a mesma tipologia clássica adotada para o rio Solimões, pois possui poucos nutrientes devido à alta acidez e baixo conteúdo mineral, já que sua cabeceira encontra-se em regiões geologicamente mais antigas, de modo que esse rio não fertiliza sua planície de inundação. Entretanto, ele apresenta alta biodiversidade e deposita sedimentos arenosos formadores de extensas praias de areia branca em suas margens, as quais são intercaladas por matas de igapó (Donatti, 2003; Neves, 2006).

A área de interflúvio é composta por colinas e morros, cortadas sazonalmente por igarapés. A cobertura vegetal original da região é a da floresta amazônica, embora haja um desmatamento intenso atualmente. Os solos apresentam pH ácido e baixa capacidade agrícola, 
em geral. Em menor proporção, existem áreas de terra de origem antrópica, as terras pretas de índio, ricas em fosfato e formadas por intenso acúmulo de matéria orgânica.

Um padrão de assentamento recorrente na região de confluência é o dos sítios situados às margens dos lagos de interflúvio, que são amplamente conectados por redes de igarapés, ligando-se tanto a rios de água branca como de água preta, dependendo da época do ano em questão. Esses sítios, em geral, ocupam o topo das penínsulas que se projetam sobre os lagos da região. Possuem topos aplainados e suas vertentes podem ser suaves ou abruptas (Lima, 2008). Na região de confluência dos rios Negro e Solimões existem mais de 100 sítios arqueológicos cadastrados. Lago Grande e Osvaldo estão inseridos nesse conjunto de sítios, nos quais as escavações sugeriram a existência de ocupações associadas às fases cerâmicas Açutuba, Manacapuru e Paredão (Donatti, 2003; Machado, 2006; Portocarrero, 2006).

O sítio Osvaldo (Fig. 2.3) está localizado em uma península, com dimensões estimadas em 700 x 250 m, sendo limitado pelo lago do Limão a norte e por igarapés a leste e oeste. São encontrados vestígios arqueológicos até cerca de $1 \mathrm{~m}$ de profundidade e é composto em sua maioria pelas terras pretas antrópicas e por cerâmicas, majoritariamente, da fase Manacapuru, num contexto unicomponencial. Esta característica de seu registro arqueológico torna o estudo do sítio relevante para estudos de padrões de assentamento e uso do espaço. Apesar de a fase cerâmica preponderante no registro arqueológico de Osvaldo ser a Manacapuru, foram encontrados fragmentos cerâmicos Paredão em menor proporção. Esse achado fortaleceria a hipótese de interações socioeconômicas entre grupos que habitavam a região no período pré-colonial. (Portocarrero, 2006; Lima, 2008). Até o momento de elaboração deste trabalho, as escavações arqueológicas no sítio Osvaldo priorizaram uma varredura espacial, na forma de tradagens e sondagens. Mongeló (2011) identificou 14\% de fragmentos Paredão e 86\% de Manacapuru na unidade S710 E1966 do sítio. 


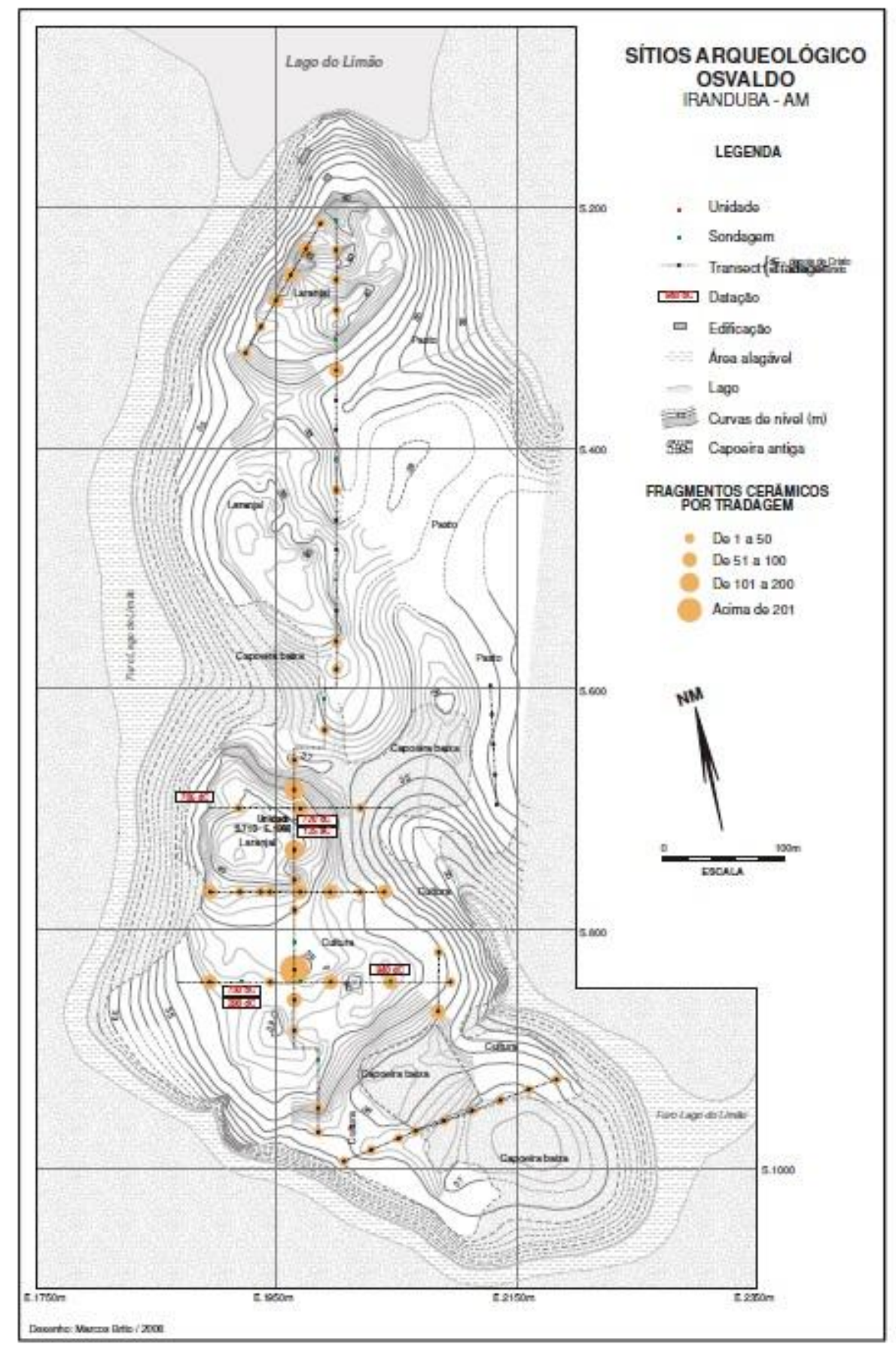

Figura 2.3 - Planta topográfica do sítio Osvaldo. Fonte: Lima (2008).

O sítio Lago Grande (Fig. 2.4) está localizado em uma área de mata secundária em uma das penínsulas que avançam para o lago de mesmo nome. Possui dimensões de aproximadamente 500 x $400 \mathrm{~m}$ (Donatti, 2003). Foi escolhido para trabalhos intensivos de 
escavação por apresentar alta densidade de material arqueológico associado à terra preta $\mathrm{e}$ estruturas bem preservadas, como valas defensivas em local estratégico. As cerâmicas estavam associadas à terra preta e apareciam, pelo menos, até 1m de profundidade (Donatti, 2003). Em termos de presença de fase cerâmica, a tendência apresentada por Lago Grande foi oposta à apresentada por Osvaldo: a maioria do material cerâmico foi classificado como Paredão, embora cerâmicas Manacapuru tenham sido encontradas em menor proporção, fortalecendo, de maneira análoga a Osvaldo, a hipótese de interação entre os grupos que habitavam a região.

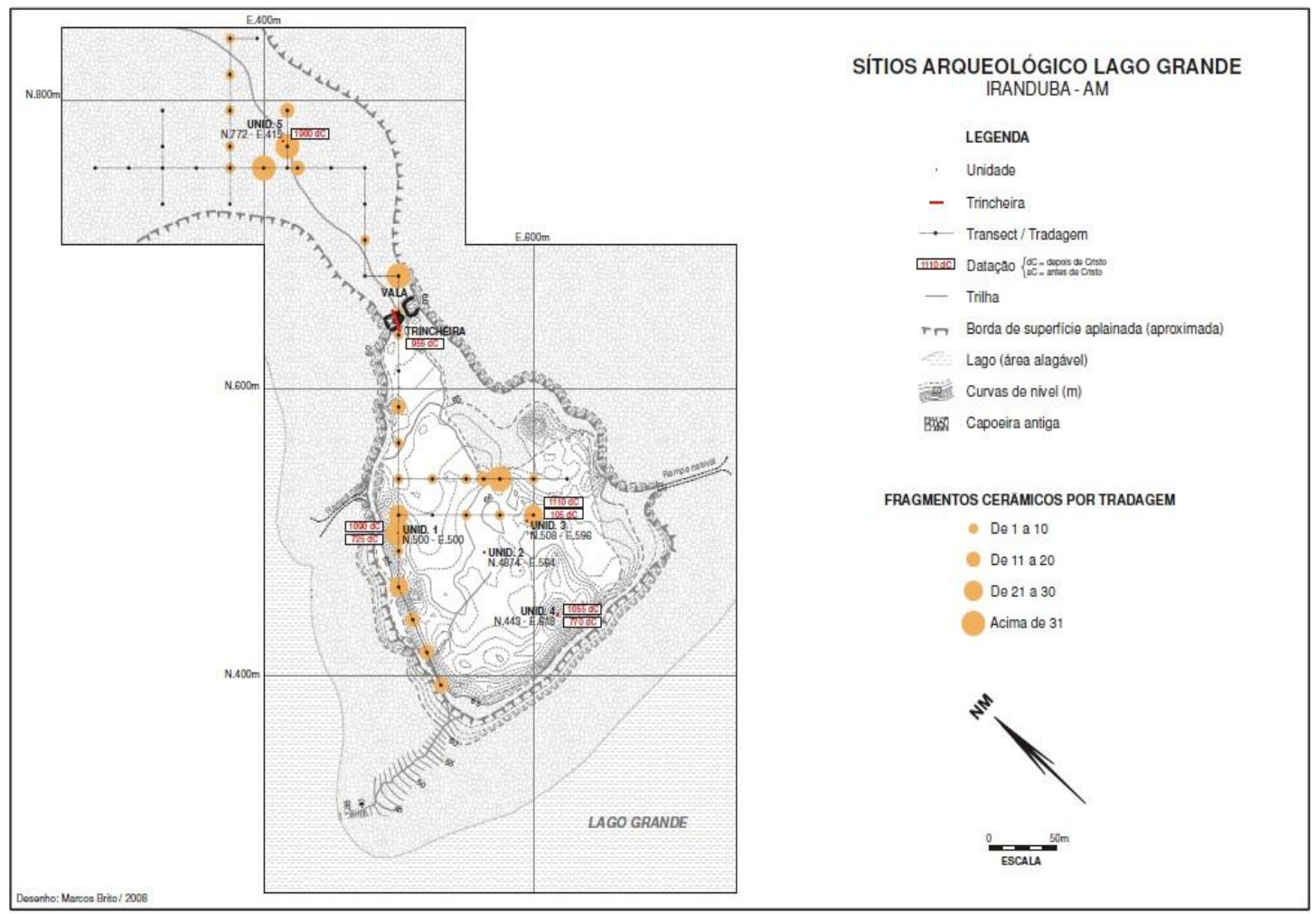

Figura 2.4 - Planta topográfica do sítio Lago Grande. Fonte: Lima (2008).

O sítio Lago Grande possui seis unidades de escavação, sendo que as amostras deste trabalho pertencem às unidades U1, U3 e U4, associadas a montículos (Donatti, 2003). Além dessas, há três outras unidades: U2, associada a uma praça central do sítio; uma unidade associada a uma trincheira localizada no istmo da península (vala); e outra, U5, fora da península (Fig. 2.4). Mongeló (2011) identificou 15\% de fragmentos Manacapuru e 85\% de 
Paredão para o sítio, além de alguns fragmentos Guarita. Essa distribuição não é uniforme ao longo da estratigrafia. Até $50 \mathrm{~cm}$ abaixo da superfície do solo, não foi identificada uma quantidade significativa de fragmentos Manacapuru. De $50 \mathrm{~cm}$ em diante, os fragmentos dessa fase cultural tornam-se mais abundantes. Acredita-se que esse sítio pertença a um contexto unicomponencial, ou ocupação contínua (Donatti, 2003), apesar de pesquisas atuais terem levantado a hipótese de multicomponencialidade, ou múltiplas ocupações, para o sítio (Guilheme Mongeló, informação pessoal). De acordo com datações radiocarbônicas (Lima, 2008), o sítio foi ocupado continuamente até o final de sua existência, tendo o ápice demográfico ocorrido em torno de 680 d.C.

Alguns fragmentos cerâmicos de Lago Grande e Osvaldo não puderam ser associados a nenhuma das fases cerâmicas, Manacapuru ou Paredão, e a existência de uma nova fase, mais antiga e denominada como Açutuba, foi identificada por Lima, Neves e Petersen (Lima et al., 2006).

A proximidade e densidade dos dois sítios estudados, bem como observações da existência de cerâmica Paredão associada à Manacapuru por toda a área do sítio Osvaldo (Portocarrero, 2007), e da relação inversa no sítio Lago Grande, como observado por Donatti (2003) e Tamura (apud Lima, 2008), tornam esses sítios interessantes para se estudar possíveis relações de troca. Do ponto de vista arqueológico, os fatos que respaldam a hipótese de trocas culturais entre os dois sítios, como troca comercial, são resumidos a seguir:

Ligação fluvial entre Lago do Limão e Lago Grande por meio de igarapés, durante o período de cheia dos rios Negro e Solimões. Essa interligação entre os lagos e a distância entre os sítios (aproximadamente $9 \mathrm{~km}$ ) facilitaria o contato entre os povos habitantes dessas regiões. Contudo, como Portocarrero relata (2006), há evidências de relações de intercâmbio por via fluvial entre áreas com distâncias de mais de 1500 km na Amazônia, fazendo com o que o fator distância não fosse necessariamente limitante.

- A evidência de sistemas regionais de troca entre povos Arawak, tronco ao qual pertenceriam os povos habitantes de Lago Grande e Osvaldo, nos quais haveria a integração de bens, territórios, lideranças e ideologia (Moraes, 2006).

- A existência de peças híbridas, com características Manacapuru e Paredão, como possíveis correlatas de casamento exogâmico (Lima, 2008; Mongeló, 2011). 
São os maiores sítios encontrados na região do Lago do Limão e Lago Grande, e um período de contemporaneidade entre os dois sítios, no final da ocupação de Osvaldo e início da ocupação de Lago Grande, a partir de 680-720 a.C., aproximadamente (Portocarrero, 2006).

Os antiplásticos mais comuns nos fragmentos arqueológicos dos dois sítios são o cauixi, e caco moído e cariapé, em menor proporção (Donatti, 2003; Portocarrero, 2006; Lima, 2008). Sua adição à pasta cerâmica tinha o objetivo de proporcionar secagem mais lenta, queima mais homogênea e melhorar as propriedades termomecânicas dos artefatos (Rice, 1987).

Na região de confluência dos rios Negro e Solimões, Lima (2008) procurou entender as relações entre as fases Manacapuru e Paredão. A autora entende que a materialidade desse sistema social está impressa na paisagem na forma de terras pretas, montículos artificiais e a circularidade dos assentamentos, além da própria indústria cerâmica. A análise comparativa da cerâmica em perspectiva cronológica, local e regional serviu como uma fonte de informações acerca de elementos indicativos de uma esfera de interações.

Esta tese de doutoramento é o primeiro estudo que visa testar tais hipóteses arqueometricamente, por meio da análise de possíveis processos de interação entre os sítios arqueológicos Lago Grande e Osvaldo, focando especificamente em trocas materiais e/ou tecnológicas potenciais entre os mesmos por métodos analíticos das ciências físicas. Pelo fato de ter sido encontrado material cerâmico exógeno e contemporâneo de fases distintas às dominantes nos dois sítios, procurou-se testar se redes de troca entre os mesmos, dentro de um contexto mais geral e complexo de esferas de interação, poderiam explicar esses padrões. Essas possíveis redes de troca entre os dois sítios poderiam ser correlatos de um contexto mais abrangente, relacionado a um possível sistema regional de interação na região, observados nas regiões periféricas da Amazônia, mas ainda pouco estudado na Amazônia Central (Mongeló, 2011). Longe de pressupor um teste definitivo para tais modelos, o objetivo principal é o de fornecer material adicional para as discussões arqueológicas por meio de novas informações geradas na análise do registro arqueológico cerâmico de Lago Grande e Osvaldo, considerados como um microcosmo da Amazônia Central. 


\section{CAPítulo 3}

\section{MATERIAIS CERÂMICOS - FUNDAMENTOS E APLICAÇÕES EM ARQUEOLOGIA}

\subsection{Introdução}

Materiais sólidos podem ser divididos em três categorias básicas: metais, cerâmicos e polímeros. Essa classificação é fundamentada, principalmente, na composição química e estrutura atômica, sendo que a maioria dos materiais encaixa-se em um grupo distinto, embora existam materiais intermediários e compósitos (Callister, 2007).

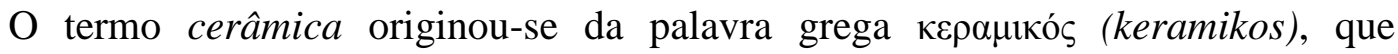
significa coisa queimada, sugerindo que as propriedades típicas e desejáveis desses materiais são normalmente conseguidas por um tratamento térmico à alta temperatura, denominado queima, ou ignição (Boch \& Nièpce, 2007; Callister, 2007).

Cerâmicas, do ponto de vista microscópico, são compostos inorgânicos formados entre elementos metálicos e não metálicos, nos quais, para a maioria dos materiais desse tipo, as ligações interatômicas são totalmente iônicas, ou predominantemente iônicas, com alguma natureza covalente (Tab. 3.1). Alguns dos compostos mais frequentes que se encaixam na classificação de compostos cerâmicos são os óxidos (ex.: $\mathrm{Si}_{2} \mathrm{O}_{3}, \mathrm{Al}_{2} \mathrm{O}_{3}, \mathrm{BaTiO}_{3}$ ), nitretos (ex.: $\mathrm{Si}_{3} \mathrm{~N}_{4}, \mathrm{Fe}_{2} \mathrm{~N}, \mathrm{BN}$ ), carbetos (ex.: $\mathrm{SiC}, \mathrm{WC}$ ), silicatos (ex.: caulinita, $\mathrm{Al}_{2} \mathrm{Si}_{2} \mathrm{O}_{5}(\mathrm{OH})_{4}$ ) e haletos (ex.: LiF) (Rahaman, 2003; Callister, 2007).

Outra classificação possível para os materiais cerâmicos é dividi-los em cerâmicas tradicionais e avançadas. As cerâmicas tradicionais são aquelas em que a matéria-prima principal é argila. As cerâmicas avançadas possuem propriedades especiais e/ou aprimoradas para aplicações específicas na indústria atual, produzidas a partir de tecnologias de processamento específicas que não utilizam materiais silicatados ou argilas, mas outras matérias-primas com alto grau de processamento devido a exigências de engenharia. Normalmente, possuem propriedades mecânicas superiores, alta resistência à corrosão e 84 
oxidação, ou propriedades ópticas, elétricas e magnéticas específicas (Barsoum, 2003; Carter \& Norton, 2007; Heimann, 2010).

Tabela 3.1 - Percentual de caráter iônico das ligações interatômicas em alguns materiais cerâmicos. Fonte: Callister (2007).

\begin{tabular}{c|c}
\hline Composto & Percentual de caráter iônico (\%) \\
\hline $\mathrm{CaF}_{2}$ & 89 \\
$\mathrm{MgO}$ & 73 \\
$\mathrm{NaCl}$ & 67 \\
$\mathrm{Al}_{2} \mathrm{O}_{3}$ & 63 \\
$\mathrm{SiO}_{2}$ & 51 \\
$\mathrm{Si}_{3} \mathrm{~N}_{4}$ & 30 \\
$\mathrm{ZnS}$ & 18 \\
$\mathrm{SiC}$ & 12 \\
\hline
\end{tabular}

Alguns objetos cerâmicos tradicionais são apresentados na Fig. 3.1. Esses materiais estão presentes em nossa vida diária, tendo aplicações nos campos da eletrônica, informática, comunicação, indústria aeroespacial, entre outras modalidades industriais.

Em relação ao comportamento mecânico, as cerâmicas são relativamente rígidas, em comparação com os metais, além de ser um material muito duro. Em contrapartida, são materiais frágeis (materiais que suportam pouca deformação até o momento da fratura, cerca de $0,1 \%$ ), apresentando baixa ductilidade e alta susceptibilidade à fratura. As cerâmicas são materiais tipicamente isolantes à passagem de calor e eletricidade, além de ser mais resistente a altas temperaturas e ambientes agressivos que metais e polímeros. Em relação às propriedades ópticas, as cerâmicas podem ser transparentes, translúcidas ou opacas. Finalmente, alguns materiais cerâmicos, como o $\mathrm{Fe}_{3} \mathrm{O}_{4}$, exibem comportamento magnético (Barsoum, 2003). 


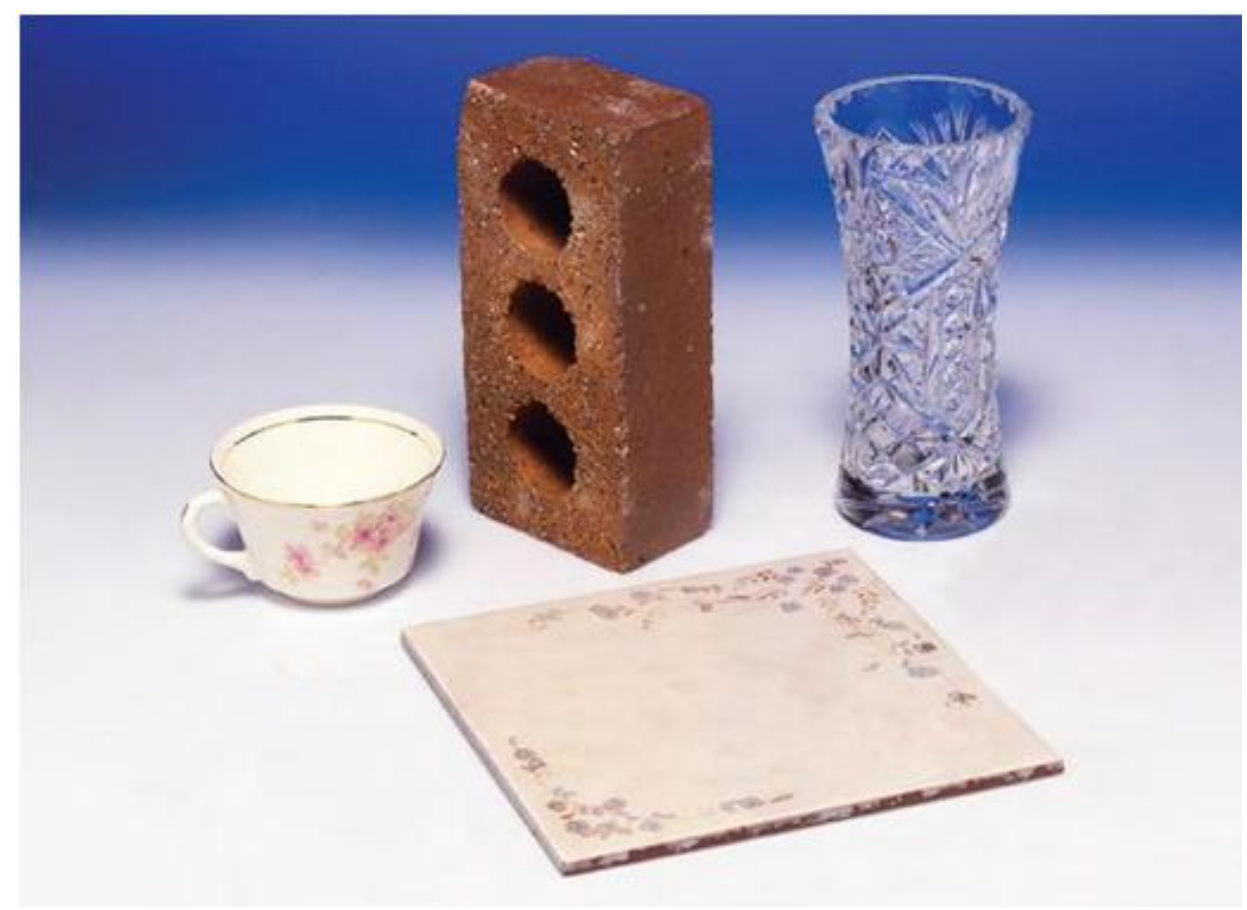

Figura 3.1 - Objetos comuns fabricados com materiais cerâmicos: xícara de chá chinesa, tijolo de construção, azulejo e vaso de vidro. Fonte: Callister (2007).

A Tab. 3.2 mostra a abundância dos minerais mais frequentemente encontrados na crosta terrestre, e que são minerais comuns em materiais cerâmicos tradicionais.

Tabela 3.2 - Abundância de minerais na crosta terrestre. Fonte: Carter \& Norton (2007).

\begin{tabular}{c|c}
\hline Grupos minerais & Volume (\%) \\
\hline Feldspatos & 58 \\
Piroxenos, anfibólios & 13 \\
Quartzo & 11 \\
Micas, cloritas, minerais argilosos & 10 \\
Carbonatos, óxidos, sulfetos, haletos & 3 \\
Olivinas & 3 \\
Epídotos, aluminossilicatos, granadas, zeólitas & 2 \\
\hline
\end{tabular}




\subsection{Origens}

Minerais silicatados, presentes nas argilas, compõem a maior parte da crosta terrestre. Sua abundância justifica a existência de artefatos cerâmicos, presentes em praticamente todas as partes do mundo.

Os primeiros materiais cerâmicos utilizados pelo homem, no período Paleolítico, foram sílex (rocha sedimentar silicatada, constituída de cristais microscópicos de quartzo, ou quartzo criptocristalino) e obsidianas (um tipo de vidro natural formado a partir de precipitados das lavas vulcânicas), as quais exibem fraturas concoidais, semelhante a muitas cerâmicas modernas, como zircônia cúbica e vidros. Essa propriedade de fratura possibilitou a obtenção de extremidades afiadas, necessárias na confecção de armas e ferramentas (Carter e Norton, 2007).

Durante a última parte do período Neolítico, ou Período da Pedra Polida, as cerâmicas tornaram-se importantes. O conjunto mais antigo de argilas queimadas que foi encontrado é composto por mais de 10.000 fragmentos de estatuetas datados em aproximadamente 25.000 anos, encontradas em 1920, na Morávia, República Tcheca, por Dolní Vestonice (Carter e Norton, 2007). As estatuetas (Fig. 3.2) retratavam lobos, cavalos, raposas, pássaros, gatos, ursos e mulheres. Esses materiais eram queimados em fornos abertos, com temperaturas que não excediam $900{ }^{\circ} \mathrm{C}$ (Boch \& Nièpce, 2007). Essas manifestações, ainda no final do Período Paleolítico, permaneceram aparentemente isoladas, até que foram encontradas as primeiras evidências de produção de vasos cerâmicos, tal como subsistiu até os dias atuais, perto de Nagasaki, no Japão. Lá foram encontrados fragmentos datados em 12.000 anos. Esse tipo de cerâmica foi denominado de cerâmica Jomon, produzida por grupos de caçadores-coletores, e já apresentava uma utilização complexa de terras argilosas, caracterizada pela adição, provavelmente voluntária, de fibras orgânicas e mica. Esses vasos, assim como os produzidos no Oriente Próximo, foram queimados a baixas temperaturas, se comparados com as cerâmicas produzidas atualmente.

Recentemente, em 2009, foram encontrados fragmentos cerâmicos ainda mais antigos, datando entre 18.300 e 15.430 AP (Antes do Presente: ano-base = 1950) (Heimann, 2010). 


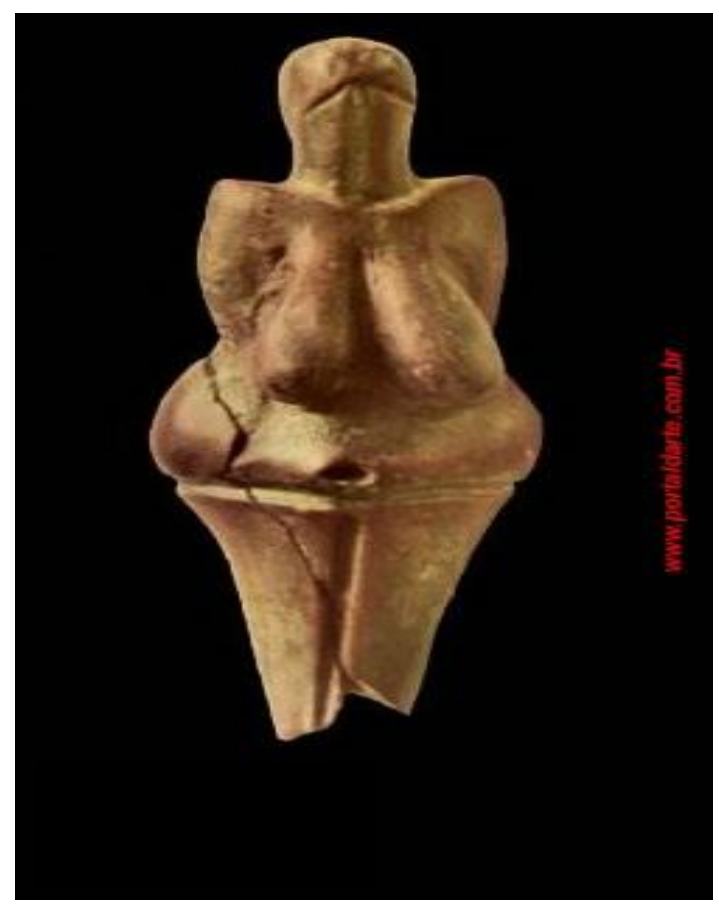

Figura 3.2 - Vênus de Vestonice, uma estatueta de terracota de 25.000 anos, com aproximadamente $10 \mathrm{~cm}$ de altura, encontrada em 1920, na República Tcheca, por Dolní Vestonice. Acredita-se tratar de um amuleto da fertilidade. Fonte: www.portaldarte.com.br.

Em torno de 6400 a.C., a produção cerâmica já era uma arte muito bem desenvolvida, e data desse milênio a explosão na utilização de materiais cerâmicos na Ásia, Orientes Próximos e Médio e na Europa. Esse fato resultou de uma mudança no estilo de vida, necessidades e crenças dos povos antigos, com o advento dos processos de sedentarismo, agricultura e criação de gado (Boch \& Nièpce, 2007).

$\mathrm{O}$ advento das cerâmicas revolucionou a dieta ao fornecer um meio para que a fervura e o cozimento fossem introduzidos no preparo da comida, além de fornecer um meio adequado ao armazenamento de bens perecíveis e às artes esculturais (Leute, 1987, p. 104).

O aparecimento da cerâmica no Novo Mundo ocorreu posteriormente em relação ao Velho Mundo, por uma diferença de aproximadamente 5000 anos. Além disso, a utilização de coberturas esmaltadas e da roda de oleiro não foram observadas em evidências arqueológicas da América pré-colombiana. Da mesma forma, os fornos não eram largamente utilizados. Em geral, as cerâmicas pré-históricas eram queimadas em fogueiras ao ar livre, em vez de câmaras fechadas. A faixa comum para as temperaturas de queima era de $700{ }^{\circ} \mathrm{C}$ até 
$900{ }^{\circ} \mathrm{C}$. Revestimentos esmaltados, rodas de oleiro e fornos foram, provavelmente, apenas introduzidos quando do contato com exploradores europeus, no século XVI (Rice, 1987, p. 20).

Os utensílios cerâmicos pré-históricos produzidos na América compreendiam artefatos utilitários para o cozimento, recipientes para a alimentação e armazenamento (pratos, tigelas, jarros, vasos, copos), e utensílios ritualísticos e decorativos, com variações locais na forma e acabamento. Grandes urnas eram produzidas na América do Sul e utilizadas para sepultamentos, sendo o ser falecido posicionado, normalmente, em posição fetal. Havia também vasos menores para armazenar vestígios de cremação (Rice, 1987, p. 22).

\subsection{Propriedades gerais das cerâmicas}

De maneira geral, as características principais dos materiais cerâmicos podem ser enunciadas qualitativamente da seguinte forma, do ponto de vista da ciência dos materiais (Barsoum, 2003):

- Alta dureza (resistência à abrasão);

- Alta resistência ao desgaste;

- Alta fragilidade (pequena deformação plástica até o momento da fratura);

- Alta resistência ao choque térmico;

- Refratários (capazes de suportar altas temperaturas);

口 Boas propriedades isolantes (térmica e elétrica);

- Alta estabilidade química;

Alta resistência à oxidação.

É importante salientar, que na tecnologia de cerâmicas atual, ou produção de cerâmicas avançadas, há exceções às propriedades listadas acima. 


\subsection{Estruturas cristalinas}

A maioria dos materiais cerâmicos, do ponto de vista microscópico, é formada por compostos policristalinos, cujos tamanhos de grão estão na faixa de 1 a $50 \mu \mathrm{m}$. A forma e tamanho dos grãos, juntamente com a porosidade característica, presença de fases secundárias e defeitos cristalinos definem a microestrutura de uma cerâmica, e dependem da maneira como os átomos estão arranjados. O conhecimento da microestrutura é importante, pois muitas das propriedades desses materiais dependem dela (Barsoum, 2003; Carter \& Norton, 2007).

As cerâmicas são compostas por pelo menos dois elementos, o que faz com que suas estruturas cristalinas sejam geralmente mais complexas que a dos metais.

Quando um material cerâmico apresenta ligações interatômicas predominantemente iônicas, as estruturas cristalinas podem ser consideradas como compostos por ânions e cátions, em vez de átomos. A estrutura do cristal, em materiais cerâmicos cristalinos, é influenciada por duas características dos íons componentes: a magnitude das cargas elétricas e os tamanhos relativos de cátions e ânions. Em relação à primeira característica, o cristal deve ser eletricamente neutro. Em relação à segunda, observa-se a tendência de um cátion ter como vizinhos o maior número de ânions possível, e o mesmo é válido para os ânions.

De maneira semelhante para os metais, as várias estruturas cristalinas cerâmicas podem ser consideradas em termos de planos de íons densamente compactados e formadas pela repetição de células unitárias. Esses planos densamente compactados são, normalmente, compostos pelos ânions, de maiores dimensões. Com o empilhamento desses planos, sítios intersticiais são criados entre eles, nos quais os cátions podem ser alojados. Existem dois tipos diferentes de sítios intersticiais, como mostrado na Fig. 3.3 (Callister, 2007):

口 Tetraédricos: quatro ânions, três em um plano e um em outro, circundam o sítio intersticial;

- Octaédricos: seis ânions, três em cada um dos planos, circundam o sítio intersticial. 


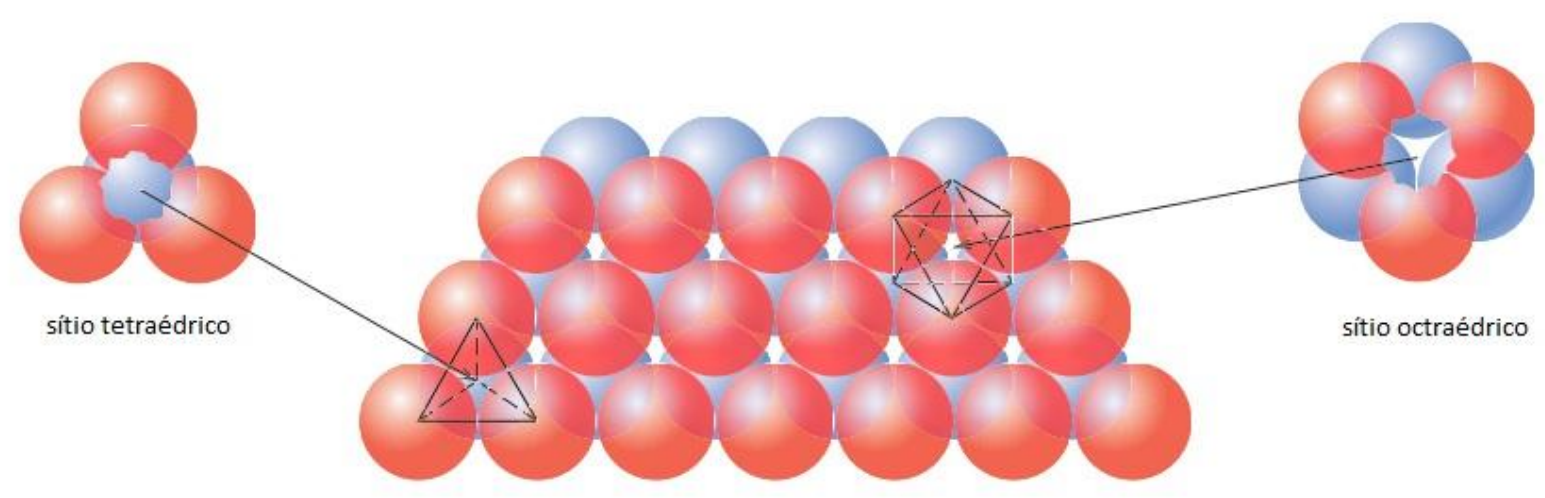

Figura 3.3 - Esquema ilustrativo das posições tetraédricas e octraédricas para cátions. As esferas azuis e vermelhas representam ânions. Fonte: Callister (2007).

\subsection{Silicatos}

A abundância dos elementos oxigênio, silício e alumínio (ver Tab. 3.3) justifica o fato de a crosta terrestre consistir predominantemente (97\%) de minerais silicatados. A maior parte das rochas, solos, argilas e areia encaixam-se na classificação de silicatos (Callister, 2007). Assim, é possível entender por que os materiais silicatados representam a maioria das cerâmicas existentes no mundo (em termos de volume produzido) (Boch \& Nièpce, 2007).

Tabela 3.3 - Abundância dos elementos químicos na crosta terrestre. Fonte: Lutgens \& Tarbuck (2000).

\begin{tabular}{c|c}
\hline Elemento & Porcentagem em peso aproximada (\%) \\
\hline $\mathrm{O}$ & 46,6 \\
$\mathrm{Si}$ & 27,7 \\
$\mathrm{Al}$ & 8,1 \\
$\mathrm{Fe}$ & 5,0 \\
$\mathrm{Ca}$ & 3,6 \\
$\mathrm{Na}$ & 2,8 \\
$\mathrm{~K}$ & 2,6 \\
$\mathrm{Mg}$ & 2,1 \\
Elementos restantes & 1,5 \\
\hline
\end{tabular}


Em vez de se discutir a estrutura cristalina desses materiais em termos de suas células unitárias, torna-se mais conveniente utilizar unidades tetraédricas de $\mathrm{SiO}_{4}^{4-}$, com átomos de oxigênio nos vértices desses tetraedros, e átomos de silício no centro, como mostrado na Fig. 3.4. Muitos silicatos surgem de diferentes arranjos dessas unidades de $\mathrm{SiO}_{4}^{4-}$, que podem ser unidimensionais, bidimensionais e tridimensionais. Nessa unidade estrutural, cada oxigênio possui apenas sete elétrons, em vez de oito na sua camada eletrônica mais externa. Há duas formas de suprir essa deficiência de elétrons (Van Vlack, 1970):

i. $\quad$ O elétron faltante pode ser obtido de outros elementos metálicos;

ii. O elétron faltante pode ser obtido pela ligação covalente com outro átomo de silício, formando estruturas tetraédricas múltiplas (Fig. 3.5) e estruturas em cadeia (Fig. 3.6).
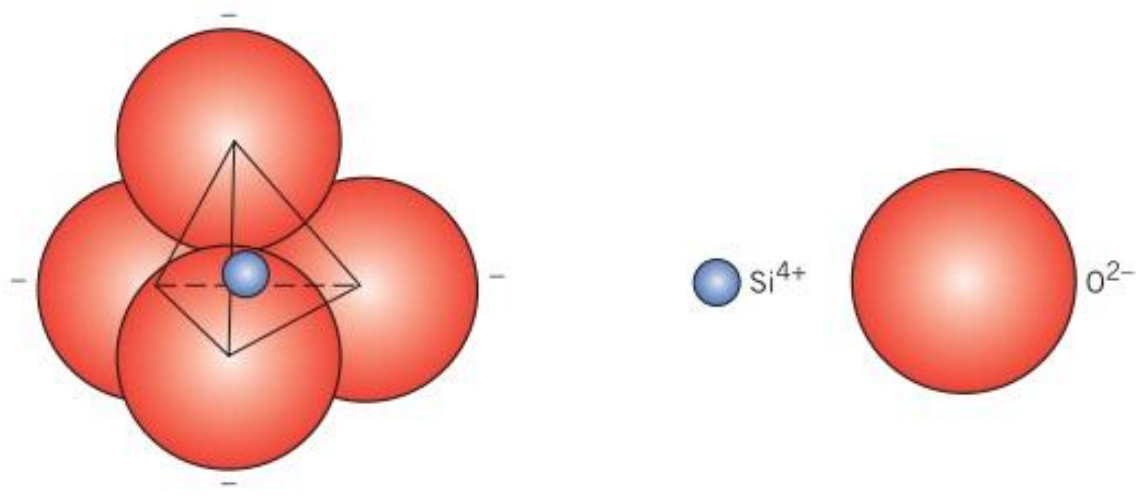

Figura 3.4 - Unidades tetraédricas de $\mathrm{SiO}_{4}^{4-}$. Fonte: Callister (2007). 


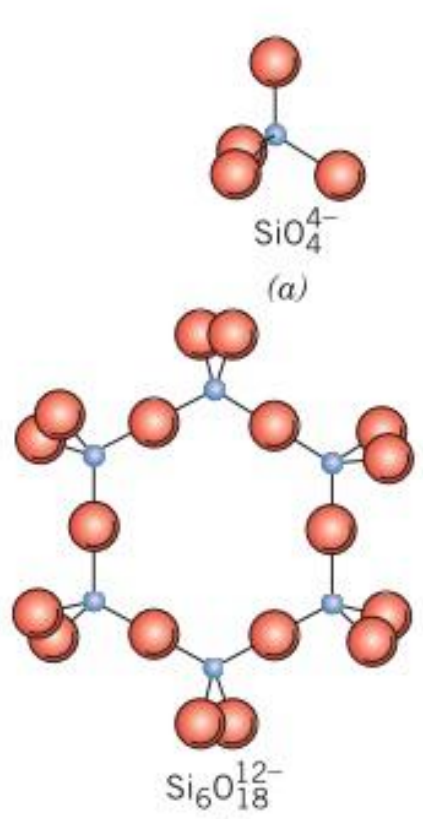

(d)

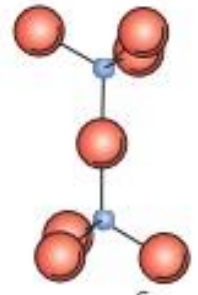

$\mathrm{Si}_{2} \mathrm{O}_{7}^{6-}$

(b)

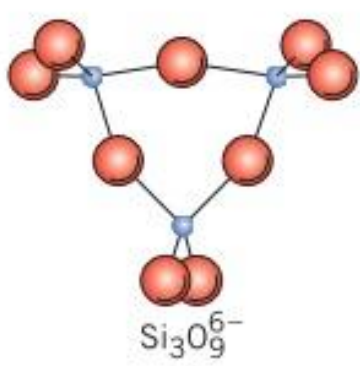

(c)

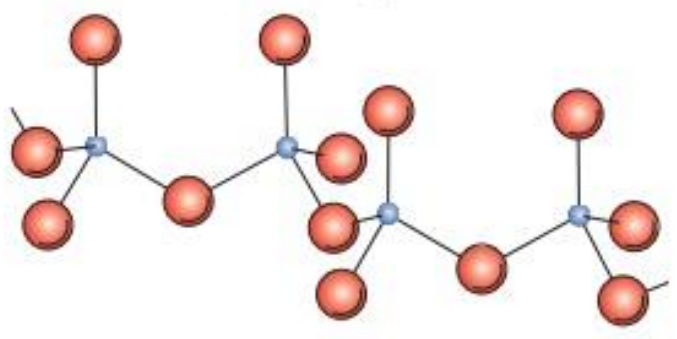

$\left(\mathrm{SiO}_{3}\right)_{n}^{2 n-}$

(e)

- $\mathrm{Si}^{4+} \mathrm{O} \mathrm{O}^{2-}$

Figura 3.5 - Cinco estruturas para íons silicato, formados a partir de tetraedros de $\mathrm{SiO}_{4}^{4-}$. Fonte: Callister (2007).

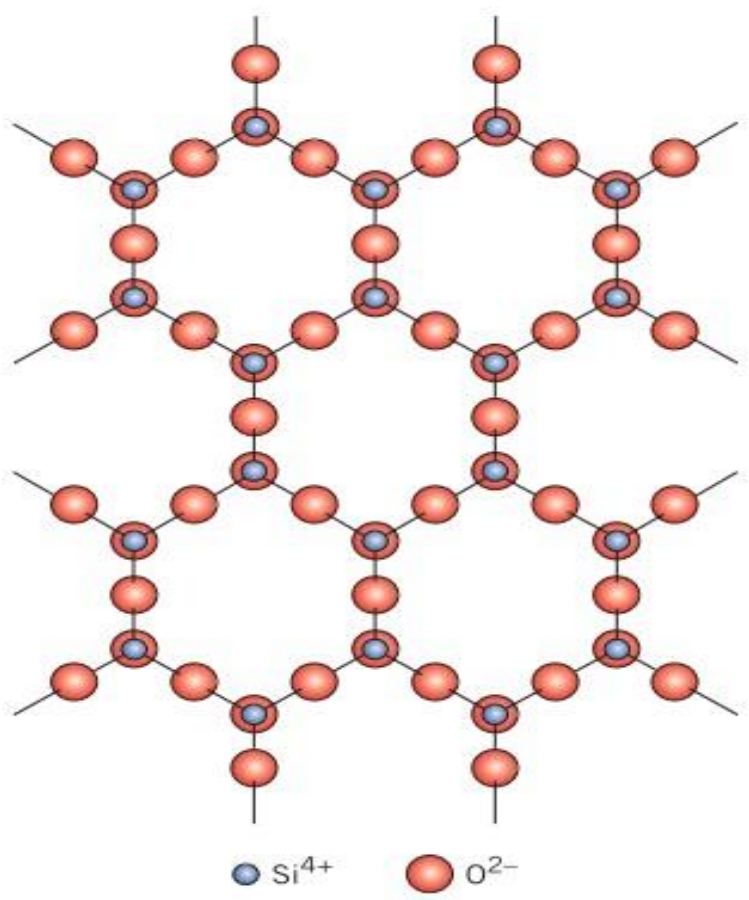

Figura 3.6 - Representação de uma lâmina de silicato bidimensional com unidade estrutural $\left(\mathrm{Si}_{2} \mathrm{O}_{5}\right)^{2-}$. Fonte: Callister (2007). 
O material mais simples à base de silicato é a sílica, ou dióxido de silício $\left(\mathrm{SiO}_{2}\right)$, cuja estrutura é caracterizada por uma rede tridimensional gerada pelo compartilhamento de todos os átomos de oxigênio por tetraedros adjacentes, de forma que todos os átomos possuem estrutura eletrônica estável e o material adquire eletroneutralidade. As três formas cristalinas polimórficas principais para a sílica são o quartzo, a cristobalita e a tridimita. Suas estruturas cristalinas são relativamente abertas e, como consequência, as sílicas cristalinas possuem densidades relativamente baixas (exemplo: 2,65 g.cm ${ }^{-3}$ para o quartzo, à temperatura ambiente). Uma fonte principal de sílica é a areia.

Para formar a estrutura de vários minerais à base de silicato, os tetraedros de $\mathrm{SiO}_{4}^{4-}$ podem compartilhar um, dois ou três átomos de oxigênio nos vértices. Cátions como

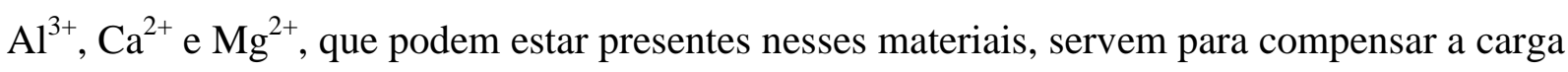
negativa das unidades de $\mathrm{SiO}_{4}^{4-}$, bem como ligar entre si os tetraedros

Um parâmetro crítico que determina a estrutura de um silicato é o número de átomos de oxigênio não formadores de ponte por tetraedro, o qual, por sua vez é função da razão O/Si. Oxigênios não formadores de ponte (ligados a apenas um átomo de silício) são formados, principalmente, pela adição de óxidos de metais alcalinos ou alcalino-terrosos à sílica, de acordo com a seguinte equação (Barsoum, 2003):

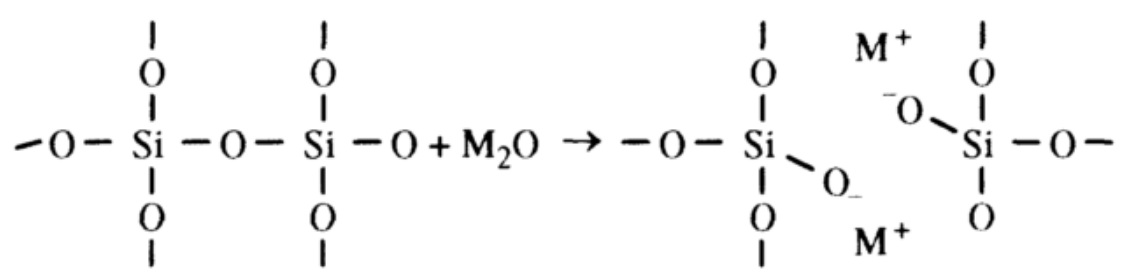

Estruturas bidimensionais em camadas, ou lâminas, podem ser geradas pelo compartilhamento de três íons oxigênio de cada um dos tetraedros, como mostrado na Fig. 3.6. A carga residual negativa está associada aos átomos de oxigênio que estão fora do plano representado, e não estão ligados. A eletroneutralidade é estabelecida ordinariamente por uma segunda camada que possui um excesso de cátions. A estrutura básica desses silicatos em camadas é característica das argilas, e outros minerais como os talcos e micas (Callister, 2007). As Fig. 3.7 e 3.8 mostram exemplos da estrutura de minerais argilosos, a caulinita e a 94 
mica. Os minerais argilosos são dispostos em camadas, ou folhas de silicato, com granulometria menor que $2 \mu \mathrm{m}$.
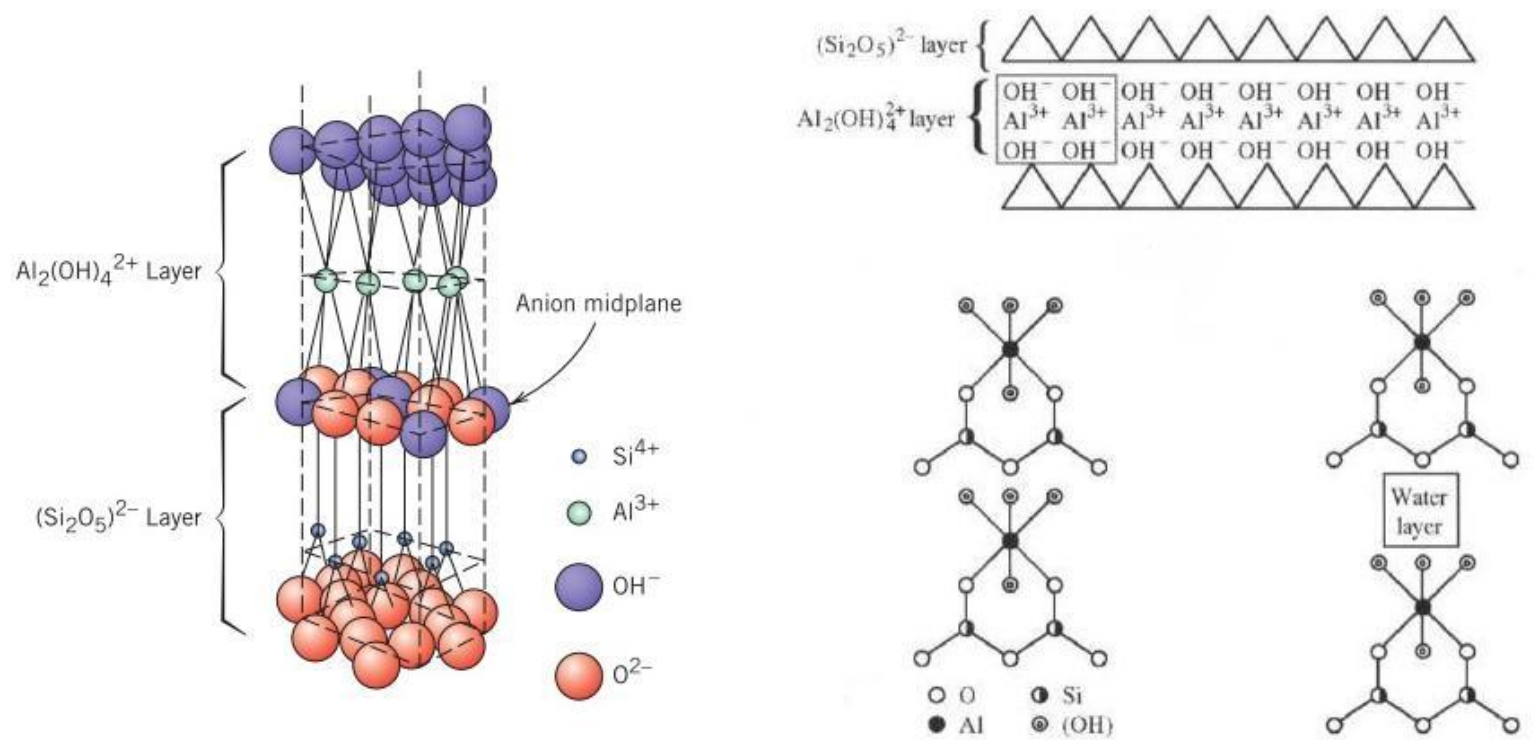

Figura 3.7 - Estrutura da caulinita $\mathrm{Al}_{2}(\mathrm{OH})_{4}\left(\mathrm{Si}_{2} \mathrm{O}_{5}\right)$. Esse tipo de argila é composto por lâminas de $\left(\mathrm{Si}_{2} \mathrm{O}_{5}\right)^{2-}$, unidas por lâminas positivamente carregadas de octaedros de $\mathrm{Al}_{2}(\mathrm{OH})_{4}^{2+}$, formando camadas duplas, empilhadas de forma paralela, formando pequenas placas planas, aproximadamente hexagonais, com menos de $1 \mu \mathrm{m}$ de diâmetro, em geral. As moléculas polares de água são facilmente absorvidas entre a parte superior das lâminas positivas e pela parte inferior das lâminas de silicato. Fontes: Barsoum (2003) e Callister (2007).

Partindo-se da convenção de se escrever a fórmula química de minerais como "misturas" de óxidos elementares, a composição química da maioria dos minerais cerâmicos silicatados pode ser localizada no pseudodiagrama ternário:

$$
\mathrm{SiO}_{2}-\mathrm{Al}_{2} \mathrm{O}_{3}-\mathrm{M}_{\mathrm{x}} \mathrm{O}_{\mathrm{y}}
$$

no qual $\mathrm{M}_{\mathrm{x}} \mathrm{O}_{\mathrm{y}}$ é um óxido como $\mathrm{Fe}_{2} \mathrm{O}_{3}, \mathrm{~K}_{2} \mathrm{O}, \mathrm{Na}_{2} \mathrm{O}, \mathrm{MgO}, \mathrm{TiO}_{2}$, entre outros. 

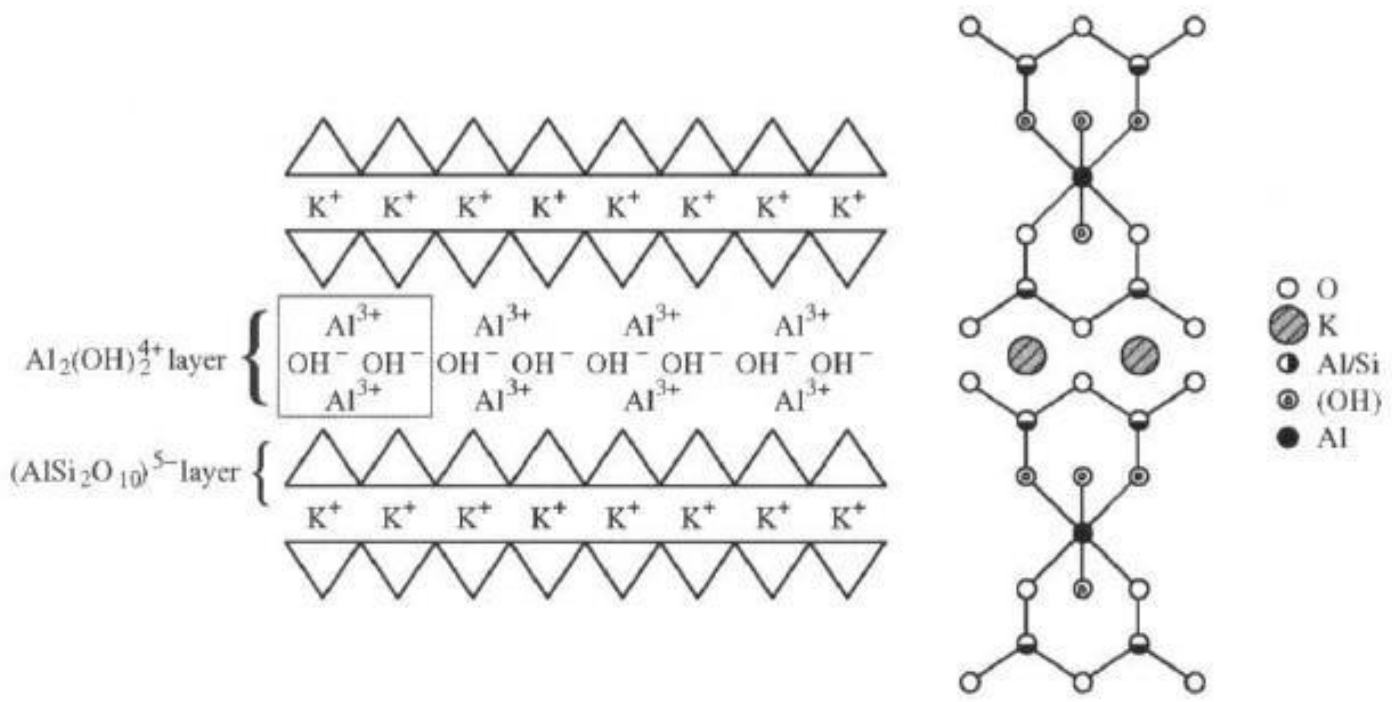

Figura 3.8 - Estrutura da mica. Nesta estrutura, íons de alumínio substituem um quarto dos átomos de silício nas camadas, o que faz necessário que íons, como o $\mathrm{K}^{+}$, liguem-se entre as camadas tetraédricas, de forma a torná-las eletricamente neutras por meio de ligações iônicas que são mais fortes que as ligações entre as camadas dos filossilicatos. Dessa forma, a mica não absorve água tão facilmente quanto as argilas. Fonte: Barsoum (2003).

\subsection{Imperfeições em cerâmicas}

Cristais reais não são perfeitos, e suas imperfeições são classificadas de acordo com sua geometria e forma em (Barsoum, 2003):

- Pontuais: qualquer ponto do retículo cristalino que não é ocupado pelo íon original, necessário para garantir a periodicidade de longo alcance da estrutura. É o tipo de defeito mais conhecido na literatura.

- Lineares ou de deslocamento: são defeitos que causam distorções no retículo cristalino e são centrados em uma linha.

口 Planares: são imperfeições superficiais em sólidos policristalinos, que separam grãos ou domínios de diferentes orientações, nas quais os contornos de grão estão incluídos.

ㄱ Tridimensionais: incluem poros, fendas e inclusões. 
Muitas das propriedades dos materiais cerâmicos serão fortemente afetadas pela presença ou ausência desses defeitos. Além disso, nos processos de difusão em sólidos, são os defeitos que se movem pelo retículo cristalino (Ropp, 2003).

Os defeitos pontuais atômicos que podem ocorrer nos compostos cerâmicos podem ser de dois tipos: lacunas e intersticiais. Em virtude da tendência à eletroneutralidade, os defeitos nas cerâmicas não ocorrem sozinhos. Podem ser caracterizados dois tipos, ilustrados na Fig. 3.9. A razão entre número de cátions e número de ânions não é alterada pela formação desses defeitos.

D Defeito de Frenkel: consiste em um par formado por cátion intersticial e uma lacuna de cátion.

D Defeito de Schottky: consiste em um par formado por uma lacuna de ânion e uma lacuna de cátion.
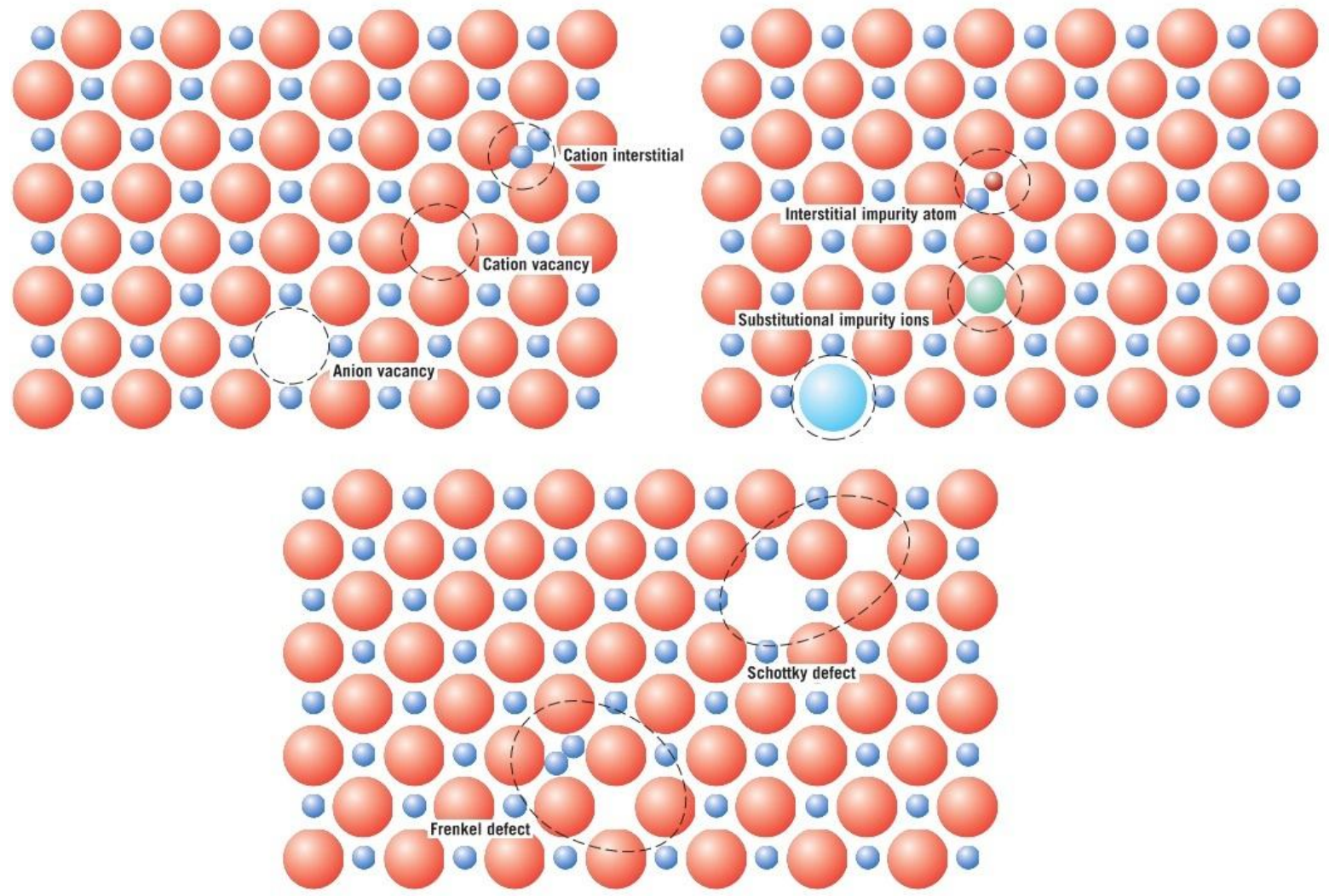

Figura 3.9 - Esquema ilustrativo dos defeitos pontuais e impurezas em estruturas cristalinas de materiais cerâmicos. Fonte: Adaptado de Callister (2007). 
Impurezas podem estar presentes em materiais cerâmicos, na forma de soluções sólidas de certos átomos, que podem ser do tipo substitucional e intersticial. Em soluções sólidas intersticiais, o raio iônico da impureza desse ser consideravelmente menor em relação ao raio do ânion (Fig. 3.9). No caso de soluções sólidas substitucionais, o raio iônico e carga da impureza devem ser próximos aos dos íons hospedeiros, e qualquer diferença de carga pode ser compensada pela formação de algum defeito pontual, de forma que a eletroneutralidade seja obtida (Callister, 2007).

\subsection{Argilas - definições e processamento}

Na discussão da história das cerâmicas arqueológicas, é necessário falar sobre o reconhecimento das argilas como uma matéria-prima útil pelos seres humanos. As argilas são um dos mais abundantes, baratos e adaptáveis recursos disponíveis para a exploração humana. As primeiras evidências de seu uso estão ligadas a diversas expressões artísticas do Paleolítico Superior na Europa central e ocidental. Muitas cavernas paleolíticas possuem desenhos feitos com argila úmida nas paredes e no chão. Esse quadro sugere que, pelo fim do Paleolítico, três princípios sobre a utilização de argilas já eram conhecidos: a argila úmida é plástica, e sua forma será mantida quando a pasta argilosa estiver seca; a queima endurece a argila; a adição de outros materiais à pasta argilosa pode melhorar suas propriedades e ampliar seus usos (Rice, 1987).

Argilas são produtos de intemperismo de feldspatos (o mineral formador de rocha mais abundante na crosta terrestre $-39 \%$ ), micas e outros minerais formadores de rochas, na forma de interação dessas últimas com soluções aquosas formadas no ambiente, na forma, principalmente, de processos de lixiviação e precipitação, para os quais o pH das soluções, tipo de rocha (e minerais constituintes) e clima são fatores determinantes (Heimann, 2010). Existem diferenças entre as reações de lixiviação entre climas tropicais e temperados, e entre as reações de precipitação que ocorrem em ambientes úmidos e áridos.

As argilas podem ser consideradas misturas mecânicas de diferentes componentes, cada qual com uma distribuição granulométrica específica, sendo os principais (Heimann, 2010): 
(i) Vestígios de intemperismo de granulometria fina: como o quartzo, feldspato, sericite e micas deficientes em intercamadas.

(ii) Minerais argilosos formados recentemente (em termos geológicos): caulinita, halloysita, ilita e montmorilonita.

(iii) Restos de organismos: consistindo em calcita ou aragonita (de conchas), microfosséis em sílica (sílex) e carbono grafítico.

(iv) Novas formações após deposição: como pirita, dolomita e glauconita.

Os minerais argilosos possuem tamanho de grão abaixo de $2 \mu \mathrm{m}$, enquanto outros vestígios de intemperismo, como quartzo, feldspatos e micas possuem tamanho de grão até 20 $\mu \mathrm{m}$.

As fontes de argila podem ser caracterizadas por possuírem argilas, areias e fundentes (materiais que auxiliam na queima devido ao desenvolvimento de fases com baixo ponto de fusão). As argilas de caulinita, por exemplo, podem ser escritas como sendo formadas por $\mathrm{Al}_{2} \mathrm{O}_{3}-2 \mathrm{SiO}_{2}-2 \mathrm{H}_{2} \mathrm{O}$, areia de quartzo $\left(\mathrm{SiO}_{2}\right)$ e feldspato potássico $\left(\mathrm{K}_{2} \mathrm{O}-\mathrm{Al}_{2} \mathrm{O}_{3}-\right.$ $6 \mathrm{SiO}_{2}$ ), usado frequentemente como fundente.

As matérias-primas naturais utilizadas na manufatura de cerâmicas à base de silicatos podem ser divididas em (Heimann, 2010):

(a) Materiais altamente plásticos: argilas, contendo minerais como caulinita, ilita ou montmorilonita.

(b) Materiais de baixa plasticidade: para aplicações eletrocerâmicas específicas, como pirofilita e talco.

(c) Materiais antiplásticos: como temperos aditivos (como o quartzo) e fundentes (feldspato, apatita, calcita, dolomita etc.) que são adicionadas para se modificar a química, plasticidade e propriedades termomecânicas das cerâmicas.

Materiais cerâmicos plásticos naturais consistem principalmente em caulinita, ilita e/ou montmorilonita, acompanhados por quartzo, feldspato, micas e calcitas residuais, assim como resíduos orgânicos. 
Inclusões e impurezas em um corpo argiloso desempenham um papel importante durante os processos de secagem e de queima. As inclusões podem estar naturalmente presentes na argila, ou terem sido adicionadas intencionalmente pelo ceramista como “tempero". Essas inclusões modificam os processos de expansão e contração da pasta argilosa e a microestrutura do corpo cerâmico (Rice, 1987, pág. 93).

\subsection{Queima de materiais cerâmicos}

Após a conformação da pasta argilosa, o futuro objeto cerâmico é submetido à secagem. Nos estágios iniciais desse processo, as partículas de argila estão envolvidas e separadas umas das outras por uma película de água. Com o decorrer do processo de secagem, ocorre a remoção da água e a separação interpartículas diminui, causando uma contração de volume (Callister, 2007).

A argila seca ainda não é um material cerâmico, embora seja utilizada na produção de tijolos rudimentares em lugares muito secos, como a África Sahariana e Oriente Médio. É o processo de queima que causa as transformações físico-químicas irreversíveis, resultando na perda da plasticidade típica de argilas hidratadas, tornando-as incapazes de reidratarem-se novamente (Boch \& Nièpce, 2007). Juntamente com os radicais hidroxila, $\mathrm{OH}^{-}$, elas são eliminadas no tratamento térmico (fenômeno denominado perda por ignição). Esses íons hidroxila correspondem à água combinada, cuja saída no processo de queima causa um distúrbio na estrutura cristalina e, consequentemente, em transformação irreversível acima de aproximadamente $500{ }^{\circ} \mathrm{C}$.

$\mathrm{O}$ fornecimento de energia térmica às argilas altera suas características físicas e químicas. As alterações que ocorrem dependem de três variáveis principais da queima: duração, temperatura e atmosfera na qual o calor é transferido e depois dissipado. Essas três variáveis devem ser analisadas conjuntamente quando do estudo tecnológico dos materiais cerâmicos arqueológicos (Rice, 1987).

A atmosfera de queima refere-se à presença de gases, principalmente oxigênio, durante a queima e o resfriamento da cerâmica. Quando há livre circulação de ar com ampla disponibilidade de oxigênio para ligar-se aos compostos da argila, a atmosfera é denominada oxidante. Já uma atmosfera pobre em oxigênio é considerada como uma atmosfera redutora. 
Em fornos, a atmosfera pode ser controlada pela escolha do combustível e pela regulação da circulação de ar dentro do forno. Em queimas em fogueiras a céu aberto, realizadas amplamente na maior parte da América pré-colombiana, o controle da atmosfera torna-se mais difícil, devido ao vento e irregularidades na combustão (Rice, 1987, p. 81).

A atmosfera afeta várias propriedades do produto final, especialmente a cor e dureza dos artefatos, além da porosidade e contração de volume. A análise da atmosfera de queima deveria englobar, idealmente, a especificação da atmosfera na qual a maior temperatura foi atingida, mantida e a atmosfera durante o resfriamento das peças, que pode ser diferente da atmosfera de queima se a peça for deixada resfriando onde a circulação de ar for livre; ou se as peças forem cobertas com uma camada de cinzas, por exemplo. Em queimas a céu aberto, a atmosfera tende a ser altamente variável, não sendo nem completamente oxidante nem completamente redutora, sendo mais bem descritas como parcialmente oxidante. Uma atmosfera completamente redutora durante a queima é difícil de ser atingida, exceto em casos de condições rigorosamente controladas (Rice, 1987).

Do ponto de vista termodinâmico, uma queima oxidante é conseguida quando a pressão parcial de oxigênio é maior ou igual à pressão de decomposição, definida termodinamicamente, dos óxidos de diferentes valências, como a magnetita. Já uma queima redutora é atingida quando a pressão parcial de oxigênio está abaixo da pressão de decomposição desses minerais (Heimann, 2010).

Em queimas relativamente rápidas em fogueira a céu aberto, frequentes em diversas partes do mundo, os artefatos cerâmicos usualmente não atingiam o equilíbrio, nem mesmo a maturação (máxima dureza e mínima porosidade para uma determinada composição da pasta argilosa) (Rice, 1987, p. 86).

Devido à variabilidade na composição das argilas, os processos mineralógicos que ocorrem durante a transformação térmica dos minerais argilosos podem ser muito complexos, pois a maioria das reações ocorre muito afastada do equilíbrio termodinâmico, sendo, portanto, dependentes da temperatura e tempo de queima.

Uma das principais reações que ocorrem em materiais contendo sílica é a transformação de quartzo $\alpha$ em quartzo $\beta$ a $537{ }^{\circ} \mathrm{C}$ (Carter \& Norton, 2007). Na Tab. 3.4 é apresentada a faixa de temperatura das principais reações e transformações que podem ocorrer durante a queima de uma cerâmica à base de silicatos. 
Tabela 3.4 -Principais transformações físico-químicas em argilas silicatadas durante o processo de queima. As faixas de temperatura são aproximadas. Fontes: (Rice, 1987; Artioli, 2010).

\begin{tabular}{|c|c|c|c|c|}
\hline $\mathbf{T}\left({ }^{\circ} \mathbf{C}\right)$ & $\begin{array}{c}\text { Perda de moléculas de } \\
\text { água }\end{array}$ & $\begin{array}{c}\text { Reações de } \\
\text { decomposição }\end{array}$ & Reações químicas & Transformações de fase \\
\hline $\mathrm{T}<100$ & $\begin{array}{c}\text { Perda de água não ligada e } \\
\text { adsorvida }\end{array}$ & & & \\
\hline $100-200$ & $\begin{array}{l}\text { Perda de água estrutural } \\
\text { fracamente ligada (sais } \\
\text { hidratados: gipsita, } \\
\mathrm{CaSO}_{4} \cdot \mathrm{H}_{2} \mathrm{O} ; \text { parte da água } \\
\text { intersticial) }\end{array}$ & & & \\
\hline $200-400$ & $\begin{array}{l}\text { Perda de água intersticial e } \\
\text { intercamadas nos minerais } \\
\text { argilosos }\end{array}$ & & $\begin{array}{l}\text { Início da oxidação de matéria } \\
\text { orgânica e migração para a } \\
\text { superfície }\end{array}$ & \\
\hline $400-600$ & $\begin{array}{l}\text { Dehidroxilação (perda de } \\
\text { água quimicamente ligada) } \\
\text { nos minerais argilosos }\end{array}$ & Perda de $\mathrm{SO}_{2}$ em sulfatos & $\begin{array}{l}\text { Oxidação de compostos } \\
\text { orgânicos }\end{array}$ & $\begin{array}{c}\text { Transformação de quartzo } \alpha \text { em quartzo } \\
\beta\left(573^{\circ} \mathrm{C}\right) \text {; transformação da caulinita } \\
\text { em metacaulinita (perda de }-\mathrm{OH})\end{array}$ \\
\hline $600-850$ & Perda de $-\mathrm{OH}$ em micas & $\begin{array}{l}\text { Perda de } \mathrm{CO}_{2} \text { em } \\
\quad \text { carbonatos }\end{array}$ & $\begin{array}{l}\text { Formação de } \mathrm{MgO} \text { e CaO pela } \\
\text { decomposição de minerais } \\
\text { argilosos e carbonatos; oxidação } \\
\text { de sulfetos; fase líquida pode se } \\
\text { formar }\end{array}$ & \\
\hline $800-1000$ & & $\begin{array}{l}\text { Perda total de água e } \\
\text { colapso irreversível da } \\
\text { estrutura dos minerais } \\
\text { argilosos (maioria das } \\
\text { caulinitas e smectitas) }\end{array}$ & Oxidação de óxidos ferrosos & $\begin{array}{c}\mathrm{MgO} \text { e } \mathrm{CaO} \text { reagem para produzir fases } \\
\text { como espinélios (decomposição da } \\
\text { metacaulinita), gehlenita e diópsido; } \\
\text { transformação de quartzo } \beta \text { em tridimita } \\
\left(867^{\circ} \mathrm{C}\right)\end{array}$ \\
\hline $1000-1300$ & & & & $\begin{array}{l}\text { Formação de mulita (a partir dos } \\
\text { espinélios) e anortita; início da fusão de } \\
\text { feldspato; transformação da tridimita } \\
\text { em cristobalita }\end{array}$ \\
\hline
\end{tabular}


Após a conformação da pasta argilosa na forma desejada, existirão poros entre as partículas. Durante o tratamento térmico, ou queima, grande parte da porosidade pode ser eliminada. No entanto, esse processo de eliminação pode ficar incompleto, e haverá porosidade residual, que implicará em uma influência negativa sobre as propriedades elásticas e resistência do material. Como exemplo da possível importância dessa influência, pode acontecer de uma porosidade de $10 \%$ em volume ser responsável por uma diminuição de $50 \%$ na resistência à flexão, em relação ao material sem porosidade (Callister, 2007).

A abundância natural do elemento ferro justifica a coloração vermelha, marrom e amarela de grande parte das cerâmicas silicatadas. A cor de uma cerâmica queimada será função do estado de valência dos íons de ferro $\left(\mathrm{Fe}^{3+}\right.$ ou $\left.\mathrm{Fe}^{2+}\right)$ no material. Esse fato é bem conhecido dos ceramistas, que modificam a atmosfera (oxidante ou redutora) dos fornos onde as argilas são queimadas (Boch \& Nièpce, 2007; Heimann, 2010).

A queima cerâmica faz a pasta argilosa resultar em um material conhecido pelas propriedades gerais de estabilidade química, resistência mecânica, e microestrutura densa e rígida (Heimann, 2010). A consequência geral da decomposição e perda de matéria orgânica, água mecanicamente combinada, carbonatos e sais é uma perda de peso e contração contínuos do corpo argiloso, para além dos efeitos da secagem. As propriedades funcionais de maior interesse em cerâmicas arqueológicas utilitárias são a durabilidade (uma combinação de integridade física e resistência à quebra durante a utilização), resistência ao estresse térmico (referente a tensões que ocorrem em mudanças de temperatura), porosidade e ausência de defeitos (Rice, 1987). Há estudos que indicam que a quantidade máxima de quartzo que pode ser adicionada para melhorar a resistência mecânica do artefato cerâmico é $25 \%$ em peso (Rice, 1987, p. 104).

\subsection{Caracterização de cerâmicas em arqueometria}

Em muitas regiões do planeta, fragmentos de vasos cerâmicos quebrados são o tipo de artefato mais comum encontrado em sítios arqueológicos, devido à sua resistência na maioria dos solos. Além de sua abundância e alta resistência a intempéries, as cerâmicas possuem várias características macroscópicas (como decoração, cor, forma e função) que as tornam indicadores culturais e cronológicos na arqueologia (Velde e Druc, 1999). Além disso, suas características microscópicas, como composição química elementar, podem ser utilizadas na abordagem de problemas referentes à sua origem. Em suma, as cerâmicas 
podem ser consideradas como um registro que, combinadas ou não com outras evidências, são capazes de revelar diversos aspectos referentes a uma cultura pré-histórica, incluindo o local provável de sua manufatura, origem das matérias-primas, métodos de produção, comércio, entre outros (Glascock \& Neff, 2003; Heimann, 2010). A combinação de análise estilístico-tipológica e outros estudos arqueológicos com análises arqueométricas tem sido de grande importância para o entendimento do modo de vida de grupos humanos ancestrais (Pollard, 2008).

A análise de cerâmicas arqueológicas inicia-se com processos taxonômicos com o objetivo de organizar os fragmentos e os vasos de um sítio arqueológico e/ou um região maior de estudo. Esses procedimentos dependem da orientação teórica adotada pelos arqueológos e as questões levantadas no problema em pesquisa. Contudo, frequentemente eles envolvem a organização das peças em grupos baseados no tratamento de superfície, decoração, morfologia e material de forma a maximizar similaridades intragrupo e diferenças intergrupos. Esses agrupamentos podem estar relacionados a diferentes questões funcionais, simbólicas e de tradição cultural. Uma vez caracterizadas, classificadas e analisadas por meio de diversas variáveis e técnicas arqueológicas tradicionais, os grupos formados são amostrados por estrato, para seleção de amostras que serão submetidas a exames detalhados adicionais por outras técnicas analíticas físicas e/ou químicas (IAEA, 2003).

A estrutura física das cerâmicas é determinada pela tecnologia de produção cerâmica de quem a produziu, à qual estão relacionadas variáveis como temperatura e tempo de queima, e tipo de atmosfera (redutora ou oxidante), que podem ser específicas de uma determinada cultura em um determinado período (Leute, 1987). As propriedades físicas são características descritivas significativas das argilas, temperos (ou antiplásticos) e cerâmicas, as quais incluem: cor, textura, plasticidade, contração e resistência. Essas propriedades avaliadas em seu conjunto fornecem evidências da tecnologia de manufatura. Como exemplos de estudos, podem-se citar: identificação de inclusões intencionais na pasta cerâmica na forma de tempero; estudo de proveniência; determinação da temperatura de queima; datação e estudos de autenticidade das peças (Toyota, 2009).

As propriedades químicas de materiais cerâmicos são tipicamente discutidas em termos de constituintes principais, secundários e traço. Os constituintes principais incluem $\mathrm{SiO}_{2}, \mathrm{Al}_{2} \mathrm{O}_{3}$ e ferro. Por sua vez, os elementos traço e secundários ocorrem em combinações e quantidades que são mais distintivas de cada material cerâmico ou 
combinações de cerâmica/antiplástico. São esses últimos, medidos em ppm ou ppb, os elementos tipicamente focados em análises químicas.

Uma das principais aplicações das técnicas analíticas físico-químicas à arqueologia é a determinação da composição de elementos em níveis macro, micro e traço de artefatos com o intuito de determinar a proveniência desses objetos, no que se refere à origem geográfica das matérias-primas utilizadas, como enuncia o postulado de proveniência (ver discussão na Introdução da Tese) (Pollard \& Heron, 1996). Dada a importância do comércio de cerâmica entre os povos antigos, não é de se estranhar que uma das principais classes de materiais analisados seja a cerâmica.

Uma abordagem frequente na caracterização química e mineralógica de cerâmicas é estudar sua trajetória, ou cadeia de eventos, desde a sua produção (identificando os centros de produção e fontes de matérias-primas, quando possível; tratamento superficial; processo de queima) até o seu uso final, e possíveis rotas de comércio, correlacionando essas análises a aspectos culturais dos grupos envolvidos, de forma a levantar hipóteses acerca de seu comportamento dentro do contexto arqueológico no qual as cerâmicas foram produzidas, distribuídas e utilizadas (IAEA, 2003; Tite, 2008; Artioli, 2010). Especificamente na análise química elementar de cerâmicas, assim como de outros materiais, é comum combinar um cuidadoso trabalho de caracterização química, com técnicas de taxonomia numérica (como alguns métodos estatísticos multivariados, devido à quantidade de variáveis geradas na determinação das concentrações elementares), e informações arqueológicas e estilísticas com o objetivo de produzir agrupamento de artefatos que possuam significado arqueológico (Harbottle, 1982a).

Outra possibilidade de um estudo arqueométrico de cerâmicas reside na investigação de mudanças tecnológicas ao longo do tempo, evidenciadas na variabilidade do registro arqueológico. Esse enfoque possibilita identificar mudanças comportamentais dos artesãos que, estando inseridos num contexto sistêmico (ou cultural) mais amplo, refletiriam mudanças comportamentais das sociedades estudadas (Schiffer, 1987a). Diferenças significativas nos tipos, tamanhos ou na quantidade de um material em particular entre duas ou mais categorias de cerâmicas podem representar escolhas conscientes feitas pelo ceramista e corroborar princípios estruturais ou físicos de engenharia, mineralogia ou química. Contudo, um cuidado que deve ser tomado é que uma associação entre duas variáveis não implica necessariamente em um comportamento 
humano intencional. Em outras palavras, correlação não implica relação causal (Rice, 1987, p. 328).

Além dos componentes principais da argila $\left(\mathrm{Al}_{2} \mathrm{O}_{3}, \mathrm{SiO}_{2}\right.$ e água), que estão tipicamente em quantidades maiores que 5\%, microelementos em forma de impurezas, como $\mathrm{Ca}, \mathrm{Fe}, \mathrm{K}, \mathrm{Mg}$, Na e Ti estão presentes em quantidades variando entre 1.000 ppm a 5\%. Contudo, são os elementos-traço, cujas concentrações estão abaixo de 1000 ppm, que fornecem a base principal para estudos de proveniência de cerâmicas arqueológicas (Glascock, 2003).

A ideia básica implícita na caracterização química de cerâmicas arqueológicas é a de que as concentrações elementares, principalmente dos elementos-traço, de cada cerâmica são indicativas da matéria-prima utilizada na sua fabricação, as argilas e antiplásticos, conhecida como postulado de proveniência (Weigand et al., 1977). Dessa forma, é possível identificar grupos de artefatos similares e realizar estudos de proveniência, procedimento frequentemente denominado como determinação da assinatura química da cerâmica (Martini, 2003; Munita, 2005; Speakman \& Glascock, 2007). Uma das técnicas mais utilizadas com esse objetivo é a análise por ativação com nêutrons (Dias \& Prudêncio, 2007; Tite, 2008).

Os constituintes minerais das cerâmicas incluem os minerais argilosos específicos da rocha original, os tipicamente presentes na argila e os eventualmente adicionados como tempero. A identidade desses minerais, combinada com suas propriedades físicas, quantidades e associações são importantes para se determinar fontes de produção cerâmica não local. As propriedades minerais das cerâmicas - tipo, quantidade, tamanho e forma das fases minerais individuais - estão relacionadas virtualmente a todas as propriedades físicas.

A composição mineralógica dos fragmentos cerâmicos pode ser determinada por meio de difração de raios X. Com base nos difratogramas, identificam-se os componentes cristalinos, característicos dos minerais presentes nas cerâmicas. A temperatura de queima pode ser determinada por esta técnica, considerando a decomposição de alguns minerais (Leute, 1987). As diferentes estruturas cristalinas presentes espalham os raios $\mathrm{X}$ em ângulos preferenciais, os quais são registrados juntamente com as respectivas intensidades, de forma a gerar um registro do número e dos tipos de espécie presentes. Durante o processo de queima da cerâmica, os minerais presentes na pasta de argila mudam de estrutura, pela decomposição de alguns minerais e 
formação de novos. Esses minerais carregam informações sobre a técnica de processamento, temperatura e atmosfera de queima utilizada por grupos humanos do passado (Häusler, 2004).

As transformações da argila, ou argilas, em uma cerâmica queimada é um processo complexo, que pode envolver diversos fatores que poderão influenciar na composição final do produto, como (Pollard \& Heron, 1996):

a. A variabilidade natural dos leitos de argila;

b. A seleção e mistura de argilas de diferentes fontes, com o objetivo de obter a coloração e demais propriedades desejadas;

c. Levigação e/ou processamento da argila original para remover materiais ou granulometrias indesejadas para atingir a textura desejada para a pasta argilosa;

d. Adição de tempero, ou antiplástico, para modificar as propriedades termomecânicas do material;

e. O próprio ciclo de queima, que pode afetar a composição elementar final pela volatilidade de alguns elementos químicos na matriz.

As argilas podem ser requeridas em grandes quantidades quando da manufatura de objetos cerâmicos, e pode ser muito inconveniente carregá-las por grandes distâncias, devido a seu peso. Porém, caso seja necessário, elas podem ser transportadas por longas distâncias até um lugar onde o ceramista possua água e combustível para queima disponíveis (Rice, 1987). Estudos etnográficos relataram grande variedade em relação às distâncias percorridas para a obtenção de argila, podendo variar de 1 a $50 \mathrm{~km}$ (Arnold, 1980/1985 apud Rice, 1987, pp. 115-116). A aquisição de argilas também é influenciada pela topografia e pelos meios de transporte disponíveis ao ceramista. A argila é um material heterogêneo formado por diferentes minerais, tornando necessária a aplicação de métodos de caracterização de sua composição química e estrutura física, que pode ser variável de acordo com o contexto geológico onde foi encontrada. Algumas características passíveis de determinação são a estrutura cristalina dos minerais presentes, seus tamanhos de grão (granulometria), a quantidade de ferro diluída, entre outras (Leute, 1987).

Embora seja possível afirmar que os padrões de concentração elementar dos vários elementos determinados sejam característicos de um depósito de argila, nos estudos composicionais é mais preciso dizer que esse padrão de composição química é característico para uma determinada pasta de argila. Os ceramistas antigos poderiam ter 
manipulado as argilas coletadas por levigação (que pode eliminar certos intervalos de tamanho de grão e/ou algumas fases minerais), adição de antiplásticos, ou mesmo pela mistura de argilas de diferentes depósitos. Assim, o que é frequentemente estudado não é a composição de um depósito de argila, mas sim da pasta argilosa resultante do processamento pré-queima. Dessa forma, Mommsen (2004) sugere que o postulado de proveniência deveria ser reformulado de forma a considerar que a dispersão de concentrações elementares em certa pasta argilosa deve ser menor que a dispersão de concentrações entre diferentes pastas (Mommsen, 2004; Neff, 2012).

Em estudos de proveniência, um procedimento utilizado para compensar possíveis transformações físico-químicas que podem ter ocorrido durante o processo de queima é o de se queimar amostras de argilas em um formato apropriado (cilíndrico, por exemplo) em condições próximas às utilizadas pelos artesãos dos povos estudados (Szakmány \& Starnini, 2007).

A heterogeneidade dos materiais cerâmicos arqueológicos reflete a combinação de diferentes fontes de argila e outros materiais, como os antiplásticos. Uma das principais preocupações na amostragem desses materiais é como obter amostras cuja variação intragrupo não obscurecerá diferenças intergrupos. Embora o número de amostras analisadas seja uma variável definitiva que afeta a possibilidade de distinções regionais, considerações sobre as características geoquímicas e geológicas da região são requeridas. Uma das razões é que o local de coleta dos materiais de fabricação (argilas e temperos) não coincidem, necessariamente, com a região onde o material arqueológico foi escavado (IAEA, 2003).

A adição de antiplásticos à pasta argilosa pode alterar os perfis de concentração química elementar, sendo o efeito mais simples o de diluição, quando os aditivos não contêm os elementos analisados na matriz cerâmica (Mommsen et al., 1988). Contudo, vários estudos demonstraram que a adição de antiplásticos não costuma ser fatal na identificação da assinatura química elementar da cerâmica (Neff, 2012). Antes de um estudo de proveniência, é importante determinar se a modificação mencionada anteriormente faz parte do processo de manufatura da cerâmica dos povos estudados. Essas determinações envolvem análises petrográficas dos cacos cerâmicos, de forma a identificar os tipos, tamanhos, formas e quantidades de inclusões; estudo da geologia local e dos solos; e amostragem de argilas locais para o exame das inclusões de ocorrência natural (Rice, 1987, p. 422). 
Cerâmicas são materiais susceptíveis a efeitos diagenéticos do ambiente, os quais podem alterar a composição química das cerâmicas arqueológicas no contexto deposicional, e acentuar a heterogeneidade dentro um grupo de artefatos associado a um determinado processo de produção, ou uma área, podendo causar problemas de classificação inadequada por métodos estatísticos multivariados. Contudo, esses efeitos diagenéticos não costumam ser fatais, e comparações entre diferentes grupos e/ou fontes de matérias-primas podem ser razoavelmente efetuadas (Schwedt et al., 2004; PopelkaFilcoff, 2006). A análise de efeitos pós-deposicionais deve ser considerada como uma possível fonte de variação química na definição de grupos de artefatos quimicamente similares por técnicas estatísticas multivariadas (Buxeda i Garrigós et al., 2001; Golitko et al., 2012).

De acordo com Schwedt e Mommsen (2007), pode haver um perfil crescente de concentração, do centro do fragmento até a superfície, do elemento Na. O enriquecimento desse elemento pode ocorrer em regiões próximas ao mar. O composto $\mathrm{NaCl}$ dissolve-se na água da pasta e os íons $\mathrm{Na}^{+}$migram para a superfície, gerando uma diferença de $25 \%$. Foram reportadas perda de U e As. O elemento Sb pode migrar durante a secagem; já durante a queima, a perda é mais homogênea ( $<10 \%)$. Os autores reportaram que os metais alcalinos foram os mais afetados pela queima. Perda e perfil de concentração para $\mathrm{Rb}$ podem ocorrer em temperaturas altas. Perda de Cs é crítica para temperaturas altas. $\mathrm{Na}$ presença de calcita e $\mathrm{NaCl}$, significantes perfis de concentração elementar podem ocorrer, mas não pode explicar todas as reduções na concentração de Cs e Rb. Terras raras e Ca não foram afetadas pelo processo de queima.

Os materiais cerâmicos, no contexto pós-deposicional, são afetados principalmente em sua superfície externa. O grau dos efeitos contaminantes e de lixiviação em um fragmento cerâmico depende das características da pasta (porosidade, dureza, temperatura de queima etc.), e do agente contaminante, exigindo que uma criteriosa consideração dessas situações seja levada em conta.

As dificuldades em se determinar a tecnologia de queima devem-se à combinação de variáveis que refletem uma escolha tecnológica dos povos ceramistas. Muitos estudos que procuram estimar as condições de queima pré-histórica comparam as cerâmicas arqueológicas com argilas queimadas, ou promovem ainda a requeima da cerâmica. As variáveis principais são taxa de aquecimento, duração da queima, temperatura e atmosfera (simplificada para oxidante ou redutora). 
Neste trabalho, tecnologia, conceito adaptado Merrill e Richter (apud Schiffer, 1987) é entendida como o conjunto dos artefatos, comportamentos e conhecimentos para criar e utilizar produtos, que é transmitido ao longo das gerações. Desta forma, a integração das análises físico-químicas que abordam a tecnologia cerâmica ao contexto arqueológico é inevitável, e vai ao encontro da interdisciplinaridade pretendida pelos estudos arqueométricos. 


\section{CAPÍtulo 4}

\section{FUNDAMENTOS TEÓRICOS DAS TÉCNICAS ANALÍTICAS}

Uma das características comuns das técnicas descritas neste capítulo é a utilização da radiação eletromagnética para fins analíticos. Sendo assim, é importante saber identificar as diferentes regiões do espectro, para fins de comparação. A Fig. 4.1 ilustra uma divisão possível. As bandas, ou regiões, no espectro eletromagnético podem ser divididas nas seguintes classes gerais (embora haja variações) em ordem crescente de energia, ou decrescente de comprimento de onda: ondas de rádio, micro-ondas, infravermelho, luz ou radiação visível, radiação ultravioleta, radiação $X$, raios gama e raios cósmicos.

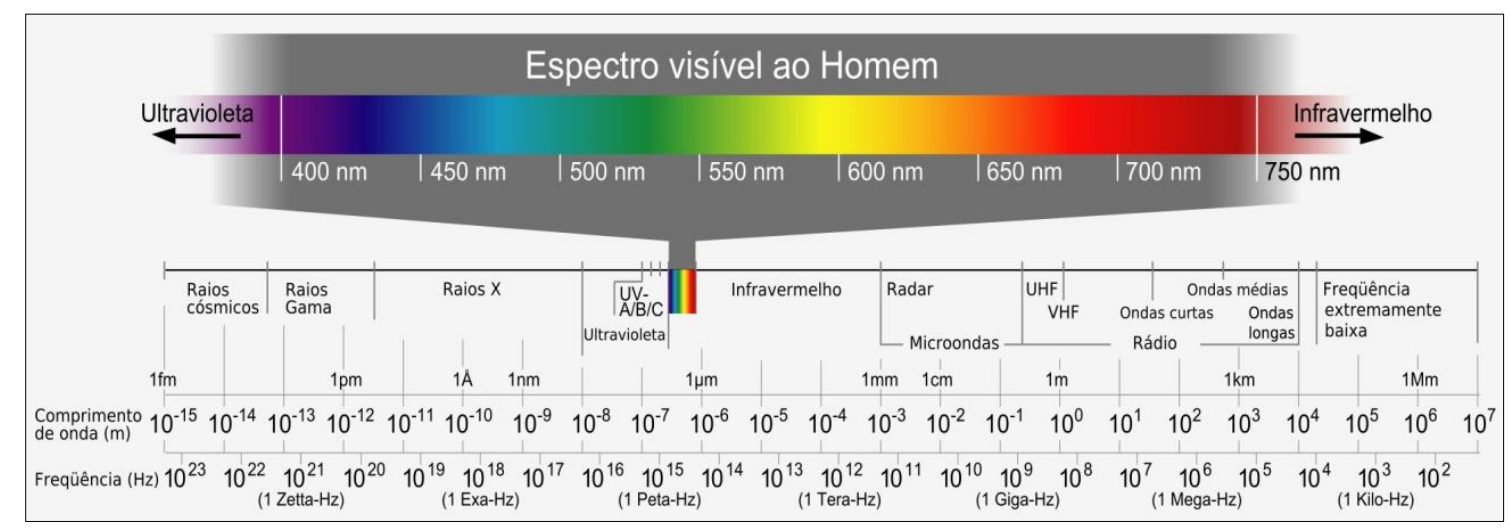

Figura 4.1 - Espectro eletromagnético. Fonte: Sociedade Brasileira de Física.

As técnicas analíticas utilizadas neste trabalho utilizam a radiação eletromagnética em bandas características, como resumido a seguir:

- Ativação com nêutrons: radiação gama, de modo geral;

口 Difração de raios X: radiação X; 
口 Datação por luminescência opticamente estimulada: luz visível $(\lambda \approx 470 \mathrm{~nm})$, embora esta técnica esteja analisando efeitos gerados por radiação cósmica e gama em materiais geológicos e arqueológicos ao longo do tempo;

口 Ressonância paramagnética eletrônica: micro-ondas.

Nas seções subsequentes, são apresentados os princípios físicos e equacionamentos fundamentais para o entendimento das técnicas analíticas.

\subsection{Análise por Ativação com Nêutrons Instrumental (INAA)}

Em termos gerais, análise por ativação pode ser definida como um método nuclear de análise elementar no qual elementos em uma amostra são bombardeados com partículas subatômicas para a produção de isótopos radioativos artificiais, que são identificados e medidos quantitativamente (Guinn e Lukens, 1965).

As partículas nucleares utilizadas em análise por ativação podem ser nêutrons, partículas carregadas (prótons, núcleos de deutério e trítio, partículas alfa e íons ${ }^{3} \mathrm{He}$ etc.) e fótons (raios gama e raios $\mathrm{X}$ ).

Muitos estudos arqueométricos de caracterização química empregam a análise por ativação com nêutrons instrumental (INAA) como técnica analítica nuclear para determinar as concentrações elementares em diversas matrizes de interesse, devido às suas muitas vantagens. Algumas dessas vantagens são enumeradas seguir (Bode, 1996; Glascock, 2004; Pollard et al., 2007; Verma, 2007):

- O método é não destrutivo, do ponto de vista da alíquota: não há necessidade de se converter uma amostra em uma solução antes da análise;

- Pequenas amostras são suficientes (aproximadamente $100 \mathrm{mg}$ );

口 Possibilidade de análise multielementar de até 40 ou 50 elementos por amostra;

口 O estado físico e químico dos elementos não influencia o resultado final, pois a INAA se baseia em processos nucleares;

- Alta sensibilidade;

- Possibilidade de análises qualitativas e quantitativas de elementos em níveis macro, micro e traço em vários tipos de amostras;

- Efeitos de matriz podem ser substancialmente reduzidos; 
- Para alguns elementos, a INAA oferece sensibilidade superior a de outros métodos, podendo chegar a ng. $\mathrm{g}^{-1}$.

Algumas desvantagens da INAA são (Verma, 2007):

- Necessidade de um reator nuclear de pesquisas disponível;

- Podem ocorrer interferências em análises multielementares pela produção de raios gama com energias próximas para diferentes elementos;

- As razões pico/radiação de fundo para um elemento não podem ser ajustadas de forma independente, pois a mesma é função da atividade dos outros radioisótopos produzidos durante a irradiação de uma amostra;

- O tempo para uma análise completa é longo (aproximadamente 35 dias no caso de irradiações no reator IEA-R1, desde a preparação até a segunda contagem), quando comparado ao de outras técnicas analíticas, como fluorescência de raios X;

- Alguns elementos têm baixa seção de choque de captura neutrônica e meia-vida curta, e são de difícil detecção por INAA. Exemplos: Pb, P e S.

\subsubsection{Fontes de nêutrons}

Feixes de nêutrons podem ser produzidos a partir de uma grande variedade de reações nucleares. Embora não possam ser acelerados como outras partículas carregadas, é possível ter um feixe inicial de alta energia e reduzi-la (para fins práticos) por meios de colisões com átomos de vários materiais. Os nêutrons podem ser classificados em relação à sua energia. Uma classificação possível é dada na Tab. 4.1, embora haja variações.

Tabela 4.1 - Classificação dos nêutrons segundo sua energia. Fonte: Terremoto (2004).

\begin{tabular}{c|c}
\hline Tipo de nêutron & Energia \\
\hline Muito rápido & $15 \mathrm{MeV}<\mathrm{E}<50 \mathrm{MeV}$ \\
Rápido & $0,1 \mathrm{MeV}<\mathrm{E}<15 \mathrm{MeV}$ \\
Intermediário & $1 \mathrm{keV}<\mathrm{E}<100 \mathrm{keV}$ \\
Epitérmico & $1 \mathrm{eV}<\mathrm{E}<1 \mathrm{keV}$ \\
Térmico & $\mathrm{E}<1 \mathrm{eV}(\approx 0,025 \mathrm{eV})$ \\
\hline
\end{tabular}


Algumas fontes de nêutrons comuns são listadas a seguir (Krane, 1988; Pollard et al., 2007, p. 129):

Fontes de berílio com emissores alfa;

ㄱontes fotoneutrônicas;

口 Fissão espontânea;

- Aceleradores de partículas;

- Reatores nucleares.

\subsubsection{Reatores nucleares como fonte de nêutrons}

Uma fonte de nêutrons muito recorrente são os reatores nucleares de pesquisa, cujos altos fluxos neutrônicos são produzidos, principalmente, pela cadeia de fissão do ${ }^{235} \mathrm{U}$. O reator à base de grafite de Brookhaven foi o primeiro reator nuclear para fins pacíficos construídos em território norte-americano no período pós-guerra. O objetivo principal do reator era a produção de nêutrons para experimentos científicos e o aperfeiçoamento da tecnologia de reatores (Brookhaven National Laboratory, 2008).

Em um reator nuclear, o fluxo de nêutrons próximo ao núcleo pode ser muito alto, da ordem de $10^{14} \mathrm{~cm}^{-2} \cdot \mathrm{s}^{-1}$. A energia dos nêutrons pode chegar até 5-7 MeV, mas o pico ocorre entre 1-2 MeV. No entanto, a energia típica dos nêutrons produzidos é alta para a manutenção da reação em cadeia (seção de choque de fissão é maior para nêutrons térmicos) e para aplicações, como análise por ativação neutrônica (Carpenter, 2004). Assim, a energia inicial desses nêutrons é geralmente reduzida a energias térmicas dentro do reator, mas nêutrons rápidos continuam presentes no núcleo.

Elementos construtivos designados como moderadores realizam a tarefa de reduzir a energia dos nêutrons dentro dos reatores nucleares. O principal moderador em reatores do tipo piscina é a água dessa piscina ao redor do núcleo (Guinn e Lukens, 1965). Colisões de nêutrons rápidos com núcleos de hidrogênio da água reduzem suas velocidades até o nível térmico do espectro, por meio de espalhamento elástico, ideal para manter a reação de fissão em cadeia do ${ }^{235} \mathrm{U}$.

No interior de um reator nuclear que utiliza ${ }^{235} \mathrm{U}$ como isótopo físsil, é possível encontrar cerca de 100 nuclídeos diferentes, representando cerca de 20 elementos. A maior parte dos fragmentos de fissão possui número de massa nas faixas de 90-100 e 135-145. 
Duas reações de fissão típicas são dadas a seguir de forma simplificada (Young \& Freedman, 2004):

$$
\begin{aligned}
& { }_{92}^{235} U+{ }_{0}^{1} n \rightarrow{ }_{92}^{236} U^{*} \rightarrow{ }_{56}^{144} \mathrm{Ba}+{ }_{36}^{89} \mathrm{Kr}+3{ }_{0}^{1} n \\
& { }_{92}^{235} U+{ }_{0}^{1} n \rightarrow{ }_{92}^{236} U^{*} \rightarrow{ }_{54}^{140} \mathrm{Xe}+{ }_{38}^{94} \mathrm{Sr}+2{ }_{0}^{1} n
\end{aligned}
$$

Reatores nucleares baseados na fissão do ${ }^{235} \mathrm{U}$ oferecem a fonte de nêutrons mais intensa para INAA. Um espectro de nêutrons típico com as três componentes, térmica, epitérmica e rápida, é ilustrado na Fig 4.2. Em um reator típico moderado a água leve, a fração de nêutrons rápidos costuma estar entre 2-3\%, enquanto a fração epitérmica costuma corresponder de 7-10\% do fluxo neutrônico (Glascock \& Neff, 2003).

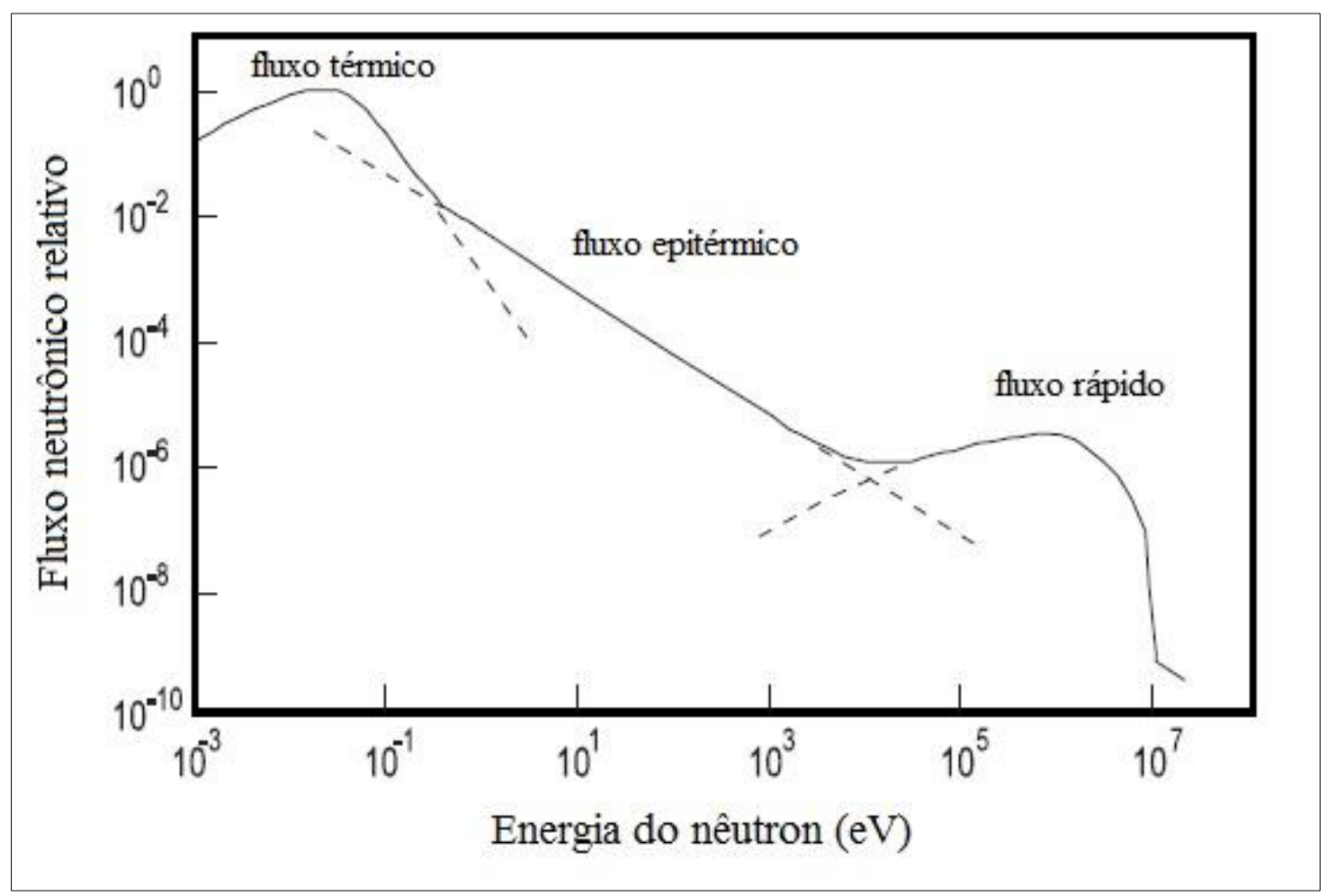

Figura 4.2 - Espectro típico de nêutrons em reatores nucleares de fissão. 
Os nêutrons térmicos dentro do reator nuclear têm aproximadamente a mesma distribuição de velocidade que as moléculas e átomos da vizinhança, ou seja, a distribuição de Maxwell-Boltzmann, na forma (Glascock \& Neff, 2003)

$$
\frac{d n}{d v}=\frac{4 n}{v_{0}^{3} \sqrt{\pi}} v^{2} e^{-\left(v / v_{0}\right)^{2}}
$$

\subsubsection{Princípios gerais de análise por ativação com nêutrons}

A análise por ativação com nêutrons instrumental compreende a modalidade dessa análise por ativação em que não são empregados procedimentos de separação química antes ou depois da irradiação.

Nessa técnica, os isótopos estáveis presentes na amostra são expostos a um fluxo de nêutrons térmicos, cuja energia cinética térmica está em equilíbrio com a da vizinhança. A energia cinética média para essas partículas a $25^{\circ} \mathrm{C}$ é de $0,025 \mathrm{eV}$. Nessas condições, um dos eventos possíveis é a captura neutrônica, com a formação de um núcleo composto excitado com número de massa $\mathrm{A}+1$, isótopo do elemento original. Quando isso ocorre, o núcleo sofre uma desexcitação, quase instantânea em termos práticos, pela emissão de um ou mais raios gama prontos em um intervalo de tempo menor que $10^{-14} \mathrm{~s}$. A equação da reação de captura é dada por (adaptado de Guinn e Lukens, 1965):

$$
X_{Z}^{A}+n_{0}^{1} \rightarrow\left[X^{*}\right]_{Z}^{A+1} \stackrel{\text { prompt }}{\longrightarrow} X_{Z}^{A+1}+\gamma
$$

A Eq. 4.4 pode ser reescrita na forma simplificada como

$$
X^{A}(n, \gamma) X^{A+1}
$$

Para a maioria dos elementos, a forma mais conveniente de ativação é a realizada com nêutrons térmicos. Duas principais razões para isso são (1) grande parte dos elementos químicos exibem seções de choque para reações $(n, \gamma)$ razoáveis para nêutrons térmicos; e (2) altos fluxos de nêutrons térmicos estão disponíveis, principalmente, em reatores nucleares. 
As reações $(n, \gamma)$ que resultam na formação de um isótopo estável de um elemento no estado fundamental não são de utilidade na forma tradicional de análise por ativação com nêutrons. Em outros casos, porém, o produto de uma reação $(n, \gamma)$ pode ser um radioisótopo ou isômero nuclear do elemento de interesse. O decaimento subsequente dessas espécies pode ser detectado, por exemplo, por espectrometria gama da radiação emitida durante o processo. Esses radioisótopos possuem utilidade analítica na análise por ativação com nêutrons, cujos processos característicos são ilustrados na Fig. 4.3.

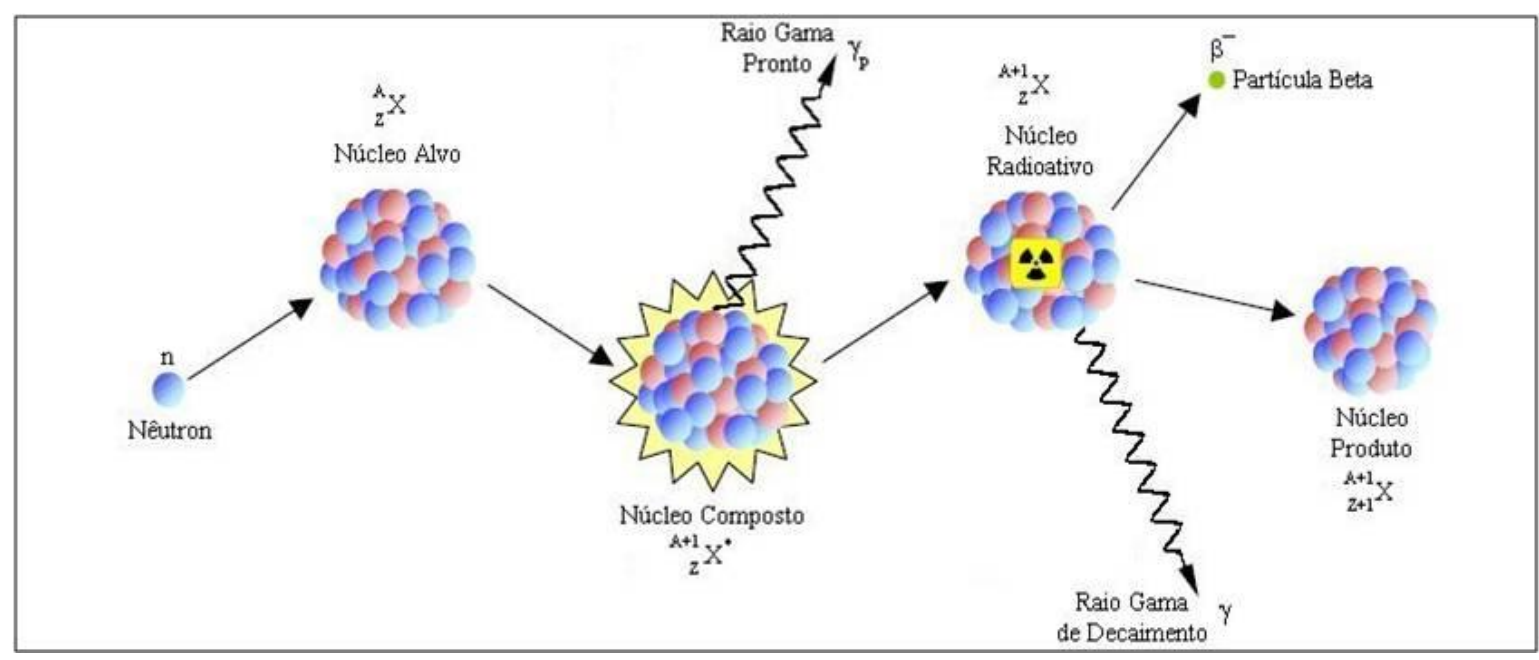

Figura 4.3 - Esquema ilustrando os processos nucleares que ocorrem pela interação de um nêutron incidente com um núcleo-alvo em análise por ativação com nêutrons.

No esquema da Fig. 4.3, é possível verificar que é formado um núcleo instável (na maioria dos casos) que decai quase instantaneamente $\left(<10^{-14} \mathrm{~s}\right)$. Em casos mais simples, o núcleo excitado decai apenas pela emissão de raios gama. Porém, em INAA, os núcleos radioativos produzidos geralmente decaem para o núcleo-filho por decaimento beta (Glascock \& Neff, 2003), transformando o núcleo-alvo da irradiação em um núcleo de um elemento adjacente na tabela periódica, o qual é radioativo e emite raios gama de utilidade para espectrometria (Leute, 1987). Contudo, já existem métodos que utilizam os raios gama prontos para fins analíticos (Glascock \& Neff, 2003).

A seção de choque de espalhamento dos núcleos varia regularmente de 0,07 barns para $\mathrm{H}^{1}$ até 2,7 barns para o $\mathrm{U}^{238}$. Já a seção de choque de captura de nêutrons 
térmicos situa-se na faixa desde $10^{-5}$ barns até $10^{5}$ barns. As reações $(n, \gamma)$ são exoenergéticas e, por isso, têm energia de limiar nula.

O decaimento radioativo pode ser definido como a transformação espontânea de átomos pela emissão de partículas ou raios gama do núcleo, ou raios $\mathrm{X}$, após a captura de elétrons pelo mesmo. Para um determinado conjunto de átomos radioativos, não é possível prever qual será o próximo a decair, pois o decaimento radioativo é um processo estatístico. Porém, as características de decaimento globais de um conjunto de átomos podem ser descritas matematicamente. A atividade de uma amostra é definida como o número de átomos decaindo, por unidade de tempo, definida na lei fundamental da radioatividade

$$
A=-\frac{d N}{d t}=\lambda N
$$

sendo $N$ o número de átomos radioativos, e $\lambda$ a constante de decaimento, que apresenta valores diferentes dependendo do radionuclídeo. Essa constante pode ser transformada em outra propriedade característica que controla a atividade de um determinado radionuclídeo: sua meia-vida, $\mathrm{T}_{1 / 2}$. A meia-vida corresponde ao período de tempo necessário para $\mathrm{o}$ decaimento da metade do número de átomos radioativos iniciais. A relação entre meia-vida e constante de decaimento é dada por

$$
T_{1 / 2}=\frac{\ln 2}{\lambda}=\frac{0,693}{\lambda}
$$

As meias-vidas dos radionuclídeos vão desde milissegundos até algumas vezes a idade do universo (Glascock, 2003). A solução para a equação diferencial de primeira ordem, Eq. 4.6, define a função que descreve a dependência temporal do número de núcleos radioativos, na forma

$$
N(t)=N_{0} e^{-\lambda t}
$$


sendo $N_{o}$ o número de átomos radioativos em $t=0$. Pela Eq. 4.8, é possível perceber que o processo de decaimento radioativo é exponencial.

Genericamente, a atividade resultante da captura neutrônica após um determinado tempo de irradiação $t$ pode ser dada por

$$
A=N \sigma \phi\left(1-e^{-\lambda t}\right)
$$

com

$$
N=\frac{m N_{A} a F}{M}
$$

sendo $\mathrm{A}=$ atividade em $\mathrm{Bq} ; \mathrm{N}=$ número de átomos do isótopo-alvo; $\sigma=$ seção de choque para a reação $(n, \gamma)$ em $\mathrm{b} ; \phi=$ fluxo de nêutrons $\left(n \cdot \mathrm{cm}^{-2} \cdot \mathrm{s}^{-1}\right) ; \lambda=$ constante de decaimento $\left(\lambda=\ln 2 / T_{1 / 2}\right) ; \mathrm{t}=$ tempo de irradiação; $\mathrm{m}=$ massa do alvo; $\mathrm{a}=$ abundância do isótopoalvo na natureza; $\mathrm{F}$ = fração do elemento no alvo; $\mathrm{N}_{\mathrm{A}}=$ número de Avogadro $\left(6,022.10^{23}\right)$; $\mathrm{M}=$ massa atômica do elemento.

Em análise por ativação com nêutrons, mede-se o número de átomos decaindo em algum momento após a irradiação. Essa quantidade de átomos radioativos observados em um tempo $t$ após a irradiação dependerá do número total de átomos radioativos produzidos durante a irradiação, do número de átomos que decaíram durante a mesma, do intervalo entre essa irradiação e o início da medição, e do tempo de duração da medição. Dessa forma, a taxa de produção $R$, a meia-vida $T_{1 / 2}$, a duração da irradiação $T_{i}$, o intervalo entre a irradiação e a medida $T_{d}$, e a duração da medida $T_{c}$, são parâmetros importantes em INAA.

Assumindo que não existiam átomos radioativos em $\mathrm{t}=0$, a equação descrevendo a atividade de um radionuclídeo medida durante a contagem pode ser expressa como (adaptado de Glascock, 2003)

$$
A=N\left(\emptyset_{t} \sigma_{t}+\emptyset_{e p i} I\right) P_{\gamma} \varepsilon\left(1-e^{-\lambda T_{i}}\right) e^{-\lambda T_{d}}\left(1-e^{-\lambda T_{c}}\right)
$$


sendo $N=$ número de átomos do isótopo-alvo, obtido da Eq. 4.10; $\emptyset_{t}$ o fluxo de nêutrons térmicos; $\sigma_{t}=$ seção de choque para nêutrons térmicos; $\emptyset_{\text {epi }}=$ fluxo de nêutrons epitérmicos; I = seção de choque epitérmica, ou integral de ressonância efetiva; $P_{\gamma}=$ intensidade do raio gama medido; $\varepsilon=$ eficiência do detector na energia do raio gama; $\left(1-e^{-\lambda T_{i}}\right)=$ fator de irradiação; $e^{-\lambda T_{d}}=$ fator de decaimento; $\left(1-e^{-\lambda T_{c}}\right)=$ fator de contagem.

Dentre as abordagens metodológicas principais em análise por ativação neutrônica, podem-se citar:

a Método absoluto

口 Método comparativo

口 Método $\mathrm{k}_{0}$

No método absoluto, a conversão de atividade medida em concentração se dá a partir do conhecimento de todos os parâmetros experimentais e nucleares necessários, como expressos na Eq. 4.11. Entretanto, o método absoluto é raramente utilizado em arqueometria, e o método comparativo é geralmente preferido (Glascock, 2003).

No método comparativo, o mais utilizado atualmente, o cálculo da concentração de um determinado elemento químico na amostra envolve a comparação de sua atividade induzida por nêutrons com a atividade induzida em uma amostra-padrão, na qual os elementos de interesse estão presentes em concentrações conhecidas. A vantagem desse método reside no fato de que parâmetros nucleares de difícil determinação, como fluxo neutrônico e seção de choque, não precisam ser medidos, como no caso do método absoluto. Os únicos parâmetros que precisam ser conhecidos são as atividades na amostra e no padrão e a massa do elemento de interesse no padrão. Essa última pode ser encontrada nos manuais dos materiais de referência. Algebricamente, pela razão das atividades do radioisótopo na amostra e no padrão (Eq. 4.11), e considerando-se os tempos de decaimento após a irradiação, o cálculo da massa de um elemento na amostra se resume a (Verma, 2007)

$$
m_{\text {amostra }}^{Z}=\frac{A_{\text {amostra }}^{Z}}{A_{\text {padrão }}^{Z}} \frac{\left(e^{-\lambda T_{d}}\right)_{\text {padrão }}}{\left(e^{-\lambda T_{d}}\right)_{\text {amostra }}} m_{\text {padrão }}^{Z}
$$


sendo $\mathrm{T}_{\mathrm{d}} \mathrm{o}$ tempo de decaimento desde a irradiação e $\mathrm{Z}$ o elemento de interesse.

A maioria dos laboratórios que utilizam INAA trabalha com um ou mais padrões de calibração multielementares. O procedimento padrão empregado consiste em irradiar e realizar a espectrometria gama em condições similares para as amostras desconhecidas e os padrões, e então utilizar a Eq. 4.12 para calcular as concentrações.

A Tab. 4.2 lista os parâmetros nucleares dos radioisótopos utilizados na análise por ativação com nêutrons instrumental deste trabalho.

\subsubsection{Espectrometria gama}

Raios gama podem interagir com a matéria por uma série de mecanismos. Um deles é o processo de absorção, no qual a energia dos raios gama é transferida aos fotoelétrons em um detector semicondutor (Glascock, 2003).

Os raios gama atrasados emitidos pelos elementos ativados com nêutrons térmicos são detectados para a identificação e quantificação dos elementos químicos presentes na amostra. Os raios gama são fótons de alta energia emitidos pelos núcleos.

Os detectores mais comuns para raios gama são os feitos a partir de iodeto de sódio (NaI) e germânio hiperpuro (HPGe). Para a determinação multielementar em análise por ativação neutrônica, os detectores de HPGe são amplamente utilizados pela sua alta resolução. Um exemplo de espectro típico para INAA de uma amostra de cerâmica arqueológica no Laboratório de Análise por Ativação Neutrônica, do IPEN, é apresentado na Fig. 4.4.

Quando um raio gama é absorvido pelo cristal do detector de germânio, ocorre uma ionização formando par elétron-buraco e, no final, um pulso elétrico é associado a cada um dos fótons de raio gama absorvidos, sendo sua amplitude proporcional à energia do fóton analisado. $\mathrm{O}$ cristal é mantido à temperatura do nitrogênio líquido para reduzir o ruído eletrônico (Pollard et al., 2007).

A vantagem de um detector semicondutor em relação a outros tipos desenvolvidos anteriormente, como detectores por cintilação, é que ele proporciona melhor resolução energética dos picos correspondentes aos raios gama de diferentes energias. Assim, a probabilidade da sobreposição de picos, que pode ocorrer quando um grande número de elementos é determinado, gerando vários picos, é reduzida. Além disso, concentrações menores podem ser medidas devido à melhor relação pico-radiação de 
fundo, associada aos raios gama por espalhamento Compton. Os níveis de detecção estão tipicamente na faixa de $10 \mathrm{ng} \cdot \mathrm{g}^{-1}$ até $10 \mu \mathrm{g} . \mathrm{g}^{-1}$ (Pollard et al., 2007).

Tabela 4.2 - Características nucleares dos radioisótopos utilizados. Fontes: Banco de dados Genie 2000 e NNDC-EUA $\left(1 \mathrm{~b}=10^{-24} \mathrm{~cm}^{2}\right)$.

\begin{tabular}{|c|c|c|c|c|c|c|}
\hline Elemento & $\begin{array}{l}\text { Isótopo } \\
\text { alvo }\end{array}$ & $\begin{array}{c}\text { Abundância } \\
\text { Isotópica (\%) }\end{array}$ & $\begin{array}{l}\text { Seção de } \\
\text { choque } \\
\text { (b) }\end{array}$ & Radiosótopo & Meia-vida & $\begin{array}{c}\text { Energia do } \\
\text { fotopico }(\mathrm{keV})\end{array}$ \\
\hline Antimônio & Sb-123 & 42,79 & 3,875 & $\mathrm{Sb}-124$ & $60,20 \mathrm{~d}$ & 1690,98 \\
\hline Arsênio & As-75 & 100 & 4,501 & As-76 & $1,0778 \mathrm{~d}$ & 559,1 \\
\hline Bário & Ba-130 & 0,106 & 8,68 & Ba-131 & $11,50 \mathrm{~d}$ & 496,28 \\
\hline Cério & Ce-140 & 88,45 & 0,5775 & Ce-141 & $32,501 \mathrm{~d}$ & 145,44 \\
\hline Césio & Cs-133 & 100 & 29 & Cs-134 & $2,0648 \mathrm{a}$ & 795,84 \\
\hline Cromo & $\mathrm{Cr}-50$ & 4,345 & 15,92 & $\mathrm{Cr}-51$ & $27,702 \mathrm{~d}$ & 320,08 \\
\hline Cobalto & Co-59 & 100 & 37,17 & Co-60 & $5,2714 \mathrm{a}$ & 1332,5 \\
\hline Európio & Eu-151 & 47,81 & 9184 & Eu-152m & $9,3116 \mathrm{~h}$ & 1408,01 \\
\hline Háfnio & Hf- 180 & 35,08 & 13,01 & Hf-181 & $42,39 \mathrm{~d}$ & 482,18 \\
\hline Ferro & $\mathrm{Fe}-58$ & 0,282 & 1,149 & $\mathrm{Fe}-59$ & $44,503 \mathrm{~d}$ & 1099,25 \\
\hline Lantânio & La-139 & 99,91 & 9,041 & La-140 & $1,6781 \mathrm{~d}$ & 1596,21 \\
\hline Lutécio & Lu-176 & 2,59 & 2097 & Lu-177 & $6,734 \mathrm{~d}$ & 208,36 \\
\hline Neodímio & Nd-146 & 17,2 & 1,489 & Nd-147 & $10,98 \mathrm{~d}$ & 531,02 \\
\hline Potássio & $\mathrm{K}-41$ & 6,7302 & 1,459 & K-42 & $12,360 \mathrm{~h}$ & 1524,58 \\
\hline Rubídio & $\mathrm{Rb}-85$ & 72,17 & 0,4935 & $\mathrm{Rb}-86$ & $18,631 \mathrm{~d}$ & 1077 \\
\hline Samário & Sm-152 & 26,75 & 206 & Sm-153 & $46,27 \mathrm{~h}$ & 103,18 \\
\hline Escândio & Sc-45 & 100 & 27,16 & Sc-46 & $83,79 \mathrm{~d}$ & 889,28 \\
\hline Sódio & $\mathrm{Na}-23$ & 100 & 0,5281 & $\mathrm{Na}-24$ & $14,9590 \mathrm{~h}$ & 1368,55 \\
\hline Tântalo & Тa-181 & 99,988 & 21,13 & Та-182 & $114,43 \mathrm{~d}$ & 1221,41 \\
\hline Térbio & Tb-159 & 100 & 23,35 & Tb-160 & $72,3 \mathrm{~d}$ & 879,38 \\
\hline Thório & Th-232 & 100 & 7,337 & $\mathrm{~Pa}-233$ & $26,967 \mathrm{~d}$ & 312,17 \\
\hline Urânio & $\mathrm{U}-238$ & 99,2742 & 2,683 & Np-239 & $2,3565 \mathrm{~d}$ & 228,18 \\
\hline Itérbio & Yb-174 & 31,83 & 63,2 & Yb-175 & $4,185 \mathrm{~d}$ & 396,32 \\
\hline Zinco & $\mathrm{Zn}-64$ & 46,83 & 1,1 & $\mathrm{Zn}-65$ & $244,26 \mathrm{~d}$ & 1115,55 \\
\hline
\end{tabular}




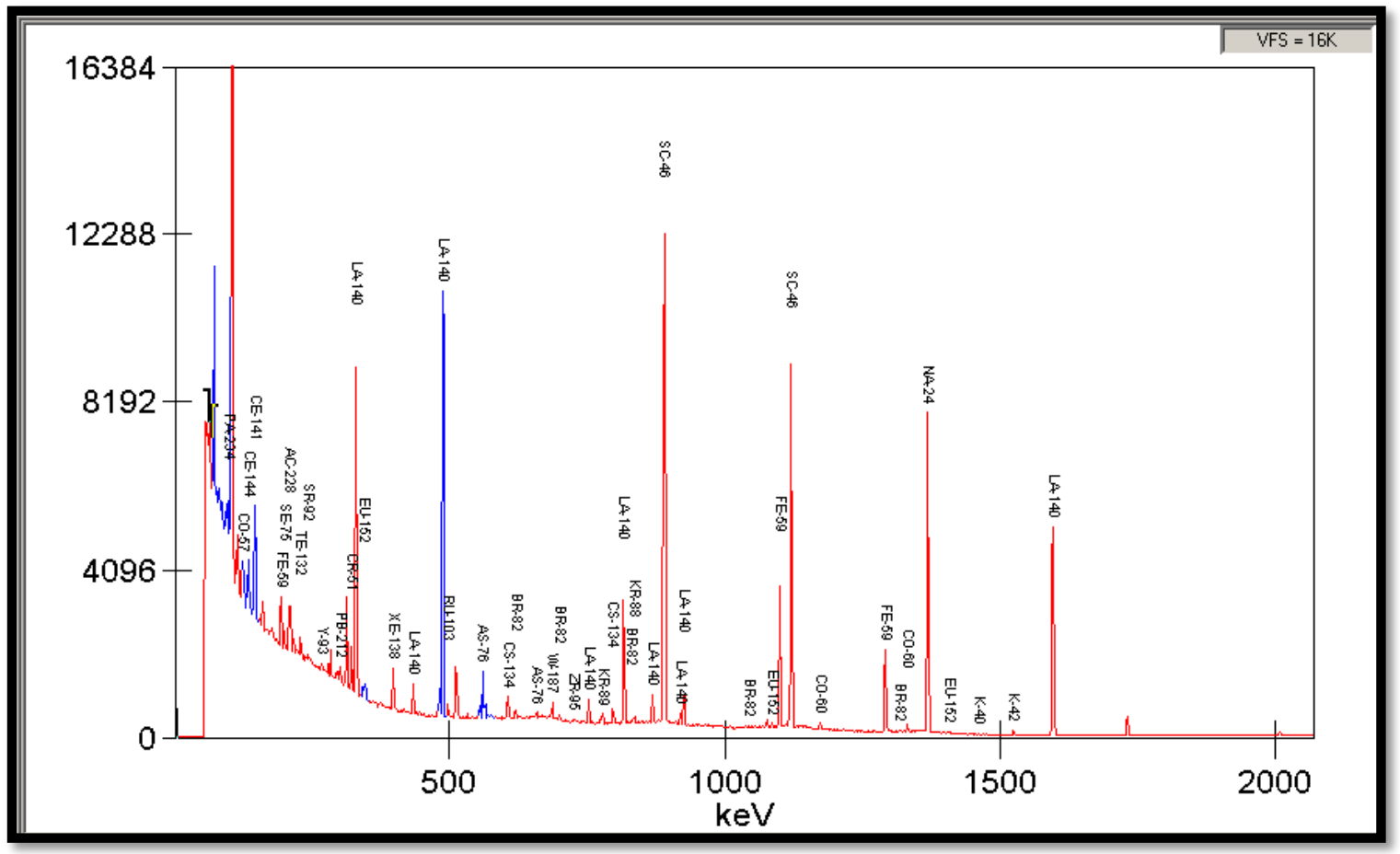

Figura 4.4 - Espectro gama típico de uma amostra de cerâmica arqueológica obtida no Laboratório de Análise por Ativação Neutrônica do IPEN - CNEN/SP.

Os raios gama são característicos dos núcleos emissores. Assim, eles podem ser utilizados para determinar qualitativamente a composição da amostra. A busca por picos é realizada no espectro por softwares adequados, sendo que os picos identificados por algoritmos específicos são comparados a uma lista de energia de raios gama tabelados, para a identificação dos radioisótopos. Os raios gama são escolhidos de acordo com sua abundância e energia. Na região de baixas energias do espectro (0-400 keV na Fig. 4.4), devido à radiação de fundo pelo efeito Compton dos raios gama emitidos pela amostra, pode ser difícil identificar o radioisótopo emissor, pela razão pico/(radiação de fundo) mais baixa, embora sua eficiência de detecção seja, frequentementee, maior que a de raios gama de energias maiores.

$\mathrm{Na}$ análise quantitativa em INAA, a área sob o pico é calculada, e a radiação de fundo é descontada para encontrar o número de contagens devido apenas ao elemento de interesse. A intensidade do sinal observada é proporcional à quantidade do radioisótopo na amostra, que por sua vez está relacionada à concentração total de um determinado elemento, como expresso na Eq. 4.12. 


\subsubsection{O reator nuclear de pesquisas brasileiro IEA-R1}

O reator IEA-R1 foi adquirido durante o programa Átomos para a Paz, após a Segunda Guerra Mundial, sendo que não houve despesas para o Brasil na época. Foi projetado e construído pela companhia norte-americana Babcock \& Wilcox, e sua primeira criticalidade ocorreu em 16 de setembro de 1957. Esse reator pertence ao Instituto de Pesquisas Energéticas e Nucleares (IPEN - CNEN/SP).

Ele é um reator do tipo piscina, moderado e refrigerado com água leve. A vazão da água de resfriamento é de $11.000 \mathrm{~L} \cdot \mathrm{min}^{-1}$, e a temperatura da água após passar pelo núcleo é de $32^{\circ} \mathrm{C}$. A água utilizada é deionizada e, além da refrigeração, serve para fins de blindagem e moderação dos nêutrons liberados durante o processo de fissão.

O núcleo do reator fica submerso a aproximadamente nove metros de profundidade, num arranjo de 24 elementos combustíveis padrões. O reator IEA-R1 possui 144 posições de irradiação no núcleo, a partir de 15 elementos de irradiação para irradiações longas, e um sistema pneumático para irradiações curtas. Também possui nove tubos de irradiação horizontais, cujo feixe de nêutrons é utilizado em experimentos de física nuclear e áreas correlatas.

Ele utiliza elementos de berílio e grafite como refletores. A potência máxima de operação do reator IEA-R1 é de $5 \mathrm{MW}$. O fluxo de nêutrons térmicos máximo que pode ser alcançado no reator é de cerca de $10^{14} \mathrm{~cm}^{-2} \cdot \mathrm{s}^{-1}$, enquanto o fluxo máximo de nêutrons epitérmicos e rápidos é da ordem de $10^{13} \mathrm{~cm}^{-2} \cdot \mathrm{s}^{-1}$.

Atualmente, o reator IEA-R1 é utilizado para as seguintes finalidades (IPEN, 2011):

․ Produção de radioisótopos para uso em medicina nuclear: como o Samário-153, utilizado como paliativo da dor em metástase óssea e no tratamento de artrite reumatóide; o Iodo-131, utilizado na terapia de câncer de tireóide e hipertiroidismo, na terapia de hepatomas, na localização e terapia de feocromocitomas, neuroblastomas e outros tumores, no estudo da função renal, na determinação do volume plasmático e volume sanguíneo total; e o Irídio-192, produzido na forma de fios metálicos, utilizados na técnica de braquiterapia para o tratamento de câncer.

- Produção de fontes radioativas para gamagrafia industrial e de radioisótopos: para uso como traçadores em processos industriais, como Cobalto-60 (fonte utilizada em gamagrafia industrial), Bromo-82 (na forma de $\mathrm{KBr}$ é utilizado para 
medição de vazão em rios e em efluentes líquidos industriais), Mercúrio-203 (utilizado no controle de processos industriais), Criptônio-79, Argônio-40 e Lantânio-140 (utilizados na inspeção de tubulações em refinarias de petróleo).

- Irradiação de amostras para análises multielementares: utilizando a técnica análise por ativação com nêutrons em materiais geológicos; produtos industriais, como plásticos e resinas; catalisadores; petróleo; metais e ligas metálicas; amostras arqueológicas; tecidos animais e humanos; vegetais; alimentos; e amostras ambientais.

\section{a Pesquisas em Física Nuclear;}

๑ Serviços de neutrongrafia;

- Treinamento de pessoal licenciado para operação de reatores.

\subsection{Difração de Raios X (XRD)}

Os níveis energéticos dos elétrons mais internos, ou próximos ao núcleo, na estrutura eletrônica orbital dos átomos mais pesados possuem diferenças de energia suficientemente altas para que as transições envolvendo esses níveis originem quanta de radiação cuja energia - ou comprimento de onda - caia dentro da região dos raios X no espectro eletromagnético (Pollard \& Heron, 1996).

O fenômeno de difração pode ser descrito como um tipo de espalhamento elástico que ocorre quando a luz interage com o material cristalino e é desviada em uma direção específica. Estruturas cristalinas são formadas por átomos dispostos em padrões tridimensionais, segundo geometrias específicas. Nessas estruturas, é possível identificar planos paralelos entre si e separados por uma distância definida $d$, característica da rede cristalina para cada fase mineral, formando uma "família" de planos (Del Castillo \& Strivay, 2012).

Se um elétron é removido de um dos níveis de energia mais internos, dois processos concorrentes podem ocorrer: a emissão de um elétron adicional (efeito Auger), ou a emissão de um raio X. A probabilidade de cada um desses fenômenos é uma função dependente do nível energético da vacância inicial e da massa atômica (Pollard \& Heron, 1996).

No efeito Auger, um elétron mais externo muda de nível energético para preencher a vacância, mas em vez de emitir um fóton, um segundo elétron é ejetado, com 
energia cinética aproximadamente igual à diferença entre os níveis energéticos envolvidos. Na prática, o efeito Auger torna-se significativo para os elementos mais leves. No entanto, vacâncias iniciais nas camadas L ou superiores podem resultar numa emissão dominante de elétrons Auger em relação à emissão de fótons de raios X.

Em relação às linhas de emissão resultantes, podem-se aplicar as regras de seleção, que definem quais transições são permitidas. De maneira geral, para as vacâncias criadas na camada K, ocorrem duas linhas de emissão separadas: uma mais intensa, denominada $\mathrm{K}_{\alpha}$, resultantes de transições $2 \mathrm{p}-1 \mathrm{~s}$, e uma linha menos intensa, denominada $\mathrm{K}_{\beta}$, resultante de transições 3p-1s, 4p-1s, 3d-1s e 4d-1s. A separação entre as linhas $\mathrm{K}_{\alpha} \mathrm{e}$ $\mathrm{K}_{\beta}$ aumenta com a massa atômica do elemento e a intensidade da linha $\mathrm{K}_{\beta}$ costuma ser $10 \%$ da linha $\mathrm{K}_{\alpha}$ (Pollard \& Heron, 1996).

A difração de raios $\mathrm{X}$ é uma ferramenta importante em mineralogia, para a identificação, quantificação e caracterização de minerais em matrizes complexas. Sua aplicação a cerâmicas arqueológicas - que podem ser descritas em termos de uma mistura de minerais argilosos, aditivos antiplásticos e seus produtos de transformação, durante o processo de queima - produz informação sobre a composição mineral desses objetos. Detalhes do processo de produção das cerâmicas, como temperaturas e atmosfera de queima podem então ser explorados (Stanjek \& Häusler, 2004).

A menor unidade que contém toda a informação estrutural e química necessária para definir univocamente um cristal é denominada de célula unitária. Células unitárias têm dimensões de vários angström $\left(1 \AA=10^{-10} \mathrm{~m}\right)$. Assim, cristais do tamanho de alguns micrometros são formados por bilhões de células unitárias, que se repetem periodicamente nas três dimensões, caracterizando uma estrutura ordenada de longo alcance. A interação de ondas com estruturas periódicas produz efeitos de difração se o comprimento de onda da radiação incidente e a periodicidade dos cristais são de magnitude similar. Os efeitos de difração podem sofrer perturbações devido a fatores que façam a periodicidade atômica fugir de sua idealidade. Dentre esses fatores, pode-se citar o tamanho pequeno de muitos cristais, que representa um desvio de um cristal infinito perfeito. Defeitos na estrutura (ver Capítulo 3), como substituição de átomos também representam alguns desses fatores (Stanjek \& Häusler, 2004).

$\mathrm{Na}$ difração, o campo elétrico dessas ondas interage com as cargas de todos os elétrons de um átomo, o qual emite então uma onda quase esférica, com o mesmo comprimento de onda da radiação incidente. A amplitude da onda emitida depende do 
número de elétrons do átomo, de forma que elementos leves (com poucos elétrons), como carbono e oxigênio, são maus espalhadores de raios X; enquanto elementos pesados, como o chumbo, são bons espalhadores (Stanjek \& Häusler, 2004).

Se não houvesse o efeito de difração, os raios $\mathrm{X}$ incidentes em um volume de amostra seriam espalhados em todas as direções. A difração redistribui a intensidade de toda a esfera de espalhamento em direções específicas. Dessa forma, picos de intensidade surgem em certas direções, enquanto que em direções intermediárias a esses picos, a intensidade cai drasticamente. Entretanto, a intensidade integrada sobre toda a esfera de espalhamento permanece constante devido à conservação de energia. Uma abordagem para descrever essas direções é a utilização do conceito de planos de espalhamento do retículo cristalino e a interferência entre ondas espalhadas por planos reticulares vizinhos. A Fig. 4.5 ilustra o fenômeno.

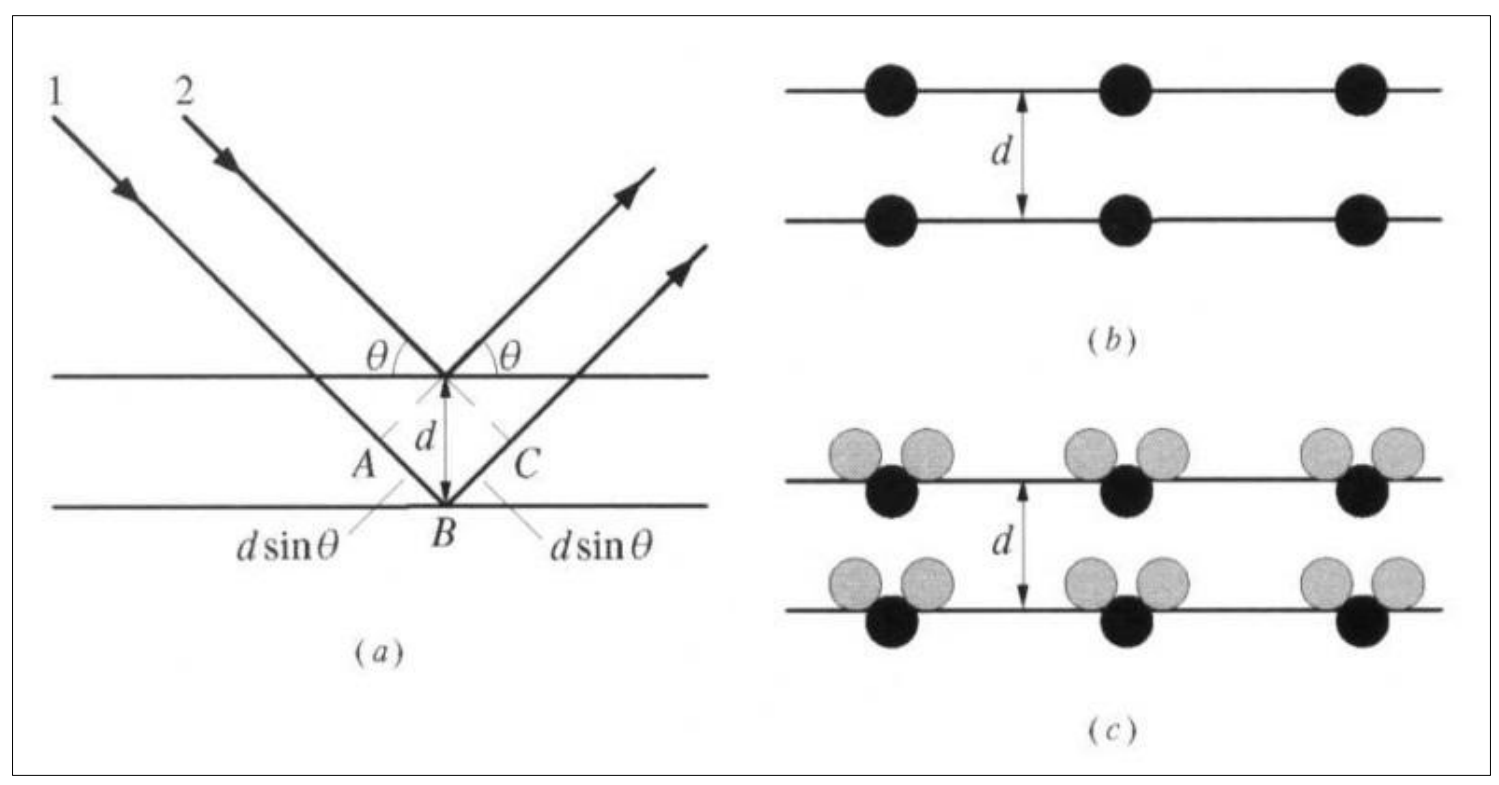

Figura 4.5 - Espalhamento de raios $\mathrm{X}$ por planos cristalinos. $\mathrm{O}$ ângulo de espalhamento $\theta$ depende apenas da distância interplanar $d$, porém a intensidade de difração dependerá da natureza célula unitária, ou estrutura cristalina. Assim, as estruturas (b) e (c) espalharão raios $\mathrm{X}$ no mesmo ângulo $\theta$, porém com intensidades diferentes. Adaptado de Barsoum (2003).

A condição de interferência construtiva de ondas, também chamada de reflexão de Bragg, é obtida quando a trajetória de planos inferiores é mais longa que a de planos superiores por uma quantidade que é um número inteiro de comprimentos de onda. Assim, a condição de interferência ocorre quando 


$$
n \lambda=2 d \operatorname{sen} \theta
$$

sendo:

n: um número inteiro;

$\lambda$ : comprimento de onda da radiação;

$d$ : distância interplanar;

$\theta$ : ângulo formado entre a radiação incidente e o plano reticular de espalhamento.

A Eq. 4.13 é conhecida como Lei de Bragg. Cada substância cristalina, ou fase, possui um padrão característico de ângulos de difração, que pode ser utilizado em sua identificação.

Os difratômetros mais comuns usam uma fonte de raios $\mathrm{X}$ quase monocromática, que emite raios $\mathrm{X}$ de uma certa energia, em um ângulo variável $\theta \mathrm{em}$ relação ao porta-amostras. Na difração de raios $\mathrm{X}$, uma fonte monocromática é disposta em certo ângulo em relação à amostra em análise, que pode variar ou permanecer fixa durante o experimento. Essa amostra normalmente é uma amostra policristalina, com pó de cristais aleatoriamente orientados (Del Castillo \& Strivay, 2012). Entre as fontes de raios X mais usuais estão as de $\mathrm{Cu}, \mathrm{Cr}$, Fe e Mo.

Para a interpretação dos espectros, utiliza-se o banco de dados do International Centre for Diffraction Data (ICDD). Os arquivos recebem a sigla de PDF (do inglês, Powder Diffraction File). Quando não se conhecem os compostos de antemão, pode-se utilizar o método de Hanawalt para busca.

$\mathrm{Na}$ análise de mistura de minerais, muitas vezes é de interesse do analista utilizar a difração de raios X não só para determinar quais minerais uma amostra contém, mas também para estimar as concentrações relativas dos minerais individuais. Um desenvolvimento relativamente recente é o método de Rietveld, que gera difratogramas calculados a partir de informações acerca das estruturas cristalinas das fases presentes e suas proporções relativas (ajuste entre difratograma real e calculado com minimização dos resíduos através de mínimos quadrados). Para cada mineral, os ângulos de Bragg e as intensidades devem ser calculados. Por ser um sistema altamente não linear, o processo de otimização dos parâmetros individuais (como a quantidade de cada mineral e dimensões da célula unitária) para a obtenção do melhor ajuste entre o espectro experimental e o teórico é um processo iterativo. 
Alguns obstáculos para a análise quantitativa em XRD são: necessidade de se preparar materiais de referência para cada amostra; orientação preferencial dos grãos; microabsorção; granulação da amostra.

\subsection{Ressonância Paramagnética Eletrônica (EPR)}

A ressonância paramagnética eletrônica, ou ressonância de spin eletrônico (ESR), é uma técnica útil para estudar materiais com pares de elétrons desemparelhados. A origem da técnica remonta a 1944 com os trabalhos de Yevgeny Zavoisky, da Kazan State University, e Brebis Bleaney, da Universidade de Oxford (Ikeya, 1993). A Fig. 4.6 ilustra resumidamente o princípio da técnica de EPR, cuja magnitude do sinal característico é devido aos elétrons desemparelhados.

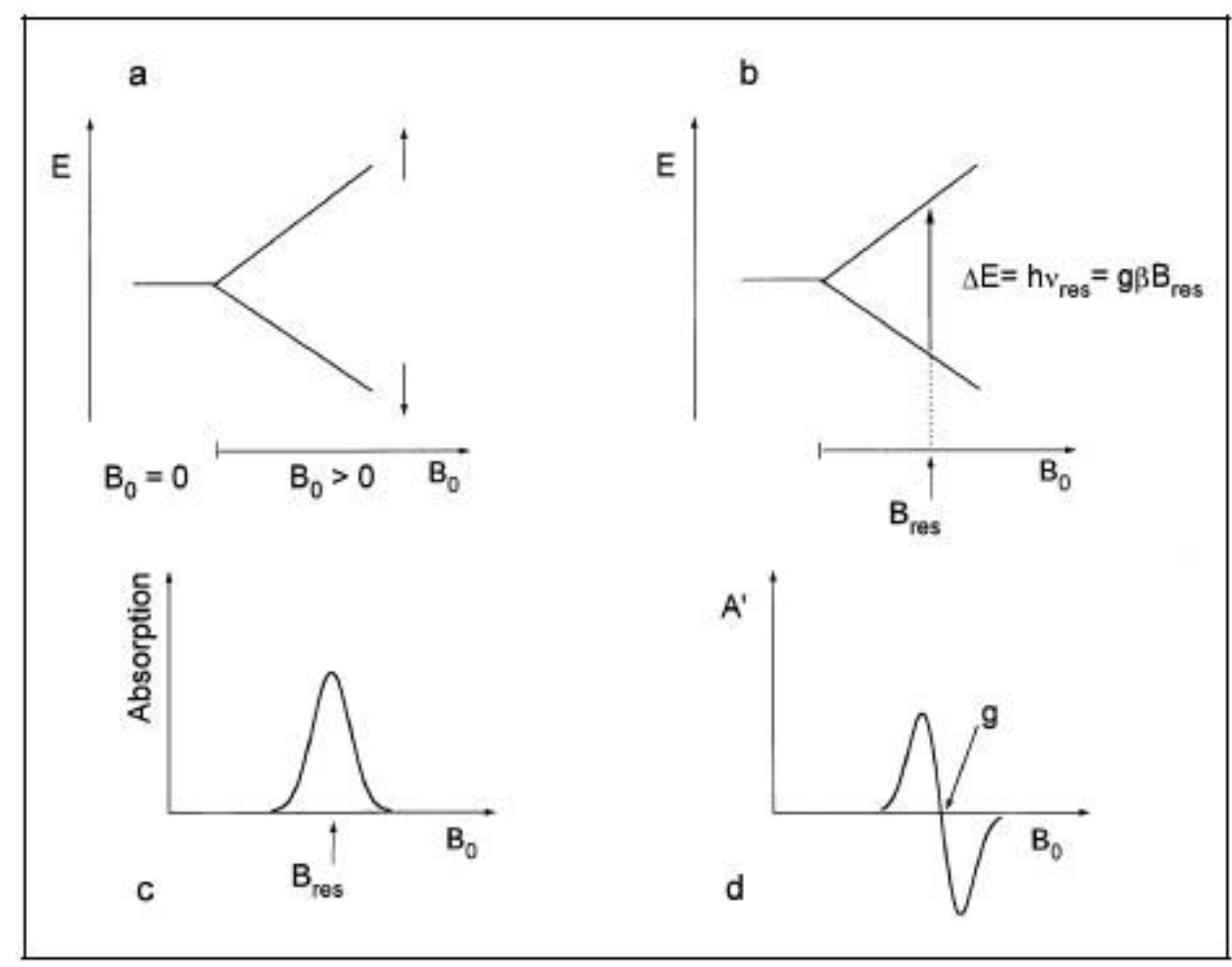

Figura 4.6 - Esquema simplificado do princípio de EPR. Fonte: Adaptado de Bartoll \& Tani (1998).

Inicialmente (Fig. 4.6a), os estados de spin eletrônico estão degenerados $\left(B_{0}=\right.$ $0)$. Contudo, por meio da aplicação de um campo magnético externo $\left(B_{0} \neq 0\right)$, ocorre um 
desdobramento energético do nível original, dependente da orientação dos spins (spin up 个ou spin down $\downarrow$ ) e da direção do campo magnético, conhecido como efeito Zeeman.

Genericamente, a diferença entre os níveis energéticos, função da indução magnética, pode ser expressa por

$$
\Delta E=g \mu_{B} B_{0}
$$

Sendo $g$ o fator de Landé, ou fator de desdobramento espectroscópico, que aparece em cálculos de perturbações de primeira ordem na energia de um átomo quando um campo magnético uniforme e fraco é aplicado ao sistema; $\mu_{B}$ é o magnéton de Bohr, que é uma constante física e a unidade natural para expressar o momento de dipolo magnético de um elétron $\left[\mu_{B}=e \hbar /\left(2 m_{e}\right)\right]$

Um elétron desemparelhado pode se deslocar entre dois níveis energéticos pela absorção de radiação eletromagnética incidente com energia

$$
E=h v
$$

Num experimento de EPR, o sistema é irradiado constantemente com radiação na região de micro-ondas (Fig. 4.6c). Quando é atingida a condição de ressonância (Fig. 4.6b) pela varredura de um campo magnético, mantendo-se a frequência de micro-ondas constante, obtém-se a equação fundamental de EPR, pela igualdade das Eqs. 4.14 e 4.15

$$
h v_{\text {res }}=g \mu_{B} B_{\text {res }}
$$

sendo $v_{\text {res }}$ a frequência de ressonância da radiação eletromagnética; e $B_{\text {res }}$ a indução magnética de ressonância. A Eq. 4.16 implica que a radiação incidente de micro-ondas tenha energia equivalente à diferença energética entre os estados. A direção do spin é mudada pela absorção da radiação.

O fator $g$ é um importante parâmetro do espectro de EPR, pois elétrons desemparelhados em diferentes ambientes terão fatores $g$ ligeiramente diferentes, resultando na aparência do sinal característico para diferentes centros paramagnéticos em diferentes campos magnéticos. Esse fato possui importância analítica para as aplicações da 130 
técnica de EPR, já que diferenças no fator $g$ podem ser monitoradas para a determinação da temperatura de queima e datação de objetos arqueológicos, por exemplo. A variação no fator $g$ ocorre indiretamente pela interação entre o momento magnético de spin e o momento magnético orbital, ou interação spin-órbita (Ikeya, 1993).

Os fatores $g$ estão geralmente em torno de 2, e são frequentemente determinados até a quarta casa decimal. Elétrons livres têm um fator $g_{e}=2,0023$, após correção relativística (Ikeya, 1993).

Normalmente, são utilizadas micro-ondas com frequência no intervalo [9,10] $\mathrm{GHz}$ e $B_{0}$ em torno de $3500 \mathrm{G}(0,35 \mathrm{~T})$. Grande parte dos espectros é registrada e publicada como a primeira derivada das curvas de absorção de micro-ondas (Fig. 4.6d) em função da indução magnética. O fator de desdobramento espectroscópico para a condição de ressonância pode ser determinado pela identificação do ponto marcado como $g$ na Fig. 4.6d.

A maioria dos materiais analisados por EPR estão na forma policristalina, ou pó dos artefatos originais, como ossos de fósseis e conchas. Os sinais de EPR, dependentes da posição angular entre o campo magnético e a estrutura cristalina, são superpostos para produzir um espectro geral (Ikeya, 1993).

Em estudos de cerâmicas arqueológicas, as espécies responsáveis pelo sinal de EPR são, principalmente, íons de alto spin $\mathrm{Fe}^{3+}(\mathrm{s}=5 / 2)$, os quais são sensíveis ao processo de queima da cerâmica.

\subsection{Datação por Luminescência Opticamente Estimulada (OSL)}

A datação por luminescência opticamente estimulada (OSL) e por termoluminescência (TL) são métodos baseados na medição e quantificação da dose de radiação acumulada nos materiais. Elementos radioativos emitem partículas alfa, beta e radiação gama, que podem produzir defeitos atômicos ou eletrônicos nos sólidos. Essa radiação emitida causa defeitos, vacâncias e intersticiais (ver Cap. 3), ao longo de uma "trilha". Esses defeitos interrompem a regularidade dos átomos no retículo cristalino (Ikeya, 1993).

Essas imperfeições geram níveis energéticos alternativos, que podem atrair e armadilhar elétrons livres por muito tempo, chegando a milhões de anos (Fig. 4.7). Assim, é possível datar materiais pela observação e medida dos defeitos acumulados causados pela 
radiação em sólidos ao longo do tempo. As principais fontes de radiação ionizante que podem produzir pares elétron-buraco são os radioisótopos naturais ${ }^{40} \mathrm{~K},{ }^{238} \mathrm{U}$ e ${ }^{232} \mathrm{Th}$, radiação cósmica e ${ }^{187} \mathrm{Rb}$, em menor importância.

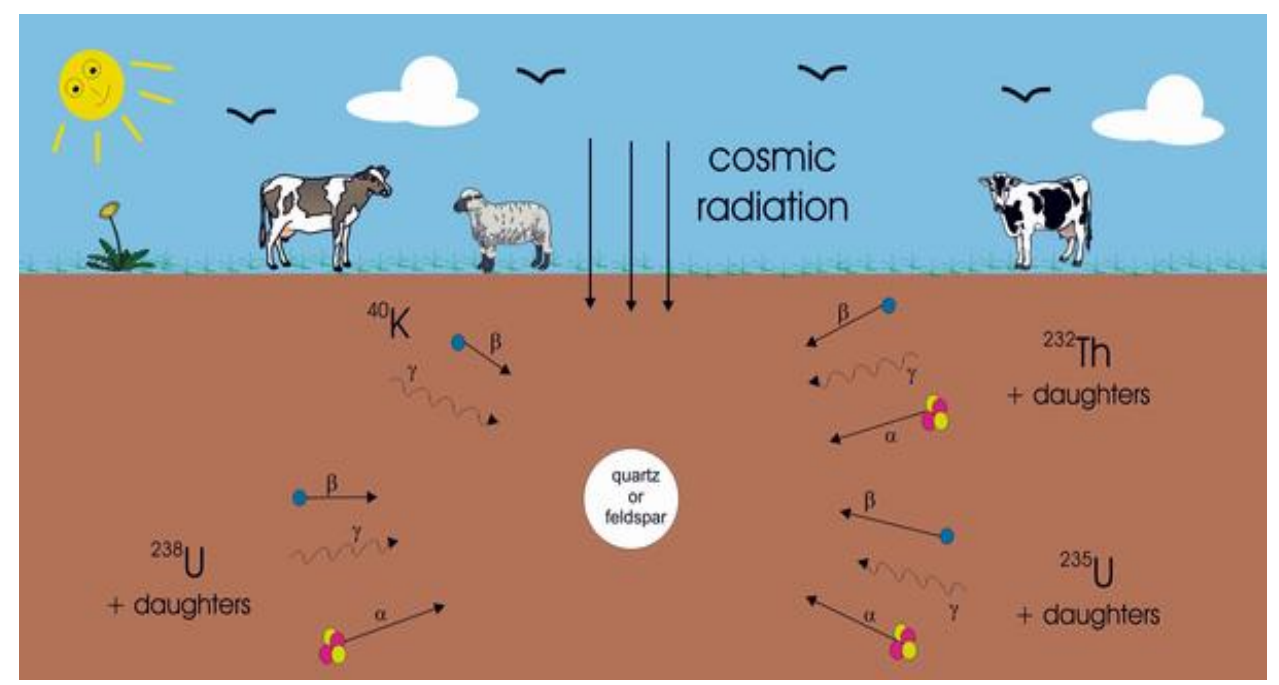

Figura 4.7 - Acúmulo de dose alfa, beta e gama nos grãos de quartzo e feldspato ao longo do tempo.

A datação por termoluminescência é baseada na emissão de luz por um material quando esse é aquecido após ter sido submetido a uma fonte de radiação ionizante, enquanto que em sua correlata por luminescência opticamente estimulada, a luminescência se dá pela estimulação com luz na região verde, azul ou infravermelha em laboratório.

A datação de sedimentos por luminescência opticamente estimulada iniciou-se em 1985. A técnica possui grande potencial para o entendimento de fenômenos da superfície planetária. A OSL possui grande sensibilidade a condições ambientais e seu sinal pode ser apagado em segundos pela exposição à luz ambiente ou aquecimento no intervalo entre $200{ }^{\circ} \mathrm{C}$ e $400{ }^{\circ} \mathrm{C}$. A datação por meio desta técnica utiliza os sinais dos grãos de quartzo ou feldspato (Rhodes, 2011).

A energia da radioatividade natural é responsável pela excitação dos elétrons dos átomos do retículo cristalino até a banda de condução, na qual eles podem mover-se livremente. A maioria dos elétrons excitados recombina-se com os íons do retículo, mas alguns são armadilhados naqueles níveis energéticos alternativos, armazenando 
parcialmente a energia da radiação incidente na forma de carga elétrica armadilhada. $\mathrm{O}$ tempo de retenção dos elétrons nas armadilhas depende da profundidade das mesmas, associada à energia requerida para liberar o elétron. Algumas armadilhas possuem profundidade suficiente para reter elétrons por centenas de milhares de anos, sendo essa a base para a acumulação de carga ao longo do tempo (Artioli, 2010).

A quantificação de elétrons armadilhados é medida pela luminescência secundária emitida na recombinação dos pares elétron-buraco, estimuladas pela incidência de luz em laboratório. Nesse processo, ilustrado na Fig. 4.8, o elétron armadilhado passa do estado fundamental para o estado excitado. Os átomos ao redor do elétron excitado se movem e o retículo cristalino "relaxa" pela emissão de fônons, pelos modos vibracionais da estrutura, levando o elétron a um estado excitado relaxado, a partir do qual, idealmente, o elétron retorna ao estado fundamental pela emissão de fóton. O estado fundamental ao qual o elétron chega tem uma configuração atômica em um estado de energia maior em relação ao estado fundamental do qual ele partiu, de forma que a energia de emissão pelo retorno ao estado fundamental é menor que a energia dos fótons incidentes, ou seja, o comprimento de onda sofre um desvio para vermelho, chamado de deslocamento de Stokes (Ikeya, 1993).

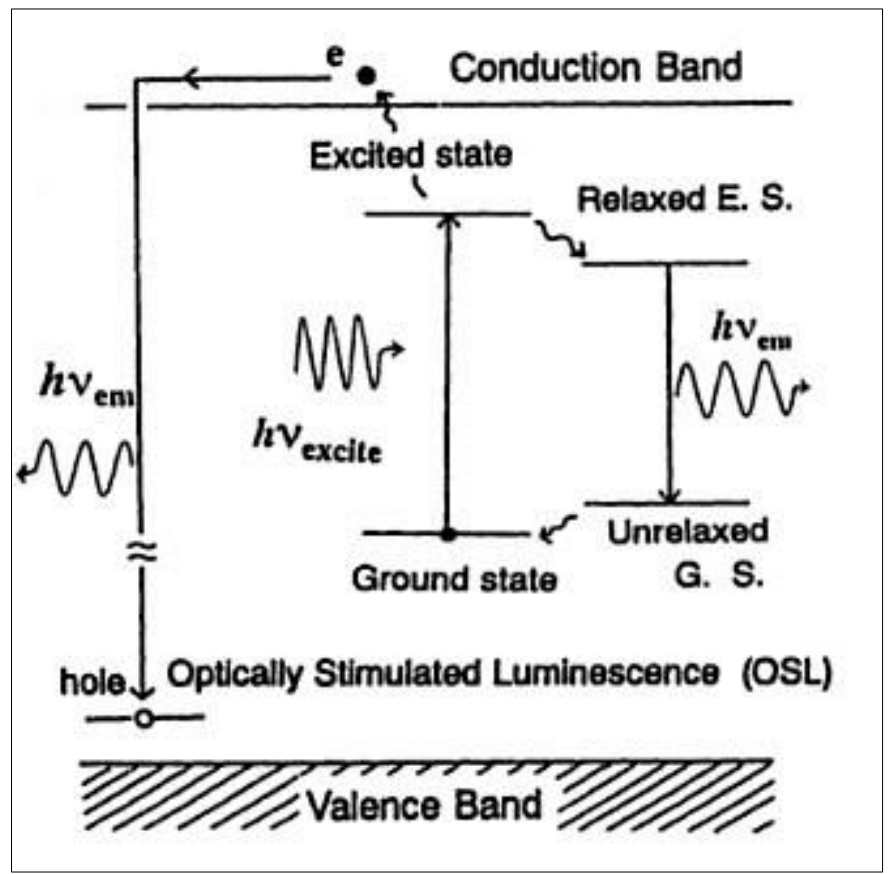

Figura 4.8 - Desenho esquemático do princípio de datação por luminescência opticamente estimulada (OSL). Fonte: adaptado de Ikeya (1993). 
A radiação luminescente emitida possui energia proporcional ao nível energético de armadilhamento do elétron. A intensidade é proporcional ao número de elétrons armadilhados ao longo do tempo, em função da dose de radiação ionizante acumulada. A idade de um artefato datado por OSL pode ser calculada por

$$
\text { Idade }=P / \dot{D}
$$

sendo $P$ a paleodose (dose de radiação ionizante acumulada desde a última queima da cerâmica, em Gy) e $\dot{D}$, a taxa anual de dose (em Gy/ano).

$\mathrm{Na}$ datação por OSL, a luminescência natural da amostra é comparada com sinais artificiais obtidos pela irradiação da amostra com fontes de radiação beta, por exemplo. Para a estimulação, as fontes de luz contínuas ou moduladas podem ser (Artioli, 2010):

ㄴaser de íon;

口 Lâmpada de arco voltaico com filtros;

口 Lâmpada de halogênio;

ㅁ Diodos infravermelhos $(\lambda=880 \pm 80 \mathrm{~nm})$ e verdes $(\lambda=470 \pm 20 \mathrm{~nm})$.

O evento "zero" para datação por OSL é a última exposição do sedimento à luz solar. Ele representa o evento datado, no qual a luminescência latente adquirida de alguma forma no passado é praticamente zerada. Para sedimentos, esse evento ocorre pela erosão, transporte e deposição. Para cerâmicas arqueológicas, na verdade, esse evento é o último aquecimento da cerâmica, que pode ser a queima quando da produção da peça, para o caso de peças produzidas para armazenamento de alimentos e líquidos, decoração, rituais etc.; ou o aquecimento durante o cozimento de alimentos.

A sensibilidade deste método, superior em comparação ao método de datação por termoluminescência, permite que protocolos de medição baseados em uma única alíquota e um único grão sejam utilizados. Protocolos baseados em pré-aquecimento e doses regenerativas foram propostos para remover componentes de sinal instáveis, especialmente em grãos de quartzo e feldspato. Um desses protocolos, o SAR (Singlealiquot Regenerative-dose Protocol), foi utilizado neste trabalho. 
Os minerais utilizados mais frequentemente em datação por OSL são quartzo e feldspato (Aitken, 1998). Antes de os sedimentos ou amostras serem depositados em seus respectivos contextos, eles possuem, provavelmente, um sinal de luminescência latente (ou residual). A eficácia com que ele é reduzido a zero é de importância crítica para as medidas. Uma das grandes vantagens da datação por luminescência opticamente estimulada, em relação à datação termoluminescente, é que qualquer sinal residual após a deposição é, pelo menos, uma ordem de grandeza menor (Aitken, 1998).

A taxa anual de dose pode ser atenuada por absorção pela água, presente no solo e na amostra, devido à sua porosidade (Ikeya \& Miki, 1985; Zacharias et al., 2001). Considerando esse efeito da umidade do solo e desconsiderando a irradiação alfa, a taxa anual de dose pode ser expressa como (Ikeya \& Miki, 1985):

$$
\dot{D}=\frac{\dot{D_{\beta}}}{1+1.25 \frac{W_{c}}{100-W_{c}}}+\frac{\dot{D_{\gamma}}}{1+1.14 \frac{W_{s}}{100-W_{s}}}+\dot{D}_{\text {cósmica }}
$$

sendo $W_{c}$ o conteúdo de água nos fragmentos cerâmicos para cálculos de irradiação beta, e $W_{s}$ o conteúdo de água nos sedimentos adjacentes, para cálculos de irradiação gama durante o período deposicional.

Já a componente cósmica da dose anual na Eq. 4.18 pode ser determinada de acordo com o procedimento sugerido em Prescott \& Hutton (1994), que estabelece um procedimento de cálculo que considera a radiação cósmica como função das coordenadas geográficas, profundidade e altitude das amostras. Para $\dot{D}_{0}$, foi utilizada a expressão completa proposta por Barbouti e Rastin (apud Prescott \& Hutton, 1994), para uma profundidade $x$ abaixo do nível do solo, expressa como

$$
\dot{D}_{0}=\frac{C}{\left[(x+d)^{\alpha}+a\right](x+H)} e^{-B x}
$$

sendo $\left[D_{0}\right]=$ Gy.ka ${ }^{-1} ;[\mathrm{x}]=$ profundidade em hg.cm ${ }^{-2} ; \mathrm{C}=6072 ; \mathrm{B}=5,50.10^{-4} ; \mathrm{d}=11,6 ; \alpha$ $=1,68 ; \mathrm{a}=75 ; \mathrm{H}=212$. A Eq. 4.19 é válida desde a superfície até uma profundidade de $10^{4} \mathrm{hg} . \mathrm{cm}^{-2}$ de rocha padrão. A latitude geomagnética pode ser calculada por 


$$
\operatorname{sen} \lambda=0,203 \cos \theta \cos (\varnothing-291)+0,979 \operatorname{sen} \theta
$$

sendo $\lambda$ a latitude geomagnética, $\theta$ a latitude geográfica e $\varnothing$ a longitude geográfica. Finalmente, a taxa anual de dose a uma latitude geomagnética $\lambda$ e altitude $h$ a partir de $\dot{D}_{0}$, na Eq. 4.19, pode ser calculada por

$$
\dot{D}=\dot{D}_{0}\left[F+J e^{h / H}\right]
$$

sendo $[D]=$ Gy $\mathrm{ka}^{-1},[\mathrm{~h}]=\mathrm{km}$ e os parâmetros F, J e H obtidos pela Fig. 2 em Prescott \& Hutton (1994). 


\section{CApítulo 5}

\section{FUNDAMENTOS TEÓRICOS DOS MÉTODOS ESTATÍSTICOS}

Em termos gerais, um experimento de caracterização química com artefatos arqueológicos ou objetos de arte pode ser baseado na determinação da concentração de um único elemento químico de interesse, ou na concentração de vários elementos químicos, que precisam ser analisados conjuntamente para a caracterização de sua estrutura multivariada (Baxter \& Buck, 2000). A razão para a coleta desse tipo de dados pode ter como objetivo a caracterização de um único objeto, ou amostra do mesmo, ou a investigação e caracterização de um grupo de objetos ou amostras.

Geralmente, a investigação em casos onde apenas uma variável é determinada pode ser efetuada com a utilização de ferramentas simples de estatística descritiva (como média aritmética, mediana e desvio-padrão), ou um gráfico simples que revele propriedades de interesse.

Quando o objetivo é a investigação de um grupo de variáveis, as ferramentas de estatística descritiva podem não ser suficientes, e a seleção de mecanismos gráficos adequados e análise numérica mais sofisticada podem ser necessárias, dentro do escopo da estatística multivariada (Baxter \& Buck, 2000).

Desde o início do século XX, a necessidade de se analisar múltiplas variáveis conjuntamente levou ao desenvolvimento de vários métodos multivariados para aplicações que vão desde as ciências sociais até às pesquisas biomédicas (Chi, 2012). Os métodos multivariados podem ser divididos em duas categorias. Os métodos exploratórios compreendem ferramentas de extração, resumo, e visualização de informação empírica visando o estudo de algum fenômeno de interesse. Por outro lado, há os métodos confirmatórios, com o objetivo de testar questões e hipóteses específicas de pesquisa.

Grande parte das ferramentas de redução dimensional e classificação de dados incluem a análise de componentes principais, análise de correlação canônica, análise fatorial exploratória, análise discriminante e análise de agrupamentos. Já técnicas 
avançadas de modelagem confirmatória abarcam o modelo linear geral, modelo misto e modelagem de equações estruturais.

A natureza das variáveis (ex.: nominal, ordinal ou contínua) é responsável, em grande parte, pela escolha do tipo de análise multivariada e a métrica utilizada, a qual, por sua vez, determinará a estrutura de covariância subjacente aos dados. Em muitos casos de aplicação de análise multivariada, a estrutura de covariância pode ter um efeito mais significativo na validade e qualidade da análise do que qualquer outra propriedade dos dados (Chi, 2012).

O modelo multivariado linear geral assume a existência de efeitos multivariados médios que são funções lineares de um conjunto fixo de preditores, e que podem ser utilizados para testar qualquer hipótese linear baseada em contrastes inter e intraobjetos. Um caso especial desse modelo é a análise multivariada de variância (MANOVA).

A caracterização química elementar de cerâmicas arqueológicas é frequentemente realizada para identificar grupos de artefatos similares por meio da aplicação de técnicas estatísticas multivariadas (Baxter et al., 2008). Essas técnicas são essenciais em arqueometria, tendo em vista o grande número de variáveis geradas como, no âmbito deste trabalho, a concentração de múltiplos elementos químicos em uma análise de INAA. No hiperespaço composicional das concentrações elementares, um grupo seria caracterizado pela localização de seu centroide e estrutura de correlação entre essas concentrações (Glascock, 1992)

Questões referentes ao tamanho amostral podem comprometer a análise multivariada. Uma regra geral de referência desenvolvida para estimar o número $n$ de amostras requeridas para $p$ variáveis é baseada no cálculo do número de graus de liberdade por variável: $\mathrm{n}-1-(p-1) / 2$, que deve ser no mínimo 30 e, preferencialmente, 60 ou mais (IAEA, 2003).

Em arqueometria, é um procedimento comum analisar gráficos bidimensionais de componentes principais de maneira iterativa com outras técnicas e análises sempre que se procura caracterizar a estrutura dos dados de interesse arqueológico, e classificar novas amostras nos grupos pré-determinados. A estrutura utilizada para inferências arqueológicas será aquela que estiver adequadamente determinada do ponto de vista analítico, e na qual outros fatores que possam complicar a correlação arqueológica, como fenômenos geoquímicos durante a deposição do registro arqueológico no solo, sejam minimizados. 
Essa discussão é mais claramente sintetizada por meio da análise da seguinte equação para a variância em sistemas cujas características combinam elementos naturais e culturais (Bishop, 2003)

$$
s_{T}^{2}=s_{N}^{2}+s_{C}^{2}+s_{P}^{2}+s_{S}^{2}+s_{A}^{2}
$$

Na Eq. 5.1, $s_{T}^{2}$ é a variância total, $s_{N}^{2}$ é a variância natural, $s_{C}^{2}$ é a variância relacionada a aspectos culturais da produção cerâmica, $s_{P}^{2}$ é a variância relacionada a efeitos atuantes sobre o registro arqueológico no contexto deposicional, $s_{S}^{2}$ é a variância associada ao método de amostragem, e $s_{A}^{2}$ é a variância introduzida pelo método analítico utilizado.

Os estudos arqueométricos de interesse costumam ser aqueles guiados por problemas arqueológicos que definem seu escopo. Dessa forma, o pesquisador necessitará que os dados reflitam principalmente padrões ligados a escolhas culturais, como seleção, mistura e modificação de matérias-primas, e que sejam minimizadas as variações relacionadas a fenômenos pós-deposicionais, ao procedimento de amostragem e à técnica analítica utilizada. Isso corresponde a minimizar os termos $s_{P}^{2}, s_{S}^{2}$ e $s_{A}^{2}$ na Eq. 5.1.

As seções seguintes versam sobre os fundamentos necessários ao entendimento dos métodos estatísticos multivariados utilizados neste trabalho. Os programas utilizados na implementação das rotinas de cálculo das análises foram:

- MURRAP 8.6 (Missouri University Analytical Package), um conjunto de rotinas desenvolvidas em GAUSS pelo grupo de arqueometria do reator de pesquisas da Universidade do Missouri.

- R Statistical Package 2.13.0.

口 Matlab 7.6.0 (R2008a).

口 Statistica 8.0.

口 Scilab 5.2.2.

口 Action 2.6. 


\subsection{Transformação dos dados}

Uma transformação linear de dados é aquela que transforma os valores de uma variável original $x$ pela aplicação de operações aritméticas simples (adição, subtração, multiplicação, ou divisão) utilizando constantes (Warner, 2013). Um exemplo de transformação linear de dados é dada a seguir

$$
z=\frac{x-\bar{x}}{s}
$$

sendo $\bar{x}$ a média amostral e $s$, o desvio-padrão amostral. Com essa transformação em escore $z$, a média dos dados passa a ser 0 , e o desvio-padrão passa a ser 1 , mas a forma da distribuição original de $x$ permanece inalterada.

No entanto, pode haver interesse em uma transformação de dados que muda a forma da distribuição original, para corrigir possíveis assimetrias e desvio da distribuição normal para cálculos estatísticos; reduzir o impacto de dados discrepantes, trazendo-os mais próximos à massa dos dados; e reduzir distância entre casos ou amostras com variáveis cujos valores variam em ordens de magnitude. Isso pode ser feito por transformações não lineares. Entretanto, nem sempre essas transformações criam novas variáveis facilmente interpretáveis.

Muitas vezes, esse tipo de transformação pode mudar uma relação não linear entre duas variáveis para uma relação linear entre as mesmas. Esse procedimento é útil porque as análises incluídas na família dos chamados modelos lineares gerais normalmente requerem relações lineares entre as variáveis estudadas (Warner, 2013). Uma das transformações lineares mais comuns é a transformação em logaritmos de base decimal, denotada por $\log _{10}(\mathrm{x})$.

Baxter \& Freestone (2006) advertiram que apesar de os méritos da transformação logarítmica terem sido debatidos durante anos, a necessidade frequentemente expressa em se transformar as variáveis para atingir a condição de normalidade tem sido exagerada. Contudo, o fato de as variáveis com valores extremos muito elevados, representada por distribuições com caudas longas, se tornar mais simétrica após a transformação logarítmica é útil para representações gráficas; e o fato de essas variáveis serem convertidas a valores comparáveis entre si em ordem de magnitude é útil 
em análise estatística, para diminuir o peso das variáveis com maior variância absoluta, por exemplo (Baxter \& Freestone, 2006).

As concentrações elementares medidas em experimentos arqueométricos de caracterização química são, normalmente, obtidas em unidades como ng.g $\mathrm{g}^{-1}, \mu \mathrm{g} \cdot \mathrm{g}^{-1} \mathrm{e}$ $\mathrm{mg} \cdot \mathrm{g}^{-1}$, que representam proporções de um todo. Há uma restrição linear subjacente a esses valores, na qual a soma de todas as concentrações dos elementos químicos existentes na amostra deve ter sempre um valor constante (1, no caso). A aplicação de métodos estatísticos multivariados usualmente desenvolvidos para tratar variáveis sem essa restrição poderia gerar efeitos espúrios na estrutura de correlação e nos resultados, de modo geral (Pawlowsky-Glahn et al., 2007).

Uma matriz $n \times p$ é denominada composicional se a soma dos elementos de uma determinada linha for sempre uma constante. Por outro lado, é chamada de subcomposicional se as variáveis da mesma forem um subconjunto dos dados composicionais (Baxter et al., 2003). Todas as matrizes obtidas em experimentos de caracterização química em arqueometria são subcomposicionais, pois nem todos os elementos químicos de ocorrência natural são medidos. A utilização de logaritmos de razões elementares é advogado como um dos métodos mais adequados e robustos para a transformação dos dados antes da aplicação de métodos estatísticos multivariados, por considerar o caráter composicional inerente às concentrações elementares (Baxter \& Freestone, 2006).

No contexto arqueométrico, Buxeda i Garrigós (1999) relatou que a transformação em razão logarítmica aditiva (alr) é a mais robusta para lidar com alterações e contaminações que podem afetar não só a concentração de um elemento químico diretamente, mas, pela natureza composicional dos dados, afetar as demais concentrações de maneira não conhecida a priori, por perturbações indiretas.

A utilização de razões elementares poderia ainda prevenir contra certos tipos de erro analítico obtidos, por exemplo, quando um conjunto de artefatos é analisado em mais de uma batelada experimental, e há variações sistemáticas instrumentais entre as bateladas (Baxter et al., 2003). A divisão entre duas variáveis que apresentam a mesma variação sistemática cancelaria esse efeito, e evitaria possíveis classificações erradas de amostras em grupos definidos nas análises multivariadas.

Outra circunstância na qual a utilização de razões elementares é útil, no contexto da análise de cerâmicas arqueológicas, é quando há inserção heterogênea de 
temperos ou elementos antiplásticos naturais durante a produção cerâmica, ou ainda quando há variações naturais na própria fonte de argila.

A não consideração da estrutura composicional dos dados pode ser mais crítica no caso de análises de vidros arqueológicos, nas quais é comum a determinação de aproximadamente dez óxidos de macroelementos. Já no caso de análise de cerâmicas, os elementos de maior interesse são os elementos-traço, e algumas vezes a análise é focada exclusivamente neles. Nesses casos, a análise logarítmica racional pode ser equivalente à análise tradicional baseada em logaritmos, e o efeito da natureza composicional dos dados pode ser menos crítico (Baxter \& Freestone, 2006).

Embora essa abordagem seja considerada a mais correta, a análise logarítmica racional (LRA - Log-Ratio Analysis) não tem sido usada extensivamente em arqueometria. Um dos motivos pode ser a existência de resultados práticos insatisfatórios. Já foi reportado na literatura (Baxter \& Freestone, 2006) que a LRA nem sempre funciona de maneira adequada, não identificando estruturas arqueologicamente interpretáveis, ou identificando de maneira menos direta que as abordagens clássicas de transformação de dados. Isso pode ser causado, em parte, pela importância superestimada por LRA atribuída a elementos com alta variação relativa devido à sua presença absoluta em baixíssimas concentrações, cuja variação pode ser de pouca utilidade prática interpretativa (Baxter et al., 2003). Muitas vezes, diferenças absolutas na concentração de elementos apresentam significado arqueológico, que pode ser obscurecido nas análises LRA. O autor advoga então a necessidade uma análise LRA ponderada, de forma a reduzir o efeito dessas variáveis com alta variação relativa devido à sua baixa presença absoluta.

Pelo fato de os logaritmos de razões serem mais facilmente manipulados do que razões em cálculos matemáticos de interesse, e pela transformação logarítmica racional promover um mapeamento dos dados de um espaço simplex (um espaço amostral natural para dados composicionais) a razões logarítmicas em um espaço real, desenvolveu-se uma série de metodologias baseadas em transformações desse tipo, que removem a restrição linear dos dados (Pawlowsky-Glahn et al., 2007). Essas metodologias permitem a utilização de métodos estatísticos multivariados aos dados transformados, sem restrições, sendo possível traduzir as inferências em termos das composições originais.

Do ponto de vista estatístico, Aitchison (1986) propôs o uso de razões para lidar com problemas devido a uma possível estrutura de covariância não interpretável quando calculada sem considerar a restrição linear subjacente aos dados composicionais (a 
soma de todos os elementos deve ser 100\%, ou 1), e outras dificuldades em modelagem paramétrica. As primeiras propostas de transformação foram a transformação em razão logarítmica centrada $(c l r)$ e a transformação em razão logarítmica aditiva (alr). A transformação $c l r$ pode ser expressa na forma (Buxeda i Garrigós, 1999)

$$
\boldsymbol{x} \in S^{d} \rightarrow \boldsymbol{y}=\log \left(\frac{x}{g(x)}\right) \in R^{D}
$$

sendo $S^{d}$ o espaço simplex d-dimensional $(\mathrm{d}=\mathrm{D}-1)$, e $g(\boldsymbol{x})$ a média geométrica para as componentes do vetor $\boldsymbol{x}$, na forma

$$
g(x)=\left(x_{1} x_{2} \ldots x_{p}\right)^{1 / p}
$$

Por sua vez, transformação alr, de natureza assimétrica, pode ser expressa por

$$
\boldsymbol{x} \in S^{d} \rightarrow \boldsymbol{y}=\log \left(\frac{\boldsymbol{x}_{-D}}{x_{D}}\right) \in R^{d}
$$

sendo $x_{D}$ o elemento escolhido como denominador da transformação.

Segundo Buxeda i Garrigós (1999), essa transformação alr enfatizaria a presença de perturbações nas concentrações elementares, tornando-as mais facilmente identificáveis, pelas variâncias da matriz de variação. Além disso, permitiria a identificação do elemento mais adequado, do ponto de vista estatístico, para ser utilizado como denominador na transformação alr, por meio de cálculos dessa mesma matriz. $\mathrm{O}$ autor ainda advoga que as desvantagens advindas da assimetria da transformação alr podem ser mantidas sob controle, e que essa transformação teria a vantagem de ser mais robusta à possível propagação de erros espúria devido a perturbações indiretas promovidas pela transformação $c l r$. Assim, a transformação alr evitaria perturbações indiretas pela divisão por uma variável não diretamente perturbada, assim como perturbações diretas, pela exclusão dos elementos cuja alta variabilidade estaria mais evidenciada nesse tipo de transformação. 
Finalmente, esse método seria ainda adequado para lidar com o efeito de diluição, na forma de redução das concentrações químicas elementares ocasionada pela adição de elementos antiplásticos às cerâmicas arqueológicas. Esse efeito já é bem conhecido nas publicações arqueométricas (Neff et al., 1989). Nessa transformação alr, a adição de antiplástico seria representada matematicamente por um vetor de perturbação, cujos detalhes matemáticos podem ser encontrados em Buxeda i Garrigós (1999).

As possíveis perturbações nos perfis químicos elementares dos dados podem ser identificadas estatisticamente pela transformação alr. Contudo, a identificação e interpretação dessas perturbações do ponto de vista físico exigiria a aplicação de técnicas analíticas apropriadas.

\subsection{Estrutura de correlação}

A covariância amostral é definida como uma medida de associação linear entre duas variáveis aleatórias, na forma de variância combinada entre dois elementos e suas médias:

$$
\operatorname{cov}(x, y)=\frac{\sum_{i=1}^{n}\left(x_{i}-\bar{x}\right)\left(y_{i}-\bar{y}\right)}{n-1}
$$

sendo $x$ e $y$ os dois elementos covariantes; $x_{i}$ e $y_{i}$ as concentrações dos elementos $x$ e $y$ na amostra $i ; \bar{x}$ e $\bar{y}$ as médias das concentrações dos elementos; e $n$ é o número de amostras.

A correlação amostral entre dois elementos pode ser definida pelo coeficiente de correlação de Pearson, que é tipicamente utilizado para descrever o grau de relação linear entre duas variáveis quantitativas de maneira padronizada (Warner, 2013)

$$
r(x, y)=\frac{\operatorname{cov}(x, y)}{s_{x} s_{y}}
$$

Enquanto a variância e covariância entre os elementos possuem as mesmas unidades de concentração ao quadrado dos elementos estudados, os valores do coeficiente de correlação de Pearson são adimensionais e podem variar no intervalo $[-1,+1]$, sendo que +1 representa uma correlação positiva perfeita, e -1 uma correlação negativa perfeita. 
No espaço multidimensional das concentrações elementares, os grupos químicos são definidos por seus centros de massa, ou centroides, e estrutura de correlação entre as concentrações elementares.

Não se deve considerar elementos altamente correlacionados como dados redundantes. Na verdade, o padrão de correlação interelementar fornece informações importantes que podem ser incorporadas em vários procedimentos estatísticos para a caracterização de grupos composicionais e atribuição de uma amostra desconhecida a um grupo, como o procedimento realizado a partir da distância de Mahalanobis (IAEA, 2003).

\subsection{Identificação de dados discrepantes (outliers)}

Everitt (1980) atenta para o fato de que muitos algoritmos de agrupamentos são sensíveis a observações discrepantes (outliers), de forma a se tornar conveniente a identificação dos mesmos antes da aplicação de métodos estatísticos multivariados, para posterior decisão sobre seu destino final. O procedimento adotado para a análise de outliers foi um teste baseado na distância de Mahalanobis utilizando a estatística lambda de Wilks, e sob a hipótese de distribuição normal dos dados.

Para isso, calculou-se a matriz de distância quadrática de Mahalanobis entre o vetor de concentrações elementares e o centroide dos dados. Os valores foram comparados com o valor crítico de Wilks (Oliveira, 2003).

$$
D_{c r i t}=\frac{p(n-1)^{2} F_{p, n-p-1, \alpha / n}}{n\left(n-p-1+p F_{p, n-p-1, \alpha / n}\right)}
$$

no qual,

$n$ é o número de amostras;

$p$ é o número de variáveis;

$F$ é a distribuição de Snedecor;

$\alpha$ é o nível de significância adotado. 
As distâncias quadráticas de Mahalanobis maiores que o valor crítico são consideradas como outliers, de acordo com o método. O nível de significância adotado para o cálculo do valor crítico é 5\% (Beckman \& Cook, 1983).

\subsection{Análise de Agrupamentos}

Algoritmos de agrupamento são métodos para se dividir um conjunto de $n$ observações em $g$ grupos, de forma que os membros de um mesmo grupo sejam mais semelhantes do que membros de diferentes grupos, ou clusters. O número de grupos $g$ pode ser pré-determinado, ou decidido pelo pesquisador. Um algoritmo de agrupamento produz um mapeamento da forma

$$
c:\{1, \ldots, n\} \rightarrow\{1, \ldots, g\}
$$

associando cada amostra a um grupo. Alguns métodos de agrupamento trabalham de forma a caracterizar cada grupo por um ponto representativo (não necessariamente um exemplo do mesmo), como é o caso dos mapas auto-organizáveis.

Todos os métodos de agrupamento, como Ward, Average Linkage e K-means, utilizados neste trabalho são apenas algoritmos. Mesmo aqueles que visam otimizar um critério de agrupamento não garantem o encontro do ótimo global. Como todos os métodos não supervisionados de reconhecimento de padrões, eles são julgados pelos seus resultados, interpretados dentro de seu contexto de aplicação.

É o método estatístico multivariado mais utilizado em arqueometria (Baxter \& Beardah, 2008). Nos métodos aglomerativos, as amostras são inicialmente tratadas de maneira individual e, em seguida, são calculadas distâncias amostra-amostra, amostragrupo e grupo-grupo, sucessivamente, até a formação de um único grupo. O resultado da análise de agrupamento é apresentado frequentemente na forma de um dendrograma, que são representações gráficas bidimensionais do processo, cujo exemplo é apresentado na Fig. 5.1. 


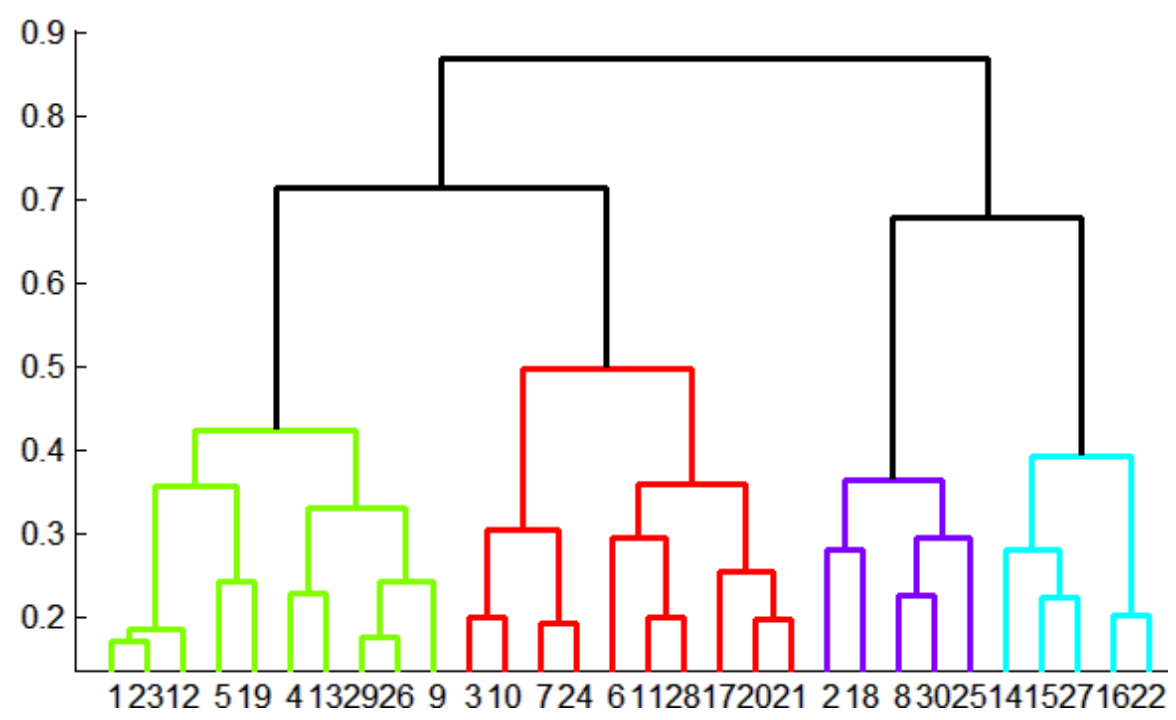

Figura 5.1 - Exemplo de dendrograma obtido em uma análise de agrupamentos. As cores dos diferentes segmentos representam cada um dos quatro grupos definidos no estudo.

Foram utilizados três diferentes algoritmos de agrupamento neste trabalho: método de Ward, Average Linkage e K-means.

\section{i. Método de Ward}

Este método possui a tendência de formar grupos com alto grau de homogeneidade interna, além de levar em consideração a estrutura do cluster (Baxter, 1994). A alocação de um elemento em um grupo pelo método de Ward é realizada de forma a minimizar uma medida de homogeneidade interna, baseada na partição da soma dos quadrados de uma análise de variância (Barroso \& Artes, 2003). O método produz clusters esféricos de tamanho similar.

\section{ii. Average Linkage}

O método Average Linkage é outra abordagem utilizada frequentemente em estudos de cerâmicas arqueológicas que também leva em consideração a estrutura do cluster, como o método de Ward. Neste método, a medida de distância entre os grupos é a média das distâncias entre os elementos dos mesmos (Barroso e Artes, 2003): 


$$
d\left[G_{1}, G_{2}\right]=\sum_{i \in G_{1}} \sum_{k \in G_{2}} \frac{d_{i k}}{g_{1} g_{2}}
$$

A comparação dos resultados entre os métodos de Ward e Average Linkage é recomendada por Baxter (1994).

\section{iii. Método K-means}

Análises hierárquicas de agrupamento podem impor uma estrutura não justificável a uma base de dados. Uma vez que um objeto é alocado em um grupo, ele permanece lá até o final do processo, de forma que essa alocação não é necessariamente ótima. Em geral, não existe motivo para esperar uma estrutura hierárquica dos dados. Assim, o método K-means pode refinar a classificação de acordo com o critério de agrupamento adotado. A aplicação deste procedimento possibilita a verificação de problemas relacionados à classificação inadequada de amostras.

No método K-means, o número de grupos deve ser escolhido a priori, de forma a reduzir as possibilidades de partição, tornando-o mais eficiente em relação ao esforço computacional requerido. O critério para análise da qualidade do agrupamento pelo método de $K$-means é baseado na minimização da partição da soma total de quadrados de uma análise de variância, como no método de Ward.

A aplicação de uma análise de agrupamentos segue as seguintes etapas esquematizadas:

1. Escolha do critério de parecença para agrupar amostras: critérios de similaridade ou dissimilaridade (distância euclidiana, euclidiana quadrática, Mahalanobis etc.);

2. Definição do número de grupos, se essa informação for conhecida a priori. Neste trabalho, essas informações não eram conhecidas;

3. Aplicação de um algoritmo de agrupamento: Average Linkage, Single Linkage, Ward etc.;

4. Identificação dos grupos segundo um critério escolhido;

5. Validação do agrupamento;

6. Interpretação dos grupos. 
A primeira ferramenta para a verificação da estrutura multivariada de uma base de dados em arqueometria costuma ser a análise de agrupamentos, na qual é possível ter uma primeira noção das possíveis partições dos resultados. Além do algoritmo, a aplicação deste método exige a seleção da medida de dissimilaridade (distância) entre as amostras para os cálculos, com o objetivo de agrupar os objetos mais próximos, segundo o critério adotado. Uma das distâncias mais frequentemente empregadas é a distância euclidiana quadrática média (do inglês Squared-mean Euclidean distance, SMED) entre os logaritmos das concentrações, dada por (adaptado de Glascock, 1992)

$$
d_{j k}^{2}=\frac{1}{\min \left(p_{j}, p_{k}\right)} \sum_{i=1}^{\min \left(p_{j}, p_{k}\right)}\left[\log \left(C_{i j}\right)-\log \left(C_{i k}\right)\right]^{2}
$$

sendo $j$ e $k$ : duas amostras da base de dados;

$p_{j}, p_{k}$ : número de variáveis disponíveis, ou sem valores faltantes, para as amostras $j$ e $k$;

$C_{i j}$ : concentração elementar do elemento $i$ para a amostra $j$.

A vantagem dessa métrica, é que o fator de escala $\min \left(p_{j}, p_{k}\right)$ (número de elementos determinados) elimina a possibilidade de problemas devido à existência de valores faltantes, uma vez que a distância resultante será uma média escalonada para aqueles elementos sem dados faltantes. Sem esse escalonamento, amostras com valores de concentração não determinados precisariam ser eliminadas.

A inspeção visual de dendrogramas pode ser útil como um método preliminar de identificação de grupos. Contudo, é sabido que a aplicação deste método tende a forçar os dados em grupos hiperesféricos. Como há uma tendência de os grupos composicionais de cerâmicas serem alongados devido à correlação interelementar, é necessário analisar os resultados com parcimônia. Assim, os grupos obtidos pela análise de agrupamentos forneceriam um ponto de partida, a partir do qual outras técnicas multivariadas que levassem em conta a estrutura de correlação das variáveis poderiam ser aplicadas para o refinamento dos grupos (Glascock, 1992). 


\subsection{Análise de componentes principais (PCA)}

A análise de componentes principais é normalmente empregada em situações na qual o pesquisador quer avaliar se os valores de um determinado número $p$ de variáveis medidas podem ser explicados por um número menor de variáveis, denominadas componentes. Por meio desta técnica, é possível ter uma indicação de quantas componentes são necessárias para representar a estrutura de correlação original entre as variáveis que foram medidas e incluídas no estudo, promovendo uma redução da dimensionalidade do sistema e permitindo, por exemplo, sua representação gráfica, que fica impossibilitada em casos envolvendo mais que três variáveis.

A análise de componentes principais é uma das técnicas mais antigas de análise estatística multivariada. A redução dimensional obtida por essa técnica é realizada pela transformação das variáveis originais em um novo conjunto de variáveis, que são as componentes principais, não correlacionadas, e ordenadas de modo que um número reduzido de componentes retenha a maior parte das informações presentes na matriz original (Jolliffe et al., 1995).

A análise de componentes principais é frequentemente associada a outros métodos de análise estatística, como a análise de agrupamento e análise discriminante, com o objetivo de obter a classificação de amostras em grupos.

Seja $x$ o vetor das variáveis originais. As componentes principais $Y_{i}$ serão as seguintes combinações lineares não correlacionadas, cujas variâncias são as maiores possíveis e decrescentes em relação à ordem das componentes principais (Ferreira, 2008):

$$
Y_{i}=l_{i}^{\prime} x \operatorname{com} \mathrm{i}=1 \ldots \mathrm{p}
$$

Seja $\mathbf{S}$ a matriz de covariância dos dados. A extração das componentes principais é feita pela resolução do seguinte problema de autovalores (Warner, 2013)

$$
(\boldsymbol{S}-\lambda \boldsymbol{I}) \boldsymbol{V}=\mathbf{0}
$$

$\mathrm{Na}$ Eq. 5.13., $\lambda \boldsymbol{I}$ representa a matriz com autovalores na diagonal, que correspondem às variâncias das novas variáveis, ou componentes, obtidas. Por serem as 
componentes não correlacionadas, ou ortogonais, todos os valores fora da diagonal dessa matriz, correspondentes a covariâncias entre as componentes, são nulos. Nessa mesma equação, $\boldsymbol{V}$ é a matriz na qual cada coluna corresponde a um autovetor associado a um autovalor da solução. O problema de autovalor da Eq. 5.13 pode ser reescrito na forma

$$
L=V^{\prime} S \boldsymbol{V}
$$

Nessa equação, $\boldsymbol{L}=\lambda \boldsymbol{I}$. Esse procedimento pode ser interpretado como um processo de diagonalização da matriz $S$, pela pré-multiplicação dessa matriz pela transposta de $\boldsymbol{V}$, e pós-multiplicação pela matriz $\boldsymbol{V}$.

As coordenadas dos autovetores são padronizadas de forma a permitir sua interpretação na forma de correlação das variáveis originais ao autovetor, ou componente, considerado. Isso é satisfeito pela condição $\boldsymbol{V}^{\prime} \boldsymbol{V}=\boldsymbol{I}$. Essa padronização pode ser realizada pela multiplicação de cada autovetor pela raiz quadrada do autovalor correspondente, na seguinte forma

$$
A=V \sqrt{L}
$$

As colunas da matriz $\boldsymbol{A}$ correspondem aos coeficientes de ponderação, ou "peso", das $p$ variáveis originais em cada uma das componentes.

O propósito da análise PCA neste trabalho é o de confirmar a plausibilidade dos grupos químicos definidos na análise de agrupamento, por meio da projeção da estrutura multivariada dos dados em um número adequado de componentes principais. Uma das vantagens desse método é o de fornecer uma ferramenta de visualização em baixa dimensionalidade da estrutura multivariada dos dados, originalmente em um espaço de alta dimensionalidade, como o das composições químicas elementares. Um exemplo de gráfico PCA é apresentado na Fig. 5.2. 


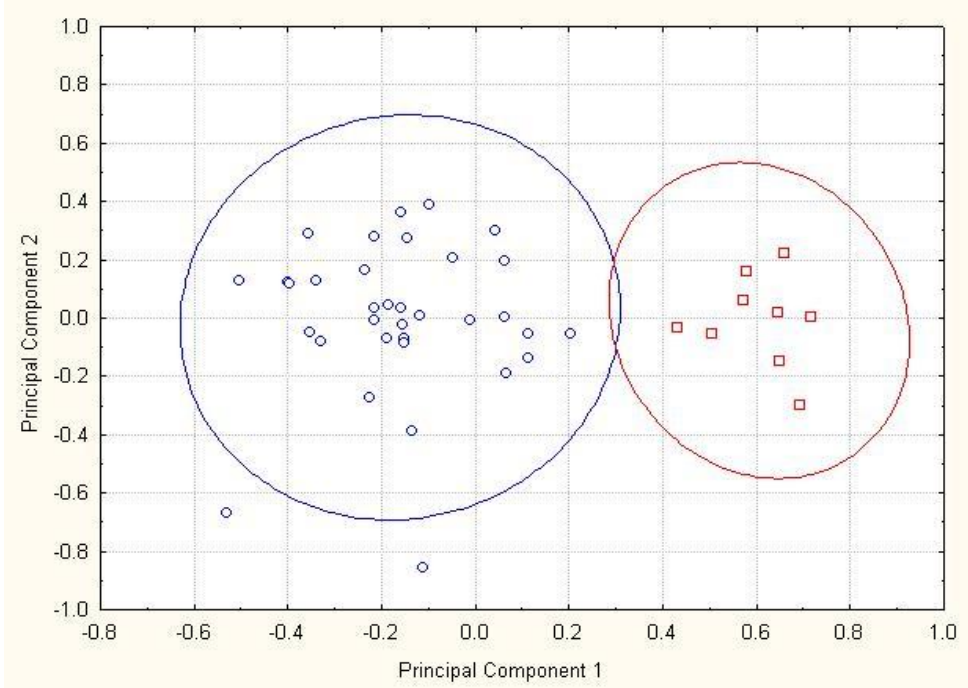

Figura 5.2 - Exemplo de gráfico obtido por PCA no software Statistica, indicando a presença de dois grupos de amostras pela projeção dos dados nas duas primeiras componentes principais, que explicaram, neste caso, cerca de $73 \%$ da variância do sistema.

É possível utilizar a matriz de covariância ou correlação nos cálculos de PCA. A análise dos coeficientes de ponderação dos autovetores é útil na identificação de variáveis correlacionadas e possíveis explicações geoquímicas e/ou culturais para a estrutura dos dados.

O modo RQ de análise por componentes principais, além de preservar a relação euclidiana entre os objetos, é conveniente para identificar graficamente as variáveis responsáveis pela maior parte da variância dos dados e seus pesos nas componentes, além da observação de como grupos de amostras distinguem-se com relação a esses elementos, devido à preservação da estrutura de covariância entre as variáveis. Assim, esse modo de análise permite que variáveis e observações sejam visualizadas no mesmo gráfico de componentes (Neff, 1994).

Por envolver cálculos a partir da matriz de correlação ou covariância, algumas hipóteses são assumidas nesta técnica: os valores de $x_{i}$, as variáveis independentes para a PCA, devem se aproximar da distribuição normal; qualquer associação entre as variáveis medidas deve ser linear; a distribuição do conjunto de variáveis deve seguir uma distribuição normal multivariada. Além disso, é esperado que as matrizes de correlação ou covariância não sejam diagonais, implicando que haja uma estrutura de correlação entre as variáveis que, se inexistente, inviabilizaria a aplicação de PCA. Nessas análises, um valor desejável para o tamanho amostral, embora não haja consenso, é $\mathrm{n}>10 p$, sendo $p \mathrm{o}$ 
número de variáveis independentes. Essa exigência está ligada ao fato de que correlações são instáveis com tamanhos amostrais pequenos (Warner, 2013).

\subsection{Refinamento por teste $F$ e distância de Mahalanobis}

A inspeção visual de dendrogramas é útil como um método de identificação de grupos preliminares. Métodos de agrupamento baseados em matrizes de distâncias euclidianas funcionam bem para discriminação de grupos de alta hiperesfericidade e multidimensionalmente bem separados. Porém, eles podem falhar quando aplicado a uma base de dados altamente correlacionada (Harbottle, 1982, p. 29).

A análise de agrupamentos tende a forçar os dados e formar grupos hiperesféricos, embora grupos químicos de cerâmicas tenham a tendência de ser alongados em determinadas direções, formando hiperelipses, devido à correlação interelementar não considerada nessa análise. Sendo assim, os grupos formados e identificados na análise de agrupamentos devem servir como um ponto de partida a partir do qual outras técnicas para o refinamento dos grupos possam ser aplicadas (Glascock, 1992).

A existência de correlação entre elementos em dados geoquímicos é bem conhecida na literatura. $\mathrm{O}$ elemento $\mathrm{Ca}$, por exemplo, aparece frequentemente correlacionado a $\mathrm{Sr}$ e $\mathrm{Ba}$. Os metais de transição, como o $\mathrm{Fe}$ e o Sc, e as terras-raras apresentam frequentemente altos índices de correlação. Desta forma, a estrutura analisada neste trabalho demanda métodos estatísticos que façam uso das propriedades correlacionais da base de dados.

Os grupos determinados preliminarmente na análise de agrupamentos, seja ela hierárquica ou não, devem ser refinados por procedimentos multivariados antes que possam ser considerados unidades químicas de referência (grupos para os quais os valores analíticos médios, desvios-padrão e correlações multielementares sejam bem conhecidas). Esses métodos demandam o cálculo da matriz de covariância dos dados e de sua inversa, requerendo que o número mínimo de amostras seja pela menos uma unidade maior que o número de elementos analisados. (Harbottle, 1982). Neste trabalho, essa condição é satisfeita.

Para refinar os resultados da análise de agrupamentos, é possível realizar um procedimento baseado no cálculo da distância de Mahalanobis de uma amostra até o centroide dos dados, que leva em consideração o tamanho e forma do grupo pela incorporação da matriz de covariância. Ela pode ser calculada por (Landim, 2010) 


$$
D=\sqrt{(x-\bar{x})^{\prime} S^{-1}(x-\bar{x})}
$$

na qual $x$ é um vetor-coluna das variáveis medidas de uma amostra, $\bar{x}$ é o vetor-coluna das médias para o grupo em questão, e $\boldsymbol{S}$ é a matriz de covariância para os dados do grupo. Essa métrica leva em consideração as correlações entre as variáveis, que tornam o grupo não esférico, sendo que a distância relativa da amostra ao mesmo dependerá não só da distância em relação ao centroide, mas também da direção.

A distância de Mahalanobis também é útil no tratamento de valores faltantes na base de dados, pela escolha de um valor imputado que minimize a distância de Mahalanobis até o centroide do grupo, de forma que essas amostras possam ser utilizadas em cálculos de análise multivariada.

A significância estatística da diferença entre dois grupos pode ser testada pela estatística $T^{2}$ de Hotelling (o equivalente multivariado de $t$ de Student) a partir da distância de Mahalanobis, pela seguinte expressão (Glascock, 1992)

$$
T^{2}=\frac{D^{2}}{\frac{1}{n_{1}}+\frac{1}{n_{2}}}
$$

sendo $n_{1}$ e $n_{2}$ o número de amostras nos grupos.

Pela equivalência de $T^{2}$ com a distância de Mahalanobis para observações individuais, as probabilidades de pertinência aos grupos podem então ser calculadas pela transformação de $T^{2}$ em seu equivalente valor de $F$ por (Glascock, 1992)

$$
F=\frac{n_{1}+n_{2}-p-1}{\left(n_{1}+n_{2}-2\right) p} T^{2}
$$

Assim, a probabilidade de que uma amostra cuja posição não coincide com o do centroide, mas ainda pode ser considerada como um membro do grupo, pode ser calculada utilizando-se um teste $F$, que inclui informação sobre a variância desse grupo. Esse procedimento pode ser realizado com as variáveis originais ou com suas projeções em análise de componentes principais ou discriminante, em casos onde o número de amostras 
seja insuficiente (menor que $p+1$ ). Para reduzir a influência da amostra sendo testada nos cálculos, ela é temporariamente removida de seu grupo, para depois ser comparada ao mesmo. No procedimento implementado no software MURRAP, a realocação das amostras é indicada por valores de probabilidade de pertinência maiores para grupos aos quais ela não pertença originalmente.

\subsection{Análise multivariada de variância (MANOVA)}

MANOVA é um termo que vem da expressão inglesa multivariate analysis of variance e corresponde a uma generalização da análise univariada de variância. Por meio dessa análise, é possível analisar o efeito de uma variável independente, como uma variável categórica grupo, em duas ou mais variáveis dependentes, que podem ser a concentração de elementos químicos, por exemplo. Para o caso de dois grupos sendo comparados, esse teste é baseado na generalização multivariada do teste $t$ para um teste chamado $T^{2}$ de Hotelling (Meyers et al., 2006).

De maneira análoga à regressão múltipla, em MANOVA, as variáveis são combinadas de forma ponderada para formar uma variável compósita linear, de forma que os pesos sejam determinados para permitir a máxima diferenciação entre os grupos que for possível (Meyers et al., 2006). A magnitude e o sinal das correlações entre as variáveis do estudo influenciam o poder estatístico dessa análise de maneira complexa.

A análise de variância multivariada é útil quando as variáveis dependentes apresentam algum grau de intercorrelação. Esse teste não deve ser usado quando as variáveis dependentes não são correlacionadas. O contexto ideal para a aplicação da técnica é quando elas são moderadamente correlacionadas $(r<0,8)$ (Meyers et al., 2006).

A estatística $T^{2}$ de Hotelling testa uma hipótese nula multivariada na seguinte forma geral (Warner, 2013)

$$
H_{0}=\left[\begin{array}{c}
\mu_{11} \\
\mu_{21} \\
\cdot \\
\cdot \\
\cdot \\
\mu_{p 1}
\end{array}\right]=\left[\begin{array}{c}
\mu_{12} \\
\mu_{22} \\
\cdot \\
\cdot \\
\cdot \\
\mu_{p 2}
\end{array}\right]=\cdots=\left[\begin{array}{c}
\mu_{1 k} \\
\mu_{2 k} \\
\cdot \\
\cdot \\
\cdot \\
\mu_{p k}
\end{array}\right]
$$


na qual o primeiro subíndice refere-se à variável dependente, e o segundo subíndice a um dos $k$ grupos. Essa hipótese nula implica que os vetores de médias sejam iguais ao longo desses grupos. A diferença principal entre a análise de variância e sua correlata multivariada é que, no caso univariado, o test $t$ compara duas médias populacionais, enquanto o teste $T^{2}$ de Hotelling compara dois vetores de médias.

$\mathrm{Na}$ análise MANOVA para apenas uma variável categórica, a matriz de soma de produtos cruzados, $\boldsymbol{S C P}$, é particionada entre suas componentes inter e intragrupos (Warner, 2103)

$$
\boldsymbol{S C} \boldsymbol{P}_{\text {total }}=\boldsymbol{S C} \boldsymbol{P}_{\text {inter }}+\boldsymbol{S C} \boldsymbol{P}_{\text {intra }}
$$

Utilizando-se álgebra matricial, é possível generalizar matematicamente o teste $t$ para seu análogo multivariado $T^{2}$. De maneira análoga a $t$, essa estatística cria uma razão entre a variabilidade intragrupo (baseado nos vetores de médias) e a variabilidade entre grupos (representada pela inversa da matriz de covariância). No final, essas matrizes são reduzidas a um determinante, que expressa a variância generalizada da matriz, corrigindo a multicolinearidade, ou variância compartilhada entre as variáveis. $\mathrm{O}$ valor computado de $T^{2}$ pode ser comparado com um valor crítico, a partir de um nível de significância $\alpha$ adotado. Se a probabilidade de ocorrência estiver abaixo de $\alpha$, é possível então rejeitar a hipótese nula de igualdade entre os vetores de médias dos dois grupos analisados.

A maioria dos pacotes estatísticos computacionais não fornecem valores de $T^{2}$ e seus correspondentes graus de liberdade e nível de confiança. Em vez disso, a estatística $T^{2}$ é transformada em valores de $F$, por meio da Eq. 5.18 (Meyers et al., 2006), embora outras variantes possam ser utilizadas.

Esses valores de $F$ são utilizados com quatro estatísticas multivariadas normalmente encontradas em programas computacionais: lambda de Wilks, traço de Pillai, traço de Hotelling, e raiz máxima de Roy. Todos esses testes são ferramentas para a análise da variabilidade intra e intergrupos, produzindo um coeficiente que, por sua vez, é convertido em um valor de $F$, analisado então na forma dessa estatística. Esses quatro testes produzem os mesmos resultados quando a variável independente possui apenas dois níveis, relacionada à existência de dois grupos, e todos eles são derivados dos autovalores associados às funções discriminantes que melhor diferencia os grupos. Os parâmetros lambda de Wilks, traço de Pillai, traço de Hotelling representam três maneiras diferentes 
de se combinar informação sobre diferenças inter e intragrupos. Uma maneira de se calcular o parâmetro $\wedge$ multivariado de Wilks é dada a seguir (Warner, 2013)

$$
\wedge=\frac{\left|\boldsymbol{S C} \boldsymbol{P}_{\text {intra }}\right|}{\left|\boldsymbol{S C} \boldsymbol{P}_{\text {inter }}+\boldsymbol{S C} \boldsymbol{P}_{\text {intra }}\right|}
$$

na qual o determinante $\left|\boldsymbol{S} \boldsymbol{C} \boldsymbol{P}_{\text {intra }}\right|$ é uma medida da variância generalizada das $p$ variáveis dependentes dentro dos grupos, sendo uma medida da variância intragrupo; já o termo $\left|\boldsymbol{S C} \boldsymbol{P}_{\text {inter }}+\boldsymbol{S} \boldsymbol{C} \boldsymbol{P}_{\text {intra }}\right|$, equivalente a $\left|\boldsymbol{S} \boldsymbol{C} \boldsymbol{P}_{\text {total }}\right|$,é uma medida da variância das $p$ variáveis dependentes, incluindo tanto as fontes intra e intergrupos de variação, e corrigindo a intercorrelação entre as variáveis. Esse parâmetro representaria a razão da variância não explicada pela variância total. Ainda, é desejável que esse parâmetro seja pequeno, implicando que as diferenças entre os grupos sejam maiores que a variabilidade dentro dos mesmos. O parâmetro $\wedge$ multivariado de Wilks pode então ser convertido em valores de $F$, para verificação da significância estatística.

O tamanho amostral mínimo para esse tipo de teste é a condição em que o número de amostras exceda o número de variáveis dependentes, embora haja autores que reportem que um número mínimo de 20 casos por grupo seja necessário para atingir níveis mínimos de poder do teste (Hair et al., 1998). Em MANOVA, assim como em outras análises multivariadas, inserir variáveis que não carregam informação relevante para a formação dos grupos, pode reduzir o poder estatístico do teste.

A análise de variância multivariada é sensível a valores discrepantes, e assume as hipóteses de homocedasticidade e normalidade multivariadas (embora alguns tipos de desvio dessa normalidade tenham provavelmente um efeito pequeno nos erros Tipo I). Transformações dos dados, como a logarítmica, podem ser eficientes em reduzir o efeito do desvio da normalidade e homocedasticidade entre os grupos. Finalmente, MANOVA pode ser pensada como uma análise discriminante reversa, sendo que a computação de ambas é idêntica e a informação gerada é complementar (Warner, 2013). 


\subsection{Análise discriminante}

A análise discriminante é uma técnica estatística multivariada, utilizada com o objetivo de discriminar populações e/ou classificar objetos em populações previamente definidas. É uma das várias técnicas que podem ser utilizadas para prever pertinência a grupos definidos por uma variável de efeito categórica.

A análise discriminante é menos uma técnica exploratória, e mais uma técnica de teste ou método de classificação. A aplicação desta técnica pode estar relacionada ao interesse do pesquisador em realizar predições precisas de pertinência de objetos amostrais a grupos já existentes e conhecidos, ou uma descrição da natureza das diferenças entre esses grupos, ou ambos os tipos de informação (Warner, 2013). Uma diferença básica com PCA, é que ela extrai um novo conjunto de variáveis, a partir das variáveis originais, que maximiza as diferenças entre dois ou mais grupos, as chamadas funções discriminantes canônicas, em vez de maximizar a variância total do conjunto de dados nas novas variáveis (Glascock, 1992). Em análise discriminante, é assumido que as variáveis originais sejam correlacionadas em um algum grau.

Uma função discriminante é uma combinação linear ótima de variáveis preditoras. No caso de apenas dois grupos, o método produzirá apenas uma função discriminante $D_{l}$, que é utilizada para prever a pertinência dos casos aos dois grupos definidos, e pode ser expressa como (adaptado de Warner, 2013)

$$
D_{1}=d_{11} x_{1}+d_{12} x_{2}+\ldots+d_{1 p} x_{p}
$$

na qual $p$ é o número de variáveis discriminantes originais. No caso de $k$ grupos, o número de funções discriminantes possível de ser obtida é o menor dentre os valores $p$, relativo ao número de variáveis, e $(k-1)$, relativo ao número de grupos considerados. Essa análise gera funções não correlacionadas. Na prática, o significado das funções discriminantes e das variáveis com os maiores pesos nessas funções podem não ser facilmente interpretáveis e, nesses casos, interpretações não devem ser forçadas.

Diferentemente da análise de agrupamento hierárquica, a análise discriminante é uma técnica supervisionada, pois neste tipo de análise há necessidade do conhecimento $a$ priori das populações às quais pertencem os objetos. 
Hipóteses subjacentes à aplicação desta técnica são que a distribuição das variáveis preditoras seja normal, sem valores discrepantes extremos; e que as matrizes de covariância sejam homogêneas entre os grupos, implicando em homocedasticidade multivariada. Essa homogeneidade entre as matrizes de covariâncias populacionais pode ser expressa na forma (Warner, 2013)

$$
H_{0}=\Sigma_{1}=\Sigma_{2}=\ldots=\Sigma_{k}
$$

sendo $k$ o número de grupos. Em alguns casos, transformações de dados, como a transformação logarítmica, podem minimizar o desvio da normalidade e o impacto de valores discrepantes.

Uma análise discriminante estatisticamente significativa em termos gerais implica que pelo menos um dos grupos difira significativamente dos outros. Entretanto, ela não implica, necessariamente, que todos os grupos possam ser estatisticamente

discriminados (Warner, 2013). É possível obter indicações sobre essa diferença entre grupos por tabelas de programas estatísticos que informam o número de casos que foram corretamente classificados como membros de cada grupo, e também indica o número de classificações erradas. Alta frequência de classificações incorretas pode indicar grupos que não sejam significativos. Além disso, é possível examinar mapas territoriais, na forma de biplots entre funções discriminantes.

Neste trabalho, a análise discriminante foi utilizada como um teste adicional dos grupos produzidos pela análise de agrupamento e de componentes principais.

\subsection{Testes de normalidade}

A hipótese de normalidade torna-se problemática quando se aplica um teste baseado na distribuição normal em variáveis que não são normalmente distribuídas. Há duas escolhas nesses casos, (a) utilizar testes alternativos não paramétricos, os quais podem ser inconvenientes por serem geralmente menos poderosos e menos flexíveis em termos de conclusões que podem ser tiradas; ou (b) em muitos casos ainda é possível utilizar métodos baseados em distribuição normal se o tamanho da amostra for suficiente. A última alternativa é baseada em um princípio muito importante e responsável pela popularidade dos testes baseados em normalidade: com o aumento do tamanho da amostra, a distribuição 
de sua média aproxima-se da distribuição normal, como demonstrado no teorema do limite central.

Muitas técnicas multivariadas supõem a normalidade dos dados em seus cálculos. Entretanto, Baxter (1997) observou que era raro encontrar artigos na literatura que testassem essa hipótese, e esse parece ainda ser o cenário dominante atualmente.

Uma distribuição lognormal é uma distribuição contínua obtida quando os logaritmos das observações seguem uma distribuição normal. Essa distribuição é observada frequentemente em dados geoquímicos (embora nem sempre), como a concentração de elementos-traço no solo, na qual a maioria das observações apresenta valores baixos, mas poucas apresentam valores altos quando comparados à média. A equação que representa a distribuição de freqüência lognormal é (Koch \& Link, 2002, p. 215):

$$
f(x)=\frac{1}{x \beta \sqrt{2 \pi}} \exp \left[-\frac{1}{2 \beta^{2}}(\ln x-\alpha)^{2}\right]
$$

com $\alpha$ e $\beta^{2}$ representando, respectivamente, a média e a variância dos logaritmos naturais da observação x.

Para o caso multivariado, se $\mathbf{x}$ é um vetor de variáveis aleatórias e segue uma distribuição normal multivariada com vetor de médias $\boldsymbol{\mu}$ e matriz de covariância $\sum$, sua função de densidade de probabilidade é (Rencher, 2002, p. 92):

$$
g(\mathbf{x})=\frac{1}{(\sqrt{2 \pi})^{p}|\mathbf{\Sigma}|^{1 / 2}} e^{-(\mathbf{x}-\boldsymbol{\mu})^{\prime} \mathbf{\Sigma}^{-1}(\mathbf{x}-\boldsymbol{\mu}) / 2}
$$

A aceitação da hipótese nula de normalidade univariada não garante a normalidade multivariada dos dados, a qual é uma condição desejável em muitos métodos estatísticos multivariados. No entanto, a normalidade multivariada implica em normalidade univariada de suas variáveis componentes.

Há vários testes referenciados na literatura para testar a normalidade uni e multivariada de um conjunto de dados, como os testes de Anderson-Darling, no caso 
univariado; e Shapiro-Wilk (Cantelmo e Ferreira, 2007) e Shenton-Bowman (Doornik \& Hansen, 2008), no caso multivariado.

\subsection{Seleção de variáveis pelo método de Procrustes}

As bases de dados originadas em estudos arqueométricos são frequentemente analisadas por diversas técnicas estatísticas multivariadas, como análise de agrupamento, análise de componentes principais e análise discriminante. Contudo, seu uso pode ser problemático, podendo levar a interpretações incorretas ao se usar muitas variáveis desnecessariamente. A adição de uma variável que não é informativa a respeito da estrutura dos dados pode obscurecer a percepção dos padrões de interesse, além de gerar problemas computacionais e de tamanho amostral nas análises (Baxter, 2001; Andrade et $a l .$, 2004, Michelaki e Hancock, 2011). Além disso, descartar variáveis pode economizar tempo, recursos e menos variáveis a serem medidas em experimentos futuros (Jolliffe, 1972). Para atingir tal objetivo, é possível selecionar um subconjunto de variáveis que retenha a maior parte da estrutura multivariada dos dados, sem danos a análises multivariadas subsequentes (Baxter, 2001). Embora a seleção de variáveis pareça ir contra a visão comum de que "quanto maior a quantidade de variáveis medidas, melhor", não é óbvio que essa visão seja apropriada para estudos taxonômicos em geologia e arqueometria.

Há muitos métodos listados na literatura para a seleção de variáveis, como os métodos baseados em análises de agrupamento; métodos baseados em correlação múltipla e em componentes principais, como a análise Procrustes (Jolliffe, 1972; Sithole, 1992). A razão para a escolha do método Procrustes foi baseada em sua boa performance e porque muitos estudos composicionais focam na representação e agrupamento de dados em componentes principais.

Hurley e Cattell foram os primeiros pesquisadores a sugerir o nome Análise Procrustes para as técnicas que comparavam conjuntos de componentes principais (Andrade et al., 2004). O nome é baseado no mito grego de Damastes (ou Procrustes), um ferreiro embusteiro da Ática, filho de Poseidon. Ele forçava seus visitantes a deitar em sua cama de ferro, e ajustava-os à força, esticando ou cortando suas pernas.

A técnica de Procrustes é um método eficiente de seleção de variáveis (Andrade et al., 2004; Munita et al., 2010). Inicialmente, as componentes principais são extraídas de uma matriz de dados $\mathbf{X}$. Então, é determinando um número apropriado de 
componentes principais $k$ para representar a variabilidade dos dados de maneira satisfatória. A quantidade $k$ pode ser decidida de maneira formal, usando métodos disponíveis, ou informalmente (Krzanowski, 1987). As coordenadas das amostras nessas componentes são consideradas como a configuração padrão, denotada por $\mathbf{Y}(\mathrm{n} \times \mathrm{k})$. Para cada variável removida por vez, as primeiras $k$ componentes principais são recalculadas para a matriz de dados $n \times(p-1)$ e a matriz de coordenadas nas componentes principais $\mathbf{Z}_{(\mathrm{j})}(\mathrm{n} \times \mathrm{k})$ é gerada para cada j-ésima variável removida. A partir da comparação de $\mathbf{Z}_{(\mathrm{j})}$ com Y, o algoritmo remove a variável que apresentar o valor mais baixo do parâmetro de discrepância $M_{(j)}^{2}$ (Andrade et al., 2004). O valor de discrepância é dado por (Krzanowski, 1987)

$$
M^{2}=\operatorname{Traço}\left(\mathbf{Y} \mathbf{Y}^{\prime}+\mathbf{Z}_{(\mathbf{j})} \mathbf{Z}_{(\mathrm{j})}^{\prime}-2 \mathbf{\Sigma}\right)
$$

na qual, pela decomposição de valor singular da matriz $Z_{(j)}^{\prime} Y(\mathrm{k} \times \mathrm{k})$ :

$$
\boldsymbol{\Sigma}=\operatorname{diag}\left(\sigma_{1}, \sigma_{2}, \ldots, \sigma_{k}\right)
$$

A quantidade $M^{2}$ dada pela Eq. 5.27 representa a soma das diferenças quadráticas entre a configuração $\mathbf{Z}_{(\mathrm{j})}$ e $\mathbf{Y}$. Ela é uma medida da perda de informação da estrutura de dados quando $q$ variáveis são utilizadas em vez das $p$ variáveis originais.

Um diagrama resumido ilustrando a dinâmica de aplicação do método é mostrado na Fig. 5.3. O procedimento explicado brevemente para o método de Procrustes é repetido até o ponto em que a medida de discrepância seja maior que um valor crítico. Matematicamente, a regra de parada adota neste trabalho quando $i$ variáveis são removidas é (Krzanowski, 1996)

$$
M^{2} \geq\left(1+c^{2}\right) \hat{\sigma}^{2} \cdot \chi^{2}(0.95, n k-0.5 k(k+1))
$$

com, 


$$
c=\sqrt{\frac{(p-i-k)}{(p-k)}}
$$

sendo $\hat{\sigma}^{2}$ um estimador conveniente para a variância amostral de $\mathbf{X}$.

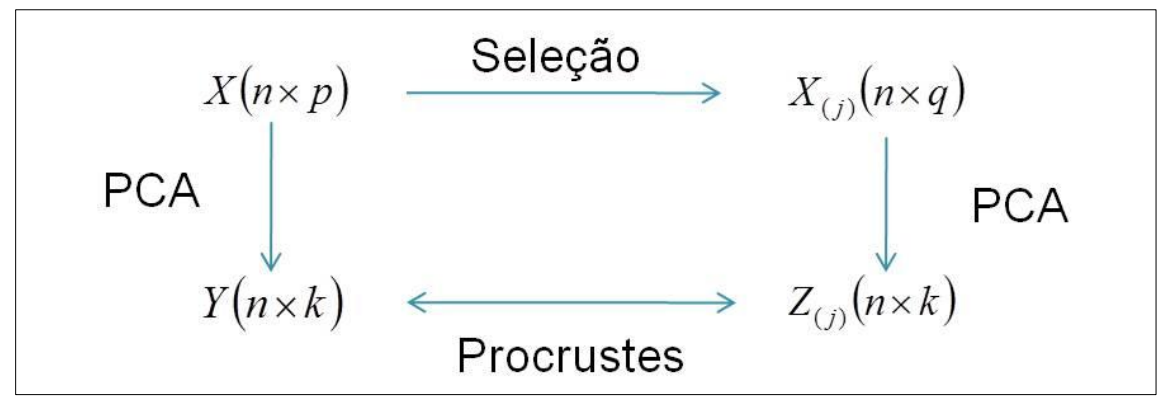

Figura 5.3 - Diagrama ilustrativo do método Procrustes para seleção de variáveis.

\subsection{Mapas auto-organizáveis}

Redes neurais artificiais representam uma alternativa a modelos tradicionais de análise multivariada, como a análise por componentes principais e análise discriminante, sendo uma ferramenta poderosa para modelagem multivariada de sistemas que apresentam relações não necessariamente lineares entre as variáveis, como em estudos de solos envolvendo retenção de nutrientes e gerenciamento de água, úteis na agricultura. Duas aplicações principais podem ser identificadas para redes neurais artificiais: (1) aproximação de funções, a partir de algoritmos de retropropagação; e (2) agrupamento ou classificação de vetores de entrada (Merdum, 2011).

As principais aplicações de inteligência artificial a estudos arqueométricos referem-se a comparações de classificação de dados geoquímicos por algoritmos tradicionais, como agrupamento hierárquico e análise por componentes principais, com métodos baseados em rede neurais, com a vantagem de esse último não ser dependente da distribuição dos dados (normal, lognormal etc.) em suas modelagens (Bell \& Croson, 1998). Também é recente a discussão sobre técnicas de agrupamento baseadas em lógica fuzzy, onde em vez de ser atribuído univocamente a um determinado cluster, um dado pode 
apresentar graus de pertinência em relação a vários clusters definidos de acordo com as necessidades do projeto (Baxter, 2009).

A última aplicação recorrente é a utilização de mapas auto-organizáveis (Toyota et al., 2009), desenvolvido por Teuvo Kohonen. Esses mapas são um tipo de rede neural artificial com estratégia de aprendizado frequentemente não supervisionada, que não exige amostras prévias de teste de uma estrutura já conhecida (Lopez-Molinero et al., 2000). Uma representação gráfica de um SOM é apresentada na Fig. 5.4. A motivação parcial do método é a forma como informações sensoriais, como a visual e auditiva, são manipuladas em partes separadas do córtex cerebral humano.

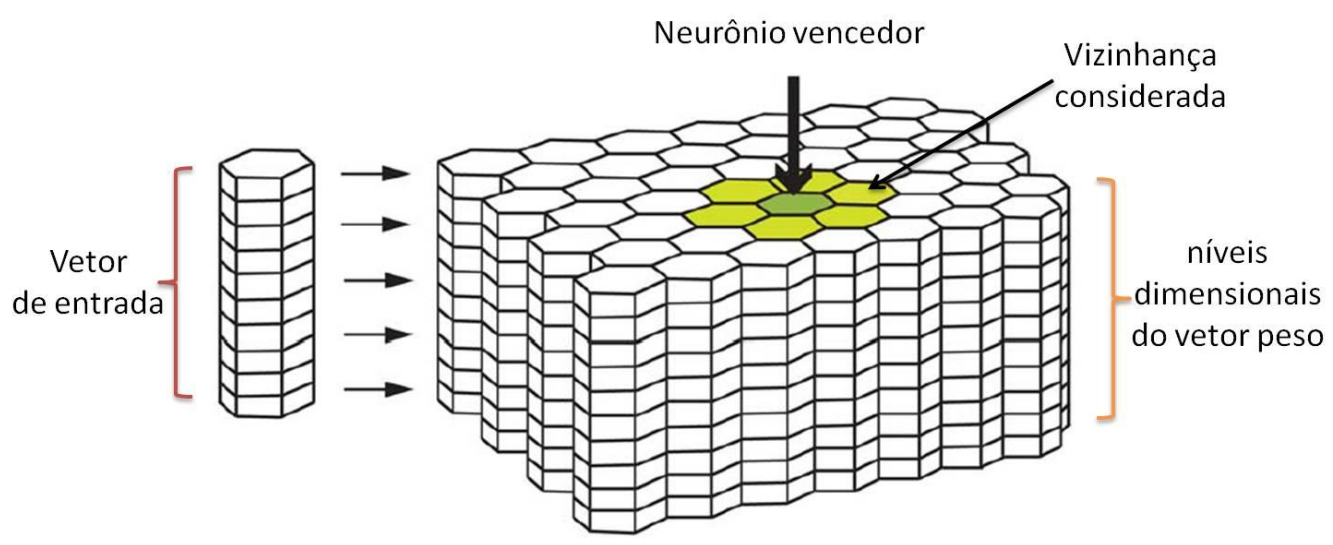

Figura 5.4 - Representação gráfica de um mapa auto-organizável, na qual os neurônios são representados por colunas verticais. A superfície da estrutura corresponde ao mapa visualizado graficamente após a aplicação do método. Fonte: Adaptado de Tanevska et al. (2007).

Assim como as componentes principais e funções discriminantes, esses mapas são uma ferramenta útil para visualização de dados de alta dimensionalidade em estruturas bi ou tridimensionais. Os mapas são constituídos por nós, ou neurônios, sendo que cada um possui um vetor peso de mesma dimensionalidade que os dados, ou vetores de entrada (inputs). A geometria dos neurônios pode ser hexagonal ou retangular, influenciando o número de vizinhos. Mapas auto-organizáveis distinguem-se de outras redes neurais artificiais pela preservação de propriedades topológicas do espaço original, ou de entrada, pela utilização de funções de vizinhança.

O método consiste no mapeamento de um espaço de alta dimensionalidade dos vetores de entrada em um espaço de menor dimensão, representado pelo arranjo neuronal. 
Um vetor de entrada é alocado no neurônio cujo vetor peso seja o mais próximo possível segundo uma métrica adequada. A ideia geral é a de que os vetores-peso representativos de cada neurônio sejam espacialmente correlacionados, de forma que vetores representativos em pontos próximos na grade são mais similares do que os mais distantes.

O treinamento de um mapa auto-organizável consiste em um aprendizado não supervisionado competitivo, no qual os neurônios "competem" para representar um determinado vetor de entrada, sendo adequado para identificar agrupamento nos dados. A cada apresentação de um exemplo, ou vetor de entrada, à rede, sua distância euclidiana a cada um dos vetores peso associados aos neurônios é calculada, de forma que o neurônio "vencedor", denominado de best matching unit (BMU), e neurônios da vizinhança tenham seus pesos ajustados em relação ao vetor de entrada. A magnitude do ajuste decresce com o tempo e com a distância ao BMU, segundo a seguinte fórmula de atualização (adaptado de Lopez-Molinero et al., 2000)

$$
\boldsymbol{W}_{\boldsymbol{v}}(t+1)=\boldsymbol{W}_{\boldsymbol{v}}(t)+\theta(v, t, d) \alpha(t)\left[\boldsymbol{D}(i)-\boldsymbol{W}_{\boldsymbol{v}}(t)\right]
$$

na qual $t=$ iteração ou época do algoritmo; $\boldsymbol{D}(\boldsymbol{i})=$ vetor de entrada ou input, com $\mathrm{i}=1 \ldots \mathrm{n}$, o tamanho amostral da base de dados de treinamento; $\boldsymbol{\theta}(v, t, d)=$ função de vizinhança, frequentemente gaussiana ou triangular, dependente da distância $d$ do neurônio vizinho ao BMU; $\alpha(t)=$ coeficiente de aprendizado monotonicamente decrescente.

O processo de aprendizagem inicia-se com vizinhanças grandes, até que, no final, a definição de vizinhança torna-se mais restrita, com os vetores peso de cada neurônio convergindo para estimativas locais no mapa. Uma época de treinamento é completa quando todos os vetores de entrada, ou amostras de treinamento, foram utilizados uma vez para a correção dos vetores peso neuronais. No final do procedimento, os neurônios, ou nós de saída, podem ser associados a grupos presentes no espaço multidimensional de entrada por procedimentos de visualização gráfica, como escala de cores representando distâncias euclidianas entre os neurônios da rede, guardados em uma matriz $U$.

O resultado do algoritmo vai depender da inicialização dos pesos (randômica ou baseada em autovetores), da ordem de apresentação dos exemplos e da sintonia das constantes do modelo. É necessário iniciar o algoritmo com vizinhanças grandes, caso contrário dificultará o aparecimento de um ordenamento global. Em vez de atualizar todos 
os neurônios da vizinhança igualmente, é natural utilizar um fator ponderado pela distância no procedimento de atualização. Segundo Ripley (2007), é possível considerar o SOM como uma versão espacialmente suavizada do algoritmo de agrupamento $K$-means.

A versão batelada do algoritmo SOM, na qual todos os inputs são apresentados simultaneamente à rede e os neurônios atualizados simultaneamente, é bem mais recente. $\mathrm{Na}$ literatura, ainda há poucos trabalhos sobre aplicação de mapas auto-organizáveis em dados arqueométricos (Lopez-Molinero et al., 2000; Toyota, 2009). 


\section{CAPítulo 6 \\ MATERIAIS E MÉTODOS}

As amostras de cerâmicas arqueológicas analisadas neste trabalho pertencem ao acervo do Museu de Arqueologia e Etnologia da Universidade de São Paulo (MAEUSP), e foram coletadas em escavações do Projeto Amazônia Central (PAC), pela equipe do Prof. Dr. Eduardo Góes Neves. As amostras de Lago Grande são provenientes das unidades de escavação 1, 3 e 4, associadas a montículos (Donatti, 2003; Lima, 2008), formados por reaproveitamento de refugos. A alta densidade material dos montículos torna essas estruturas adequadas para representar o registro arqueológico do sítio. Em relação a Osvaldo, há fragmentos de diferentes tradagens, sondagens e da unidade de escavação S710 E1966, buscando uma amostragem geográfica adequada e a representação, principalmente, da estratigrafia entre 0 e $40 \mathrm{~cm}$, associada à alta densidade de material arqueológico e solos antropogênicos, reflexo provável do pico demográfico de Osvaldo. Cinco amostras de argila foram coletadas pelo Prof. Dr. Emílio Soares, do Departamento de Geociências da Universidade Federal do Amazonas, três próximas a Lago Grande e duas próximas a Osvaldo. Há ainda oito amostras de argila coletadas em Osvaldo por Lima (2008) em diferentes estratigrafias.

A amostragem da maior área possível, como feito com as amostras do sítio Osvaldo, é conveniente, pois há evidências de que os centros de produção cerâmica eram autônomos, centrados em unidades familiares, apesar da coexistência de ideologias hierárquicas dos antigos habitantes do sítio (Portocarrero, 2006).

A maioria dos fragmentos cerâmicos pertence às fases culturais Paredão e Manacapuru, de principal interesse neste estudo. Há também cinco amostras da fase cultural Açutuba (mais antiga) do sítio Lago Grande e uma amostra Guarita, mais recente que as demais, associada à chegada de povos Tupi à Amazônia Central. Na Fig. 6.1 são apresentadas as fotografias de algumas amostras para análise. 


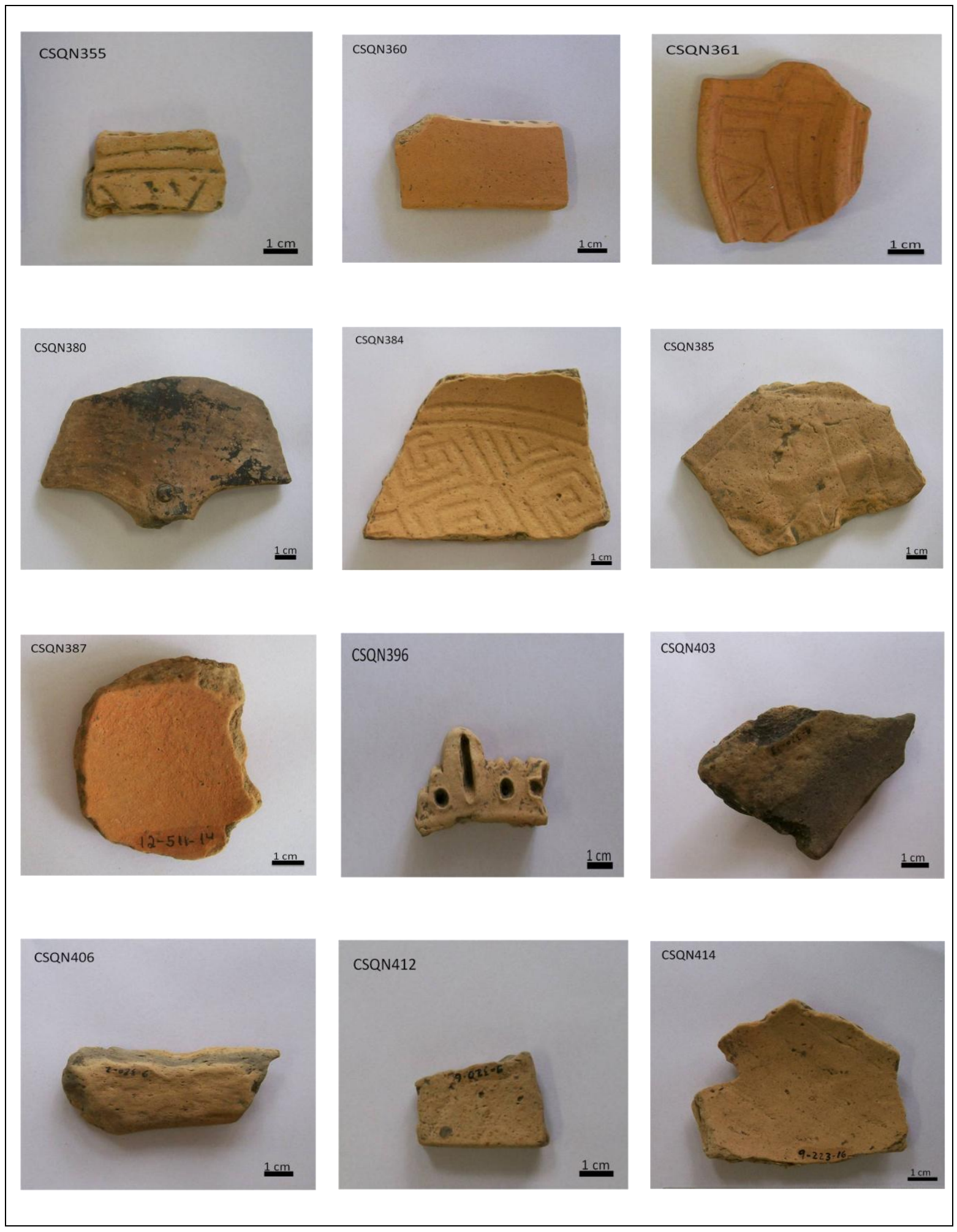

Figura 6.1 - Exemplos de amostras dos sítios arqueológicos Lago Grande e Osvaldo para análise. 


\subsection{Análise por Ativação com Nêutrons Instrumental (INAA)}

\subsubsection{Preparação de amostras}

A superfície lateral dos fragmentos cerâmicos foi lixada com uma broca de desbaste de carbeto de tungstênio com diâmetro de cabeça de $9,5 \mathrm{~mm}$ e comprimento de cabeça de 19,6 mm, adaptada a uma furadeira de velocidade regulável por potenciômetro, a fim de se reduzir as contaminações. A remoção da superfície lateral das amostras é necessária, pois o fragmento cerâmico ficou em contato direto com o solo e sedimentos durante o contexto deposicional no sítio arqueológico, e as possíveis alterações dessas superfícies pelo contato direto com o meio podem interferir em etapas subsequentes de análise. A seguir, cerca de $500 \mathrm{mg}$ de amostra na forma de pó foram obtidos a partir de 3 a 7 orifícios na parte lateral do fragmento (Fig. 6.2), evitando-se que a broca atravessasse suas paredes, onde frequentemente havia alguma decoração (Munita et al., 2003). As brocas utilizadas possuíam 1,5 ou 2,2 mm de diâmetro, dependendo da espessura do fragmento cerâmico. Esse pó foi então recolhido e armazenado em potes de polietileno (Fig. 6.3). As amostras de argila foram moídas em almofariz de ágata e peneiradas em peneira de 100 a 200 mesh para obter um pó suficientemente fino (IAEA, 2003).

Os múltiplos orifícios em lados diferentes dos fragmentos cerâmicos são indicados para a obtenção de uma alíquota mais representativa do fragmento amostrado (Bishop et al., 1988). A utilização de broca de carbeto de tungstênio tem como objetivo diminuir o efeito de eventuais contaminações nas análises elementares. Mesmo com esse procedimento, contaminações significativas de W, Co e Ta podem ocorrer pela utilização de brocas desse material (Attas, 1984). 


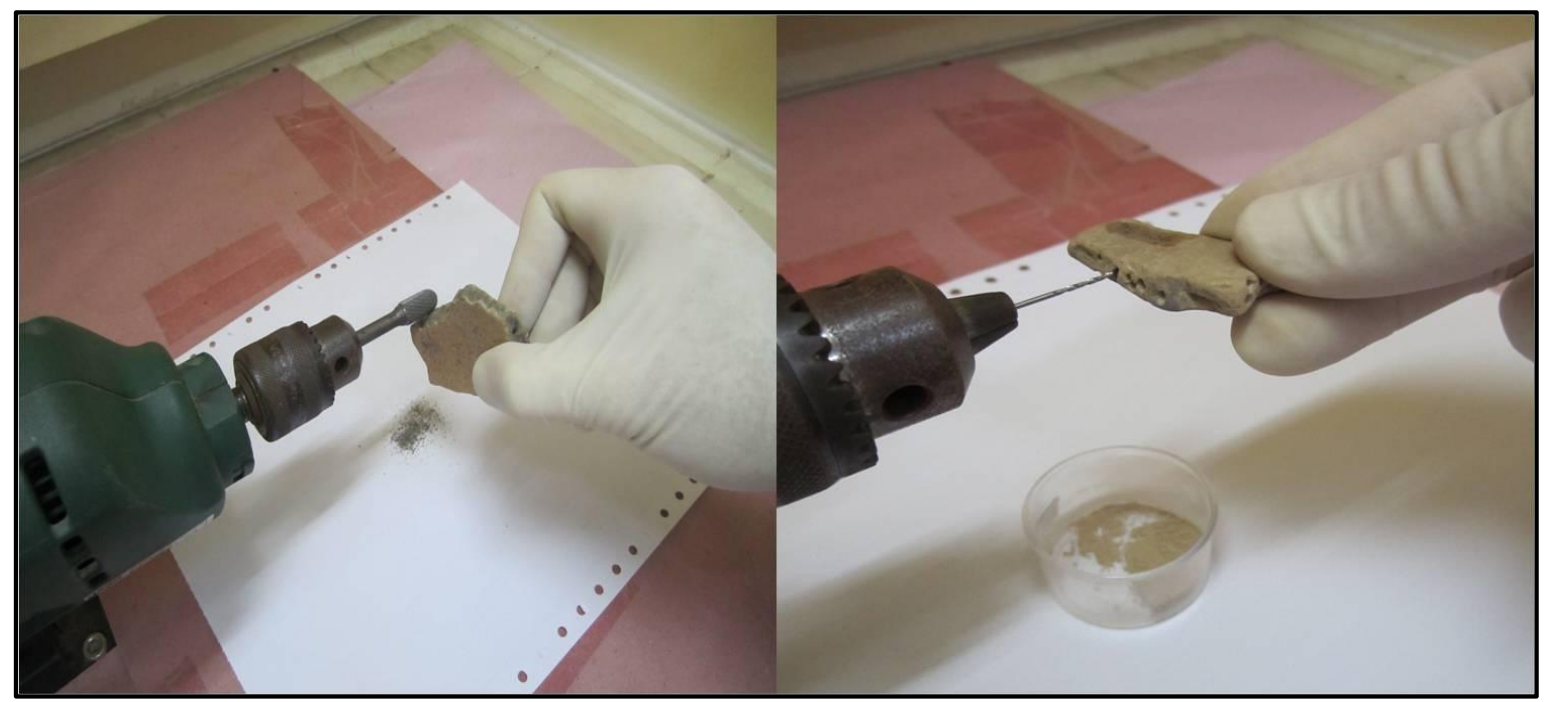

Figura 6.2 - Remoção de superfície lateral e incisão de broca para obtenção de pó de fragmentos cerâmicos arqueológicos dos sítios Lago Grande e Osvaldo.

Segundo testes de peneiramento, as amostras obtidas por incisões com broca de carbeto de tungstênio têm tamanhos de partícula menores que $149 \mu \mathrm{m}$ (100 mesh).

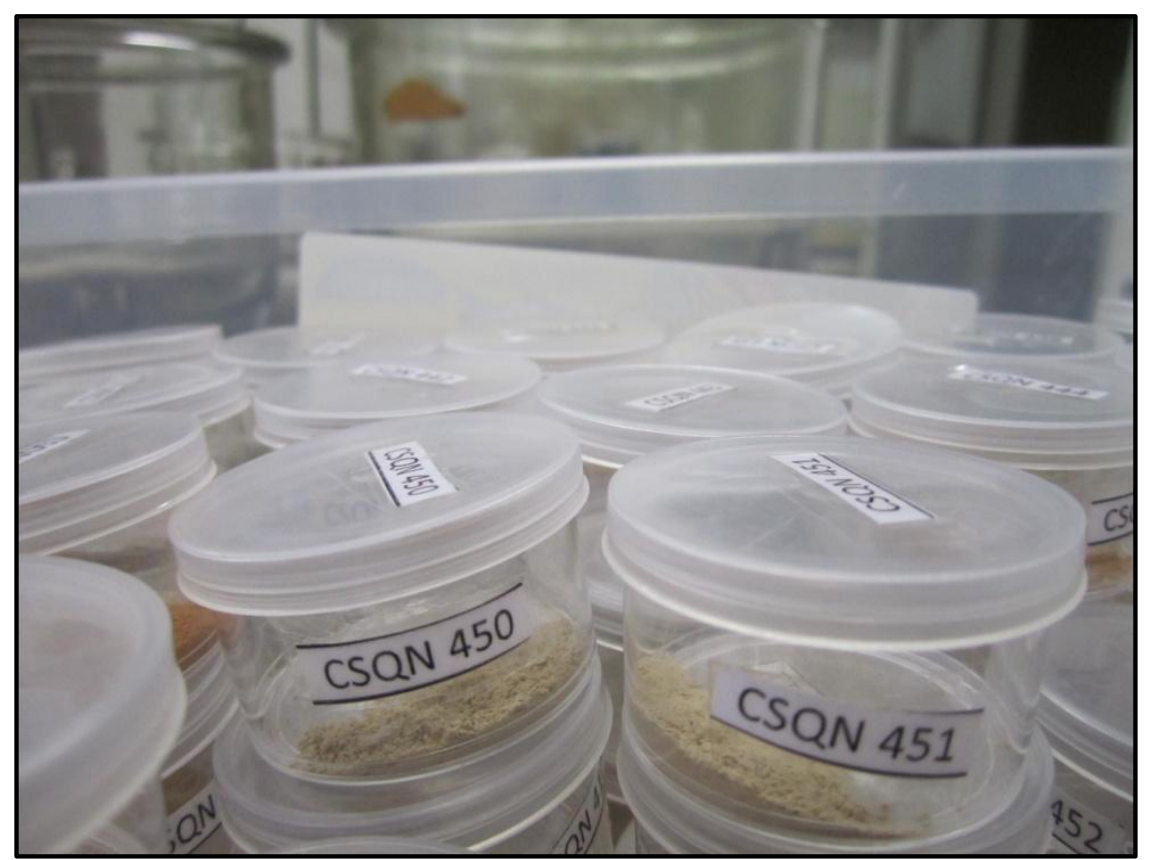

Figura 6.3 - Acondicionamento do pó obtido na preparação de amostras para INAA. 


\subsubsection{Irradiação}

Para a irradiação com nêutrons térmicos, cerca de $120 \mathrm{mg}$ de cada amostra (cerâmica, argila ou material de referência) foram pesados em invólucros de polietileno (Fig. 6.4), posicionados sob folhas de celofane (Fig.6.5) e selados com ferro elétrico para solda. Os invólucros foram envoltos em folhas de alumínio .

A escolha da quantidade de material adequada para irradiação com nêutrons térmicos está baseada em estudos anteriores do Grupo de Arqueometria do IPEN e de outros laboratórios (Mommsen, 2004).

O material de referência NIST-SRM 1633 (Constituent Elements in Coal Fly Ash) foi utilizado como padrão de referência para o método comparativo de INAA (Blackman \& Bishop, 2007). O controle de qualidade analítico foi realizado analisando-se uma amostra do material de referência IAEA-Soil-7 (Trace Elements in Soil) como amostra desconhecida para aferir a precisão, exatidão e a sensibilidade do método.

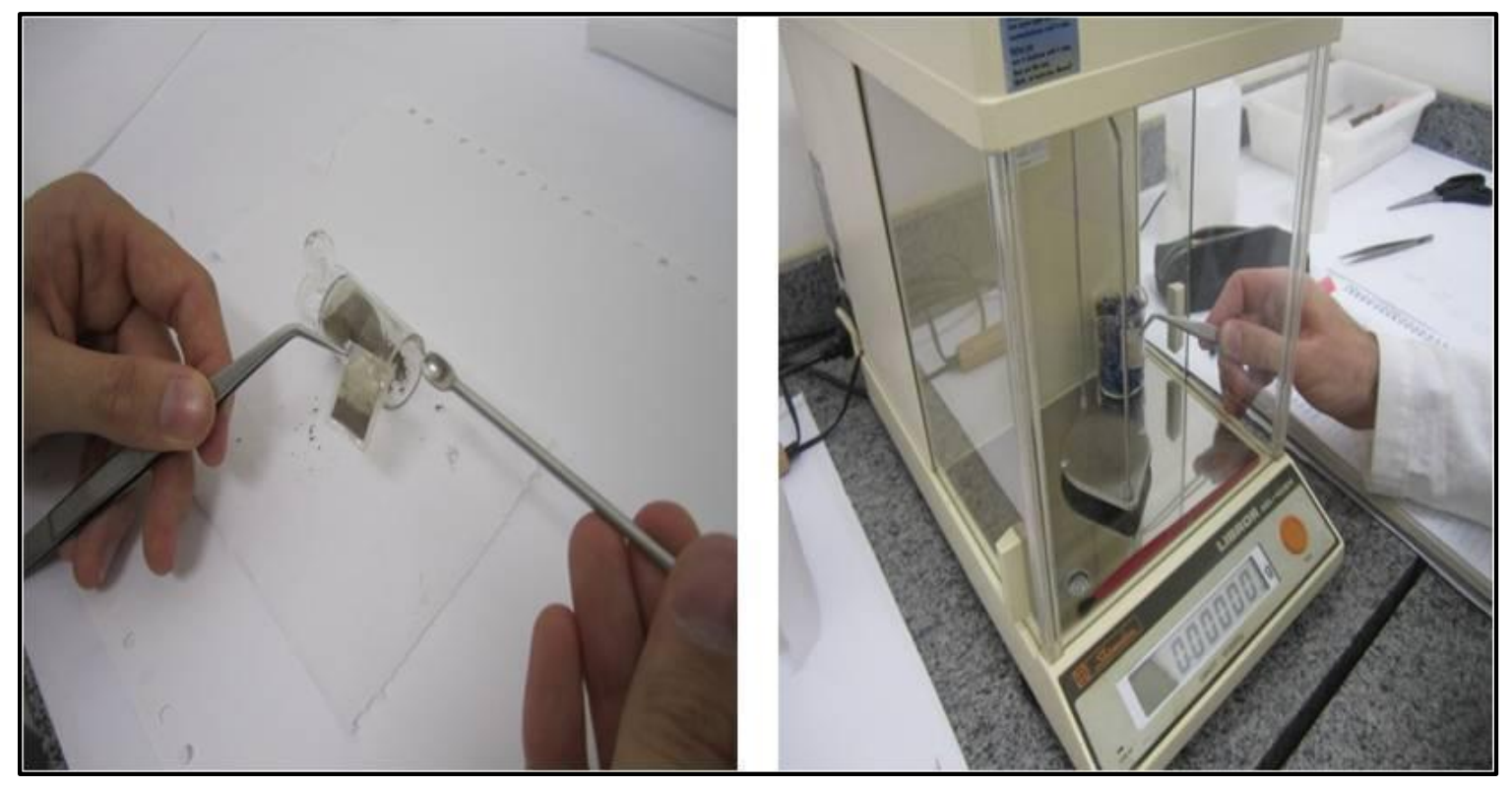

Figura 6.4 - Pesagem de amostra de cerâmica arqueológica para irradiação com nêutrons térmicos. 


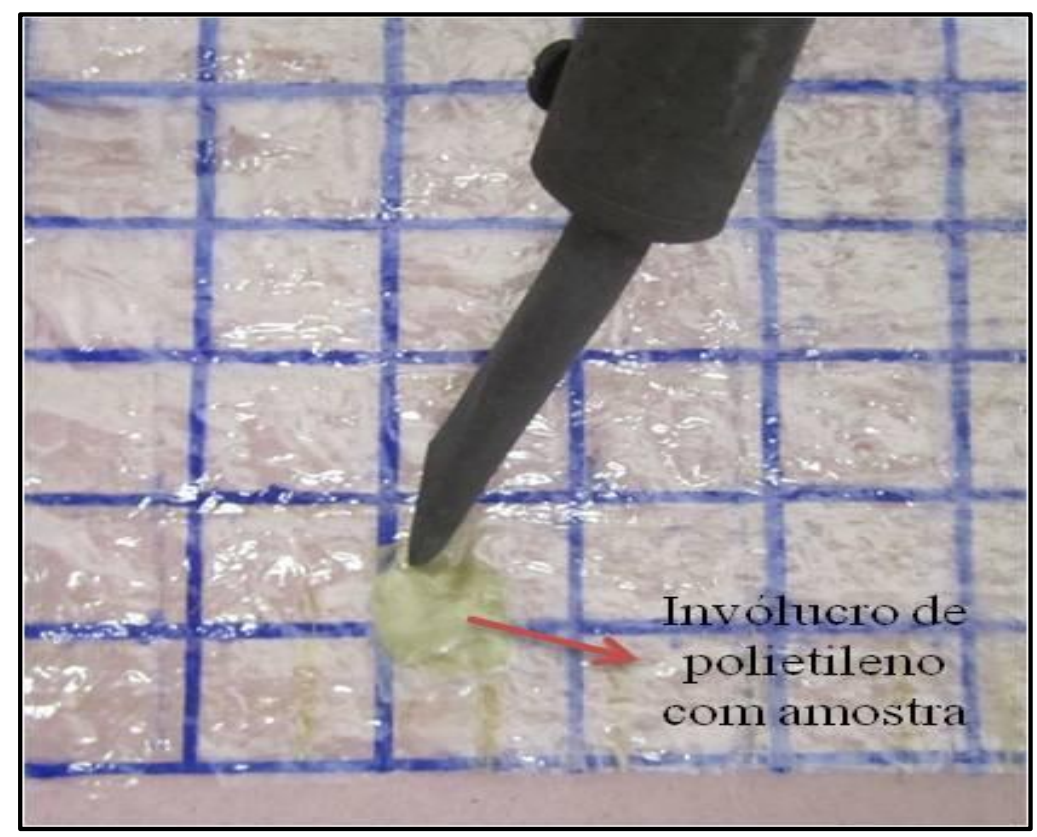

Figura 6.5 - Soldagem dos invólucros de polietileno sob papel celofane.

Uma série de sete amostras de composição desconhecida e uma amostra de cada material de referência foi organizada na forma de uma pilha e envolta por outra folha de papel alumínio. A seguir, essa pilha foi inserida em uma cápsula cilíndrica de alumínio, denominada "coelho", e enviada para o setor de irradiação. O esquema é ilustrado na Fig.6.6. As amostras foram submetidas à irradiação por 8 horas no reator IEA-R1 do IPEN - CNEN/SP, sob um fluxo de nêutrons térmicos de 1,2 a $1,6.10^{12} \mathrm{~cm}^{-2} \mathrm{~s}^{-1}$ para a maioria das amostras.

Neste trabalho, utilizaram-se oito elementos certificados (As, Ba, Fe, Cr, K, $\mathrm{Na}$, Th e U) e dezesseis não certificados (Ce, Co, Cs, Eu, Hf, La, Lu, Nd, Rb, Sb, Sc, Sm, $\mathrm{Ta}, \mathrm{Tb}, \mathrm{Yb}$ e Zn) para o material de referência NIST-SRM 1633b. Embora o NIST (National Institute of Standards \& Technology) não recomende a utilização de elementos não certificados para calibração e controle de qualidade (NIST, 2004), eles foram utilizados neste trabalho, pois a precisão e exatidão das determinações foram estudadas pela irradiação do material de referência IAEA-Soil-7, eliminando-se das análises estatísticas subsequentes os elementos que não atendessem aos parâmetros de qualidade analítica adotados neste trabalho. Para o IAEA-Soil-7 os elementos não certificados são $\mathrm{Ba}, \mathrm{Fe}, \mathrm{K}$, Lu e Na. 


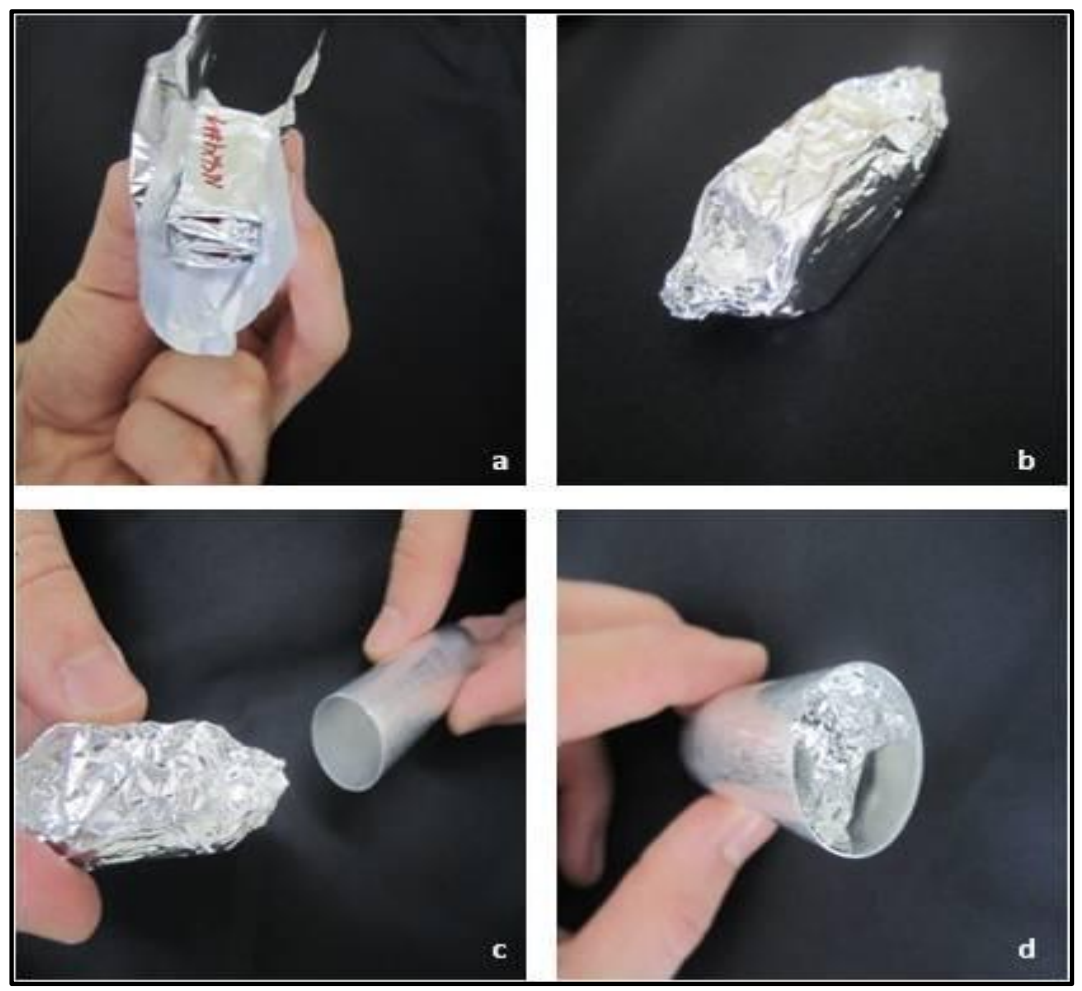

Figura 6.6 - Montagem de "coelho" contendo amostras para irradiação com nêutrons térmicos.

Na metodologia deste trabalho, foi utilizado um material de referência certificado como padrão (NIST-SRM 1633b), em vez de padrões sintéticos. O procedimento é comum entre laboratórios que trabalham com análise multielementar por INAA (Glascock, 1992; Harbottle \& Holmes, 2007; Mommsen \& Sjöberg, 2007). Algumas razões para essa escolha são apresentadas a seguir:

- Muitos elementos analisados: alto tempo de preparação (uma solução para cada faixa de elementos de meia-vida curta, intermédia e longa) de soluções quando muitas amostras são analisadas, aumentando significativamente o tempo para obtenção dos resultados.

u Utilização de material de referência de solos pode minimizar possíveis efeitos matriciais.

- Introdução de fontes adicionais de erro, como o erro de pipetagem dos vários elementos para os padrões sintéticos, pode ser evitada. 
口 É empregado um procedimento de controle de qualidade analítico com o material de referência IAEA-Soil-7 para identificar possíveis problemas na determinação das concentrações elementares.

\subsubsection{Espectrometria gama}

As medidas de atividade gama induzida pela irradiação das amostras com nêutrons térmicos foram obtidas com um detector de germânio hiperpuro da Canberra, modelo GX 2519, com resolução de $1,90 \mathrm{keV}$ para o pico de $1332,5 \mathrm{keV}$ do ${ }^{60} \mathrm{Co}$, acoplado ao analisador multicanal S-100 MCA, da Canberra, com 8192 canais. Os espectros de raios gama foram obtidos e analisados por meio do programa Genie-2000 Gamma Acquisition \& Analysis, versão 3.1.a (2007), desenvolvido também pela Canberra, para a identificação dos radionuclídeos e integração das contagens sob os picos.

Aproximadamente um terço das medidas de espectrometria gama foi realizado com o auxílio de um trocador automático, desenvolvido pelo laboratório em colaboração com a CCHEN (Comisión Chilena de Energía Nuclear). A foto do trocador é apresentada na Fig.6.7. Para as medidas, os invólucros de polietileno com as amostras são removidos de suas coberturas de alumínio em três ou quatro dias após a irradiação das amostras, e acondicionados em cápsulas de polietileno apropriadas para o transporte das mesmas pela tubulação pneumática do trocador automático até o espectrômetro gama (Fig.6.8).

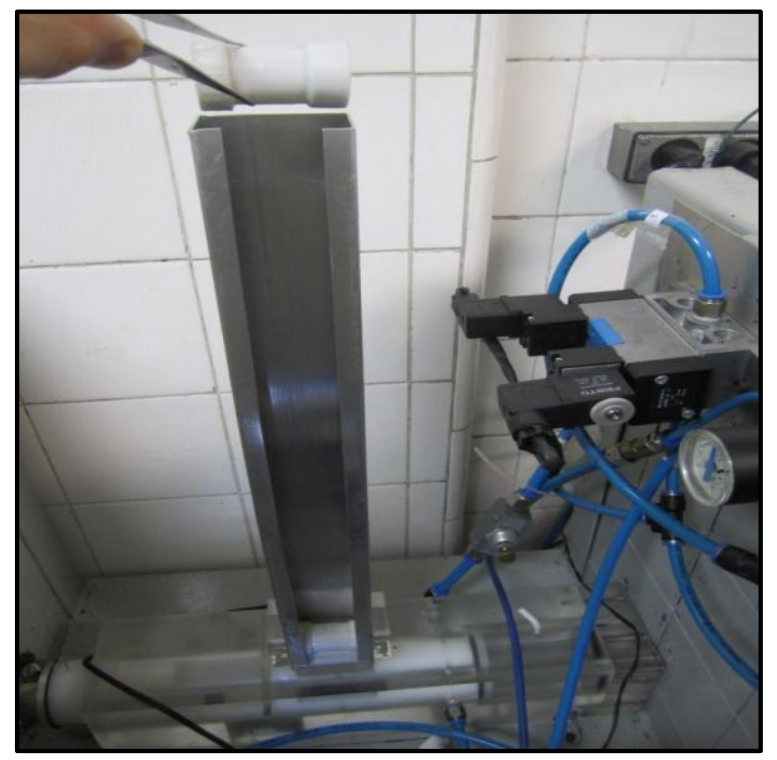

Figura 6.7 - Acondicionamento de cápsulas de polietileno, contendo as amostras irradiadas, no trilho do trocador automático para espectrometria gama. 


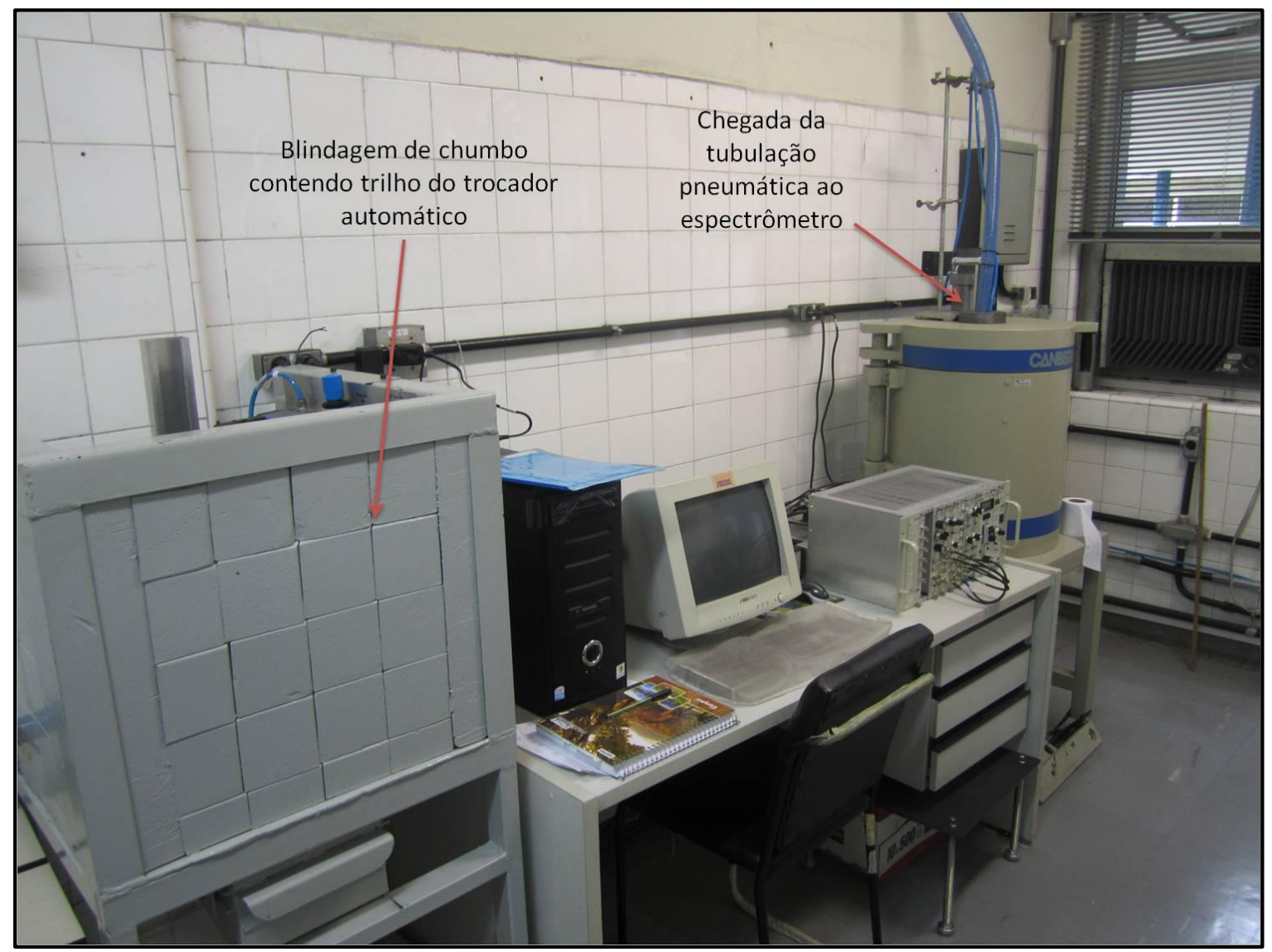

Figura 6.8 - Chegada da tubulação pneumática do trocador automático ao espectrômetro gama.

As amostras foram posicionadas a $8 \mathrm{~cm}$ de distância do detector.

Foram realizadas duas medidas, sendo determinados após cerca de 5-7 dias de decaimento os elementos As, K, La, Lu, Na, Nd, Sb, Sm, U e Yb e, após 25-30 dias de decaimento, Ba, Ce, Co, Cr, Cs, Eu, Fe, Hf, Rb, Sc, Ta, Tb, Th e Zn (Glascock, 1992; Glascock \& Neff, 2003; Munita, 2005). O tempo de contagem das amostras foi de 1-2 h.

\subsection{Ressonância Paramagnética Eletrônica (EPR)}

Foram selecionadas nove amostras a partir das análises estatísticas preliminares dos dados de INAA, de forma a amostrar os grupos de composição química elementar definidos até então. As amostras selecionadas são apresentadas na Tab. 6.1. 
Tabela 6.1 - Amostras de cerâmica arqueológica selecionadas para EPR.

\begin{tabular}{cccc}
\hline $\begin{array}{c}\text { Amostra (Código } \\
\text { MAE) }\end{array}$ & $\begin{array}{c}\text { Amostra (código } \\
\text { IPEN) }\end{array}$ & Sítio arqueológico & Profundidade $(\mathrm{cm})$ \\
\hline $12-237$ & CSQN59 & Lago Grande & $120-130$ \\
$12-57$ & CSQN60 & Lago Grande & $20-30$ \\
$12-373-2$ & CSQN61 & Lago Grande & $0-10$ \\
$12-120$ & CSQN64 & Lago Grande & $70-80$ \\
$12-79$ & CSQN66 & Lago Grande & $50-60$ \\
- & CSQN94 & Osvaldo & $70-80$ \\
$7-490$ & CSQN100 & Osvaldo & $60-70$ \\
$7-481$ & CSQN101 & Osvaldo & $80-90$ \\
$9-320-13$ & CSQN403 & Osvaldo & $0-10$ \\
\hline
\end{tabular}

Cerca de $70 \mathrm{mg}$ do pó obtido na preparação de amostras para INAA foram pesados em cápsulas de polietileno, de forma a obter um conjunto de 11 cápsulas para cada amostra. As alíquotas foram posteriormente transferidas para cadinhos de porcelana para queima em mufla a partir de $400{ }^{\circ} \mathrm{C}$, em incrementos de $50{ }^{\circ} \mathrm{C}$, até $850{ }^{\circ} \mathrm{C}$, por $20 \mathrm{~min}$. Assim, foram submetidas à EPR dez alíquotas queimadas em mufla e uma "natural" (não queimada) para cada amostra. A seleção desse intervalo deve-se ao fato de a maioria das cerâmicas arqueológicas apresentarem temperatura de queima entre 500 e $900{ }^{\circ} \mathrm{C}$. A taxa de aquecimento foi de $10{ }^{\circ} \mathrm{C} \cdot \mathrm{min}^{-1}$. Essa taxa é adequada para evitar efeitos cinéticos e rachaduras nas amostras (Bensimon et al., 1998).

O sistema de medição utilizado para determinar a temperatura de queima pela técnica de EPR foi um espectrômetro EPR Bruker EMX, com cavidade modelo ER 4102ST que opera na banda $X(9,75 \mathrm{GHz})$. As medidas foram realizadas com $70 \mathrm{mg}$ de amostra em pó, colocadas em tubos de quartzo de $4,3 \mathrm{~mm}$ de diâmetro, com os seguintes parâmetros experimentais do espectrômetro EPR: amplitude de 1 G, frequência de modulação de 100 $\mathrm{kHz}$ e potência de $1 \mathrm{~mW}$. O intervalo de varredura foi de 500 a 6500 gauss (Bensimon et al., 1998).

As análises de EPR foram realizadas em colaboração com o Dr. Nilo Francisco Cano Mamani, do Laboratório de Cristais Iônicos, Filmes Finos e Datação, do Instituto de Física da USP, liderado pelo Prof. Dr. Shigueo Watanabe. 


\subsection{Difração de raios $X(X R D)$}

Foram selecionados 17 fragmentos cerâmicos de Lago Grande e Osvaldo a partir das análises estatísticas preliminares dos dados de INAA, de forma a amostrar os grupos de composição química elementar então definidos. As amostras são apresentadas na Tab. 6.2. Também foram analisadas três amostras de argila queimada, coletadas na unidade S710 E1966 de Osvaldo, e quatro amostras de sedimentos coletadas nos arredores de Manaus pelo Prof. Dr. Emílio Soares, da Universidade Federal do Amazonas.

Tabela 6.2 - Amostras de cerâmica arqueológica selecionadas para XRD.

\begin{tabular}{cccc}
\hline $\begin{array}{c}\text { Amostra (Código } \\
\text { MAE) }\end{array}$ & $\begin{array}{c}\text { Amostra (código } \\
\text { IPEN) }\end{array}$ & Sítio arqueológico & Profundidade $(\mathrm{cm})$ \\
\hline $12-237$ & CSQN59 & Lago Grande & $120-130$ \\
$12-57$ & CSQN60 & Lago Grande & $20-30$ \\
$12-373-2$ & CSQN61 & Lago Grande & $0-10$ \\
$12-366$ & CSQN63 & Lago Grande & $120-130$ \\
$12-120$ & CSQN64 & Lago Grande & $70-80$ \\
$12-79$ & CSQN66 & Lago Grande & $50-60$ \\
$12-85-9$ & CSQN67 & Lago Grande & $60-70$ \\
$7-205$ & CSQN83 & Osvaldo & $20-30$ \\
$7-358$ & CSQN85 & Osvaldo & $40-50$ \\
$7-454$ & CSQN88 & Osvaldo & $70-80$ \\
- & CSQN92 & Osvaldo & $50-60$ \\
- & CSQN94 & Osvaldo & $70-80$ \\
$7-481$ & CSQN101 & Osvaldo & $80-90$ \\
$12-224$ & CSQN123 & Lago Grande & $110-120$ \\
$12-320$ & CSQN124 & Lago Grande & $40-50$ \\
$9-320-2$ & CSQN406 & Osvaldo & $0-10$ \\
$9-320-4$ & CSQN408 & Osvaldo & $0-10$ \\
$9-320-6$ & CSQN412 & Osvaldo & $0-10$ \\
$9-223-4$ & CSQN416 & Osvaldo & $30-40$ \\
$9-223-1$ & CSQN419 & Osvaldo & $30-40$ \\
\hline
\end{tabular}

Cerca de $250 \mathrm{mg}$ de pó dos fragmentos cerâmicos obtido na preparação de amostras para INAA foram transferidos com uma espátula de polietileno para um portaamostra de quartzo com cavidade para depósito de amostras de dimensões 20 × 20 × 0,5 
$\mathrm{mm}$. O excesso de amostra foi removido da cavidade com uma placa de vidro, de forma a preenchê-la de forma regular.

Para a análise da fração de minerais argilosos, as amostras brutas foram inicialmente quarteadas. A seguir, em béqueres de $250 \mathrm{~mL}$ identificados e tarados, pesaram-se $15 \mathrm{~g}$ de amostra e 0,25 g de pirofosfato de sódio (para dispersão da argila). Completou-se o béquer com $100 \mathrm{~mL}$ de água destilada, para então submeter o sistema à agitação por 15 minutos em agitador mecânico Fisatom. Depois, a mistura foi macerada com auxílio de almofariz e pistilo de borracha, antes de ser transferida para uma proveta de $250 \mathrm{~mL}$. Após $2 \mathrm{~h}$ da transferência do sistema para a proveta, removeram-se $20 \mathrm{~mL}$ da mistura com pipeta a uma profundidade de $10 \mathrm{~cm}$ da superfície do líquido. De acordo com a lei de Stokes, nessa profundidade os grãos pipetados possuem aproximadamente 0,004 $\mathrm{mm}$ de diâmetro (silte fino a argila). Esta alíquota foi pipetada sobre a lâmina para XRD e deixada para secar em temperatura ambiente .

O porta-amostra com o pó de cerâmica obtido instrumentalmente foi inserido no difratômetro de raios X Miniflex II, da Rigaku Corporation. Já para a análise da fração argilosa, utilizou-se um difratômetro Siemens Bruker D5000. O intervalo de varredura utilizado foi $[3,80]^{\circ}$, com velocidades de $4 \%$ min e $1 \%$ min e passo de $0,02^{\circ}$, à temperatura ambiente.

$\mathrm{O}$ tubo de raios $\mathrm{X}$ possuía fonte de $\mathrm{Cu}$ e filtro de Ni para supressão da radiação $\mathrm{k}_{\beta}$, com tensão de $30 \mathrm{kV}$ e corrente de $15 \mathrm{~mA}$. Para a espectrometria, utilizou-se um detector cintilador de $\mathrm{NaI}(\mathrm{Tl})$, com janela de berílio. Os espectros foram obtidos pelo programa Standard Measurement.

As análises de XRD foram realizadas em colaboração com a Prof. ${ }^{a}$ Dr. ${ }^{a}$ Sonia Hatsue Tatumi e com o Prof. Dr. Juan Carlos Mittani, no antigo Laboratório de Vidros e Datação, da FATEC-SP, e com o Dr. Flávio Machado de Souza Carvalho, do Laboratório de Difração de Raios X, do Instituto de Geociências da USP.

\subsection{Datação por Luminescência Opticamente Estimulada (OSL)}

Foram selecionados seis fragmentos cerâmicos (Tab. 6.3) sem decoração superficial para determinação do tempo transcorrido desde o uso final das peças originárias dos fragmentos até o período de escavação. 
Tabela 6.3 - Amostras de cerâmica arqueológica selecionadas para datação por OSL.

\begin{tabular}{ccccc}
\hline Amostra & Código MAE & Código OSL & $\begin{array}{c}\text { Sítio } \\
\text { Arqueológico }\end{array}$ & $\begin{array}{c}\text { Profundidade } \\
(\mathrm{cm})\end{array}$ \\
\hline CSQN379 & $12-208-1$ & R6 & Lago Grande & $110-120$ \\
CSQN387 & $12-511-14$ & R1 & Lago Grande & $30-40$ \\
CSQN390 & $12-558-1$ & R3 & Lago Grande & $60-70$ \\
CSQN406 & $9-320-2$ & R2 & Osvaldo & $0-10$ \\
CSQN414 & $9-223-16$ & R4 & Osvaldo & $30-40$ \\
CSQN420 & $9-223-3$ & R5 & Osvaldo & $30-40$ \\
\hline
\end{tabular}

A preparação das amostras para datação por OSL seguiu as seguintes etapas:

i. Lixamento de todas as superfícies das amostras com lixa comum 80 de forma a remover de 1 a 2 mm espessura.

ii. Trituração dos fragmentos em almofariz de alumina com o devido cuidado para não dar golpes muito fortes e atritar a amostra, gerando triboluminescência.

iii. Remoção de materiais magnéticos por meio de um ímã.

iv. Peneiramento para obter amostra com granulometria entre 100 mesh (149 $\mu \mathrm{m})$ e 60 mesh $(250 \mu \mathrm{m})$, que é a fração preferencial para datação.

v. Transferência do material pulverizado para um béquer.

As etapas de limpeza química das amostras para datação por OSL são discriminadas a seguir (Mosquera \& Sánchez, 2008). É necessário lavar quatro vezes as amostras entre cada ataque químico. Este mesmo procedimento foi utilizado para a limpeza do cauixi na análise de INAA.

i. Adição de quantidade de $\mathrm{H}_{2} \mathrm{O}_{2}$ (34-37\% em volume) suficiente para cobrir a amostra no béquer. Deixar por $24 \mathrm{~h}$ para a remoção da matéria orgânica.

ii. Adição de HF (aproximadamente 0,09\% em volume) para corrosão da superfície dos cristais de quartzo, de forma a descontar os efeitos da irradiação natural alfa, e para a dissolução de feldspatos. Deixar agir por $2 \mathrm{~h}$.

iii. Se a amostra ainda apresentar coloração escura, repetir a etapa anterior com HF $28 \%$ em volume.

iv. Adição de $\mathrm{HCl}$ (aproximadamente 14\%) para remover carbonatos que podem emitir sinais espúrios para OSL. 
As amostras foram aquecidas a $180{ }^{\circ} \mathrm{C}$ antes de cada medida, durante 10 segundos. Esse procedimento de pré-aquecimento é usado para esvaziar os níveis energéticos associados a armadilhas instáveis. Utilizaram-se 8 alíquotas para a amostra R1, devido a seu menor sinal relativo de luminescência em testes preliminares, e 5 alíquotas para as demais amostras. As doses de irradiação beta foram de 2, 3 e 4 Gy para as amostras $\mathrm{R} 1$; e 2 e 4 Gy para as amostras R2, R3, R4 e R5, devido à sua luminescência relativamente mais alta. As medidas foram efetuadas a $120^{\circ} \mathrm{C}$ e seguiram o protocolo $\mathrm{SAR}$ (Single Aliquot Regenerative-dose protocol).

Para as medidas, o equipamento utilizado foi o Ris $\varnothing$ TL/OSL com fonte de partículas beta ${ }^{90} \mathrm{Sr} /{ }^{90} \mathrm{Y}$ e tubo fotomultiplicador 9635QA. A estimulação ocorreu com luz azul, com comprimento de onda de $470 \mathrm{~nm}$ e, para fins de detecção, foi utilizado um filtro óptico de 7,5 mm Hoya U-340.

A técnica analítica de datação por OSL foi empregada em colaboração com o Prof. Dr. Juan Carlos Mittani, da UNIFESP.

\subsection{Microscopia Óptica}

Foi utilizada uma lente ocular com aumento 10x, associada a uma objetiva de aumento 10x, resultando em um aumento total de 100x. As amostras selecionadas para microscopia óptica foram escolhidas ao acaso na base de dados utilizada para INAA, com o objetivo de se analisar a presença de espículas indicativas de cauixi, o antiplástico majoritariamente utilizado nas cerâmicas dos sítios arqueológicos estudados neste trabalho. O equipamento utilizado foi o microscópio óptico biológico trinocular L-1000T, da Equipar. Foram preparadas lâminas com uma alíquota de pó de cerâmica suficiente para o espalhamento por uma área circular de $1 \mathrm{~cm}$, aproximadamente, tomando o cuidado para que não haja excesso de amostra, prejudicando a transmissão da luz pela lâmina e impedindo a observação das espículas. 


\section{CAPÍtulo 7}

\section{RESULTADOS E DISCUSSÃO}

Neste capítulo, são apresentados os resultados experimentais das cinco técnicas analíticas utilizadas neste trabalho (INAA, XRD, EPR, datação OSL e microscopia óptica), aplicadas ao estudo dos fragmentos cerâmicos arqueológicos de Lago Grande e Osvaldo. No final da seção de cada técnica analítica, os resultados são interpretados quanto às suas implicações arqueológicas, sempre que possível.

\subsection{Estudo de composição química elementar parcial por INAA}

\subsubsection{Controle de qualidade analítico}

Inicialmente, avaliou-se a qualidade analítica dos resultados de INAA, compreendendo as medidas de concentrações elementares em fragmentos cerâmicos dos sítios Lago Grande e Osvaldo e em amostras de argila já queimadas. Para isso, foi analisado o material de referência IAEA-Soil-7 da Agência Internacional de Energia Atômica, tratada como amostra desconhecida junto às demais amostras arqueológicas.

Neste trabalho, adotaram-se as seguintes convenções de nomenclatura (VIM, 2012):

口 Precisão: grau de concordância entre valores medidos, obtidos por medições repetidas em um mesmo objeto ou em objetos similares, sob condições especificadas. Os materiais de referência com valores conhecidos podem ser utilizados para controlar a precisão das medições.

- Exatidão: reflete a proximidade da medida em relação ao valor verdadeiro do mensurando.

A precisão e a exatidão dos resultados são importantes tanto do ponto de vista analítico como arqueológico. Pela importância da determinação de elementos em níveis 
micro e traço, em concentrações de até $n g . g^{-1}$, em estudos de caracterização química de cerâmica, faz-se necessário um controle de qualidade robusto do método analítico de análise por ativação com nêutrons, de forma a minimizar possíveis interferências analíticas nos resultados e, consequentemente, na interpretação do ponto de vista arqueológico (ver Cap. 3 e 5$)$.

A precisão reflete a adequabilidade do método e é um parâmetro importante para a confiabilidade do mesmo. Uma precisão pobre dos resultados poderia obscurecer padrões geoquímicos das amostras e prejudicar a capacidade discriminante dos métodos estatísticos multivariados em separar grupos de composição química elementar distintos. A exatidão dos resultados é importante para correlação com outras medidas geoquímicas e interpretação dos mesmos em termos de quantidades absolutas, compreendendo a comparação com resultados obtidos por outros laboratórios.

Foi aplicado um teste de identificação de dados discrepantes para as concentrações elementares em IAEA-Soil-7, baseado no escore z modificado, mais robusto e menos afetado por esses dados discrepantes, a partir da seguinte equação (Seo, 2006)

$$
M_{i}=\frac{0,6745\left(x_{i}-m\right)}{D A M}
$$

Na qual $m$ é a mediana, e $D A M$ é o desvio absoluto da mediana, dado por

$$
D A M=\operatorname{med}\left(\left|x_{i}-m\right|\right)
$$

Iglewicz \& Hoaglin (1993) sugeriram considerar como dados discrepantes aqueles com $\left|M_{i}\right|>3,5$, a partir de simulações realizadas com 10, 20 e 40 amostras. Foram necessárias três iterações para que mais nenhum dado discrepante fosse identificado na base de dados de IAEA-Soil-7.

$\mathrm{Na}$ Tabela 7.1, são apresentadas as médias das concentrações experimentais junto com o desvio-padrão, o desvio-padrão relativo experimental (DPR exp); as médias das concentrações junto com o desvio-padrão após a eliminação de dados discrepantes (Refinado); o desvio-padrão relativo experimental após a remoção de dados discrepantes, considerado como a precisão do método INAA para o elemento em questão neste trabalho; os valores certificados; o intervalo de confiaça de $95 \%$ reportado no certificado para IAEA- 
Soil-7; e o erro relativo (Tendência) dos valores determinados em relação aos valores certificados e de referência para os 24 elementos químicos analisados.

O desvio-padrão dos valores certificados e informativos das concentrações elementares em IAEA-Soil-7 foi estimado pela Eq. 7.3, a partir dos intervalos de $95 \%$ de confiança para a mediana das médias dos laboratórios participantes na certificação desse material de referência. Assumiram-se, por aproximação, intervalos simétricos em torno da mediana, e que esta última seria igual à média. Desvios altos são esperados para os elementos que apresentam distribuição assimétrica, com mediana diferente da média.

$$
s_{r e f}=\frac{\frac{I C}{2} \sqrt{n}}{t_{0,05 ; n-1}}
$$

sendo
IC: Intervalo de confiança para a mediana.
n: número de amostras (neste estudo, representa o número de médias de diferentes laboratórios utilizados na certificação).

Pela Tab. 7.1, a maior parte das médias das concentrações elementares (21 elementos, com exceção de As, La e Sm) determinadas estão dentro do intervalo de confiança de $95 \%$ para o valor recomendado ou informativo do material de referência IAEA-Soil-7. As amostras de cerâmicas arqueológicas que estavam na mesma cápsula de irradiação que as amostras de IAEA-Soil-7 para as quais foram identificados valores discrepantes univariados na Tab. 7.1 foram analisadas para identificação de possíveis discrepâncias em suas concentrações, e descartadas quando necessário. 
Tabela 7.1 - Resultados de INAA para o material de referência IAEA-Soil-7. As unidades estão em $\mu$ g.g ${ }^{-1}$, quando não indicadas.

\begin{tabular}{|c|c|c|c|c|c|c|c|c|c|c|}
\hline Elemento & $\mathrm{n}$ & $\begin{array}{c}\text { Experimental } \\
\bar{x} \pm \mathrm{s} \\
\end{array}$ & $\begin{array}{c}\text { DPR exp } \\
(\%)\end{array}$ & Outliers & $\begin{array}{c}\text { Refinado } \\
\bar{x} \pm \mathrm{s}\end{array}$ & $\begin{array}{c}\text { Precisão } \\
(\%)\end{array}$ & $\begin{array}{c}\mathrm{n} \\
\text { certificado }\end{array}$ & $\begin{array}{c}\text { Valor no } \\
\text { Certificado* }^{*}\end{array}$ & $\begin{array}{l}\text { I.C. cert. } \\
(95 \%)\end{array}$ & $\begin{array}{c}\text { Tendência } \\
(\%)\end{array}$ \\
\hline As & 34 & $15,1 \pm 2,0$ & 13,2 & 5 & $14,9 \pm 0,8$ & 5,6 & 25 & $13,4 \pm 2,1$ & $12,5-14,2$ & 11,2 \\
\hline $\mathrm{K}(\mathrm{mg} / \mathrm{g})$ & 32 & $12,6 \pm 1,8$ & 14,4 & 0 & $12,6 \pm 1,8$ & 14,4 & 27 & $(12,1 \pm 1,8)$ & $(11,3-12,7)$ & 3,7 \\
\hline $\mathrm{La}$ & 34 & $30,6 \pm 1,2$ & 3,9 & 1 & $30,7 \pm 1,0$ & 3,4 & 12 & $28,0 \pm 1,6$ & $27-29$ & 9,5 \\
\hline Lu (ng/g) & 34 & $364 \pm 44$ & 12,1 & 3 & $369 \pm 28$ & 7,5 & 8 & $(300 \pm 179)$ & $(100-400)$ & 23,1 \\
\hline $\mathrm{Na}(\mathrm{mg} / \mathrm{g})$ & 34 & $2,3 \pm 0,1$ & 5,1 & 0 & $2,3 \pm 0,1$ & 5,1 & 33 & $(2,4 \pm 0,3)$ & $(2,3-2,5)$ & $-2,5$ \\
\hline $\mathrm{Nd}$ & 30 & $26 \pm 7$ & 26,8 & 1 & $25 \pm 5$ & 19,1 & 7 & $30 \pm 6$ & $22-34$ & $-17,0$ \\
\hline $\mathrm{Sb}$ & 15 & $1,9 \pm 0,6$ & 33,6 & 3 & $1,8 \pm 0,3$ & 19,4 & 18 & $1,7 \pm 0,4$ & $1,4-1,8$ & 5,4 \\
\hline $\mathrm{Sm}$ & 34 & $5,5 \pm 2,9$ & 53,9 & 3 & $4,7 \pm 1,8$ & 38,3 & 12 & $5,1 \pm 0,6$ & $4,8-5,5$ & $-7,2$ \\
\hline $\mathrm{U}$ & 34 & $2,5 \pm 0,7$ & 26,5 & 1 & $2,4 \pm 0,5$ & 20,2 & 14 & $2,6 \pm 1,0$ & $2,2-3,3$ & $-8,3$ \\
\hline $\mathrm{Yb}$ & 34 & $2,3 \pm 0,2$ & 7,2 & 1 & $2,3 \pm 0,1$ & 6,2 & 12 & $2,4 \pm 0,6$ & $1,9-2,6$ & $-5,1$ \\
\hline $\mathrm{Ba}$ & 6 & $249 \pm 158$ & 63,6 & 1 & $191 \pm 77$ & 40,3 & 22 & $(159 \pm 73)$ & $(131-196)$ & 20,1 \\
\hline $\mathrm{Ce}$ & 31 & $62 \pm 10$ & 16,0 & 1 & $61 \pm 6$ & 9,4 & 15 & $61 \pm 12$ & $50-63$ & $-0,5$ \\
\hline Co & 31 & $9,0 \pm 0,5$ & 5,3 & 0 & $9,0 \pm 0,5$ & 5,3 & 32 & $8,9 \pm 2,4$ & $8,4-10,1$ & 1,6 \\
\hline $\mathrm{Cr}$ & 31 & $70 \pm 4$ & 6,2 & 0 & $70 \pm 4$ & 6,2 & 41 & $60 \pm 40$ & $49-74$ & 16,6 \\
\hline $\mathrm{Cs}$ & 31 & $5,7 \pm 0,6$ & 10,6 & 0 & $5,7 \pm 0,6$ & 10,6 & 16 & $5,4 \pm 1,4$ & $4,9-6,4$ & 5,9 \\
\hline $\mathrm{Eu}$ & 31 & $1,1 \pm 0,1$ & 9,0 & 0 & $1,1 \pm 0,1$ & 9,0 & 10 & $1,0 \pm 0,3$ & $0,9-1,3$ & 5,3 \\
\hline $\mathrm{Fe}(\mathrm{mg} / \mathrm{g})$ & 31 & $26,3 \pm 1,2$ & 4,7 & 1 & $26,2 \pm 1,0$ & 3,8 & 46 & $(25,7 \pm 1,9)$ & $(25,2-26,3)$ & 2,0 \\
\hline Hf & 31 & $5,0 \pm 0,4$ & 8,2 & 0 & $5,0 \pm 0,4$ & 8,2 & 11 & $5,1 \pm 0,5$ & $4,8-5,5$ & $-1,9$ \\
\hline $\mathrm{Rb}$ & 28 & $51 \pm 13$ & 25,0 & 3 & $52 \pm 7$ & 13,6 & 24 & $51 \pm 11$ & $47-56$ & 2,8 \\
\hline $\mathrm{Sc}$ & 31 & $8,7 \pm 0,4$ & 4,3 & 1 & $8,6 \pm 0,3$ & 3,7 & 22 & $8,3 \pm 2,4$ & $6,9-9,0$ & 4,0 \\
\hline $\mathrm{Ta}(\mathrm{ng} / \mathrm{g})$ & 29 & $742 \pm 188$ & 25,3 & 1 & $761 \pm 159$ & 20,9 & 12 & $800 \pm 315$ & $600-1000$ & $-4,9$ \\
\hline $\mathrm{Tb}(\mathrm{ng} / \mathrm{g})$ & 29 & $594 \pm 195$ & 32,8 & 0 & $594 \pm 195$ & 32,8 & 12 & $600 \pm 315$ & $500-900$ & $-1,1$ \\
\hline $\mathrm{Th}$ & 31 & $8.3 \pm 0.6$ & 7,7 & 1 & $8,2 \pm 0,5$ & 6,4 & 18 & $8,2 \pm 2,2$ & $6,5-8,7$ & 0,4 \\
\hline $\mathrm{Zn}$ & 22 & $204 \pm 257$ & 125,8 & 8 & $102 \pm 7$ & 7,3 & 44 & $104 \pm 20$ & $101-113$ & $-2,1$ \\
\hline
\end{tabular}

*Valores informativos entre parênteses. I.C. cert. $=$ intervalo de confiança de $95 \%$ dos valores certificados ou informativos. 
Para as análises multivariadas em estudos de cerâmicas arqueológicas, nos quais o foco é a separação de grupos, a precisão é mais crítica que a exatidão. Um critério utilizado é o de selecionar, como adequados para análises estatísticas multivariadas, aqueles elementos químicos cujo desvio-padrão relativo não ultrapasse $10 \%$, para o material de referência utilizado no controle de qualidade (IAEA, 2003; Munita et al., 2004). Neste trabalho, para não ser muito restritivo num primeiro momento, eliminando de uma vez 10 elementos químicos da análise sem analisar seu poder discriminatório nas cerâmicas, decidiu-se adotar um limite crítico para desvio-padrão ligeiramente menos restritivo. Além disso, o coeficiente de variação para alguns elementos na Tab. 7.1 é maior que os obtidos em laboratórios cujos pesquisadores reportaram o valor de $10 \%$ como referência (Blackman \& Bishop, 2007). Também foram pesquisados parâmetros para limite de precisão aceitáveis em outros trabalhos recentes (IAEA, 2006; 2010), e foram calculados valores críticos de desvio-padrão para avaliação da reprodutibilidade experimental a partir da equação de Horwitz (Thompson, 2000; Thompson, 2007). Assim, verificou-se que $15 \%$ é um valor aceitável como limite do desvio-padrão experimental. Não foram identificados problemas devido à utilização desse limite para a identificação de padrões nas análises multivariadas, como será visto adiante neste capítulo.

Para complementar o controle de qualidade analítico, foram elaboradas cartas de controle para os experimentos de INAA com IAEA-Soil-7, cujo exemplo para o elemento Hf é apresentado na Fig. 7.1 (ver demais elementos no Apêndice C). Cartas de controle são ferramentas estatísticas que auxiliam na avaliação de variabilidade em um processo, permitindo identificar variações aleatórias e inesperadas, e variações de ordem sistemática, a partir da definição de uma zona de controle (normalmente, a região

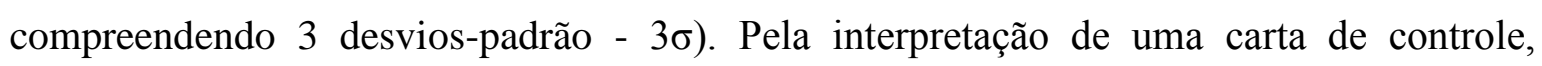
podem-se analisar a estabilidade das medições e as condições de operação de um aparelho. Assim, pela análise dessas cartas, pode ser feita uma avaliação dos resultados e subsequente elaboração de procedimentos corretivos.

$\mathrm{Na}$ abcissa da Fig. 7.1, os números representam os diferentes experimentos, que foram organizados em ordem temporal crescente. A primeira determinação corresponde a 2 de junho de 2003, e a última corresponde a 26 de fevereiro de 2013. Não foram observados efeitos sistemáticos, ou tendências, nas concentrações elementares ao longo dos 10 anos de análise, que poderiam indicar deterioração do material de referência ou heterogeneidades pela separação ou aglomeração de partículas durante o 
acondicionamento, ou mesmo contaminações (Bode \& Dijk, 1996). Como os experimentos compreendem as determinações de dois analistas diferentes (o autor deste trabalho, para a maioria das amostras; e Rosimeiri Toyota, para análises anteriores a 2009), as cartas de controle também demonstraram independência em relação ao analista, fornecendo uma indicação de reprodutibilidade adequada dos resultados.

Para as cartas de controle com z-scores, foi utilizada a seguinte equação (Konieczka \& Namiesnik, 2009)

$$
z_{\text {score }}=\frac{C_{\text {lab }}-C_{\text {referência }}}{\sigma}
$$

sendo $\sigma$ foi adotado como o desvio-padrão estimado a partir dos valores recomendados ou informativos de concentração para o material de referência IAEA-Soil-7.

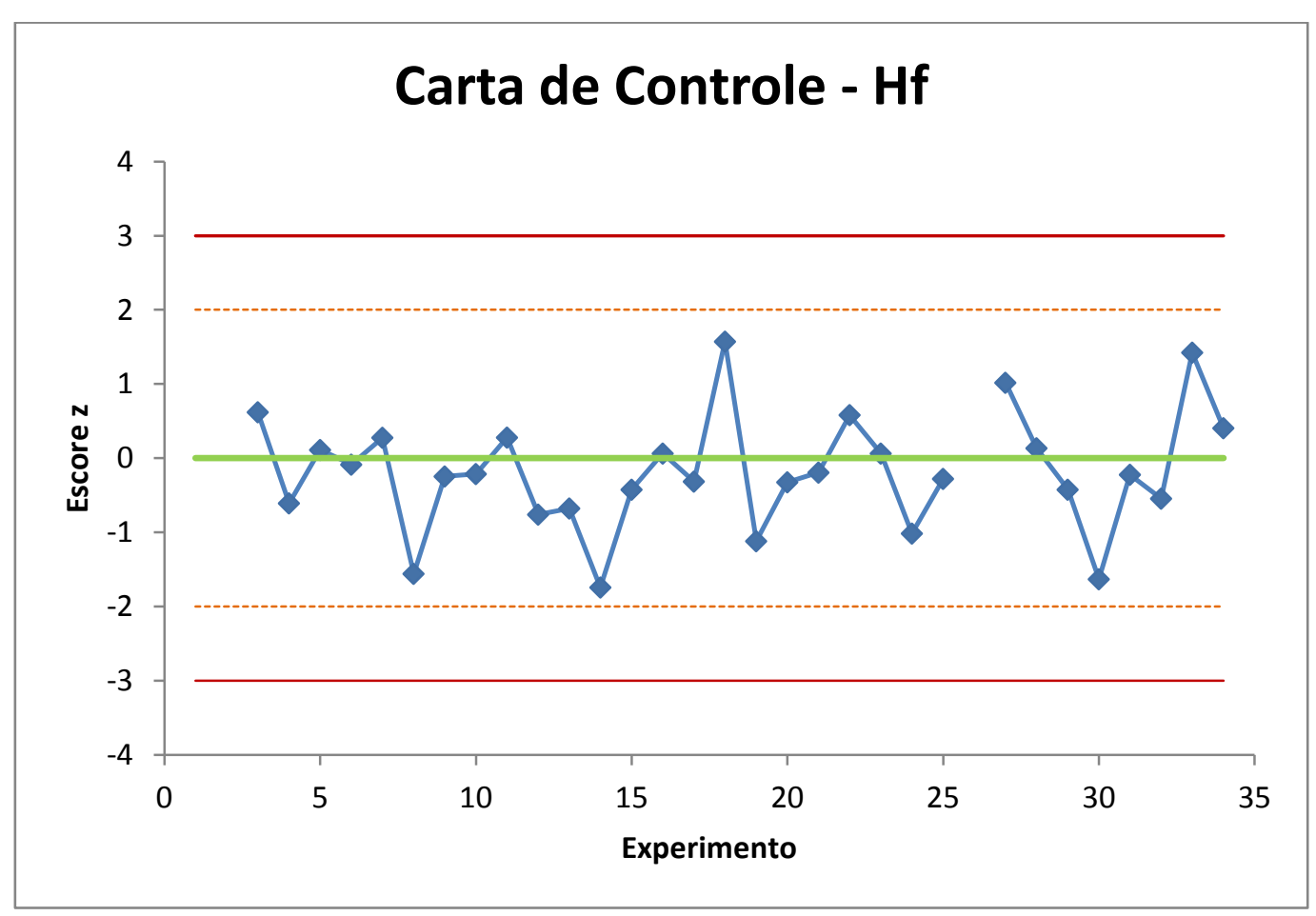

Figura 7.1 - Exemplo de carta de controle para as determinações de concentração do elemento químico Hf por INAA no material de referência IAEA-Soil-7. As demais cartas encontram-se no Apêndice C. 
Os critérios adotados no controle de qualidade são descritos a seguir, baseados na discussão anterior e em trabalhos recentes da Agência Internacional de Energia Atômica (IAEA, 2006; IAEA, 2010):

- Aprovado: desvio-padrão relativo $<15 \%$; $\mid$ Tendência $\mid<10 \%$

- Atenção: desvio-padrão relativo < $15 \%$ e $\mid$ Tendência $\mid>10 \%$, mas menor que 25\%;

口 Reprovado: desvio-padrão relativo $>20 \%$ e/ou $\mid$ Tendência $\mid>25 \%$.

Na análise da carta de controle para o elemento As, observou-se que a medição de sua concentração melhorou com o tempo, a partir, aproximadamente, da $13^{\mathrm{a}}$ medição. Observou-se que os escores $\mathrm{z}$ tendem a ser positivos, indicando que a concentração elementar de As, determinada por INAA, tende a ser sistematicamente maior que a do certificado, e dentro dos limites de controle, com exceção para 3 medições. Pela Tab. 7.1, a precisão analítica do As $(5,6 \%)$ é menor que $15 \%$, e a tendência absoluta $(11,2 \%)$ é maior que o valor crítico de $10 \%$. Assim, o elemento As foi aprovado com status de "Atenção".

$\mathrm{Na}$ análise da carta de controle para o elemento $\mathrm{K}$, não se observou efeito sistemático em sua determinação por INAA ao longo do tempo, pois os escores $\mathrm{z}$ distribuem-se aleatoriamente ao longo do valor nulo, e dentro dos limites de controle. Em dois experimentos, a radioatividade gama induzida desse elemento não foi detectada (dois valores faltantes na base de dados). Pela análise dos arquivos de contagem, foi possível inferir que o motivo desses valores não determinados foi o tempo decorrido entre a irradiação com nêutrons e a primeira medição de espectrometria gama, que foi de 8 dias para ambos os experimentos. Para a detecção do elemento $K$, verificou-se que a primeira medição deve ser feita idealmente entre 4 e 6 dias após a irradiação. É crítico controlar esse parâmetro, pois seu tempo de meia-vida é de 12,4 h (Tab. 4.2). Pela Tab. 7.1, verificou-se que sua precisão analítica $(14,4 \%)$ é menor que $15 \%$, e a tendência absoluta $(3,7 \%)$ é menor que o valor crítico. Assim, o elemento K foi aprovado.

$\mathrm{Na}$ análise da carta de controle para o elemento La, observou-se que os escores $\mathrm{z}$ tendem a ser positivos em praticamente todos os experimentos, e dentro dos limites de controle. Pela Tab. 7.1, a precisão analítica do La (3,4\%) é menor que 15\%, e a tendência absoluta é menor que $10 \%$ (9,5\%). Assim, o elemento La foi aprovado. 
$\mathrm{Na}$ análise da carta de controle para o elemento Lu, observou-se que os escores $\mathrm{z}$ tendem a ser ligeiramente positivos em praticamente todos os experimentos, e dentro dos limites de controle, não ultrapassando a faixa de $1 \sigma$ em nenhum experimento. Pela Tab. 7.1, a precisão analítica do $\mathrm{Lu}(7,5 \%)$, é menor que 15\%, mas sua tendência absoluta é maior que $10 \%(23,1 \%)$. Assim, o elemento Lu foi aprovado com status de "Atenção".

$\mathrm{Na}$ análise da carta de controle para o elemento $\mathrm{Na}$, observou-se que os escores $\mathrm{z}$ tendem a ser negativos, e dentro dos limites de controle, raramente ultrapassando a faixa de $1 \sigma$. Pela Tab. 7.1 , a precisão analítica do $\mathrm{Na}(5,1 \%)$ é menor que $15 \%$, e a tendência absoluta é menor que $10 \%$ (2,5\%). Assim, o elemento Na foi aprovado.

$\mathrm{Na}$ análise da carta de controle para o elemento $\mathrm{Nd}$, observou-se que os escores $\mathrm{z}$ tendem a ser negativos, ultrapassando a zona de controle de $3 \sigma$ em um experimento (08/11/2011). Em 4 experimentos (12\%), a radioatividade gama induzida do $\mathrm{Nd}$ não pôde ser medida. O Nd é considerado um elemento-traço, cuja concentração é da ordem de $\mu \mathrm{g} . \mathrm{g}^{-1}$, sua seção de choque para nêutrons térmicos é relativamente baixa dentre os elementos analisados (comparar valores na Tab. 4.2), e a abundância isotópica do ${ }^{146} \mathrm{Nd}$ é 17,2\%. A combinação desses três fatores é responsável pela relação pico/radiação de fundo insatisfatória nos 4 experimentos citados. Compare-se, por exemplo, a seção de choque do $\mathrm{Nd}$, com a dos elementos $\mathrm{K}$ e Fe, cujos valores são parecidos, sendo que as abundâncias isotópicas de ${ }^{41} \mathrm{~K}$ e ${ }^{58} \mathrm{Fe}$ são ainda menores que para o ${ }^{146} \mathrm{Nd}$. Contudo, a concentração desses elementos é três ordens de grandeza maior, fazendo com que a relação pico/radiação de fundo seja, geralmente, satisfatória. Pela Tab. 7.1, observou-se que a precisão analítica do $\mathrm{Nd}(19,1 \%)$ é maior que $15 \%$, e sua tendência absoluta é maior que $10 \%(17,0 \%)$. Assim, o elemento $\mathrm{Nd}$ foi reprovado.

$\mathrm{Na}$ análise da carta de controle para o elemento $\mathrm{Sb}$, observou-se que os escores z distribuem-se aleatoriamente ao longo do valor nulo até o experimento 12 (2003-2005), e tende a apresentar valores positivos a partir do experimento 13 (17/08/2009). As concentrações desse elemento não foram detectadas em 19 experimentos (56\%). O elemento Sb é um dos elementos-traço com concentração na ordem de $\mu \mathrm{g} \cdot \mathrm{g}^{-1}$ (ver Tab. 7.1). Sua seção de choque para nêutrons térmicos é 3,875 b e a abundância isotópica para ${ }^{123} \mathrm{Sb}$ é $42,79 \%$. A combinação de sua concentração relativamente baixa e sua seção de choque não ser alta o suficiente para compensá-la, faz com que a relação pico/radiação de fundo seja, frequentemente, insatisfatória. Para fins de comparação, o elemento Eu possui concentração elementar próxima ao do Sb no material de referência IAEA-Soil-7, 
apresentando, inclusive, abundância isotópica similar para o isótopo de interesse $(47,81 \%$ para $\left.{ }^{151} \mathrm{Eu}\right)$. Porém, sua seção de choque para nêutrons térmicos é três ordens de grandeza maior (9184 b), compensando a concentração baixa. Ainda, pela Tab. 7.1, a precisão analítica do $\mathrm{Sb}(19,4 \%)$ é maior que $15 \%$, e a tendência absoluta $(5,4 \%)$ é menor que $10 \%$. Assim, o elemento $\mathrm{Sb}$ foi reprovado.

$\mathrm{Na}$ análise da carta de controle para o elemento Sm, observou-se que os escores $\mathrm{z}$ tendem a se estabilizar ao longo do tempo, a partir do experimento 20, correspondente a outubro de 2010, embora uma medida de abril de 2012 tenha caído fora da região de controle $(z=-5,3)$. Pela Tab. 7.1, a precisão analítica do $\operatorname{Sm}(38,3 \%)$, é maior que 15\%, e a tendência absoluta $(7,2 \%)$ é menor que $10 \%$. O alto desvio-padrão apresentado para este elemento está relacionado à região do espectro com alta radiação de fundo na qual o pico de interesse está situado (103,18 keV), além de possível interferência do pico de $104 \mathrm{keV}$ do ${ }^{239} \mathrm{~Np}$. Assim, o elemento Sm foi reprovado.

$\mathrm{Na}$ análise da carta de controle para o elemento U, observou-se que os escores $\mathrm{z}$ apresentam tendência negativa e dentro da faixa de $2 \sigma$, embora um experimento de agosto de 2009 tenha apresentado escore $\mathrm{z}=2,5$. Pela Tab. 7.1, a precisão analítica do $\mathrm{U}$ $(20,2 \%)$ é maior que $15 \%$, e a tendência absoluta $(8,3 \%)$ é menor que $10 \%$. Assim, o elemento $\mathrm{U}$ foi reprovado.

$\mathrm{Na}$ análise da carta de controle para o elemento $\mathrm{Yb}$, observou-se que os escores z tendem a valores negativos dentro do limite de $1 \sigma$. Pela Tab. 7.1, a precisão analítica do $\mathrm{Yb}(6,2 \%)$ é menor que $15 \%$, e a tendência absoluta $(5,1 \%)$ é menor que o valor crítico de $10 \%$. Assim, o elemento $\mathrm{Yb}$ foi aprovado.

$\mathrm{Na}$ análise da carta de controle para o elemento $\mathrm{Ba}$, observou-se que a atividade desse elemento não foi determinada para a maioria dos experimentos (81\%). Nas análises em que foi possível a determinação de sua concentração elementar, os escores z, com exceção de uma medida em julho de 2004, ficaram dentro da região crítica de controle. Pela Tab. 4.2, observa-se que a seção de choque do Ba para nêutrons térmicos é relativamente baixa (comparar com as seções do Eu e Sm, por exemplo) e a abundância isotópica do nuclídeo de interesse, o ${ }^{130} \mathrm{Ba}$, é a mais baixa dentre os nuclídeos-alvo, com apenas $0,106 \%$. Esses dois fatores combinados são responsáveis pelo sinal baixo de radioatividade gama induzida para esse elemento. Ainda, pela Tab. 7.1, a precisão analítica do $\mathrm{Ba}(40,3 \%)$ é maior que $15 \%$, e a tendência absoluta $(20,1 \%)$ é maior que o valor crítico de $10 \%$. Assim, o elemento Ba foi reprovado. 
$\mathrm{Na}$ análise da carta de controle para o elemento Ce, observou-se uma tendência geral aleatória para a distribuição dos escores $\mathrm{z}$ ao longo do tempo, com um experimento com valor de z fora da região crítica (março de 2010). Pela Tab. 7.1, a precisão analítica do Ce $(9,4 \%)$ é menor que $15 \%$, e a tendência absoluta $(0,5 \%)$, é menor que o valor crítico de $10 \%$. Assim, o elemento Ce foi aprovado.

$\mathrm{Na}$ análise da carta de controle para o elemento Co, observou-se uma tendência geral aleatória para a distribuição dos escores $\mathrm{z}$ ao longo do tempo, sempre dentro dos limites críticos, sem ultrapassar $1 \sigma$. Pela Tab. 7.1 , a precisão analítica do Co $(5,3 \%)$ é menor que $15 \%$, e a tendência absoluta $(1,6 \%)$ é menor que $10 \%$. Assim, o elemento Co foi aprovado.

$\mathrm{Na}$ análise da carta de controle para o elemento $\mathrm{Cr}$, observou-se uma tendência geral de valores positivos para os escores $\mathrm{z}$ ao longo do tempo, sempre dentro dos limites críticos, sem ultrapassar $1 \sigma$. Pela Tab. 7.1 , a precisão analítica do $\mathrm{Cr}(6,2 \%)$ é menor que $15 \%$, e a tendência absoluta $(16,6 \%)$ é maior que o limite crítico de $10 \%$. Assim, o elemento Cr foi aprovado com status de "Atenção".

$\mathrm{Na}$ análise da carta de controle para o elemento Cs, observou-se uma tendência geral de valores aleatórios para os escores $\mathrm{z}$ em torno de zero, sempre dentro dos limites críticos, sem ultrapassar $2 \sigma$. Um grupo de 7 experimentos consecutivos (agosto de 2009 a março de 2010), apresentou uma tendência positiva para os escores z. Contudo, não foram encontradas razões que justificassem um efeito sistemático para esses experimentos, como erro de pesagem. Pela Tab. 7.1, a precisão analítica do Cs (10,6\%) é menor que $15 \%$, e a tendência absoluta $(5,9 \%)$ é menor que $10 \%$. Assim, o elemento Cs foi aprovado.

$\mathrm{Na}$ análise da carta de controle para o elemento Eu, observou-se uma tendência geral aleatória de valores para os escores $z$, sempre dentro do limite de $1 \sigma$. Pela Tab. 7.1, a precisão analítica do Eu $(9,0 \%)$ é menor que $15 \%$, e a tendência absoluta $(5,3 \%)$ é menor que $10 \%$. Assim, o elemento Eu foi aprovado.

$\mathrm{Na}$ análise da carta de controle para o elemento Fe, observou-se uma tendência geral de valores razoavelmente aleatórios para os escores z, sempre dentro do limite de $2 \sigma$, com exceção para 1 experimento (9/12/2009). Pela Tab. 7.1, a precisão analítica de Fe $(3,8 \%)$ é menor que $15 \%$, e a tendência absoluta $(2,0 \%)$ é menor que o valor crítico de $10 \%$. Assim, o elemento Fe foi aprovado.

$\mathrm{Na}$ análise da carta de controle para o elemento Hf, observou-se uma tendência para valores negativos dos escores $\mathrm{z}$, sempre dentro dos limites críticos de controle, e 
nunca ultrapassando $2 \sigma$. Pela Tab. 7.1, a precisão analítica do Hf $(8,2 \%)$ é menor que $15 \%$, e a tendência absoluta (1,9\%) é menor que o valor crítico de $10 \%$. Assim, o elemento Hf foi aprovado.

$\mathrm{Na}$ análise da carta de controle para o elemento $\mathrm{Rb}$, observou-se uma tendência geral para valores aleatórios dos escores z ao longo do tempo. Houve 3 experimentos nos quais a radioatividade gama induzida não foi determinada (agosto e setembro de 2009). Para o experimento de 2009, o motivo foi o tempo de decaimento excessivo, devido à manutenção de equipamento ( $2^{\mathrm{a}}$ contagem após 56 dias da irradiação). Um dos

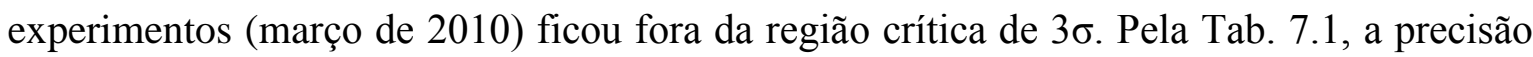
analítica do $\mathrm{Rb}(13,6 \%)$ é menor que $15 \%$, e a tendência absoluta $(2,8 \%)$ é menor que $10 \%$. Esse elemento seria aprovado segundo os critérios adotados. Contudo, observou-se que a quantidade de dados faltantes desse elemento chega a $27 \%$, fazendo com que um número excessivo de amostras ficasse sem rastreabilidade de qualidade analítica. Assim, o elemento $\mathrm{Rb}$ foi excluído.

$\mathrm{Na}$ análise da carta de controle para o elemento Sc, observou-se uma tendência para valores positivos dos escores z, embora sempre dentro do limites críticos, e raramente ultrapassando $1 \sigma$. Pela Tab. 7.1, a precisão analítica do Sc $(3,7 \%)$ é menor que $15 \%$, e a tendência absoluta $(4,0 \%)$ é menor que o limite crítico de $10 \%$. Assim, o elemento Sc foi aprovado.

$\mathrm{Na}$ análise da carta de controle para o elemento Ta, observou-se uma tendência para valores negativos dos escores z, embora sempre dentro dos limites críticos, e nunca ultrapassando $2 \sigma$. Em dois experimentos de agosto de 2009, a radioatividade induzida do Ta não foi determinada. Pela Tab. 7.1, a precisão analítica do Ta $(20,9 \%)$ é maior que $15 \%$, e a tendência absoluta $(4,9 \%)$ é menor que $10 \%$. Assim, o elemento Ta foi reprovado.

$\mathrm{Na}$ análise da carta de controle para o elemento $\mathrm{Tb}$, observou-se uma tendência geral de distribuição aleatória dos escores z, porém sempre dentro dos limites críticos, e

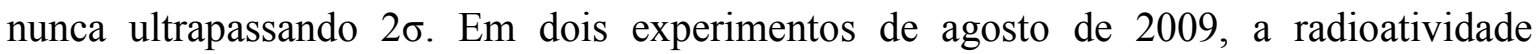
induzida do Tb não foi determinada. Pela Tab. 7.1 , a precisão analítica do Tb $(32,8 \%)$ é maior que $15 \%$, e a tendência absoluta $(1,1 \%)$ é menor que $10 \%$. Assim, o elemento Tb foi reprovado.

$\mathrm{Na}$ análise da carta de controle para o elemento Th, observou-se uma tendência geral de distribuição aleatória dos escores z, sempre dentro dos limites críticos, e nunca ultrapassando $1 \sigma$. Pela Tab. 7.1 , a precisão analítica do Th $(6,4 \%)$ é menor que $15 \%$, e a 
tendência absoluta $(0,4 \%)$ é menor que o valor crítico de $10 \%$. Assim, o elemento Th foi aprovado.

$\mathrm{Na}$ análise da carta de controle para o elemento $\mathrm{Zn}$, observou-se uma tendência negativa para os valores dos escores z nas medidas realizadas em 2003 e 2004. A partir daí, a distribuição passa a ser mais aleatória, com 5 valores fora dos limites de $3 \sigma$, sendo que 4 medidas estão bem afastadas $(\mathrm{z}>10)$. Além disso, em 10 experimentos (32\%), a radioatividade induzida do Zn ficou abaixo do limite de detecção. Pela Tab. 7.1, a precisão analítica do $\mathrm{Zn}(7,3 \%)$ é menor que $15 \%$, e a tendência absoluta $(2,1 \%)$ é menor que o valor crítico de $10 \%$. Esse elemento seria aprovado pelos critérios adotados para o controle de qualidade. Contudo, a quantidade de dados discrepantes (8) e de valores faltantes na base de dados após a aplicação de escores z modificados, em torno de 60\%, são excessivamente altas, deixando mais da metade das amostras de cerâmica sem rastreabilidade de qualidade analítica. Assim, decidiu-se pela exclusão desse elemento. Pela Tab. 4.2, pode-se observar que a seção de choque do $\mathrm{Zn}(1,1 \mathrm{~b})$ é uma das mais baixas dentre os elementos determinados. Assim, o elemento $\mathrm{Zn}$ foi reprovado.

A partir da discussão anterior, pelos critérios adotados $(\mathrm{s}<15 \%$, Tendência $<10 \%$ e estabilidade na carta de controle), foram aprovados 12 elementos: K, La, $\mathrm{Na}, \mathrm{Yb}, \mathrm{Ce}, \mathrm{Co}, \mathrm{Cs}, \mathrm{Eu}, \mathrm{Fe}, \mathrm{Hf}, \mathrm{Sc}$ e Th.

Três elementos químicos foram aprovados com status de "Atenção", requerendo uma análise mais cuidadosa: As, Lu e Cr.

Nove elementos foram reprovados: Nd, Sb, Sm, U, Ba, Ta, Tb, Rb e Zn.

Neste trabalho, procurou-se implementar um teste adicional de controle de qualidade atualizado com tendências metrológicas atuais, que analisasse tanto a precisão como a exatidão dos resultados de espectrometria gama do material de referência de maneira combinada, para fins de comparação com a análise anterior. Para tanto, foram adaptados critérios do teste de proficiência realizado pelo laboratório da Agência Internacional de Energia Atômica (IAEA) em Seibersdorf, Áustria, para comparações interlaboratoriais (IAEA, 2010).

O novo teste aplicado é baseado no cálculo do $u$-score, em vez de z-score. A desvantagem na utilização do z-score é que a incerteza na medida do laboratório não é considerada na avaliação do desempenho analítico, diferentemente do parâmetro u-score, que inclui a incerteza do laboratório. Elementos que apresentam um bom desempenho no 
teste clássico não apresentarão, necessariamente, um bom desempenho quando as incertezas do laboratório são consideradas.

O valor de $u$-score é calculado pela equação (Konieczka \& Namiesnik, 2009)

$$
u_{\text {score }}=\frac{\left|C_{\text {referência }}-C_{\text {laboratóní }}\right|}{\sqrt{\sigma_{\text {referência }}^{2}+\sigma_{\text {laboratórí }}^{2}}}
$$

Quando u < 2.58 (99\%), a exatidão e precisão dos resultados são consideradas satisfatórias. São definidos três status para os resultados (IAEA, 2010):

- Aceitável: exatidão e precisão aceitáveis.

- Atenção: um dos critérios, exatidão ou precisão, apresentam valores inaceitáveis, mas a tendência, ou tendência, encontra-se abaixo de um limite pré-especificado.

ㄱão Aceitável: quando as condições anteriores não forem atendidas.

A qualidade analítica é analisada pela desigualdade $A_{1} \leq A_{2}$, a partir da manipulação da Eq. 7.5, sendo:

$$
\begin{gathered}
A_{1}=\left|C_{\text {referência }}-C_{\text {laboratónó }}\right| \\
A_{2}=2,58 \sqrt{\sigma_{\text {referência }}^{2}+\sigma_{\text {laboratón }}^{2}}
\end{gathered}
$$

A tendência dos resultados representa a diferença percentual entre a média das concentrações elementares determinadas pelo laboratório e os valores de referência.

Para este teste, assume-se a hipótese de que os resultados experimentais e o valor de referência seguem distribuições normais, descritas pela média e variância $\mathrm{N}\left(\mathrm{x}_{\mathrm{lab}}\right.$, $\left.\mathrm{u}_{\text {lab }}^{2}\right)$ e $\mathrm{N}\left(\mathrm{x}_{\mathrm{ref}}, \mathrm{u}_{\text {ref }}^{2}\right)$.

No Apêndice D, está resumido o procedimento adotado para o controle de qualidade analítica segundo essa abordagem. $\mathrm{O}$ valor crítico para o parâmetro de precisão (P) foi $30 \%$ (estimado a partir de $\mathrm{s}=15 \%$ adotado no outro teste) e tendência (B) foi de $25 \%$, assim como no outro teste, para fins de comparação. 
Os resultados dessa segunda avaliação de qualidade analítica são resumidos a seguir, segundo os critérios estabelecidos.

Aprovados (16): As, K, La, Na, Nd, Yb, Ce, Co, Cs, Eu, Fe, Hf, Rb, Sc, Th e Zn.

口 Atenção: 0

Reprovados (8): Lu, Sb, Sm, U, Ba, Cr, Ta e Tb.

Dos elementos aprovados, dois deles, $\mathrm{Rb}$ e $\mathrm{Zn}$ não seriam utilizados por sua quantidade de valores faltantes excessivamente alta na base de dados. Assim, quatorze elementos seriam utilizados.

Concluiu-se que os dois métodos de controle de qualidade adotados apresentaram resultados gerais regularmente compatíveis. Contudo, no teste baseado no teste de proficiência da IAEA, os elementos $\mathrm{Cr}$ e Lu foram reprovados, pois o parâmetro de precisão $\mathrm{P}$ é afetado por altas incertezas estimadas para os valores de referência desses elementos, diferentemente do desvio-padrão experimental $s$, utilizado como parâmetro de precisão no primeiro teste. Como o parâmetro de incerteza experimental $s$ é mais significativo para as análises multivariadas, consideraram-se como aprovados os 15 elementos classificados com status de "Aprovado" e "Atenção" no primeiro teste de qualidade analítica, que são os que também foram aprovados no segundo teste, mais os elementos Lu e Cr, e menos o $\mathrm{Nd}$.

Assim, os quinze elementos aprovados no controle de qualidade analítico foram: As, K, La, Lu, Na, Yb, Ce, Co, Cr, Cs, Eu, Fe, Hf, Sc e Th. 


\subsubsection{Medidas de INAA dos fragmentos cerâmicos arqueológicos}

Os elementos químicos determinados neste trabalho, do ponto de vista dos grupos periódicos, podem ser divididos em:

- Metais alcalinos (1): $\mathrm{Na}, \mathrm{K}, \mathrm{Rb}$ e Cs;

- Metais alcalino-terrosos (2): Ba;

- Metais de transição:

3: Sc;

4: Hf;

5: Ta;

6: $\mathrm{Cr}$;

8: Fe;

9: $\mathrm{Co}$;

12: $\mathrm{Zn}$;

- 15: As e $\mathrm{Sb}$;

- Lantanídeos: La, Ce, Nd, Sm, Eu, Tb, Yb e Lu;

口 Actinídeos: Th e U.

Os elementos denominados terras raras, compreendem os lantanídeos, mais o Sc e o Y. Devido às suas propriedades geoquímicas, esses elementos encontram-se tipicamente dispersos e não são encontrados com frequência em forma de minérios concentrados e exploráveis economicamente. Esses elementos são importantes porque se diferenciam durante o processo de formação das rochas ígneas, contribuindo na diferenciação de argilas, formada por intemperismo das rochas originais (Munita, 2005).

Devido ao tamanho da base de dados, apenas os parâmetros descritivos dos mesmos foram organizados na Tab. 7.2. Os dados completos encontram-se no Apêndice B. Note-se que embora todos os elementos determinados por INAA estejam listados na Tab. 7.2, apenas os 15 aprovados pelo controle de qualidade (seção 7.1.1), e hachurados nessa tabela, serão utilizados em seções subsequentes. 
Tabela 7.2 - Parâmetros descritivos da base de dados de concentrações elementares em fragmentos cerâmicos arqueológicos dos sítios Lago Grande e Osvaldo e argilas queimadas (concentrações em $\mu \mathrm{g} / \mathrm{g}$, a menos que seja indicado).

\begin{tabular}{|c|c|c|c|c|c|c|c|c|c|c|c|c|c|}
\hline \multirow{2}{*}{ Elemento } & \multirow{2}{*}{ n } & \multicolumn{4}{|c|}{ Cerâmicas de Lago Grande } & \multicolumn{4}{|c|}{ Cerâmicas de Osvaldo } & \multicolumn{4}{|c|}{ Argilas de Osvaldo } \\
\hline & & Mín & Máx & Média & DP $(\%)$ & Mín & Máx & Média & DP $(\%)$ & Mín & Máx & Média & DP $(\%)$ \\
\hline As & 176 & 2,4 & 17,3 & 8,2 & 39,6 & 0,5 & 18,6 & 5,7 & 56,9 & 5,8 & 13,6 & 9,9 & 24,3 \\
\hline $\mathrm{K}(\mathrm{mg} / \mathrm{g})$ & 142 & 2,0 & 30,6 & 11,2 & 45,9 & 3,2 & 21,9 & 10,0 & 41,5 & 3,7 & 10,9 & 6,5 & 45,8 \\
\hline $\mathrm{La}$ & 181 & 23 & 127 & 42 & 27 & 21 & 86 & 42 & 25 & 76 & 92 & 82 & 6 \\
\hline $\mathrm{Lu}(\mathrm{ng} / \mathrm{g})$ & 180 & 151 & 1303 & 481 & 26 & 284 & 884 & 498 & 21 & 703 & 923 & 810 & 11 \\
\hline $\mathrm{Na}(\mathrm{mg} / \mathrm{g})$ & 181 & 0,3 & 6,3 & 2,1 & 71,6 & 0,3 & 5,0 & 1,8 & 63,6 & 0,3 & 0,8 & 0,5 & 37,4 \\
\hline $\mathrm{Nd}$ & 147 & 7 & 105 & 37 & 47 & 7 & 113 & 37 & 57 & 25 & 58 & 41 & 28 \\
\hline $\mathrm{Sb}$ & 15 & 0,2 & 1,4 & 0,8 & 51,2 & 0,7 & 1,2 & 0,9 & 42,5 & 2,4 & 2,4 & 2,4 & - \\
\hline $\mathrm{Sm}$ & 181 & 0,4 & 11,9 & 4,9 & 44,3 & 1,8 & 12,2 & 5,8 & 34,8 & 1,8 & 12,4 & 5,4 & 69,9 \\
\hline $\mathrm{U}$ & 180 & 0,8 & 10,6 & 3,9 & 31,2 & 1,5 & 7,4 & 4,0 & 25,1 & 5,5 & 7,0 & 6,6 & 7,9 \\
\hline $\mathrm{Yb}$ & 181 & 1,4 & 8,1 & 3,0 & 25,5 & 2,1 & 5,9 & 3,1 & 20,2 & 4,6 & 5,9 & 5,1 & 11,1 \\
\hline $\mathrm{Ba}$ & 131 & 114 & 972 & 503 & 39 & 261 & 2435 & 1040 & 52 & 1146 & 2051 & 1599 & 40 \\
\hline $\mathrm{Ce}$ & 177 & 42 & 298 & 88 & 38 & 30 & 161 & 82 & 32 & 91 & 161 & 143 & 15 \\
\hline Co & 177 & 2 & 47 & 10 & 59 & 3 & 121 & 12 & 129 & 2 & 4 & 3 & 30 \\
\hline $\mathrm{Cr}$ & 177 & 36,4 & 108,9 & 67,7 & 18,4 & 33,2 & 100,3 & 63,4 & 18,5 & 57,9 & 125,9 & $\mathbf{9 7 , 9}$ & 19,8 \\
\hline Cs & 175 & 1,3 & 19,1 & 9,3 & 36,7 & 3,2 & 17,6 & 8,9 & 34,7 & 8,4 & 16,5 & 10,7 & 27,5 \\
\hline Eu & 176 & 0,4 & 3,4 & 1,3 & 32,0 & 0,4 & 2,8 & 1,3 & 30,6 & 1,8 & 2,4 & 2,1 & 8,4 \\
\hline $\mathrm{Fe}(\mathrm{mg} / \mathrm{g})$ & 177 & 13,2 & 60,4 & 37,9 & 24,6 & 23,4 & 48,6 & 34,1 & 18,2 & 37,8 & 64,3 & 49,8 & 18,9 \\
\hline $\mathrm{Hf}$ & 177 & 2,9 & 17,3 & 6,8 & 35,1 & 3,0 & 18,8 & 7,9 & 39,9 & 15,9 & 24,9 & 21,6 & 13,2 \\
\hline $\mathrm{Rb}$ & 171 & 18 & 280 & 100 & 48 & 35 & 191 & 92 & 33 & 16 & 100 & 69 & 38 \\
\hline Sc & 177 & 7,6 & 26,4 & 15,6 & 18,6 & 9,8 & 24,9 & 15,1 & 20,5 & 14,5 & 19,8 & 17,7 & 12,4 \\
\hline $\mathrm{Ta}$ & 169 & 0,4 & 3,7 & 1,4 & 38,1 & 0,5 & 16,7 & 2,1 & 119,5 & 2,4 & 3,1 & 2,9 & 9,3 \\
\hline $\mathrm{Tb}(\mathrm{ng} / \mathrm{g})$ & 147 & 247 & 2011 & 753 & 43 & 304 & 1390 & 779 & 33 & 1039 & 1686 & 1382 & 17 \\
\hline Th & 177 & 7,6 & 23,7 & 14,5 & 16,6 & 8,6 & 24,1 & 15,0 & 20,3 & 18,0 & 36,2 & 30,7 & 18,3 \\
\hline $\mathrm{Zn}$ & 127 & 63 & 6510 & 404 & 255 & 50 & 1423 & 262 & 107 & 134 & 261 & 206 & 22 \\
\hline
\end{tabular}

DP = desvio-padrão. Linhas hachuradas: Elementos aprovados no controle de qualidade.

Pela Tab. 7.2, observou-se uma tendência regular de aumento do desvio-padrão relativo entre as cerâmicas arqueológicas, quando comparadas às argilas de Osvaldo. Esse é um resultado esperado ao se considerar que a produção cerâmica pode envolver a inserção de elementos antiplásticos, como esponjas, cacos moídos e areia, e que as fontes de argila utilizadas podem ser diferentes, sendo possível, inclusive, a utilização de misturas de diferentes fontes.

Duas fontes importantes de possível interferência para amostras de origem geológica são a interação de nêutrons rápidos com macroelementos da matriz, como o ferro $\left({ }^{56} \mathrm{Fe}(\mathrm{n}, \mathrm{p}){ }^{56} \mathrm{Mn}\right)$, e a fissão de ${ }^{235} \mathrm{U}$ naturalmente presente na amostra, interferindo na 196 
determinação de terras raras como La (por ${ }^{140} \mathrm{La}$ ), Ce (por ${ }^{141} \mathrm{Ce}$ ), $\mathrm{Nd}$ (por ${ }^{147} \mathrm{Nd}$ ) e $\mathrm{Zr}$ (por ${ }^{95} \mathrm{Zr}$ ). Apesar de o reator IEA-R1 ser térmico, propiciando preferencialmente as reações $(\mathrm{n}, \gamma)$, existe uma pequena produção (cerca de 10\% para o reator IEA-R1 operando a 3,5 MW) de nêutrons com energias mais altas, que podem provocar a ocorrência de reações (n, p). Porém, como não foi determinado Mn neste trabalho, a verificação de sua possível interferência por Fe não se fez necessária. A correção por fissão do urânio é recomendada quando sua concentração exceder $5 \mu \mathrm{g} \cdot \mathrm{g}^{-1}$, ou a concentração dos elementos terras raras for extraordinariamente pequena. A verificação da base de dados de concentrações elementares indicou que, apesar de algumas amostras apresentarem concentração de urânio até $10,6 \mu \mathrm{g} / \mathrm{g}$, a maioria (82\%) encontra-se abaixo de $5 \mu \mathrm{g} / \mathrm{g}$. Dessa forma, a correção para tais interferências não foi considerada crítica para os dados de INAA deste trabalho (Glascock, 1992).

Os invólucros de polietileno foram analisados para verificar se as concentrações dos elementos presentes poderiam interferir nos resultados das amostras de cerâmicas. Para isso, realizaram-se 3 experimentos e os resultados mostraram que, nas condições analíticas adotadas neste trabalho, os elementos presentes estavam numa concentração menor que o limite de detecção. Assim, foi descartada qualquer influência dos invólucros de polietileno nas análises.

Na Fig. 7.2, são apresentadas as variações nas concentrações elementares das cerâmicas arqueológicas em relação às argilas queimadas, provenientes do sítio Osvaldo, no intuito de se analisar, ainda que de forma semiquantitativa (por estar na mesma região geológica, já que não é possível afirmar com certeza se essas argilas foram as utilizadas na produção cerâmica), possíveis tendências de enriquecimento ou depleção dos elementos devido à adição de antiplásticos durante a produção cerâmica; ou outros efeitos, como alterações nos perfis composicionais pela queima e efeitos diagenéticos. Foram inseridos no gráfico os elementos com desvio-padrão experimental menor que 50\% (valor máximo: $32,8 \%$ para o $\mathrm{Tb}$ ), tendência menor que $25 \%$ (valor máximo: $21,3 \%$ para o $\mathrm{Lu}$ ). Assim, ficaram fora da análise os elementos $\mathrm{Ba}, \mathrm{Sm}, \mathrm{Zn}$ e o $\mathrm{Sb}$ (para o qual $92 \%$ das concentrações não puderam ser determinadas).

Os elementos que apresentaram depleção relativa em suas concentrações nas cerâmicas foram (16): As, La, Lu, Nd, U, Yb, Ce, Cr, Cs, Eu, Fe, Hf, Sc, Ta, Tb e Th. Os elementos que apresentaram aumento relativo de suas concentrações elementares foram: $\mathrm{K}$, 
$\mathrm{Rb}, \mathrm{Na}$ e Co. Esses dois últimos elementos, por questões de escala, são apresentados na Fig. 7.3.

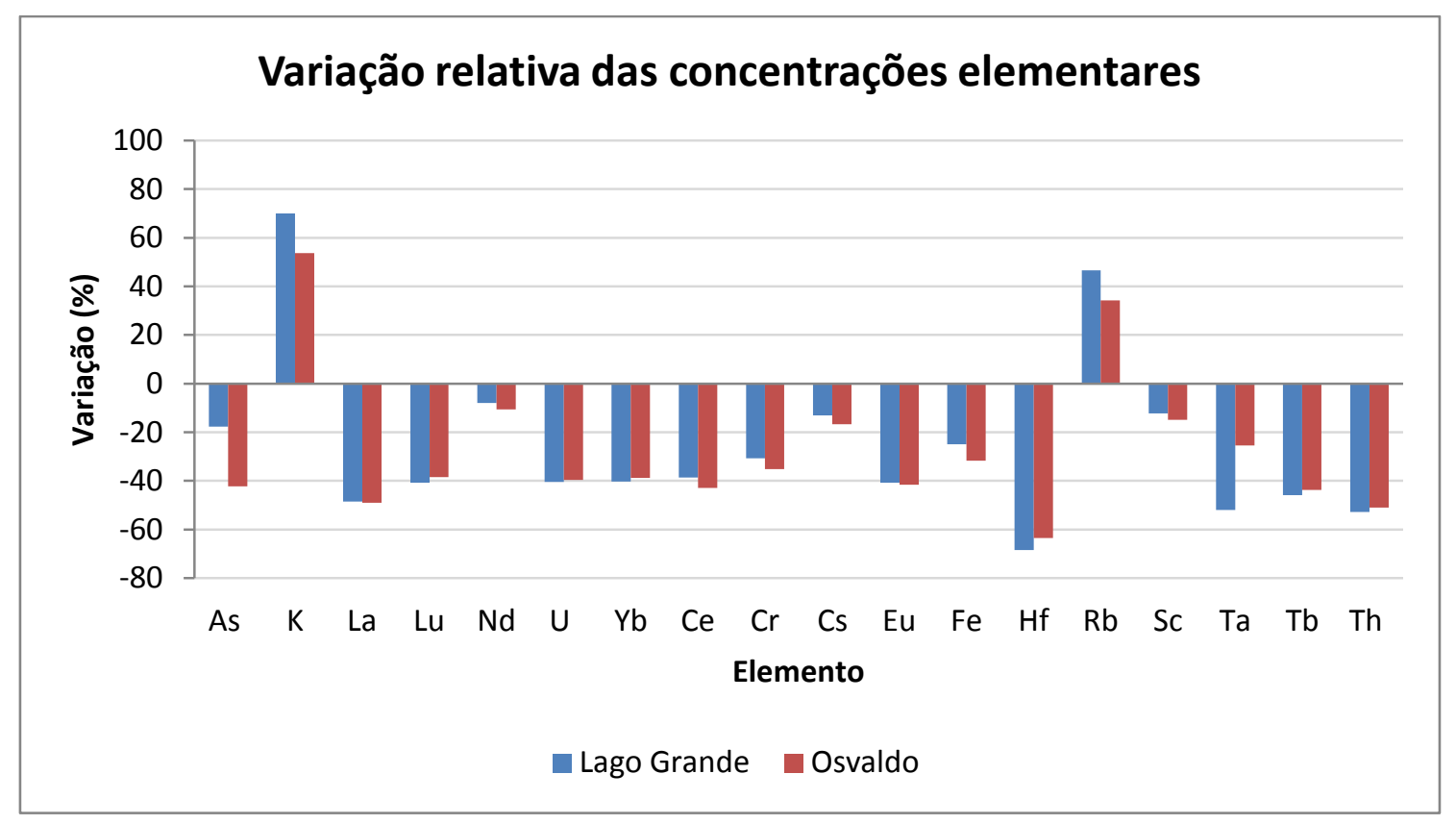

Figura 7.2 - Variação percentual das concentrações elementares nos fragmentos cerâmicos dos sítios Lago Grande e Osvaldo em relação às concentrações médias dos mesmos elementos nas argilas queimadas do sítio Osvaldo.

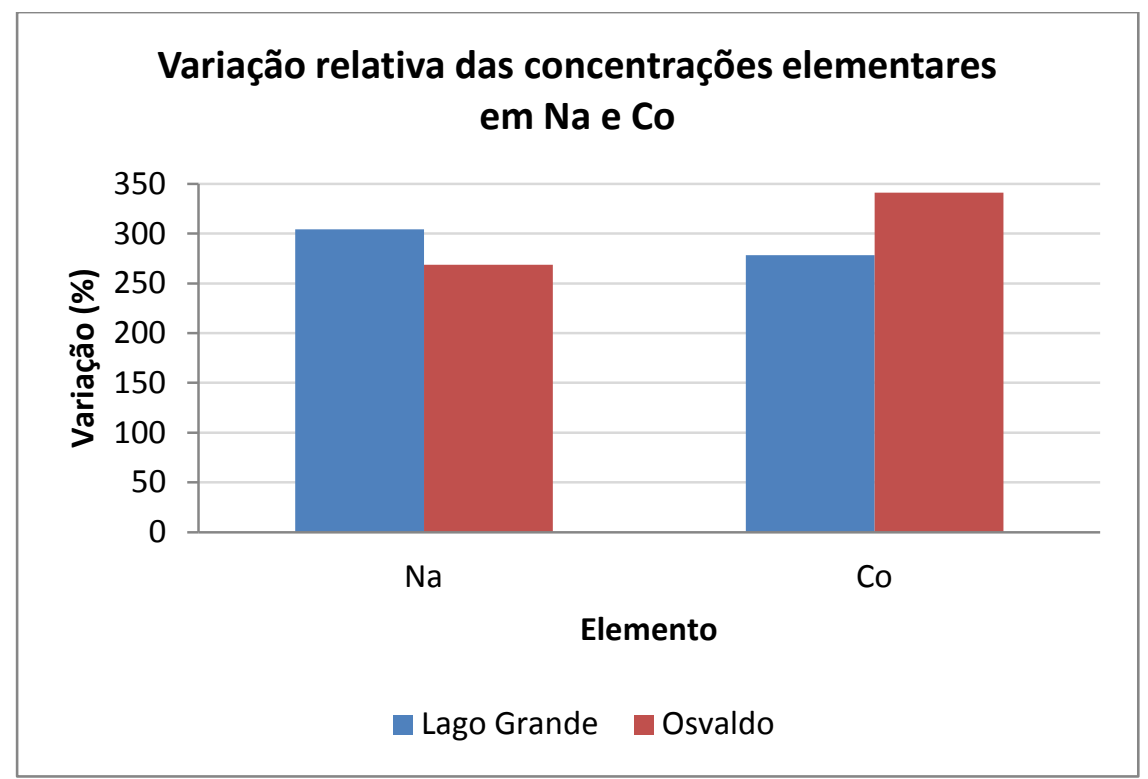

Figura 7.3 - Variação percentual das concentrações elementares de $\mathrm{Na}$ e Co nos fragmentos cerâmicos dos sítios Lago Grande e Osvaldo em relação às concentrações médias desses elementos nas argilas queimadas do sítio Osvaldo. 
Pela Fig. 7.2, observou-se uma tendência geral de depleção na concentração dos elementos químicos nas cerâmicas de Lago Grande e Osvaldo, em relação às argilas queimadas. Essa tendência geral pode ser explicada pela adição deliberada de antiplásticos por parte dos ceramistas, um efeito bem conhecido na literatura, como foi explicado nos Capítulos 2 e 3. Observou-se, ainda, que as variações percentuais são parecidas para as amostras dos dois sítios, com exceção dos elementos As, Ta, $\mathrm{Na}$, K e Co, cujas diferenças de variação foram maiores que $20 \%$ entre as amostras de Lago Grande e Osvaldo.

É interessante notar, ainda pelas Fig. 7.2 e 7.3, que dois microelementos, os metais alcalinos $\mathrm{Na}$ e $\mathrm{K}$, apresentaram uma tendência contrária no sentido de aumento em suas concentrações em relação às argilas. Os elementos-traço Rb, outro metal alcalino, e Co, um metal de transição, também apresentaram tendência de enriquecimento nas concentrações elementares. As maiores variações percentuais foram observadas para os elementos $\mathrm{Na}(+269 \%$ e $+304 \%)$, Co $(+278 \%$ e $+341 \%)$, K $(+70 \%$ e $+54 \%)$, Hf $(-68 \%$ e $-64 \%)$ e $\mathrm{Th}(-53 \%$ e $-51 \%)$. As variações percentuais positivas dos elementos $\mathrm{Na}$ e Co, uma ordem de grandeza maior que as observadas para os demais elementos, foram analisadas para a identificação de possíveis contaminações e/ou efeitos diagenéticos, ocorridos no contexto deposicional dos fragmentos cerâmicos, que possam explicar seu alto enriquecimento (ver considerações para $\mathrm{Na}$ e $\mathrm{K}$ na seção 7.1.9). Esses efeitos poderiam prejudicar a interpretação das análises multivariadas para tentar identificar padrões de concentração elementar que reflitam aspectos culturais.

Os elementos Co e Ta podem sofrer contaminação pela broca de carbeto de tungstênio, utilizada para perfurar os fragmentos cerâmicos durante o processo de preparação de amostras (Attas et al., 1984). Assim, o aumento superior a $250 \%$ na concentração de cobalto nas amostras de cerâmica dos sítios Lago Grande e Osvaldo deve estar relacionado a esse tipo de contaminação durante a remoção do pó para análise por ativação com nêutrons (seção 6.1.1).

A estrutura utilizada para inferências arqueológicas será aquela que estiver adequadamente determinada do ponto de vista analítico, e na qual outros fatores que possam complicar a correlação arqueológica, como fenômenos geoquímicos atuantes no contexto deposicional, sejam minimizados (ver Cap. 5). 


\subsubsection{INAA e microscopia óptica de cauixi}

As fotografias resultantes da microscopia óptica de quinze fragmentos cerâmicos de Osvaldo e Lago Grande e três argilas do sítio Osvaldo estão organizadas no Apêndice E. Na Fig. 7.4, são apresentados exemplos de duas microscopias ópticas das amostras.
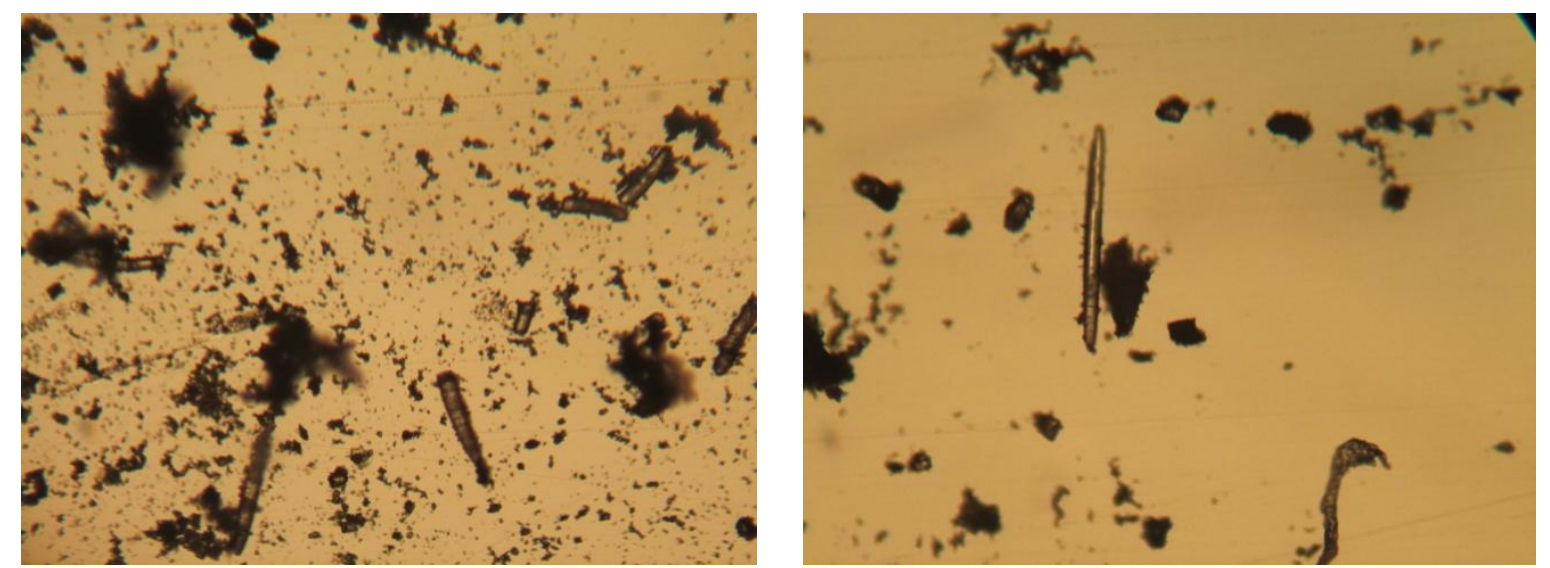

Figura 7.4 - Microscopia óptica (100x) das amostras CSQN109 (esquerda) e CSQN130 (direita) ilustrando a presença de espículas de sílica biogênica, provenientes do cauixi, esponja de água doce considerada o principal antiplástico utilizado nas cerâmicas dos sítios Lago Grande e Osvaldo.

As espículas observadas na Fig. 7.4 representam sílica amorfa, sintetizada pelos organismos, as esponjas de água doce denominadas cauixi, em solução aquosa e sob condições ambientes em um processo de catálise biológica. Essas espículas formam o esqueleto da esponja. Jensen et al. (2009) mostraram que água é o principal componente volátil das espículas, em torno de 5,5\% em massa, sendo que a água estrutural representaria apenas $400 \mu \mathrm{g} \cdot \mathrm{g}^{-1}$ (grupos hidroxila), e o restante seria proveniente dos mesoporos das espículas (Keding et al., 2009). Após a remoção da água, a parte inorgânica consiste em aproximadamente $99,7 \%$ de $\mathrm{SiO}_{2}$ em massa, e traços de $\mathrm{CaO}$ e $\mathrm{Al}_{2} \mathrm{O}_{3}$. O comprimento médio determinado pelos autores por espectrometria óptica foi de $305 \pm 18$ $\mu \mathrm{m}$; e a largura média foi de 15,6 $\pm 1,5 \mu \mathrm{m}$. Keding et al. (2010) também demonstraram que o ligante orgânico das espículas de sílica de cauixi foram destruídos em um tratamento térmico a $550^{\circ} \mathrm{C}$. 
No sítio arqueológico Osvaldo, Portocarrero (2006) identificou dois padrões diferentes no uso de cauixi, com inserção em grandes quantidades de espículas pequenas, com aproximadamente $100 \mu \mathrm{m}$ de comprimento; e inserção em quantidades geralmente menores de espículas de dimensões maiores, com aproximadamente $300 \mu \mathrm{m}$ de comprimento. Esses padrões seriam indicativos de coleta e uso específicos de cauixi, para atender a diferentes necessidades de performance das cerâmicas, dependendo do tipo de vasilha produzida (Portocarrero, 2006, p. 71).

Foi observada uma quantidade relativamente menor de espículas nas amostras de argila CSQN83, 85 e 88. Essas espículas estariam relacionadas também à sílica biogênica, que representa corpos silicosos que podem ser naturalmente encontrados em solos (Costa et al., 2010). Sua menor quantidade nessas argilas é outra indicação de que as espículas normalmente encontradas nas cerâmicas arqueológicas de Lago Grande e Osvaldo são consequência da adição deliberada de antiplásticos pelos antigos ceramistas.

$\mathrm{Na}$ Tab. 7.3 são apresentados os resultados de INAA para amostras de cauixi coletadas na região de confluência dos rios Negro e Solimões. Denominou-se, neste trabalho, esponjas "limpas" como as amostras de cauixi que foram submetidas a tratamento ácido com $\mathrm{HF}, \mathrm{HNO}_{3}$ e $\mathrm{H}_{2} \mathrm{O}_{2}$ (foram utilizadas as mesmas concentrações do tratamento ácido para datação OSL - seção 6.4), para remoção do material orgânico da superfície das espículas (Jensen et al., 2009), visando análise por DRX (seção 7.2). As linhas hachuradas representam os elementos que foram aprovados no controle de qualidade analítico (seção 7.1.1).

Pela Tab. 7.3 observou-se, para as amostras de cauixi in natura, concentrações químicas elementares que variam de $3 \%(\mathrm{Na})$ do valor da concentração do mesmo elemento nas cerâmicas arqueológicas de Osvaldo e Lago Grande, até $26 \%$ para Co e Fe. O ferro encontra-se presente recobrindo as espículas de cauixi, principalmente, na forma de óxido de ferro, $\mathrm{Fe}_{2} \mathrm{O}_{3}$, de origem fluvial (Keding et al., 2010). O tratamento ácido reduziu o nível de todos os elementos a traço, com exceção do ferro. 
Tabela 7.3 - Resultados de INAA para a esponja de água doce (cauixi) usada como antiplástico principal nas cerâmicas arqueológicas dos sítios Lago Grande e Osvaldo.

\begin{tabular}{|c|c|c|c|c|c|}
\hline \multirow{2}{*}{ Elemento } & \multicolumn{3}{|c|}{ Cauixi in natura } & \multicolumn{2}{|c|}{ Cauixi "limpo" } \\
\hline & Amostra 1 & Amostra 2 & Cauixi/Cerâmicas (\%) & Amostra & Cauixi/Cerâmicas (\%) \\
\hline As (ng/g) & $684 \pm 70$ & $516 \pm 92$ & 8 & - & - \\
\hline $\mathrm{K}(\mathrm{mg} / \mathrm{g})$ & $0,9 \pm 0,2$ & $1,5 \pm 0,4$ & 11 & - & - \\
\hline $\mathrm{La}(\mathrm{ug} / \mathrm{g})$ & $11,6 \pm 0,1$ & $9,4 \pm 0,1$ & 24 & $1,1 \pm 0,0$ & 2 \\
\hline $\mathrm{Lu}(\mathrm{ng} / \mathrm{g})$ & $73 \pm 10$ & $78 \pm 9$ & 15 & - & - \\
\hline $\mathrm{Na}(\mathrm{ug} / \mathrm{g})$ & $60 \pm 3$ & $56 \pm 4$ & 3 & $28 \pm 1$ & 1 \\
\hline $\mathrm{Nd}(\mathrm{ug} / \mathrm{g})$ & $7,9 \pm 3,1$ & $11 \pm 3,7$ & 25 & - & - \\
\hline $\mathrm{Sb}(\mathrm{ug} / \mathrm{g})$ & - & - & - & - & - \\
\hline $\mathrm{Sm}(\mathrm{ug} / \mathrm{g})$ & $0,91 \pm 0,01$ & $1,54 \pm 0,01$ & 23 & $0,120 \pm 0,003$ & 2 \\
\hline $\mathrm{U}(\mathrm{ng} / \mathrm{g})$ & $474 \pm 221$ & $825 \pm 198$ & 16 & - & - \\
\hline $\mathrm{Yb}(\mathrm{ng} / \mathrm{g})$ & $498 \pm 45$ & $486 \pm 38$ & 16 & - & - \\
\hline $\mathrm{Ba}(\mathrm{ug} / \mathrm{g})$ & - & - & - & - & - \\
\hline $\mathrm{Ce}(\mathrm{ug} / \mathrm{g})$ & $20 \pm 1$ & $18 \pm 1$ & 21 & $3 \pm 1$ & 3 \\
\hline Co (ug/g) & $3,1 \pm 0,2$ & $2,4 \pm 0,2$ & 26 & $0,4 \pm 0,1$ & 4 \\
\hline $\mathrm{Cr}$ (ug/g) & $8,0 \pm 1,6$ & $5,2 \pm 1,1$ & 10 & - & - \\
\hline Cs (ng/g) & $959 \pm 198$ & $537 \pm 170$ & 8 & - & - \\
\hline $\mathrm{Eu}(\mathrm{ng} / \mathrm{g})$ & $317 \pm 36$ & $235 \pm 46$ & 21 & - & - \\
\hline $\mathrm{Fe}(\mathrm{mg} / \mathrm{g})$ & $10,0 \pm 0,4$ & $9,4 \pm 0,4$ & 26 & $1,1 \pm 0,1$ & 3 \\
\hline Hf (ng/g) & $651 \pm 104$ & $466 \pm 112$ & 7 & $81 \pm 55$ & 1 \\
\hline $\mathrm{Rb}(\mathrm{mg} / \mathrm{g})$ & - & - & - & - & - \\
\hline Sc (ug/g) & $1,9 \pm 0,1$ & $1,7 \pm 0,0$ & 12 & $0,1 \pm 0,1$ & 1 \\
\hline $\mathrm{Ta}(\mathrm{mg} / \mathrm{g})$ & - & - & - & - & - \\
\hline $\mathrm{Tb}(\mathrm{ng} / \mathrm{g})$ & $132 \pm 73$ & $160 \pm 123$ & 18 & - & - \\
\hline Th (ug/g) & $3,0 \pm 0,2$ & $2,6 \pm 0,2$ & 18 & - & - \\
\hline Zn (ug/g) & - & - & - & $5,6 \pm 1,2$ & 2 \\
\hline
\end{tabular}

Pelos resultados de microscopia óptica de fragmentos cerâmicos dos dois sítios, foi observado que a quantidade de cauixi estimada estaria sempre abaixo de $20 \%$ em relação à quantidade dos demais componentes da pasta cerâmica, em unidade de área. Aproximando-se a proporção em área pela proporção em volume, considerando uma densidade de $2 \mathrm{~g} / \mathrm{cm}^{3}$ para o cauixi (Demaster, 2005) e, para as cerâmicas, uma densidade de $1,3 \mathrm{~g} / \mathrm{cm}^{3}$ (a partir de cálculos de massa para o porta-amostra de DRX), a proporção mássica relativa do cauixi nas cerâmicas foi estimada como sendo inferior a $30 \%$ para todas as cerâmicas observadas no microscópio óptico. Assim, desprezando-se qualquer possível volatilidade de elementos químicos associados à sílica biogênica na pasta 
cerâmica durante a queima, a variação máxima na concentração das cerâmicas seria sempre menor que $-22,2 \%$ para o elemento Fe, o elemento menos afetado; e sempre menor que $29,1 \%$ para o sódio, o elemento mais afetado. Os coeficientes negativos indicariam o efeito de diluição nas concentrações.

Os resultados da análise de cauixi corroboraram a discussão anterior (seção 7.1.2.), pois a tendência ao enriquecimento de $\mathrm{Na}, \mathrm{K}$, Co e $\mathrm{Rb}$ não poderia estar associada à inserção de antiplásticos, mas sim a fatores de contaminação pela broca de carbeto de tungstênio, no caso de Co; e possíveis efeitos diagenéticos, para $\mathrm{Na}, \mathrm{K}$ e $\mathrm{Rb}$. $\mathrm{Na}$ ausência desses fatores, observar-se-ia uma tendência de diluição para todos os elementos químicos analisados, como mostrado pelas estimativas para os elementos $\mathrm{Fe}$ e $\mathrm{Na}$, dois casos extremos de variação pela adição de cauixi na produção cerâmica de Lago Grande e Osvaldo.

\subsubsection{Seleção dos elementos químicos para as análises multivariadas}

Define-se Cenário 1, neste trabalho, como o conjunto máximo dos elementos químicos que podem ser utilizados nas análises estatísticas multivariadas, cujos resultados sejam satisfatórios segundo o controle de qualidade analítico adotado, não ultrapassem uma quantidade pré-determinada de valores faltantes (quantidade de concentrações elementares não determinadas) e estejam livres de interferências críticas.

É necessário diagnosticar o grau de aleatoriedade dos processos de perda de dados em um experimento. Há testes diagnósticos para a determinação desses níveis de aleatoriedade, sendo que um caso extremo seria o de dados completamente perdidos ao acaso. No presente trabalho, a perda de dados de concentração elementar nas medidas de INAA não é aleatória, pois os dados faltantes estão geralmente associados a concentrações abaixo do limite de detecção do método para o elemento químico considerado. Como não é possível verificar se as correlações dos elementos nesse domínio de concentrações segue a tendência observada para as demais faixas de concentração, decidiu-se não explorar métodos de imputação neste trabalho, e utilizá-los apenas conforme necessário nos cálculos dos métodos multivariados. Um valor máximo recomendado seria $10 \%$ de valores faltantes para variáveis ou amostras (Schlomer et al., 2010). O histograma de frequências para valores de concentração abaixo do limite de detecção é apresentado na Fig. 7.5.

Pela Fig. 7.5, observou-se que o potássio foi o único elemento que apresentou quantidade de valores de faltantes superior a $10 \%$ (22\%). Apesar de esse valor ser superior 
ao limite máximo estabelecido, optou-se por manter o elemento $\mathrm{K}$ nas análises subsequentes por ser um dos elementos que, assim como o $\mathrm{Na}, \mathrm{Rb}$ e $\mathrm{Co}$, apresentaram tendência de enriquecimento, em vez de depleção na Fig. 7.2, e é de interesse neste trabalho analisar possíveis particularidades e/ou efeitos diagenéticos que estejam afetando este ou outros elementos químicos.

O elemento Co foi eliminado da análise, mesmo tendo sido aprovado no controle de qualidade analítico e não ter apresentado nenhum valor faltante, pois é um elemento susceptível de contaminação pela broca de carbeto de tunsgstênio, durante o processo de obtenção do pó para INAA e outras técnicas (Attas, 1984).

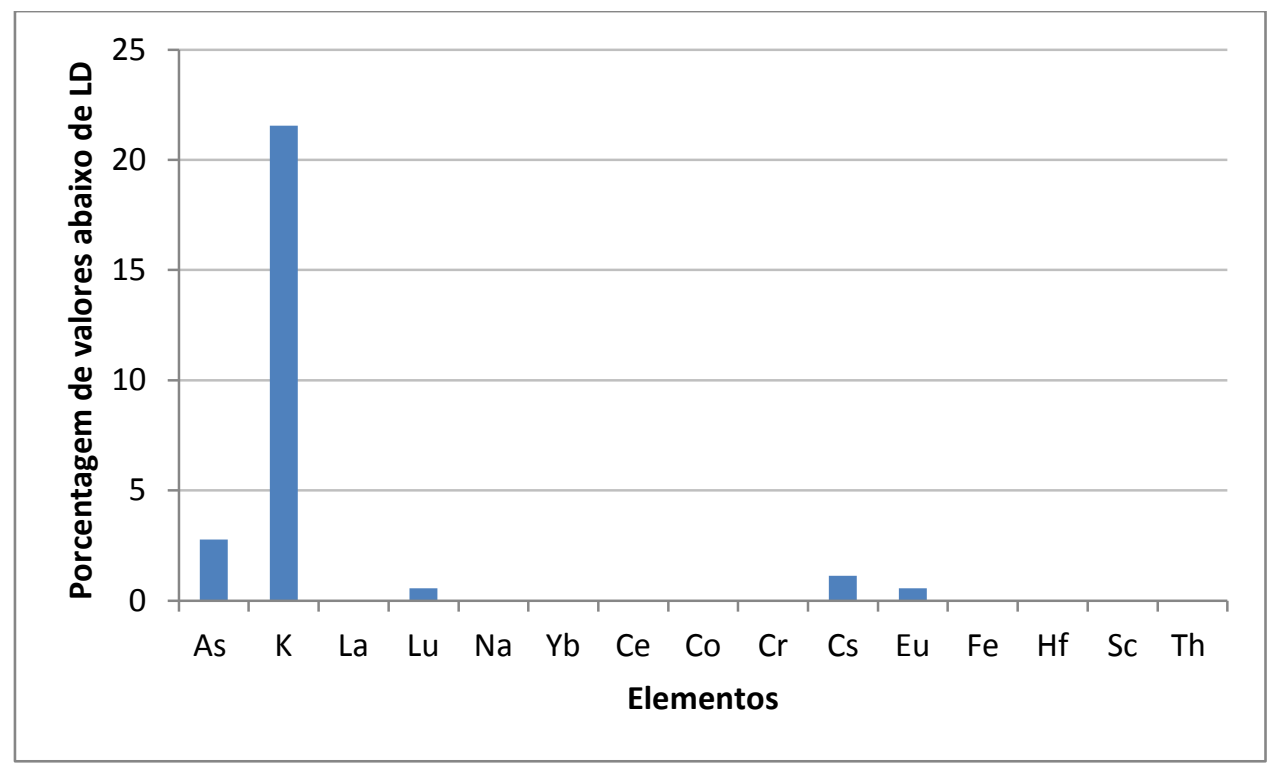

Figura 7.5 - Distribuição de frequências de valores de concentração não determinados por INAA para a base de dados de Lago Grande e Osvaldo.

Assim, o Cenário 1 é dado pelo seguinte conjunto de 14 elementos:

Cenário 1: Os 14 elementos As, K, La, Lu, Na, Yb, Ce, Cr, Cs, Eu, Fe, Hf, Sc e Th com transformação logarítmica $\left(\log _{10}\right)$. 
Esse cenário é formado por 11 elementos que foram aprovados no controle de qualidade analítico e três elementos aprovados com status "Atenção" (As, Lu e Cr). A interferência desse último grupo nas análises será analisada conforme for conveniente.

\subsubsection{Transformação dos dados}

As variáveis selecionadas para as análises estatísticas multivariadas (seção 7.1.4) tiveram suas concentrações elementares transformadas em logaritmos de base decimal $\left(\log _{10}\right)$, antes da aplicação de técnicas multivariadas. Um dos objetivos desta transformação é prevenir a atribuição de pesos excessivos a elementos químicos que estejam presentes em altas concentrações (ex.: macroelementos $\mathrm{Na}$, Fe e K, em mg.g ${ }^{-1}$ ), em relação aos elementos presentes em nível traço (de $\mu \mathrm{g} \cdot \mathrm{g}^{-1}$ para baixo). Esta estratégia está em sintonia com o segundo princípio de taxonomia de Sneath e Sokal, que trata da atribuição a priori de pesos iguais aos atributos dos objetos em análises multivariadas (Harbottle, 1982a, p. 27).

A distribuição de muitos elementos-traço é frequentemente considerada como lognormal na literatura (Sayre, 1975; Beier and Mommsem, 1994; Koch and Link, 2002, pp. 213-215). Além disso, o Archaeometry Group do reator nuclear de pesquisas da Universidade do Missouri chegou à conclusão interna de que a maioria dos elementos em suas análises está lognormalmente distribuída (Glascock, 1992). Assim, os resultados de concentração elementar também foram transformados para melhorar a condição de normalidade, desejável em algumas técnicas multivariadas, como análise discriminante.

Adotou-se, neste trabalho, a convenção de se utilizar todas as concentrações em $\mu \mathrm{g} . \mathrm{g}^{-1}$, independentemente da diferença de magnitude entre os elementos, para que toda compensação de diferenças de escala entre os elementos em nível macro, micro e traço seja efetuada unicamente pelo processo de transformação dos dados. O Missouri University Research Reactor também utiliza esta convenção (Glascock, 1992).

A transformação logarítmica na base decimal também pode ser vista como uma semipadronização mais "absoluta", apresentando vantagens sobre procedimentos clássicos de padronização que utilizam a média e o desvio-padrão dos dados, uma vez que para novos dados introduzidos na base, as coordenadas padronizadas de uma determinada amostra deveriam ser atualizadas, devido à modificação da média e do desvio (Harbottle, 1976). Adicionalmente, a transformação logarítmica é um tipo de transformação não linear que traz potenciais dados discrepantes da extremidade das distribuições de concentrações 
elementares para mais perto da média, reduzindo seu impacto nas análises multivariadas (Warner, 2013).

A segunda transformação de dados testada neste trabalho (ver Cap. 5) foi a transformação em razão logarítmica aditiva (alr), na qual um dos elementos da base de dados é selecionado para ser o denominador da razão. A escolha do elemento se deu pelo cálculo da matriz de variação dos dados subcomposicionais (ver seção 7.1.10). O objetivo da utilização dessa transformação foi o de se estudar, por meios estatísticos, o efeito da adição de aditivos antiplásticos na produção cerâmica dos sítios Lago Grande e Osvaldo, para comparação com resultados obtidos pela transformação logarítmica decimal, e com os resultados de irradiação neutrônica de cauixi (seção 7.1.3).

\subsubsection{Estrutura geral de correlação}

Nesta seção, é a apresentada a estrutura de correlação para os dados combinados de Lago Grande e Osvaldo. A interpretação de correlações entre variáveis em dados de natureza composicional a partir da estatística multivariada "clássica" pode gerar interpretações equivocadas (Pawlowsky-Glahn et al., 2007). Contudo, há evidências na literatura arqueométrica de que mesmo a abordagem tradicional aplicada a dados composicionais, considerada muitas vezes como "patológica" por parte da comunidade estatística (reflexo de uma polarização entre interesses teóricos e práticos) pode fornecer resultados que fazem sentido arqueologica e geologicamente. Um dos motivos para isso parece ser o fato já relatado na literatura (Baxter \& Freestone, 2006) de a análise logarítmica racional de um conjunto de dados formado apenas por elementos-traço ser equivalente à análise tradicional baseada em logaritmos. Empiricamente, segundo os mesmos autores, mesmo quando outros elementos foram utilizados, a análise a partir de dados padronizados ou transformados logaritmicamente forneceram resultados similares. $\mathrm{Na}$ base de dados deste trabalho, os únicos elementos que não estão em nível traço são Na, $\mathrm{K}$ e Fe. De qualquer forma, foram observadas tendências gerais, em vez de uma análise criteriosa dos valores absolutos dos coeficientes de correlação.

A existência de correlação entre elementos em dados geoquímicos é conhecida na literatura. $\mathrm{O}$ elemento $\mathrm{Ca}$, por exemplo, aparece frequentemente correlacionado a $\mathrm{Sr}$ e $\mathrm{Ba}$. Os metais de transição, como o Fe e o Sc, e as terras-raras apresentam frequentemente altos índices de correlação. Na Tab. 7.4, é apresentada a matriz de coeficientes de correlação de Pearson para os 14 elementos do Cenário 1. 
Os coeficientes de correlação mais altos foram observados para as terras raras $\mathrm{r}(\mathrm{Yb}, \mathrm{Lu})=0,87 ; \mathrm{r}(\mathrm{La}, \mathrm{Yb})=0,84 ; \mathrm{r}(\mathrm{La}, \mathrm{Eu})=0,80 ; \mathrm{r}(\mathrm{La}, \mathrm{Lu})=0,78$. Entre os metais de transição também foram observados coeficientes altos, como $\mathrm{r}(\mathrm{Cr}, \mathrm{Sc})=0,82 ; \mathrm{r}(\mathrm{Cr}, \mathrm{Fe})=$ 0,$74 ; \mathrm{r}(\mathrm{Fe}, \mathrm{Sc})=0,71$. O que há em comum entre todas essas correlações altas é que os elementos estão em um mesmo período da tabela periódica. Essa tendência, e mais especificamente a existência de correlações altas entre terras raras e metais de transição são esperadas na literatura (Glascock, 1992). Além desses, observaram-se correlações altas para $\mathrm{r}(\mathrm{Th}, \mathrm{Cr})=0,78 ; \mathrm{r}(\mathrm{Hf}, \mathrm{Th})=0,80$ e r $(\mathrm{Th}, \mathrm{La})=0,73$.

Tabela 7.4 - Estrutura geral de correlação para as variáveis do Cenário 1, referente aos coeficientes de correlação de Pearson para a base de dados de Lago Grande e Osvaldo com transformação $\log _{10}$.

\begin{tabular}{ccccccccccccccc}
\hline Elemento & $\mathbf{A s}$ & $\mathbf{K}$ & $\mathbf{L a}$ & $\mathbf{L u}$ & $\mathbf{N a}$ & $\mathbf{Y b}$ & $\mathbf{C e}$ & $\mathbf{C r}$ & $\mathbf{C s}$ & $\mathbf{E u}$ & $\mathbf{F e}$ & $\mathbf{H f}$ & $\mathbf{S c}$ & $\mathbf{T h}$ \\
\hline $\mathbf{A s}$ & 1 & 0,15 & 0,21 & 0,32 & $-0,11$ & 0,29 & 0,07 & 0,29 & 0,13 & 0,09 & 0,26 & 0,19 & 0,19 & 0,23 \\
$\mathbf{K}$ & 0,15 & 1 & $-0,02$ & $-0,03$ & 0,45 & $-0,01$ & 0,08 & 0,08 & 0,01 & 0,01 & 0,23 & $-0,24$ & 0,22 & $-0,06$ \\
$\mathbf{L a}$ & 0,21 & $-0,02$ & 1 & 0,78 & $-0,01$ & 0,84 & 0,65 & 0,56 & 0,03 & 0,80 & 0,36 & 0,63 & 0,43 & 0,73 \\
$\mathbf{L u}$ & 0,32 & $-0,03$ & 0,78 & 1 & 0,06 & 0,87 & 0,44 & 0,44 & $-0,03$ & 0,57 & 0,32 & 0,66 & 0,30 & 0,59 \\
$\mathbf{N a}$ & $-0,11$ & 0,45 & $-0,01$ & 0,06 & 1 & 0,02 & 0,06 & $-0,02$ & 0,09 & 0,20 & 0,25 & $-0,32$ & 0,20 & $-0,21$ \\
$\mathbf{Y b}$ & 0,29 & $-0,01$ & 0,84 & 0,87 & 0,02 & 1 & 0,51 & 0,54 & $-0,04$ & 0,66 & 0,37 & 0,65 & 0,39 & 0,64 \\
$\mathbf{C e}$ & 0,07 & 0,08 & 0,65 & 0,44 & 0,06 & 0,51 & 1 & 0,65 & 0,11 & 0,68 & 0,45 & 0,42 & 0,62 & 0,63 \\
$\mathbf{C r}$ & 0,29 & 0,08 & 0,56 & 0,44 & $-0,02$ & 0,54 & 0,65 & 1 & 0,08 & 0,58 & 0,74 & 0,51 & 0,82 & 0,78 \\
$\mathbf{C s}$ & 0,13 & 0,01 & 0,03 & $-0,03$ & 0,09 & $-0,04$ & 0,11 & 0,08 & 1 & 0,01 & 0,06 & 0,07 & 0,04 & 0,14 \\
$\mathbf{E u}$ & 0,09 & 0,01 & 0,80 & 0,57 & 0,20 & 0,66 & 0,68 & 0,58 & 0,01 & 1 & 0,45 & 0,40 & 0,60 & 0,59 \\
$\mathbf{F e}$ & 0,26 & 0,23 & 0,36 & 0,32 & 0,25 & 0,37 & 0,45 & 0,74 & 0,06 & 0,45 & 1 & 0,24 & 0,71 & 0,52 \\
$\mathbf{H f}$ & 0,19 & $-0,24$ & 0,63 & 0,66 & $-0,32$ & 0,65 & 0,42 & 0,51 & 0,07 & 0,40 & 0,24 & 1 & 0,17 & 0,80 \\
$\mathbf{S c}$ & 0,19 & 0,22 & 0,43 & 0,30 & 0,20 & 0,39 & 0,62 & 0,82 & 0,04 & 0,60 & 0,71 & 0,17 & 1 & 0,56 \\
$\mathbf{T h}$ & 0,23 & $-0,06$ & 0,73 & 0,59 & $-0,21$ & 0,64 & 0,63 & 0,78 & 0,14 & 0,59 & 0,52 & 0,80 & 0,56 & 1 \\
\hline
\end{tabular}

Os elementos que apresentaram os menores coeficientes de correlação, de modo geral, foram $\mathrm{Cs}$, As, $\mathrm{K}$ e Na. Essa tendência à falta de correlação com todos os demais elementos químicos da base de dados pode ser indicativa de efeitos pósdeposicionais que alteraram preferencialmente o perfil de concentrações desses elementos.

Como correlações altas entre alguns elementos químicos no contexto geológico esperadas na literatura foram encontradas no presente trabalho, concluiu-se que o tempero não provocou perturbações significativas nas correlações naturais. Essa pode ser considerada outra indicação indireta de que o efeito da adição do antiplástico cauixi, o 
principal tempero das cerâmicas, é o de diluição geral dos elementos químicos, sem enriquecimento preferencial de algum elemento, e corrobora a discussão da seção 7.1.3.

Harbottle (1976) observou que coeficientes de correlação menores que 0,5 não ofereciam problemas operacionais para análise de agrupamentos utilizando distância euclidiana como medida de dissimilaridade. Na estrutura de correlação do presente trabalho, há vários coeficientes acima desse valor, corroborando a necessidade de se refinar a análise por procedimentos multivariados que levem em conta a estrutura de correlação, como refinamento de grupos químicos de cerâmicas arqueológicas a partir distância de Mahalanobis (seção 7.1.12).

\subsubsection{Análise de dados discrepantes (outliers)}

A identificação de dados discrepantes multivariados em relação à base de dados completa (Cenário 1) foi realizada utilizando-se a distância de Mahalanobis e o critério lambda de Wilks como valor crítico, pela Eq. 5.8. Foram encontrados 11 outliers dentre 177 amostras analisadas (as que não apresentaram valores faltantes), que apresentaram distância de Mahalanobis em relação ao centroide dos dados maior que o valor crítico $\lambda_{\text {Wilks. }}$ A relação dos dados discrepantes encontra-se na Tab. 7.5. Foram necessárias três iterações. Na primeira iteração do algoritmo, foram identificados 8 outliers (as oito primeiras amostras na Tab. 7.5). Na segunda iteração foram encontrados mais três outliers e, na última iteração, nenhum outlier foi identificado.

Tabela 7.5 - Dados discrepantes na base de dados dos sítios Osvaldo e Lago Grande.

\begin{tabular}{ccccccc}
\hline Amostra & Sítio & Fase & Unidade & Nível $(\mathrm{cm})$ & $D_{\text {crít }}$ & $\lambda_{\text {Wilks }}$ \\
\hline CSQN84 & Argila & - & - & - & 36,9 & 40,5 \\
CSQN100 & Osvaldo & Paredão & S710 E1966 & $60-70$ & 36,9 & 56,1 \\
CSQN126 & Lago Grande & - & 1 & $100-110$ & 36,9 & 42,5 \\
CSQN355 & Lago Grande & Manacapuru & 1 & $110-120$ & 36,9 & 40,0 \\
CSQN357 & Lago Grande & Manacapuru & 1 & $80-90$ & 36,9 & 40,7 \\
CSQN378 & Lago Grande & Manacapuru & 1 & $60-70$ & 36,9 & 62,5 \\
CSQN417 & Osvaldo & Manacapuru & Tradagem & $30-40$ & 36,9 & 64,3 \\
CSQN444 & Osvaldo & - & - & - & 36,9 & 40,0 \\
CSQN389 & Lago Grande & Paredão & 3 & $50-60$ & 36,6 & 37,0 \\
CSQN397 & Osvaldo & Manacapuru & Tradagem & $10-20$ & 36,6 & 37,3 \\
CSQN423 & Osvaldo & Manacapuru & Tradagem & $30-40$ & 36,9 & 42,3 \\
\hline
\end{tabular}


Para as amostras CSQN355, CSQN357 e CSQN378, houve rompimento do invólucro de polietileno após a irradiação com nêutrons, que pode ter ocasionado perda de massa, alterando o perfil de concentrações elementares. Essas amostras foram eliminadas das análises estatísticas posteriores. Como a existência de dados discrepantes pode ser devida a diversos fatores que não apenas problemas experimentais, mas também grupos químicos sub-representados, efeitos diagenéticos e alguma outra variação intencional por parte dos ceramistas, decidiu-se manter as demais amostras nas análises de agrupamento e componentes principais, para avaliar as características desses dados e informações úteis que eles possam representar. Em caso negativo, seriam eliminados das análises sempre que necessário.

\subsubsection{Análise de agrupamento}

Os dendrogramas gerados para esta seção encontram-se no Apêndice F. Os resultados da análise de agrupamento serviram de base para definir grupos químicos tentativos para explorar vários cenários de elementos químicos e transformação de dados nas seções subsequentes.

Inicialmente, foram comparados os métodos de agrupamento Average Linkage, Ward e K-means, alguns dos métodos mais utilizados na literatura, com distância euclidiana quadrática, no programa Statistica 8.0 em 127 amostras dos sítios Lago Grande e Osvaldo, adotando-se três grupos como critério de corte do dendrograma. Os resultados classificatórios encontram-se na Tab. 7.6. Comparando-se os resultados entre os métodos Average Linkage e Ward, observou-se a mesma classificação para 89\% (113) das amostras. O método $K$-means foi o que apresentou resultados mais discrepantes: $36 \%$ de variação (46 amostras) em relação ao Average Linkage; e 39\% de variação (50 amostras), em relação ao método Ward. A análise da base de dados mostrou que o método K-means alocava também amostras cerâmicas ao grupo das argilas, diferentemente dos métodos Ward e Average Linkage, que agruparam as argilas isoladamente. Uma possível explicação para o fato é a dispersão dos dados dos demais grupos, fazendo com que algumas amostras estejam na região de intersecção entre os mesmos. 
Tabela 7.6 - Análise comparativa de três métodos de agrupamento: Average Linkage, Ward e K-means para uma base de dados de 127 amostras de Lago Grande e Osvaldo.

\begin{tabular}{|c|c|c|c|c|c|c|c|c|c|c|c|c|c|c|c|}
\hline Amostra & $\mathbf{W}$ & $\mathbf{A L}$ & KM & Amostra & $\mathbf{W}$ & $\mathbf{A L}$ & $\mathbf{K M}$ & Amostra & $\mathbf{W}$ & $\mathbf{A L}$ & $\mathbf{K M}$ & Amostra & $\mathbf{W}$ & $\mathbf{A L}$ & KM \\
\hline 58 & 1 & 1 & 1 & 92 & 1 & 1 & 1 & 131 & 2 & 2 & 3 & 390 & 1 & 2 & 3 \\
\hline 59 & 2 & 2 & 3 & 93 & 1 & 1 & 2 & 132 & 1 & 1 & 1 & 391 & 1 & 2 & 3 \\
\hline 60 & 1 & 1 & 1 & 94 & 1 & 1 & 2 & 133 & 1 & 1 & 1 & 392 & 1 & 2 & 3 \\
\hline 61 & 1 & 1 & 1 & 95 & 1 & 2 & 3 & 358 & 1 & 1 & 1 & 393 & 2 & 2 & 3 \\
\hline 62 & 1 & 1 & 2 & 97 & 2 & 1 & 1 & 360 & 1 & 1 & 2 & 395 & 2 & 2 & 3 \\
\hline 63 & 1 & 1 & 2 & 98 & 2 & 1 & 1 & 361 & 1 & 1 & 1 & 398 & 1 & 1 & 1 \\
\hline 64 & 2 & 2 & 3 & 99 & 2 & 1 & 1 & 362 & 1 & 1 & 1 & 399 & 1 & 1 & 1 \\
\hline 65 & 1 & 1 & 1 & 100 & 1 & 3 & 2 & 364 & 2 & 2 & 3 & 400 & 1 & 1 & 1 \\
\hline 66 & 1 & 1 & 1 & 101 & 1 & 1 & 1 & 365 & 1 & 1 & 1 & 401 & 1 & 1 & 1 \\
\hline 67 & 1 & 1 & 2 & 104 & 1 & 1 & 1 & 366 & 2 & 2 & 3 & 402 & 1 & 1 & 1 \\
\hline 68 & 1 & 1 & 1 & 105 & 2 & 2 & 3 & 367 & 2 & 2 & 2 & 403 & 1 & 1 & 1 \\
\hline 70 & 2 & 2 & 3 & 106 & 1 & 1 & 1 & 368 & 1 & 1 & 2 & 404 & 1 & 1 & 1 \\
\hline 72 & 1 & 1 & 1 & 107 & 1 & 1 & 1 & 369 & 2 & 2 & 2 & 405 & 2 & 2 & 3 \\
\hline 73 & 1 & 1 & 3 & 108 & 1 & 1 & 1 & 370 & 1 & 1 & 1 & 406 & 2 & 2 & 3 \\
\hline 74 & 1 & 1 & 1 & 109 & 1 & 1 & 1 & 371 & 2 & 2 & 3 & 407 & 1 & 1 & 1 \\
\hline 75 & 1 & 1 & 2 & 110 & 2 & 2 & 2 & 372 & 1 & 1 & 1 & 408 & 1 & 1 & 1 \\
\hline 76 & 1 & 1 & 1 & 111 & 1 & 1 & 1 & 374 & 1 & 1 & 1 & 409 & 1 & 1 & 1 \\
\hline 77 & 1 & 1 & 1 & 112 & 1 & 1 & 1 & 375 & 2 & 2 & 3 & 410 & 1 & 1 & 1 \\
\hline 78 & 1 & 1 & 2 & 113 & 1 & 1 & 1 & 376 & 1 & 1 & 1 & 411 & 1 & 1 & 1 \\
\hline 79 & 1 & 1 & 1 & 114 & 1 & 1 & 1 & 377 & 1 & 1 & 1 & 412 & 1 & 1 & 1 \\
\hline 80 & 1 & 1 & 1 & 115 & 2 & 2 & 3 & 378 & 1 & 3 & 2 & 413 & 1 & 1 & 2 \\
\hline 81 & 2 & 1 & 1 & 116 & 1 & 1 & 1 & 379 & 1 & 1 & 1 & 414 & 1 & 1 & 1 \\
\hline 82 & 3 & 3 & 3 & 117 & 1 & 1 & 2 & 380 & 1 & 1 & 1 & 415 & 1 & 1 & 2 \\
\hline 83 & 3 & 3 & 3 & 118 & 1 & 1 & 1 & 381 & 1 & 1 & 1 & 416 & 1 & 1 & 1 \\
\hline 84 & 3 & 3 & 3 & 120 & 1 & 1 & 2 & 382 & 1 & 1 & 2 & 417 & 1 & 2 & 1 \\
\hline 85 & 3 & 3 & 3 & 121 & 2 & 2 & 2 & 383 & 2 & 2 & 3 & 418 & 1 & 2 & 2 \\
\hline 86 & 3 & 3 & 3 & 122 & 1 & 1 & 2 & 384 & 1 & 1 & 1 & 419 & 2 & 2 & 3 \\
\hline 87 & - & - & - & 123 & 1 & 1 & 1 & 385 & 1 & 1 & 1 & 420 & 2 & 2 & 3 \\
\hline 88 & 3 & 3 & 3 & 126 & 2 & 2 & 3 & 386 & 2 & 2 & 3 & 421 & 1 & 1 & 1 \\
\hline 89 & 3 & 3 & 3 & 128 & - & - & - & 387 & 1 & 1 & 1 & 422 & 2 & 2 & 3 \\
\hline 90 & 1 & 1 & 1 & 129 & 2 & 2 & 3 & 388 & 1 & 1 & 1 & 423 & 1 & 2 & 3 \\
\hline 91 & 1 & $?$ & 3 & 130 & 1 & 1 & 1 & 389 & 1 & 1 & 1 & & & & \\
\hline
\end{tabular}

$\mathrm{W}=\mathrm{Ward} ; \mathrm{AL}=$ Average Linkage $; \mathrm{KM}=\mathrm{K}$-means

Assim, a análise comparativa foi considerada satisfatória, principalmente entre os métodos Average Linkage e Ward. Mesmo as diferenças maiores observadas em relação ao método $K$-means não foram consideradas críticas, uma vez que as amostras que apresentaram mais variações de classificação por diferentes métodos são as que estão na 
região de intersecção entre dois grupos, segundo análises de PCA, e a classificação das amostras foi refinada por um método baseado na minimização da distância de Mahalanobis (seção 7.1.12). Esse método é mais adequado para tratar desses dados mais limítrofes por considerar a estrutura de correlação dos dados, diferentemente dos métodos de agrupamento. Essa análise comparativa permitiu verificar que a estrutura de agrupamento gerada não sofreria influência crítica do método utilizado e, consequentemente, não induziria a uma interpretação geoquímica e/ou arqueológica que poderia variar de acordo com o método de agrupamento escolhido.

Após a análise comparativa, adotou-se como padrão o método de agrupamento Average Linkage com distância euclidiana quadrática média (Eq. 5.11), que é o método empregado no software MURRAP 8.6. Os valores abaixo do limite de detecção na base de dados não precisaram ser estimados, nem suas amostras correspondentes excluídas, pois o fator de escala $p$ (número de elementos determinados) dessa métrica elimina a possibilidade de problemas devido à existência de valores faltantes.

Como critério de corte do dendrograma, estabeleceu-se que o número mínimo de grupos formados a partir do corte deveria ser suficiente para ao menos diferenciar as argilas de Osvaldo das demais amostras, pois a inspeção univariada das concentrações médias dos elementos químicos já havia sido suficiente para revelar diferenças (Tab. 7.2). Cortes em distâncias menores de ligação no dendrograma foram analisados procurando-se alguma correlação arqueológica que justificasse a formação de mais grupos. Na ausência da mesma, adotou-se o corte mínimo.

Numa primeira abordagem, optou-se por analisar os dados dos sítios Osvaldo e Lago Grande conjuntamente, para avaliar as tendências gerais da base de dados, e analisar, a posteriori, se a procedência das amostras seria um fator que definiria o padrão multivariado de concentrações.

Inicialmente, realizou-se a análise de agrupamentos para o Cenário 1. O corte mínimo no dendrograma para a diferenciação de argilas gerou três grupos de composição química elementar, sendo um grupo "A" formado por 51 amostras; um grupo " $\mathrm{C}$ ", referente às argilas (e algumas cerâmicas), formado por 10 amostras; e um grupo maior "D" formado por 111 amostras.

Por razões que serão exploradas na seção 7.1.9, a análise de agrupamentos foi repetida para o Cenário 1 com a exclusão sucessiva de $\mathrm{Na}, \mathrm{K}$, e do grupo Cs, As e Hf; e com diferentes transformações de dados, originando os Cenários 2-5. 
$\mathrm{Na}$ análise de agrupamento com 13 elementos químicos, correspondente ao Cenário 1 sem $\mathrm{Na}$, o corte mínimo do dendrograma para a diferenciação de argilas gerou dois grupos de composição química elementar: um com 11 amostras (3 cerâmicas e 8 argilas), e outro grupo com as demais amostras.

$\mathrm{Na}$ análise de agrupamentos para o Cenário 2 (definido na seção 7.1.9, correspondente ao Cenário 1 sem o $\mathrm{Na}$ e K), o corte mínimo do dendrograma para a diferenciação das argilas gerou 4 grupos de composição química elementar, sendo um grupo denominado "A" composto por 32 amostras; um grupo denominado "B" composto por 29 amostras; o grupo de argilas (e algumas cerâmicas), denominado "C", composto por 10 amostras; e um grupo denominado "D" composto por 101 amostras.

$\mathrm{Na}$ análise de agrupamentos para o Cenário 3 (definido na seção 7.1.9, correspondente ao Cenário 1 sem o $\mathrm{Na}, \mathrm{K}$, Cs, As e Hf), o corte mínimo do dendrograma para a diferenciação das argilas gerou 2 grupos de composição química elementar, sendo o grupo de argila composto por 10 amostras, e o grupo restante, por 162 amostras.

$\mathrm{Na}$ análise de agrupamentos para o Cenário 4 (definido na seção 7.1.9, correspondente ao Cenário 2, com mudança na transformação de dados), o corte mínimo do dendrograma para a diferenciação das argilas gerou seis grupos de composição química elementar, sendo um grupo denominado "A" composto por 18 amostras; um grupo "B" composto por 42 amostras; o grupo de argilas (e algumas cerâmicas), denominado "C", composto por 12 amostras; um grupo "D" composto por 60 amostras; um grupo "E" composto por 28 amostras; e um grupo "F" composto por 12 amostras.

$\mathrm{Na}$ análise de agrupamentos para o Cenário 5 (definido na seção 7.1.9, correspondente ao Cenário 3, com mudança na transformação de dados), o corte mínimo do dendrograma para a diferenciação das argilas gerou três grupos de composição química elementar, sendo um grupo maior, denominado "D", composto por 148 amostras; um grupo de argilas e mais algumas cerâmicas, denominado "C", composto por 12 amostras; e um grupo "E" composto por 12 amostras.

Numa segunda abordagem, optou-se por analisar os dados dos sítios Osvaldo e Lago Grande separadamente, para fins de simplificação, pois as análises de agrupamento e PCA auxiliaram na identificação de efeitos diagenéticos potenciais em $\mathrm{Na}, \mathrm{K}, \mathrm{Cs}$, As e Hf, mas não evidenciaram qualquer correlação óbvia dos grupos químicos definidos em relação a parâmetros arqueológicos, como sítio de proveniência, fase cerâmica, unidade, 
profundidade e objeto. Os resultados obtidos para os dois sítios seriam subsequentemente comparados (seções 7.1.9 e 7.1.12).

Há autores que não indicam a utilização da métrica euclidiana em análise de agrupamentos com a transformação logarítmica aditiva (alr), devido a possíveis distorções, já que essa transformação não preserva distâncias (Pawlowsky-Glahn et al., 2007). Contudo, ela é a transformação recomendada como adequada para dados composicionais de cerâmicas arqueológicas (Buxeda i Garrigós, 1999; mais informações no Cap. 5). Foram realizados testes comparativos de agrupamento com outras transformações possíveis para dados composicionais: a transformação em razão logarítmica centrada (clr) e transformação logarítmica isométrica (ilr). Foi verificado que essas duas últimas não apresentaram relação com os resultados de agrupamento por transformação alr ou $\log _{10}$. Além disso, enfraqueceram correlações já observadas entre grupos e fases cerâmicas observadas nessas outras transformações na análise por sítio (seção 7.1.20). Os resultados dos agrupamentos clr e ilr apresentaram mais relação entre si do que com qualquer uma das outras duas transformações. Finalmente, por ser empregado um processo de refinamento da classificação preliminar de amostras por agrupamento, utilizando a distância de Mahalanobis (operando no espaço das componentes principais) e a distribuição F, quaisquer distorções, provavelmente mais críticas para as amostras na fronteira entre os dois grupos, seriam devidamente corrigidas nesse procedimento mais robusto, pela consideração da estrutura de correlação entre as variáveis (Glascock, 1992). Assim, decidiu-se manter o foco das análises nas transformações $\log _{10}$ e alr.

$\mathrm{Na}$ análise por sítio (seção 7.1.12), realizaram-se análises de agrupamentos para as amostras de Lago Grande isoladamente. Para o Cenário 3, o corte mínimo no dendrograma gerou dois grupos de composição química elementar, após a eliminação de amostras discrepantes evidentes no dendrograma, sendo o maior, "A", formado por 68 amostras, e o grupo menor, "B”, formado por 36 amostras, num total de 104 amostras. Para o Cenário 5, o corte mínimo no dendrograma gerou dois grupos após a eliminação de amostras discrepantes evidentes no dendrograma, sendo um grupo maior, "A", formado por 54 amostras, e um grupo menor, "B”, formado por 50 amostras, indicando que o grupo $\mathrm{B}$ foi expandido nesse último cenário, gerando grupos químicos mais equilibrados em termos de quantidade da amostras.

Ainda na mesma análise por sítio, realizaram-se análises de agrupamento para as amostras de Osvaldo isoladamente. Para o Cenário 3, o corte mínimo no dendrograma 
gerou dois grupos de composição química elementar, após a eliminação de amostras discrepantes evidentes, sendo o grupo maior, "A", formado por 38 amostras, e o grupo menor, "B", formado por 17 amostras, num total de 55 amostras. Para o Cenário 5, o corte mínimo no dendrograma gerou dois grupos, após a remoção de amostras discrepantes evidentes, sendo um grupo maior, “A”, formado por 25 amostras, e um grupo menor, "B”, formado por 23 amostras, num total de 48 amostras, indicando que o tamanho dos dois grupos apareceram mais equilibrados na transformação de dados utilizada no Cenário 5 (seção 7.1.12).

\subsubsection{Análise de componentes principais (PCA) com transformação $\log _{10}$}

Nesta seção, são apresentadas as análises de componentes principais, realizadas para diferentes cenários definidos segundo os elementos utilizados e a transformação de dados empregada. Optou-se por apresentar as projeções entre as duas primeiras componentes principais (PC2 vs. PC1), e entre a primeira e a terceira (PC3 vs. PC1), para aumentar a visualização da variância, uma vez que as duas primeiras componentes explicavam frequentemente menos que $80 \%$ da variância do sistema nas análises efetuadas. Contudo, as projeções entre demais componentes principais também foram analisadas sempre que necessário, embora suas projeções gráficas não tenham sido mostradas neste trabalho por economia de espaço.

O objetivo principal ao se estabelecer cortes tentativos nos dendrogramas gerados na análise de agrupamentos não foi, num primeiro momento, o estabelecimento de grupos químicos definitivos para interpretações arqueológicas. O foco inicial foi o de observar as tendências gerais da base de dados, identificando, inclusive, grupos que poderiam estar associados a anomalias nas concentrações de alguns elementos químicos. $\mathrm{O}$ estabelecimento definitivo dos grupos químicos para interpretação arqueológica foi realizado nas seções 7.1.12 e 7.1.13.

Inicialmente, foi realizada uma análise de componentes principais baseada na matriz de covariância a partir dos resultados de agrupamento para o Cenário 1 (definido na seção 7.1.4). A utilização da matriz de covariância foi escolhida por ser um procedimento comum entre outros laboratórios (para fins de comparação), e porque foi observado que a análise baseada na matriz de correlação pode gerar resultados cuja interpretação seria mais difícil, como já foi reportado na literatura (Baxter, 1994). Uma razão sugerida para essa possibilidade é a diluição da importância das variáveis mais discriminatórias quando a 
matriz de correlação é utilizada nos cálculos. Além disso, utiliza-se a matriz de correlação em casos no qual as variáveis estudadas apresentam escalas diferentes. Como já discutido (seção 7.1.5), o equilíbrio entre a escala de concentrações dos diferentes elementos químicos já foi promovido pela transformação logarítmica dos dados, sendo que a matriz de correlação poderia forçar uma padronização grosseira. Por outro lado, a utilização da matriz de covariância poderia favorecer variáveis com maior variância absoluta. No entanto, esse fator não é crítico, uma vez que o efeito das variáveis nas componentes principais foi analisado sistematicamente no intuito de se identificar possíveis efeitos diagenéticos em elementos químicos, geradores de anomalias em suas concentrações e variabilidade.

Os coeficientes de ponderação dos autovetores que representam o peso das variáveis originais são listados na Tab. 7.7 para as primeiras quatro componentes principais, juntamente com os autovalores (variância), a porcentagem de variância representada por cada componente, e a variância acumulada. Os valores hachurados representam os maiores coeficientes de ponderação para cada componente. A Fig. 7.6 mostra as projeções dos dados de Osvaldo e Lago Grande nas duas primeiras componentes principais para um corte tentativo de cinco grupos no dendrograma, para PCA modo RQ. A Fig. 7.7, por sua vez, mostra as projeções dos dados na primeira e terceira componentes principais, para o mesmo corte tentativo de cinco grupos.

A Tab. 7.7 indica que as duas primeiras componentes principais, as mais utilizadas em redução de dados, representam conjuntamente $66,5 \%$ da variância total do sistema. Os coeficientes de ponderação da PC1, na Tab. 7.7, indicaram que há uma grande dominância relativa dos elementos $\mathrm{Na}$ e K na primeira componente principal. A segunda componente é dominada pelo metal de transição Hf, e pelos lantanídeos Eu e Ce, embora outros elementos, como o As, apresentem coeficientes de ponderação na mesma ordem de grandeza. A terceira componente principal é dominada por $\mathrm{Cs}$, As e Eu. A quarta componente é dominada por As, Cs e Hf. 
Tabela 7.7 - Coeficientes de ponderação e variância das quatro primeiras componentes principais para o Cenário 1 com dados de Lago Grande e Osvaldo.

\begin{tabular}{ccccc}
\hline Variável & PC1 & PC2 & PC3 & PC4 \\
\hline $\mathrm{Na}$ & $-0,88628$ & 0,069122 & $-0,05856$ & $-0,02336$ \\
$\mathrm{~K}$ & $-0,3881$ & $-0,05901$ & 0,185847 & 0,112244 \\
$\mathrm{Sc}$ & $-0,04929$ & 0,195473 & $-0,00018$ & 0,10562 \\
$\mathrm{Cr}$ & $-0,00672$ & 0,236345 & 0,025632 & 0,060852 \\
$\mathrm{Fe}$ & $-0,06704$ & 0,220369 & 0,038412 & 0,155972 \\
$\mathrm{As}$ & 0,08737 & 0,325720 & 0,569806 & 0,655467 \\
$\mathrm{Cs}$ & $-0,04805$ & 0,079552 & 0,729787 & $-0,63976$ \\
$\mathrm{La}$ & $-0,00712$ & 0,30152 & $-0,1423$ & $-0,07215$ \\
$\mathrm{Ce}$ & $-0,03069$ & 0,346986 & $-0,08732$ & $-0,06714$ \\
$\mathrm{Eu}$ & $-0,09121$ & 0,356658 & $-0,19179$ & $-0,05836$ \\
$\mathrm{Yb}$ & $-0,00776$ & 0,268144 & $-0,1177$ & $-0,03696$ \\
$\mathrm{Lu}$ & $-0,01512$ & 0,281256 & $-0,12842$ & $-0,04713$ \\
$\mathrm{Hf}$ & 0,183857 & 0,402007 & $-0,08725$ & $-0,29936$ \\
$\mathrm{Th}$ & 0,059716 & 0,292492 & 0,004222 & $-0,04919$ \\
\hline Autovalor & 0,166565 & 0,087882 & 0,039296 & 0,030372 \\
Variância $(\%)$ & 43,5 & 23,0 & 10,3 & 7,9 \\
Var. Acum. $(\%)$ & 43,5 & 66,5 & 76,7 & 84,6 \\
\hline
\end{tabular}

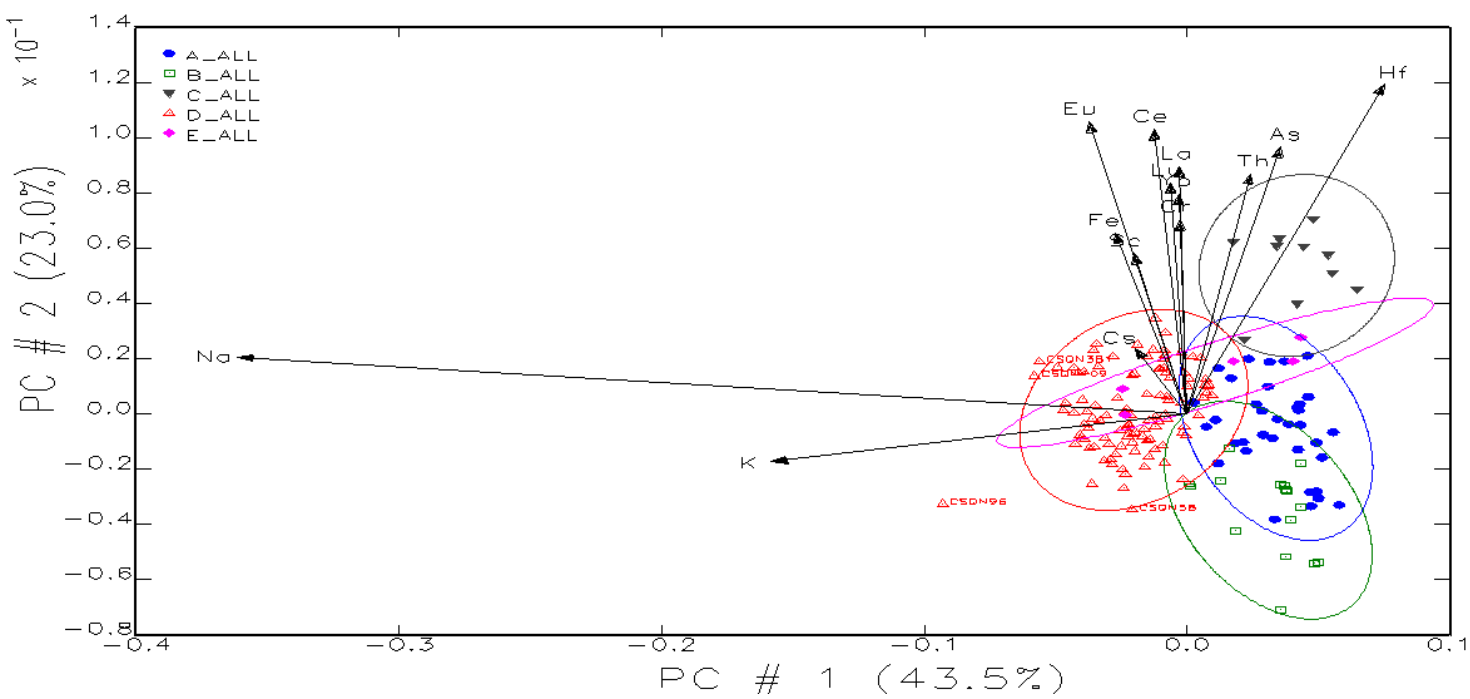

Figura 7.6 - Escores nas duas primeiras componentes principais dos dados do Cenário 1 para os sítios Lago Grande e Osvaldo. As elipses representam a região de confiança de $95 \%$. 


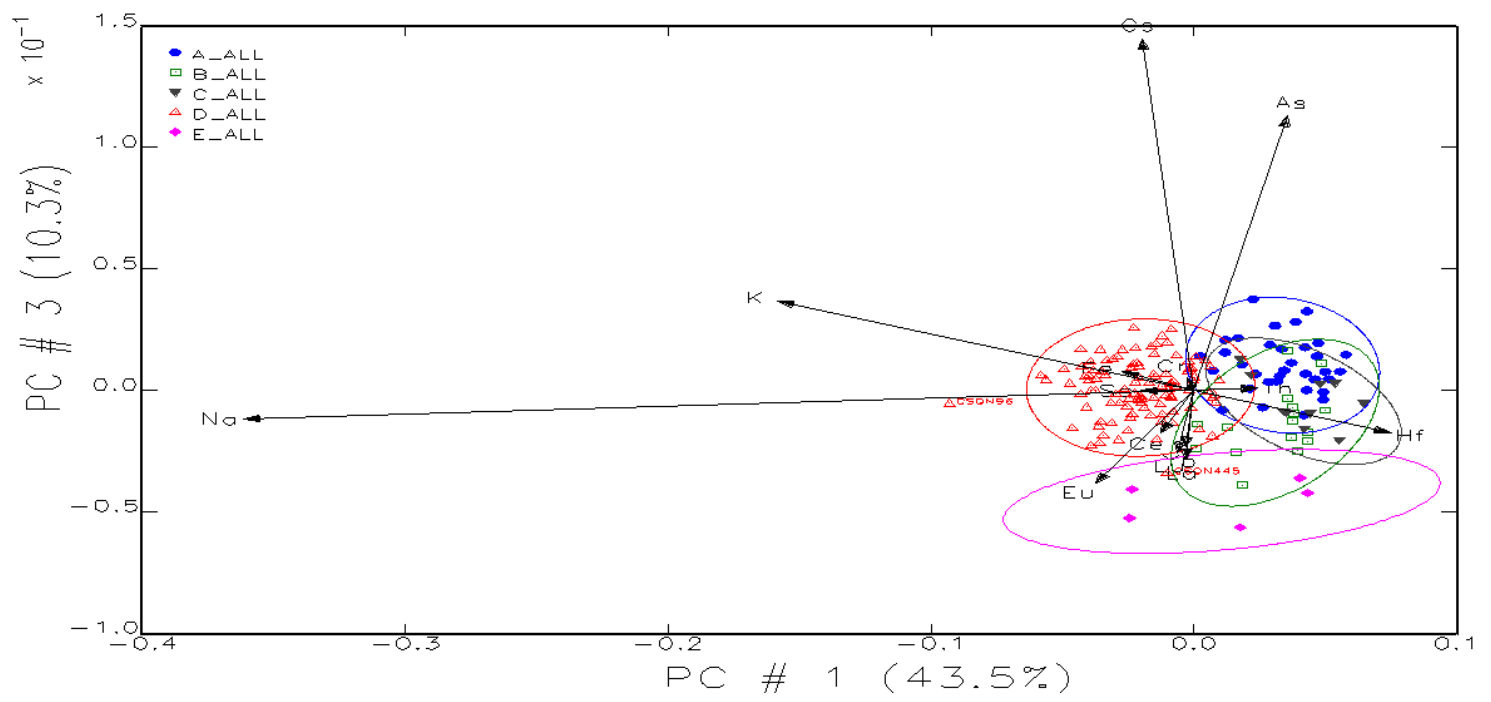

Figura 7.7 - Escores na primeira e terceira componentes principais dos dados do Cenário 1 para os sítios Lago Grande e Osvaldo. As elipses representam a região de confiança de $95 \%$.

Observou-se, pela Fig. 7.6, que o grupo químico que mais se distingue dos demais é o grupo C, compreendendo as argilas queimadas do sítio Osvaldo. Esse fato está de acordo com o esperado, pois a inspeção univariada dos dados da Tab. 7.2 já havia detectado diferenças observáveis para as argilas. O grupo E apareceu sobreposto aos demais e verificou-se que a terceira componente principal é que mais diferencia esse grupo (Fig. 7.7). Pelos coeficientes de ponderação na Tab. 7.7, conclui-se que os elementos desse grupo diferenciam-se dos demais principalmente pelas concentrações dos elementos Cs e As. Esses elementos já foram reportados como passíveis de efeitos pós-deposicionais, como será discutido adiante nesta seção.

A dominância dos elementos $\mathrm{Na}$ e $\mathrm{K}$ nas duas primeiras componentes fica ainda mais evidente graficamente, pela visualização do tamanho da projeção dos vetores relativos a $\mathrm{Na}$ e K no modo RQ da análise de componentes principais nas Fig. 7.6 e 7.7. Como já discutido nos Capítulos 1 e 3, os elementos-traço, como terras raras e metais de transição, são os elementos químicos que geralmente distinguem diferentes fontes de argila ou pastas cerâmicas, por terem um comportamento geoquímico distinto, característico do ambiente geológico. Portanto, a dominância de Na e K nas análises deve ser explicada e, para isso, formularam-se hipóteses para a geoquímica desses dois metais alcalinos nas amostras deste trabalho.

Inicialmente, foi analisada a possibilidade de a transformação logarítmica dos dados não ter sido suficiente para compensar a diferença de magnitude desses 
macroelementos em relação aos elementos-traço. Contudo, um argumento contra essa hipótese seria a observação dos coeficientes de ponderação do elemento Fe nas primeiras quatro componentes principais na Tab. 7.7. Não há dominância crítica desse elemento em nenhuma das componentes, embora ele seja o macroelemento com as maiores concentrações na base de dados, segundo a Tab. 7.2. Assim, essa hipótese foi refutada.

A seguir, repetiu-se a análise PCA para os mesmos grupos definidos nas Fig. 7.6 e 7.7, extraindo-se o elemento Na das análises, com o objetivo de se verificar seu efeito na estrutura dos dados. Os coeficientes de ponderação dos autovetores que representam o peso das variáveis originais são listados na Tab. 7.8 para as primeiras quatro componentes principais, juntamente com os autovalores (variância), a porcentagem de variância representada por cada componente, e a variância acumulada. Os valores hachurados representam os maiores coeficientes de ponderação para cada componente. As Fig. 7.8 e 7.9 ilustram a projeção dos dados nas três primeiras componentes principais para 13 elementos do Cenário 1, sem o Na, para PCA modo RQ.

Tabela 7.8 - Coeficientes de ponderação e variância das quatro primeiras componentes principais para o Cenário 1, sem o Na, com dados de Lago Grande e Osvaldo.

\begin{tabular}{ccccc}
\hline Variável & PC1 & PC2 & PC3 & PC4 \\
\hline $\mathrm{K}$ & $-0,10657$ & $-0,78991$ & 0,272677 & $-0,01686$ \\
$\mathrm{Sc}$ & 0,183118 & $-0,15037$ & 0,109916 & 0,035468 \\
$\mathrm{Cr}$ & 0,232825 & $-0,08961$ & 0,031759 & 0,036028 \\
$\mathrm{Fe}$ & 0,205126 & $-0,19319$ & 0,086652 & 0,098788 \\
$\mathrm{As}$ & 0,308072 & $-0,23556$ & $-0,48503$ & 0,736837 \\
$\mathrm{Cs}$ & 0,072732 & $-0,33375$ & $-0,70026$ & $-0,60111$ \\
$\mathrm{La}$ & 0,302074 & $-0,00123$ & 0,154569 & $-0,10023$ \\
$\mathrm{Ce}$ & 0,338605 & $-0,09459$ & 0,167214 & $-0,15829$ \\
$\mathrm{Eu}$ & 0,339843 & $-0,10647$ & 0,284383 & $-0,16999$ \\
$\mathrm{Yb}$ & 0,271774 & 0,017424 & 0,105821 & $-0,0203$ \\
$\mathrm{Lu}$ & 0,285858 & 0,034404 & 0,098877 & $-0,01208$ \\
$\mathrm{Hf}$ & 0,43743 & 0,345358 & $-0,16015$ & $-0,12919$ \\
$\mathrm{Th}$ & 0,300518 & 0,012102 & $-0,00934$ & $-0,04358$ \\
\hline Autovalor & 0,087571 & 0,046181 & 0,037861 & 0,02915 \\
Variância $(\%)$ & 35,7 & 18,8 & 15,4 & 11,9 \\
Var. Acum. $(\%)$ & 35,7 & 54,5 & 69,9 & 81,8 \\
\hline
\end{tabular}




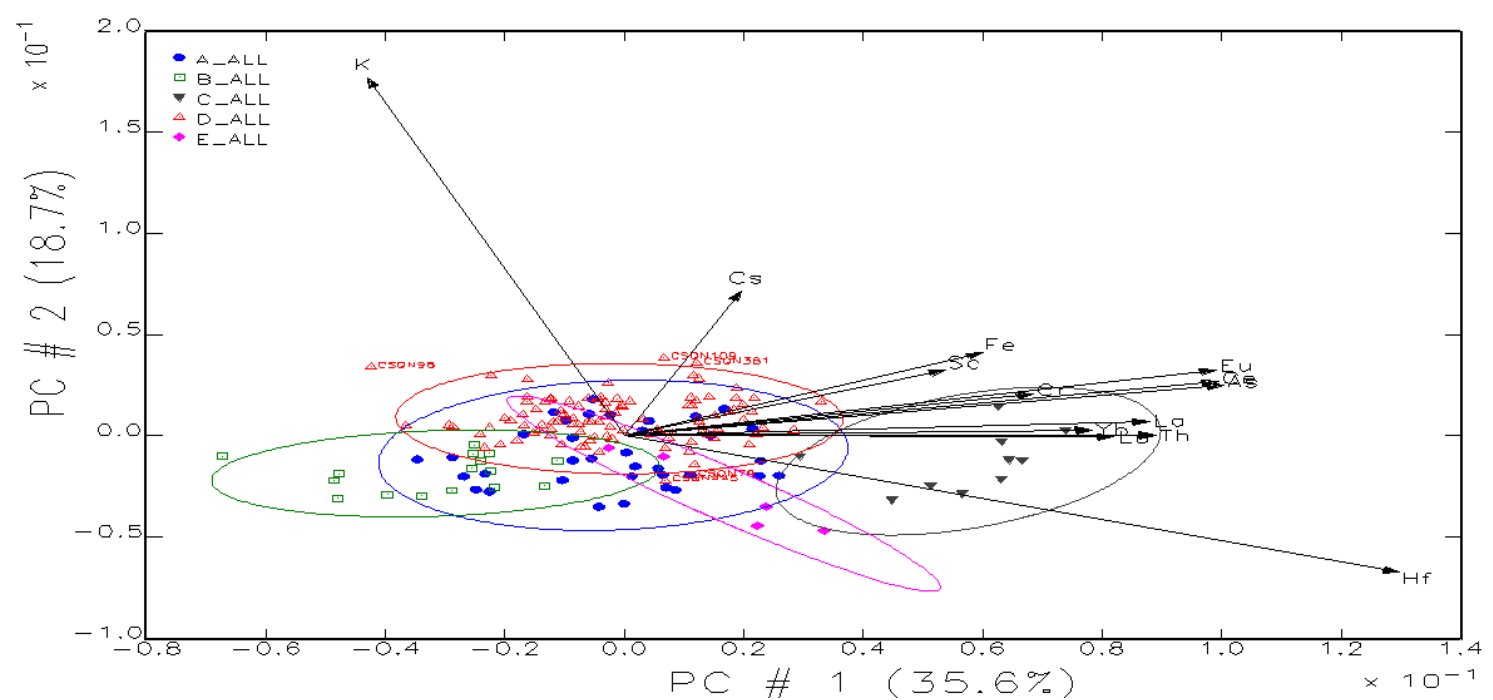

Figura 7.8 - Escores nas duas primeiras componentes principais dos dados do Cenário 1, sem o $\mathrm{Na}$, para os sítios Lago Grande e Osvaldo. As elipses representam a região de confiança de $95 \%$.

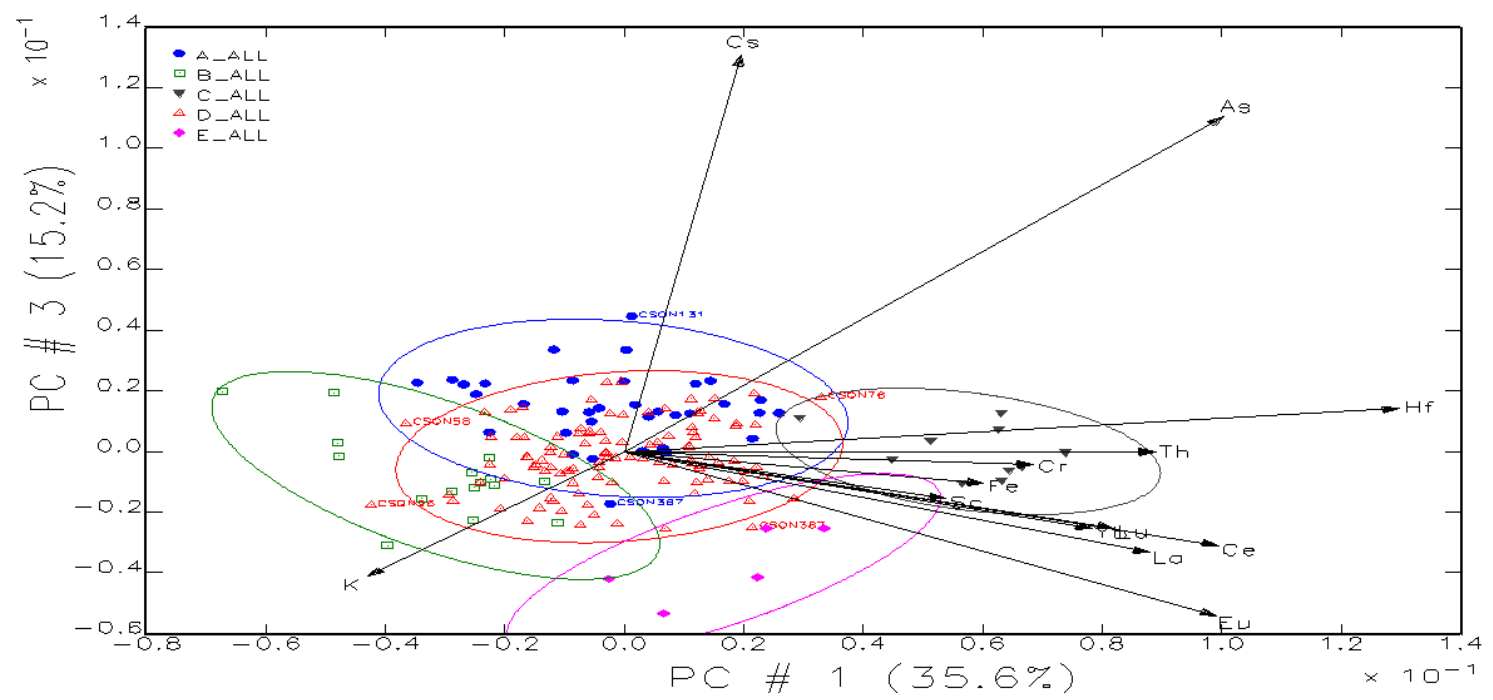

Figura 7.9 - Escores na primeira e terceira componentes principais dos dados do Cenário 1, sem o $\mathrm{Na}$, para os sítios Lago Grande e Osvaldo. As elipses representam a região de confiança de $95 \%$.

A Tab. 7.8 indica que as duas primeiras componentes principais, as mais utilizadas em redução de dados, representam conjuntamente $54,5 \%$ da variância total do sistema. Os coeficientes de ponderação da PC1 indicaram dominância dos elementos Hf, Eu e Ce, embora outros elementos também apresentem coeficientes de ponderação relativamente significativos. Os coeficientes da PC1 indicam um balanço maior entre elementos químicos na primeira componente principal, quando comparada com análise incluindo o sódio (Tab. 7.7). A segunda componente é dominada pelo elemento K. A terceira e quarta componentes principais são dominadas por Cs e As. 
Na Fig. 7.8, observou-se graficamente a dominância mais equilibrada de elementos químicos pela comparação do tamanho da projeção dos vetores na primeira componente principal, quando comparada às mesmas projeções para o Cenário 1 na Fig. 7.6. Nas duas projeções das Fig. 7.8 e 7.9, os grupos A e D apareceram mais superpostos, em comparação com a análise PCA com o elemento Na.

Observando-se as médias para o elemento sódio, verificou-se que o grupo A é o que apresenta a menor concentração, igual a $0,60 \mathrm{mg} / \mathrm{g}$, sendo a mais próxima à concentração do grupo das argilas, igual a $0,55 \mathrm{mg} / \mathrm{g}$. O grupo B apresentou concentração de sódio igual a 0,63 mg/g; o grupo D, igual a 2,69 mg/g; e o grupo E, igual a 1,70 mg/g. O grupo A pode representar um grupo para o qual houve pouca inserção de antiplásticos à pasta cerâmica e/ou não houve nenhum efeito diagenético significativo para o Na. Assim, a extração desse elemento com grande coeficiente de ponderação na primeira componente principal (Tab. 7.7) foi a responsável pelo aumento da superposição dos grupos A e D nas Fig. 7.8 e 7.9, em relação às Fig. 7.6 e 7.7, já que a concentração de sódio era a principal diferença entre esses grupos. Se considerados posteriormente, esses grupos químicos iriam prejudicar a interpretação dos dados do ponto de vista arqueológico, devido a indícios identificados de modificação nas concentrações de sódio.

As evidências de que a concentração desse elemento tenha sido alterada por efeitos diagenéticos no contexto deposicional das cerâmicas de Lago Grande e Osvaldo são resumidas a seguir:

a. A partir da discussão da Fig. 7.3, observou-se a tendência a um alto enriquecimento de $\mathrm{Na}$ em relação às argilas de Osvaldo, contrária à tendência para a maior parte dos elementos, e numa magnitude de efeito maior;

b. O antiplástico cauixi não apresentou concentrações significativas de $\mathrm{Na}$ que justificassem as alterações desse elemento (Tab. 7.3). A concentração de $\mathrm{Na}$ em cauixi representa em torno de $3 \%$ da concentração desse mesmo elemento nas cerâmicas arqueológicas. Assim, o efeito do antiplástico seria de diluição, e não de enriquecimento (seção 7.1.3);

c. Os baixos coeficientes de correlação desse elemento (Tab. 7.4). Esses baixos coeficientes podem ser indicativos de fenômenos geoquímicos que afetem preferencialmente o sódio (seção 7.1.6); 
d. A dominância do elemento Na nas componentes principais, sendo responsável pela definição de grupos, sem que haja algum fator que justifique a preponderância desse elemento como diferenciador preferencial de contextos geoquímicos na região de confluência dos rios Negro e Solimões, como a utilização de argilas calcáreas (Buxeda i Garrigós et al., 2001);

e. Evidências na literatura de que uma mudança no perfil de sódio é possível em cerâmicas queimadas a baixas temperaturas (Buxeda i Garrigós et al., 2002; Bishop, 2003; Schwedt et al., 2004).

Assim, decidiu-se pela exclusão do elemento químico $\mathrm{Na}$ das análises multivariadas, pois a dominância desse elemento na análise de componentes principais, associada a evidências de efeitos diagenéticos, obscureceria padrões que refletissem aspectos culturais de interesse, devido às anomalias em suas concentrações e alta variabilidade.

No intuito de se elaborar hipóteses acerca dos possíveis mecanismos de alteração de sódio nas amostras, foi feita uma pesquisa na literatura geoquímica da região. Dois fatores críticos para efeitos diagenéticos são a temperatura de queima e o ambiente deposicional (Buxeda i Garrigós et al., 2001). Verificou-se que a região amazônica é caracterizada por forte intemperismo químico de sedimentos (Vital \& Stattegger, 2000). $\mathrm{Na}$ calha principal do rio Amazonas, o mineral mais abundante encontrado por Martinelli et al. (1993) foi plagioclásio sódico, com uma concentração média de $29 \pm 7 \%$ ( $\mathrm{n}=18$ ), seguido por quartzo, com $24 \% \pm 11 \%(\mathrm{n}=18)$. Os autores notaram que as concentrações dos minerais quartzo e caulinita aumentavam, enquanto as de Na-plagioclásio, Caplagioclásio e smectita-vermiculita diminuíam a jusante do rio Amazonas, como indicação de maior maturidade dos sedimentos ao longo da calha do rio.

Quando a descarga de água aumenta na região da Amazônia Central, os rios transbordam e a matéria suspensa nos mesmos acumula-se nos sedimentos de várzea (Viers et al., 2005). O período de cheia do rio Amazonas é de novembro a julho, e diminui entre julho e outubro. Os sedimentos superficiais das planícies de inundação são expostos nos períodos secos, quando ficam isolados das águas do rio Solimões/Amazonas.

Os elementos químicos mobilizados por intemperismo de silicatos, como feldspatos, reportados por Gaillardet et al. (1997) foram Rb, U, Ba, K, Na, Sr e Ca. A 
concentração desses elementos apresentou uma diminuição alta nas fases suspensas em rios da bacia amazônica, em relação às suas concentrações na crosta continental superior.

A partir desse quadro ambiental, propôs-se a hipótese de um dos mecanismos de alteração no elemento $\mathrm{Na}$, que resultou em seu enriquecimento nas cerâmicas ao longo do tempo, ser devido à disponibilidade de sódio na região, a partir do intemperismo de feldspatos à caulinita dos sedimentos advindos de regiões andinas e sub-andinas, pelo ciclo de depósito desses sedimentos nas planícies de inundação e subsequente reinserção ao fluxo do rio Amazonas (Martinelli et al., 1993). Minerais argilosos podem ser utilizados como indicadores da fonte de sedimentos, intensidade de intemperismo, e maturidade de rochas sedimentares e de sedimentos fluviais e marinhos. Um desses minerais é a caulinita, que pode ser produzida pelo intenso intemperismo em ambientes tropicais úmidos (Guyot et al., 2007). Esse processo liberaria $\mathrm{Ca}, \mathrm{Na}$ e $\mathrm{Mg}$ das estruturas minerais. O elemento sódio seria então liberado em meio aquoso (Martinelli et al., 1993) e migraria ao longo das camadas mais profundas de solo, atingindo os fragmentos cerâmicos. Assim, pela repetição dos ciclos de cheia e seca ao longo do tempo, o intemperismo de feldspatos seria um dos mecanismos responsáveis pela disponibilidade de sódio elementar no contexto deposicional dos fragmentos cerâmicos estudados neste projeto.

Além disso, Gaillardet et al. (1997), também reportaram que a água da chuva pode ser uma fonte de $\mathrm{NaCl}$, pela análise da presença de cloro na água dos rios da região, uma vez que a concentração desse elemento em rochas é muito baixa para ser atribuída a efeito de intemperismo. No Rio Negro, foi calculado que $54 \%$ de sódio era de fonte atmosférica, e $46 \%$ de intemperismo de silicatos; enquanto que no rio Solimões, $16 \%$ era de fonte atmosférica, $25 \%$ pelo intemperismo de silicatos e $36 \%$ pelo intemperismo de evaporitos (Gaillardet et al., 1997, pág. 161).

Dessa forma, a hipótese levantada neste trabalho para explicar a anomalia das concentrações de sódio nas amostras é devida a uma combinação de intemperismo de feldspatos e disponibilidade de cloreto de sódio de águas pluviais. Há ainda a possibilidade de inserção deliberada de areia ou fragmentos de rochas, na qual feldspatos contendo sódio estivessem em quantidade considerável (Costa et al., 2004), embora essa hipótese não seja suficiente para explicar toda a variação desse elemento (ver seção 7.2).

Estudou-se, também, a influência do elemento $\mathrm{K}$ nas análises, outro elemento dominante na primeira componente principal (Tab. 7.7). Após a exclusão do sódio, verificou-se que esse elemento é dominante na segunda componente principal, pelo seu 
coeficiente de ponderação na Tab. 7.8. As evidências de que a concentração desse elemento tenha sido alterada por efeitos diagenéticos no contexto deposicional das cerâmicas de Lago Grande e Osvaldo são resumidas a seguir:

a. A partir da discussão da Fig. 7.3, observou-se a tendência a um enriquecimento de $\mathrm{K}$ com relação às argilas de Osvaldo, contrária à tendência para a maior parte dos elementos químicos analisados;

b. O antiplástico cauixi não apresentou concentrações significativas de $\mathrm{K}$ que justificassem as alterações desse elemento (Tab. 7.3). A concentração de K em cauixi representa em torno de $11 \%$ da concentração do mesmo elemento nas cerâmicas. Assim, o efeito do antiplástico seria de diluição, e não de enriquecimento (seção 7.1.3).

c. Os baixos coeficientes de correlação desse elemento (Tab. 7.4). Esses baixos coeficientes podem indicar fenômenos geoquímicos que afetem preferencialmente o K (seção 7.1.6).

d. A dominância do elemento K na PCA (cujo coeficiente de ponderação na primeira componente principal é somente menor que o do Na, segundo Tab. 7.7) sem que haja algum fator que justifique a preponderância desse elemento como diferenciador preferencial de contextos geoquímicos na região de confluência dos rios Negro e Solimões.

e. Evidências na literatura de que uma mudança no perfil de potássio é possível em cerâmicas arqueológicas (Bishop, 2003).

Assim, pela importância relativa de potássio na análise de componentes principais, associada a evidências de efeitos diagenéticos atuantes nesse elemento, decidiuse pela sua exclusão das análises multivariadas. O princípio norteador dessa exclusão, de maneira análoga ao $\mathrm{Na}$, é o de minimizar variabilidade química elementar associada a outros fatores que não os naturais e culturais, os quais não refletiriam aspectos de interesse arqueológico.

De maneira análoga à análise do elemento $\mathrm{Na}$, levantou-se a hipótese de as alterações diagenéticas atuantes no elemento $\mathrm{K}$ serem devidas ao intemperismo de feldspatos (potássicos) na região de confluência dos rios Negro e Solimões. Outra hipótese seria a inserção deliberada de areia ou fragmentos de rochas, na qual feldspato potássico 
estivesse em quantidade considerável (Costa et al., 2004), embora essa hipótese não seja suficiente para explicar toda a variação desse elemento, ou mesmo do sódio (seção 7.2).

Foram calculados os coeficientes de correlação de Pearson entre os elementos alcalinos Na, K e Cs dentro de cada sítio. Para Lago Grande, a maior correlação de Na foi observada com o elemento $\mathrm{K}\left(\mathrm{r}_{\mathrm{Na}, \mathrm{K}}=0,62\right)$. As demais correlações foram consideradas baixas, sendo $\mathrm{r}_{\mathrm{Na}, \mathrm{Cs}}=-0,01$ ( $\mathrm{p}>0,05$; não sendo estatisticamente significativa) e $\mathrm{r}_{\mathrm{K}, \mathrm{Cs}}=$ 0,12 ( $\mathrm{p}>0,05$; não sendo estatisticamente significativa). Para Osvaldo, a maior correlação de $\mathrm{Na}$ foi observada com o elemento $\mathrm{K}\left(\mathrm{r}_{\mathrm{Na}, \mathrm{K}}=0,55\right)$. As demais correlações foram $\mathrm{r}_{\mathrm{Na}, \mathrm{Cs}}=$ 0,45 e $r_{K, C s}=0,16$ ( $p>0,05$, não sendo estatisticamente significativa). A correlação relativamente alta entre sódio e potássio nos dois sítios sugere que os mecanismos diagenéticos afetando esses dois elementos seriam parcialmente correlacionados, favorecendo a hipótese de esses elementos terem sido alterados pelo intemperismo de feldspatos alcalinos (combinações de feldspatos sódicos e potássicos) na região de confluência dos rios Negro e Solimões.

A partir da base de dados com 12 elementos após a exclusão de $\mathrm{Na}$ e K (As, $\mathrm{La}, \mathrm{Lu}, \mathrm{Yb}, \mathrm{Ce}, \mathrm{Cr}, \mathrm{Cs}, \mathrm{Eu}, \mathrm{Fe}, \mathrm{Hf}, \mathrm{Sc}$ e Th), realizaram-se outras análises de agrupamento para analisar possíveis grupos químicos de cerâmicas que não fossem determinados pela influência de $\mathrm{Na}$ e K na base de dados (seção 7.1.8).

Assim como para $\mathrm{Na}$ e K, foram identificadas evidências de possíveis efeitos diagenéticos afetando os elementos Cs e As, pelos baixos coeficientes de correlação, e por parâmetros calculados a partir da matriz de variação, na qual também foi identificada evidência de possível efeito diagenético atuante no elemento Hf (ver seção 7.1.10). Assim, foram realizadas duas análises de agrupamento para dois novos cenários definidos a partir da extração de elementos do Cenário 1. O Cenário 2 foi originado a partir do Cenário 1, pela exclusão de sódio e potássio:

Cenário 2: Os 12 elementos As, La, Lu, Yb, Ce, Cr, Cs, Eu, Fe, Hf, Sc e Th com transformação logarítmica $\log _{10}$.

E o Cenário 3 foi definido a partir do Cenário 2, pela exclusão de As, Cs e Hf:

Cenário 3: Os 9 elementos La, Lu, Yb, Ce, Cr, Eu, Fe, Sc e Th com transformação logarítmica $\log _{10}$. 
A definição desses cenários deu-se com o objetivo de analisar os efeitos das possíveis alterações diagenéticas em $\mathrm{Cs}$, As e Hf nas análises multivariadas e alguma possível perda de informação pela sua exclusão. A seguir, são apresentados alguns comentários sobre o que já foi relatado na literatura sobre esses elementos, cujas implicações para este trabalho foram consideradas relevantes.

O elemento As geralmente não é utilizado pelo grupo de arqueometria de Bonn, de Hans Mommsen, assim como os elemento Na, Ca e Ba (Schwedt et al., 2004; Mommsen, 2004; Schwedt \& Mommsen, 2007), devido à sua alta dispersão frequentemente identificada dentro de grupos químicos de cerâmicas. No caso do arsênio, o processo de queima pode ser responsável pela alta dispersão desse elemento, embora a hipótese de alta variabilidade natural das fontes de argila também seja plausível (Schwedt et al., 2004). Nas amostras analisadas de Lago Grande e Osvaldo, a dispersão de As está entre as maiores (Tab. 7.2). Dentre os elementos químicos do Cenário 1, apenas $\mathrm{Na}$ e K apresentaram desvios-padrão relativos maiores que As nas amostras de Lago Grande; e apenas $\mathrm{Na}$ apresentou desvio-padrão maior, no caso de Osvaldo. Considerando-se que Na e $\mathrm{K}$, com altas dispersões, foram afetados por efeitos diagnéticos, essa dispersão alta para As pode ser indicativa do efeito do processo de queima, ou outro efeito sem relevância arqueológica para este trabalho.

O elemento Cs pode ser afetado por mecanismos de substituição iônica, com outros elementos alcalinos. Schwedt et al. (2004) já reportaram alterações desse elemento que, junto com outros metais alcalinos, foram fortemente afetados por alterações no contexto deposicional de cerâmicas micênicas, encontradas na península do Peloponeso. Os autores chegaram a essas conclusões pela análise de amostras da superfície e do centro de fragmentos cerâmicos. Não é possível afirmar se as alterações potenciais de césio neste trabalho são de enriquecimento ou lixiviação. Em caso de enriquecimento, uma explicação possível do efeito seria a alta capacidade de troca catiônica exibida por cerâmicas queimadas a baixas temperaturas, abaixo de $750^{\circ} \mathrm{C}$ (ver temperaturas na seção 7.3 ), já que sua capacidade de adsorção em argilas, principalmente no mineral argiloso ilita, é muito maior que a capacidade dos demais elementos alcalinos (Gauddette et al., 1966). Por apresentar o menor raio iônico hidratado dentre os elementos alcalinos, o elemento césio poderia se mover facilmente do ambiente para o corpo cerâmico.

Schwedt et al. (2004) também apontaram que alterações diagenéticas podem ocorrer no elemento Hf, embora em menor intensidade em relação aos metais alcalinos. 
Numa simulação de PCA, extraindo-se os elementos Na, K, Cs e As do Cenário 1, verificou-se que o elemento $\mathrm{Hf}$ apresentou os maiores coeficientes de ponderação nas duas primeiras componentes principais, fazendo com que sua influência seja crítica, caso alterações diagenéticas estejam afetando esse elemento. Além disso, cálculos a partir da matriz de variação dos dados (seção 7.1.10) também forneceram evidências adicionais de que esse elemento pode ter sofrido alterações nas amostras de Lago Grande e Osvaldo.

Foi então realizada uma nova PCA a partir do corte mínimo da análise de agrupamentos para o Cenário 2 (seção 7.1.8), na qual foram definidos quatro grupos químicos de cerâmicas. Os coeficientes de ponderação dos autovetores que representam o peso das variáveis originais são listados na Tab. 7.9 para as primeiras quatro componentes principais, juntamente com os autovalores (variância), a porcentagem de variância representada por cada componente, e a variância acumulada. Os valores hachurados representam os maiores coeficientes de ponderação para cada componente.

Tabela 7.9 - Coeficientes de ponderação e variância das quatro primeiras componentes principais para o Cenário 2, com dados de Lago Grande e Osvaldo.

\begin{tabular}{ccccc}
\hline Variável & PC1 & PC2 & PC3 & PC4 \\
\hline $\mathrm{Sc}$ & 0,190515 & $-0,03343$ & 0,036989 & 0,261827 \\
$\mathrm{Cr}$ & 0,236452 & 0,001912 & 0,04246 & 0,120949 \\
$\mathrm{Fe}$ & 0,214454 & 0,002313 & 0,107019 & 0,261526 \\
$\mathrm{As}$ & 0,30449 & 0,515702 & 0,758891 & $-0,00383$ \\
$\mathrm{Cs}$ & 0,064625 & 0,807795 & $-0,56345$ & 0,096417 \\
$\mathrm{La}$ & 0,308301 & $-0,12389$ & $-0,09067$ & 0,078564 \\
$\mathrm{Ce}$ & 0,344294 & $-0,09255$ & $-0,16276$ & 0,297265 \\
$\mathrm{Eu}$ & 0,349011 & $-0,18799$ & $-0,16559$ & 0,36938 \\
$\mathrm{Yb}$ & 0,277383 & $-0,10413$ & $-0,01568$ & $-0,05986$ \\
$\mathrm{Lu}$ & 0,289239 & $-0,09812$ & $-0,01432$ & $-0,1292$ \\
$\mathrm{Hf}$ & 0,422916 & $-0,0259$ & $-0,16394$ & $-0,7644$ \\
$\mathrm{Th}$ & 0,300097 & 0,000242 & $-0,05029$ & $-0,05953$ \\
\hline Autovalor & 0,086756 & 0,039022 & 0,030048 & 0,025148 \\
Variância $(\%)$ & 41,5 & 18,7 & 14,4 & 12,0 \\
Var. Acum. $(\%)$ & 41,5 & 60,2 & 74,6 & 86,6 \\
\hline
\end{tabular}

As Fig. 7.10 e 7.11 ilustram a projeção dos dados nas três primeiras componentes principais para o Cenário 2, para PCA modo RQ. 


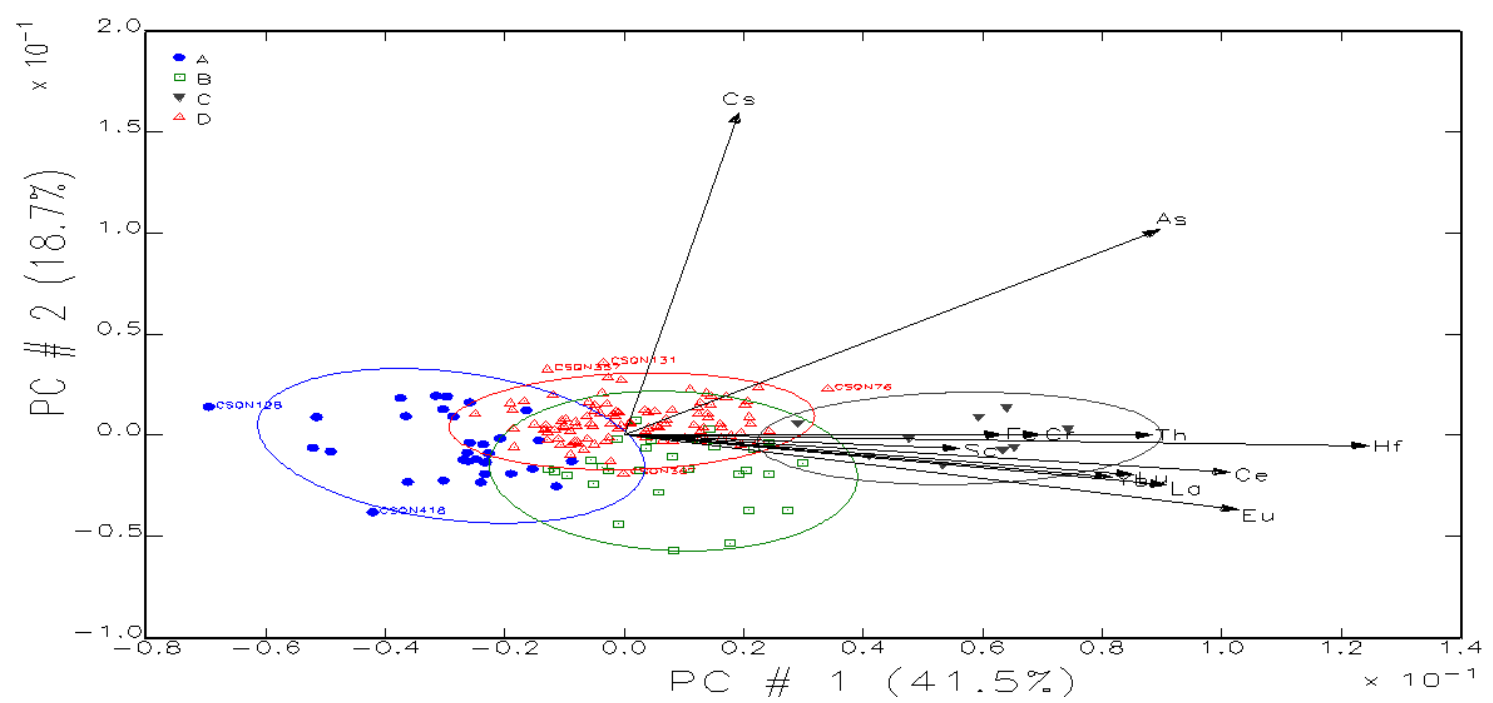

Figura 7.10 - Escores nas duas primeiras componentes principais dos dados do Cenário 2 para os sítios Lago Grande e Osvaldo. As elipses representam a região de confiança de $95 \%$.

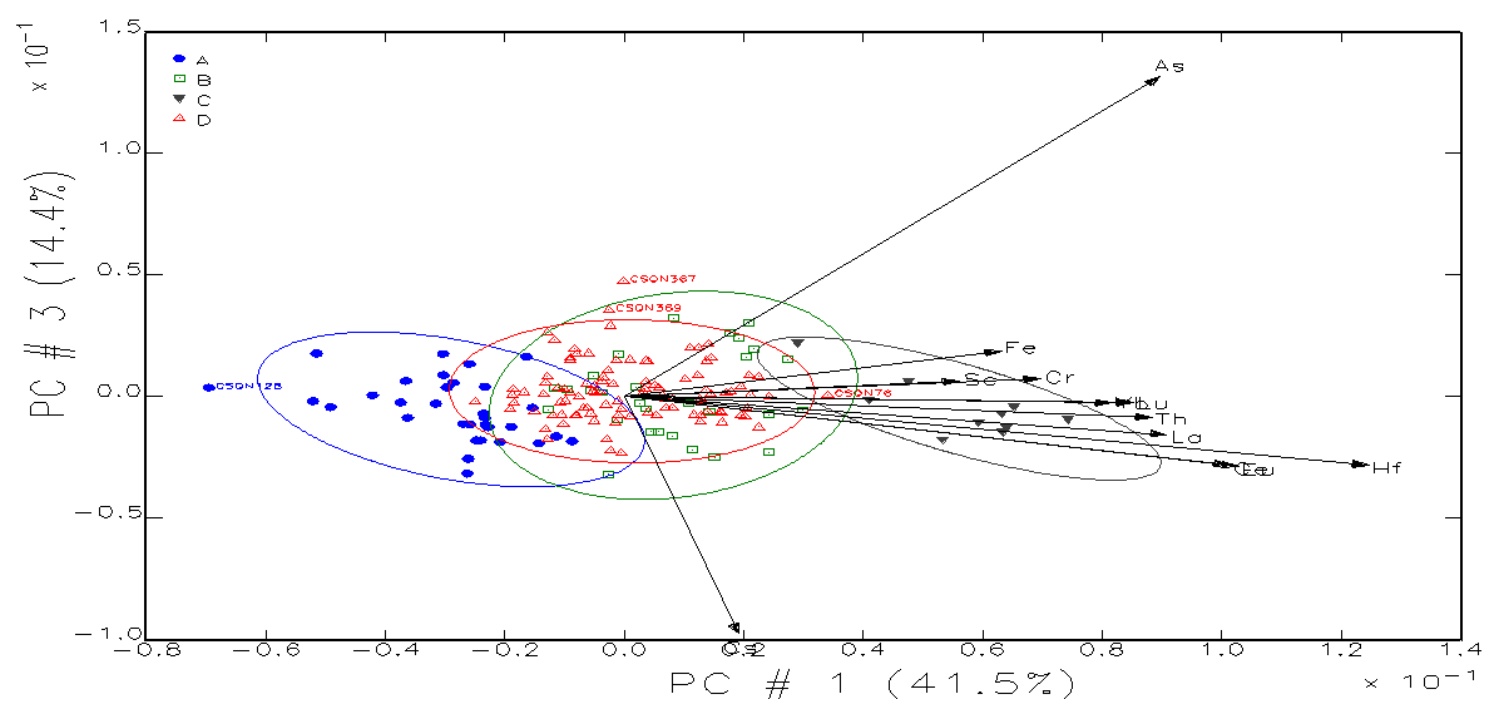

Figura 7.11 - Escores na primeira e terceira componentes principais dos dados do Cenário 2 para os sítios Lago Grande e Osvaldo. As elipses representam a região de confiança de $95 \%$.

A Tab. 7.9 indica que as duas primeiras componentes principais, as mais utilizadas em redução de dados, representam conjuntamente 60,2\% da variância total do sistema. Pela mesma tabela, observou-se que a extração dos elementos químicos $\mathrm{Na}$ e K resultou em uma primeira componente principal com dominância mais equilibrada de elementos químicos, sendo os maiores coeficientes relativos aos elementos $\mathrm{Hf}, \mathrm{Eu}$ e Ce, embora outros elementos, como La, As e Th também apresentem coeficientes de 
ponderação comparativamente significativos. Verificou-se que o elemento Hf, um dos elementos analisados quanto à sua possível exclusão, também domina a quarta componente. Juntas, a primeira e quarta componente representam $54 \%$ da variância do sistema. A segunda e terceira componentes são dominadas pelos elementos Cs e As, cujos perfis químicos elementares podem ter sido alterados em função de alterações diagenéticas, como discutido anteriormente. A influência dominante desses elementos nessas componentes também pode ser observada nas Fig. 7.10 e 7.11, pelo tamanho da projeção dos vetores desses elementos em PC2 e PC3. Juntas, essas componentes representam 33\% da variância do sistema. Assim, a necessidade de se analisar a extração de Hf, Cs e As foi novamente justificada, em virtude de sua importância na PCA.

Pelas projeções PC2 vs. PC1 (Fig 7.10) e PC3 vs. PC1 (Fig. 7.11), observou-se que os grupos A e C são os que apresentam elipses mais distintas das demais. As elipses dos grupos B e D apresentaram as maiores superposições, indicando que a junção desses dois grupos, gerando uma partição de dados em três grupos químicos, seria plausível.

Para comparação com o Cenário 2, foi realizada uma nova PCA a partir do corte para quatro grupos químicos de cerâmica na análise de agrupamentos para o Cenário 3 (seção 7.1.8). Os coeficientes de ponderação dos autovetores que representam o peso das variáveis originais são listados na Tab. 7.10 para as primeiras quatro componentes principais, juntamente com os autovalores (variância), a porcentagem de variância representada por cada componente, e a variância acumulada. Os valores hachurados representam os maiores coeficientes de ponderação para cada componente.

As Fig. 7.12 e 7.13 ilustram a projeção dos dados nas três primeiras componentes principais para o Cenário 3, para a PCA modo RQ.

A Tab. 7.10 indica que as duas primeiras componentes principais, as mais utilizadas em redução de dados, representam conjuntamente $77,4 \%$ da variância total do sistema. Pela mesma tabela, observou-se que a extração dos elementos químicos Cs, As e Hf resultou em uma primeira componente principal equilibrada na dominância de elementos químicos, sendo os maiores coeficientes relativos aos elementos $\mathrm{Eu}, \mathrm{Ce}$ e La. Os elementos com maiores coeficientes de ponderação na segunda componente foram $\mathrm{Fe}, \mathrm{Sc}$, $\mathrm{La}$ e $\mathrm{Cr}$; na terceira componente, foram $\mathrm{Ce}, \mathrm{Lu}$ e $\mathrm{Yb}$; e na quarta componente, foram $\mathrm{Th}$, Eu e Fe. 
Tabela 7.10 - Coeficientes de ponderação e variância das quatro primeiras componentes principais para o Cenário 3, com dados de Lago Grande e Osvaldo.

\begin{tabular}{ccccc}
\hline Variável & PC1 & PC2 & PC3 & PC4 \\
\hline Sc & 0,242955 & 0,375888 & 0,068551 & $-0,02254$ \\
$\mathrm{Cr}$ & 0,269036 & 0,351793 & $-0,13096$ & 0,165569 \\
$\mathrm{Fe}$ & 0,254458 & 0,622113 & $-0,23252$ & $-0,41584$ \\
$\mathrm{La}$ & 0,369211 & $-0,35614$ & 0,00648 & 0,018445 \\
$\mathrm{Ce}$ & 0,438936 & $-0,00086$ & 0,565513 & 0,370232 \\
$\mathrm{Eu}$ & 0,44679 & $-0,16850$ & 0,3792 & $-0,53524$ \\
$\mathrm{Yb}$ & 0,298202 & $-0,28636$ & $-0,38879$ & $-0,12265$ \\
$\mathrm{Lu}$ & 0,288499 & $-0,31095$ & $-0,48823$ & $-0,06399$ \\
$\mathrm{Th}$ & 0,321069 & 0,118313 & $-0,2663$ & 0,596762 \\
\hline Autovalor & 0,063214 & 0,012529 & 0,008619 & 0,005502 \\
Variância $(\%)$ & 64,6 & 12,8 & 8,8 & 5,6 \\
Var. Acum. $(\%)$ & 64,6 & 77,4 & 86,2 & 91,8 \\
\hline
\end{tabular}

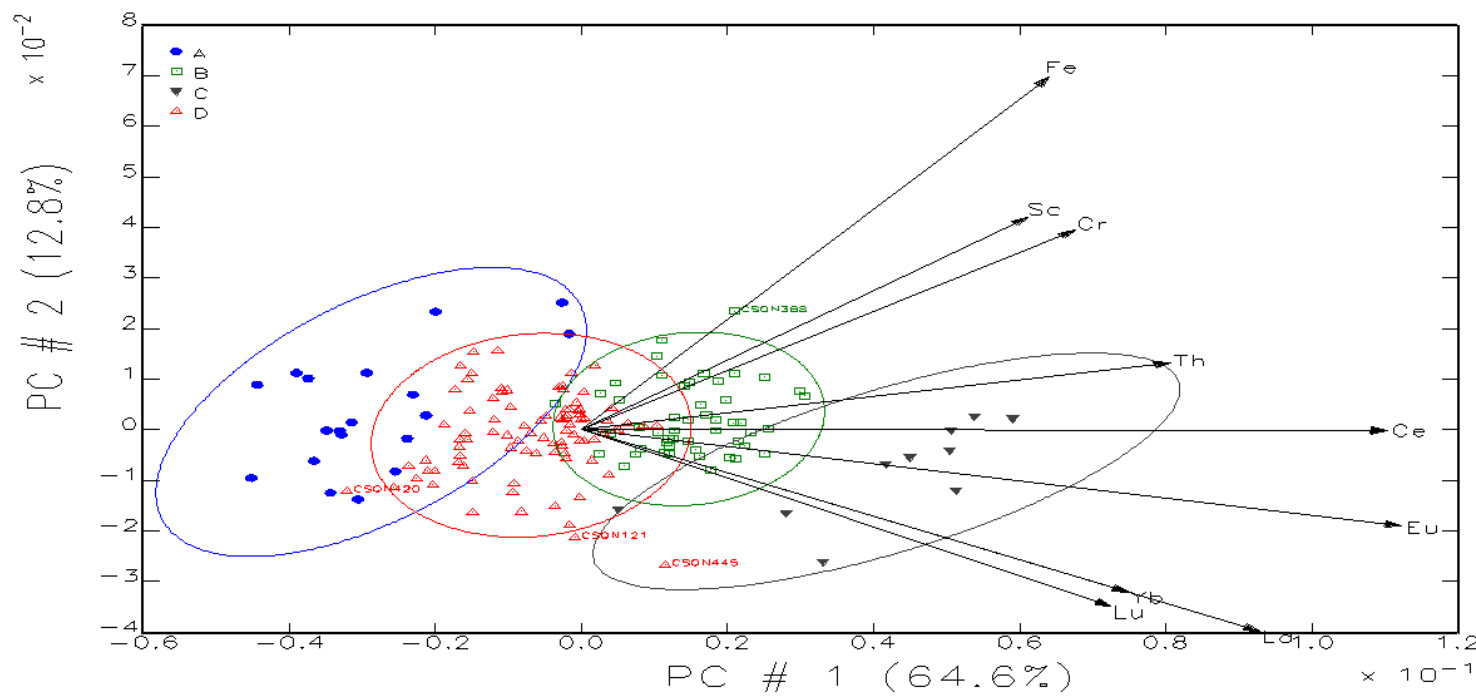

Figura 7.12 - Escores nas duas primeiras componentes principais dos dados do Cenário 3 para os sítios Lago Grande e Osvaldo. As elipses representam a região de confiança de $95 \%$. 


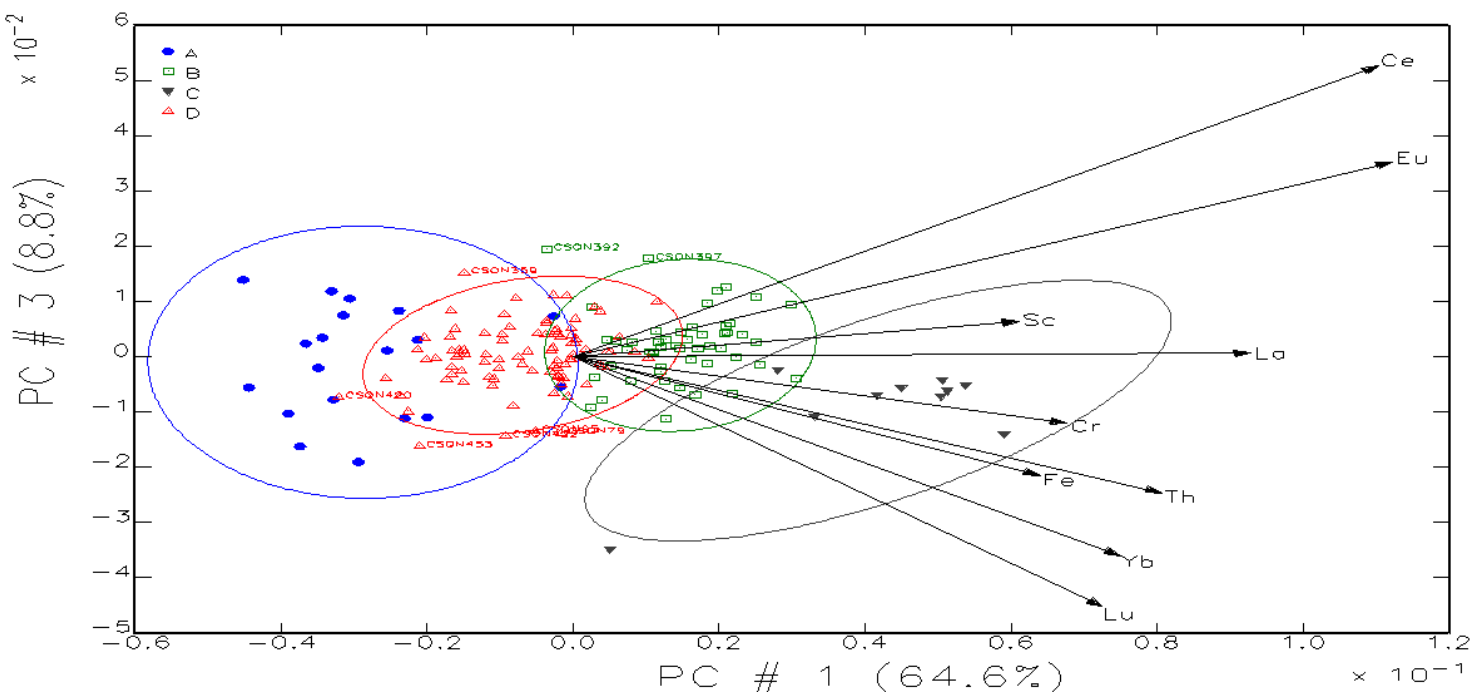

Figura 7.13 - Escores na primeira e terceira componentes principais dos dados do Cenário 3 para os sítios Lago Grande e Osvaldo. As elipses representam a região de confiança de $95 \%$.

Pelas Fig. 7.12 e 7.13, verificou-se que a elipse representando o grupo das argilas (C) é o que mais se diferencia das demais, conforme o esperado. Além disso, foram formados três grupos de cerâmicas, representadas pelas elipses A, B e D. O grupo A do Cenário 3 foi reduzido em relação ao grupo A do Cenário 2, de 32 para 19 amostras, das quais 14 (74\%) são coincidentes entre os dois cenários. Sua separação relativa aos demais grupos não sofreu modificações pela mudança de cenário (comparar com Fig. 7.10 e 7.11). O grupo B sofreu uma expansão pela mudança do Cenário 2 para o Cenário 3 , aumentando de 29 para 51 amostras. Das 29 amostras do Cenário 2, 16 (55\%) continuaram no grupo B. O grupo $\mathrm{C}$ não sofreu alterações pela mudança de cenário. $\mathrm{O}$ grupo D sofreu uma redução de 101 amostras, no Cenário 2, para 90 amostras no Cenário 3. Das 90 amostras do grupo D no Cenário 3, 61 delas (68\%) são coincidentes entre os dois cenários. Em relação à resolução das elipses, percebeu-se uma melhora na separação dos novos grupos B e D do Cenário 3 nas Fig. 7.12 e 7.13, quando comparados aos equivalentes a esses grupos nas Fig. 7.10 e 7.11, relativos ao Cenário 2.

Pela discussão apresentada até aqui, concluiu-se que o Cenário 1 é inadequado pela influência de potenciais alterações diagenéticas em Na e K. Portanto, esse cenário foi descartado para a interpretação arqueológica.

O Cenário 2 apresenta três elementos, Cs, As e Hf, que também são passíveis de alterações diagenéticas, embora aparentemente em menor intensidade que em Na e K. Esses três elementos são dominantes nas três primeiras componentes principais (comparar 230 
tamanho dos vetores nas Fig. 7.10 e 7.11) Ainda, verificou-se que sua extração alterou significativamente os três grupos de cerâmicas A, B e D do Cenário 2. Pela sua influência nas análises de agrupamento e componentes principais, e pela possibilidade de gerar padrões geoquímicos multivariados afetados por efeitos diagenéticos, que poderiam obscurecer correlações arqueológicas e culturais dos dados, o Cenário 2 também foi descartado.

Assim, dentre os cenários analisados até aqui, decidiu-se pela adoção do Cenário 3 como o mais adequado para a interpretação arqueológica. Dos três elementos determinados com status de "Atenção" (As, Lu e Cr) no controle de qualidade analítico, na seção 7.1.1, apenas Lu e Cr continuaram nas análises, e não foram identificados problemas para os mesmos.

\subsubsection{PCA com transformação de dados em razão logarítmica aditiva (alr)}

Foi realizada a transformação em razão logarítmica aditiva (alr) para comparação com a transformação $\log _{10}$. Como reportado no Capítulo 5 , essa transformação é recomendada para analisar efeitos pós-deposicionais que afetem as concentrações químicas elementares e também compensar o efeito da adição de elementos antiplásticos à pasta cerâmica (Buxeda i Garrigós, 1999). Como as cerâmicas da Tradição Borda Incisa, como as de Lago Grande e Osvaldo, possuem o antiplástico cauixi em sua composição (seção 7.1.3), e outros em menor quantidade (Donatti, 2003; Portocarrero, 2006), é conveniente analisar estatisticamente os possíveis efeitos que sua inserção possa ter na definição de grupos químicos por análises multivariadas.

Inicialmente, foi calculada a matriz de variação para os elementos químicos do Cenário 1, com o objetivo de se analisar o elemento com menor variabilidade para ser o denominador na transformação alr. Os resultados são apresentados na Tab. 7.11 e foram calculados no software MURRAP 8.6. O cálculo dessa matriz de variação também foi realizado no software $R$ 2.12.1, com substituição de valores faltantes por minimização da distância de Mahalanobis, e foram encontrados os mesmos resultados. 
Tabela 7.11 - Matriz de variação dos elementos químicos do Cenário 1 para os dados de Lago Grande e Osvaldo.

\begin{tabular}{ccccccccccccccc}
\hline & $\mathbf{N a}$ & $\mathbf{K}$ & $\mathbf{S c}$ & $\mathbf{C r}$ & $\mathbf{F e}$ & $\mathbf{A s}$ & $\mathbf{C s}$ & $\mathbf{L a}$ & $\mathbf{C e}$ & $\mathbf{E u}$ & $\mathbf{Y b}$ & $\mathbf{L u}$ & $\mathbf{H f}$ & $\mathbf{T h}$ \\
\hline $\mathrm{Na}$ & 0 & 0,379 & 0,623 & 0,694 & 0,622 & 0,95 & 0,806 & 0,705 & 0,694 & 0,6 & 0,699 & 0,69 & 1,081 & 0,806 \\
$\mathrm{~K}$ & 0,379 & 0 & 0,2 & 0,234 & 0,218 & 0,391 & 0,336 & 0,279 & 0,29 & 0,291 & 0,267 & 0,278 & 0,504 & 0,283 \\
$\mathrm{Sc}$ & 0,623 & 0,2 & 0 & 0,011 & 0,027 & 0,179 & 0,219 & 0,052 & 0,051 & 0,058 & 0,05 & 0,058 & 0,18 & 0,034 \\
$\mathrm{Cr}$ & 0,694 & 0,234 & 0,011 & 0 & 0,027 & 0,164 & 0,21 & 0,048 & 0,053 & 0,067 & 0,041 & 0,048 & 0,138 & 0,023 \\
$\mathrm{Fe}$ & 0,622 & 0,218 & 0,027 & 0,027 & 0 & 0,182 & 0,239 & 0,082 & 0,087 & 0,086 & 0,068 & 0,074 & 0,195 & 0,057 \\
$\mathrm{As}$ & 0,95 & 0,391 & 0,179 & 0,164 & 0,182 & 0 & 0,329 & 0,21 & 0,237 & 0,264 & 0,193 & 0,195 & 0,289 & 0,179 \\
$\mathrm{Cs}$ & 0,806 & 0,336 & 0,219 & 0,21 & 0,239 & 0,329 & 0 & 0,249 & 0,254 & 0,283 & 0,245 & 0,256 & 0,328 & 0,215 \\
$\mathrm{La}$ & 0,705 & 0,279 & 0,052 & 0,048 & 0,082 & 0,21 & 0,249 & 0 & 0,042 & 0,035 & 0,024 & 0,031 & 0,132 & 0,038 \\
$\mathrm{Ce}$ & 0,694 & 0,29 & 0,051 & 0,053 & 0,087 & 0,237 & 0,254 & 0,042 & 0 & 0,045 & 0,067 & 0,076 & 0,174 & 0,057 \\
$\mathrm{Eu}$ & 0,6 & 0,291 & 0,058 & 0,067 & 0,086 & 0,264 & 0,283 & 0,035 & 0,045 & 0 & 0,056 & 0,065 & 0,199 & 0,073 \\
$\mathrm{Yb}$ & 0,699 & 0,267 & 0,05 & 0,041 & 0,068 & 0,193 & 0,245 & 0,024 & 0,067 & 0,056 & 0 & 0,015 & 0,11 & 0,041 \\
$\mathrm{Lu}$ & 0,69 & 0,278 & 0,058 & 0,048 & 0,074 & 0,195 & 0,256 & 0,031 & 0,076 & 0,065 & 0,015 & 0 & 0,099 & 0,043 \\
$\mathrm{Hf}$ & 1,081 & 0,504 & 0,18 & 0,138 & 0,195 & 0,289 & 0,328 & 0,132 & 0,174 & 0,199 & 0,11 & 0,099 & 0 & 0,093 \\
$\mathrm{Th}$ & 0,806 & 0,283 & 0,034 & 0,023 & 0,057 & 0,179 & 0,215 & 0,038 & 0,057 & 0,073 & 0,041 & 0,043 & 0,093 & 0 \\
\hline Tsum & $\mathbf{9 , 3 4 9}$ & $\mathbf{3 , 9 5}$ & 1,743 & 1,758 & 1,963 & $\mathbf{3 , 7 6 3}$ & $\mathbf{3 , 9 6 9}$ & 1,926 & 2,128 & 2,122 & 1,876 & 1,928 & $\mathbf{3 , 5 2 1}$ & 1,943 \\
relvar & $\mathbf{0 , 1 6 0}$ & $\mathbf{0 , 3 7 9}$ & 0,859 & 0,852 & 0,763 & $\mathbf{0 , 3 9 8}$ & $\mathbf{0 , 3 7 7}$ & 0,778 & 0,704 & 0,706 & 0,799 & 0,777 & $\mathbf{0 , 4 2 5}$ & 0,771 \\
correl & $-0,613$ & 0,28 & 0,996 & 0,995 & 0,989 & 0,878 & 0,793 & 0,987 & 0,985 & 0,967 & 0,986 & 0,98 & 0,92 & 0,984 \\
totvar & 1,498 & & & & & & & & & & & & \\
\hline
\end{tabular}

Cada coluna na matriz simétrica da Tab. 7.11 refere-se à diagonal da matriz de covariância de um elemento (no caso, o elemento que nomeia a coluna) selecionado para ser o denominador na transformação alr (Eq. 5.5). O termo Tsum refere-se ao traço, ou soma dos elementos da diagonal da matriz de covariância para cada elemento utilizado como denominador. O termo relvar refere-se à porcentagem do traço de cada matriz de covariância alr explicada por uma medida da variação total da estrutura de covariância dos dados subcomposicionais originais (totvar). Esse termo é mais bem compreendido ao se considerar o seu complementar (1 - relvar $)$, que é uma medida da variabilidade imposta na matriz original de covariância pela escolha do elemento em questão (na coluna) na transformação alr. Dessa forma, quanto maior o valor de relvar, mais "estável" é esse elemento, e menor será a variação imposta na estrutura de covariância original por sua escolha como denominador na transformação em questão. Assim, pela análise dos termos Tsum e relvar na Tab. 7.11, concluiu-se que o elemento que impõe a maior variabilidade na base de dados é o Na, e o elemento com a menor contribuição para variabilidade é o Sc, que foi o elemento selecionado como denominador na transformação alr. 
O elemento escândio é também interessante do ponto de vista geoquímico. Em contextos de pouca variabilidade geoquímica presumida, ou estudos de caráter intrarregional correspondente a contextos geológicos similares, a diferenciação de pastas cerâmicas, correspondentes a diferentes fontes ou combinação de fontes argilosas, pode ser difícil. A utilização de um elemento litogênico conservativo como referência, não afetado por processos diagenéticos (como mobilização e lixiviação), pode auxiliar na compensação de certos efeitos antropogênicos na variabilidade dos dados, como a adição de antiplásticos, e melhorar a determinação da "assinatura química" das fontes de argila. Dias \& Prudêncio (2007) reportaram que os elementos Si, Al, Li, Sc, Fe e Mn; carbono orgânico; e carbonatos são bons fatores químicos de normalização de dados geoquímicos, para compensar anomalias de origem natural nas concentrações. Li e Sc são dois elementos que são combinados estruturalmente a minerais argilosos e micas, sendo bons indicadores desses minerais. Além disso, verificou-se que o escândio é o elemento que apresentou a segunda menor concentração no cauixi dentre os elementos químicos do Cenário 3 (Tab. 7.3), considerados como adequados para as análises multivariadas com transformação $\log _{10}$. Assim, o elemento escândio foi selecionado para normalização dos dados na análise alr, porque satisfez tanto o critério estatístico (menor variabilidade), quanto o critério geoquímico na sua escolha (Dias \& Prudêncio, 2007).

Além das evidências citadas na seção 7.1.9, a matriz de variação da Tab. 7.11 também evidenciou a contribuição maior dos elementos $\mathrm{Na}$ e K à variabilidade do sistema, pelos valores mínimos de relvar. Com valores de Tsum e relvar próximos aos do $\mathrm{K}$, e significativamente menor que os dos demais elementos, Cs, As e Hf também contribuem mais à variabilidade do sistema, em relação aos demais elementos químicos. Como há evidências de que esses três elementos possam sofrer alterações pós-deposicionais, já discutidas na seção 7.1.9, foram criados mais dois cenários para comparação com a transformação $\log _{10}$, verificação de possíveis interferências de efeitos pós-deposicionais de Cs, As e Hf nos resultados e perturbações indiretas relacionadas à adição de cauixi.

Assim, foi definido o Cenário 4, sem $\mathrm{Na}$ e K, que corresponde ao Cenário 2, com mudança na transformação de dados.

Cenário 4: Os 12 elementos As, La, Lu, Yb, Ce, Cr, Cs, Eu, Fe, Hf, Sc e Th com transformação em razão logarítmica aditiva (alr). 
Finalmente, foi definido o Cenário 5, sem Na, K, Cs, As e Hf, que corresponde ao Cenário 3, com mudança na transformação de dados.

Cenário 5: Os 9 elementos $\mathrm{La}, \mathrm{Lu}, \mathrm{Yb}, \mathrm{Ce}, \mathrm{Cr}, \mathrm{Eu}, \mathrm{Fe}, \mathrm{Sc}$ e Th com transformação em razão logarítmica aditiva (alr).

Foi realizada uma nova PCA a partir do corte mínimo da análise de agrupamentos para o Cenário 4 (seção 7.1.8), na qual foram definidos seis grupos químicos de cerâmicas. Os coeficientes de ponderação dos autovetores que representam o peso das variáveis originais são listados na Tab. 7.12 para as primeiras quatro componentes principais, juntamente com os autovalores (variância), a porcentagem de variância representada por cada componente, e a variância acumulada. Os valores hachurados representam os maiores coeficientes de ponderação para cada componente.

Tabela 7.12 - Coeficientes de ponderação e variância das quatro primeiras componentes principais para o Cenário 4, com dados de Lago Grande e Osvaldo.

\begin{tabular}{ccccc}
\hline Variável & PC1 & PC2 & PC3 & PC4 \\
\hline $\mathrm{Cr} / \mathrm{Sc}$ & 0,11081 & 0,011587 & 0,026665 & $-0,07515$ \\
$\mathrm{Fe} / \mathrm{Sc}$ & 0,039281 & $-0,02304$ & 0,071571 & $-0,03799$ \\
$\mathrm{As} / \mathrm{Sc}$ & 0,331835 & $-0,35584$ & 0,830078 & 0,221599 \\
$\mathrm{Cs} / \mathrm{Sc}$ & 0,391568 & $-0,76944$ & $-0,49732$ & 0,056517 \\
$\mathrm{La} / \mathrm{Sc}$ & 0,267103 & 0,199775 & $-0,07135$ & 0,353903 \\
$\mathrm{Ce} / \mathrm{Sc}$ & 0,153763 & 0,155699 & $-0,15293$ & 0,372673 \\
$\mathrm{Eu} / \mathrm{Sc}$ & 0,136706 & 0,234279 & $-0,16629$ & 0,548743 \\
$\mathrm{Yb} / \mathrm{Sc}$ & 0,287574 & 0,176533 & $-0,00259$ & 0,146374 \\
$\mathrm{Lu} / \mathrm{Sc}$ & 0,312689 & 0,198343 & 0,014123 & 0,083708 \\
$\mathrm{Hf} / \mathrm{Sc}$ & 0,609531 & 0,289582 & $-0,03329$ & $-0,57504$ \\
$\mathrm{Th} / \mathrm{Sc}$ & 0,238873 & 0,085262 & $-0,01905$ & $-0,12751$ \\
\hline Autovalor & 0,065891 & 0,039911 & 0,030487 & 0,016294 \\
Variância $(\%)$ & 37,8 & 22,9 & 17,5 & 9,4 \\
Var. Acum. (\%) & 37,8 & 60,7 & 78,2 & 87,6 \\
\hline
\end{tabular}

As Fig. 7.14 e 7.15 ilustram a projeção dos dados nas três primeiras componentes principais para o Cenário 4, para PCA modo RQ. 


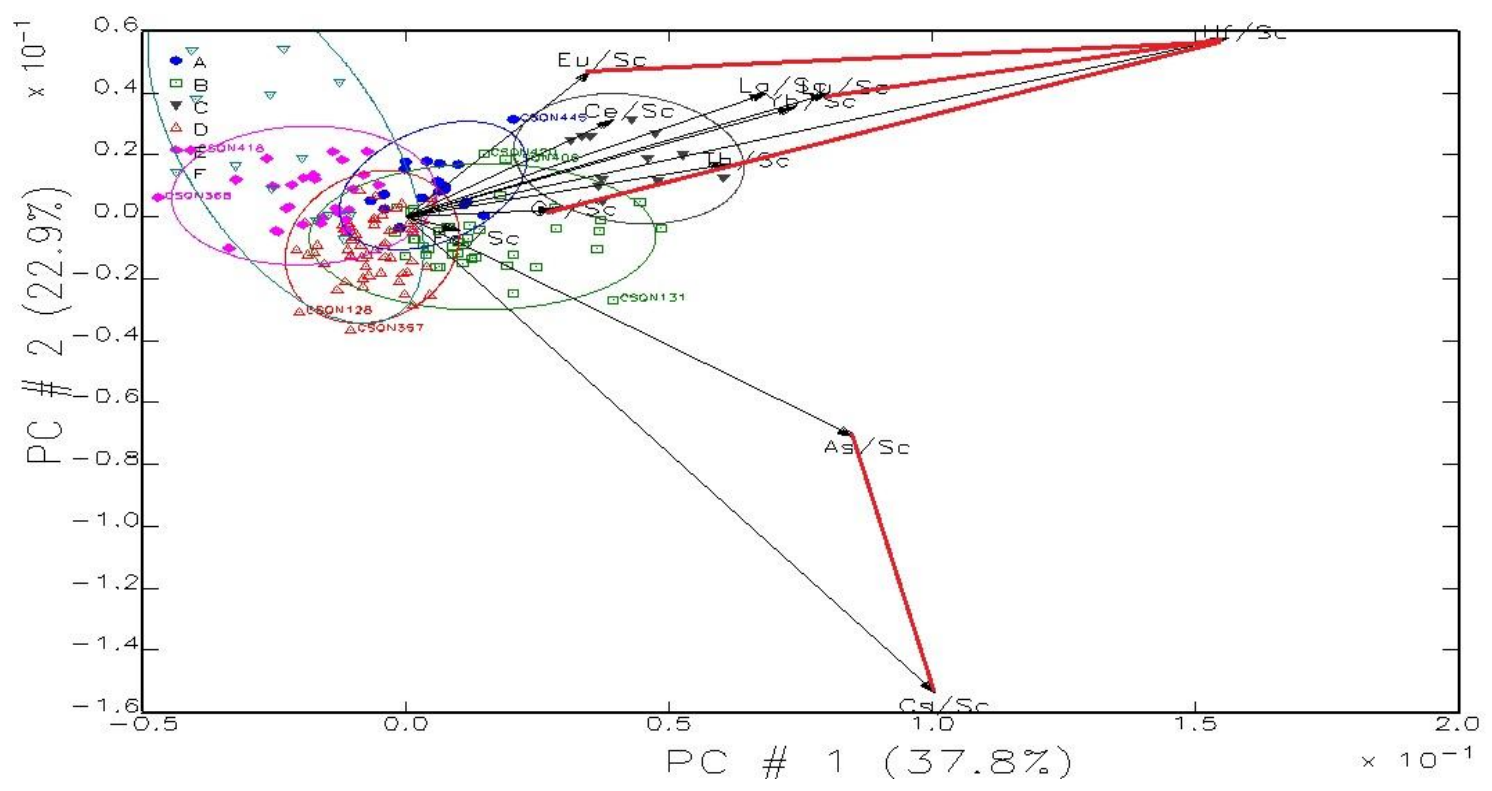

Figura 7.14 - Escores nas duas primeiras componentes principais dos dados do Cenário 4 para os sítios Lago Grande e Osvaldo. As elipses representam a região de confiança de $95 \%$.

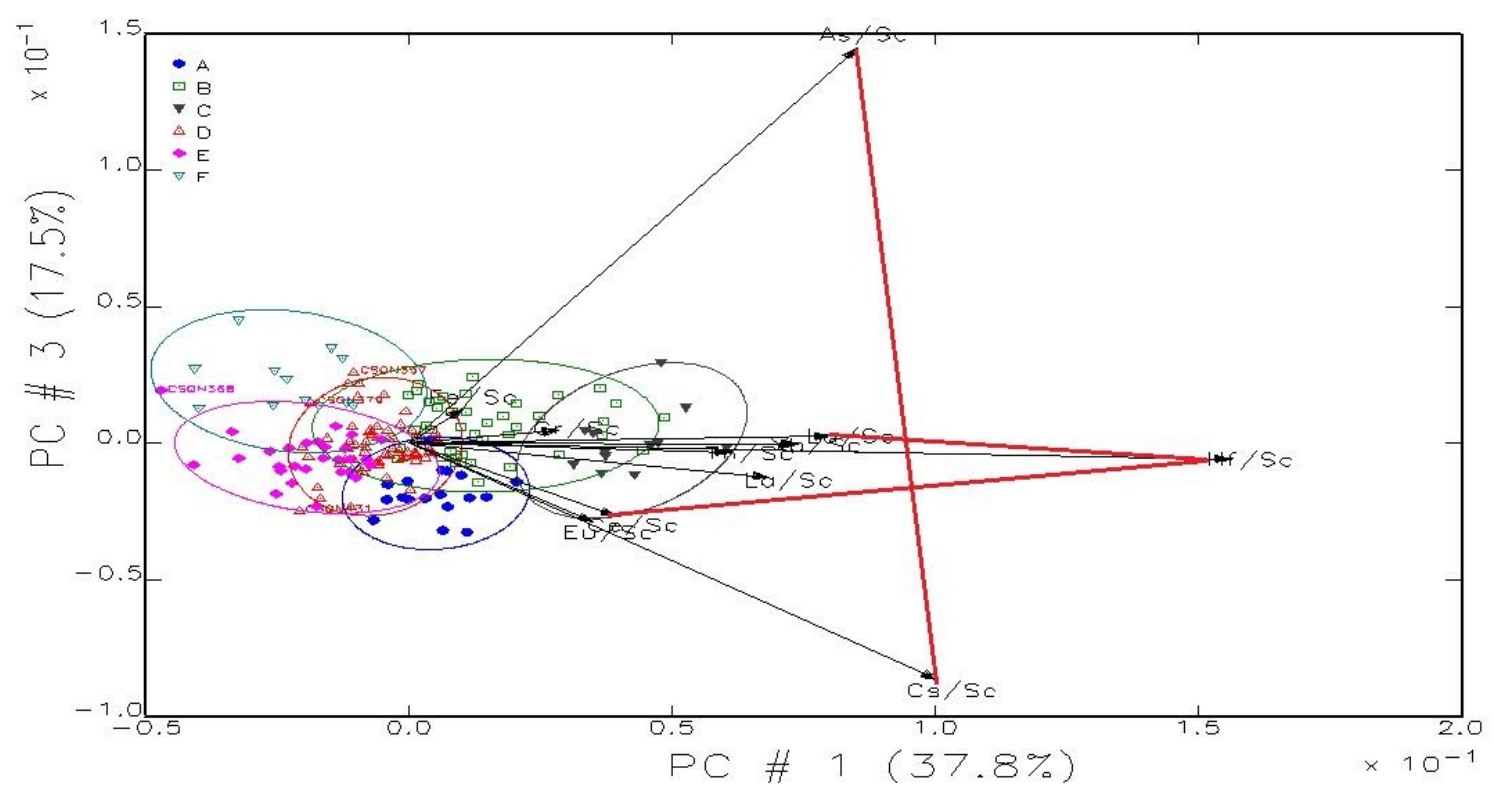

Figura 7.15 - Escores na primeira e terceira componentes principais dos dados do Cenário 4 para os sítios Lago Grande e Osvaldo. As elipses representam a região de confiança de $95 \%$.

A Tab. 7.12 indica que as duas primeiras componentes principais, as mais utilizadas em redução de dados, representam conjuntamente $60,7 \%$ da variância total do sistema. Ainda pela mesma tabela, verificou-se que as razões $\mathrm{Hf} / \mathrm{Sc}, \mathrm{Cs} / \mathrm{Sc}$ e As/Sc 
dominam a primeira componente. A segunda componente, que explica $22,9 \%$ da variância do sistema, também é dominada pelas razões $\mathrm{Cs} / \mathrm{Sc}$, As/Sc e $\mathrm{Hf} / \mathrm{Sc}$, compreendendo justamente os três elementos que estão sendo analisados quanto à sua influência nos dados, devido a evidências de efeitos diagenéticos. A influência de As e Cs estende-se à terceira componente. Juntas, a segunda e terceira componentes explicam cerca de $40 \%$ da variância do sistema, reforçando a necessidade de se analisar a influência de Cs e As em PCA. Finalmente, a quarta componente é dominada por $\mathrm{Hf} / \mathrm{Sc}, \mathrm{Eu} / \mathrm{Sc}$ e $\mathrm{Ce} / \mathrm{Sc}$.

Pelas Fig. 7.14 e 7.15, algumas observações podem ser feitas considerando-se os vetores e, principalmente, as ligações entre os mesmos (exemplos em vermelho), definidas como os segmentos ligando os seus vértices terminais. Os maiores vetores nas duas figuras, correspondendo a $\mathrm{Hf} / \mathrm{Sc}, \mathrm{Cs} / \mathrm{Sc}$ e As/Sc representam as razões dominantes para a explicação da variação na base de dados composicionais, evidenciando novamente a importância de se avaliar seu efeito nas análise multivariadas. As ligações entre Cs/Sc e $\mathrm{As} / \mathrm{Sc}$, e entre Hf/Sc e as demais razões aproximam-se do ângulo reto, indicando que esses grupos subcomposicionais estariam pouco correlacionados (Pawlowsky-Glahn et al., 2007). Essa configuração sugere que efeitos geoquímicos, possíveis alterações diagenéticas ou alterações pela queima, afetando a variabilidade de As e Cs seriam independentes dos efeitos geoquímicos afetando a variabilidade dos demais elementos. Esse seria outro indício de efeitos pós-deposicionais atuantes em Cs e As.

Foi então realizada uma nova PCA a partir de um corte tentativo em cinco grupos na análise de agrupamentos para o Cenário 5, que foi identificado como o melhor corte para comparação com o Cenário 4, no intuito de continuar a avaliação da influência de Cs, As e Hf nas análises. Os coeficientes de ponderação dos autovetores que representam o peso das variáveis originais são listados na Tab. 7.13 para as primeiras quatro componentes principais, juntamente com os autovalores (variância), a porcentagem de variância representada por cada componente, e a variância acumulada. Os valores hachurados representam os maiores coeficientes de ponderação para cada componente.

As Fig. 7.16 e 7.17 ilustram a projeção dos dados nas três primeiras componentes principais para o Cenário 5, para PCA modo RQ. 
Tabela 7.13 - Coeficientes de ponderação e variância das quatro primeiras componentes principais para o Cenário 5, com dados de Lago Grande e Osvaldo.

\begin{tabular}{ccccc}
\hline Variável & PC1 & PC2 & PC3 & PC4 \\
\hline $\mathrm{Cr} / \mathrm{Sc}$ & 0,102364 & 0,173989 & $-0,21708$ & 0,250066 \\
$\mathrm{Fe} / \mathrm{Sc}$ & 0,021577 & 0,272133 & 0,27784 & 0,874052 \\
$\mathrm{La} / \mathrm{Sc}$ & 0,482387 & $-0,06793$ & $-0,03209$ & $-0,1387$ \\
$\mathrm{Ce} / \mathrm{Sc}$ & 0,332357 & $-0,55865$ & $-0,44754$ & 0,263615 \\
$\mathrm{Eu} / \mathrm{Sc}$ & 0,40697 & $-0,49766$ & 0,522045 & 0,107397 \\
$\mathrm{Yb} / \mathrm{Sc}$ & 0,442885 & 0,328151 & 0,149883 & $-0,14412$ \\
$\mathrm{Lu} / \mathrm{Sc}$ & 0,462076 & 0,416407 & 0,132929 & $-0,17938$ \\
$\mathrm{Th} / \mathrm{Sc}$ & 0,265729 & 0,224091 & $-0,60141$ & 0,142426 \\
\hline Autovalor & 0,036542 & 0,010613 & 0,005695 & 0,004891 \\
Variância $(\%)$ & 56,6 & 16,4 & 8,8 & 7,6 \\
Var. Acum. $(\%)$ & 56,6 & 73,0 & 81,9 & 89,4 \\
\hline
\end{tabular}

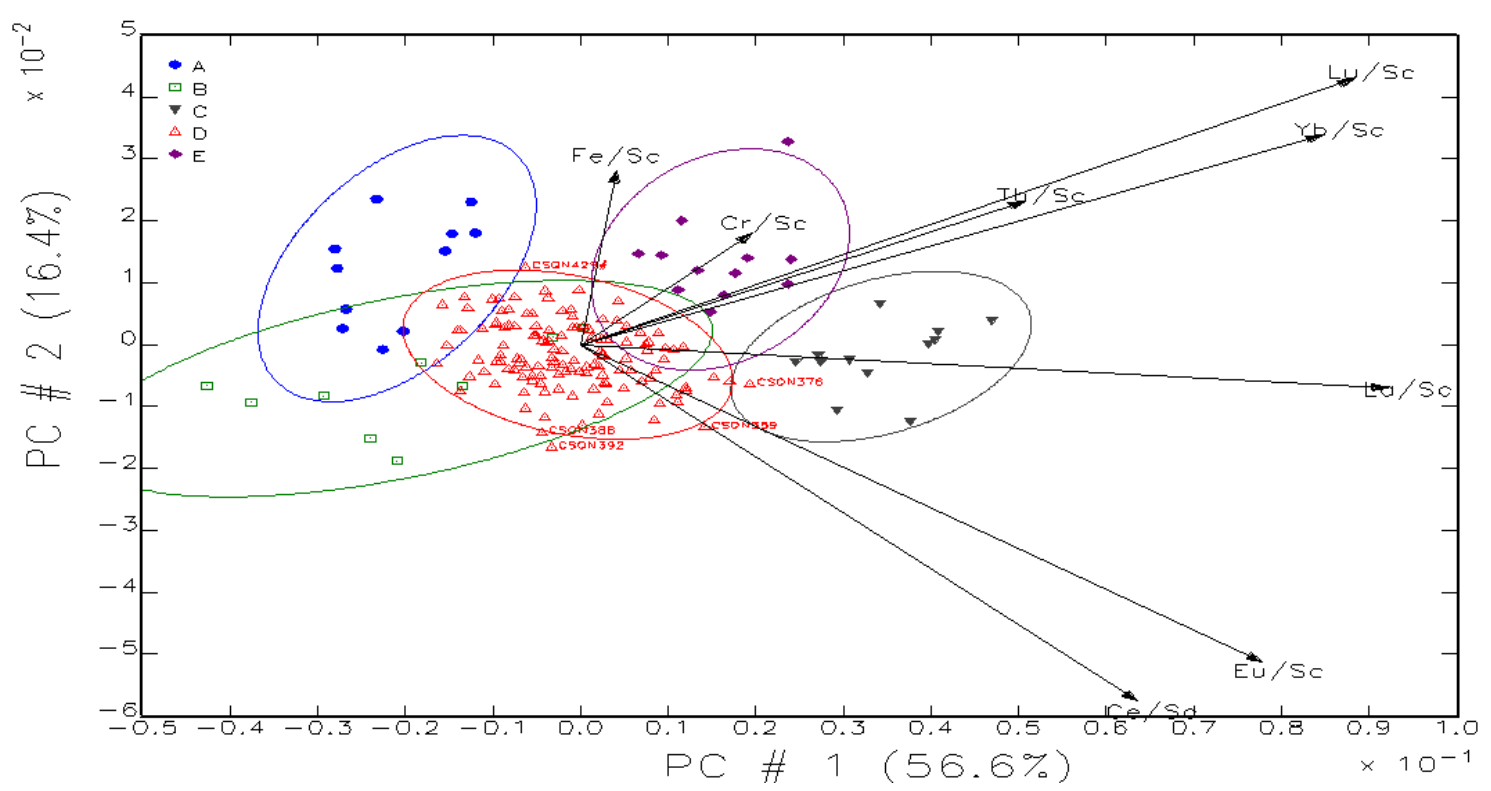

Figura 7.16 - Escores nas duas primeiras componentes principais dos dados do Cenário 5 para os sítios Lago Grande e Osvaldo. As elipses representam a região de confiança de $95 \%$. 


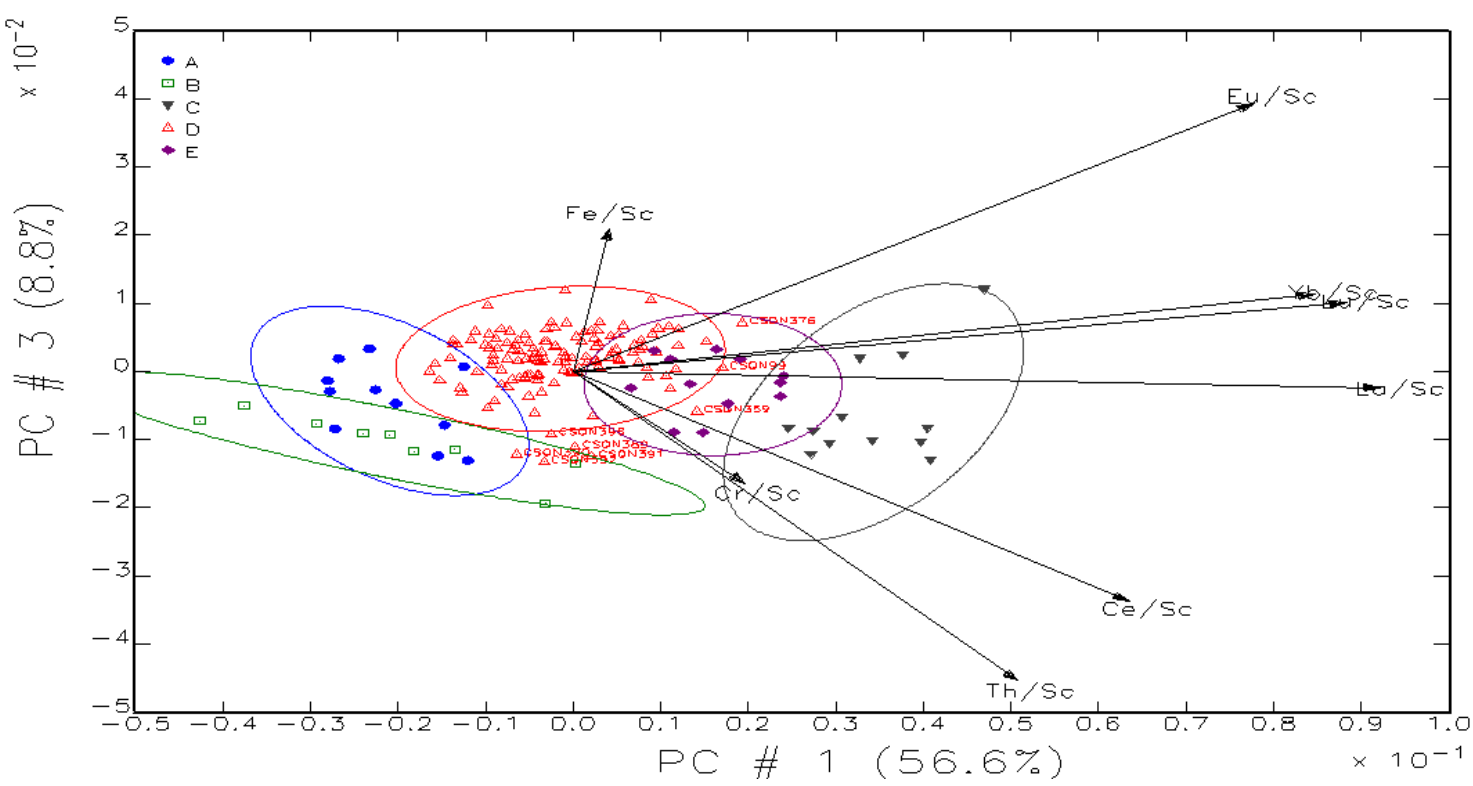

Figura 7.17 - Escores na primeira e terceira componentes principais dos dados do Cenário 5 para os sítios Lago Grande e Osvaldo. As elipses representam a região de confiança de $95 \%$.

A Tab. 7.13 indica que as duas primeiras componentes principais, as mais utilizadas em redução de dados, representam conjuntamente $73,0 \%$ da variância total do sistema. Ainda pela mesma tabela, verificou-se que as razões elementares dominando a primeira componente principal de forma equilibrada são $\mathrm{La} / \mathrm{Sc}, \mathrm{Lu} / \mathrm{Sc}, \mathrm{Yb} / \mathrm{Sc}$ e Eu/Sc. A segunda componente principal é dominada pelas razões $\mathrm{Ce} / \mathrm{Sc} / \mathrm{Eu} / \mathrm{Sc}$ e Lu/Sc. A terceira componente foi dominada pelas razões $\mathrm{Th} / \mathrm{Sc}, \mathrm{Eu} / \mathrm{Sc}$ e $\mathrm{Ce} / \mathrm{Sc}$. Por sua vez, a quarta componente principal é dominada pela razão $\mathrm{Fe} / \mathrm{Sc}$.

Pelas Fig. 7.16 e 7.17, foi observado um equilíbrio maior entre os tamanhos dos vetores, quando comparados aos das Fig. 7.14 e 7.15, sem que haja um ou um pequeno grupo de elementos com vetores dominantes. Também foi observada uma boa separação dos grupos A, C, D e E, melhor que a separação entre as elipses nas Fig. 7.14 e 7.15. O grupo B apareceu com uma superposição considerável ao grupo D na Fig. 7.16 e ao grupo A, na Fig. 7.17, indicando uma partição dos dados com um grupo a menos, em quatro grupos químicos de cerâmica, seria plausível.

Mesmo sem realizar refinamento utilizando a distância de Mahalanobis neste ponto (realizada na seção 7.1.12), tendências gerais puderam ser identificadas por terem sido muito críticas. A análise dos grupos formados nos Cenários 4 e 5 mostrou que há reclassificação de várias amostras quando se muda de um cenário para outro na análise estatística multivariada. O maior grupo químico identificado nos dois cenários, grupo D, 
foi expandido, praticamente dobrando (de 60 para 128 amostras) no Cenário 5, indicando que sua alocação em outros grupos no Cenário 4 era influenciada pela presença de Cs, As e Hf nas análises. Além disso, os integrantes dos grupos menores A, B e E no Cenário 5 (Fig. 7.16 e 7.17) também são consideravelmente diferentes. O grupo A, por exemplo, foi reduzido de 18 para 11 amostras totalmente diferentes. O grupo no qual estão localizadas as argilas, grupo C, não apresentou diferenças significativas entre os dois cenários. Tal fato é esperado uma vez que ele já foi identificado como o mais distinto em análises estatísticas anteriores em $\log _{10}$, e pela simples inspeção univariada das concentrações elementares (Tab. 7.2).

A mudança nos integrantes dos grupos químicos pela mudança de cenário com transformação alr pode ser explicada pelo domínio de razões elementares com maiores variâncias na análise com logaritmos de razões (Baxter \& Freestone, 2006). O Cenário 4 apresenta razões com três elementos, (Cs, As e Hf) que são passíveis de alterações diagenéticas, embora aparentemente em menor intensidade que em $\mathrm{Na}$ e K. Além disso, verificou-se que sua extração alterou significativamente os grupos químicos de cerâmicas no Cenário 5. A influência de Cs, As, e Hf nas análises de agrupamento e componentes principais poderia gerar padrões geoquímicos multivariados afetados por efeitos pósdeposicionais, os quais poderiam obscurecer correlações culturais potenciais dos dados, ou gerar correlações espúrias, de forma crítica na análise alr (Buxeda i Garrigós, 1999; Baxter \& Freestone, 2006). Assim, o Cenário 4 foi descartado.

Finalmente, considerou-se o Cenário 5 como o mais adequado para a comparação com o Cenário 3, com transformação $\log _{10}$ dos dados, para discussão do efeito da adição do antiplástico cauixi nas análises químicas multivariadas, e posterior interpretação arqueológica tentativa, realizadas nas próximas seções.

\subsubsection{Comparação preliminar entre as transformações de dados $\log _{10}$ e alr}

Nesta seção, são comparados os resultados gerais de agrupamento e PCA do Cenário 3, com os mesmos resultados do Cenário 5.

O grupo D, o maior grupo definido nas análises pelas duas transformações de dados, aumentou de 90 para 128 amostras na transformação alr. Dessas 90 amostras de D do Cenário 3, 74 (82\%) correspondem às mesmas amostras no Cenário 5. O grupo A do Cenário 3 apresentou 19 amostras, enquanto que no Cenário 5 esse grupo apresentou 11 amostras, das quais sete $(64 \%)$ coincidiram neste grupo quando se mudou de cenário. $\mathrm{O}$ 
grupo B apresentou 51 amostras no Cenário 3, e apenas 9 amostras no Cenário 5. A maioria das amostras que eram de B no primeiro cenário, migraram para o grupo D na transformação alr, explicando grande parte da ampliação desse grupo no Cenário 5 (de 90 para 128 amostras). Das 9 amostras de B do Cenário 5, apenas 4 (44\%) também eram de B no Cenário 3. O grupo E, com 12 amostras, presente apenas no Cenário 5, é composto, em sua maioria (83\%), de amostras que pertenciam ao grupo D, no Cenário 3.

A transformação alr, uma modalidade de análise logarítmica racional (LRA, do inglês Log-ratio Analysis), pode ajudar a minimizar o efeito de diluição, causado pela inserção de aditivos antiplásticos, e comparar as características geoquímicas das pastas cerâmicas quanto à utilização de diferentes fontes de argila. Contudo, também já foi reportado na literatura (Baxter \& Freestone, 2006) que a LRA nem sempre funciona de maneira adequada, não identificando estruturas arqueologicamente interpretáveis, ou identificando de maneira menos direta que as abordagens clássicas de transformação de dados. Além disso, Aitchison et al. (2002) relataram que a análise LRA de dados subcomposicionais que consistem basicamente de elementos-traço é equivalente à análise logarítmica tradicional (ignorando-se efeitos de diluição).

Na LRA, Baxter \& Freestone (2006) alertaram sobre a necessidade de se remover variáveis que não carreguem informações relevantes sobre padrões da estrutura multivariada, e que apresentem alta variância. Os autores tiveram a impressão de que PCA utilizando razões logarítmicas não padronizadas é mais sensível ao problema de inclusão dessas variáveis do que a PCA de dados padronizados.

Neste trabalho, embora não seja utilizada PCA de dados padronizados, mas sim de dados transformados em $\log _{10}$, observações análogas foram realizadas. No Cenário 4 , verificou-se que as razões elementares dominantes, $\mathrm{Hf} / \mathrm{Sc}, \mathrm{Cs} / \mathrm{Sc}$ e As/Sc, são relativas aos elementos com maior variância, sendo os coeficientes de variação iguais a 70,0\%, 36,7\% e $44,1 \%$, respectivamente para a base de dados combinada de Lago Grande e Osvaldo $(n=172)$. Verificou-se que a importância desses três elementos, analisados quanto à possibilidade de efeitos diagenéticos, é maior na análise PCA alr do que na PCA $\log _{10}$, pela comparação dos coeficientes de ponderação dos dois cenários ("2" e "4" nas Tab. 7.9 e 7.12), e pelo tamanho relativo dos vetores associados a Cs, As e Hf nas três primeiras componentes principais (Fig. 7.10, 7.11, 7.14 e 7.15). Além disso, comparando-se as mudanças nos grupos químicos pela mudança de cenário com transformação $\log _{10}$ (seção 
7.1.9) e transformação alr (seção 7.1.10), verificou-se que a influência desses elementos também é mais crítica nessa última.

Diferenças absolutas, presentes nas transformações de dados "clássicas", podem revelar a utilização de diferentes receitas de produção cerâmica e utilização de fontes argilosas mais facilmente (Baxter \& Freestone, 2006) em vários casos. Essas diferenças absolutas podem ser de interesse em arqueometria e gerar informações úteis e interpretáveis arqueologicamente que a LRA pode não revelar, devido ao seu foco em variações relativas.

Assim, conclui-se que diferentes ferramentas estatísticas são necessárias para diferentes aspectos da análise. Seguindo-se essa abordagem, a combinação da análise $\log _{10}$ e da análise alr foi utilizada para procurar padrões arqueologicamente interpretáveis nos grupos químicos sugeridos pelas análises de agrupamento e PCA, definidos na próxima seção, compreendendo a análise estatística multivariada por sítio arqueológico e sua subsequente comparação para identificar possíveis indícios de interação cultural entre Lago Grande e Osvaldo.

\subsubsection{Estudo de agrupamento e PCA por sítio arqueológico}

Nas seções anteriores, a base de dados foi tratada conjuntamente com o intuito de se conhecer os padrões gerais de concentrações dos elementos químicos, e analisar particionamentos potenciais dos dados que indicassem uma possível correlação com fatores que poderiam definir diferentes grupos químicos de cerâmica, como fase arqueológica, sítio de proveniência, estratigrafia e tipo de objeto cerâmico. Nenhuma correlação óbvia foi identificada nessa primeira análise.

Assim, para aprofundar o entendimento dos padrões geoquímicos das amostras dos dois sítios estudados, a análise de agrupamento e componentes principais foram refeitas separadamente com a base de dados de cada sítio, para então relacionar e comparar os padrões encontrados nas amostras de Lago Grande e Osvaldo.

Nesta seção, os dados de INAA são reanalisados a partir de cada sítio separadamente, segundo os parâmetros do Cenário 3 e Cenário 5, considerados os mais adequados para a interpretação arqueológica, a partir de discussões anteriores nas seções 7.1.9, 7.1.10 e 7.1.11. 
a. Lago Grande

Foi realizada uma nova PCA a partir do corte mínimo na análise de agrupamentos para o Cenário 3, com as amostras de Lago Grande. Os coeficientes de ponderação dos autovetores que representam o peso das variáveis originais são listados na Tab. 7.14 para as primeiras quatro componentes principais, juntamente com os autovalores (variância), a porcentagem de variância representada por cada componente, e a variância acumulada. Os valores hachurados representam os maiores coeficientes de ponderação para cada componente.

Tabela 7.14 - Coeficientes de ponderação e variância das quatro primeiras componentes principais para o Cenário 3, apenas com as amostras de Lago Grande.

\begin{tabular}{ccccc}
\hline Variável & PC1 & PC2 & PC3 & PC4 \\
\hline Sc & 0,300618 & 0,270327 & $-0,16608$ & 0,012662 \\
$\mathrm{Cr}$ & 0,270859 & 0,328147 & $-0,07685$ & 0,201358 \\
$\mathrm{Fe}$ & 0,326737 & 0,695659 & 0,093612 & $-0,31209$ \\
$\mathrm{La}$ & 0,312503 & $-0,34231$ & 0,065699 & 0,023886 \\
$\mathrm{Ce}$ & 0,442879 & $-0,27451$ & $-0,61985$ & 0,242567 \\
$\mathrm{Eu}$ & 0,482295 & $-0,31825$ & 0,078685 & $-0,66564$ \\
$\mathrm{Yb}$ & 0,298128 & $-0,06995$ & 0,472303 & 0,207312 \\
$\mathrm{Lu}$ & 0,27148 & $-0,10059$ & 0,555759 & 0,396549 \\
$\mathrm{Th}$ & 0,201288 & 0,162723 & $-0,17632$ & 0,398971 \\
\hline Autovalor & 0,045536 & 0,01205 & 0,007069 & 0,005078 \\
Variância (\%) & 59,2 & 15,7 & 9,2 & 6,6 \\
Var. Acum. $(\%)$ & 59,2 & 74,8 & 84,0 & 90,6 \\
\hline
\end{tabular}

A partir da Tab. 7.14, verificou-se que as duas primeiras componentes principais, as mais utilizadas em redução de dados, representam conjuntamente $74,8 \%$ da variância total do sistema. Pela mesma tabela, observou-se uma primeira componente principal com dominância equilibrada de elementos químicos, sendo que os maiores coeficientes de ponderação para os elementos $\mathrm{Eu}, \mathrm{Ce}, \mathrm{Fe}$ e La. A segunda componente principal foi dominada principalmente pelo elemento Fe. A terceira componente principal apareceu dominada por $\mathrm{Ce}, \mathrm{Lu}$ e $\mathrm{Yb}$. Por sua vez, a quarta componente foi dominada pelos elementos Eu, Th e Lu. Essa dominância de elementos químicos é regularmente parecida com a dominância na PCA do Cenário 3, com os dados dos dois sítios (Tab. 7.10). 
As Fig. 7.18 e 7.19 ilustram a projeção dos dados nas três primeiras componentes principais para o Cenário 3, com as amostras de Lago Grande.

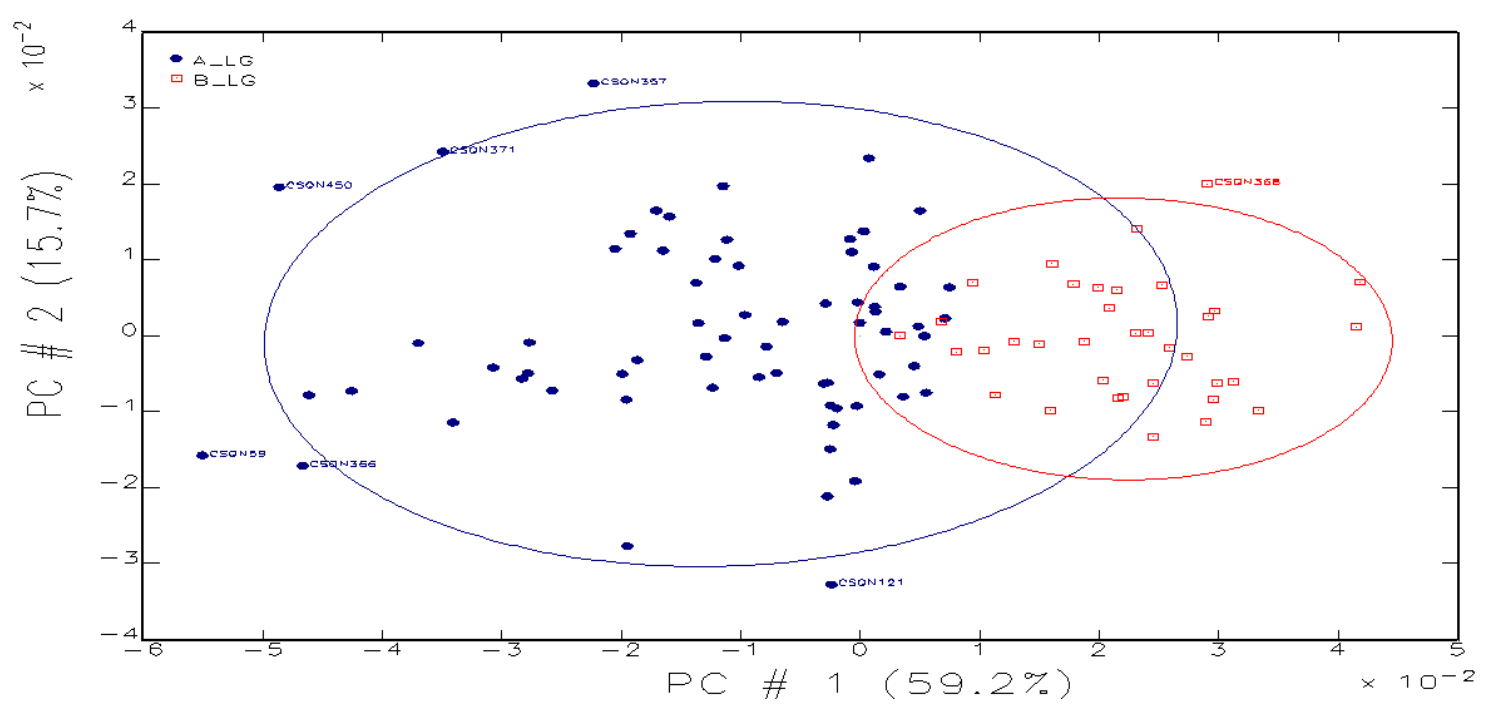

Figura 7.18 - Escores nas duas primeiras componentes principais dos dados do Cenário 3 para o sítio Lago Grande. As elipses representam a região de confiança de $95 \%$.

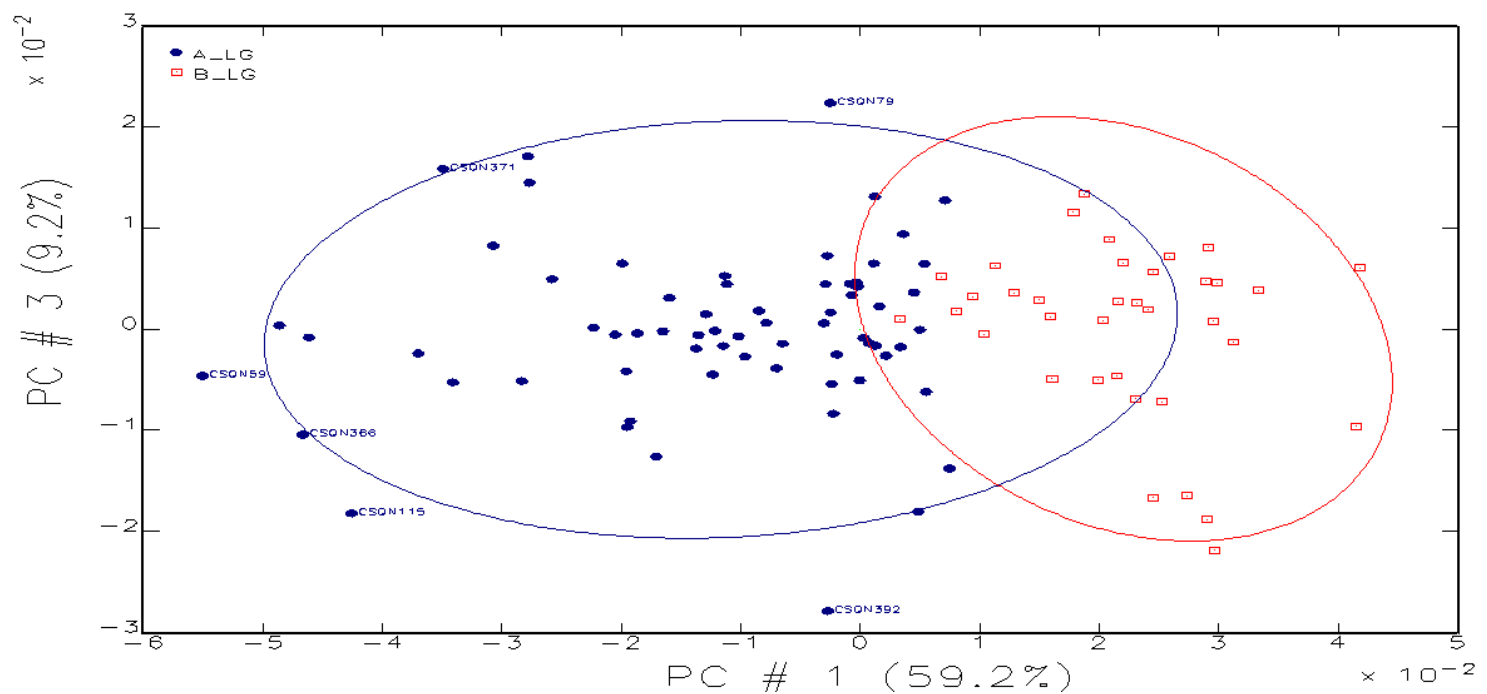

Figura 7.19 - Escores na primeira e terceira componentes principais dos dados do Cenário 3 para o sítio Lago Grande. As elipses representam a região de confiança de $95 \%$.

Pelas Fig. 7.18 e 7.19, verificou-se que os dois grupos definidos a partir do dendrograma para Lago Grande apresentaram uma boa separação, segundo o que é esperado de análises envolvendo caracterização química de cerâmicas de regiões próximas, 
de ambiente geológico similar, que tendem a apresentar algum grau de superposição. O grupo maior, A, é composto por 68 amostras, enquanto o grupo B é composto por 36.

Após a análise de agrupamento e visualização por PCA, os grupos foram então refinados levando-se em conta sua estrutura de correlação. Primeiramente extraíram-se dez amostras fora da região de 95\% de confiança da elipse A na Fig. 7.18, para aumentar sua compactação, e mais algumas amostras com probabilidade de pertinência muito baixa (menor que 1\%, segundo Glascock \& Neff, 2003) a qualquer um dos grupos (CSQN59, 79, 121, 127, 355, 357, 366, 371, 392 e 450). A seguir, por cálculos de probabilidade de pertinência aos grupos formados, a partir da extração das componentes principais pela decomposição da matriz de covariância dos dados, utilizando-se a distância estatística de Mahalanobis e a distribuição F, quatro amostras foram realocadas (CSQN60, 72, 123 e 133). Amostras com baixa probabilidade de pertinência aos dois grupos, que frequentemente eram associadas a amostras fora das elipses de 95\% de confiança em alguma projeção de componentes principais; ou com probabilidades muito próximas, indicando incerteza na sua alocação, não foram alteradas, pois o processo iterativo não convergiria, e essas amostras seriam realocadas indefinidamente. Por fim, excluíram-se as amostras CSQN376, 388, 389, 390, 391 e 392 por estarem associadas a dados discrepantes do material de referência IAEA-Soil-7 (seção 7.1.1), e por sua influência em simulações realizadas. Os gráficos de PCA refinados para o Cenário 3, com as amostras de Lago Grande, são apresentados nas Fig. 7.20 e 7.21.

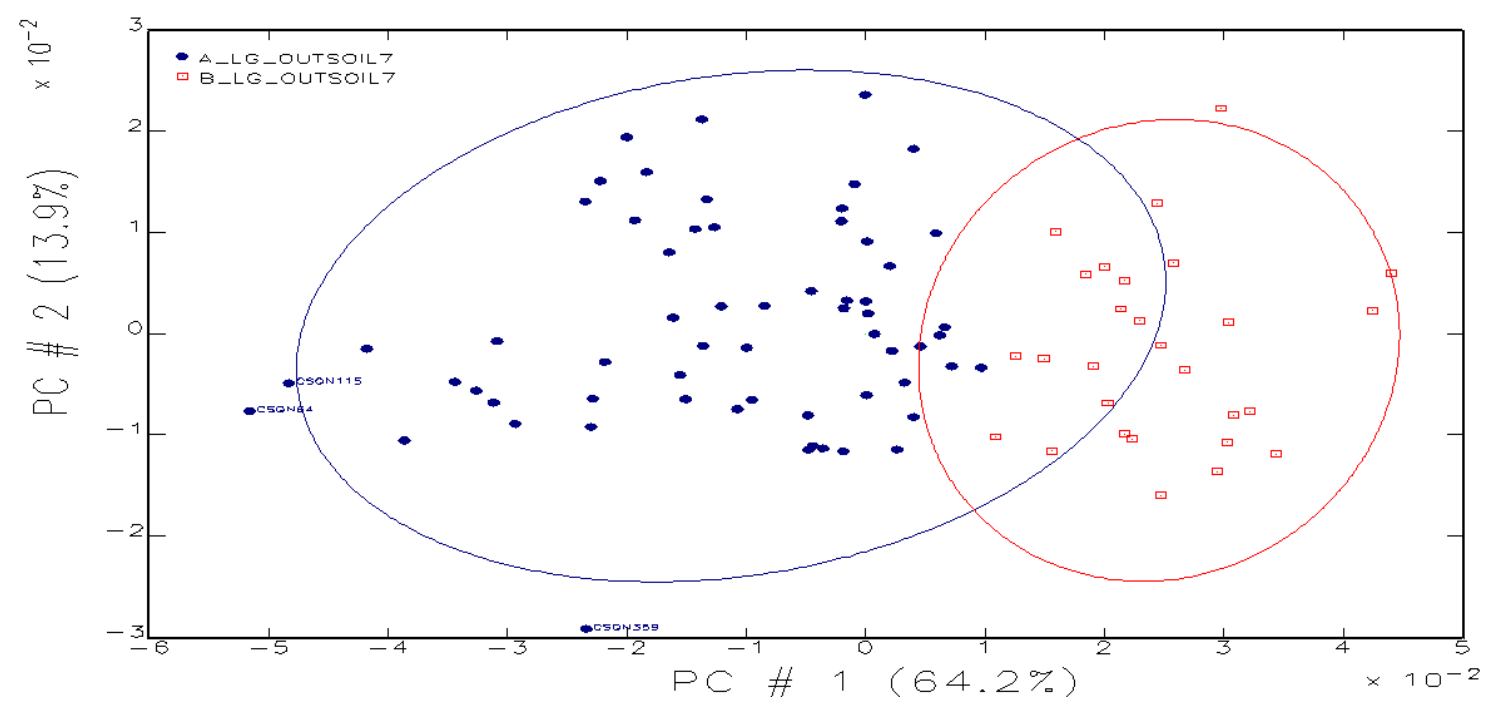

Figura 7.20 - Escores nas duas primeiras componentes principais dos dados do Cenário 3 para o sítio Lago Grande com grupos químicos refinados utilizando-se distância de Mahalanobis e distribuição F. As elipses representam a região de confiança de $95 \%$. 


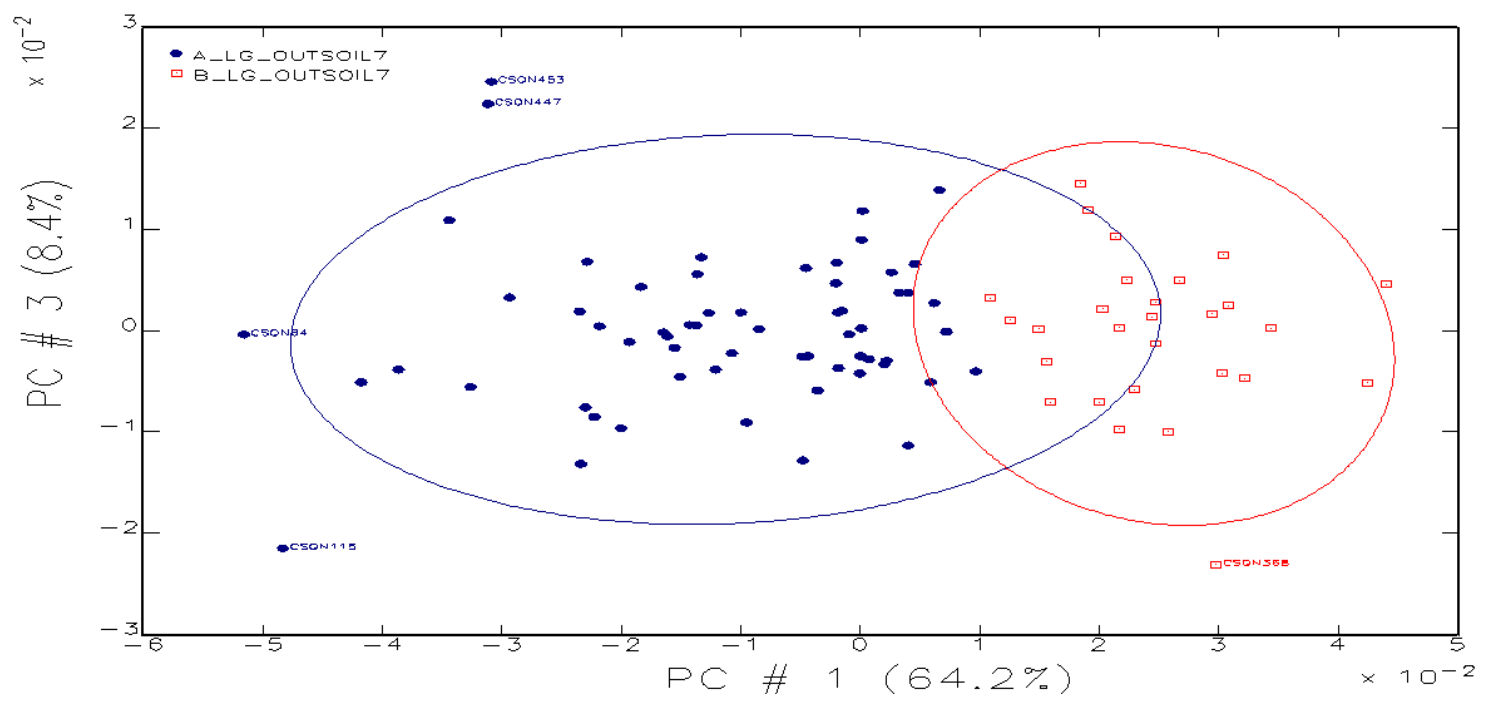

Figura 7.21 - Escores na primeira e terceira componentes principais dos dados do Cenário 3 para o sítio Lago Grande com grupos químicos refinados utilizando-se distância de Mahalanobis e distribuição F. As elipses representam a região de confiança de $95 \%$.

Pela comparação da Fig. 7.18 com a Fig. 7.20, e da Fig. 7.19 com a 7.21, observou-se uma ligeira melhora na resolução dos dois grupos em suas projeções nas componentes principais. A ausência de reclassificação de muitas amostras no processo de refinamento dos grupos químicos indica que a análise de agrupamentos pelo método Average Linkage, utilizando-se distância euclidiana quadrática e transformação $\log _{10}$, resultou numa primeira aproximação satisfatória de partição dos dados de Lago Grande.

Após a análise PCA do Cenário 3, foi realizada uma nova PCA a partir do corte mínimo da análise de agrupamentos para o Cenário 5 (seção 7.1.8) com as amostras de Lago Grande. A matriz de variação recalculada apenas com os dados desse sítio indicou, de maneira análoga ao cálculo da mesma matriz para os dados combinados dos dois sítios (seção 7.1.10), que o elemento que impõe a menor variabilidade química ao sistema e, portanto, o mais estável para ser utilizado como divisor da transformação alr, é o elemento Sc (relvar $=0,703$ ). Os coeficientes de ponderação dos autovetores que representam o peso das variáveis originais são listados na Tab. 7.15 para as primeiras quatro componentes principais, juntamente com os autovalores (variância), a porcentagem de variância representada por cada componente, e a variância acumulada. Os valores hachurados representam os maiores coeficientes de ponderação para cada componente. 
Tabela 7.15 - Coeficientes de ponderação e variância das quatro primeiras componentes principais para o Cenário 5, apenas com as amostras de Lago Grande.

\begin{tabular}{ccccc}
\hline Variável & PC1 & PC2 & PC3 & PC4 \\
\hline $\mathrm{Cr} / \mathrm{Sc}$ & 0,033715 & 0,193996 & $-0,10497$ & 0,164826 \\
$\mathrm{Fe} / \mathrm{Sc}$ & $-0,08929$ & 0,388644 & 0,601394 & 0,561607 \\
$\mathrm{La} / \mathrm{Sc}$ & 0,469569 & $-0,05324$ & $-0,11297$ & $-0,19544$ \\
$\mathrm{Ce} / \mathrm{Sc}$ & 0,403011 & $-0,52407$ & $-0,1811$ & 0,707448 \\
$\mathrm{Eu} / \mathrm{Sc}$ & 0,48699 & $-0,29134$ & 0,597317 & $-0,33301$ \\
$\mathrm{Yb} / \mathrm{Sc}$ & 0,419015 & 0,419865 & 0,010768 & 0,061194 \\
$\mathrm{Lu} / \mathrm{Sc}$ & 0,431502 & 0,502289 & $-0,16157$ & $-0,03946$ \\
$\mathrm{Th} / \mathrm{Sc}$ & 0,095139 & 0,142737 & $-0,4458$ & 0,050532 \\
\hline Autovalor & 0,022895 & 0,009034 & 0,006164 & 0,004539 \\
Variância $(\%)$ & 47,6 & 18,8 & 12,8 & 9,4 \\
Var. Acum. $(\%)$ & 47,6 & 66,4 & 79,2 & 88,6 \\
\hline
\end{tabular}

A partir da Tab. 7.15, verificou-se que as duas primeiras componentes principais, as mais utilizadas em redução de dados, representam conjuntamente $66,4 \%$ da variância total do sistema. Ainda pela mesma tabela, observou-se uma primeira componente principal com dominância equilibrada de razões elementares, sendo que os maiores coeficientes de ponderação foram observados para as razões Eu/Sc, La/Sc e Lu/Sc. A segunda componente principal foi dominada pelas razões $\mathrm{Ce} / \mathrm{Sc}, \mathrm{Lu} / \mathrm{Sc}$ e $\mathrm{Yb} / \mathrm{Sc}$. A terceira componente principal apareceu dominada por $\mathrm{Fe} / \mathrm{Sc}, \mathrm{Eu} / \mathrm{Sc}$ e $\mathrm{Th} / \mathrm{Sc}$. A quarta componente principal apareceu dominada por $\mathrm{Ce} / \mathrm{Sc}$ e Fe/Sc. Para a primeira componente principal, a dominância de elementos é regularmente parecida com a PCA com transformação alr para os dados conjuntos (Tab. 7.13), sendo que as diferenças são maiores nas demais componentes.

As Fig. 7.22 e 7.23 ilustram a projeção dos dados nas três primeiras componentes principais para o Cenário 5. 


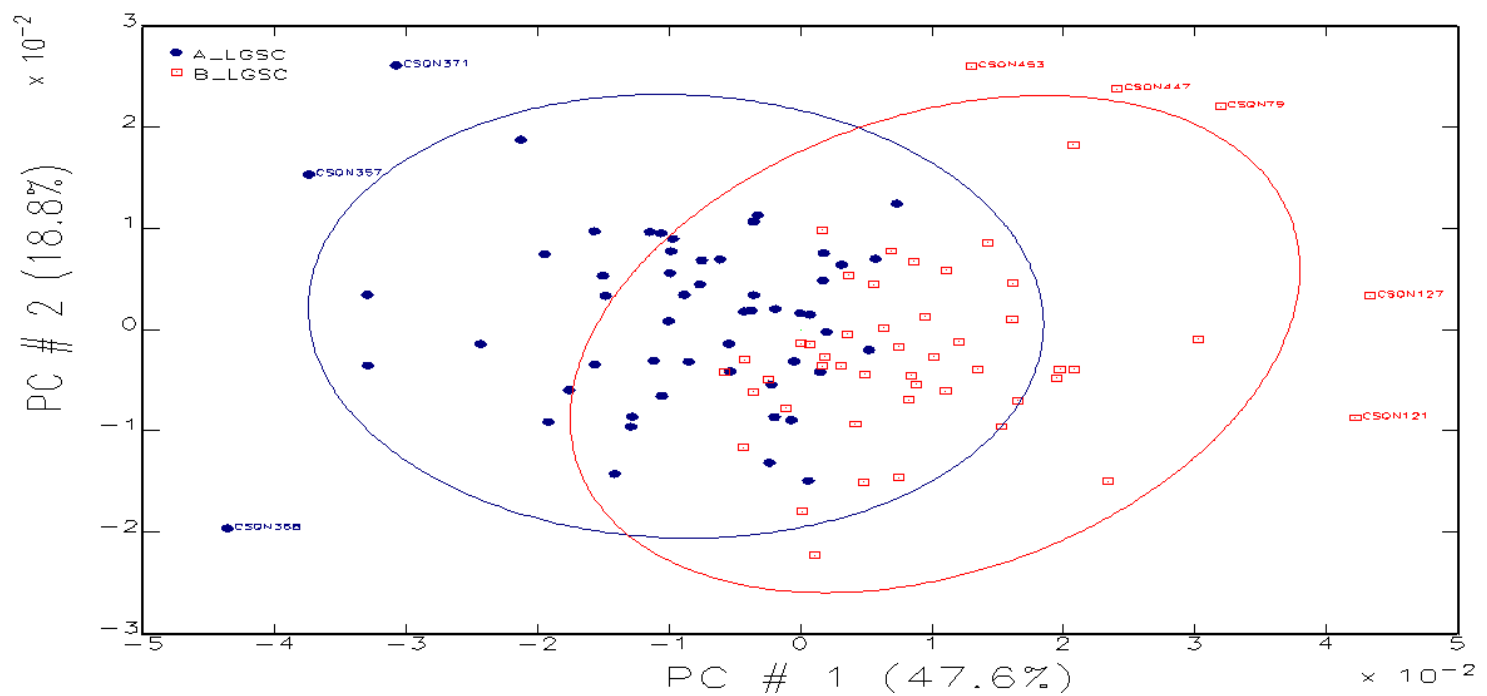

Figura 7.22 - Escores nas duas primeiras componentes principais dos dados do Cenário 5 para o sítio Lago Grande. As elipses representam a região de confiança de $95 \%$.

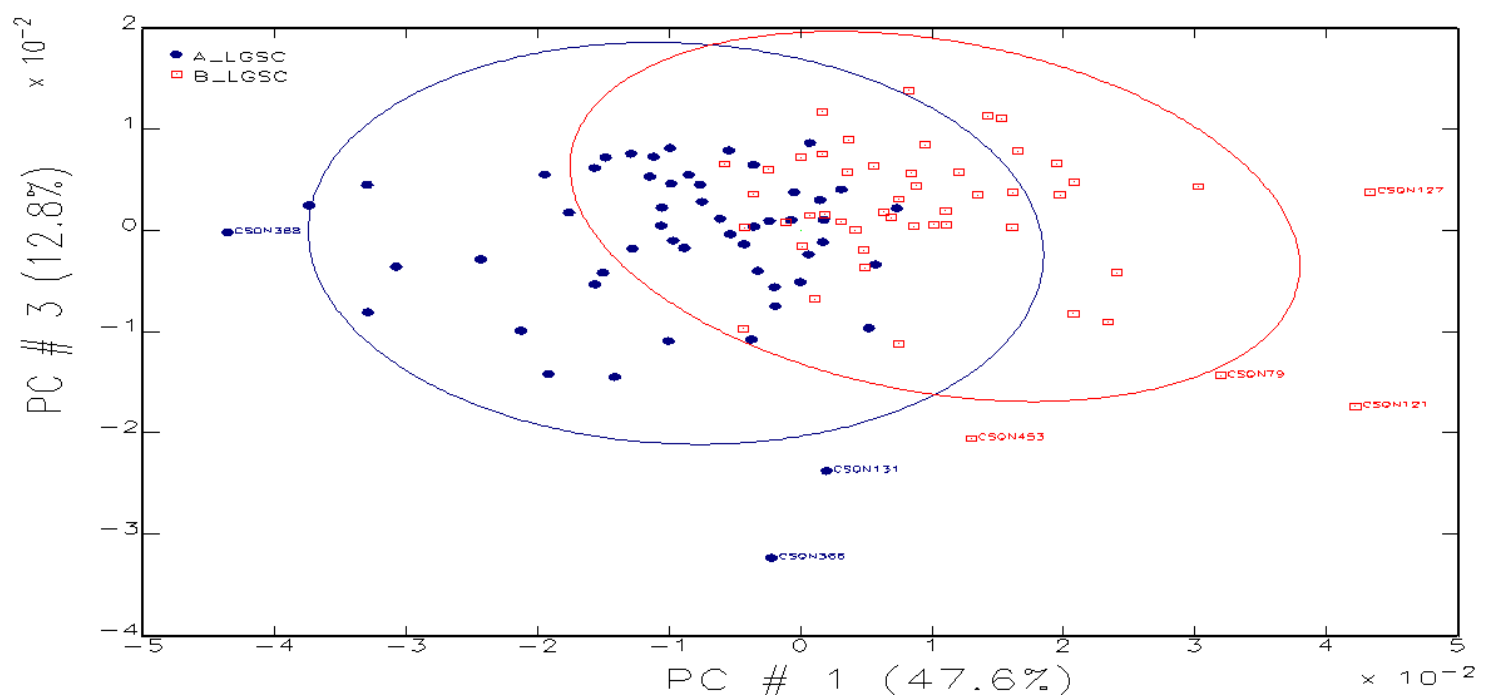

Figura 7.23 - Escores na primeira e terceira componentes principais dos dados do Cenário 5 para o sítio Lago Grande. As elipses representam a região de confiança de $95 \%$.

Pelas Fig. 7.22 e 7.23, verificou-se que os dois grupos definidos a partir do dendrograma para Lago Grande apresentaram uma separação razoável, segundo o que é esperado de análises envolvendo caracterização química de cerâmicas de regiões próximas, de ambiente geológico similar, que tendem a apresentar algum grau de superposição. Em comparação com a análise $\log _{10}$, houve uma "piora" na separação dos grupos, diminuindo sua resolução. Além disso, os grupos A e B apresentaram um maior equilíbrio de tamanho, 
tendo o grupo A 54 amostras, e o grupo B, 50 amostras. Esse novo grupo A é composto por $80 \%$ das amostras que eram provenientes de "A" na transformação $\log _{10}$.

Após a análise de agrupamento e visualização por PCA, os grupos foram então refinados levando-se em conta sua estrutura de correlação. Primeiramente extraíram-se oito amostras fora da região de 95\% de confiança na Fig. 7.22 (CSQN79, 121, 127, 357, 368, 371, 447 e 453), para aumentar a compactação das elipses. A seguir, amostras foram realocadas por cálculos de probabilidade de pertinência aos grupos formados, a partir da extração das componentes principais pela decomposição da matriz de covariância dos dados, utilizando-se a distância estatística de Mahalanobis e a distribuição F. Doze amostras foram realocadas na primeira iteração (CSQN60, 77, 80, 112, 114, 133, 351, 363, 372, 381, 433 e 454). Na segunda iteração, quatro amostras foram realocadas (CSQN72, 80, 81 e 360). Finalmente, na terceira iteração, duas amostras foram realocadas (CSQN80 e 104). Amostras com baixa probabilidade de pertinência aos dois grupos, que frequentemente eram associadas a amostras fora das elipses de 95\% de confiança em alguma projeção de componentes principais; ou com probabilidades muito próximas, indicando incerteza na sua alocação, não foram realocadas, pois o processo iterativo não convergiria, e essas amostras seriam realocadas indefinidamente. Por fim, excluíram-se as amostras CSQN376, 388, 389, 390, 391 e 392 por estarem associadas a dados discrepantes do material de referência IAEA-Soil-7 (seção 7.1.1), e por sua influência em simulações realizadas. Os gráficos de PCA refinados para o Cenário 5, com as amostras de Lago Grande, são apresentados nas Fig. 7.24 e 7.25.

Pela comparação da Fig. 7.24 com a Fig. 7.22, e da Fig. 7.25 com a 7.23 observou-se uma ligeira melhora na resolução dos dois grupos em suas projeções nas componentes principais. O processo de refinamento dos grupos químicos definidos para o Cenário 5 necessitou de mais iterações que para o Cenário 3, indicando que a análise de agrupamentos pelo método Average Linkage foi uma melhor aproximação inicial da partição dos dados com transformação $\log _{10}$ do que com alr. 


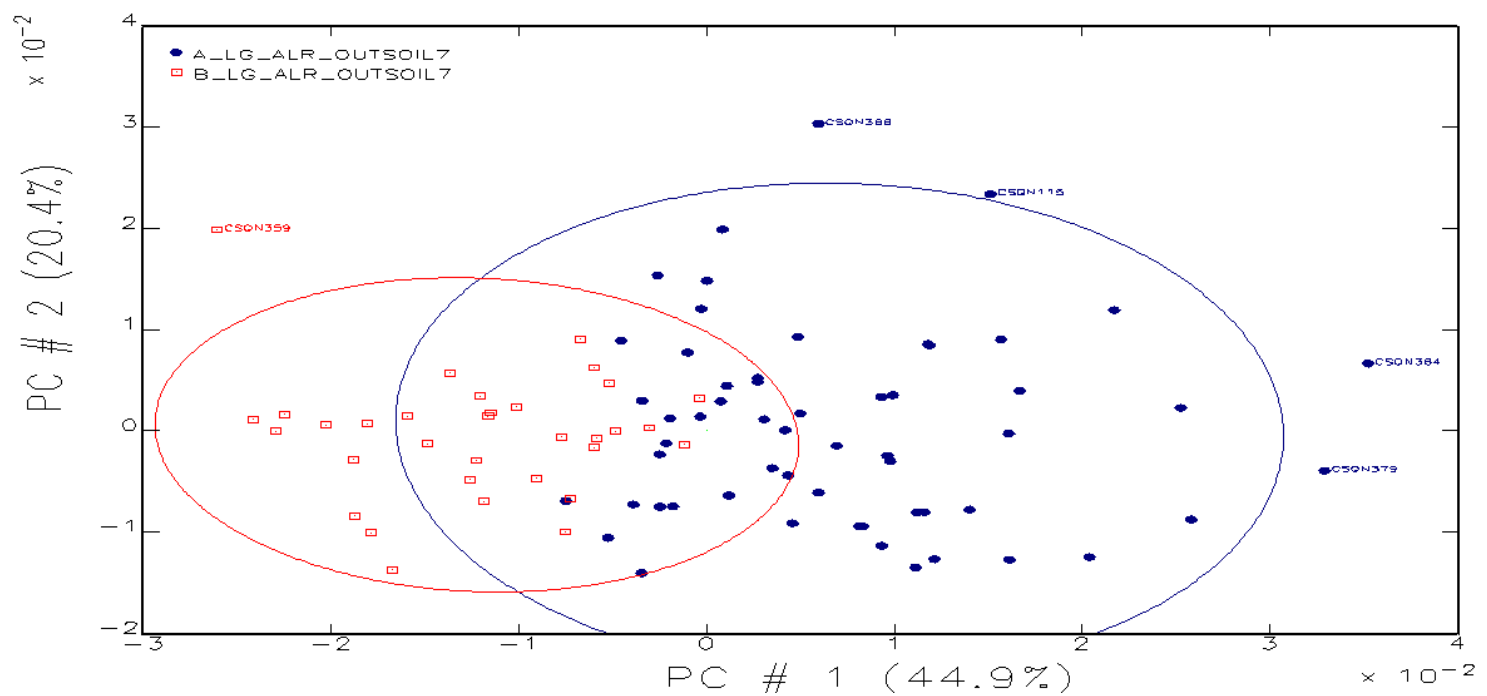

Figura 7.24 - Escores nas duas primeiras componentes principais dos dados do Cenário 5 para o sítio Lago Grande com grupos químicos refinados utilizando-se distância de Mahalanobis e distribuição F. As elipses representam a região de confiança de $95 \%$.

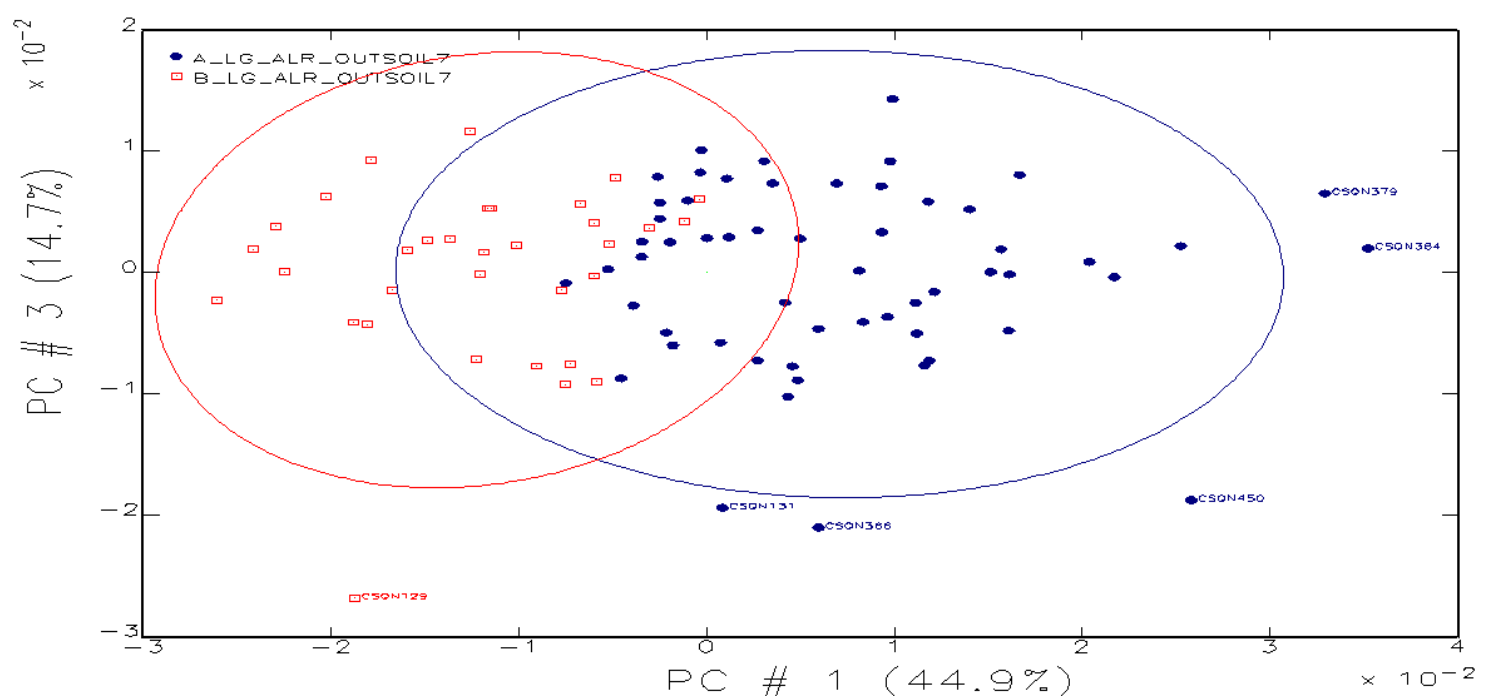

Figura 7.25 - Escores na primeira e terceira componentes principais dos dados do Cenário 5 para o sítio Lago Grande com grupos químicos refinados utilizando-se distância de Mahalanobis e distribuição F. As elipses representam a região de confiança de $95 \%$.

\section{b. Osvaldo}

Foi realizada uma nova PCA a partir do corte mínimo da análise de agrupamentos para o Cenário 3 com as amostras de Osvaldo (seção 7.1.8). Os coeficientes de ponderação dos autovetores que representam o peso das variáveis originais são listados na Tab. 7.16 para as primeiras quatro componentes principais, juntamente com os autovalores (variância), a porcentagem de variância representada por cada componente, e a 
variância acumulada. Os valores hachurados representam os maiores coeficientes de ponderação para cada componente.

Tabela 7.16 - Coeficientes de ponderação e variância das quatro primeiras componentes principais para o Cenário 3, apenas com as amostras de Osvaldo.

\begin{tabular}{ccccc}
\hline Variável & PC1 & PC2 & PC3 & PC4 \\
\hline Sc & 0,357672 & 0,380057 & $-0,04776$ & $-0,00497$ \\
$\mathrm{Cr}$ & 0,278213 & 0,313489 & $-0,18257$ & $-0,08554$ \\
$\mathrm{Fe}$ & 0,239348 & 0,456221 & $-0,22127$ & 0,450809 \\
$\mathrm{La}$ & 0,305917 & $-0,38661$ & 0,008017 & 0,085746 \\
$\mathrm{Ce}$ & 0,504725 & $-0,07361$ & 0,465254 & $-0,53525$ \\
$\mathrm{Eu}$ & 0,482868 & $-0,21409$ & 0,32449 & 0,589634 \\
$\mathrm{Yb}$ & 0,191118 & $-0,40038$ & $-0,35329$ & $-0,09951$ \\
$\mathrm{Lu}$ & 0,187411 & $-0,35964$ & $-0,60724$ & 0,019105 \\
$\mathrm{Th}$ & 0,290239 & 0,242454 & $-0,31631$ & $-0,37101$ \\
\hline Autovalor & 0,046836 & 0,010016 & 0,005877 & 0,003413 \\
Variância $(\%)$ & 65,2 & 14,0 & 8,2 & 4,8 \\
Var. Acum $(\%)$ & 65,2 & 79,2 & 87,4 & 92,1 \\
\hline
\end{tabular}

Pela Tab. 7.16, verificou-se que as duas primeiras componentes principais, as mais utilizadas em redução de dados, representam conjuntamente $79,2 \%$ da variância total do sistema. Ainda pela mesma tabela, observou-se uma primeira componente principal com maiores coeficientes de ponderação para os elementos Ce, Eu e Sc. A segunda componente principal foi dominada principalmente pelos elementos $\mathrm{Fe}, \mathrm{Yb}$, La e Sc. A terceira componente principal apareceu dominada principalmente por $\mathrm{Lu}, \mathrm{Ce}$ e $\mathrm{Yb}$. Por sua vez, a quarta componente foi dominada pelos elementos Eu, Ce e Fe. Essa dominância de elementos químicos é regularmente parecida com a dominância na PCA do Cenário 3 com os dados dos dois sítios (Tab. 7.10).

As Fig. 7.26 e 7.27 ilustram a projeção dos dados nas três primeiras componentes principais para o Cenário 5, com as amostras de Osvaldo. 


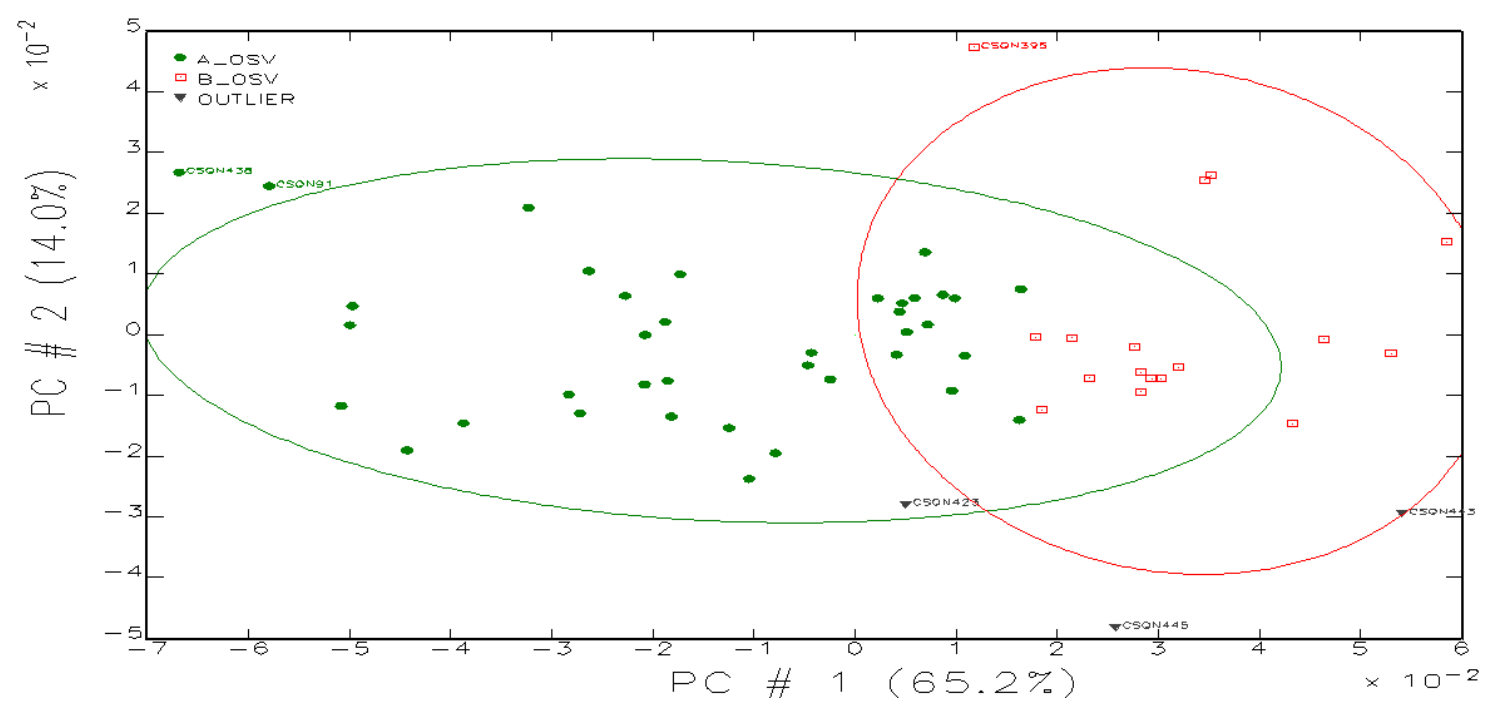

Figura 7.26 - Escores nas duas primeiras componentes principais dos dados do Cenário 3 para o sítio Osvaldo. As elipses representam a região de confiança de $95 \%$.

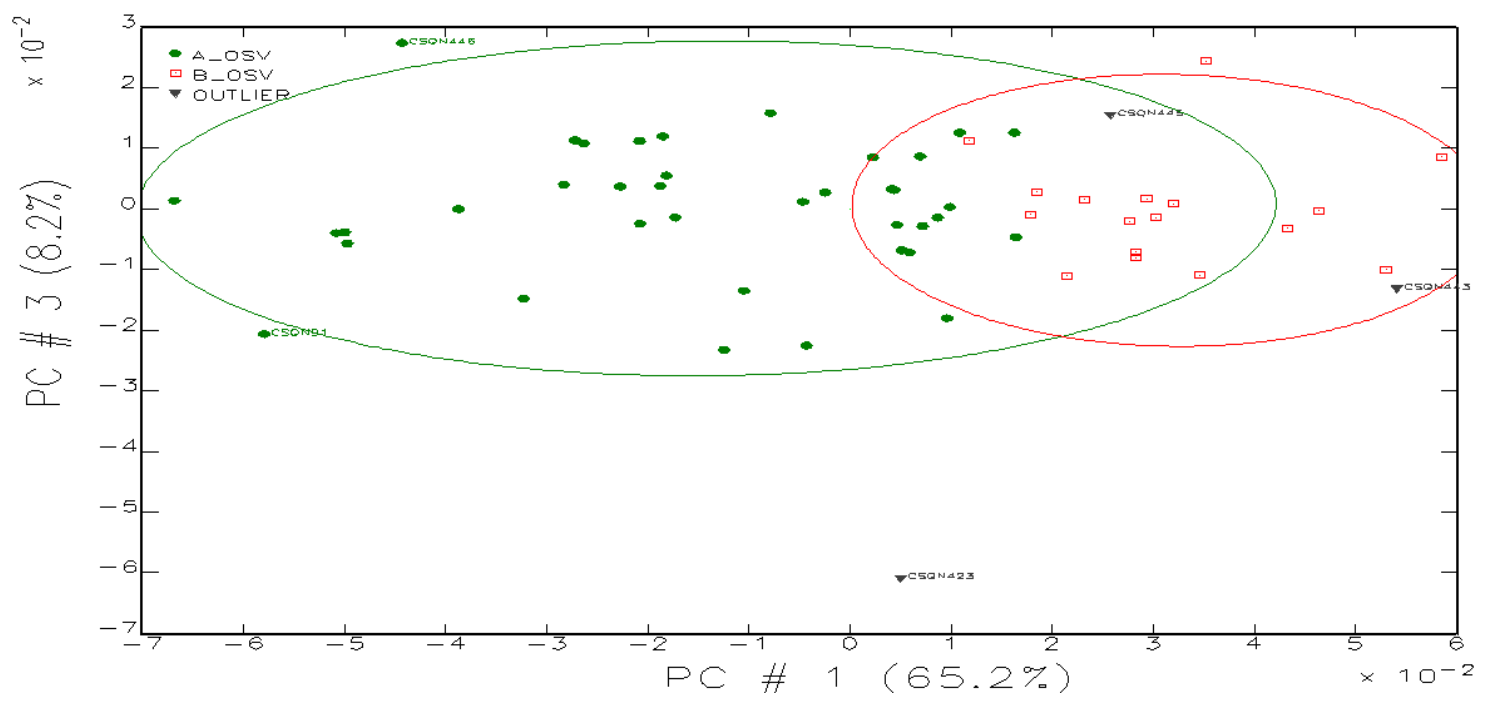

Figura 7.27 - Escores na primeira e terceira componentes principais dos dados do Cenário 3 para o sítio Osvaldo. As elipses representam a região de confiança de $95 \%$.

Pelas Fig. 7.26 e 7.27, verificou-se que os dois grupos definidos a partir do dendrograma para Osvaldo apresentaram uma boa separação, segundo o que é esperado de análises envolvendo caracterização química de cerâmicas de regiões próximas, de ambiente geológico similar, que tendem a apresentar algum grau de superposição. O grupo maior, A, é composto por 38 amostras, enquanto o grupo B é composto por 17, num total de 55 amostras. 
Após a análise de agrupamento e visualização por PCA, os grupos foram então refinados levando-se em conta sua estrutura de correlação. Primeiramente extraíram-se três amostras fora da região de $95 \%$ de confiança para os dois grupos definidos na Fig. 7.26 (CSQN91, 395 e 438), para aumentar a compactação das elipses dos grupos A e B. A seguir, por cálculos de probabilidade de pertinência aos grupos formados, a partir da extração das componentes principais pela decomposição da matriz de covariância dos dados, utilizando-se a distância estatística de Mahalanobis e a distribuição F, uma amostra foi realocada (CSQN424). Amostras com baixa probabilidade de pertinência aos dois grupos, que frequentemente eram associadas a amostras fora das elipses de $95 \%$ de confiança em alguma projeção de componentes principais; ou com probabilidades muito próximas, indicando incerteza na sua alocação, não foram realocadas, pois o processo iterativo não convergiria, e essas amostras seriam realocadas indefinidamente.

Os gráficos de PCA refinados para o Cenário 3, com as amostras de Osvaldo, são apresentados nas Fig.7.28 e 7.29.

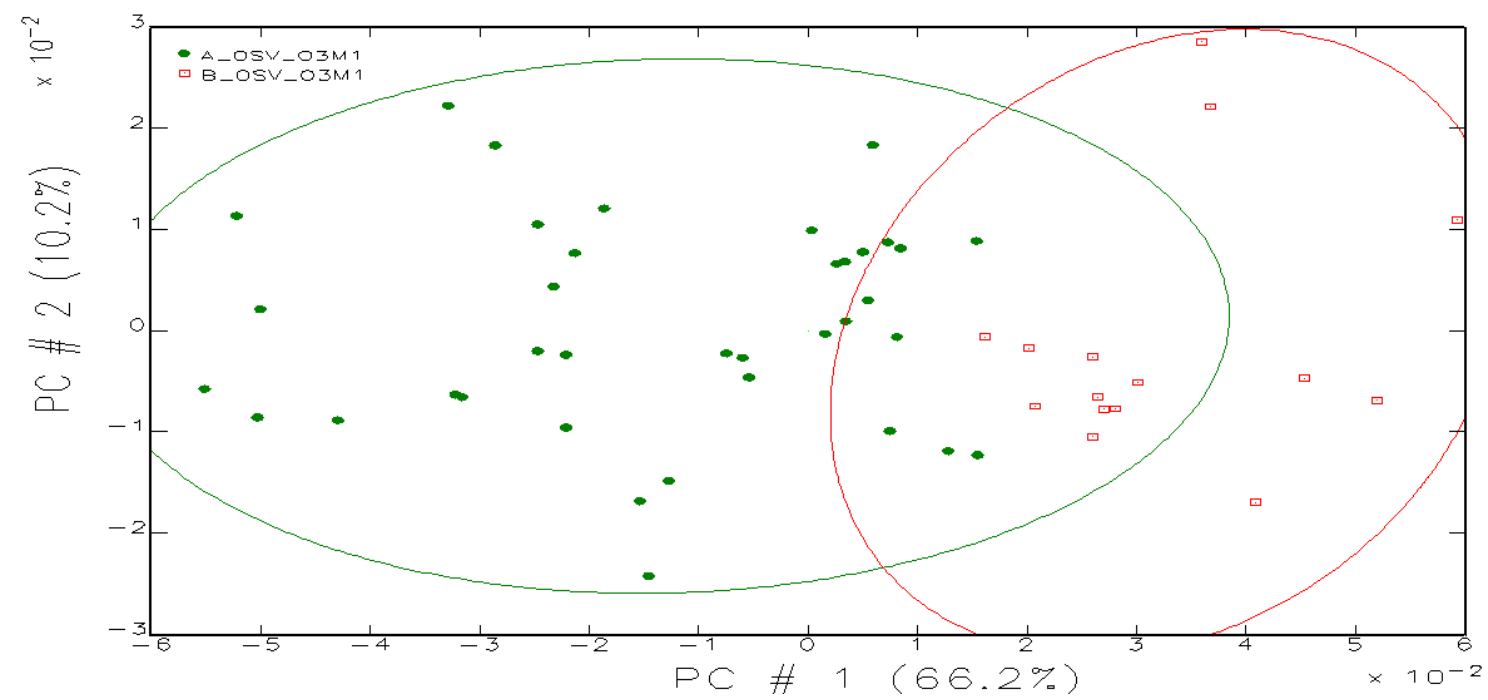

Figura 7.28 - Escores nas duas primeiras componentes principais dos dados do Cenário 3 para o sítio Osvaldo com grupos químicos refinados utilizando-se distância de Mahalanobis e distribuição F. As elipses representam a região de confiança de $95 \%$. 


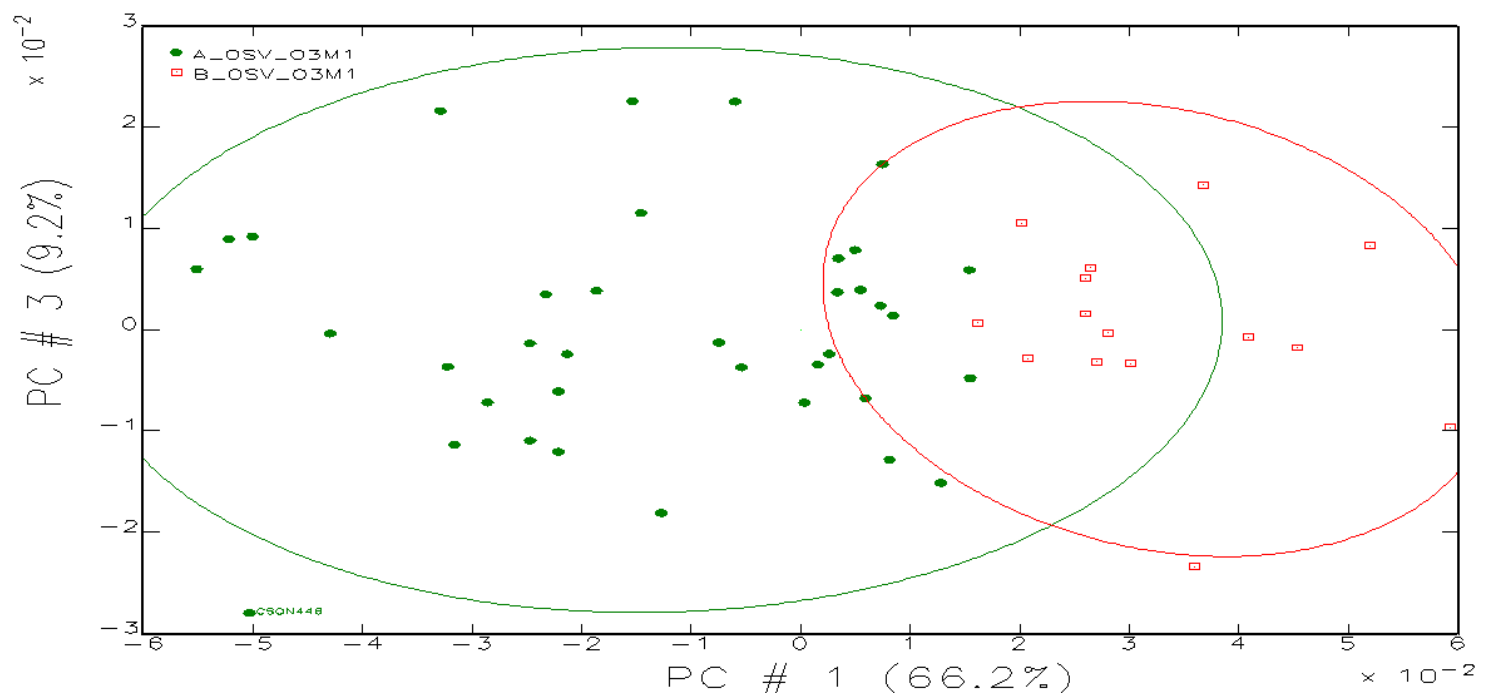

Figura 7.29 - Escores na primeira e terceira componentes principais dos dados do Cenário 3 para o sítio Osvaldo com grupos químicos refinados utilizando-se distância de Mahalanobis e distribuição F. As elipses representam a região de confiança de $95 \%$.

Pela comparação da Fig. 7.28 com a Fig. 7.26, e da Fig. 7.29 com a 7.27, observou-se uma ligeira melhora na resolução dos dois grupos em suas projeções nas componentes principais, mais evidente na Fig. 7.29.

Após a análise PCA do Cenário 3, foi realizada uma nova PCA a partir do corte mínimo da análise de agrupamentos para o Cenário 5 com as amostras de Osvaldo (seção 7.1.8). A matriz de variação recalculada apenas com os dados de Osvaldo indicou que o elemento que impõe a menor variabilidade química ao sistema, e portanto o mais estável para ser utilizado como divisor da transformação alr, é o elemento $\mathrm{Cr}$ (relvar = 0,645). No entanto, escolheu-se o segundo elemento mais estável, Sc (relvar $=0,618)$ para facilitar a comparação com os dados de Lago Grande e dos dados conjuntos, para os quais o elemento Sc foi indicado como o mais estável. Os coeficientes de ponderação dos autovetores que representam o peso das variáveis originais são listados na Tab. 7.17 para as primeiras quatro componentes principais, juntamente com os autovalores (variância), a porcentagem de variância representada por cada componente, e a variância acumulada. Os valores hachurados representam os maiores coeficientes de ponderação para cada componente. 
Tabela 7.17 - Coeficientes de ponderação e variância das quatro primeiras componentes principais para o Cenário 5, apenas com as amostras de Osvaldo.

\begin{tabular}{ccccc}
\hline Variável & PC1 & PC2 & PC3 & PC4 \\
\hline $\mathrm{La} / \mathrm{Sc}$ & 0,384647 & $-0,286$ & 0,069837 & 0,167555 \\
$\mathrm{Lu} / \mathrm{Sc}$ & 0,552278 & 0,377573 & 0,015358 & 0,14364 \\
$\mathrm{Yb} / \mathrm{Sc}$ & 0,53395 & 0,184072 & $-0,19091$ & $-0,07407$ \\
$\mathrm{Ce} / \mathrm{Sc}$ & 0,330033 & $-0,63816$ & $-0,14701$ & 0,319322 \\
$\mathrm{Cr} / \mathrm{Sc}$ & 0,203909 & 0,138272 & 0,111119 & 0,282376 \\
$\mathrm{Eu} / \mathrm{Sc}$ & 0,141798 & $-0,49681$ & 0,464728 & $-0,47492$ \\
$\mathrm{Fe} / \mathrm{Sc}$ & 0,054333 & 0,215159 & 0,839288 & 0,194069 \\
$\mathrm{Th} / \mathrm{Sc}$ & 0,297278 & 0,149267 & $-0,06407$ & $-0,70774$ \\
\hline Autovalor & 0,014777 & 0,006062 & 0,002627 & 0,002125 \\
Variância $(\%)$ & 51,0 & 20,9 & 9,1 & 7,3 \\
Var. Acum. $(\%)$ & 51,0 & 72,0 & 81,1 & 88,4 \\
\hline
\end{tabular}

Pela Tab. 7.17, observou-se que as duas primeiras componentes principais, as mais utilizadas em redução de dados, representam conjuntamente $72,0 \%$ da variância total do sistema. Ainda pela mesma tabela, observou-se uma primeira componente principal com os maiores coeficiente de ponderação para as razões Lu/Sc, Yb/Sc e La/Sc. A segunda componente principal foi dominada pelas razões $\mathrm{Ce} / \mathrm{Sc}, \mathrm{Eu} / \mathrm{Sc}$ e $\mathrm{Lu} / \mathrm{Sc}$. A terceira componente principal foi dominada por Fe/Sc e Eu/Sc. Por sua vez, a quarta componente principal foi dominada por $\mathrm{Th} / \mathrm{Sc}$, Eu/Sc e Ce/Sc. A dominância de elementos químicos nas quatro componentes principais é razoavelmente parecida com a PCA com transformação alr para os dados conjuntos (Tab. 7.13).

As Fig. 7.30 e 7.31 ilustram a projeção dos dados nas três primeiras componentes principais para o Cenário 5, com as amostras de Osvaldo. 


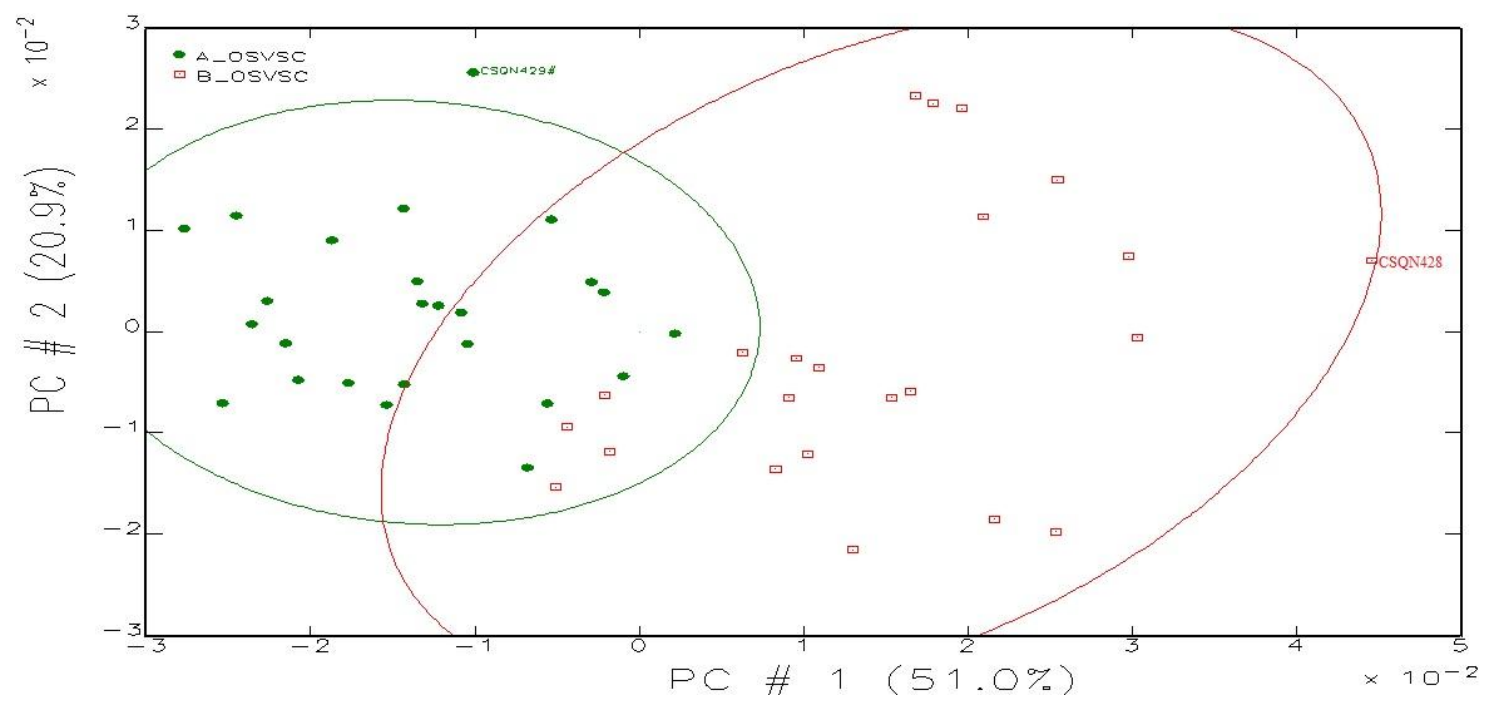

Figura 7.30 - Escores nas duas primeiras componentes principais dos dados do Cenário 5 para o sítio Osvaldo. As elipses representam a região de confiança de $95 \%$.

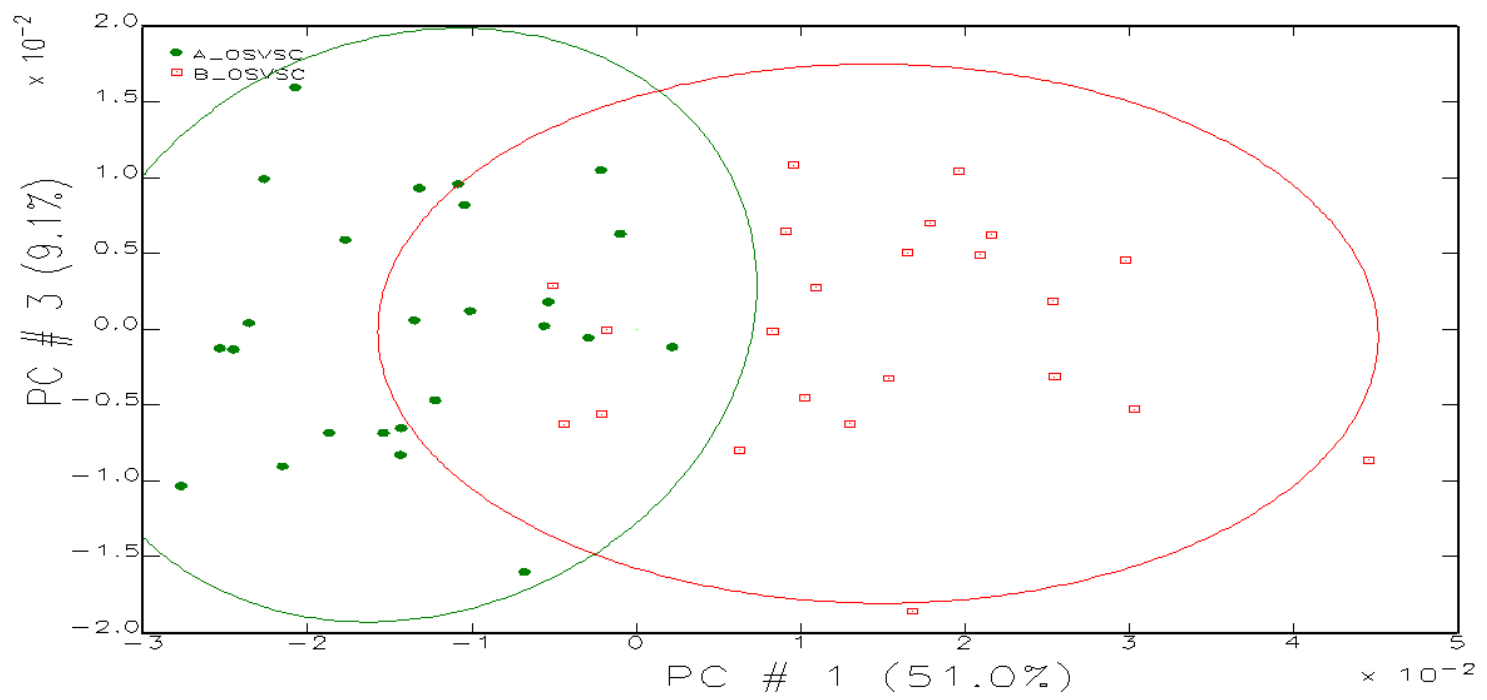

Figura 7.31 - Escores na primeira e terceira componentes principais dos dados do Cenário 5 para o sítio Osvaldo. As elipses representam a região de confiança de $95 \%$.

Pelas Fig. 7.30 e 7.31, verificou-se que os dois grupos definidos a partir do dendrograma para Osvaldo apresentaram uma separação razoável, segundo o que é esperado de análises envolvendo caracterização química de cerâmicas de regiões próximas, com ambientes geológicos similares, que tendem a apresentar algum grau de superposição. Em comparação com a análise $\log _{10}$, não houve alterações significativas na separação dos grupos, apenas uma dispersão relativamente maior das amostras do grupo B dentro da elipse de $95 \%$ de confiança. Além disso, assim como para Lago Grande, os grupos A e B 
apresentaram um maior equilíbrio de tamanho, tendo o grupo A 25 amostras, e o grupo B, 23 amostras. O grupo A é composto por $72 \%$ das amostras que eram provenientes de A na transformação $\log _{10}$, enquanto apenas $26 \%$ das amostras do grupo B na análise alr são provenientes do grupo B na análise $\log _{10}$.

Após a análise de agrupamento (seção 7.1.8), os grupos foram então refinados levando-se em conta sua estrutura de correlação. Primeiramente extraíram-se duas amostras extremas na Fig. 7.30 (CSQN428, que estava fora da elipse de 95\% de confiança, e CSQN429, a amostra mais extrema do grupo B), para aumentar a compactação das elipses. A seguir, amostras foram realocadas por cálculos de probabilidade de pertinência aos grupos formados, a partir da extração das componentes principais pela decomposição da matriz de covariância dos dados, utilizando-se a distância estatística de Mahalanobis e a distribuição F. Três amostras foram realocadas na primeira iteração (CSQN101, 426 e 427). Na segunda iteração, uma amostra foi realocada (CSQN98). Finalmente, na terceira iteração, duas amostras foram realocadas (CSQN400 e 427). Amostras com baixa probabilidade de pertinência aos dois grupos, que frequentemente eram associadas a amostras fora das elipses de $95 \%$ de confiança em alguma projeção de componentes principais; ou com probabilidades muito próximas, indicando incerteza na sua alocação, não foram realocadas, pois o processo iterativo não convergiria, e essas amostras seriam realocadas indefinidamente no processo de refinamento. Os gráficos de PCA refinados para o Cenário 5, com as amostras de Osvaldo, são apresentados nas Fig. 7.32 e 7.33.

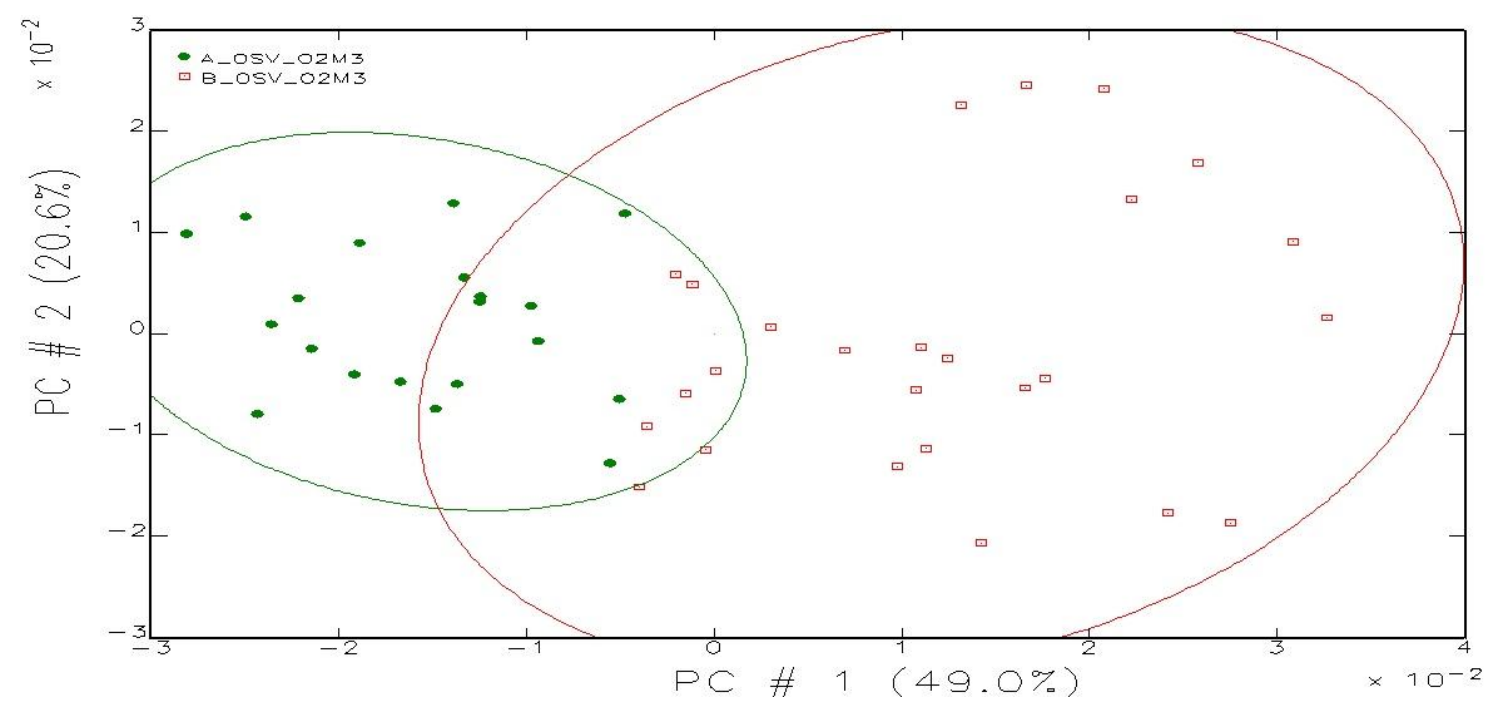

Figura 7.32 - Escores nas duas primeiras componentes principais dos dados do Cenário 5 para o sítio Osvaldo com grupos químicos refinados utilizando-se distância de Mahalanobis e distribuição F. As elipses representam a região de confiança de $95 \%$. 


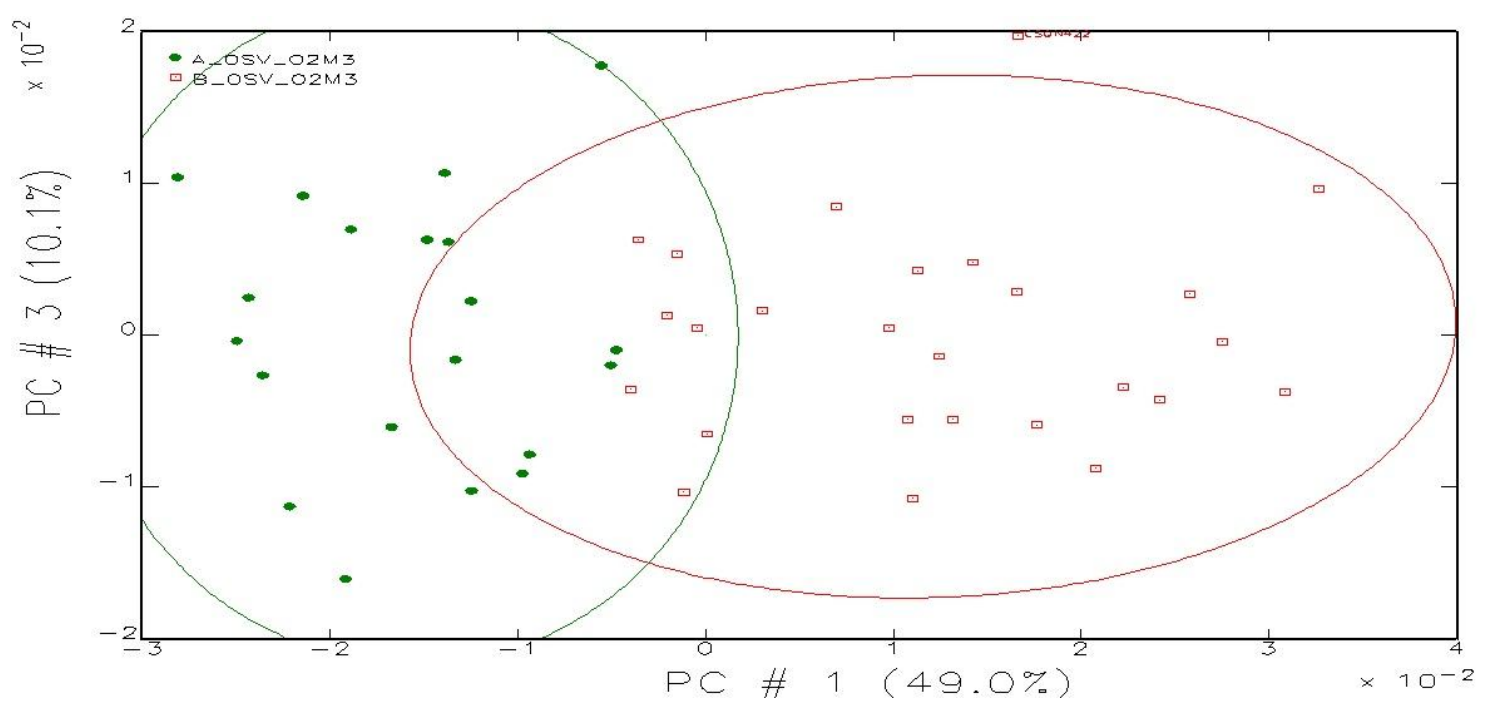

Figura 7.33 - Escores na primeira e terceira componentes principais dos dados do Cenário 5 para o sítio Osvaldo com grupos químicos refinados utilizando-se distância de Mahalanobis e distribuição F. As elipses representam a região de confiança de $95 \%$.

Pela comparação da Fig. 7.32 com a Fig. 7.30, e da Fig. 7.33 com a 7.31, não foram observadas diferenças significativas na resolução dos dois grupos em suas projeções nas três primeiras componentes principais após o processo de refinamento.

\subsubsection{Análise comparativa entre Lago Grande e Osvaldo}

a. Transformação $\log _{10}$

Nas Fig. 7.34 e 7.35 são apresentadas as projeções nas três primeiras componentes principais dos dois grupos químicos definidos para Lago Grande e Osvaldo na análise PCA com transformação $\log _{10}$ (Cenário 3), por sítio, tratada na seção 7.1.12.

Pelas Fig. 7.34 e 7.35, foi verificado que o grupo A de Lago Grande apresentou boa superposição com o grupo A de Osvaldo, enquanto o grupo B de Lago Grande apresentou boa superposição com o grupo B de Osvaldo. Essas superposições podem ser indicativas de que os grupos químicos de cerâmicas definidos para cada sítio tenham relação entre si, implicando em semelhanças nas pastas cerâmicas produzidas por antigos habitantes dos dois sítios, sugerindo interação cultural entre Lago Grande e Osvaldo por algum mecanismo como troca comercial, casamento exogâmico e/ou compartilhamento de territórios. 


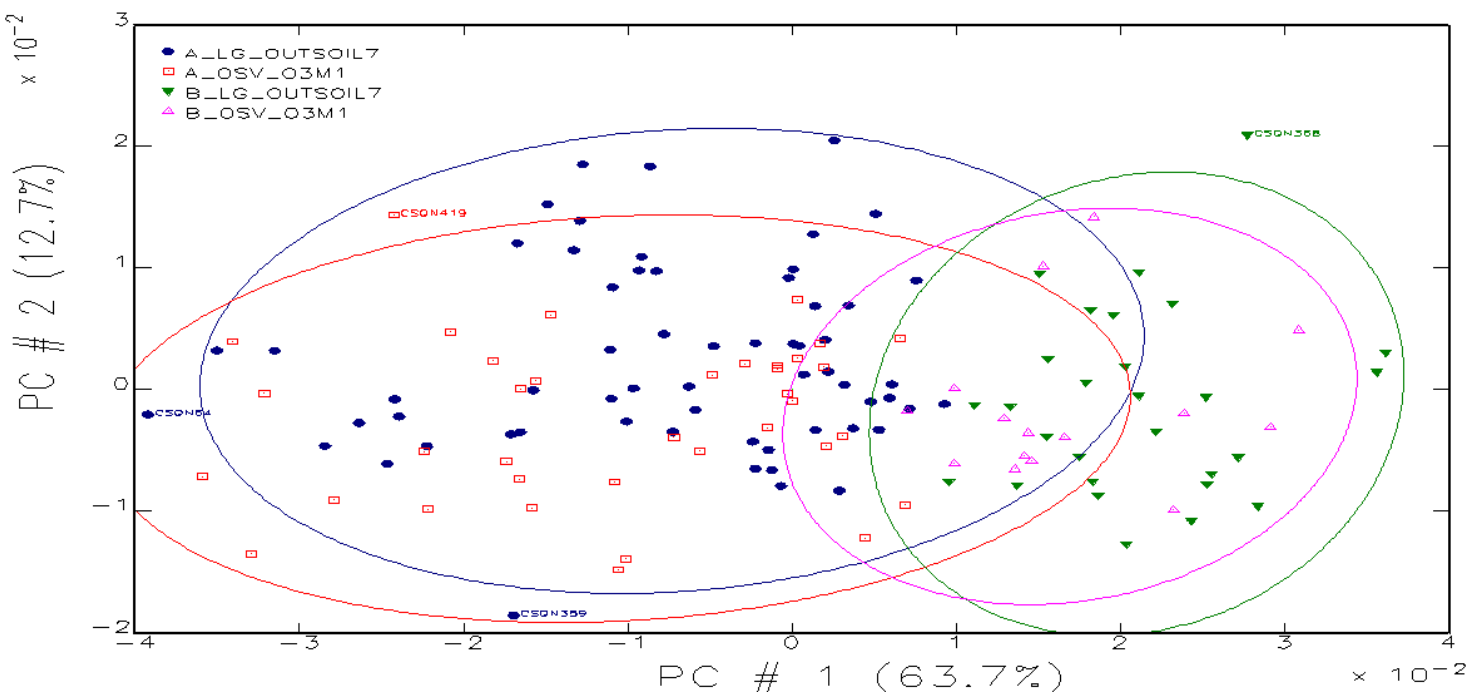

Figura 7.34 - Escores nas duas primeiras componentes principais dos dados do Cenário 3 para os dois grupos químicos de Lago Grande e Osvaldo. As elipses representam a região de confiança de $95 \%$.

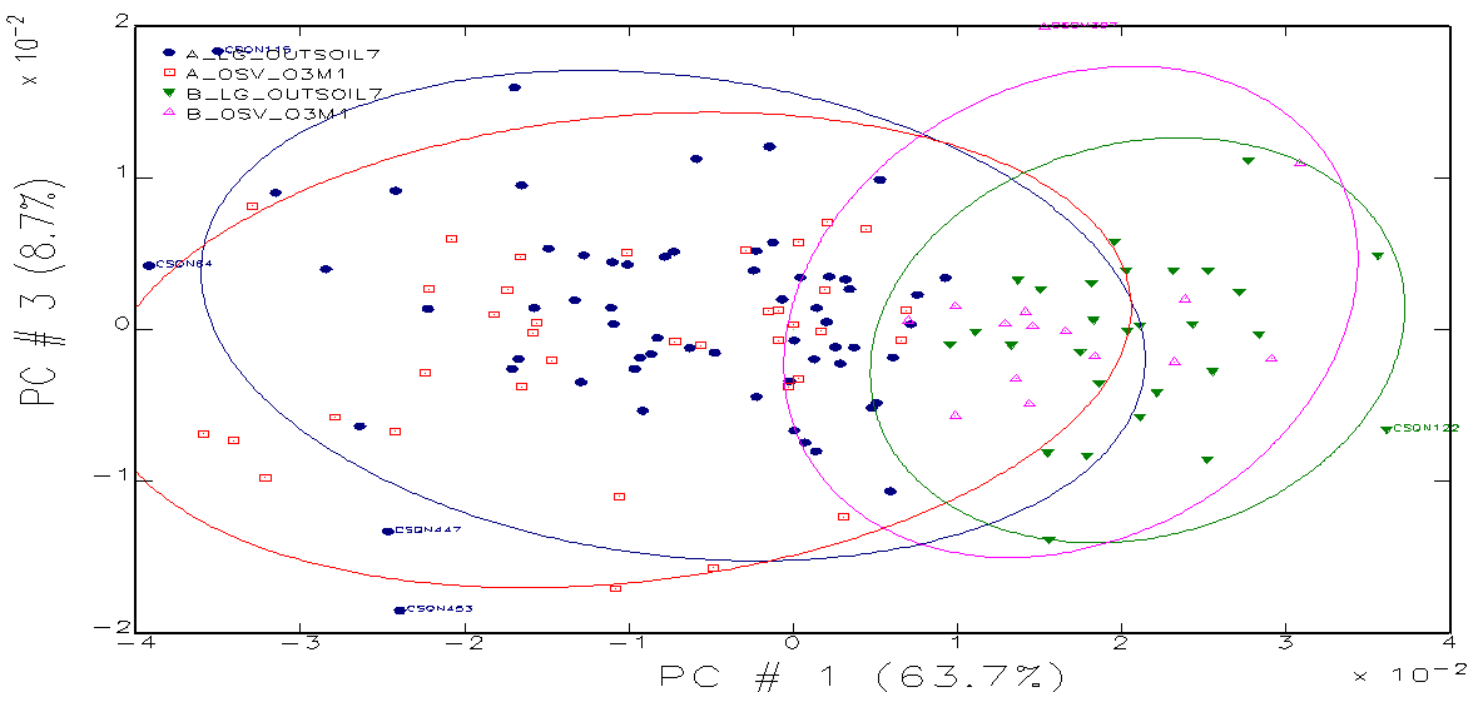

Figura 7.35 - Escores na primeira e terceira componentes principais dos dados do Cenário 3 para os dois grupos químicos de Lago Grande e Osvaldo. As elipses representam a região de confiança de $95 \%$.

Na Tab. 7.18, são apresentadas as concentrações médias dos elementos químicos em cada um dos grupos definidos para Lago Grande e Osvaldo, presentes nas Fig. 7.34 e 7.35 . 
Tabela 7.18 - Concentrações médias em $\mu \mathrm{g} \cdot \mathrm{g}^{-1}$ dos elementos nos grupos químicos de cerâmicas de Lago Grande e Osvaldo, com transformação $\log _{10}$ (Cenário 3).

\begin{tabular}{c|c|c|c|c}
\hline \multirow{2}{*}{ Variável } & \multicolumn{2}{|c|}{ Lago Grande } & \multicolumn{2}{c}{ Osvaldo } \\
\cline { 2 - 5 } & $\mathrm{A}(\mathrm{n}=61)$ & $\mathrm{B}(\mathrm{n}=28)$ & $\mathrm{A}(\mathrm{n}=37)$ & $\mathrm{B}(\mathrm{n}=15)$ \\
\hline $\mathrm{Sc}$ & $14,8 \pm 1,9$ & $18,6 \pm 2,1$ & $13,8 \pm 2,0$ & $18,7 \pm 2,3$ \\
$\mathrm{Cr}$ & $64,3 \pm 8,3$ & $79,1 \pm 10,2$ & $59,0 \pm 7,4$ & $75,3 \pm 9,6$ \\
$\mathrm{Fe}$ & $36543 \pm 7991$ & $44197 \pm 6505$ & $32432 \pm 5723$ & $39165 \pm 3728$ \\
$\mathrm{La}$ & $38 \pm 5$ & $50 \pm 5$ & $38 \pm 4$ & $47 \pm 7$ \\
$\mathrm{Ce}$ & $75 \pm 11$ & $104 \pm 17$ & $71 \pm 12$ & $107 \pm 24$ \\
$\mathrm{Eu}$ & $1,1 \pm 0,2$ & $1,7 \pm 0,2$ & $1,1 \pm 0,2$ & $1,5 \pm 0,2$ \\
$\mathrm{Yb}$ & $2,7 \pm 0,4$ & $3,5 \pm 0,4$ & $2,9 \pm 0,4$ & $3,3 \pm 0,4$ \\
$\mathrm{Lu}$ & $0,45 \pm 0,07$ & $0,56 \pm 0,07$ & $0,47 \pm 0,07$ & $0,55 \pm 0,06$ \\
$\mathrm{Th}$ & $13,7 \pm 1,5$ & $16,6 \pm 2,0$ & $13,8 \pm 2,2$ & $17,2 \pm 2,4$ \\
\hline
\end{tabular}

Pela Tab. 7.18,verificou-se que as concentrações dos grupos B de Lago Grande e Osvaldo, que aparecem superpostos nas Fig. 7.34 e 7.35 apresentaram concentrações elementares sistematicamente maiores que as do grupo A. Ainda, as concentrações de grupos equivalentes de cada sítio apresentaram concentrações semelhantes, que se superpõem quando considerados os intervalos de dispersão em torno da média, representados aqui pelos desvios-padrão de cada elemento. Essas semelhanças refletem-se na superposição das elipses A e B nas Fig. 7.34 e 7.35.

Uma indicação de validação indireta dos grupos químicos formados pode ser feita pela análise de seus coeficientes de variação (desvio-padrão relativo). Para o grupo A de Lago Grande, os coeficientes de variação oscilaram entre $11 \%$ e $20 \%$ para a maioria dos elementos, com exceção do elemento Fe, cuja variação ficou em torno de $22 \%$. O grupo B de Lago Grande apresentou coeficientes de variação entre $11 \%$ e $15 \%$ para todos os elementos, com exceção do Ce, com 17\%. Para o grupo A de Osvaldo, os coeficientes de variação oscilaram entre $11 \%$ e $20 \%$. O grupo B de Osvaldo apresentou coeficientes de variação entre $10 \%$ e $14 \%$ para todos os elementos, com exceção de Ce, com $23 \%$. Assim, observou-se que a dispersão dos grupos equivalentes dos dois sítios também é parecida. Os coeficientes de variação menores para os grupos B de cada sítio refletem as concentrações elementares maiores para esses grupos, em relação aos grupos A.

Bishop (2003) observou que procedimentos para confirmar grupos químicos de cerâmica estatisticamente significativos podem ser realizados internamente aos mesmos, ou pela comparação entre diferentes grupos. Baseado na comparação de diversos estudos 
arqueométricos de cerâmicas realizados em todo o mundo, o autor observou que grupos bem caracterizados possuíam dispersão univariada de elementos químicos entre 10-15\%, dependendo da precisão com o qual esses elementos eram determinados. Pela discussão anterior, o grupo B de cada sítio é o que mais se encaixa nos parâmetros sugeridos pelo autor. Por sua vez, Harbottle (1982b) sugeriu um intervalo em torno de 15-20\%. Neste trabalho, os coeficientes de variação calculados para os grupos A e B de Lago Grande e Osvaldo estão regularmente em concordância com esses intervalos estimados por Harbottle. Assim, essa seria outra indicação de que os grupos químicos encontrados são estatisticamente significativos.

No intuito de se relacionar os resultados de grupos químicos cerâmicos a uma proveniência geográfica, o critério de abundância é frequentemente empregado (Harbottle, 1982a; Buxeda i Garrigós et al., 2001). Segundo esse princípio, o grupo com o maior número de membros seria característico do local analisado, enquanto grupos menores poderiam ser exógenos, e correlatos de troca comercial, por exemplo. Neste trabalho, não é possível aplicar o critério de abundância, pois a amostragem dos sítios Lago Grande e Osvaldo não foi totalmente aleatória, mas parcialmente enviesada no sentido de se aumentar o número de amostras que fossem características da fase cerâmica não preponderante em cada sítio, para melhorar sua caracterização química.

Resultados similares no que tange o tamanho dos grupos com transformação logarítmica dos dados foi relatado por Lima (2008) em estudo preliminar com fragmentos cerâmicos e argilas queimadas de Osvaldo.

b. Transformação alr

Nas Fig. 7.36 e 7.37 são apresentadas as projeções nas três primeiras componentes principais dos dois grupos químicos definidos para Lago Grande e Osvaldo na análise PCA com transformação alr (Cenário 5), por sítio, tratada na seção 7.1.12. 


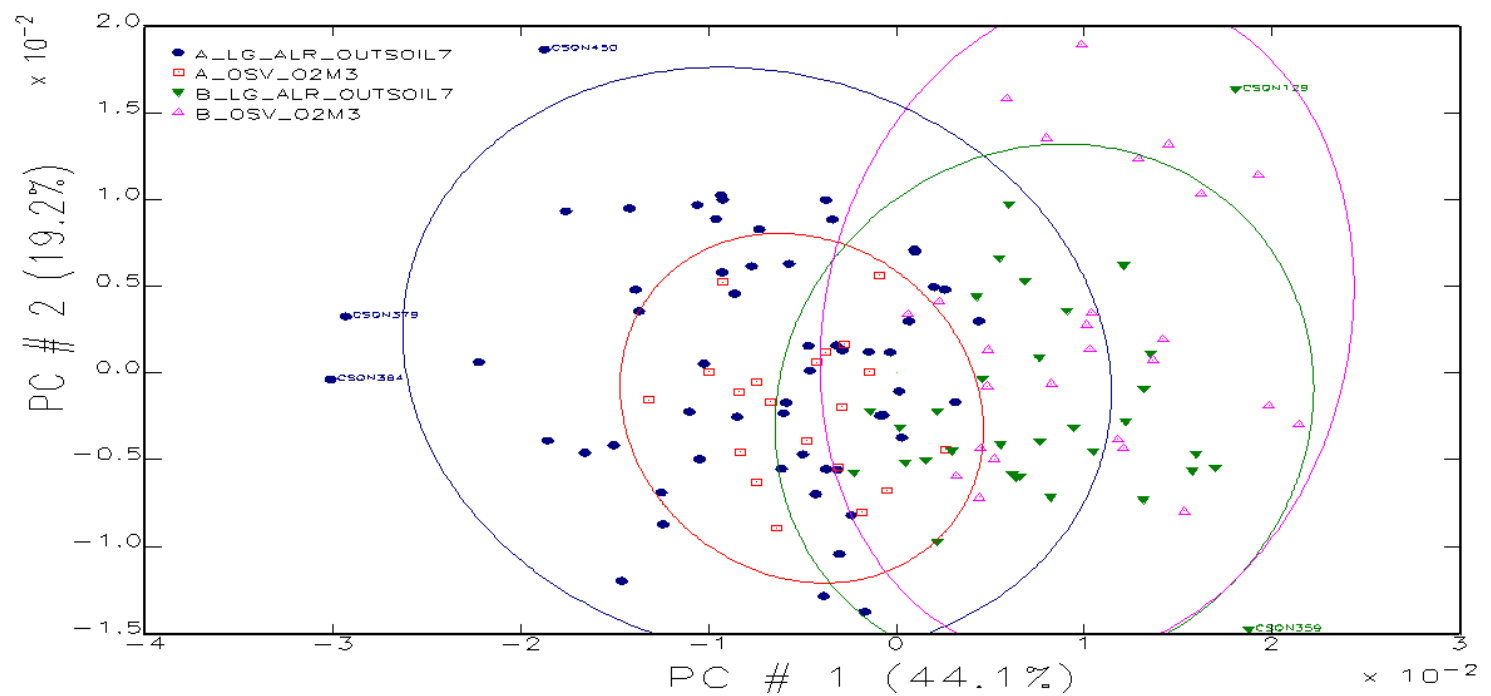

Figura 7.36 - Escores nas duas primeiras componentes principais dos dados do Cenário 5 para os dois grupos químicos de Lago Grande e Osvaldo. As elipses representam a região de confiança de $95 \%$.

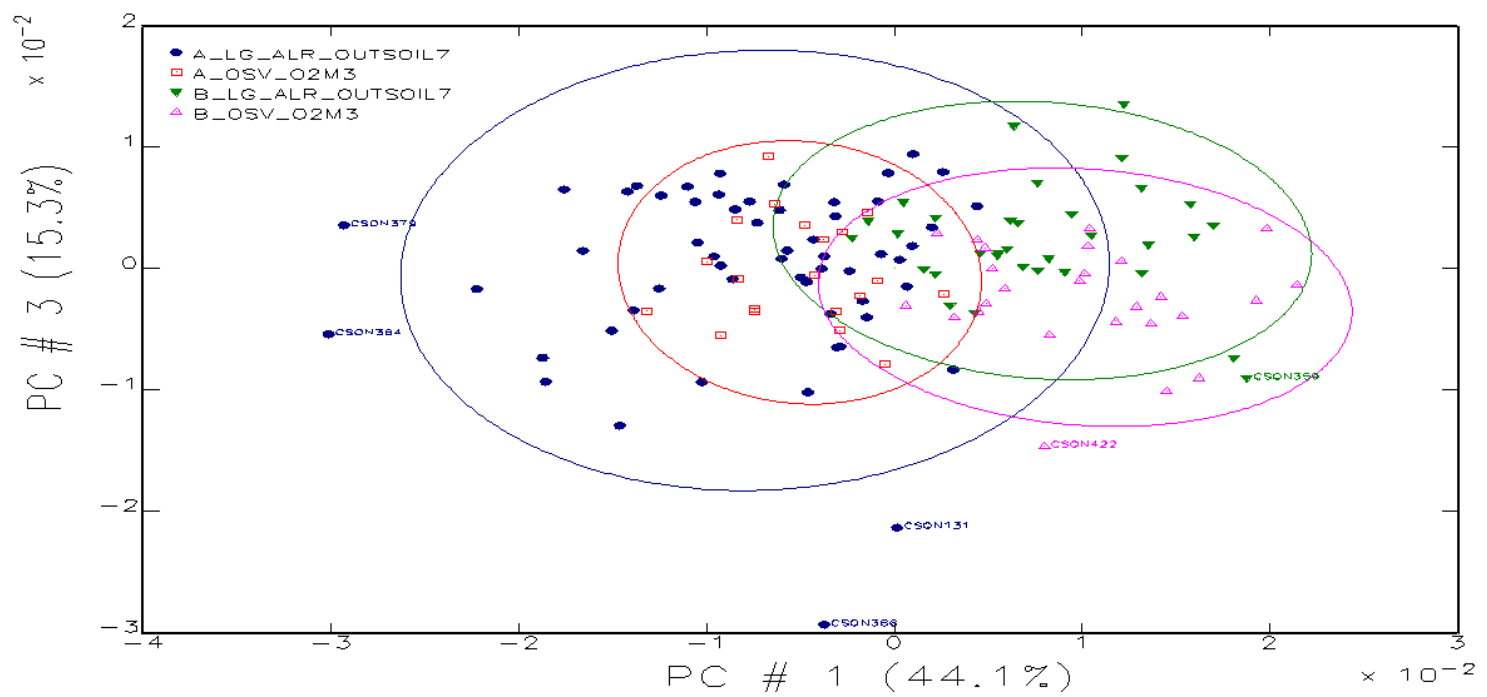

Figura 7.37 - Escores na primeira e terceira componentes principais dos dados do Cenário 5 para os dois grupos químicos de Lago Grande e Osvaldo. As elipses representam a região de confiança de $95 \%$.

Pelas Fig. 7.36 e 7.37, foi verificado que o grupo A de Osvaldo está contido no grupo A de Lago Grande, indicando uma menor variabilidade nos dados de Osvaldo para esse grupo. Por sua vez, o grupo B de Lago Grande apresentou superposição considerável com o grupo B de Osvaldo. Essas superposições podem ser indicativas de que os grupos químicos de cerâmicas definidos para cada sítio podem ter relação entre si, implicando em semelhanças nas pastas cerâmicas produzidas por antigos ceramistas dos dois sítios, 
descontado o efeito de aditivos antiplásticos, sugerindo interação cultural entre Lago Grande e Osvaldo por algum mecanismo como troca comercial, casamento exogâmico e/ou compartilhamento de territórios.

$\mathrm{Na}$ Tab. 7.19, são apresentadas as concentrações médias das razões químicas elementares, tendo o elemento escândio como divisor, para cada um dos grupos definidos para Lago Grande e Osvaldo, presentes nas Fig. 7.36 e 7.37.

Tabela 7.19 - Concentrações médias de razões elementares para os grupos químicos de cerâmicas de Lago Grande e Osvaldo, com transformação alr (Cenário 5).

\begin{tabular}{l|c|c|c|c}
\hline \multirow{2}{*}{ Razão } & \multicolumn{2}{|c|}{ Lago Grande } & \multicolumn{2}{c}{ Osvaldo } \\
\cline { 2 - 5 } & $\mathrm{A}(\mathrm{n}=57)$ & $\mathrm{B}(\mathrm{n}=33)$ & $\mathrm{A}(\mathrm{n}=20)$ & $\mathrm{B}(\mathrm{n}=26)$ \\
\hline $\mathrm{Cr} / \mathrm{Sc}$ & $4,3 \pm 0,4$ & $4,3 \pm 0,3$ & $4,0 \pm 0,3$ & $4,4 \pm 0,3$ \\
$\mathrm{Fe} / \mathrm{Sc}$ & $2469 \pm 451$ & $2383 \pm 310$ & $2274 \pm 285$ & $2330 \pm 265$ \\
$\mathrm{La} / \mathrm{Sc}$ & $2,5 \pm 0,3$ & $2,9 \pm 0,3$ & $2,5 \pm 0,2$ & $3,0 \pm 0,3$ \\
$\mathrm{Ce} / \mathrm{Sc}$ & $4,9 \pm 0,5$ & $5,9 \pm 0,9$ & $4,9 \pm 0,7$ & $5,7 \pm 0,8$ \\
$\mathrm{Eu} / \mathrm{Sc}$ & $0,073 \pm 0,012$ & $0,095 \pm 0,011$ & $0,080 \pm 0,008$ & $0,088 \pm 0,011$ \\
$\mathrm{Yb} / \mathrm{Sc}$ & $0,18 \pm 0,02$ & $0,21 \pm 0,02$ & $0,18 \pm 0,01$ & $0,23 \pm 0,03$ \\
$\mathrm{Lu} / \mathrm{Sc}$ & $0,029 \pm 0,004$ & $0,033 \pm 0,004$ & $0,029 \pm 0,002$ & $0,037 \pm 0,005$ \\
$\mathrm{Th} / \mathrm{Sc}$ & $0,92 \pm 0,12$ & $0,92 \pm 0,12$ & $0,92 \pm 0,11$ & $1,01 \pm 0,11$ \\
\hline
\end{tabular}

Pela Tab. 7.19, verificou-se que as concentrações dos grupos B de Lago Grande e Osvaldo, tenderam a apresentar razões elementares maiores que as do grupo A, com exceção das razões $\mathrm{Cr} / \mathrm{Sc}, \mathrm{Fe} / \mathrm{Sc}$ e $\mathrm{Th} / \mathrm{Sc}$ em Lago Grande. Ainda, as razões elementares dos grupos similares de cada sítio apresentam valores semelhantes, que se superpõem quando considerados desvios-padrão de cada razão.

Para o grupo A de Lago Grande, os coeficientes de variação oscilaram entre $9 \%$ e $18 \%$. Já o grupo B de Lago Grande apresentou coeficientes de variação entre $7 \%$ e $15 \%$ para todas as razões elementares. Para o grupo A de Osvaldo, os coeficientes de variação oscilaram entre $6 \%$ e 14\%, enquanto o grupo B desse sítio apresentou coeficientes de variação entre $8 \%$ e 14\%. Enquanto os grupos B de Lago Grande e Osvaldo apresentaram coeficientes de variação parecidos para as razões elementares, observou-se que esses coeficientes foram menores para o grupo A de Osvaldo, quando comparado ao grupo A de Lago Grande. Essa tendência reflete a elipse menor desse grupo A de Osvaldo, contida na elipse do grupo A de Lago Grande, nas Fig. 7.36 e 7.37. 
Os gráficos desta seção foram refeitos no programa computacional Statistica 8.0 e foram obtidos os mesmos resultados.

\subsubsection{Teste de normalidade}

Grande parte dos métodos estatísticos multivariados assume a hipótese de normalidade multivariada dos dados, como mencionado no Capítulo 5. Primeiramente, foi testada a normalidade univariada pelo método de Anderson-Darling para cada um dos nove elementos nos grupos químicos definidos no Cenário 3, com resultados organizados na Tab. 7.20, e no Cenário 5, com resultados organizados na Tab. 7.21. Os testes foram implementados no software Action 2.6.

Tabela 7.20 - Valores de $p$ dos testes de normalidade univariada de Anderson-Darling para os grupos químicos do Cenário $3(\alpha=0,05)$.

\begin{tabular}{c|cc|cc}
\hline \multirow{2}{*}{ Elemento } & \multicolumn{2}{|c|}{ Lago Grande } & \multicolumn{2}{c}{ Osvaldo } \\
\cline { 2 - 5 } & $\mathbf{A}(\mathbf{n}=\mathbf{6 0})$ & $\mathbf{B}(\mathbf{n = 2 8})$ & $\mathbf{A}(\mathbf{n}=\mathbf{3 6})$ & $\mathbf{B}(\mathbf{n = 1 4})$ \\
\hline $\mathrm{La}$ & 0,043643 & 0,2399 & 0,631649 & 0,00251 \\
$\mathrm{Lu}$ & 0,149838 & 0,264696 & 0,160971 & 0,039981 \\
$\mathrm{Yb}$ & 0,05084 & 0,002763 & 0,427137 & 0,033731 \\
$\mathrm{Ce}$ & 0,506644 & 0,025065 & 0,296718 & 0,002637 \\
$\mathrm{Cr}$ & 0,378891 & 0,159446 & 0,013811 & 0,027728 \\
$\mathrm{Eu}$ & 0,563641 & 0,901683 & 0,063012 & 0,554448 \\
$\mathrm{Fe}$ & 0,248432 & 0,296281 & 0,56075 & 0,511368 \\
$\mathrm{Sc}$ & 0,008016 & 0,131379 & 0,157144 & 0,328645 \\
$\mathrm{Th}$ & 0,24786 & 0,07225 & 0,868809 & 0,748368 \\
\hline
\end{tabular}

Os valores hachurados na Tab. 7.20 representam testes para os quais a estatística foi significativa, ou seja, a hipótese nula de normalidade dos elementos foi rejeitada. Pelos resultados, observou-se que o grupo B de Osvaldo apresentou o maior número de elementos com distribuição não normal. Além disso, todos os grupos químicos apresentaram pelo menos um elemento com distribuição não normal. 
Tabela 7.21 - Valores de $p$ dos testes de normalidade univariada de Anderson-Darling para os grupos químicos do Cenário $5(\alpha=0,05)$.

\begin{tabular}{l|cc|cc}
\hline \multirow{2}{*}{ Razão } & \multicolumn{2}{|c|}{ Lago Grande } & \multicolumn{2}{c}{ Osvaldo } \\
\cline { 2 - 5 } & $\mathbf{A ~ ( n = 5 6 )}$ & $\mathbf{B}(\mathbf{n}=\mathbf{3 3})$ & $\mathbf{A ~ ( n = 2 0 )}$ & $\mathbf{B}(\mathbf{n = 2 5})$ \\
\hline $\mathrm{La} / \mathrm{Sc}$ & 0,004637 & 0,067796 & 0,069117 & 0,025253 \\
$\mathrm{Lu} / \mathrm{Sc}$ & 0,87236 & 0,350926 & 0,113628 & 0,273365 \\
$\mathrm{Yb} / \mathrm{Sc}$ & 0,129739 & 0,391851 & 0,377009 & 0,317933 \\
$\mathrm{Ce} / \mathrm{Sc}$ & 0,037581 & 0,003541 & 0,026944 & 0,144595 \\
$\mathrm{Cr} / \mathrm{Sc}$ & 0,06591 & 0,334115 & 0,871947 & 0,66031 \\
$\mathrm{Eu} / \mathrm{Sc}$ & 0,318077 & 0,162665 & 0,002829 & 0,239338 \\
$\mathrm{Fe} / \mathrm{Sc}$ & 0,581865 & 0,541478 & 0,325849 & 0,57471 \\
$\mathrm{Th} / \mathrm{Sc}$ & 0,000832 & $3,93 \mathrm{E}-05$ & 0,265544 & 0,034237 \\
\hline
\end{tabular}

Os valores hachurados na Tab. 7.21 representam testes para os quais a estatística foi significativa, ou seja, a hipótese nula de normalidade dos elementos foi rejeitada. Pelos resultados, observou-se que as razões $\mathrm{Ce} / \mathrm{Sc}$ e $\mathrm{Th} / \mathrm{Sc}$ foram as que tiveram a normalidade rejeitada com mais frequência, em três grupos cada. Além disso, todos os grupos químicos apresentaram pelo menos dois elementos com distribuição não normal.

Após os testes univariados, prosseguiu-se com os testes multivariados de normalidade de Shapiro-Wilk, implementado no software $R$ 2.13.0, e de Shenton-Bowman, cuja rotina de cálculo foi programada no software Scilab 5.2.2 (Apêndice G), a partir do artigo com a versão modificada do teste de Shenton \& Bowman (1977), proposta por Doornik \& Hansen (2008). Os resultados para o Cenário 3 e para o Cenário 5 estão organizados na Tab. 7.22 e 7.23, respectivamente.

Tabela 7.22 - Testes de normalidade multivariada de Shenton-Bowman e Shapiro-Wilk para os grupos químicos do Cenário $3(\alpha=0,05)$.

\begin{tabular}{c|cccc|ccc}
\hline \multirow{2}{*}{ Grupo } & \multicolumn{4}{|c|}{ Shenton-Bowman } & \multicolumn{4}{c}{ Shapiro-Wilk } \\
\cline { 2 - 8 } & $\chi \mathbf{2}$ (inf) & $\chi \mathbf{2}$ (sup) & $\mathbf{E}_{\mathbf{p}}$ & Normalidade & MVW & $\mathbf{p}$ & Normalidade \\
\hline LG A & 9,390455 & 28,8693 & 348,18777 & não & 0,9174 & $2,2.10-16$ & não \\
LG B & 9,390455 & 28,8693 & 50,2519 & não & 0,944 & 0,00681 & não \\
Osv A & 9,390455 & 28,8693 & 66,339196 & não & 0,949 & 0,000954 & não \\
Osv B & 9,390455 & 28,8693 & 29,973277 & não & 0,9431 & 0,632 & sim \\
\hline \multicolumn{3}{c}{ LG = Lago Grande. Osv = Osvaldo. E $_{\mathrm{p}}$ e MVW são as estatísticas de teste. }
\end{tabular}


A partir da Tab. 7.22, observou-se que a hipótese nula de normalidade multivariada foi rejeitada para todos os grupos pelos dois testes, com exceção para o grupo B, pelo teste de Shapiro-Wilk.

Tabela 7.23 - Testes de normalidade multivariada de Shenton-Bowman e Shapiro-Wilk para os grupos químicos do Cenário $5(\alpha=0,05)$.

\begin{tabular}{c|cccc|ccc}
\hline \multirow{2}{*}{ Grupo } & \multicolumn{4}{|c|}{ Shenton-Bowman } & \multicolumn{3}{c}{ Shapiro-Wilk } \\
\cline { 2 - 8 } & $\boldsymbol{\chi 2}$ (inf) & $\boldsymbol{\chi 2}$ (sup) & $\mathbf{E}_{\mathbf{p}}$ & Normalidade & $\mathbf{M V W}$ & $\mathbf{p}$ & Normalidade \\
\hline LG A & 7,961646 & 26,29623 & 102,3602 & não & 0,9577 & $3,80 \mathrm{E}-05$ & não \\
LG B & 7,961646 & 26,29623 & 87,76615 & não & 0,9322 & $1,78 \mathrm{E}-05$ & não \\
Osv A & 7,961646 & 26,29623 & 100,6785 & não & 0,9034 & $4,92 \mathrm{E}-05$ & não \\
Osv B & 7,961646 & 26,29623 & 55,70561 & não & 0,9362 & 0,005006 & não \\
\hline
\end{tabular}

LG = Lago Grande. Osv = Osvaldo. $\mathrm{E}_{\mathrm{p}}$ e MVW são as estatísticas de teste.

A partir da Tab. 7.23, observou-se que a hipótese nula de normalidade multivariada foi rejeitada para todos os grupos pelos dois testes.

Pelos resultados desta seção, observou-se que a normalidade multivariada foi praticamente rejeitada para todos os grupos químicos definidos tanto no Cenário $\mathbf{3}$, como no Cenário 5. Esse fato era esperado, uma vez que alguns elementos não apresentaram distribuição normal nesses grupos, e é sabido que a normalidade multivariada implica normalidade das variáveis individuais.

A rejeição da normalidade multivariada torna necessário cuidado quando da interpretação dos resultados obtidos por métodos estatísticos multivariados, principalmente para grupos de dados que estão muito próximos, embora esses desvios não sejam necessariamente "fatais" para as conclusões.

\subsubsection{Teste de homogeneidade das matrizes de covariância}

Além da normalidade, vários métodos estatísticos multivariados assumem a hipótese homogeneidade das matrizes de covariância dos grupos de dados, como a análise discriminante e a análise multivariada de variância (ver Cap. 5). Assim, realizaram-se testes $M$ de Box para verificar a homogeneidade das matrizes de covariância dos grupos definidos no Cenário 3, cujos resultados estão organizados na Tab. 7.24, e dos grupos definidos no Cenário 5, cujos resultados estão organizados na Tab. 7.25. O teste $M$ de Box 
foi implementado por meio da função MBoxtest(X, alfa), no software Matlab 7.6.0 (R2008a).

Tabela 7.24 - Teste de homogeneidade das matrizes de covariância para os grupos químicos do Cenário $3(\alpha=0,05)$.

\begin{tabular}{ccccccc}
\hline Grupos & $\mathbf{n}_{\mathbf{1}}, \mathbf{n}_{\mathbf{2}}$ & $\boldsymbol{M}_{\text {Box }}$ & $\chi^{\mathbf{2}}$ & g.l. & $\boldsymbol{p}$ & Homogeneidade \\
\hline Todos & - & 458,8193 & 385,9705 & 135 & $<10^{-4}$ & Não \\
A(LG) vs. B(LG) & 60,28 & 165,3911 & 143,4399 & 45 & $<10^{-4}$ & Não \\
A (Osv) vs. B (Osv) & 36,14 & 115,1674 & 84,6167 & 45 & 0,0003 & Não \\
A (LG) vs. A (Osv) & 60,36 & 167,164 & 148,8933 & 45 & $<10^{-4}$ & Não \\
B (LG) vs. B (Osv) & 28,14 & 96,7081 & 69,7515 & 45 & 0,0104 & Não \\
\hline
\end{tabular}

$\mathrm{LG}=$ Lago Grande. Osv = Osvaldo. "n" é o tamanho dos grupos.

Pela Tab. 7.24, observou-se que a hipótese de homocedasticidade não é válida para nenhum dos pares de matrizes de covariância dos grupos químicos no Cenário 3.

Tabela 7.25 - Teste de homogeneidade das matrizes de covariância para os grupos químicos do Cenário $5(\alpha=0,05)$.

\begin{tabular}{ccccccc}
\hline Grupos & $\mathbf{n}_{\mathbf{1}}, \mathbf{n}_{\mathbf{2}}$ & $\boldsymbol{M}_{\text {Box }}$ & $\chi^{\mathbf{2}}$ & g.l. & $\boldsymbol{p}$ & Homogeneidade \\
\hline Todos & - & 227,4422 & 198,6024 & 108 & $<10^{-4}$ & Não \\
A(LG) vs. B(LG) & 56,33 & 78,2481 & 69,9472 & 36 & 0,0006 & Não \\
A (Osv) vs. B (Osv) & 20,25 & 62,9421 & 50,4383 & 36 & 0,0557 & Sim \\
A (LG) vs. A (Osv) & 56,20 & 95,034 & 79,8069 & 36 & $<10^{-4}$ & Não \\
B (LG) vs. B (Osv) & 33,25 & 42,9507 & 36,3379 & 36 & 0,4529 & Sim \\
\hline
\end{tabular}

LG = Lago Grande. Osv = Osvaldo. "n" é o tamanho dos grupos.

Pela Tab. 7.25, referente ao Cenário 5, observou-se que a hipótese de homocedasticidade é válida apenas entre as matrizes de covariância dos grupos $\mathrm{A}$ e $\mathrm{B}$ de Osvaldo, e entre as matrizes de covariância dos grupos B de Lago Grande e B de Osvaldo.

O fato de a hipótese de homogeneidade das matrizes de covariância ter sido rejeitada totalmente no Cenário 3, e não ter sido rejeitada apenas entre dois pares de grupos químicos no Cenário 5, traz a necessidade de se analisar com cuidado os resultados 
dos métodos multivariados, como análise discriminante e análise multivariada de variância, empregados em seções adiante neste capítulo. A violação da hipótese de homocedasticidade é menos crítica quando o número de amostras de cada grupo é parecido (Meyers et al., 2006), o que não ocorre nas análises deste trabalho, como observado nas colunas “ $\mathrm{n}_{1}, \mathrm{n}_{2}$ ”, nas Tab. 7.24 e 7.25. No entanto, deve ser observado que os desvios de normalidade multivariada podem ter afetado os resultados do teste $\mathrm{M}$ de Box.

\subsubsection{Análise discriminante}

a. Cenário $3\left(\log _{10}\right)$

Foi realizada uma análise discriminante canônica a partir dos dois grupos químicos definidos para as cerâmicas de Lago Grande e Osvaldo no Cenário 3 (seção 7.1.12). Os resultados são apresentados nas Fig. 7.38 e 7.39.

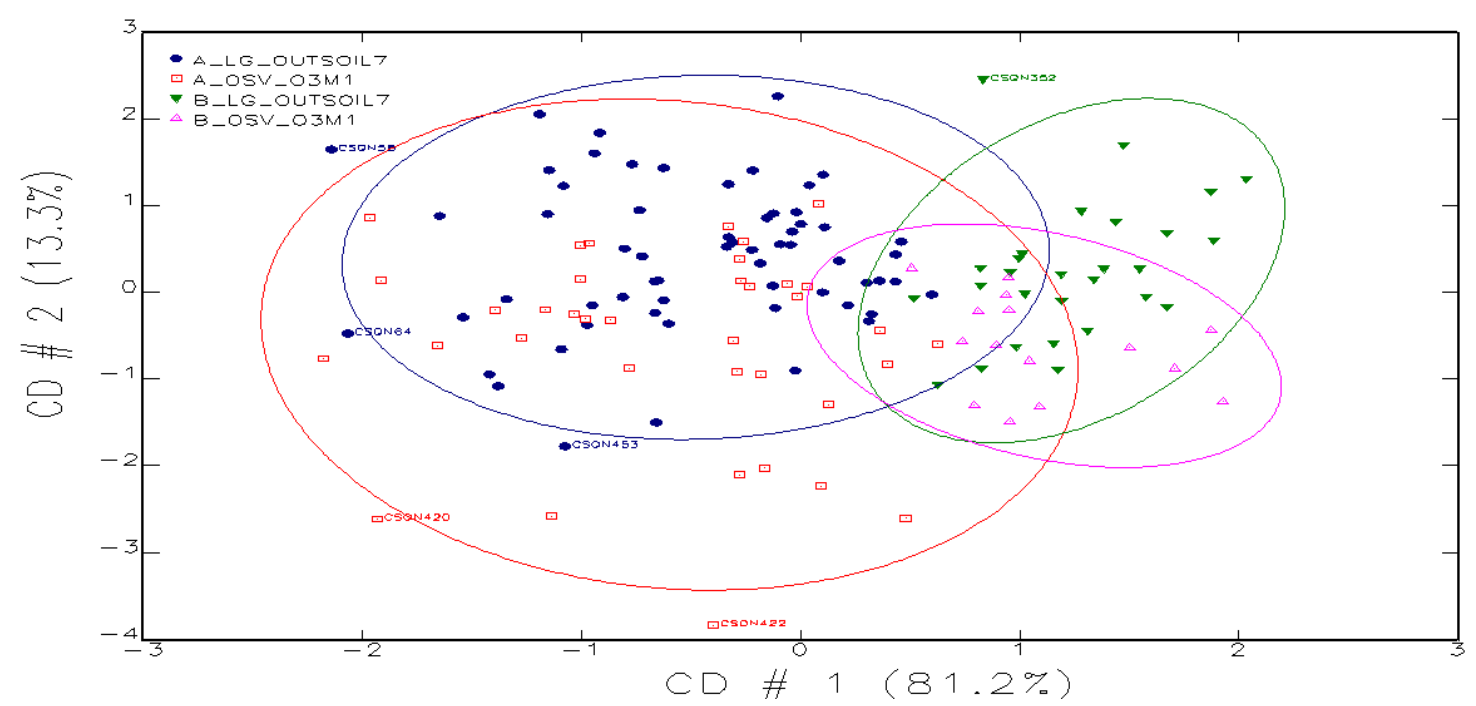

Figura 7.38 - Projeção CD2xCD1 da análise discriminante canônica a partir dos grupos químicos de Lago Grande e Osvaldo, definidos para o Cenário 3. As elipses representam a região de confiança de $95 \%$. 


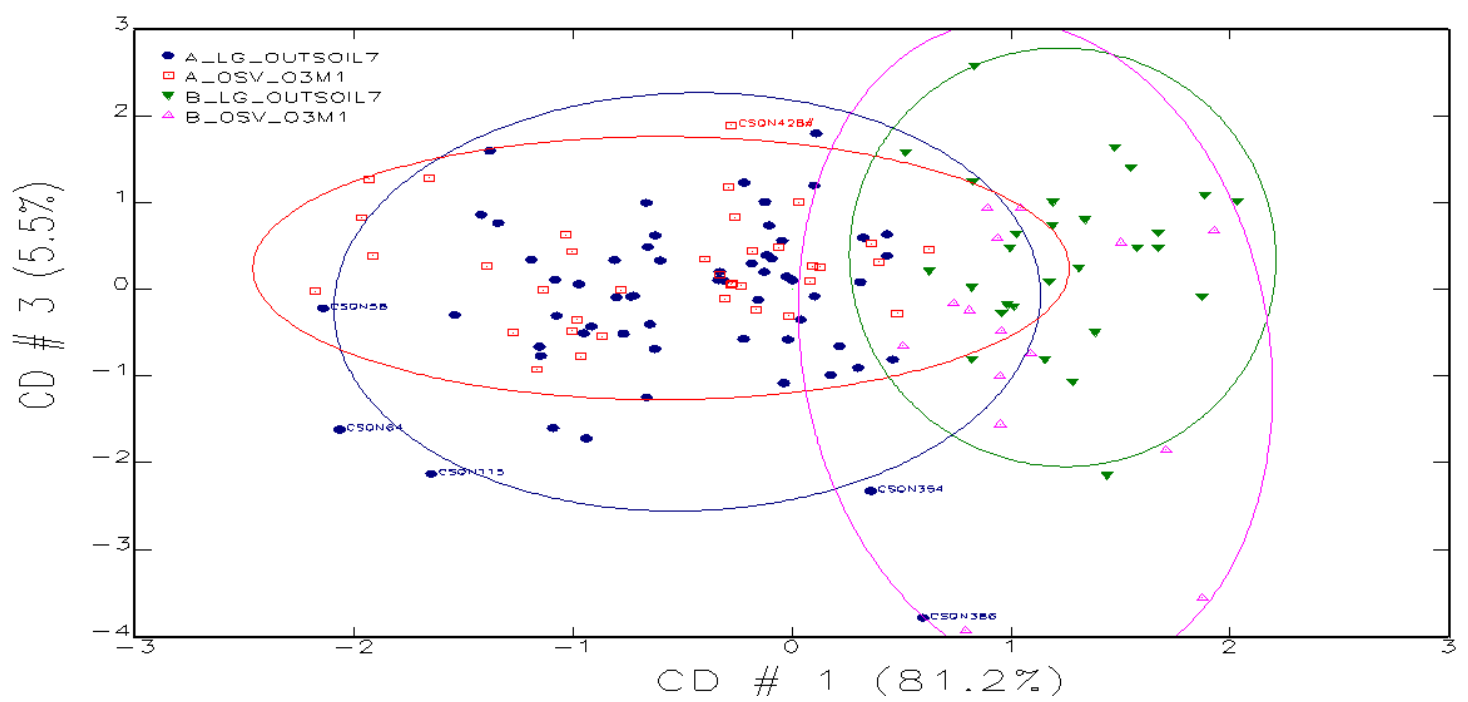

Figura 7.39 - Projeção CD3xCD1 da análise discriminante canônica a partir dos grupos químicos de Lago Grande e Osvaldo, definidos para o Cenário 3. As elipses representam a região de confiança de $95 \%$.

Observou-se, a partir das Fig. 7.38 e 7.39, que os grupos A e B de cada sítio apresentaram boa separação entre si. Contudo, numa comparação intersítio, os grupos A de Lago Grande e Osvaldo e B dos mesmos sítios apresentaram uma considerável superposição. A tendência geral desses gráficos corrobora a análise comparativa PCA nas Fig. 7.34 e 7.35, fornecendo mais uma indicação de que os grupos definidos a partir do Cenário 3 são plausíveis e estáveis. Foram calculadas as matrizes de confusão no software Statistica, e observou-se que 99\% das amostras de Lago Grande e 100\% das amostras de Osvaldo foram corretamente classificadas. $\mathrm{Na}$ análise com todos os grupos, a taxa de acertos caiu para $73 \%$. A razão da queda seria a superposição pareada dos grupos químicos de cada sítio.

Os maiores coeficientes para a primeira função discriminante canônica, responsável por $81,2 \%$ da variância do sistema, foram observados para os elementos La, Lu e Ce.

\section{b. Cenário 5 (alr)}

Foi realizada uma análise discriminante canônica a partir dos dois grupos químicos definidos para as cerâmicas de Lago Grande e Osvaldo no Cenário 5 (seção 7.1.12). Os resultados são apresentados nas Fig. 7.40 e 7.41. 


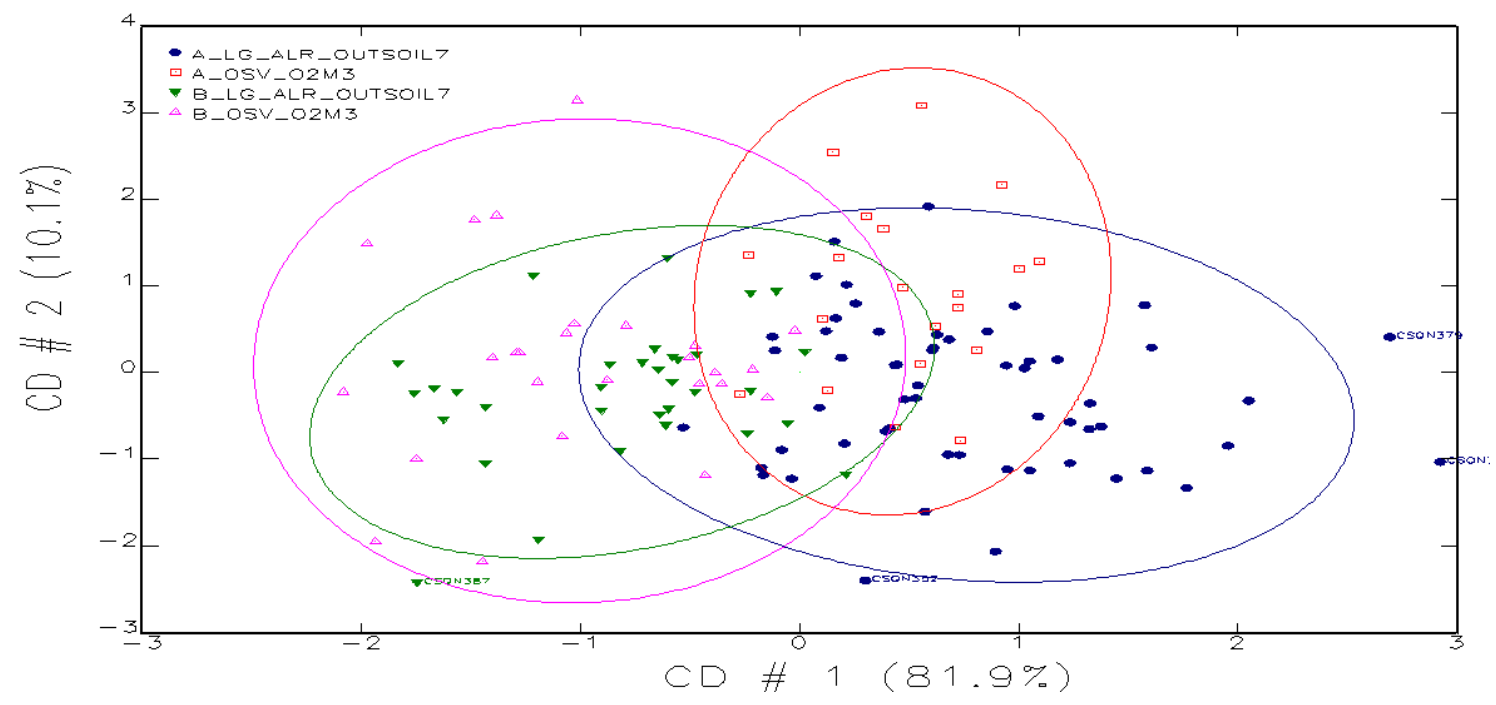

Figura 7.40 - Projeção CD2xCD1 da análise discriminante canônica a partir dos grupos químicos elementares de Lago Grande e Osvaldo, definidos para o Cenário 5. As elipses representam a região de confiança de $95 \%$.

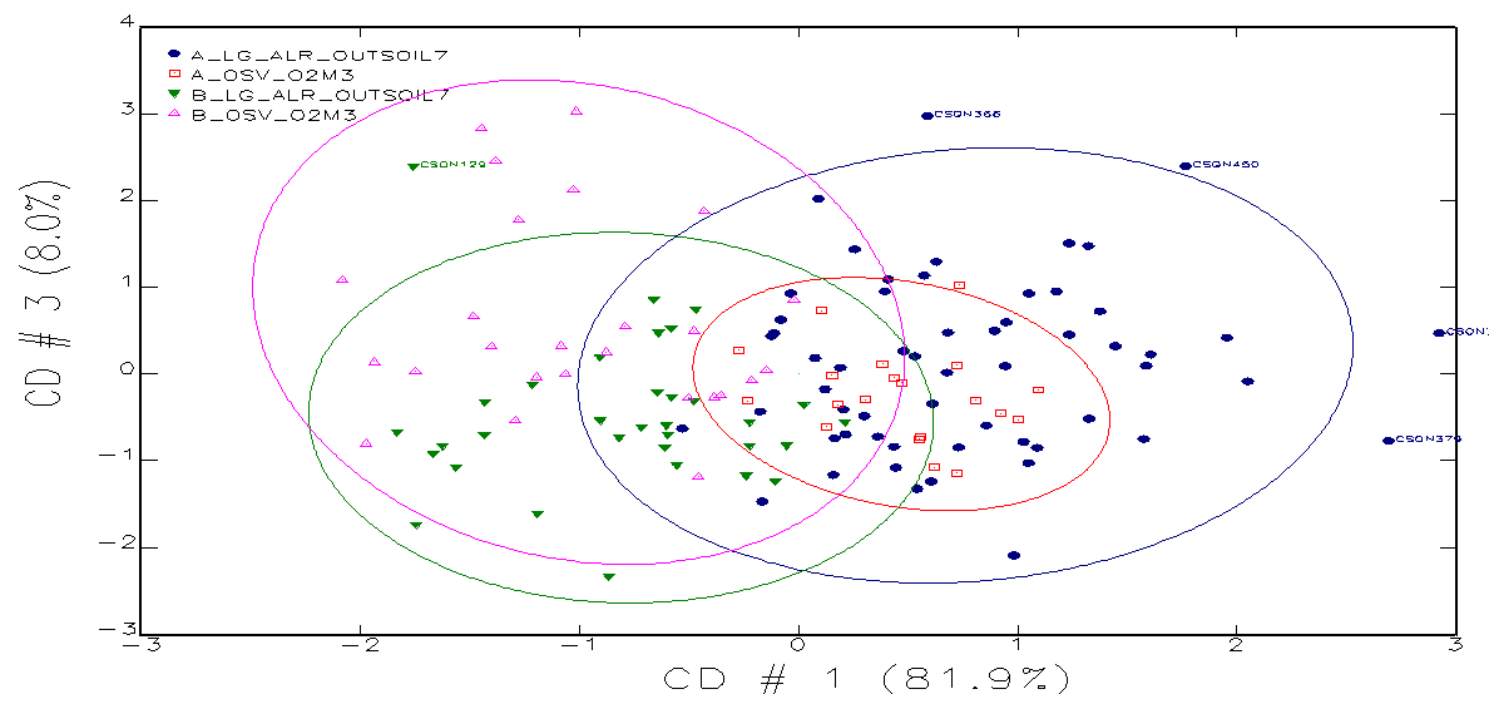

Figura 7.41 - Projeção CD3xCD1 da análise discriminante canônica a partir dos grupos químicos elementares de Lago Grande e Osvaldo, definidos para o Cenário 5. As elipses representam a região de confiança de $95 \%$.

Observou-se, a partir das Fig. 7.40 e 7.41, que os grupos A e B de cada sítio apresentaram boa separação entre si. Contudo, numa comparação intersítio, os grupos A de Lago Grande e Osvaldo e B dos mesmos sítios apresentaram uma considerável superposição. A tendência geral desses gráficos corrobora a análise comparativa PCA nas Fig. 7.36 e 7.37, fornecendo mais uma indicação de que os grupos definidos a partir do Cenário 5 são plausíveis e estáveis. Foram calculadas as matrizes de confusão no software 
Statistica, e observou-se que $94 \%$ das amostras de Lago Grande e $98 \%$ das amostras de Osvaldo foram corretamente classificadas. $\mathrm{Na}$ análise com todos os grupos juntos, a taxa de acertos caiu para 69\%. A razão da queda seria a superposição pareada dos grupos químicos de cada sítio.

Os maiores coeficientes para a primeira função discriminante canônica, responsável por $81,9 \%$ da variância do sistema foram observados para as razões elementares $\mathrm{Yb} / \mathrm{Sc}, \mathrm{Eu} / \mathrm{Sc}$ e $\mathrm{Ce} / \mathrm{Sc}$.

\subsubsection{Seleção do conjunto mínimo de variáveis pelo método Procrustes}

\section{a. Cenário $3\left(\log _{10}\right)$}

Foi realizado um procedimento de seleção de variáveis pelo método de Procrustes, aplicado ao Cenário 3, com os dados de Lago Grande e Osvaldo combinados.

A Tab.7.26 resume os resultados da implementação do algoritmo Procrustes no software $R$ 2.13.0 para o Cenário 3. Três amostras com concentrações abaixo do limite de detecção foram excluídas para os cálculos (CSQN96, 356 e 394). O valor de discrepância $M^{2}$ e os valores críticos são apresentados para cada etapa representando a eliminação de uma variável. A análise foi baseada nas quatro primeiras componentes principais, que representam $91 \%$ da variância total do sistema original com nove variáveis, ou elementos químicos. O número de amostras utilizado foi 141.

Tabela 7.26 - Seleção de variáveis pelo método Procrustes para o Cenário 3, com os dados combinados de Lago Grande e Osvaldo.

\begin{tabular}{c|c|c}
\hline Elemento eliminado & $\boldsymbol{M}^{\mathbf{2}}$ & $\boldsymbol{c v}$ \\
\hline $\mathrm{Sc}$ & 12,1 & 182,6 \\
$\mathrm{La}$ & 32,6 & 162,3 \\
$\mathrm{Lu}$ & 71,4 & 142,0 \\
$\mathrm{Cr}$ & 117,3 & 121,7 \\
$\mathrm{Ce}$ & 184,0 & 101,4 \\
\hline
\end{tabular}

Pela Tab. 7.26, observou-se que na primeira etapa, correspondente à extração do escândio, o valor de discrepância $M^{2}$ é muito menor que o valor crítico $c v$. Isso significa 
que esse elemento não carrega informações relevantes em relação à estrutura multivariada dos dados. O valor de $M^{2}$ permanece menor que o valor crítico $c v$ até a quarta etapa, correspondente à extração do elemento cromo. A partir da próxima etapa, correspondente à extração de cério, o valor de discrepância $M^{2}$ torna-se maior que o valor crítico $c v$, sendo possível concluir que alterações na estrutura multivariada dos dados começam a se tornar estatisticamente significativas a partir desse ponto. Assim, o processo de eliminação sugerido pelo método Procrustes corresponde à exclusão dos elementos $\mathrm{Sc}, \mathrm{La}, \mathrm{Lu}$ e Cr.

Os elementos não eliminados pela análise Procrustes foram $\mathrm{Yb}, \mathrm{Ce}, \mathrm{Eu}, \mathrm{Fe}$ e Th, num total de cinco elementos químicos. Esse grupo representa o conjunto dos elementos diagnósticos, representativos da estrutura multivariada dos dados para o Cenário 3, projetada nas componentes principais com o intuito de se identificar grupos químicos de cerâmicas arqueológicas.

É interessante observar que entre os elementos selecionados pela análise Procrustes, há três terras raras ( $\mathrm{Yb}, \mathrm{Ce}$ e Eu), um metal de transição (Fe) e um actinídeo (Th). Desses seis elementos, todos, com exceção do Fe, estão em concentrações da ordem de $\mu \mathrm{g} . \mathrm{g}^{-1}$, ou menor (Tab. 7.2). Esse é o reflexo de um fato bem conhecido na literatura arqueométrica, de que esses tipos de elementos traço, como terras raras e metais de transição, têm um comportamento geoquímico distinto, que é característico do ambiente geológico, e por isso são especialmente úteis para distinção de materiais produzidos a partir de diferentes sedimentos argilosos (Glascock et al., 2004).

Na Fig. 7.42 é apresentada a análise de componentes principais para os nove elementos do Cenário 3 antes da seleção de variáveis, e a mesma análise com os cinco elementos selecionados pelo método Procrustes ( $\mathrm{Yb}, \mathrm{Ce}, \mathrm{Eu}, \mathrm{Fe}$ e Th).

A partir da Fig 7.42, observou-se que os resultados de PCA permaneceram praticamente os mesmos em termos de resolução na separação e sobreposição entre os grupos químicos equivalentes de Lago Grande e Osvaldo. Essa figura é uma indicação gráfica de que nenhuma informação significativa foi perdida no que diz respeito aos padrões químicos multivariados dos dados, para os grupos definidos neste trabalho, confirmando a eficiência da análise Procrustes como método de seleção de variáveis. Além disso, a estabilidade dos resultados antes e após a eliminação de variáveis evidencia que não haviam sido inseridas variáveis que poderiam obscurecer os padrões identificados.

Dessa forma, concluiu-se que os elementos $\mathrm{Yb}, \mathrm{Ce}, \mathrm{Eu}, \mathrm{Fe}$ e Th devem ser priorizados na performance analítica de INAA em análises futuras com amostras de Lago 
Grande e Osvaldo, pois esses elementos formam o conjunto mínimo de variáveis necessárias para a reprodução do padrão multivariado de concentrações elementares dos grupos químicos definidos para o Cenário 3. Isso não implica que mais elementos não possam ser determinados no futuro para checar um possível particionamento dos dados em mais grupos dentro dos dois grupos definidos para cada sítio, buscando refinar a interpretação do registro arqueológico, como sugerido na discussão sobre o significado arqueológico dos grupos químicos na seção 7.1.19.

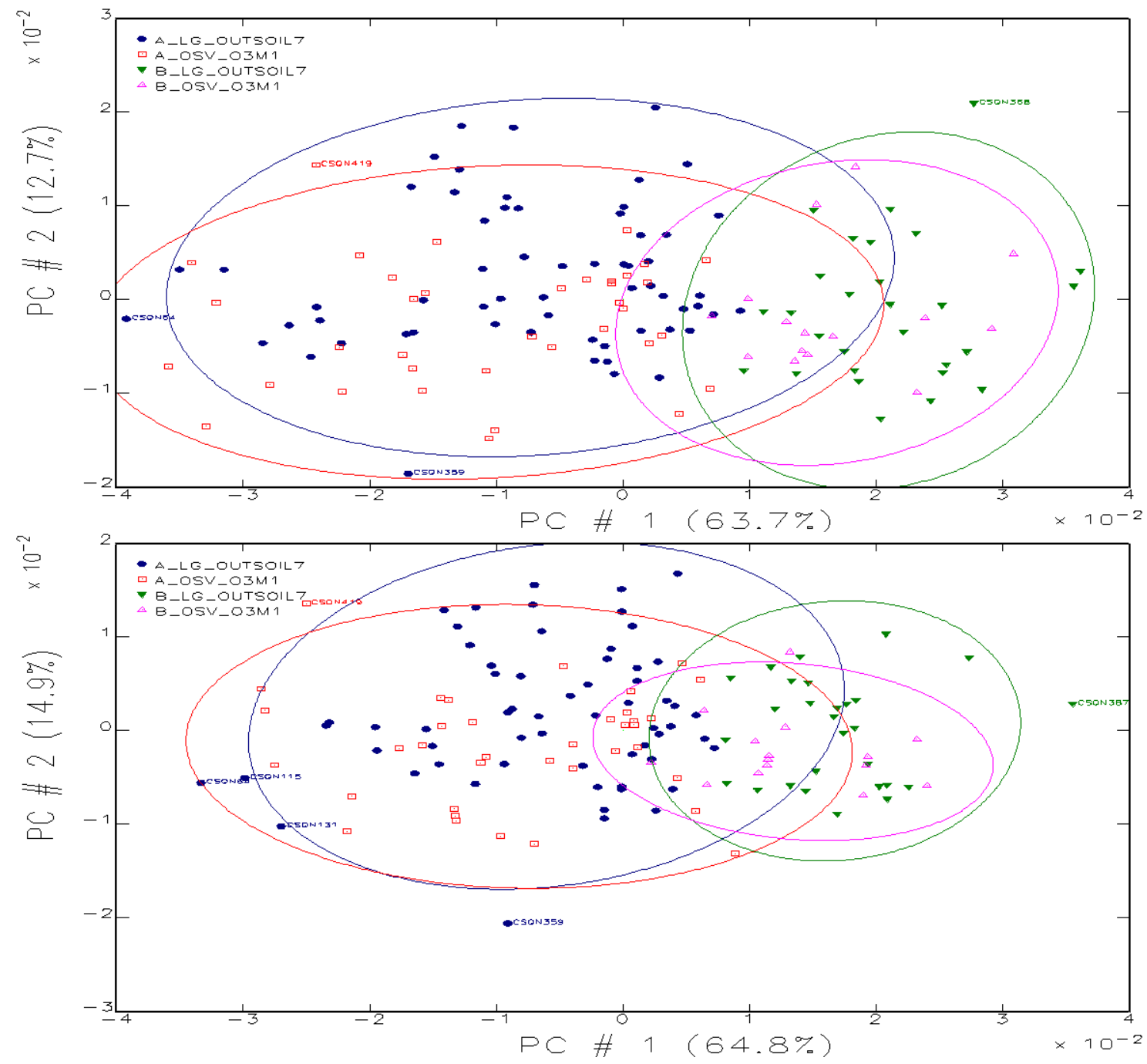

Figura 7.42 - PCA comparativo (PC2xPC1) para a base de dados dos sítios Lago Grande e Osvaldo com nove elementos (acima, Cenário 3) e os cinco elementos (abaixo) selecionados pelo método Procrustes. 


\section{b. Cenário 5 (alr)}

Foi realizado um procedimento de seleção de variáveis pelo método Procrustes, aplicado ao Cenários 5, com os dados de Lago Grande e Osvaldo combinados.

A Tab.7.27 resume os resultados da implementação do algoritmo Procrustes no software R 2.13.0 para o Cenário 5. Três amostras com concentrações abaixo do limite de detecção foram excluídas para os cálculos (CSQN96, 356 e 394). O valor de discrepância $M^{2}$ e os valores críticos são apresentados para cada etapa representando a eliminação de uma variável. A análise foi baseada nas três primeiras componentes principais, que representam $78 \%$ da variância total do sistema original com oito variáveis, ou razões elementares.

Tabela 7.27 - Seleção de variáveis pelo método Procrustes para o Cenário $\mathbf{5}$, com os dados combinados de Lago Grande e Osvaldo.

\begin{tabular}{c|c|c}
\hline Razão eliminada & $\boldsymbol{M}^{\mathbf{2}}$ & $\boldsymbol{c v}$ \\
\hline $\mathrm{La} / \mathrm{Sc}$ & 17,3 & 317,5 \\
$\mathrm{Cr} / \mathrm{Sc}$ & 54,6 & 282,2 \\
$\mathrm{Lu} / \mathrm{Sc}$ & 95,8 & 246,9 \\
$\mathrm{Ce} / \mathrm{Sc}$ & 145,7 & 211,7 \\
$\mathrm{Th} / \mathrm{Sc}$ & 236,7 & 176,4 \\
\hline
\end{tabular}

Pela Tab. 7.27, observou-se que na primeira etapa, correspondente à extração de $\mathrm{La} / \mathrm{Sc}$, o valor de discrepância $M^{2}$ é muito menor que o valor crítico $c v$. Isso significa que essa razão elementar não carrega informações relevantes em relação à estrutura multivariada dos dados. $\mathrm{O}$ valor de $M^{2}$ permanece menor que o valor crítico $c v$ até a quarta etapa, correspondente à extração de $\mathrm{Ce} / \mathrm{Sc}$. A partir da próxima etapa, correspondente à extração de Th/Sc, o valor de discrepância $M^{2}$ torna-se maior que o valor crítico $c v$, sendo possível concluir que alterações na estrutura multivariada dos dados começam a se tornar estatisticamente significativas a partir desse ponto. Assim, o processo de eliminação sugerido pelo método Procrustes corresponde à exclusão das razões elementares $\mathrm{La} / \mathrm{Sc}$, $\mathrm{Cr} / \mathrm{Sc}, \mathrm{Lu} / \mathrm{Sc}$ e $\mathrm{Ce} / \mathrm{Sc}$.

As razões elementares não eliminadas pela análise Procrustes foram $\mathrm{Yb} / \mathrm{Sc}$, $\mathrm{Eu} / \mathrm{Sc}, \mathrm{Fe} / \mathrm{Sc}$ e $\mathrm{Th} / \mathrm{Sc}$, num total de quatro razões. Esse grupo representa o conjunto de 
razões elementares diagnósticas, representativas da estrutura multivariada dos dados para o Cenário 5, projetada nas componentes principais com o intuito de se identificar grupos químicos de cerâmicas arqueológicas.

Na Fig. 7.43 é apresentada a análise de componentes principais para as oito razões elementares do Cenário 5 antes da seleção de variáveis, e a mesma análise com as quatro razões selecionadas pelo método Procrustes ( $\mathrm{Yb} / \mathrm{Sc}, \mathrm{Eu} / \mathrm{Sc}, \mathrm{Fe} / \mathrm{Sc}$ e Th/Sc).
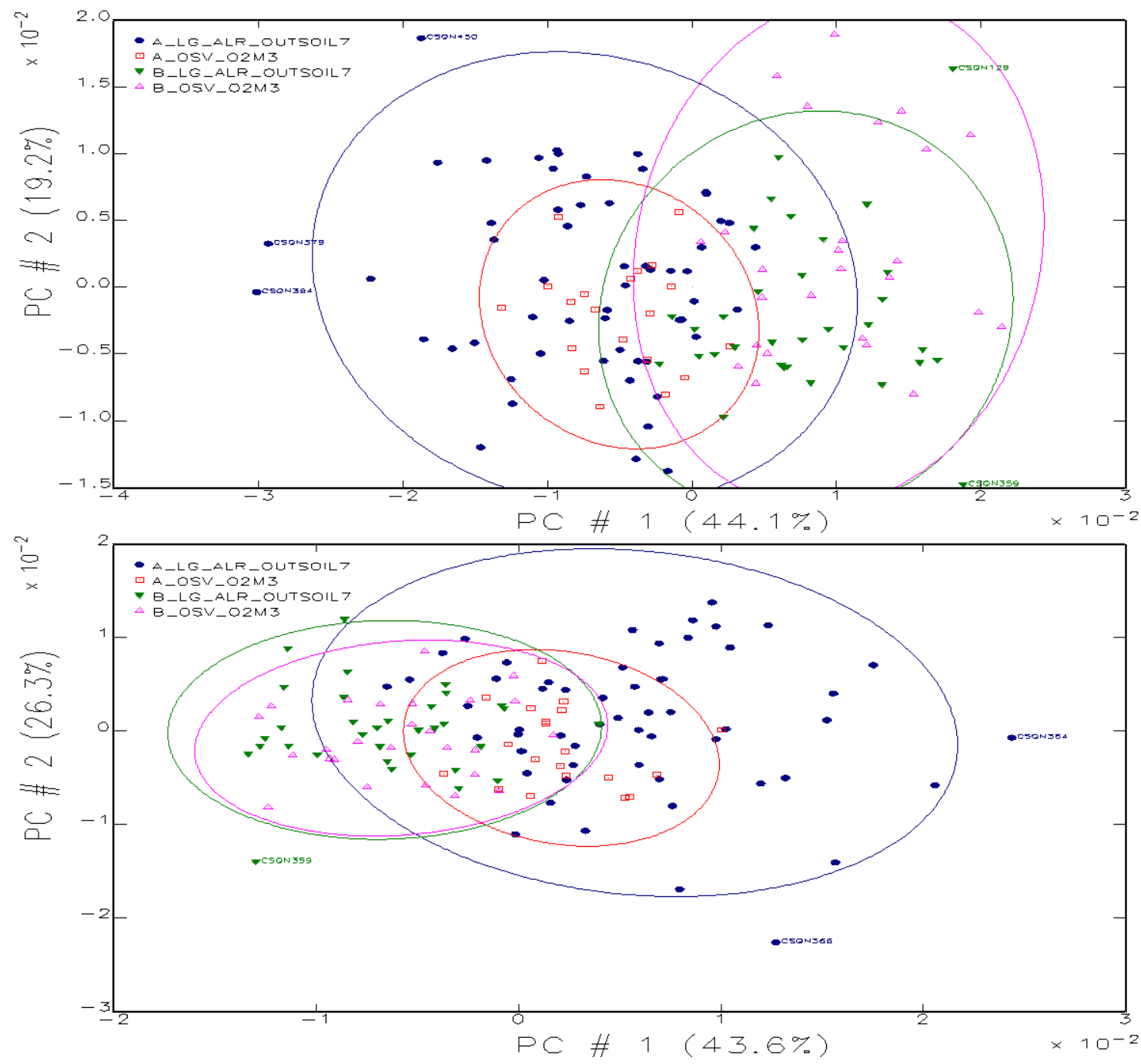

Figura 7.43 - PCA comparativo (PC2xPC1) para a base de dados dos sítios Lago Grande e Osvaldo com oito razões elementares (acima, Cenário 5) e as quatro razões (abaixo) selecionadas pelo método Procrustes.

A partir da Fig 7.43, observou-se que os resultados de PCA permaneceram praticamente os mesmos em termos de resolução na separação e sobreposição entre os 
grupos químicos equivalentes de Lago Grande e Osvaldo. Essas figuras são uma indicação gráfica de que nenhuma informação significativa foi perdida no que diz respeito aos padrões químicos multivariados dos dados, confirmando a eficiência da análise Procrustes como método de seleção de variáveis. Além disso, a estabilidade dos resultados antes e após a eliminação de variáveis evidencia que não haviam sido inseridas variáveis que poderiam obscurecer os padrões identificados.

Dessa forma, concluiu-se que os elementos $\mathrm{Yb}, \mathrm{Eu}, \mathrm{Fe}$, Th e $\mathrm{Sc}$ devem ser priorizados na performance analítica de INAA em análises futuras com amostras de Lago Grande e Osvaldo, pois esses elementos formam o conjunto mínimo de variáveis necessárias para a reprodução do padrão multivariado de concentrações elementares dos grupos químicos definidos para o Cenário 5. Isso não implica que mais elementos não possam ser determinados no futuro para checar um possível particionamento dos dados em mais grupos dentro dos dois grupos definidos para cada sítio, buscando refinar a interpretação do registro arqueológico, como sugerido na discussão sobre o significado arqueológico dos grupos químicos na seção 7.1.19.

Assim, de modo geral para os dois cenários, os elementos que devem ser priorizados em análises futuras que busquem reproduzir as análises dos cenários $\mathbf{3}$ e $\mathbf{5}$ são $\mathrm{Yb}, \mathrm{Ce}, \mathrm{Eu}, \mathrm{Fe}, \mathrm{Th}$ e Sc.

\subsubsection{Estudo com redes neurais}

O estudo com mapas auto-organizáveis foi realizado para comparação com resultados de padrões multivariados identificados pela combinação de análise de agrupamentos e componentes principais. Foi utilizado o pacote Kohonen and CP-ANN implementado em Matlab 7.6.0 (R2008a), com a função newsom, para calcular os mapas auto-organizáveis (Ballabio et al., 2009; Ballabio \& Vasighi, 2012). Utilizou-se a forma não supervisionada do mapa auto-organizável para que a classificação prévia das amostras, realizada por agrupamentos e PCA, não tivesse peso no treinamento da rede. Somente após a convergência do mapa é que se realizaram as comparações. Os parâmetros escolhidos para os cálculos do algoritmo foram (Lopez-Molinero et al., 2000; Tanevska et al., 2007; Toyota, 2009; Ballabio \& Vasighi, 2012): 
․ Modelo: mapa não supervisionado de Kohonen;

a Geometria de rede: hexagonal;

․ Número de neurônios: 7x7;

口 Número de épocas: 500;

口 Função de vizinhança: gaussiana;

a Algoritmo de treino: batelada;

- Inicialização dos pesos neuronais: linear (a partir dos autovetores dos dados);

口 Transformação dos dados: $\log _{10} \mathrm{e}$ alr;

口 Taxa de aprendizado inicial: 0,5 ;

ㅁ Taxa de aprendizado final: 0,01 .

A seguir, são apresentados os mapas auto-organizáveis para cada um dos cenários de interesse para interpretação arqueológica (3 e 5).

a. Cenário 3 (transformação $\log _{10}$ )

Nas Fig. 7.44, 7.45 e 7.46, são apresentados os mapas-auto-organizáveis para as amostras de Lago Grande, Osvaldo e dos dois sítios combinados, respectivamente. 


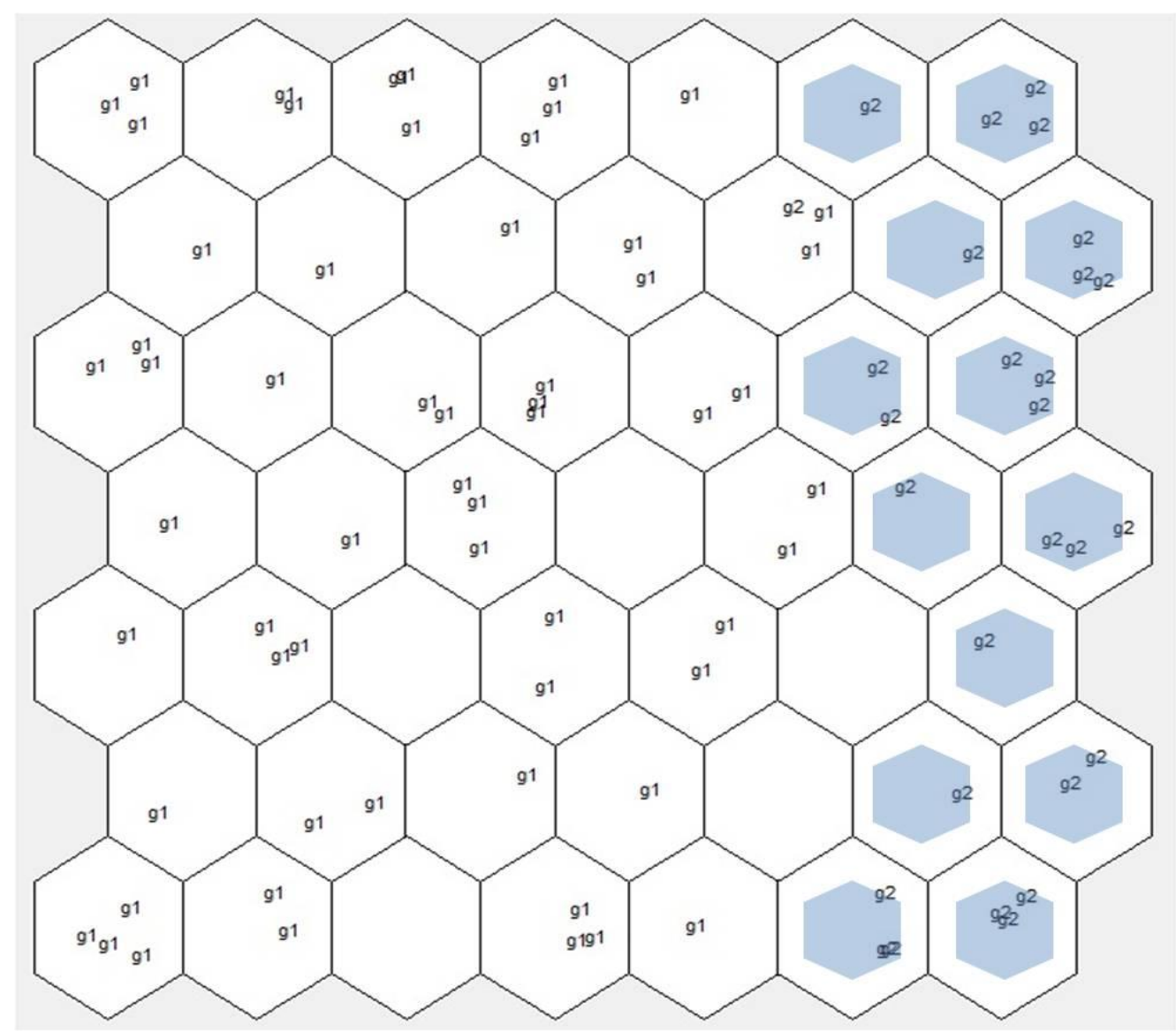

Figura 7.44 - Mapa de Kohonen para os grupos químicos de Lago Grande definidos no Cenário 3. Nomenclatura: $\mathrm{g} 1$ = grupo A; g2 = grupo B.

Pela Fig. 7.44, observou-se que o treinamento do SOM convergiu para um estado no qual as amostras dos grupos A (g1) e B (g2) de Lago Grande foram alocadas em regiões distintas do mapa, sendo que os hexágonos brancos representam aproximadamente a região do grupo $\mathrm{A}$, e os hexágonos destacados representam aproximadamente a região do grupo B. Pelo maior número de neurônios relacionados ao grupo A, inferiu-se que esse grupo é relacionado a uma maior variabilidade geoquímica. De fato, pela comparação da Fig 7.44 com a Fig. 7.20, referente ao PCA refinado para Lago Grande, pode-se observar que a elipse referente ao grupo A é maior que a do grupo B, sendo também um indicativo dessa maior variabilidade. 


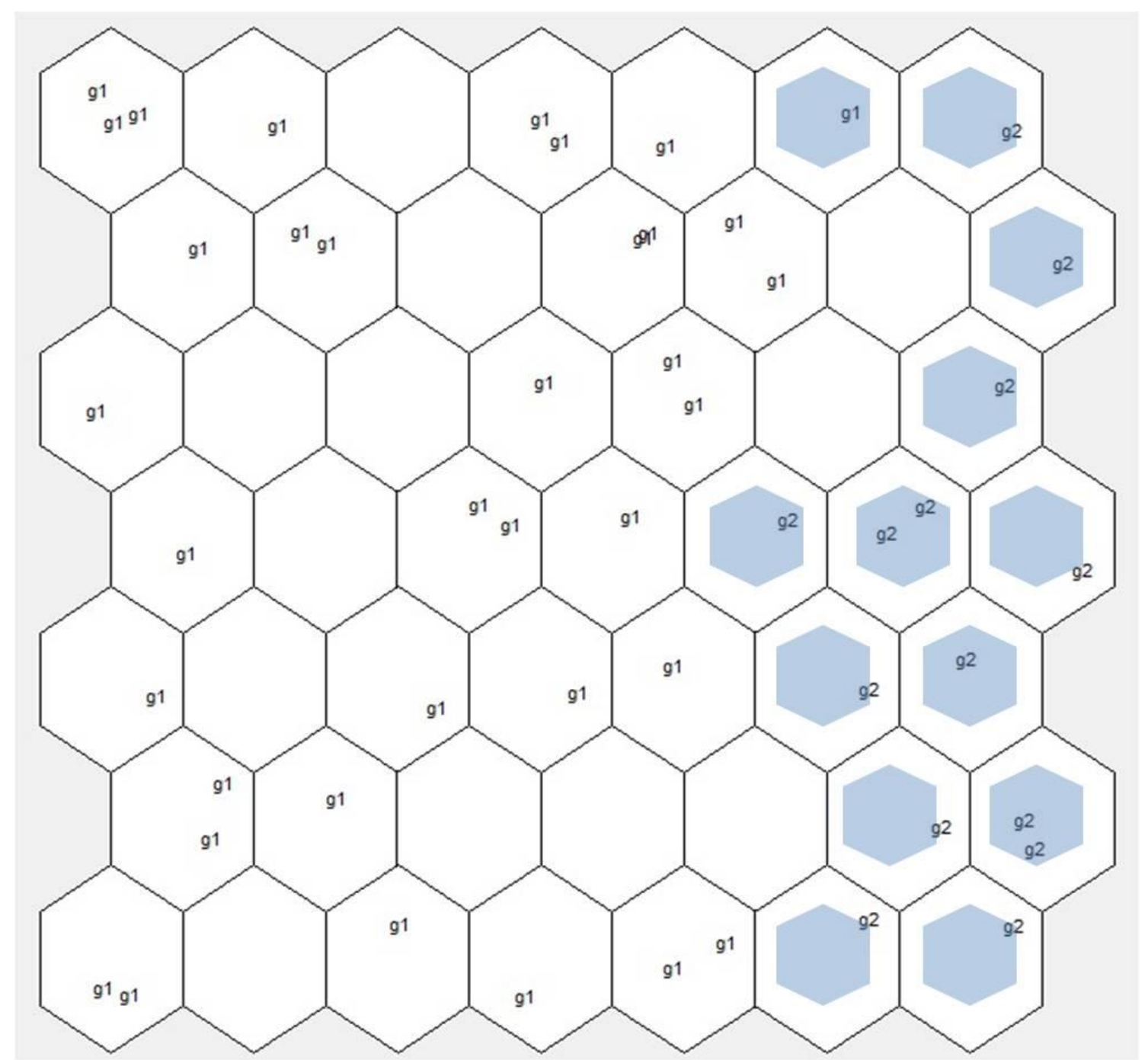

Figura 7.45 - Mapa de Kohonen para os grupos químicos de Osvaldo definidos no Cenário 3. Nomenclatura: g1 = grupo A; g2 = grupo B.

Pela Fig. 7.45, observou-se que o treinamento do SOM convergiu para um estado no qual as amostras dos grupos A (g1) e B (g2) de Osvaldo foram alocadas em regiões distintas do mapa, sendo que os hexágonos brancos representam aproximadamente a região do grupo $\mathrm{A}$, e os hexágonos destacados representam aproximadamente a região do grupo B. Pelo maior número de neurônios relacionados ao grupo A, inferiu-se que esse grupo é relacionado a uma maior variabilidade geoquímica. De fato, pela comparação da Fig 7.45 com a Fig. 7.29, referente ao PCA refinado para Lago Grande, pode-se observar que a elipse referente ao grupo A é maior que a do grupo B, principalmente na sua projeção na primeira componente principal, sendo também um indicativo dessa maior variabilidade. 


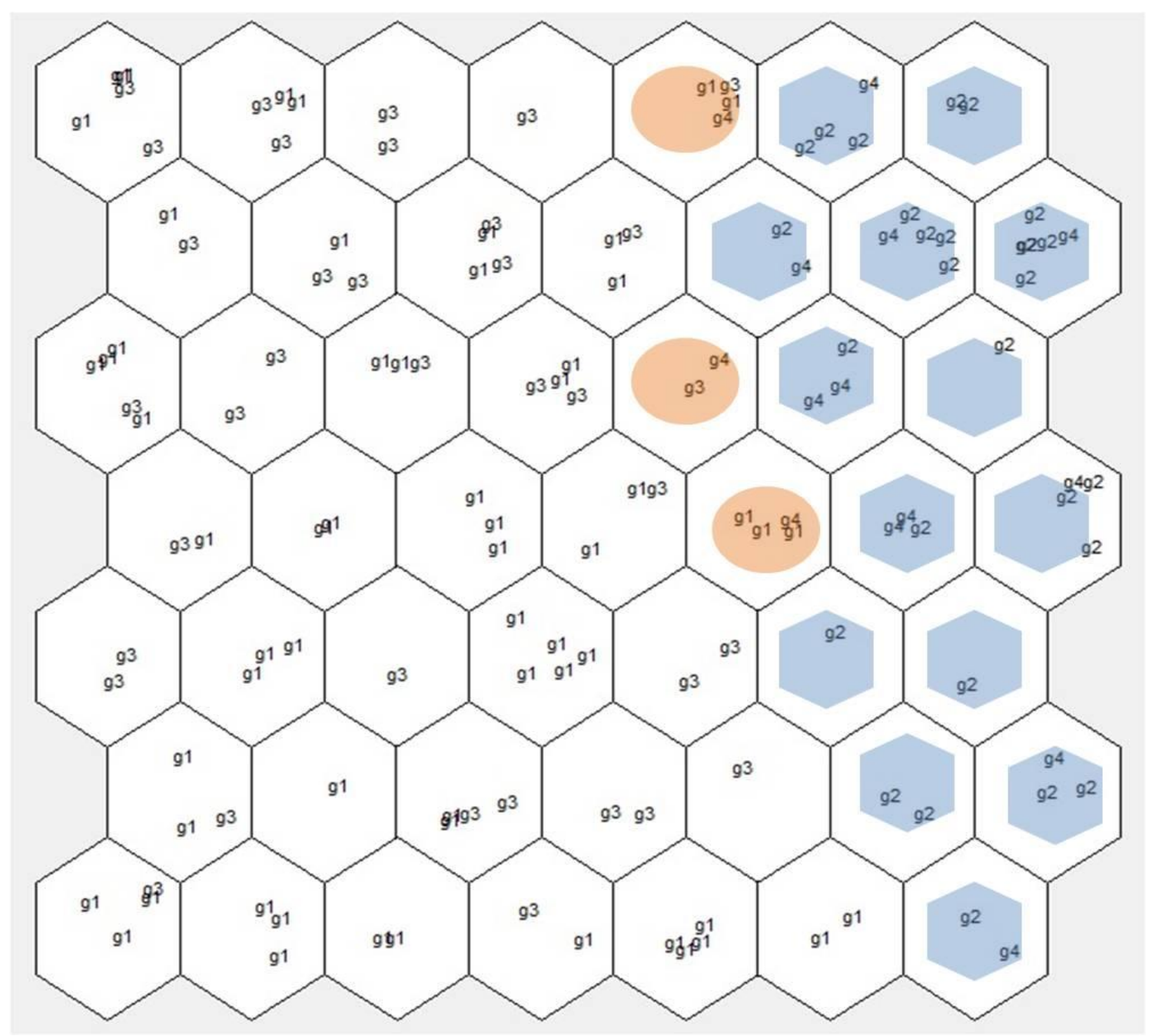

Figura 7.46 - Mapa de Kohonen para os grupos químicos de Lago Grande e Osvaldo definidos no Cenário 3. Nomenclatura: g1 = grupo A de Lago Grande; g2 = grupo B de Lago Grande; g3 = grupo A de Osvaldo; g4 = grupo B de Osvaldo.

Pela Fig. 7.46, observou-se que o treinamento do SOM convergiu para um estado no qual as amostras do grupo A de Lago Grande (g1) e A de Osvaldo (g3) apresentaram superposição e foram alocadas em uma região comum do mapa (hexágonos brancos) e distinta da região na qual as amostras dos grupos B de Lago Grande (g2) e B de Osvaldo (g4), que também apresentaram superposição, foram alocadas (hexágonos destacados em azul). Os neurônios destacados com uma elipse representam a região de transição, na qual houve uma mistura de amostras dos grupos A e B de cada sítio.

Assim, os resultados de SOM para o Cenário 3 estão em concordância com a análise PCA para o mesmo cenário, como discutido na seção 7.1.13 (Fig. 7.34 e 7.35). 


\section{b. Cenário 5 (transformação alr)}

Nas Figs. 7.47, 7.48 e 7.49, são apresentados os mapas-auto-organizáveis para as amostras de Lago Grande, Osvaldo e dos dois sítios combinados, respectivamente.

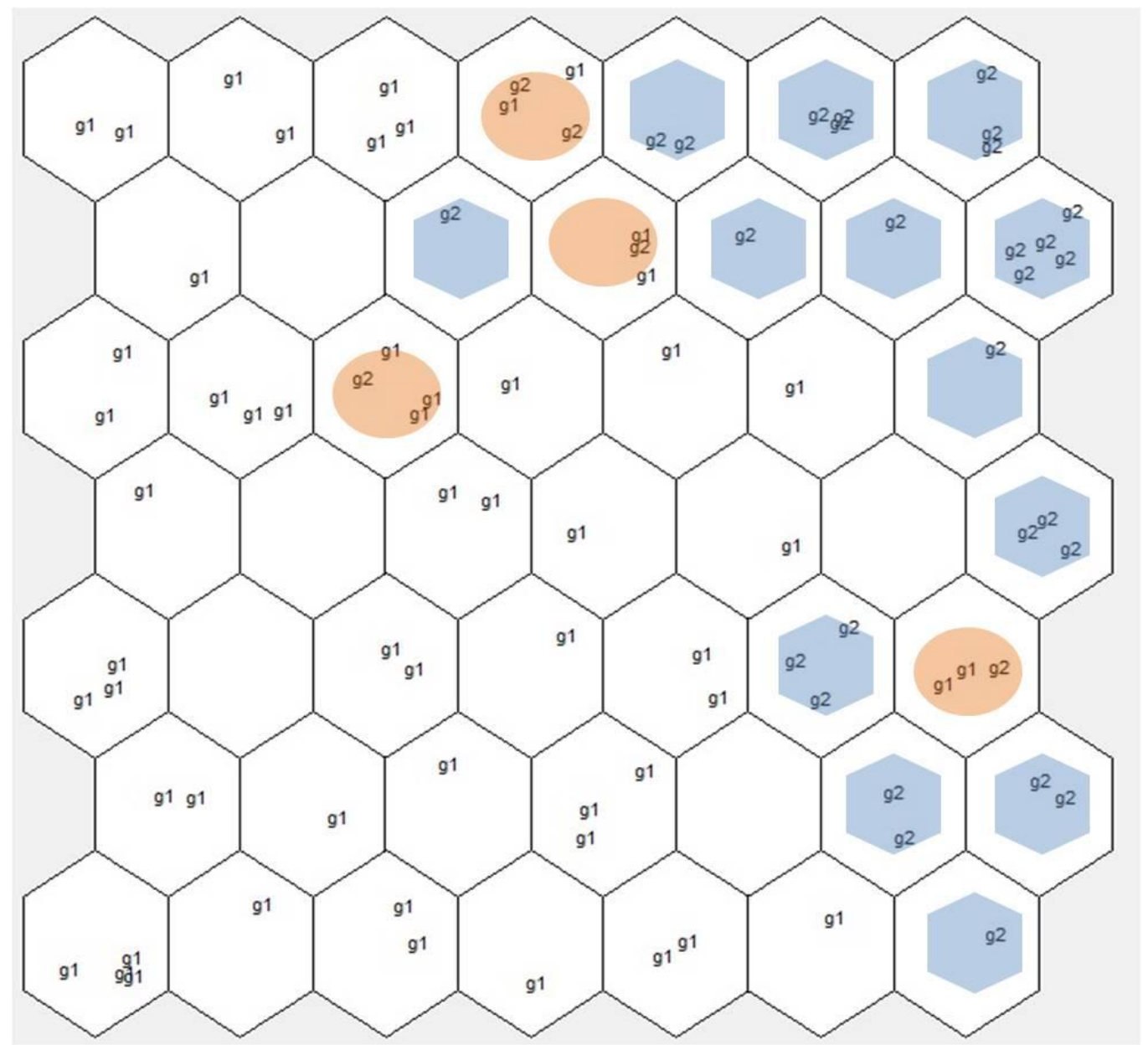

Figura 7.47 - Mapa de Kohonen para os grupos químicos de Lago Grande definidos no Cenário 5. Nomenclatura: g1 = grupo A; g2 = grupo B.

Pela Fig. 7.47, observou-se que o treinamento do SOM convergiu para um estado no qual as amostras dos grupos A (g1) e B (g2) de Lago Grande foram alocadas em regiões distintas do mapa, sendo que os hexágonos brancos representam aproximadamente a região do grupo $\mathrm{A}$, e os hexágonos destacados em azul representam aproximadamente a região do grupo B. Contudo, essa divisão foi menos óbvia que no caso do SOM para o mesmo sítio segundo o Cenário 3 (Fig 7.44), apresentando também neurônios (destacados com elipse laranja) para os quais houve mistura de amostras dos dois grupos. Pelo maior 
número de neurônios relacionados ao grupo A, inferiu-se que esse grupo é relacionado a uma maior variabilidade geoquímica. De fato, pela comparação da Fig 7.47 com a Fig. 7.24, referente ao PCA refinado para Lago Grande (Cenário 5), pode-se observar que a elipse referente ao grupo A é maior, sendo também um indicativo dessa maior variabilidade.

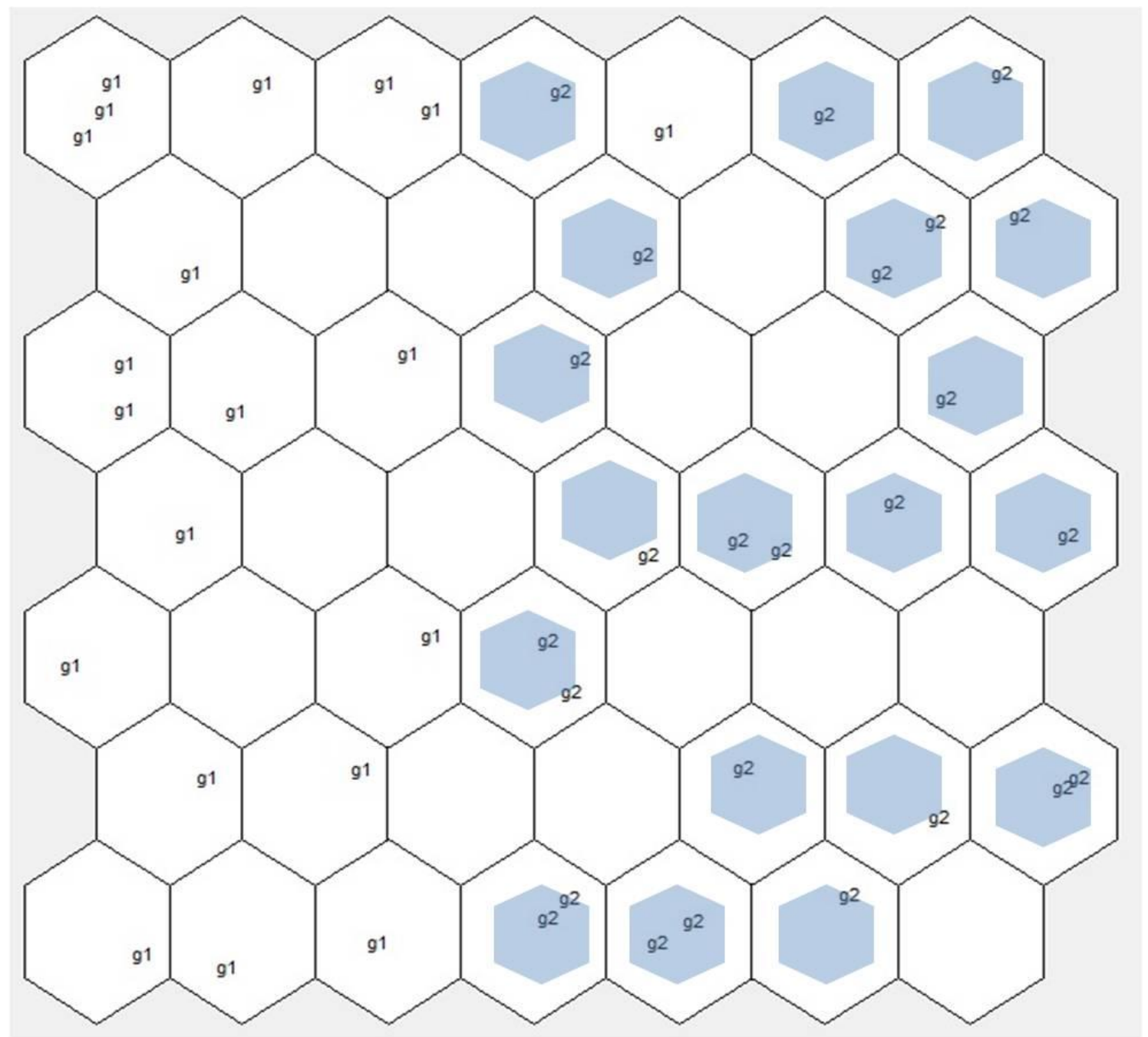

Figura 7.48 - Mapa de Kohonen para os grupos químicos de Osvaldo definidos no Cenário 5. Nomenclatura: g1 = grupo A; g2 = grupo B.

Pela Fig. 7.48, observou-se que o treinamento do SOM convergiu para um estado no qual as amostras dos grupos A (g1) e B (g2) de Osvaldo foram alocadas em regiões distintas do mapa, sendo que os hexágonos brancos representam aproximadamente a região do grupo $\mathrm{A}$, e os hexágonos destacados representam aproximadamente a região do grupo B. Para o Cenário 5 com as amostras de Osvaldo, o grupo B apresentou um 
equilíbrio com o grupo A em termos de número de neurônios nos quais suas amostras foram alocadas. De fato, pela análise PCA nas Fig. 7.36 e 7.37, observou-se que a elipse do grupo A de Osvaldo no Cenário 5 é menor que a do grupo B do mesmo sítio, e menor também que a do grupo A de Lago Grande. Esse é um indicativo, em concordância com a PCA, de que o grupo A de Osvaldo apresentou menor variabilidade geoquímica para a transformação de dados alr.

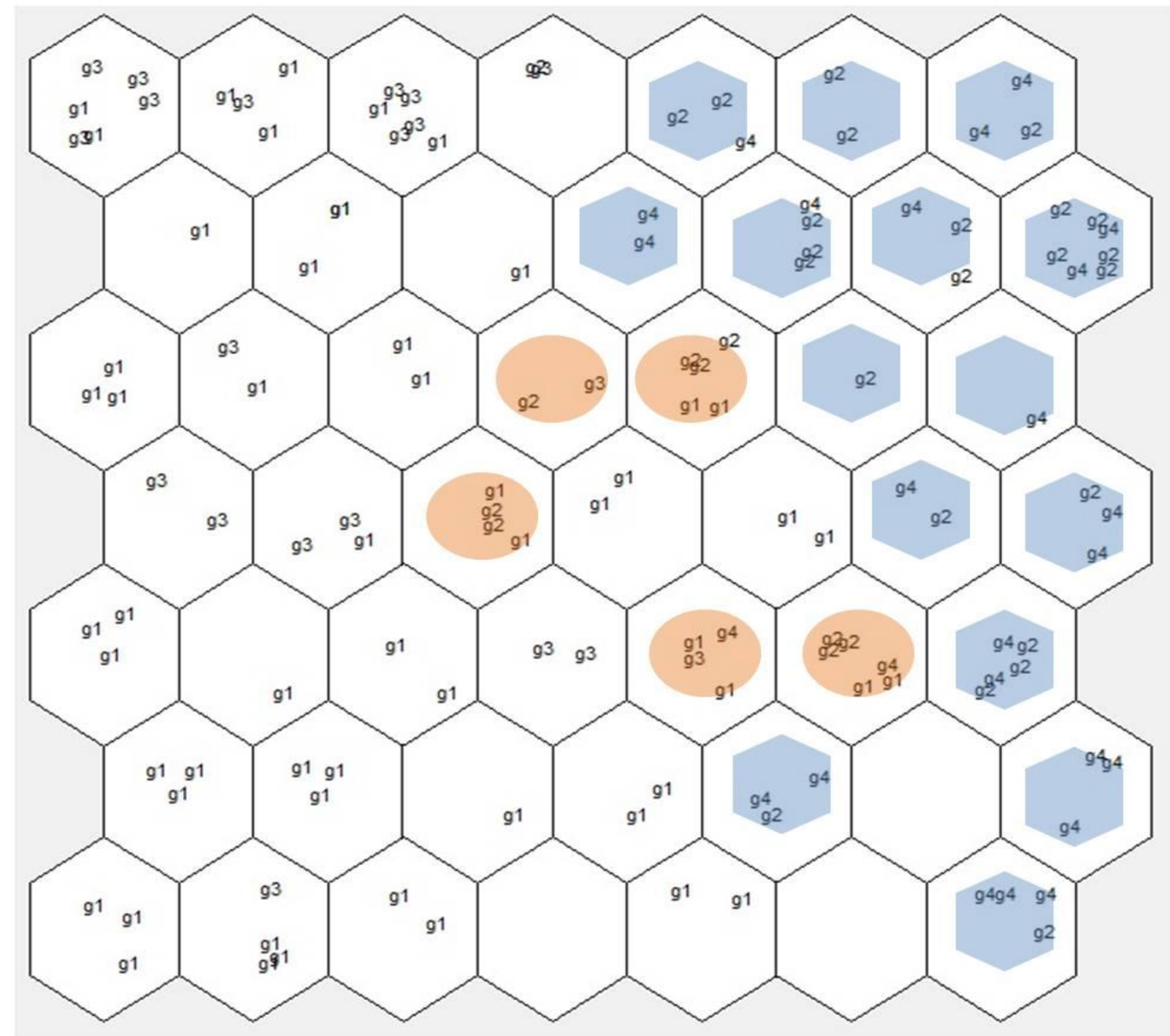

Figura 7.49 - Mapa de Kohonen para os grupos químicos de Lago Grande e Osvaldo definidos no Cenário 5. Nomenclatura: g1 = grupo A de Lago Grande; g2 = grupo B de Lago Grande; g3 = grupo A de Osvaldo; g4 = grupo B de Osvaldo.

Pela Fig. 7.49, observou-se que o treinamento do SOM convergiu para um estado no qual as amostras dos grupos A de Lago Grande (g1) e A de Osvaldo (g3) apresentaram superposição e foram alocadas em uma região comum do mapa (hexágonos brancos) e distinta da região na qual as amostras dos grupos B de Lago Grande (g2) e B de 
Osvaldo (g4), que também apresentaram superposição, foram alocadas (hexágonos destacados em azul). Os neurônios destacados com uma elipse representam a região de transição, na qual houve uma mistura de amostras dos grupos A e B de cada sítio.

Assim, os resultados de SOM para o Cenário 5 estão de acordo com a análise PCA para o mesmo cenário, como discutido na seção 7.1.13 (Fig. 7.36 e 7.37).

De maneira geral, os mapas de Kohonen apresentaram resultados em concordância com a análise de componentes principais e discriminante. Dessa forma, verificou-se a potencialidade de os mapas auto-organizáveis serem utilizados para comparação com os métodos estatísticos multivariados que dependem de hipóteses sobre a distribuição normal dos dados e homogeneidade das matrizes de covariância, indicando se o não atendimento dessas hipóteses, como ocorreu neste trabalho (seções 7.1.14 e 7.1.15), afetou os resultados desses métodos estatísticos.

\subsubsection{O significado arqueológico dos grupos químicos definidos}

Idealmente, os grupos químicos, delimitados por elipses de $95 \%$ de confiança para os vetores de concentrações elementares, seriam correlatos de apenas uma receita de produção cerâmica, para o Cenário 3, e uma fonte de argila, para o Cenário 5. Contudo, há fatores que tornam essa correlação menos óbvia e bem mais complexa.

O primeiro fator de complexidade é a possibilidade de combinação de argilas de diferentes fontes para a produção de um objeto cerâmico, em vez de apenas um tipo de argila. Como indicado pelas análises de Portocarrero (2006) e Lima (2008), que identificaram diferentes tipos de argila a partir de análises cromáticas dos fragmentos cerâmicos, essa possibilidade é alta para as cerâmicas estudadas neste trabalho. Ainda, segundo Lima (2008, p. 290), em sua análise da Tradição Borda Incisa, formas específicas de objetos cerâmicos exigiriam tipos particulares de argila, antiplástico e tratamentos posteriores, relacionados aos diferentes usos desses objetos e suas características de performance requisitadas.

Em casos de sociedades nas quais a produção de cerâmica não é centralizada, as famílias podem ter acesso irrestrito a fontes de argila e outras matérias-primas com alta variabilidade interna. Nesses casos, seria de se esperar a ocorrência de múltiplos grupos, ou mesmo falta de tendências fortes de agrupamento (Bishop, 2003). Nesse cenário, os grupos químicos, como os definidos neste trabalho, representariam, na verdade, grandes aglomerados de grupos menores, ou inúmeras pastas cerâmicas a partir de diferentes 
combinações de fontes de argila e antiplásticos. Mesmo em um cenário de produção cerâmica centralizada é possível encontrar subgrupos de objetos cerâmicos muito similares entre si dentro de grupos mais gerais (Bishop, 2003, p. 40).

Foram realizados testes para definir cortes em distâncias de agrupamento menores nos dendrogramas, correspondentes a um particionamento dos dados em mais grupos, tendo sido definidos sete grupos para Lago Grande e quatro para Osvaldo. Contudo, houve problemas com o número de amostras em alguns casos, fazendo com que fosse necessário expandir a amostragem para trabalhar num grau de resolução geoquímica maior na definição de grupos. Além disso, não foram observadas correlações arqueológicas mais óbvias, além das exploradas nas seções 7.1.20, que justificassem um maior particionamento dos dados. Assim, decidiu-se manter a definição de dois grupos químicos para cada sítio arqueológico neste trabalho. A comparação com outros sítios já estudados na Amazônia Central, como o Hatahara (Nunes, 2009) e o São Paulo II (Ribeiro, 2013) também poderiam ajudar a investigar melhor a variabilidade geoquímica e a possível definição de mais grupos que traga alguma informação arqueológica adicional.

Ainda, pela pesquisa bibliográfica realizada, não foi identificado nenhum estudo geoquímico sistemático focando na determinação de elementos-traço de interesse em solos argilosos da região, em diferentes níveis estratigráficos, para a caracterização da variabilidade geoquímica que pode ser esperada na Amazônia Central, ou pelo menos na região próxima à confluência dos rios Negro e Solimões.

Assim, os grupos químicos definidos neste trabalho podem estar representando não apenas uma pasta cerâmica ou fonte de argila, mas podem ser correlatos de um aglomerado de grupos de diferentes pastas e combinações de fontes argilosas, cuja identificação seria possível apenas pelo aumento do número de amostras e, talvez, elementos determinados por INAA, assim como o aumento da precisão analítica dos resultados. Dessa forma, aumentar-se-ia a resolução geoquímica da região estudada, visando à caracterização de um número maior de grupos químicos que podem estar contidos nos grupos A e B de cada sítio, definidos neste trabalho.

Esses fatores que afetam a interpretação dos grupos de cerâmicas são importantes e devem ser considerados na tentativa de correlacionar os dados geoquímicos elementares obtidos por INAA ao contexto arqueológico da região, como será visto na seção seguinte. 


\subsubsection{Comparação entre os Cenários 3 e 5 e implicações arqueológicas}

Realizaram-se análises multivariadas de variância (MANOVA) para testar diferenças entre os vetores de médias dos grupos A e B definidos para os sítios Lago Grande e Osvaldo, pela análise PCA com transformação $\log _{10}$ (Cenário 3), com os dados em $\mu \mathrm{g} \cdot \mathrm{g}^{-1}$, e transformação alr (Cenário 5), com razões elementares, cuja plausibilidade também foi confirmada nas análises discriminante e de redes neurais. Para os cálculos, foi utilizado o software livre Action 2.6. Por se tratar, em sua maioria, de elementos em nível traço, as variáveis determinadas, que na realidade são proporções $\left(\mu \mathrm{g} \cdot \mathrm{g}^{-1}\right)$, foram aproximadas por variáveis com valores absolutos (Woronow \& Love, 1990). Os resultados estão organizados na Tab. 7.28.

Tabela 7.28 - Análise multivariada de variância (MANOVA) para os grupos químicos de cerâmicas determinados por análise de agrupamentos e PCA para Lago Grande e Osvaldo. Nível de significância $\alpha=0,05$.

\begin{tabular}{|c|c|c|c|c|c|c|}
\hline Teste & Grupos testados & $\mathrm{n}_{1}, \mathrm{n}_{2}$ & Sítio & Transformação & $p$ & Conclusão \\
\hline 1 & $\mathrm{~A}_{\mathrm{LG}}, \mathrm{B}_{\mathrm{LG}}$ & 61,28 & $\mathrm{LG}$ & $\log _{10}$ & $3,9 \cdot 10^{-19}$ & $\mathrm{~A}_{\mathrm{LG}} \neq \mathrm{B}_{\mathrm{LG}}$ \\
\hline 2 & $\mathrm{~A}_{\mathrm{O}}, \mathrm{B}_{\mathrm{O}}$ & 37,15 & $\mathrm{O}$ & $\log _{10}$ & $6,5.10^{-8}$ & $\mathrm{~A}_{\mathrm{O}} \neq \mathrm{B}_{\mathrm{O}}$ \\
\hline 3 & $A_{L G}, A_{O}$ & 61,37 & LG vs. O & $\log _{10}$ & $2,1.10^{-3}$ & $A_{L G} \neq A_{O}$ \\
\hline 4 & $\mathrm{~B}_{\mathrm{LG}}, \mathrm{B}_{\mathrm{O}}$ & 28,15 & LG vs. O & $\log _{10}$ & 0,02 & $\mathrm{~B}_{\mathrm{LG}} \neq \mathrm{B}_{\mathrm{O}}$ \\
\hline 5 & $\mathrm{~A}_{\mathrm{LG}}^{\prime}, \mathrm{B}_{\mathrm{LG}}^{\prime}$ & 57,33 & $\mathrm{LG}$ & alr & $1,1.10^{-13}$ & $\mathrm{~A}^{\prime}{ }_{\mathrm{LG}} \neq \mathrm{B}_{\mathrm{LG}}^{\prime}$ \\
\hline 6 & $\mathrm{~A}_{\mathrm{O}}^{\prime}, \mathrm{B}_{\mathrm{O}}^{\prime}$ & 20,26 & $\mathrm{O}$ & alr & $1,3 \cdot 10^{-7}$ & $\mathrm{~A}^{\prime}{ }_{\mathrm{O}} \neq \mathrm{B}_{\mathrm{O}}^{\prime}$ \\
\hline 7 & $\mathrm{~A}^{\prime}{ }_{\mathrm{LG}}, \mathrm{A}^{\prime} \mathrm{O}$ & 57,20 & $\mathrm{LG} v s . \mathrm{O}$ & alr & $6,6 \cdot 10^{-3}$ & $\mathrm{~A}^{\prime}{ }_{\mathrm{LG}} \neq \mathrm{A}_{\mathrm{O}}^{\prime}$ \\
\hline 8 & $\mathrm{~B}^{\prime}{ }_{\mathrm{LG}}, \mathrm{B}_{\mathrm{O}}$ & 28,15 & LG vs. O & alr & 0,01 & $\mathrm{~B}^{\prime}{ }_{\mathrm{LG}} \neq \mathrm{B}_{\mathrm{O}}$ \\
\hline 9 & $\mathrm{~A}_{\mathrm{LG}}, \mathrm{A}_{\mathrm{LG}}^{\prime}$ & 61,57 & LG & $\log _{10}$ vs. alr* & 0,44 & $A_{L G}=A^{\prime}{ }_{L G}$ \\
\hline 10 & $\mathrm{~B}_{\mathrm{LG}}, \mathrm{B}_{\mathrm{LG}}^{\prime}$ & 28,33 & LG & $\log _{10}$ vs. alr* & 0,38 & $\mathrm{~B}_{\mathrm{LG}}=\mathrm{B}^{\prime}{ }_{\mathrm{LG}}$ \\
\hline 11 & $\mathrm{~A}_{\mathrm{O}}, \mathrm{A}_{\mathrm{O}}^{\prime}$ & 37,20 & $\mathrm{O}$ & $\log _{10}$ vs. alr* & 0,08 & $\mathrm{~A}_{\mathrm{O}}=\mathrm{A}_{\mathrm{O}}^{\prime}$ \\
\hline 12 & $\mathrm{~B}_{\mathrm{O}}, \mathrm{B}_{\mathrm{O}}$ & 37,26 & $\mathrm{O}$ & $\log _{10}$ vs. alr* & 0,02 & $\mathrm{~B}_{\mathrm{O}} \neq \mathrm{B}_{\mathrm{O}}$ \\
\hline
\end{tabular}

LG = Lago Grande. $\mathrm{O}=$ Osvaldo.

*Resultados $\log _{10}$ dos testes $9,10,11$ e 12 foram transformados em alr para que a comparação dos grupos fizesse sentido.

Pela Tab. 7.28, em relação ao Cenário 3, correspondente à transformação $\log _{10}$, os grupos químicos definidos para os sítios Lago Grande e Osvaldo apresentaram diferenças estatisticamente significativas nas concentrações elementares pela aplicação de 
MANOVA aos dados (Testes 1 e 2). As mesmas diferenças entre os grupos de cada sítio foram encontradas pela mudança de transformação $\log _{10}$ para alr, correspondente ao Cenário 5, pela aplicação dessa mesma análise (Testes 5 e 6). Esse resultado implica que, a despeito de qualquer influência da adição de antiplástico aos resultados de INAA, ao menos dois grupos químicos distintos podem ser definidos para os artefatos cerâmicos de cada sítio analisados neste trabalho.

Ainda pela Tab. 7.28, verificou-se, pelos valores de $p$, que mesmo os grupos que apresentaram boa superposição de suas elipses (os grupos A e B de cada sítio), tanto no Cenário 3 como no Cenário 5, apresentaram diferenças estatisticamente significativas em seus vetores de concentrações elementares (Testes 3, 4, 7, 8). Essas diferenças podem ser devidas a particularidades de produção dos antigos ceramistas de cada sítio, e a outros fatores relacionados a possíveis padrões de troca comercial, como será visto adiante. Além disso, os valores $p$ dependem do design experimental e, como já relatado anteriormente, a amostragem neste trabalho foi parcialmente enviesada, além de oportunística.

O último conjunto de testes (9-12) foi realizado com os dados transformados em razões elementares, para fins de comparação. Admitindo-se a hipótese de a adição dos elementos antiplásticos não causar perturbações significativas na análise multivariada (como no caso de temperos com concentrações baixas dos elementos químicos de interesse, promovendo uma diluição uniforme para todos eles) seria de se esperar que os grupos químicos definidos fossem diferentes entre si apenas por uma constante de diluição. Com exceção para o grupo B e B' de Osvaldo, os testes de MANOVA comparando grupos dos cenários 3 e 5, indicaram que eles são semelhantes do ponto de vista estatístico, quando eliminado o efeito de diluição pela divisão por escândio, sugerindo que a adição de antiplásticos não alterou significativamente os padrões geoquímicos gerais por enriquecimento não linear de alguns elementos químicos.

No entanto, como já discutido na seção 7.1.12, amostras foram reclassificadas pela mudança na transformação de dados, mesmo após o processo de refinamento dos grupos químicos. Essa reclassificação pode ter ocorrido por diferenças na quantidade e combinações de antiplásticos inseridos na fabricação de diferentes objetos cerâmicos. Esse fato tem implicações para as correlações arqueológicas, como será visto adiante. Além disso, deve-se considerar que essas conclusões servem para o nível de resolução geoquímica adotado neste trabalho, com dois grupos de cerâmicas para cada sítio. Em caso 
de futuros trabalhos, operando numa resolução geoquímica maior pela definição de mais grupos dentro dos já definidos, esses testes e essas considerações devem ser reavaliados.

Para Lago Grande, 25 amostras (28\%), de um total de 89, foram reclassificadas. Já para Osvaldo, 26 amostras (50\%), de um total de 52, foram reclassificadas. Assim, concluiu-se que as amostras do sítio Osvaldo foram mais afetadas pela mudança na transformação dos dados. A partir das informações disponíveis, não foram identificados padrões para explicar as amostras alteradas em sua classificação, referente à concentração de algum elemento químico ou alguma correlação arqueológica, com exceção para Lago Grande, cuja maioria das amostras reclassificadas foi identificada como Paredão. Sugere-se que as inclusões nessas amostras reclassificadas sejam analisadas para tentar identificar alguma diferença nos padrões de adição do(s) tempero(s). Uma técnica potencial seria a análise petrográfica.

Os grupos químicos de cerâmicas definidos neste trabalho foram testados direta e indiretamente quanto à sua significância estatística. Indiretamente, eles foram testados pela análise das dispersões apresentadas por cada elemento químico dentro de cada grupo (seção 7.1.13), e confrontados com as tendências estatisticamente observáveis em estudos de caracterização química de cerâmicas arqueológicas em todo o mundo. A análise direta, nesta seção, foi realizada pela aplicação de MANOVA aos dados. Contudo, ainda é necessário e mandatório, num trabalho arqueométrico que busque a interdisciplinaridade de fato, que os diferentes grupos químicos definidos sejam interpretados quanto à sua significância arqueológica, no sentido de se correlacionar a análise físico-química e estatística às informações tipológicas e de proveniência disponíveis para os artefatos estudados, e ao contexto arqueológico geral da região. Nas próximas subseções, são analisados os resultados do Cenário 3 e do Cenário 5 quanto às suas potenciais correlações arqueológicas.

\section{a. Fase cerâmica}

A Tab. 7.29 resume a classificação das amostras de cada grupo químico definido nos cenários $\mathbf{3}$ e $\mathbf{5}$ de INAA em relação à fase arqueológica das cerâmicas. É importante salientar que a diferenciação das cerâmicas Manacapuru e Paredão nem sempre é uma tarefa trivial, devido a elementos comuns às duas fases e homogeneizadores de toda a Tradição Borda Incisa, como a utilização de cauixi como antiplástico preferencial e 
certos motivos decorativos. Dessa forma, imprecisões na classificação são esperadas (Portocarrero, 2006).

Tabela 7.29 - Classificação das amostras nos grupos químicos do Cenário 3 e Cenário 5 segundo a fase cerâmica, para os sítios Lago Grande e Osvaldo.

\begin{tabular}{c|cccc|cccc}
\hline \multirow{2}{*}{ Fase } & \multicolumn{4}{c|}{ Cenário 3 } & \multicolumn{4}{c}{ Cenário 5 } \\
\cline { 2 - 10 } & \multicolumn{2}{|c}{ Lago Grande } & \multicolumn{2}{c|}{ Osvaldo } & \multicolumn{2}{c}{ Lago Grande } & \multicolumn{3}{c}{ Osvaldo } \\
& A & B & A & B & A $^{\prime}$ & B' & A $^{\prime}$ & B' $^{\prime}$ \\
\hline Manacapuru & 22 & 4 & 15 & 9 & 20 & 6 & 12 & 8 \\
Paredão & 35 & 25 & 11 & 2 & 30 & 32 & 5 & 8 \\
Açutuba & 3 & 1 & - & - & 3 & 0 & - & - \\
Guarita & outlier & outlier & - & - & 1 & 0 & - & - \\
Sem classificação & 3 & 1 & 11 & 4 & 3 & 1 & 3 & 10 \\
Total & 63 & 31 & 37 & 15 & 57 & 39 & 20 & 26 \\
\hline
\end{tabular}

A partir da Tab. 7.29, foram elaboradas as seguintes distribuições de frequências nas Fig. 7.50 e 7.51.

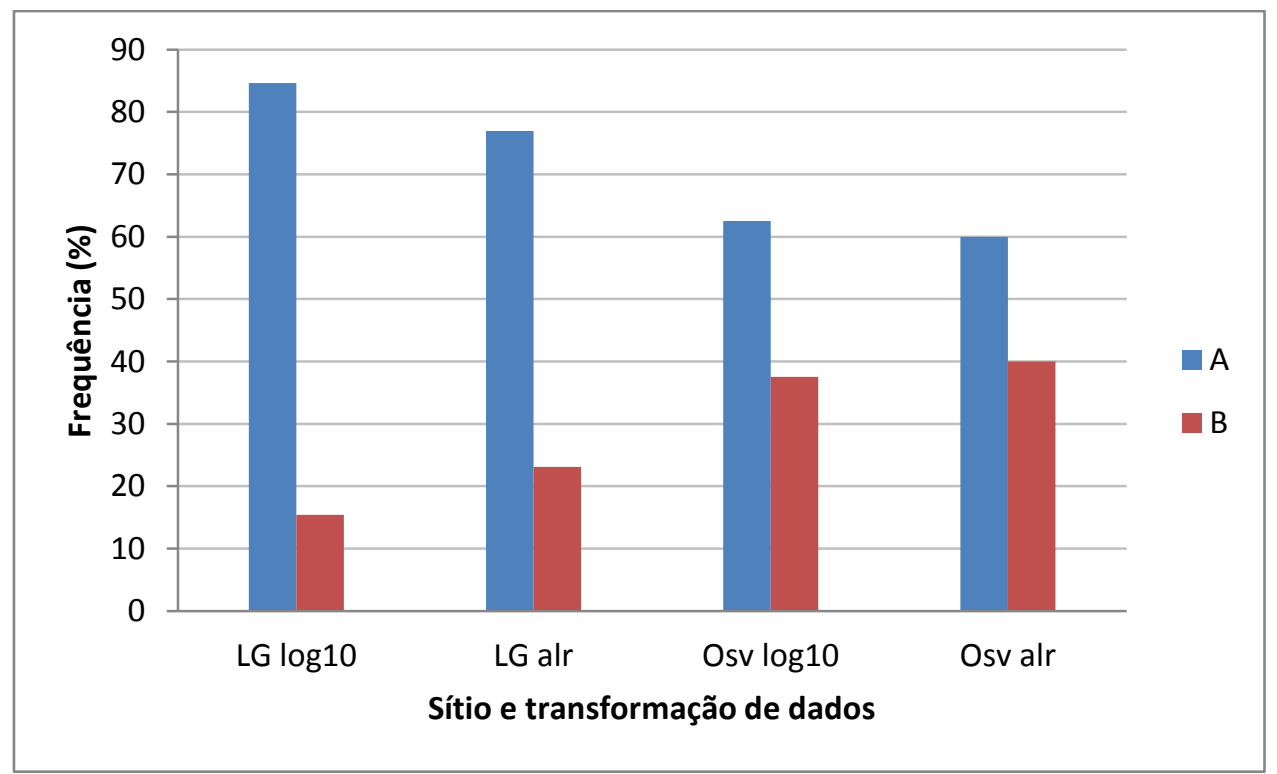

Figura 7.50 - Histograma de classificação de amostras Manacapuru de Lago Grande (LG) e Osvaldo (Osv) em grupos químicos definidos no Cenário 3 ( $\left.\log _{10}\right)$ e Cenário 5 (alr). 


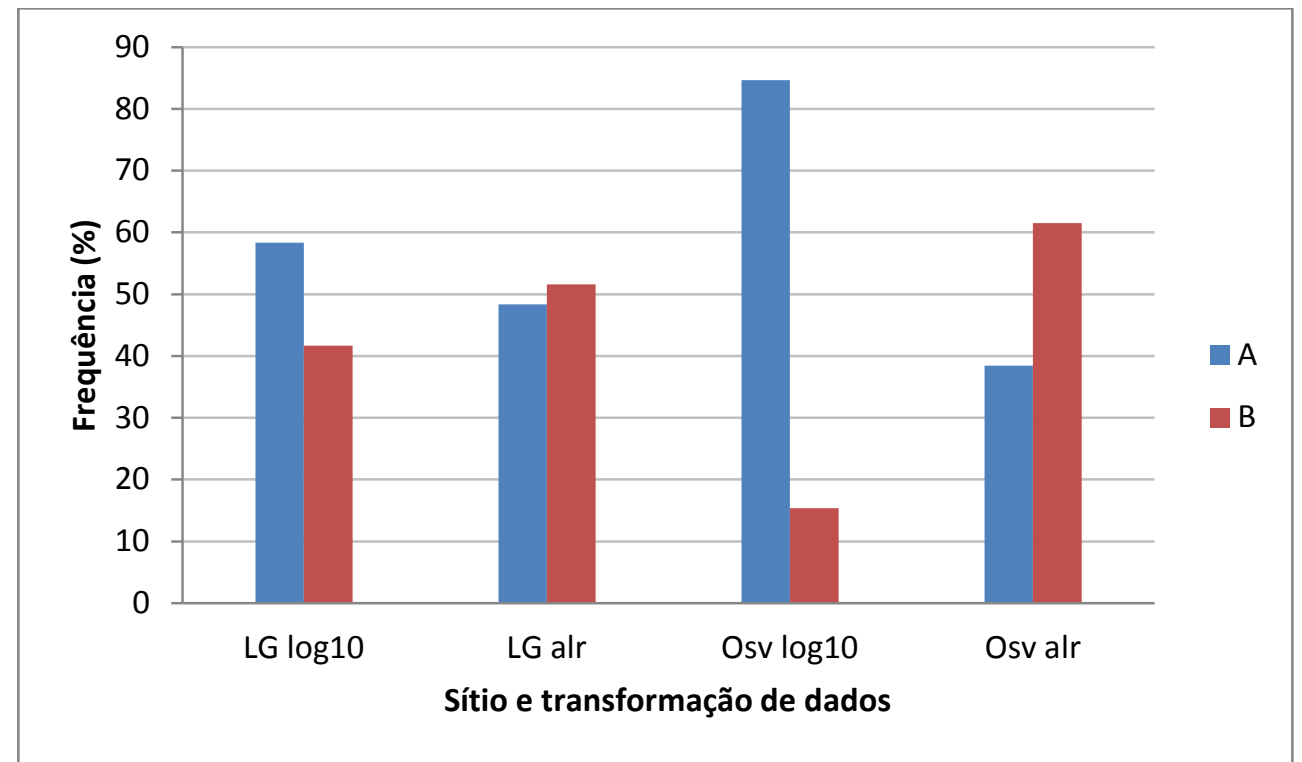

Figura 7.51 - Histograma de classificação de amostras Paredão de Lago Grande (LG) e Osvaldo (Osv) em grupos químicos definidos no Cenário 3 ( $\left.\log _{10}\right)$ e Cenário 5 (alr).

Primeiramente, algumas observações gerais podem ser feitas em relação aos histogramas. Pela Fig. 7.50, observou-se que os fragmentos cerâmicos Manacapuru tenderam a se concentrar nos grupos A de cada sítio, independentemente da transformação de dados utilizada, e de forma mais intensa em Lago Grande. Esse fato sugere que a(s) receita(s) de pasta cerâmica, ou fontes de argila, representadas por esses grupos seriam as utilizadas preferencialmente pelos ceramistas de Osvaldo. Em relação às amostras Paredão, na Fig. 7.51, não foi observado o mesmo padrão, indicando que esse tipo de cerâmica poderia ser produzido a partir de diferentes receitas e/ou fontes de argila, inclusive as preferenciais para a fase Manacapuru, característica de Osvaldo.

Ainda pelas Fig. 7.50 e 7.51, verificou-se que o efeito da transformação de dados foi bem menos expressivo nas cerâmicas Manacapuru que nas cerâmicas Paredão. Apesar de as proporções de amostras Manacapuru terem mudado com a mudança da transformação $\log _{10}$ do Cenário 3, para a alr do Cenário 5, os mesmos padrões foram observados em todos os casos. Já as amostras Paredão tiveram resultados consideravelmente afetados pela mudança na transformação de dados, a ponto de haver inversão do grupo mais característico dessa fase. Esses resultados indicariam que os perfis químicos elementares das cerâmicas Paredão seriam mais afetados pela adição de antiplásticos do que os das cerâmicas Manacapuru. Ainda, esse efeito seria mais pronunciado nos dados de Osvaldo, que nos dados de Lago Grande. 
Uma primeira hipótese para a diferença nos padrões observados para as cerâmicas Paredão de Lago Grande e Osvaldo, na Fig. 7.51, seria o fato de as cerâmicas Paredão de Osvaldo não terem entrado no sítio apenas por trocas com Lago Grande, e por isso sua classificação nos diferentes grupos químicos de Osvaldo não teria semelhança com amostras dessa mesma indústria cerâmica produzida em Lago Grande.

Assumindo-se um contexto de troca comercial, outra hipótese para essa alteração seria padrões diferentes de escolha de matérias-primas, argilas e antiplásticos, por parte dos produtores de cerâmica Paredão em Lago Grande para as cerâmicas que teriam como destino a troca comercial (não necessariamente com Osvaldo, já que as amostras de Lago Grande compreendem um período maior, a partir do final da ocupação de Osvaldo), indicando um comportamento deliberado no sentido de aprimoramento tecnológico das cerâmicas que serviriam como base de troca, visando aumentar a qualidade segundo algum parâmetro de performance.

Como sugestão para testar se essa hipótese acerca da diferença no processo produtivo para fins de troca comercial também ocorreria para as cerâmicas Manacapuru, podendo explicar a proporção maior de cerâmicas dessa fase nos grupos A de Lago Grande, indica-se a amostragem sistemática, em trabalhos futuros, das Concentrações 3 e 5 de Osvaldo. Portocarrero (2006) relatou percentuais superiores de ocorrência de cerâmicas Paredão e bolotas de argila nessas Concentrações, sugerindo que a maior produção cerâmica nessas regiões do sítio poderia estar ligada à produção de excedente destinado ao intercâmbio com grupos produtores da indústria Paredão, como os antigos habitantes de Lago Grande.

Pensando cronologicamente, apesar da contemporaneidade de ao menos dois séculos assumida entre essas duas fases, a fase Paredão é mais recente do que a Manacapuru, e coincide com um pico demográfico na Amazônia Central (Lima, 2007; Neves, 2008). Dessa forma, os resultados poderiam refletir uma mudança tecnológica na produção dessas cerâmicas, quanto aos padrões de utilização de antiplástico e/ou escolha das fontes de argila. $\mathrm{O}$ maior equilíbrio de fragmentos Paredão entre os grupos químicos na Fig. 7.51 para o sítio Lago Grande, em comparação aos fragmentos Manacapuru na Fig. 7.50, poderia indicar uma maior variação na escolha de matérias-primas por parte dos produtores dessa indústria cerâmica. Nesse pico demográfico na Amazônia Central, mais cerâmica utilitária deve ter sido produzida, sendo que essa maior variabilidade geoquímica para as cerâmicas Paredão poderia estar associada à sazonalidade na oferta de fontes 
argilosas e outras matérias-primas nos períodos de cheia e de seca. O aumento da demanda por objetos cerâmicos faria com que fosse impraticável esperar apenas os períodos de seca, nos quais outras matérias-primas estivessem disponíveis, para a produção de cerâmica utilitária (Moraes, 2006).

Em relação às fases cerâmicas menos representadas, verificou-se uma tendência de agrupamento das cerâmicas Açutuba em grupos A, ou seja, as cerâmicas dessa fase cultural tenderam a se agrupar junto com as cerâmicas Manacapuru, nos dois cenários (Tab. 7.29). Ao se considerar a cronologia de desenvolvimento das fases cerâmicas da Tradição Borda Incisa, a fase Açutuba é a mais antiga, seguida pela Manacapuru. Esses resultados poderiam ser indicativos de que houve uma continuidade tecnológica entre as duas fases no que tange a escolha de matérias-primas. No entanto, mais amostras precisariam ser analisadas para aumentar a representatividade da fase Açutuba e realizar comparações mais assertivas com as cerâmicas Manacapuru e Paredão. A única amostra Guarita foi considerada um dado discrepante no Cenário 3, enquanto foi classificada no grupo A, no Cenário 5. Esse fato sugere que a adição de antiplástico, provavelmente cariapé, pode ter um efeito de diluição considerável nessa cerâmica, contudo, assim como os fragmentos Açutuba, mais amostras precisariam ser analisadas para comparações estatisticamente significativas.

Foi realizada uma comparação preliminar de PCA das amostras de Lago Grande e Osvaldo com amostras dos sítios Hatahara (Nunes, 2009) e Açutuba, também na Amazônia Central, próximos de Lago Grande e Osvaldo por cerca de 10-20 km. A partir dos resultados, foi inferido um quadro de pouca variabilidade geoquímica para os elementos químicos analisados no Cenário 3 e Cenário 5 entre esses quatro sítios arqueológicos (Apêndice $\mathrm{H}$ ). Esse quadro tem três interpretações possíveis. A primeira delas, analítica, indicaria a necessidade de se aumentar o número de elementos analisados por INAA e tentar diminuir as incertezas analíticas para aumentar a resolução dos dados geoquímicos na região delimitada e melhorar a diferenciação entre as amostras. Além disso, seria conveniente uma amostragem sistemática de argilas na confluência do Negro e Solimões, principalmente da região próxima aos sítios, para que se tivesse uma melhor mensuração da real variabilidade geoquímica das argilas da região, e da aplicabilidade do postulado de proveniência a esse contexto.

A segunda interpretação, assumindo que haja variabilidade geoquímica adequada, seria uma padronização na escolha das fontes de argila por parte dos grupos 
habitantes de Açutuba, Hatahara, Lago Grande e Osvaldo. Essa hipótese poderia ser contrariada logisticamente, argumentando-se que a alta disponibilidade de fontes de argila na região (Lima, 2008) não tornaria necessária a busca preferencial por determinadas fontes, situadas em regiões não imediatamente adjacentes aos sítios. Contudo, outras implicações de ordem simbólica e/ou tecnológica poderiam reforçar essa hipótese. Lima (2008) interpretou a presença de cauixi em sítios que não estão próximos a rios de água preta (como o rio Negro, onde o cauixi seria encontrado preferencialmente) como correlato de transporte e armazenamento desse antiplástico. A autora ainda afirma que a escolha do cauixi não foi casual, embora haja variações de seu uso internamente às fases cerâmicas da Tradição Borda Incisa, referente ao tamanho e orientação das espículas biogênicas (Portocarrero, 2006; Lima, 2008). Assim como ocorreu para esse elemento da pasta cerâmica, esse argumento poderia ser estendido às argilas quanto à distância que poderia ser percorrida para a sua coleta.

A terceira interpretação seria que essa sobreposição geoquímica seria um indicativo de uma rede extensa de trocas operante na região, que faria com que amostras com padrões geoquímicos similares pudessem ser encontradas nesses quatro sítios. As hipóteses arqueológicas de redes de trocas regionais atuantes na Amazônia Central, como discutido no Capítulo 2, corrobora esta interpretação.

Há ainda dois fatores que poderiam reduzir a resolução de grupos geoquímicos de cerâmicas da região como correlatos de diferentes fontes argilosas. O primeiro seria a mistura de diferentes argilas em uma mesma receita de pasta. Essa mistura poderia gerar padrões geoquímicos médios a partir da mistura de argilas com perfis químicos recorrentes na região de confluência.

O segundo fator redutor da resolução geoquímica seria a utilização de cacos moídos (de outros objetos cerâmicos descartados e/ou quebrados) buscando a redução da plasticidade da pasta. Essa inserção tem o potencial de obscurecer diferentes padrões geoquímicos, e é mais crítica quanto mais delimitada for a área de estudo e, consequentemente, menor a variabilidade geoquímica do contexto. Isso ocorreria pelo fato de os cacos moídos terem concentrações elementares comparáveis ao das fontes de argila, diferentemente do que ocorre com outros elementos antiplásticos, como o cauixi, como mostrado na seção 7.1.3. Assim, a inserção de caco moídos, provenientes de outros contextos de produção cujas fontes argilosas podem ter sido distintas, reduziria a resolução geográfica dos resultados que buscassem atribuir as fontes de proveniência aos materiais 
cerâmicos (Neff et al., 1989). Portocarrero relatou que 41,3\% dos fragmentos Manacapuru de Osvaldo apresentaram alguma proporção de caco moído em sua pasta cerâmica (Portocarrero, 2006, p. 69).

Dessa forma, para se testar as hipóteses relatadas acerca da variabilidade geoquímica da região, reforça-se aqui novamente a necessidade de se analisar de maneira mais sistemática as argilas da confluência dos rios Negro e Solimões, principalmente no entorno dos sítios, de forma a tentar inferir se as semelhanças nas pastas cerâmicas seriam devidas a uma uniformidade geoquímica intrínseca dos elementos analisados dentro daquela região, a uma padronização na escolha das argilas, a uma rede regional de trocas ou outros fatores redutores da resolução geoquímica.

Embora não seja possível afirmar a partir dos resultados de INAA, de maneira unívoca, que as amostras Paredão analisadas de Osvaldo sejam provenientes de Lago Grande, assim como as Manacapuru de Lago Grande sejam provenientes de Osvaldo, há indícios na literatura arqueológica (citados no Cap. 3) que reforçariam que a troca entre esses dois sítios tenha ocorrido, embora provavelmente não tenham sido as únicas. Mongeló (2011) relatou que há outros 15 sítios Manacapuru e outros 14 sítios Paredão que devem ter sido contemporâneos a Lago Grande e Osvaldo na Amazônia Central, indicando que as relações de troca entre esses dois sítios não seriam casos isolados, dificultando a interpretação das relações entre os grupos químicos de cerâmica como correlato direto de interação entre Lago Grande e Osvaldo.

As Fig. 7.36 e 7.37, referente à análise alr dos dados, segundo o Cenário 5 de INAA, possuem indícios da possibilidade de mais trocas entre Lago Grande e outros sítios Manacapuru, que não apenas Osvaldo, no período de contemporaneidade entre os mesmos. Foi observado nessa figura, além da tendência de superposição entre grupos químicos equivalentes nos dois sítios, que a elipse do grupo A de Osvaldo é menor e contida na elipse desse mesmo grupo em Lago Grande. Se pela análise desta seção foi identificado que o grupo A estaria associado preferencialmente às cerâmicas Manacapuru, é possível considerar a hipótese de que a maior variabilidade geoquímica dessas cerâmicas no sítio Lago Grande indicaria que elas estariam entrando no sítio por relações de troca não apenas com o sítio Osvaldo, mas também com outros sítios habitados por grupos produtores de cerâmica Manacapuru, embora tenha sido observado que a variabilidade geoquímica do grupo A de Lago Grande também aumentou parcialmente pela presença de amostras Paredão. Além disso, essa rede mais extensa de trocas poderia explicar ao menos 
parcialmente as semelhanças geoquímicas observadas na comparação preliminar das amostras de Lago Grande e Osvaldo com a dos sítios Açutuba e Hatahara, como já discutido anteriormente, que foram contemporâneos por volta de 650 a.C. a 690 a.C., segundo Portocarrero (2006, p. 27). Ainda, por cronologia relativa, o autor apontou que outros 15 sítios Manacapuru podem ter sido contemporâneos a Lago Grande.

A não observância desse mesmo padrão nos grupos $\mathrm{B}$, com maior quantidade de cerâmicas Paredão, pode ser devido à maior variabilidade na escolha de matérias-primas para a produção dessa cerâmica em Lago Grande, como já discutido anteriormente.

A confirmação dessa hipótese de interação de Lago Grande com outros sítios Manacapuru, que não apenas Osvaldo, corroboraria a existência de um sistema regional de interação, no qual etnias diferentes compartilhariam uma ideologia e uma cultura comuns através de extensas redes de troca, casamento exogâmicos e alianças intercomunitárias. Esses sistemas foram indicados arqueologicamente nas áreas periféricas da Amazônia, mas ainda foram pouco estudados na região da Amazônia Central (Mongeló, 2011).

Não foi possível distinguir, a partir dos resultados deste trabalho, qual modalidade de troca estaria ocorrendo preferencialmente: troca comercial, casamento exogâmico ou integração territorial. Contudo, há evidências na literatura arqueológica e etnográfica de que esses três mecanismos tenham ocorrido (ver Cap. 3). A hipótese mais provável, a partir dos dados deste trabalho, é que, durante um determinado período, os antigos ceramistas de Lago Grande e Osvaldo utilizaram fontes de argila comuns para produção de suas cerâmicas características, devido a algum grau de integração territorial, já que as amostras dos dois sítios não são caracterizadas por apenas um perfil de concentrações químicas elementares; e ainda praticaram trocas comerciais, evidenciadas na semelhança regular no padrão de distribuição de cerâmicas Manacapuru em Lago Grande e Osvaldo (Fig. 7.50).

Para além do sugerido neste trabalho, o quadro etnográfico da região demonstra a existência da prática de casamentos exogâmicos na atualidade (Moraes, 2006). Este fato reforçaria hipóteses, em trabalhos futuros, que envolvessem essa prática na interpretação dos dados. Além disso, Lima (2008) observou que os fragmentos cerâmicos são de difícil distinção no sítio Osvaldo, sugerindo que as duas fases cerâmicas tenham sido produzidas num contexto semelhante. Tamura ainda relatou que em Lago Grande há artefatos que pela pasta, queima e antiplástico seriam Paredão, mas pela decoração seriam 
Manacapuru (Tamura, 2005 apud Lima, 2008). Essas peças híbridas poderiam ser correlatas de casamentos exogâmicos (Mongeló, 2011).

De qualquer forma, por Lago Grande e Osvaldo representarem um microcosmo da Amazônia Central, os dados deste trabalho fortalecem a hipótese de redes de troca atuantes entre povos habitantes da região estudada, provavelmente povos falantes de línguas do tronco Arawak, indo ao encontro de teorias que questionam o determinismo ambiental como vetor para o entendimento dos processos de ocupação da Amazônia Central pré-colonial, como discutido no Capítulo 3.

\section{b. Estratigrafia}

A informação sobre a estratigrafia estava disponível para aproximadamente $70 \%$ das amostras de Osvaldo e $84 \%$ das amostras de Lago Grande.

O levantamento da classificação dos fragmentos cerâmicos a partir dos níveis estratigráficos definidos em níveis artificiais de $10 \mathrm{~cm}$ não gerou padrões facilmente observáveis nas tabelas. Então, para fins de simplificação da análise, e aumento do número de amostras nas categorias estratigráficas, definiram-se três níveis arbitrários:

口 Superficial: nível de 0 a 50 cm;

口 Intermediário: nível de 50 a 90 cm;

a Profundo: acima de $90 \mathrm{~cm}$.

Os resultados da classificação dos fragmentos cerâmicos de Lago Grande e Osvaldo segundo essas categorias para cada grupo químico estão organizados na Tab. 7.30.

Tabela 7.30 - Classificação das amostras nos grupos químicos do Cenário 3 e Cenário 5 segundo estratigrafia, para os sítios Lago Grande e Osvaldo.

\begin{tabular}{c|cccc|cccc}
\hline \multirow{3}{*}{ Nível } & \multicolumn{4}{|c|}{ Cenário 3 } & \multicolumn{4}{c}{ Cenário 5 } \\
\cline { 2 - 9 } & \multicolumn{2}{|c}{ Lago Grande } & \multicolumn{2}{c|}{ Osvaldo } & \multicolumn{2}{c}{ Lago Grande } & Osvaldo \\
\cline { 2 - 9 } & $\mathrm{A}$ & $\mathrm{B}$ & $\mathrm{A}$ & $\mathrm{B}$ & $\mathrm{A}^{\prime}$ & $\mathrm{B}^{\prime}$ & $\mathrm{A}^{\prime}$ & $\mathrm{B}^{\prime}$ \\
\hline Superior & 12 & 10 & 20 & 11 & 15 & 8 & 16 & 11 \\
Intermediário & 21 & 9 & 6 & 0 & 17 & 13 & 1 & 5 \\
Profundo & 19 & 6 & 0 & 0 & 17 & 10 & 0 & 0 \\
\hline
\end{tabular}


A partir da Tab. 7.30, foram elaboradas as seguintes distribuições de frequências nas Fig. 7.52 e 7.53.

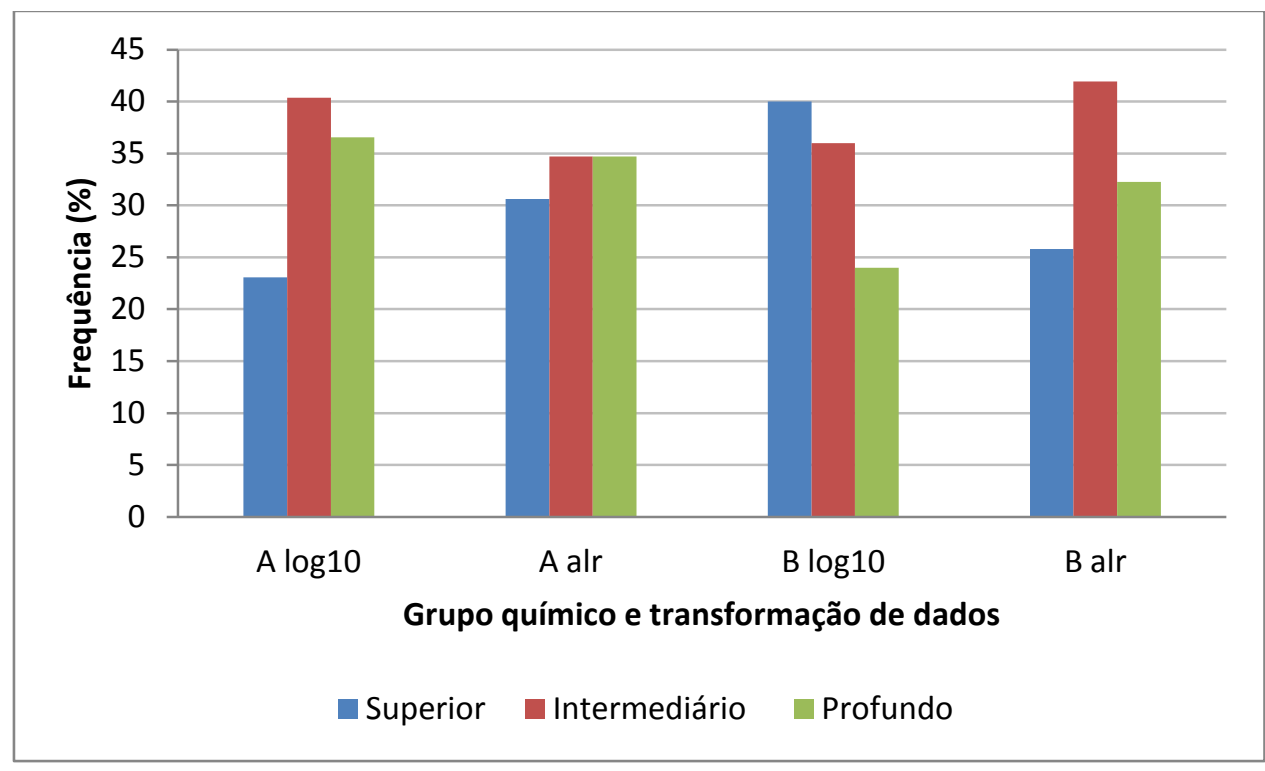

Figura 7.52 - Histograma de classificação de amostras dos grupos químicos de cerâmicas de Lago Grande a partir do Cenário $3\left(\log _{10}\right)$ e Cenário 5 (alr) segundo a estratigrafia.

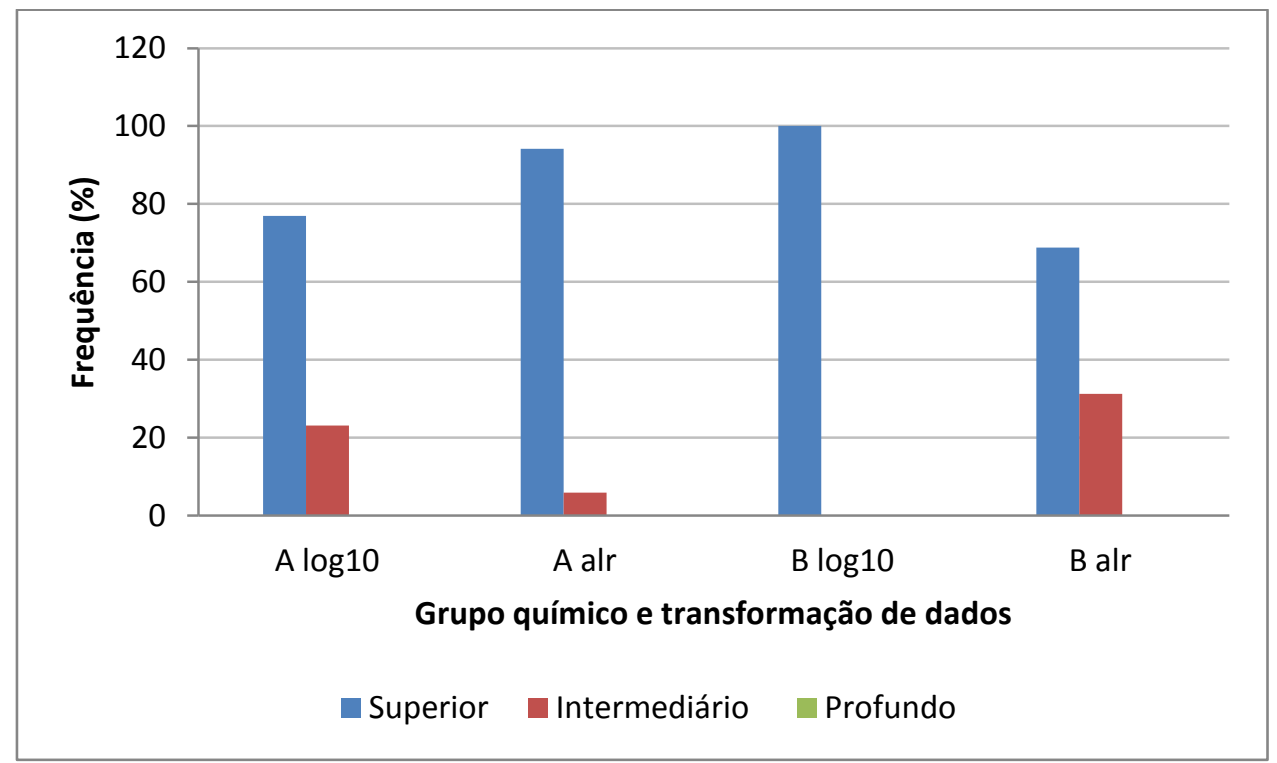

Figura 7.53 - Histograma de classificação de amostras dos grupos químicos de cerâmicas de Osvaldo a partir do Cenário $3\left(\log _{10}\right)$ e Cenário 5 (alr) segundo a estratigrafia. 
A partir das Fig. 7.52 e 7.53, nenhuma correlação arqueológica pôde ser feita. Assumindo-se que as três unidades de escavação de onde as amostras analisadas neste trabalho foram retiradas estão associadas a montículos (Donatti, 2003), correlatos de reutilização de material cerâmico de refugo, é possível que tenha havido inversão estratigráfica ao longo das sequências. Pela Fig. 7.53, é possível observar que as amostras analisadas de Osvaldo correspondem a níveis estratigráficos mais superficiais quando comparadas as de Lago Grande.

Resultados similares de estudos preliminares indicando a ausência de correlação dos grupos definidos a partir de INAA com a estratigrafia também foram relatados por Lima (2008), para 12 fragmentos cerâmicos de Osvaldo e 50 fragmentos de Lago Grande.

$\mathrm{Na}$ ausência de perturbações estratigráficas, essa falta de correlação da estratigrafia com grupos químicos de cerâmicas poderia estar representando um caráter conservador da produção cerâmica, refletido em receitas similares de pastas sendo empregadas por diversas gerações, em contraste com a decoração e forma, que tenderiam a mudar mais rapidamente (Bishop, 2003).

\section{c. Unidade de escavação}

Os resultados da classificação dos fragmentos cerâmicos de Lago Grande e Osvaldo segundo a unidade de escavação para cada grupo químico estão organizados na Tab. 7.31.

Tabela 7.31 - Classificação das amostras nos grupos químicos do Cenário 3 e Cenário 5 segundo a unidade de escavação, para os sítios Lago Grande e Osvaldo.

\begin{tabular}{c|cccc|cccc}
\hline \multirow{2}{*}{ Unidade } & \multicolumn{4}{|c|}{ Cenário 3 } & \multicolumn{4}{c}{ Cenário 5 } \\
\cline { 2 - 9 } & \multicolumn{2}{|c}{ Lago Grande } & \multicolumn{2}{c}{ Osvaldo } & \multicolumn{2}{c}{ Lago Grande } & \multicolumn{2}{c}{ Osvaldo } \\
& A & B & A & B & A' & B' & $A^{\prime}$ & B' $^{\prime}$ \\
\hline U1 & 49 & 19 & - & - & 37 & 30 & - & - \\
U3 & 5 & 9 & - & - & 11 & 7 & - & - \\
U4 & 9 & 3 & - & - & 9 & 2 & - & - \\
Tradagem & - & - & 16 & 11 & - & - & 14 & 9 \\
S710 E1966 & - & - & 21 & 4 & - & - & 6 & 17 \\
\hline
\end{tabular}


A partir da Tab. 7.31, foram elaboradas as seguintes distribuições de frequências nas Fig. 7.54 e 7.55.

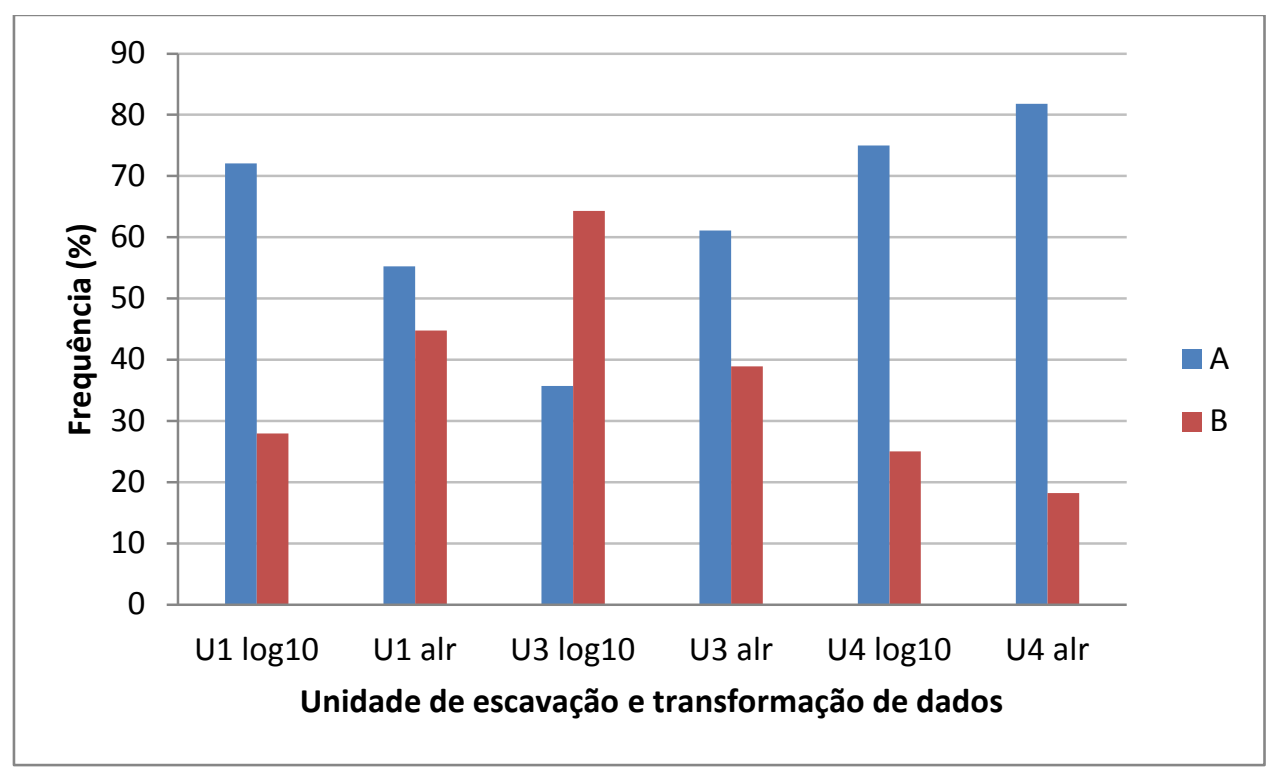

Figura 7.54 - Histograma de classificação de amostras das unidades de escavação U1, U3 e U4 de Lago Grande em grupos químicos de cerâmicas, definidos a partir do Cenário 3 $\left(\log _{10}\right)$ e Cenário 5 (alr).

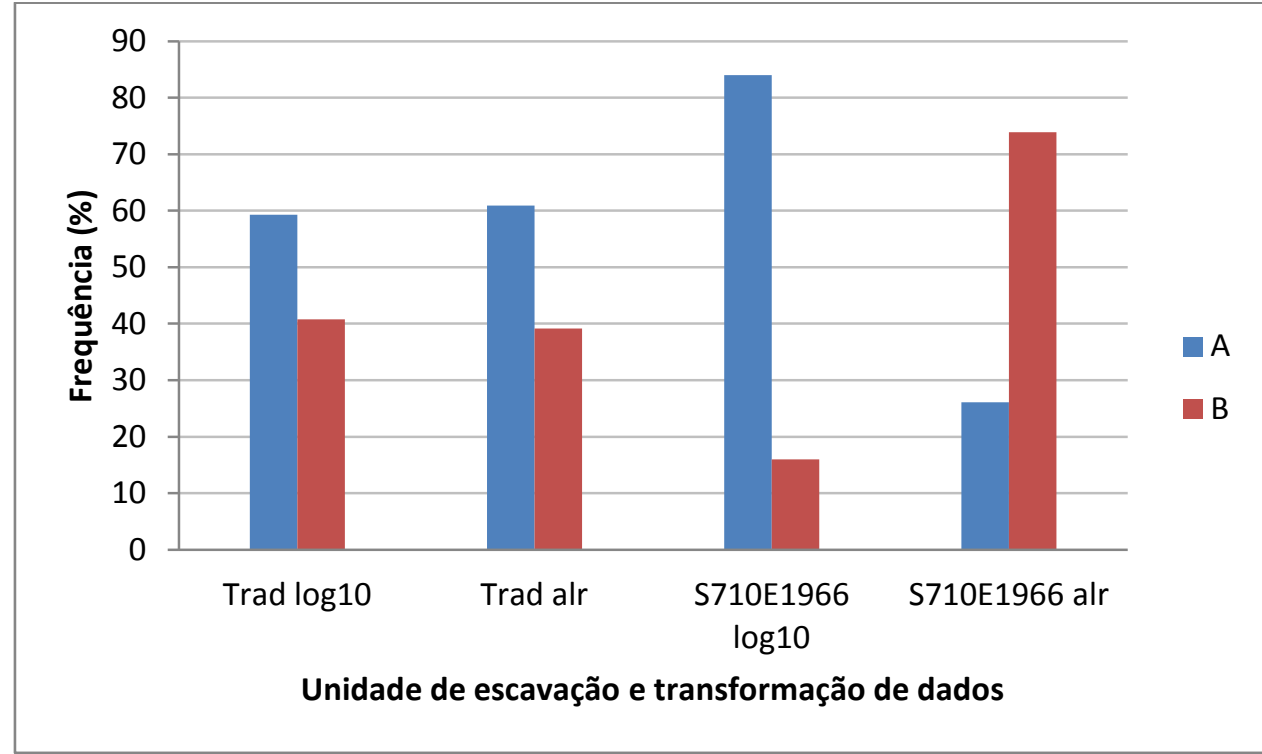

Figura 7.55 - Histograma de classificação de amostras da unidade de escavação S710 E1966 e de tradagem de Osvaldo em grupos químicos de cerâmicas, definidos a partir do Cenário $3\left(\log _{10}\right)$ e Cenário 5 (alr). 
Pela comparação das Fig. 7.50, 7.51, 7.54 e 7.55, observou-se que a classificação dos fragmentos nos grupos químicos a partir das unidades de escavação gerou padrões distribucionais que refletem a fase cerâmica, uma vez que, como já relatado, a amostragem foi parcialmente enviesada.

A unidade 4 de Lago Grande, por exemplo, cujos fragmentos analisados (para os quais a classificação em fase cerâmica estava disponível) são quase exclusivamente Manacapuru, tiveram suas amostras concentradas no grupo A. O mesmo aconteceu com as amostras Manacapuru da unidade 1. Assim, esse fato é sugestivo de que não há diferenças entre as amostras Manacapuru das duas unidades. A maioria das amostras da unidade de escavação 3 é Paredão, e concentraram-se mais no grupo B (ligeiramente), no Cenário 3, e em A', no Cenário 5.

Em relação ao sítio Osvaldo, a maioria das amostras da unidade de escavação S710 E1966 foi classificada no grupo A, no Cenário 3, e em B, no Cenário 5. Essa tendência deve estar refletindo o fato de a maior parte das amostras Paredão, que são provenientes dessa unidade de escavação em Osvaldo, terem sido classificadas no grupo A no Cenário 3, e em B, no Cenário 5. No entanto, mais da metade dos fragmentos cerâmicos analisados dessa unidade não possuem classificação de fase. Assim, essa distribuição de frequências pode ser indicativa de que a maioria das cerâmicas provenientes da unidade S710 E1966 de Osvaldo sejam Paredão. Em relação às amostras de tradagem, verificou-se que a maioria caiu nos grupos A de cada cenário. A maioria das amostras Manacapuru coletadas são provenientes de tradagem. Assim, esse padrão também estaria refletindo essa tendência.

\section{d. Tipo de objeto}

Schiffer (1987b) propõe a forma como um parâmetro de avaliação da variabilidade do registro. Para entender o papel que este parâmetro pode ter no contexto em questão, basta verificar que entender os significados da variabilidade formal é importante para se compreender os usos a que se destinavam os objetos depois de prontos. Por meio da análise do registro arqueológico da região, foi possível constatar que determinadas categorias de objetos com finalidade cotidiana estariam vinculadas a uma grande variabilidade em termos de processos de fabricação e escolha de matéria-prima, mas não de sua morfologia, cujas mudanças seriam pequenas com o passar das gerações (Lima, 2008, p. 290). 
A informação sobre o tipo de objeto estava disponível para aproximadamente 84\% das amostras de Osvaldo e 87\% das amostras de Lago Grande. Com exceção das urnas funerárias, não há evidência registrada de que qualquer outro objeto analisado possua função ritual. Os resultados da classificação dos fragmentos cerâmicos de Lago Grande e Osvaldo segundo essas categorias para cada grupo químico estão organizados na Tab. 7.32.

Tabela 7.32 - Classificação das amostras nos grupos químicos do Cenário 3 e Cenário 5 segundo o tipo de objeto cerâmico, para os sítios Lago Grande e Osvaldo.

\begin{tabular}{|c|c|c|c|c|c|c|c|c|}
\hline \multirow{3}{*}{ Objeto } & \multicolumn{4}{|c|}{ Cenário 3} & \multicolumn{4}{|c|}{ Cenário 5} \\
\hline & \multicolumn{2}{|c|}{ Lago Grande } & \multicolumn{2}{|c|}{ Osvaldo } & \multicolumn{2}{|c|}{ Lago Grande } & \multicolumn{2}{|c|}{ Osvaldo } \\
\hline & A & B & A & $\mathrm{B}$ & $\mathrm{A}^{\prime}$ & $\mathrm{B}^{\prime}$ & $\mathrm{A}^{\prime}$ & $\mathrm{B}^{\prime}$ \\
\hline alça & 0 & 1 & - & - & 1 & 0 & - & - \\
\hline base & 3 & 6 & 1 & 1 & 3 & 7 & 0 & 1 \\
\hline borda & 16 & 4 & 16 & 10 & 15 & 4 & 14 & 9 \\
\hline borda externa & - & - & 6 & 3 & - & - & 1 & 6 \\
\hline cabeça & 2 & 1 & - & - & 2 & 1 & - & - \\
\hline cesta & 4 & 1 & - & - & 3 & 2 & - & - \\
\hline cesta com alça & 0 & 1 & - & - & 0 & 1 & - & - \\
\hline copo & 2 & 1 & - & - & 1 & 2 & - & - \\
\hline cuia & 1 & 0 & - & - & 1 & 0 & - & - \\
\hline cuia pintada & 0 & 7 & - & - & 1 & 6 & - & - \\
\hline panela & 5 & 0 & - & - & 2 & 3 & - & - \\
\hline parede decorada & 5 & 3 & - & - & 7 & 2 & - & - \\
\hline prato & 3 & 0 & - & - & 2 & 2 & - & - \\
\hline prato fundo & 3 & 1 & - & - & 2 & 2 & - & - \\
\hline prato raso & 2 & 0 & - & - & 2 & 1 & - & - \\
\hline tigela decorada & 0 & 0 & 5 & 1 & - & - & 2 & 4 \\
\hline urna & 3 & 1 & - & - & 2 & 2 & - & - \\
\hline vaso com pescoço & 5 & 1 & - & - & 4 & 2 & - & - \\
\hline
\end{tabular}

Devido ao número reduzido de amostras referentes a muitas das classes, não foram elaborados histogramas para mostrar a distribuição de frequências dos tipos de objetos nos grupos químicos definidos. Em vez disso, procurou-se destacar, com valores hachurados, padrões sugestivos de predominância de um grupo químico para uma dada categoria na Tab. 7.32. A predominância de algumas classes de objetos em grupos químicos específicos reflete a fase cerâmica associada a esse objeto. A maioria das bordas, 
por exemplo, são Manacapuru e caíram no grupo A de Lago Grande, no Cenário 3, refletindo o padrão observado para a fase Manacapuru, como já discutido.

Devido à ausência de informações sobre a fase de algumas categorias de objeto (Apêndice B), não foi possível determinar se a concentração das mesmas em algum grupo químico seria reflexo dos padrões gerais da fase cerâmica à qual pertenceriam, ou alguma especificidade de produção desses objetos cerâmicos.

As cuias pintadas, por exemplo, concentraram-se nos grupos B de Lago Grande, nos dois cenários estudados. Devido à ausência de classificação dessas amostras em fase cerâmica, não é possível afirmar se esse padrão seria reflexo de preferência das receitas ou fontes argilosas representadas por esses grupos, ou se apenas seriam correlatos do padrão geral da fase à qual pertenceriam.

Em estudo preliminar de caracterização química com fragmentos cerâmicos do sítio Lago Grande, em parceria com o IPEN, Lima (2008) também não encontrou correlação entre os grupos químicos e a morfologia dos objetos cerâmicos.

\section{e. Fonte de argila}

Foram analisadas oito argilas queimadas de Osvaldo, enviadas para análise por Lima (2008), provenientes de diferentes níveis estratigráficos (de 10-20 cm até $80-90 \mathrm{~cm}$ ), além de três argilas próximas a Lago Grande e outras duas próximas a Osvaldo, coletadas pelo Dr. Emílio Soares. Os resultados para as três primeiras componentes principais dos dados de Lago Grande e Osvaldo (seção 7.1.12), projetados para comparação com os resultados de INAA das argilas, referente ao Cenário 5, são apresentados nas Fig. 7.56 e 7.57. Esse cenário foi considerado como o adequado para comparação de fontes, já que é esperado que o efeito da adição de antiplásticos tenha sido reduzido pela transformação de dados alr. 


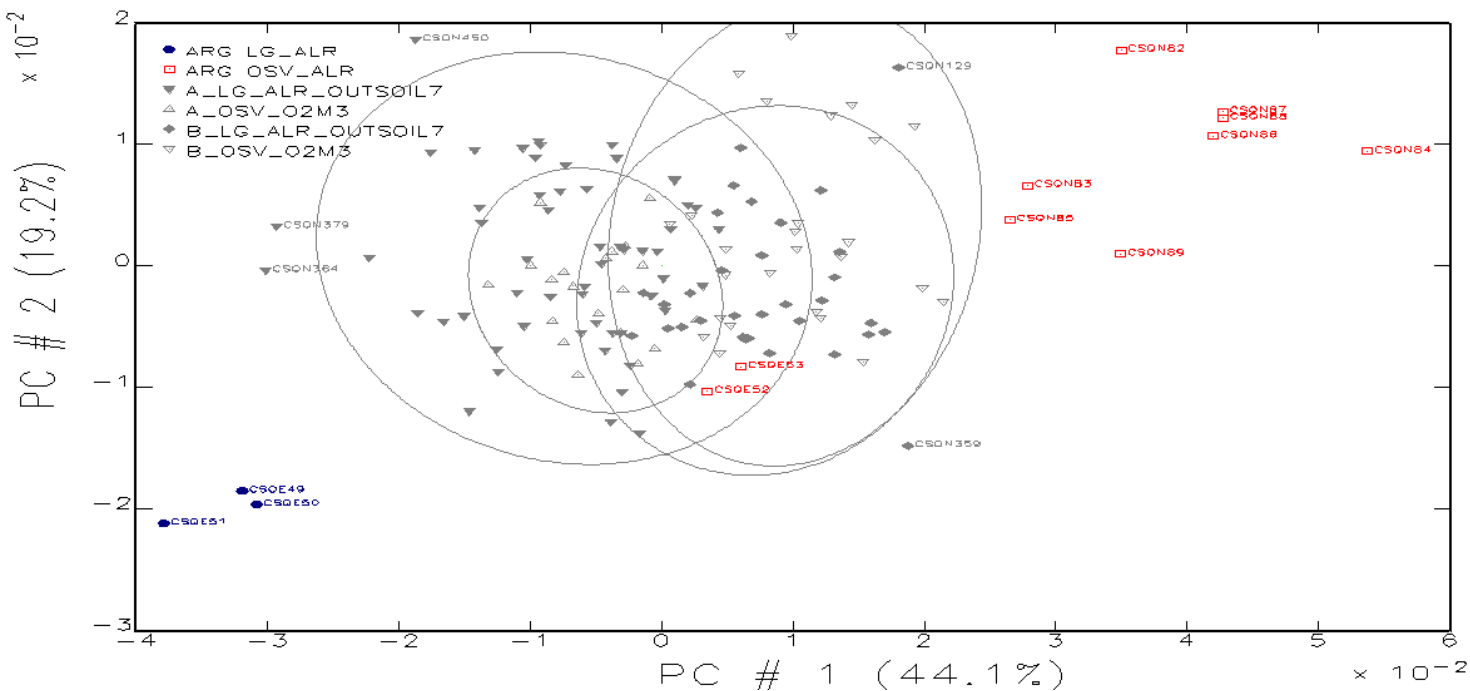

Figura 7.56 - Escores nas duas primeiras componentes principais dos dados do Cenário 5 para as argilas projetadas contra os dois grupos químicos de Lago Grande e Osvaldo. As elipses representam a região de confiança de $95 \%$.

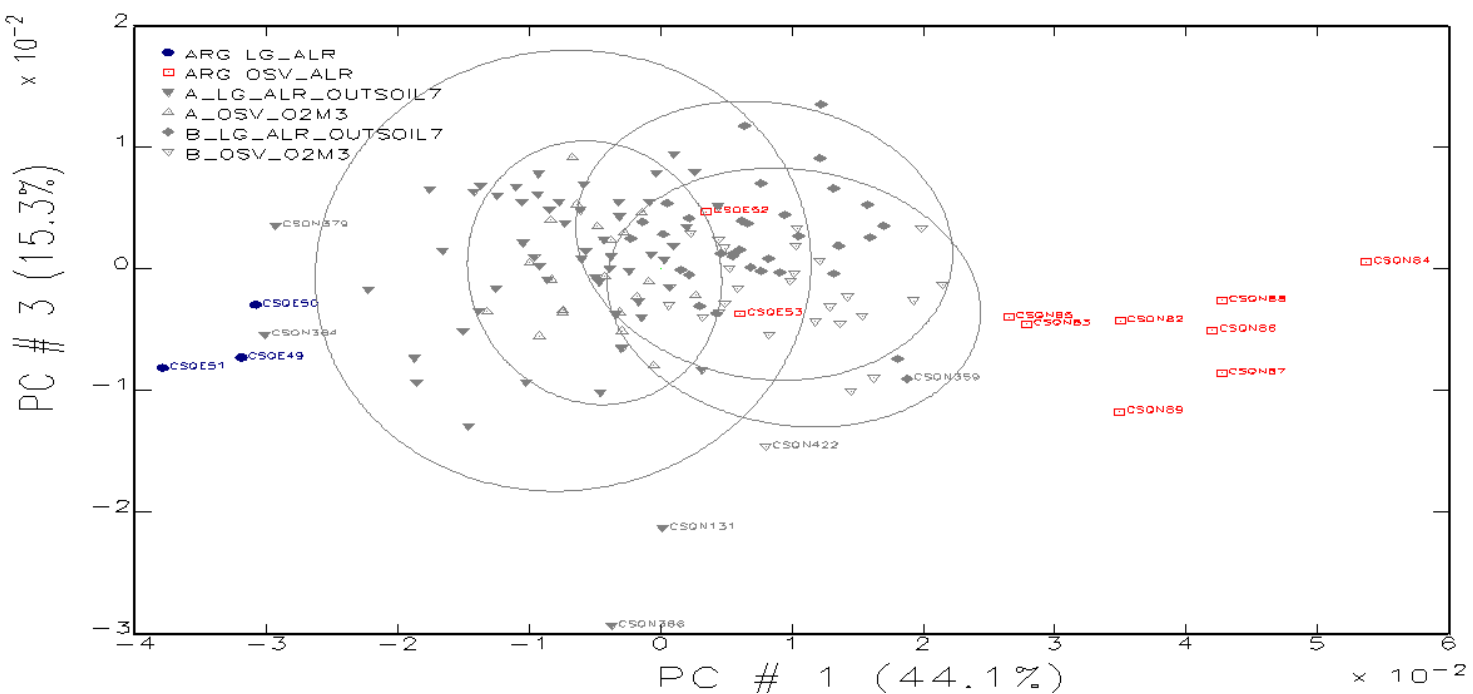

Figura 7.57 - Escores na primeira e terceira componentes principais dos dados do Cenário 5 para as argilas projetadas contra os dois grupos químicos de Lago Grande e Osvaldo. As elipses representam a região de confiança de $95 \%$.

Os resultados das Fig. 7.56 e 7.57 indicaram que as argilas com composição química elementar mais próxima a das cerâmicas de Lago Grande e Osvaldo foram as das proximidades de Osvaldo, coletadas pelo Dr. Emílio Soares (CSQE52 e CSQE53), que apresentaram boa superposição aos grupos químicos B. Por outro lado, não é possível afirmar que essas argilas tenham sido as utilizadas de fato pelos ceramistas desses sítios, uma vez que é possível que tenha havido combinação de argilas para a produção dos 
artefatos, como já discutido. É possível, por exemplo, pensar em combinações entre as argilas próximas a Lago Grande (CSQE49, 50 e 51), à esquerda das elipses, com argilas de Osvaldo, à direita das elipses, gerando perfis geoquímicos médios que se situassem sobre as elipses dos grupos químicos.

Para que o postulado de proveniência (Weigand et al., 1977) possa ser aplicado, a diferença de composição química entre as fontes de matéria-prima deve ser maior que a variabilidade química dentro de uma mesma fonte. As hipóteses que devem ser seguidas pelos dados para que o postulado de proveniência possa ser aplicado pode ser resumido como (Wilson \& Pollard, 2001 apud Popelka-Filcoff, 2006):

1. A "impressão digital" química de uma fonte é representada no artefato, sem alterações; ou as alterações podem ser previstas e modeladas.

2. A fonte existiu em tempos antigos e está relacionada a uma identidade geográfica.

3. As diferenças nas "impressões digitais" entre as fontes pode ser medida com precisão adequada para sua diferenciação.

4. A mistura de matérias-primas de diferentes fontes é inexistente, ou suas possibilidades são conhecidas.

5. Processos diagenéticos (alteração do material ao longo do tempo) não afetam a “impressão digital” química das amostras, ou esses processos são conhecidos.

6. A interpretação dos dados de um projeto arqueométrico pode ser feita a partir de um contexto arqueológico definido, que presume comportamentos culturais.

Para atender essas seis hipóteses, todas as fontes relevantes e prováveis de matéria-prima devem ser caracterizadas para associar um artefato às mesmas de maneira confiável. Assim, a única hipótese que pode ser realmente aceita neste trabalho é a hipótese 6. As demais hipóteses exigem testes adicionais que estão fora do escopo deste doutoramento. Particularmente, a hipótese 4 pode ser refutada, uma vez que já foi relatada a ocorrência de mistura de argilas em artefatos da região (Lima, 2008).

Dessa forma, não é possível, com os dados deste trabalho e as evidências disponíveis na literatura, afirmar se as fontes de argila analisadas foram as utilizadas na produção das cerâmicas de Lago Grande e Osvaldo. Portanto, o enfoque da análise estatística multivariada de INAA, nesta tese, deve ser mantida na variabilidade geoquímica dos fragmentos cerâmicos em si, sem a aplicação do postulado de proveniência. 


\subsection{Estudo de composição mineralógica por Difração de Raios X (XRD)}

Na seção 7.2.1., são apresentados os difratogramas de raios $X$ para fração de minerais argilosos de três argilas de Osvaldo e de quatro amostras de sedimentos da região próxima à confluência dos rios Negro e Solimões, compostas, principalmente por silt e argila (Soares et al., 2012).

A seguir, na seção 7.2.2., são apresentados dois difratogramas de difração de pó de cauixi sem tratamento químico.

Finalmente, na seção 7.2.3., são apresentados os resultados de difração de pó de nove fragmentos cerâmicos de Lago Grande, e outros nove de Osvaldo.

A Tab. 7.33, com reflexões características, auxiliou na identificação dos minerais argilosos.

Tabela 7.33 - Distâncias interplanares de reflexões basais características de minerais argilosos. Fonte: Adaptado de Albers et al. (2002).

\begin{tabular}{cccc}
\hline Classe Mineral & $\mathrm{d}($ natural $)$ & $\mathrm{d}($ glicolada $)$ & $\mathrm{d}\left(\mathrm{T}=500{ }^{\circ} \mathrm{C}, 4 \mathrm{~h}\right)$ \\
\hline Caulinita (001) & $7 \AA$ & $7 \AA$ & destruída \\
Clorita (002) & $7 \AA$ & $7 \AA$ & $7 \AA$ \\
Smectita (001) & $14 \AA$ & $17 \AA$ & $10 \AA$ \\
Clorita (001) & $14 \AA$ & $14 \AA$ & $14 \AA$ \\
Vermiculita (001) & $14 \AA$ & $14 \AA$ & $10 \AA$ \\
Ilita (001) & $10 \AA$ & $10 \AA$ & $10 \AA$ \\
\hline
\end{tabular}

\subsubsection{Difração de raios $X$ de argilas e sedimentos}

Três argilas queimadas coletadas no sítio Osvaldo, correspondentes às amostras CSQN83, CSQN85 e CSQN88 foram submetidas à separação de grãos compreendendo a fração menor que $2 \mu \mathrm{m}$ para determinação de minerais argilosos. Os difratogramas dessas amostras são apresentados na Fig. 7.58. 


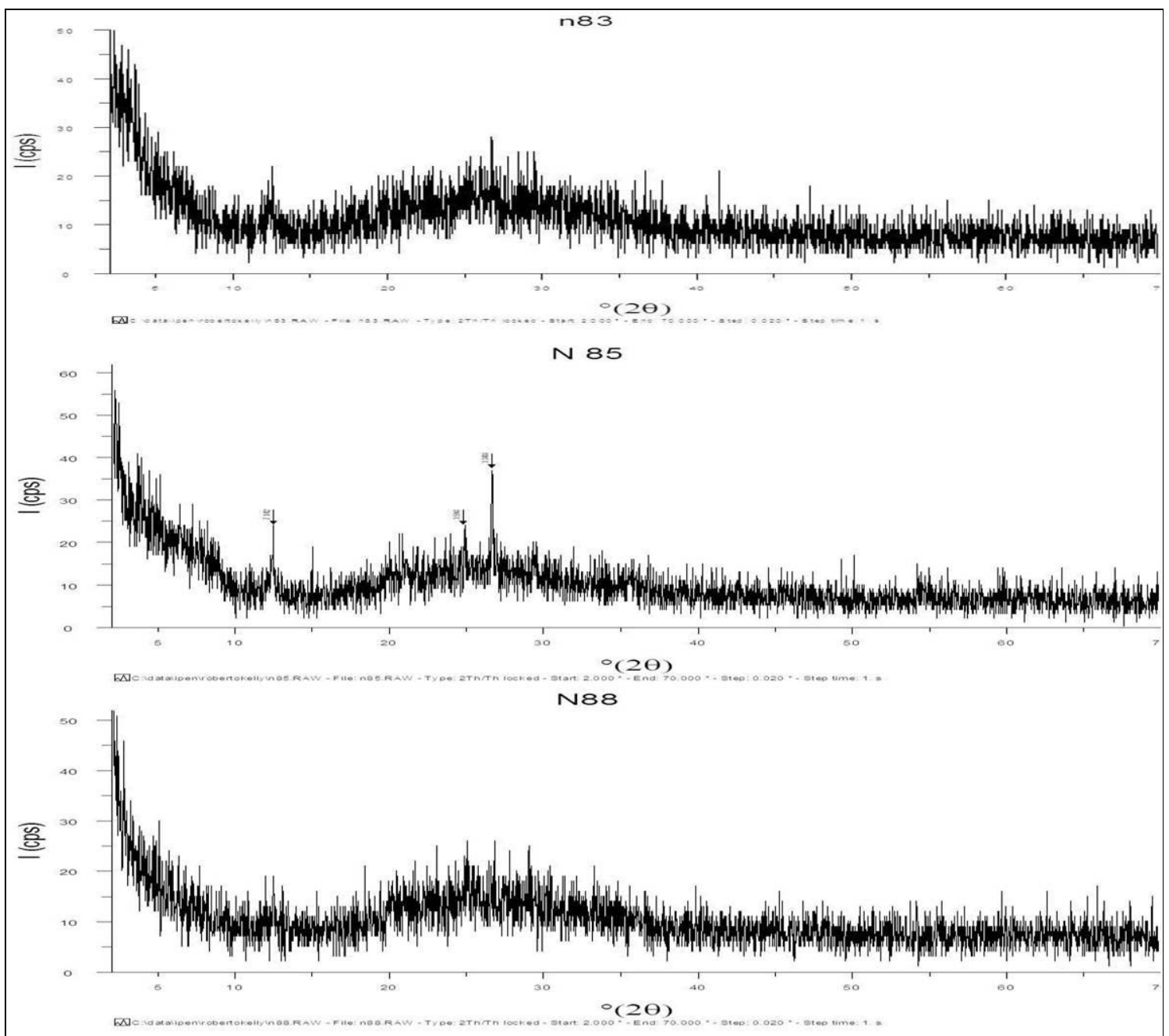

Figura 7.58 - Difratograma de fração argilosa das amostras de argilas CSQN83 (superior), CSQN85(meio) e CSQN88 (inferior) coletadas no sítio Osvaldo.

Pela Fig. 7.58, em nenhuma das amostras de argila foram encontrados minerais argilosos. Os picos para a amostra CSQN85 podem ser devidos às substâncias utilizadas na separação da fração argilosa dessas argilas, ou caulinita residual. A ausência de minerais argilosos foi útil para confirmação de que as amostras sofreram um tratamento térmico anterior acima de $500{ }^{\circ} \mathrm{C}$ em outro estudo, e estavam adequadas para comparação com a PCA de cerâmicas arqueológicas (seção 7.1.20).

Quatro amostras de sedimentos das proximidades de Manaus (CSQE148, 156, 167 e 197), coletadas pelo Dr. Emílio Soares (Soares et al., 2012) e analisadas por INAA, foram submetidas à separação de granulometria envolvendo a fração menor que $2 \mu \mathrm{m}$, a tratamento com etilenoglicol por $24 \mathrm{~h}$ e a aquecimento a $500{ }^{\circ} \mathrm{C}$ para determinação de 
minerais argilosos. Os difratogramas dessas amostras são apresentados nas Fig. 7.59, 7.60, 7.61 e 7.62 .

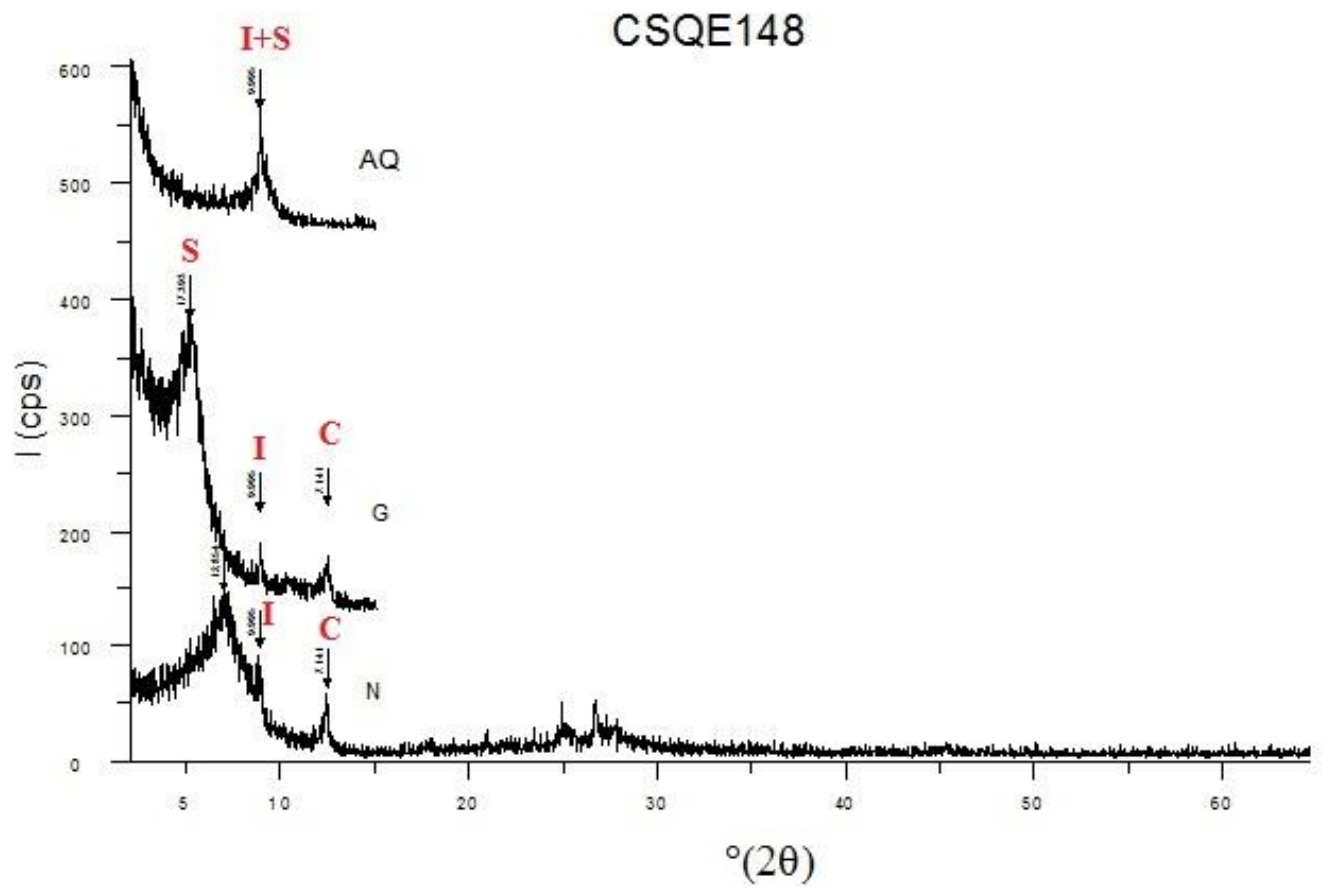

Figura 7.59 - Difratograma da amostra de sedimento CSQE148 de região próxima à confluência dos rios Negro e Solimões.

Na amostra CSQE148, foram encontrados os minerais caulinita em 7,141 nas amostras natural (N) e glicolada $(\mathrm{G})$; ilita em 9,995 $\AA$ nas amostras natural $(\mathrm{N})$, glicolada (G) e aquecida a $500{ }^{\circ} \mathrm{C}(\mathrm{AQ})$; e smectita, pelo deslocamento do pico de 12.854 $\AA$ na amostra natural $(\mathrm{N})$ para $17,393 \AA$ na amostra glicolada $(\mathrm{G})$. Na amostra aquecida, o pico em 9,995 Å refere-se a uma mistura de ilita e smectita. 


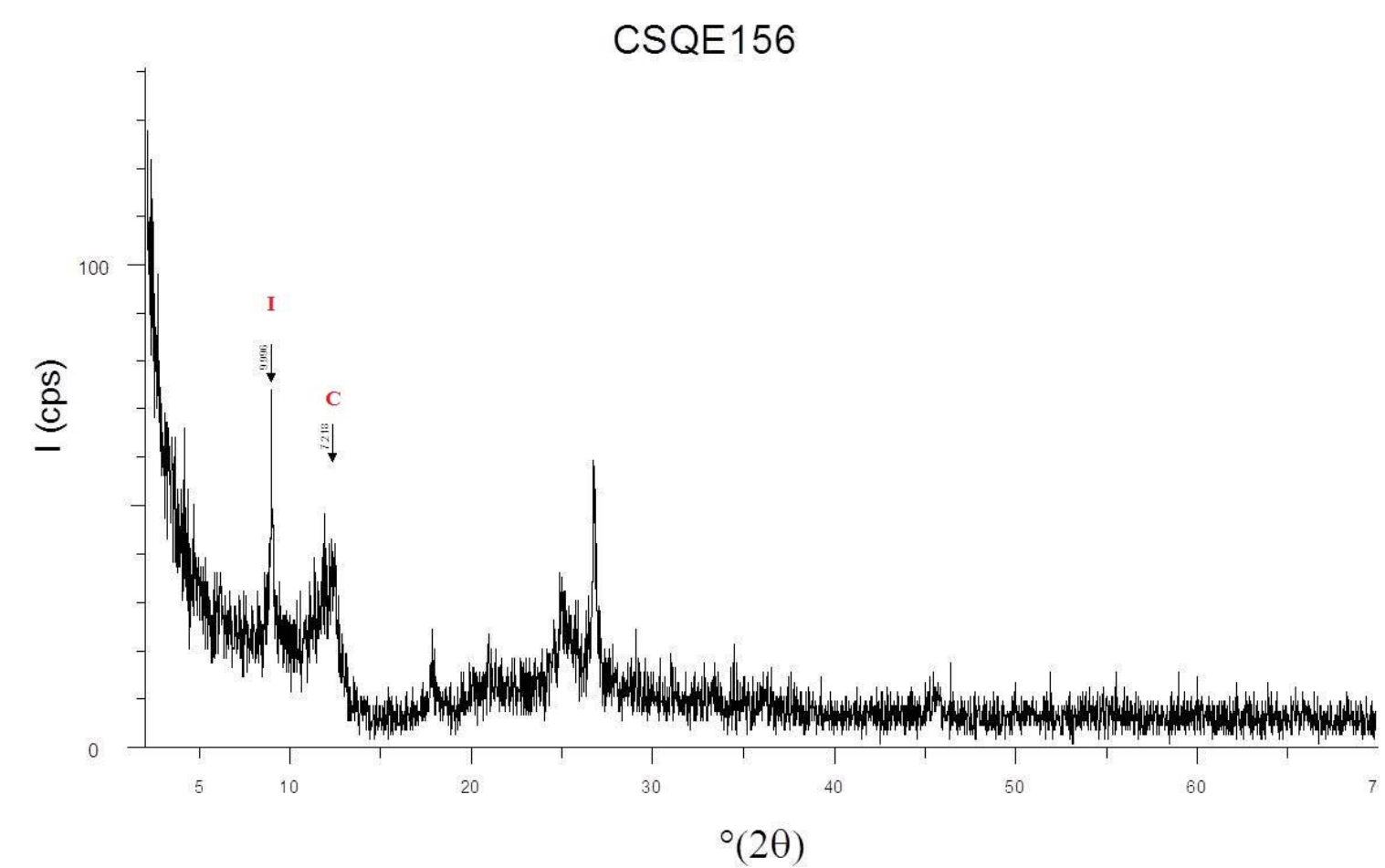

Figura 7.60 - Difratograma da amostra de sedimento CSQE156 de região próxima à confluência dos rios Negro e Solimões.

$\mathrm{Na}$ amostra CSQE156 foi encontrada ilita, sem smectita associada, pelo pico de 9,996 A. Esta amostra foi considerada atípica pelo pico alargado em torno de $7 \AA$, que costuma ser a região da caulinita, e que pode ter implicação geológica. Sabe-se que para cristais muito pequenos, pode haver o alargamento dos picos de difração. No entanto, mais análises são necessárias para explorar o difratograma adequadamente. 


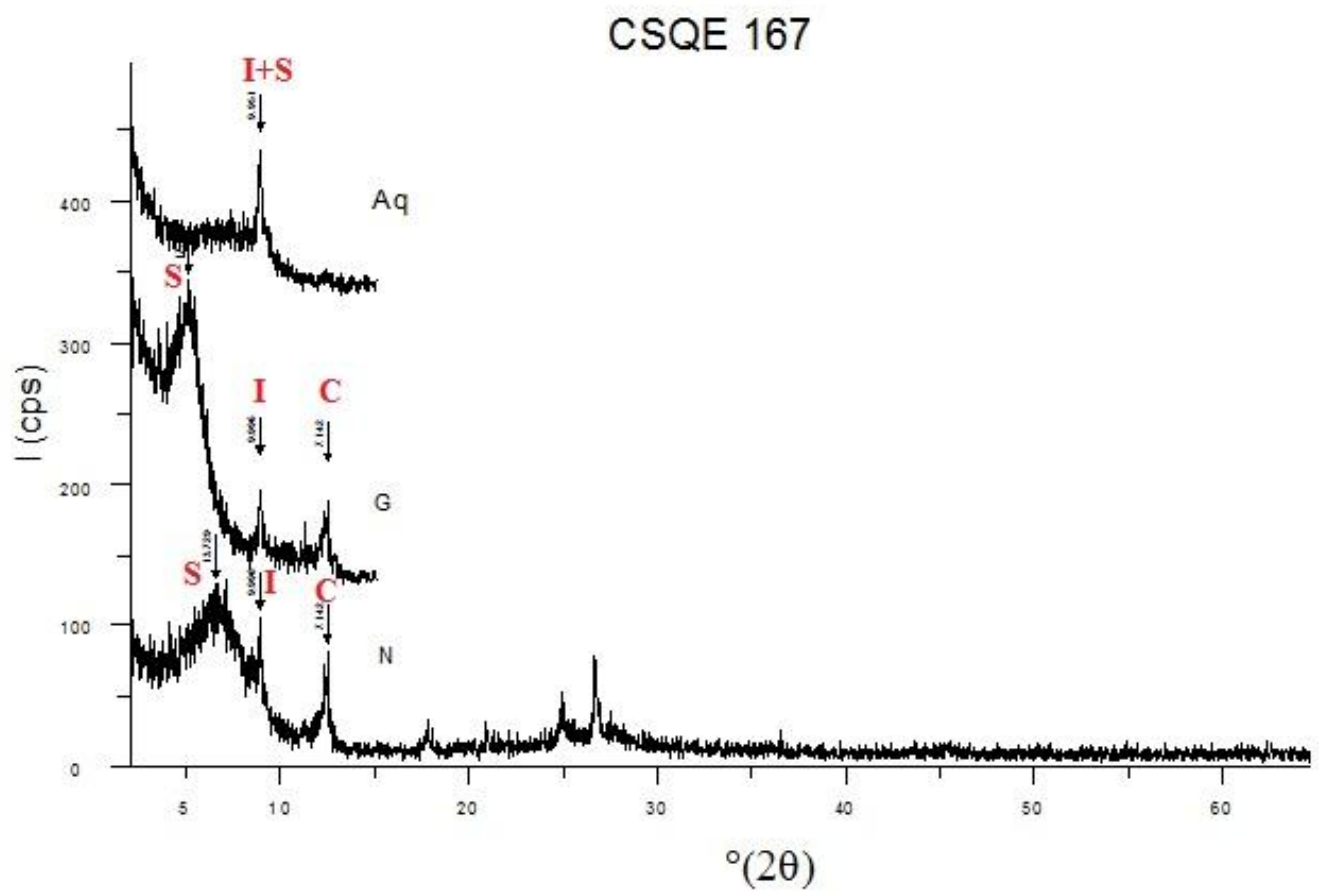

Figura 7.61 - Difratograma da amostra de sedimento CSQE167 de região próxima à confluência dos rios Negro e Solimões.

Na amostra CSQE167, foram encontrados os minerais caulinita em 7,141 nas amostras natural (N) e glicolada $(\mathrm{G})$; ilita em 9,995 $\AA$ nas amostras natural (N), glicolada $(\mathrm{G})$ e aquecida a $500^{\circ} \mathrm{C}(\mathrm{AQ})$; e smectita, pelo deloscamento do pico de $13,729 \AA$ na amostra natural (N) para 17,393 $\AA$ na amostra glicolada $(\mathrm{G})$. Na amostra aquecida, o pico em 9,951 Å refere-se a uma mistura de ilita e smectita. 


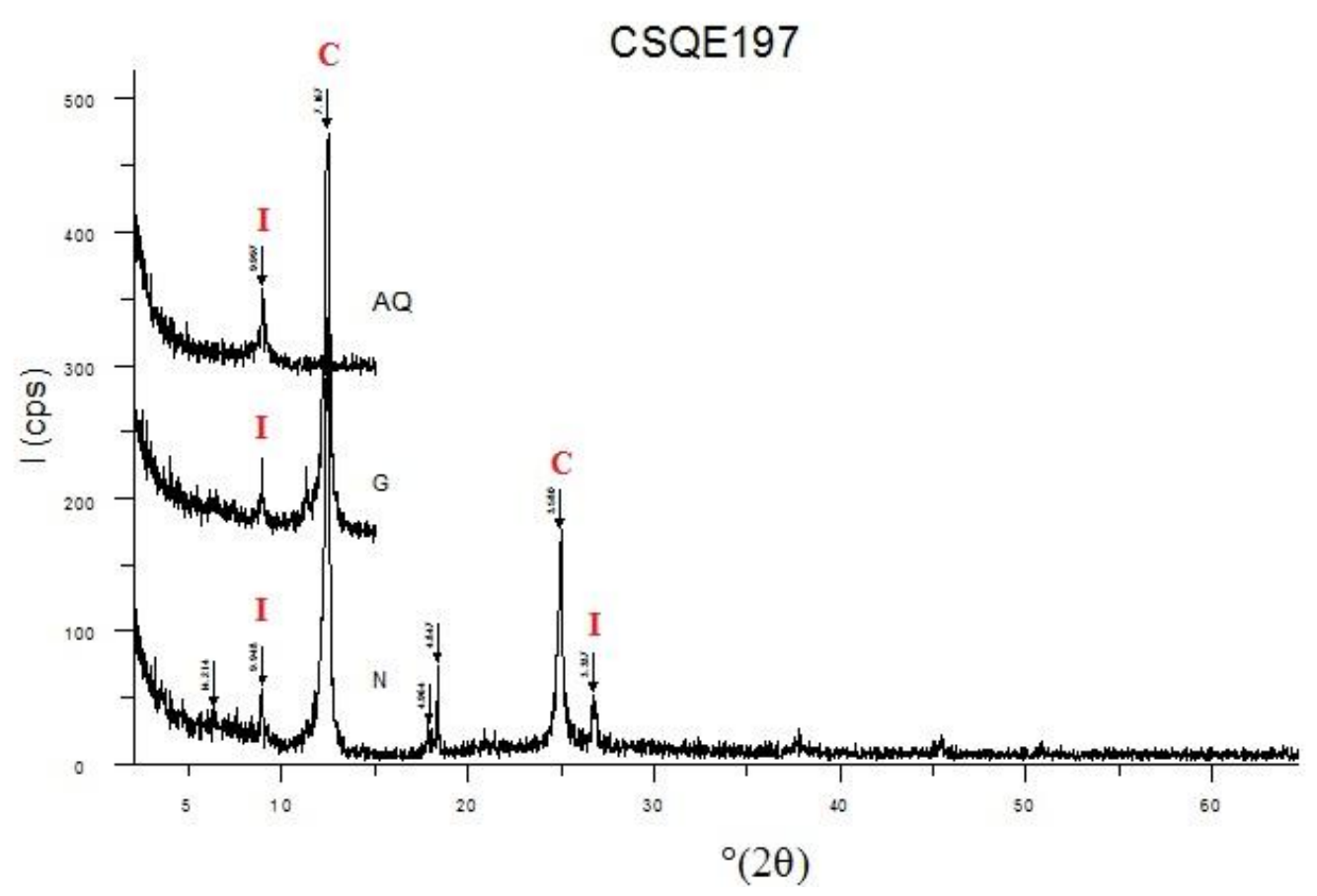

Figura 7.62 - Difratograma da amostra de sedimento CSQE197 de região próxima à confluência dos rios Negro e Solimões.

Na amostra CSQE197, foram encontrados os minerais caulinita em 7,167 $\AA$ nas amostras natural $(\mathrm{N})$ e glicolada $(\mathrm{G})$, em proporção relativamente maior que nas outras amostras de sedimento; e ilita em 9,997 $\AA$ nas amostras natural (N), glicolada (G) e aquecida a $500^{\circ} \mathrm{C}(\mathrm{AQ})$.

Assim, pelas quatro amostras analisadas, pode-se esperar a presença de caulinita, ilita e smectita nos sedimentos da região. Caulinita é o mineral mais comum em sedimentos argilosos, como produto de intemperismo, na região amazônica (Costa et al., 2004). Por sua vez, Martinelli et al. (1993) relataram a presença de caulinita, smectita, vermiculita, ilita e gibbsita em sedimentos da planície de inundação do rio Amazonas. Caulinita e smectita também foram reportados como os minerais mais comuns por Guyot et al. (2007) nas planícies de inundação amazônicas, refletido no aumento da maturidade dos sedimentos do rio Amazonas em seu curso em direção ao oceano Atlântico, devido a processos de intemperismo na bacia amazônica a partir dos Andes. Essa discussão também auxiliou na elaboração da hipótese para o enriquecimento de Na e K nas amostras de Lago Grande e Osvaldo na seção 7.1.9. 


\subsubsection{Difração de raios $X$ de cauixi}

Dois difratogramas da esponja de água doce cauixi são apresentados nas Fig. 7.63 e 7.64, nas quais os espectros em verde representam o background devido ao equipamento e porta-amostras.

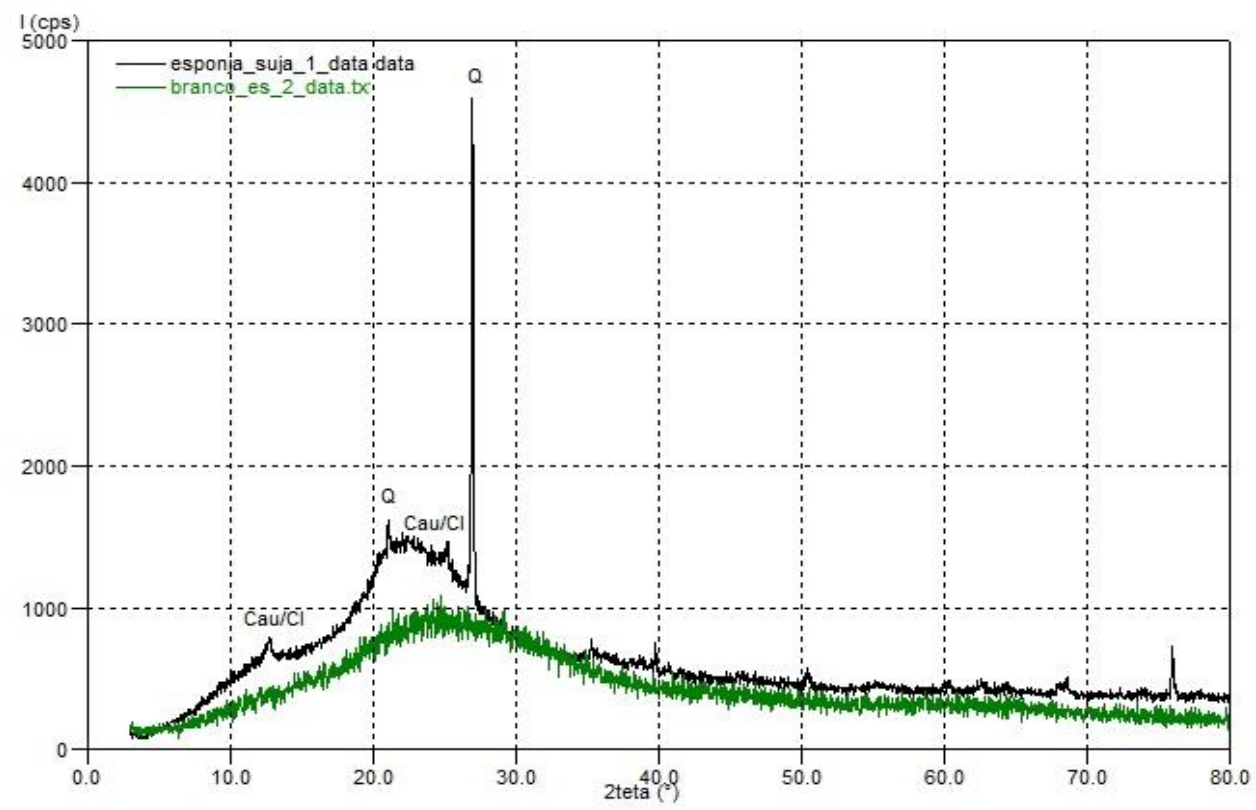

Figura 7.63 - Difratograma de cauixi 1, coletado na região de confluência dos rios Negro e Solimões.

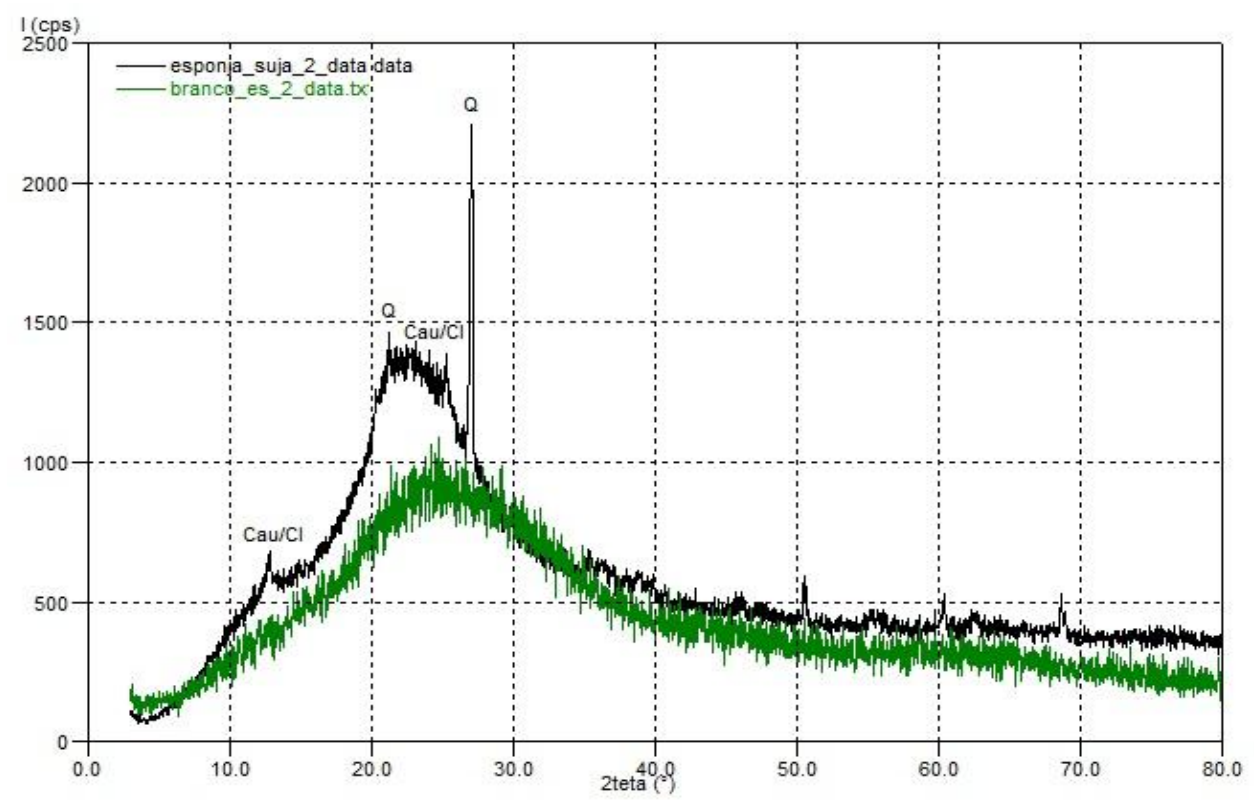

Figura 7.64 - Difratograma de cauixi 2, coletado na região de confluência dos rios Negro e Solimões. 
As Fig. 7.63 e 7.64 apresentam um pico largo entre $15^{\circ}$ e $30^{\circ}$, característico de sílica amorfa, a constituinte principal das espículas de cauixi observadas na seção 7.1.3. Além de sílica amorfa, foi identificado também quartzo nas duas amostras, cuja quantidade encontrada na amostra 1 (Fig. 7.63) foi praticamente o dobro que a encontrada na amostra 2 (Fig. 7.64), pela comparação relativa da intensidade do pico de quartzo em torno de $26,7^{\circ}$, referente à reflexão $(101)(\mathrm{d}=3,3 \AA$ ) .

Foi também identificado, pelos picos em torno de $12^{\circ}$ e $25^{\circ}(d=7$ e $3,5 \AA$ A ), a presença de caulinita nas duas amostras. Como não há detalhes sobre a coleta das amostras de cauixi, é possível que a caulinita e pelo menos parte do quartzo encontrados sejam devidos à mistura de sedimento às amostras dessa esponja.

Não foram encontradas evidências da presença de hematita, como relatado por Keding et al. (2010) nas amostras de cauixi deste trabalho.

\subsubsection{Difração de raios $X$ de fragmentos cerâmicos arqueológicos}

As análises instrumentais de XRD dos fragmentos cerâmicos não foram efetuadas separando-se a fração de minerais argilosos. Na análise instrumental, os principais minerais buscados são o quartzo, feldspato, carbonatos e hematita. A procura desse último justifica-se pela observação, relatada por Lima (2008), de que poderia haver a manutenção deliberada de algumas "impurezas" nas argilas, como grãos de quartzo e hematita.

Os difratogramas para nove fragmentos cerâmicos arqueológicos do sítio Lago Grande são apresentados na Fig. 7.65. 


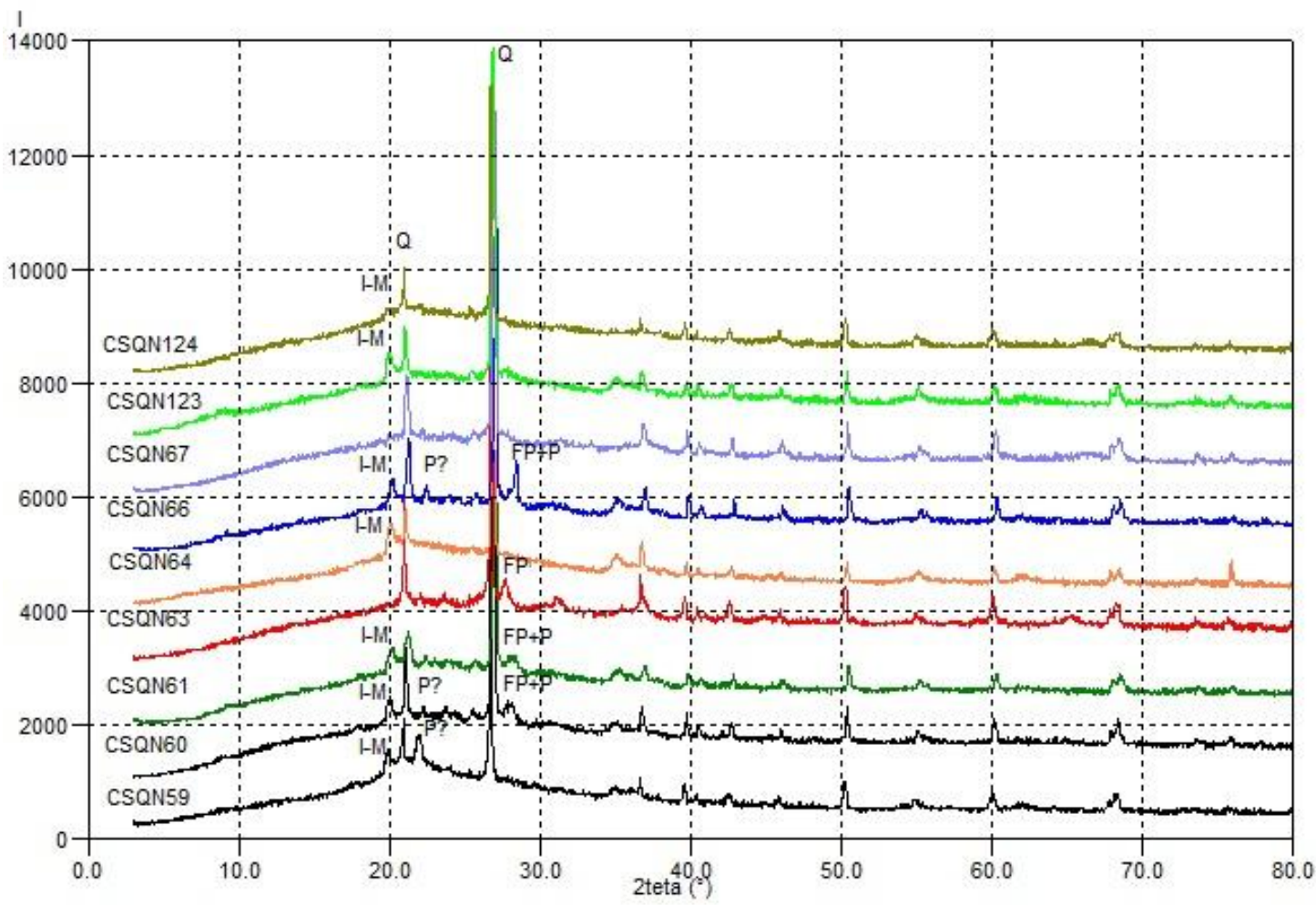

Figura 7.65 - Difratograma de fragmentos cerâmicos arqueológicos do sítio Lago Grande.

Pela Fig. 7.65, foi possível identificar a presença de quartzo em todos as amostras, pelas reflexões características em aproximadamente $21^{\circ}(4,2 \AA)$ e $26,8^{\circ}(3,3 \AA)$.

Além disso, os picos em torno de $27,7^{\circ}(3,2 \AA)$ parecem sugerir a presença de feldspato potássico nas amostras CSQN60, 61, 63 e 66; além da presença de plagioclásio, outra variedade de feldspato (Na-Ca-feldspato), cujo pico característico é próximo ao do feldspato potássico, na amostra CSQN60, 61 e 66. O feldspato pode ser considerado um tipo de inclusão em um corpo cerâmico, podendo estar associado a micas. Esses minerais são encontrados, principalmente, em granitos e pegmatitos. Feldspatos são as rochas parentais primárias dos minerais argilosos, podendo estar naturalmente presentes em pequenas quantidades em fontes de argila, devido ao intemperismo incompleto das rochas (Rice, 1987, p. 96).

Nas amostras CSQN59, 60, 61, 64, 66, 123 e 124, o pico em torno de $20^{\circ}(4,4$ Å) é sugestivo da presença de ilita e/ou muscovita (mica). A presença de ilita-muscovita, cuja faixa de destruição completa está entre 950-1000 º (Rice, 1987), indicaria que as temperaturas de queima dessas amostras estariam abaixo de $950{ }^{\circ} \mathrm{C}$, corroborando os dados de EPR (seção 7.3). 
A Tab. 7.34 foi elaborada com o intuito de se verificar possíveis relações entre os grupos determinados por INAA nos Cenários $\mathbf{3}$ e 5, e se as concentrações de sódio e potássio estariam correlacionadas à presença de plagioclásio e feldspatos potássicos, respectivamente.

Tabela 7.34 - Classificação das amostras de Lago Grande analisadas por XRD em grupos químicos, presença de feldspatos e concentrações de $\mathrm{Na}$ e K por INAA.

\begin{tabular}{ccccccc}
\hline Amostra & Grupo $\left(\log _{\mathbf{1 0}}\right)$ & Grupo (alr) & K-feldspato & {$[\mathbf{K}](\mathbf{m g} / \mathbf{g})$} & Plagioclásio (Na, Ca) & [Na] $(\mathbf{m g} / \mathbf{g})$ \\
\hline CSQN59 & outlier & B & & 4,312 & & 0,347 \\
CSQN60 & A & A & x & 12,891 & x & 3,928 \\
CSQN61 & A & B & x & 11,635 & $\mathrm{x}$ & 3,275 \\
CSQN63 & B & B & x & 10,601 & & 3,074 \\
CSQN64 & A & A & & 6,183 & & 0,539 \\
CSQN66 & B & B & x & 12,770 & x & 4,824 \\
CSQN67 & B & B & & 2,895 & & 1,333 \\
CSQN123 & A & B & & 0,496 & & 1,486 \\
CSQN124 & outlier & outlier & & n,d, & & n.d. \\
\hline
\end{tabular}

Pela comparação da Tab. 7.34 com a Fig. 7.65, não se verificou nenhuma correlação evidente dos grupos químicos aos quais os fragmentos pertencem e a presença de algum mineral específico. Ainda pela mesma tabela, observou-se que as quatro maiores concentrações de potássio para as amostras CSQN60, 61, 63 e 66 coincidiram com a presença de feldspatos potássicos. Não foi observada uma correlação direta da concentração de potássio com o tamanho relativo do pico de K-feldspato na Fig. 7.8, já que a maior concentração de potássio, CSQN66, não está associada ao maior pico, que foi identificado para a amostra CSQN63. De forma análoga, as três maiores concentrações de sódio para as amostras CSQN60, 61 e 66 coincidiram com a presença de plagioclásio no espectro da Fig. 7.8. Ainda, a amostra CSQN66, com a maior concentração de Na, também apresentou o maior pico de plagioclásio no espectro.

Os difratogramas para nove fragmentos cerâmicos arqueológicos do sítio Osvaldo são apresentados na Fig. 7.66. 


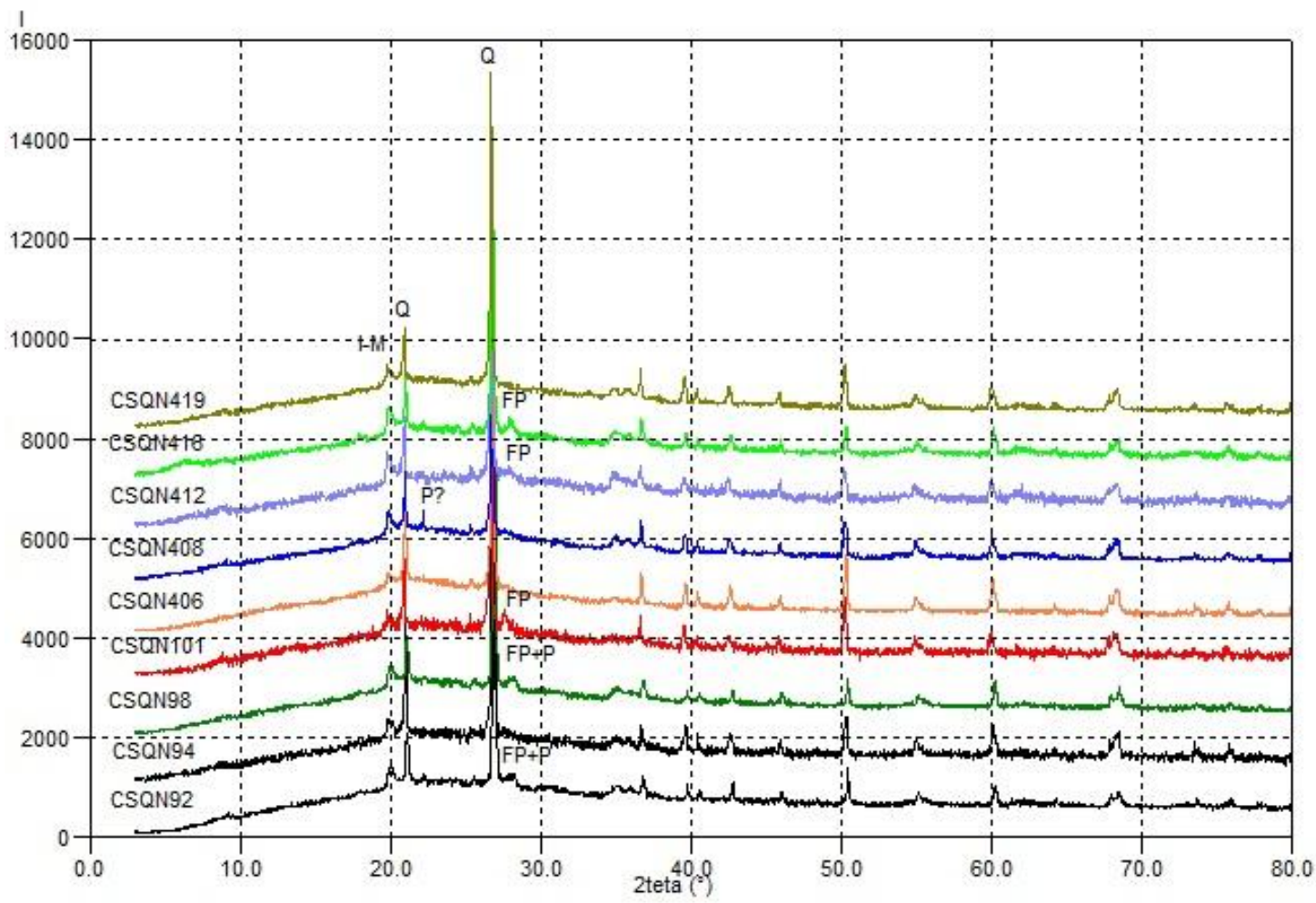

Figura 7.66 - Difratograma de fragmentos cerâmicos arqueológicos do sítio Osvaldo.

Pela Fig. 7.66, foi possível identificar a presença de quartzo em todos as amostras, pelas reflexões características em aproximadamente $21^{\circ}(4,2 \AA)$ e $26,8^{\circ}(3,3 \AA)$.

Além disso, os picos em torno de $27,7^{\circ}(3,2 \AA)$ sugerem a presença de feldspato potássico nas amostras CSQN92, 98, 101, 412 e 416; além da presença de plagioclásio, outra variedade de feldspato (Na-Ca-feldspato), cujo pico característico é próximo ao do feldspato potássico, nas amostras CSQN92 e 98.

A Tab. 7.35 foi elaborada com o intuito de se verificar possíveis relações entre os grupos determinados por INAA nos Cenários 3 e 5, e se as concentrações de sódio e potássio estariam correlacionadas à presença de plagioclásio e feldspatos potássicos, respectivamente. 
Tabela 7.35 - Classificação das amostras de Osvaldo analisadas por XRD em grupos químicos, presença de feldspatos e concentrações de Na e K por INAA.

\begin{tabular}{ccccccc}
\hline Amostra & Grupo $\left(\log _{10}\right)$ & Grupo (alr) & K-feldspato & {$[\mathbf{K}](\mathbf{m g} / \mathbf{g})$} & Plagioclase (Na, Ca) & {$[\mathbf{N a}](\mathbf{m g} / \mathbf{g})$} \\
\hline CSQN92 & A & A & x & n.d. & x & 3,446 \\
CSQN94 & A & B & & n.d. & & 1,296 \\
CSQN98 & A & B & x & 11,213 & x & 2,724 \\
CSQN101 & A & B & x & 13,330 & & 2,097 \\
CSQN406 & A & B & & - & & 0,510 \\
CSQN408 & A & B & & 10,643 & & 1,269 \\
CSQN412 & B & A & x & 8,981 & & 2,663 \\
CSQN416 & A & A & x & 7,779 & & 2,916 \\
CSQN419 & A & outlier & & 13,844 & & 0,365 \\
\hline
\end{tabular}

Pela comparação da Tab. 7.35 com a Fig. 7.66, não se verificou nenhuma correlação evidente dos grupos químicos aos quais os fragmentos pertencem e a presença de algum mineral específico. Ainda pela mesma tabela, em contraste com o que ocorreu para Lago Grande, não se observou correlação das concentrações de potássio com a presença de feldspatos potássicos. Observe-se, por exemplo, que não foi identificada a presença de K-feldspato, na Fig. 7.66, para as amostras CSQN408 e CSQN419, cujas concentrações de potássio são maiores que as das amostras CSQN412 e CSQN416, e para as quais foi identificado esse mineral. Duas das maiores concentrações de sódio para as amostras CSQN92 e CSQN98 coincidiram com a presença de plagioclásio no espectro da Fig. 7.9, embora para amostras com concentrações parecidas, como CSQN412 e CSQN416, não tenha sido detectado o plagioclásio, não sendo possível afirmar que haja uma correlação inequívoca desse mineral com a concentração de sódio.

Esses desvios na correlação entre a presença de feldspatos e as concentrações sódio e potássio podem ser indícios adicionais de que os mecanismos de enriquecimento discutidos na seção 7.1.9 estejam ocorrendo para esses dois elementos químicos.

Em todas as amostras da Fig. 7.66, o pico em torno de $20^{\circ}(4,4 \AA$ A é sugestivo da presença de ilita e/ou muscovita (mica). A presença de ilita-muscovita, cuja faixa de destruição completa está entre $950-1000{ }^{\circ} \mathrm{C}$ (Rice, 1987), indicaria que as temperaturas de queima dessas amostras estariam abaixo de $950^{\circ} \mathrm{C}$, corroborando os dados de EPR (seção 7.3). 
Em nenhuma das amostras foi encontrada evidências de carbonatos, como a calcita, que poderia ser outro mineral útil na estimativa da temperatura de queima (Rice, 1987).

A ausência de caulinita nos fragmentos cerâmicos arqueológicos pode ser correlacionada a uma temperatura de queima maior que $500{ }^{\circ} \mathrm{C}$, que é a temperatura mínima na qual a caulinita se transforma em metacaulinita, amorfa para XRD (Rice, 1987).

Como reportado na seção 7.1.9, foram encontrados indícios de que o elemento sódio tenha sofrido alterações diagenéticas ao longo do tempo nas cerâmicas analisadas. Buxeda i Garrigós (2001) sugeriu que o mineral analcite, uma zeólita de sódio, seria responsável por fixar sódio do ambiente, resultando no enriquecimento desse elemento em cerâmicas calcáreas queimadas a altas temperaturas. Não foram encontradas evidências da presença de analcite nas amostras analisadas por XRD neste trabalho, cujos picos característicos estão em torno de $16^{\circ}$ e $26^{\circ}$. Isso faz com que a fixação de sódio nas amostras de Lago Grande e Osvaldo, se confirmadas, não poderiam ser explicadas por esse mesmo mecanismo.

A Fig. 7.67 ilustra a comparação entre os espectros de XRD para as amostras arqueológicas de Lago Grande e Osvaldo, com a medição da radiação de fundo, relacionada ao aparelho e porta-amostras.

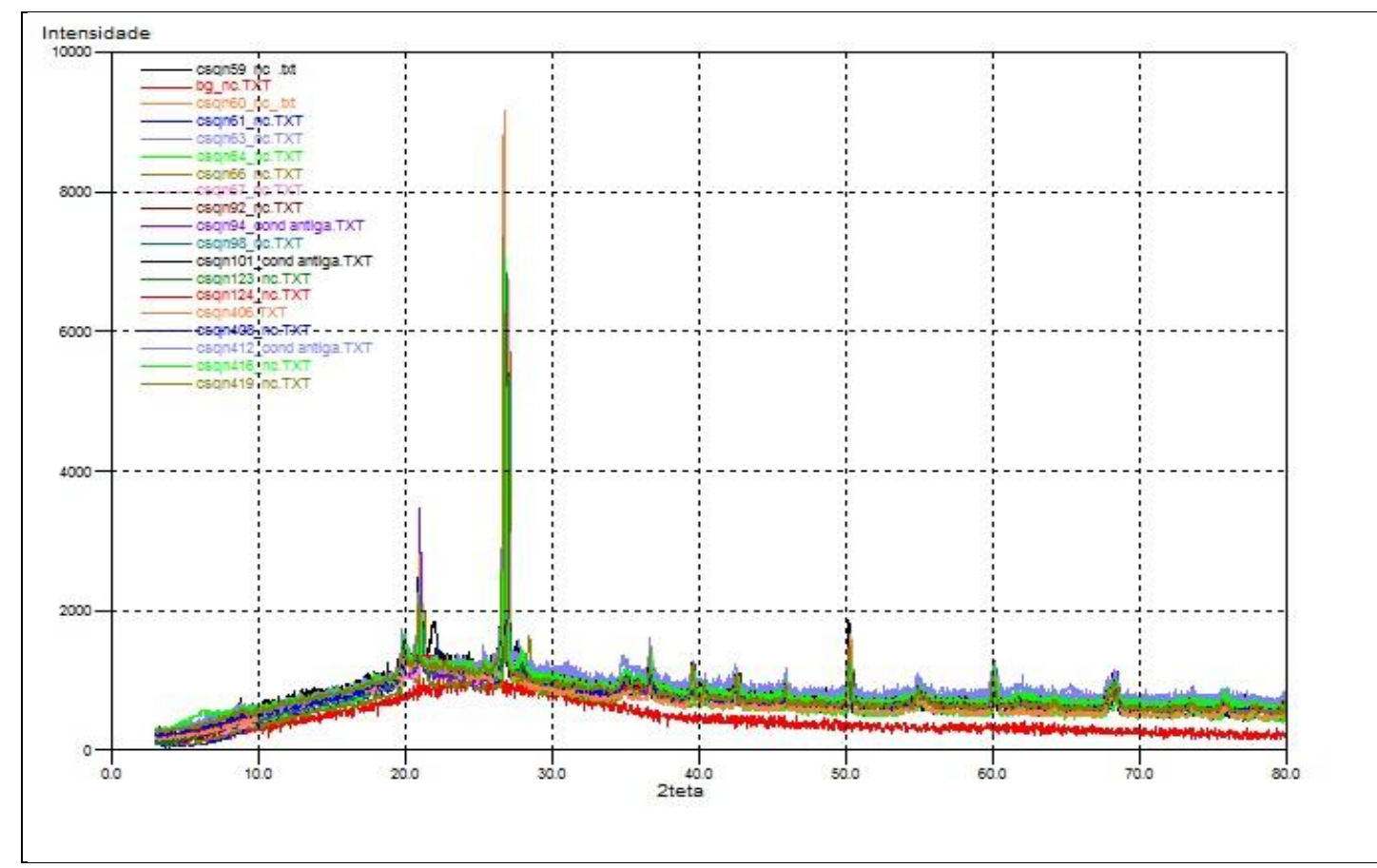

Figura 7.67 - Difratograma de fragmentos cerâmicos arqueológicos de Lago Grande e Osvaldo, e comparação com radiação de fundo (padrão em vermelho). 
Pela Fig. 7.67, observou-se que a grande parte da radiação de fundo é devida ao aparelho e porta-amostras. A diferença entre as linhas de base do BG (vermelho) e dos demais espectros, deve-se à presença de material amorfo nas amostras, como a sílica biogênica pela adição de antiplásticos (seção 7.1.3). Pela subtração das linhas da base da radiação de fundo, relacionada ao aparelho e porta-amostras, da linha de base para as amostras cerâmicas na região entre $70^{\circ}$ e $80^{\circ}$, calculou-se uma dispersão de valores $(2 \sigma)$ de $34 \%$ nas amostras do sítio Osvaldo, e $42 \%$ nas amostras de Lago Grande. Essa variação estaria correlacionada à variação de sílica amorfa nas amostras. Assim, esses valores fornecem uma aproximação indireta da variação na quantidade de material amorfo (associado, por exemplo, ao cauixi) nessas amostras de Lago Grande e Osvaldo.

A presença de ilita (mica) nos sedimentos e em vários fragmentos cerâmicos, confirma o fato de as matérias primas terem sido retirados de solos de planícies de inundação (Lima et al., 2002), nas quais a mica pode ser encontrada, como a área nas quais os sítios Osvaldo e Lago Grande se encontram.

Embora a presença de feldspatos possa estar associada à adição intencional de material antiplástico nas pastas cerâmicas, sua presença também pode ser esperada nos sedimentos da região, segundo o trabalho de Martinelli et al. (1993), no qual relataram que os picos característicos de quartzo e plagioclásio dominavam os difratogramas de sedimentos ao longo das planícies de inundação do rio Amazonas.

Em geral, pela ausência de caulinita nas amostras, pode-se inferir que a temperatura mínima de queima era de $500{ }^{\circ} \mathrm{C}$ para as cerâmicas de Lago Grande e Osvaldo. Ainda, pela presença de ilita-muscovita e ausência de minerais formados em queima a altas temperaturas, pode-se estimar o limite superior de $900{ }^{\circ} \mathrm{C}$ para a temperatura de queima. O intervalo estimado corrobora os resultados de EPR (seção 7.3).

Recomenda-se a análise de mais amostras por XRD e outras técnicas que possam identificar minerais que são de difícil determinação por difração de raios X, para melhor caracterização da estrutura mineralógica das cerâmicas de Lago Grande e Osvaldo e tentativa de correlação com a concentração de elementos químicos, como a avaliação da correlação de potássio e sódio com feldspatos, realizada nesta seção. Além disso, a determinação de outros minerais poderia auxiliar no refinamento da estimativa de temperaturas de queima, para comparação com a técnica de EPR. Algumas das técnicas sugeridas são SEM (Microscopia de Varredura Eletrônica) e FT-IR (Espectroscopia de 
Infravermelho por Transformada de Fourier) (Freestone \& Middleton, 1987; Costa et al., 2004; Ravisankar et al., 2013). 


\subsection{Determinação da temperatura de queima por Ressonância Paramagnética Eletrônica (EPR)}

Inicialmente, foram realizados testes de reprodutibilidade com o objetivo de se verificar a menor massa possível de ser utilizada para as medidas de EPR. Utilizando-se massas de 50, 70 e $100 \mathrm{mg}$ para a amostra CSQN60, de Lago Grande, verificou-se que 50 mg já eram suficientes para gerar resultados analíticos adequados. Esse valor para a massa mínima para EPR é equivalente ao valor verificado por Bensimon et al. (1998). Nas medições deste trabalho, foram utilizados entre 50 e $70 \mathrm{mg}$ para cada medida.

$\mathrm{Na}$ amostragem para determinação da temperatura de queima por ressonância paramagnética eletrônica, procurou-se representar os grupos formados em análises multivariadas preliminares.

A partir das medidas de EPR, obtiveram-se curvas da primeira derivada intensidade de absorção versus campo magnético. Por meio da Eq. 4.14, a abscissa referente ao campo magnético foi transformada em valores de $g$ (fator de desdobramento espectroscópico), cujo exemplo é apresentado na Fig. 7.68. As demais curvas encontram-se no Apêndice I. Em argilas, o elemento ferro pode ser encontrado, frequentemente, na forma $\mathrm{Fe}^{3+}$, além de traços de $\mathrm{Mn}^{2+}$ e outros centros paramagnéticos. O sinal típico de $\mathrm{Fe}^{3+}$ foi identificado em todos os espectros de todas as amostras obtidos para a faixa de temperatura $400-850{ }^{\circ} \mathrm{C}$, além das amostras que não foram reprocessadas termicamente (sinais característicos da Fig. 7.68). O sinal correspondente às linhas de interações hiperfinas de $\mathrm{Mn}^{2+}$ não foi identificado em nenhuma amostra. Essa ausência pode ser justificada pelo fato de o sinal desse íon ser característico da calcita $\left(\mathrm{CaCO}_{3}\right)$, na qual ocorre como impureza substitucional do íon $\mathrm{Ca}^{2+}$, com concentrações na ordem de $\mu \mathrm{g} \cdot \mathrm{g}^{-1}$. A calcita está presente em conchas de moluscos utilizadas como antiplástico em algumas cerâmicas antigas, o que não é o caso das cerâmicas da Tradição Borda Incisa na Amazônia Central. 

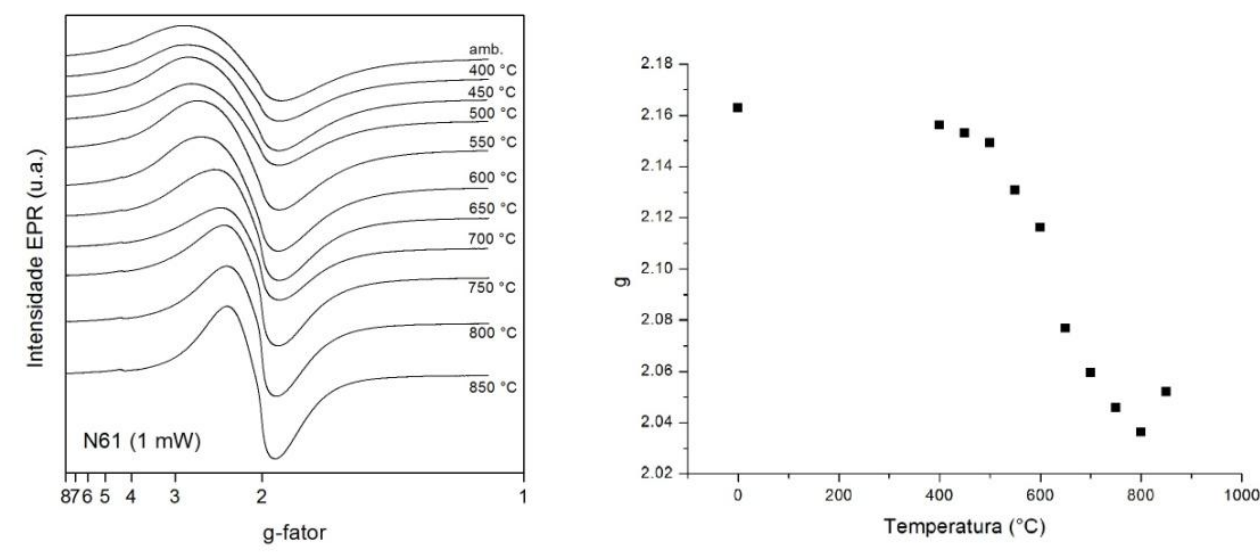

Figura 7.68 - Espectro de EPR para banda X (esquerda) em temperatura ambiente e fator espectroscópico experimental $g$ em função da temperatura de aquecimento (direita) para determinação da temperatura de queima da amostra CSQN61.

As grandes variações observadas em $\mathrm{g} \approx 2$ correspondem aos íons $\mathrm{Fe}^{3+}$ de alto spin (5/2) em sítio octraédrico, que interagem entre si por interação dipolo-dipolo magnético (Felicíssimo et al., 2010). Em cerâmicas e argilas, esse sinal está associado a espécies hidratadas de $\mathrm{Fe}^{3+}$ que podem ser oxidadas a $\mathrm{Fe}_{\mathrm{x}} \mathrm{O}_{\mathrm{y}}$, ou $\mathrm{FeOOH}$ (Mangueira et al., 2011). O aumento da amplitude do sinal em $\mathrm{g} \approx 2$ com o aumento da temperatura está associado à progressiva oxidação de $\mathrm{Fe}^{2+}$ a $\mathrm{Fe}^{3+}$. Além disso, o seu largo sinal característico reflete o caráter superparamagnético de microdomínios de óxido de ferro na estrutura cerâmica, responsáveis por essa absorção característica (Bensimon et al., 1999).

Já o sinal de menor intensidade em $\mathrm{g} \approx 4,3$ (Fig. 7.68) corresponde ao mesmo íon $\mathrm{Fe}^{3+}$ em sítio ortorrômbico, substituindo o íon $\mathrm{Al}^{3+}$ (Ikeya, 1993). O possível decréscimo desse sinal com a temperatura pode ser interpretado por um aumento de simetria em torno desse íon, devido a mudanças na estrutura cristalina, que ocorrem durante a queima das cerâmicas (Bartoll et al., 1996).

Pela grande sensibilidade do fator $g$ dos centros paramagnéticos em relação à vizinhança eletrônica do cristal, espera-se que a mudança no espectro de EPR ocorra apenas em temperaturas maiores que a temperatura de queima, assumindo-se que mudanças na estrutura cristalina (associadas a transformações termodinâmicas) não ocorreriam pela requeima dos artefatos em temperaturas menores que a utilizada pelos antigos ceramistas na produção cerâmica. Sendo assim, a análise dos gráficos consiste na identificação de uma variação brusca nos valores de $g$ com a temperatura de requeima em 
laboratório, indicando a temperatura estimada na qual a cerâmica foi queimada (Bensimon et al., 1998).

A Tabela 7.36 agrupa os resultados de temperatura de queima, obtidas pela identificação de diferenças expressivas no sinal em $\mathrm{g} \approx 4,3$, causadas pelo reaquecimento das amostras. As duas variáveis "Grupo" referem-se à classificação das amostras segundo os grupos químicos definidos nos Cenários 3 e 5, por INAA.

Tabela 7.36 - Resultados de temperatura de queima por EPR para os fragmentos cerâmicos de Lago Grande e Osvaldo.

\begin{tabular}{l|c|c|c|c|c|c|c}
\hline Amostra & Código MAE & Sítio & Profundidade (cm) & Fase & $\begin{array}{c}\text { Grupo } \\
\left(\log _{10}\right)\end{array}$ & $\begin{array}{c}\text { Grupo } \\
(\mathbf{a l r})\end{array}$ & $\mathbf{T}_{\mathbf{q}}\left({ }^{\mathbf{0}} \mathbf{C}\right)$ \\
\hline CSQN59 & $12-237$ & LG & $120-130$ & - & Outlier & B & $625 \pm 25$ \\
CSQN60 & $12-57$ & LG & $20-30$ & - & A & A & $525 \pm 25$ \\
CSQN61 & $12-373-2$ & LG & $0-10$ & - & A & B & $525 \pm 25$ \\
CSQN64 & $12-120$ & LG & $70-80$ & - & A & A & $525 \pm 25$ \\
CSQN66 & $12-79$ & LG & $50-60$ & - & B & B & $525 \pm 25$ \\
CSQN94 & - & O & $70-80$ & Paredão & A & B & $<550$ \\
CSQN100 & $7-490$ & O & $60-70$ & Paredão & Outlier & Outlier & $525 \pm 25$ \\
CSQN101 & $7-481$ & O & $80-90$ & Paredão & A & B & $<600$ \\
CSQN403 & $9-320-13$ & O & $0-10$ & Paredão & B & B & $525 \pm 25$ \\
\hline
\end{tabular}

As temperaturas de queima usuais para cerâmicas arqueológicas estão na faixa 600-1000 ${ }^{\circ} \mathrm{C}$ (Tite, 2009). Warashina (apud Bartoll e Tani, 1998) e Felicissimo et al. (2010) realizaram alguns experimentos a partir da requeima do pó de fragmentos cerâmicos arqueológicos, como no presente trabalho, e encontraram a temperatura de aproximadamente $550^{\circ} \mathrm{C}$ no primeiro estudo, e no máximo de $650{ }^{\circ} \mathrm{C}$, no último caso, para a maioria das amostras, concluindo que as populações pré-históricas de seus estudos não utilizavam fornos para produzir suas cerâmicas, pois a temperatura de queima costuma ser maior nesses dispositivos. Levando-se em consideração a semelhança dos resultados desses autores com os resultados de temperatura de queima na Tab. 7.36, na qual todas as temperaturas estimadas são menores que $625{ }^{\circ} \mathrm{C}$, é possível supor que os antigos 
ceramistas de Osvaldo e Lago Grande também não utilizavam fornos na produção das cerâmicas Paredão e Manacapuru.

Assim, esses resultados corroboram as observações na literatura de que a maneira mais comum de queima cerâmica por povos antigos das Américas era a utilização de fogueiras a céu aberto e buracos no chão, embora a utilização de fornos também fosse possível (Rice, 1987, p. 20). Nesses tipos de queima, a atmosfera é determinada pelo balanço entre oxigênio, dióxido e monóxido de carbono, e de difícil controle (Felicíssimo et al., 2010). Segundo Maggetti et al. (2011), queimas a céu aberto podem ser caracterizadas por altas taxas de aquecimento $\left(35-115^{\circ} \mathrm{C} / \mathrm{min}\right)$ e altas variações de temperatura no gás de queima (foram registrados diferenças de até $200{ }^{\circ} \mathrm{C}$ ). Além disso, um pote pode ser "ceramizado" num pequeno intervalo, em torno de 10-20 min.

Pela Tab. 7.36 não foram identificadas diferenças entre amostras de Lago Grande e Osvaldo, entre grupos químicos determinados por INAA e entre estratigrafias distintas quanto à temperatura de queima, cujos resultados foram uniformes. Essa uniformidade de resultados sugere que não havia diferença quanto aos detalhes do processo produtivo que influenciariam a temperatura de queima das cerâmicas nos dois sítios, independentemente da fonte de argila ou receita de pasta cerâmica utilizada. Além disso, a estabilidade dos resultados ao longo da estratigrafia dos dois sítios, com exceção da amostra CSQN59, pode ser indicativa de estabilidade temporal do processo produtivo, ou pelo menos dos parâmetros que influenciam a temperatura de queima. Esse resultado está de acordo com os resultados de INAA, na qual os grupos químicos definidos de cerâmicas não foram distinguidos em função da estratigrafia (seção 7.1.20).

Ainda pela Tab. 7.36, a amostra com temperatura de queima mais alta foi a CSQN59, com $100{ }^{\circ} \mathrm{C}$ a mais que a maioria dos demais fragmentos. Duas hipóteses foram levantadas para essa amostra. A primeira é que ela representa realmente uma condição de queima atípica em relação às demais amostras analisadas, na qual a temperatura atingida na queima da cerâmica foi $100{ }^{\circ} \mathrm{C}$ mais alta. $\mathrm{O}$ fato de essa amostra ter sido considerada como discrepante no Cenário 3, correspondente à transformação de dados $\log _{10}$, favorece essa hipótese. Outra possibilidade é a amostra ter sido queimada em condições praticamente redutoras, e a requeima, realizada em condições oxidantes, ter alterado a forma do espectro EPR na banda X (Bensimon et al., 1998). Se confirmada a primeira hipótese, esse resultado pode indicar uma diferença na temperatura de queima utilizada para amostras de estratos mais profundos, representando uma época mais antiga. Contudo, mais amostras 
dessas estratigrafias precisariam ser analisadas para confirmar essa afirmação, uma vez que outra possibilidade para esse resultado discrepante seria o fato de esse fragmento não ter sido representativo do objeto cerâmico original, correspondente a uma região que atingiu uma temperatura mais alta que o restante da peça.

Nunes (2009), em seu estudo de caracterização físico-química do sítio Hatahara, também na Amazônia Central, relatou temperaturas de queima de $550 \pm 50{ }^{\circ} \mathrm{C}$ para duas amostras, uma da fase Paredão e outra desconhecida; $500 \pm 50{ }^{\circ} \mathrm{C}$ para uma amostra Paredão, e $650 \pm 50^{\circ} \mathrm{C}$, para uma amostra Manacapuru. Os resultados encontrados neste trabalho estão no mesmo intervalo de temperatura encontrado pela autora. Por esses resultados, seria possível inferir uma uniformidade tecnológica referente à tecnologia de queima entre os antigos habitantes de Hatahara, Lago Grande e Osvaldo. Contudo, mais amostras precisariam ser analisadas, principalmente do sítio Hatahara, por ser multicomponencial, e ter apresentado quatro ocupações identificadas (Nunes, 2009).

Ribeiro (2013) realizou um estudo de caracterização físico-química do sítio São Paulo II, localizado em uma área próxima à calha do rio Solimões, no município de Coari (363 km de Manaus). Esse sítio apresenta prevalência de material cerâmico Guarita, da Tradição Polícroma. O autor determinou a temperatura de queima para seis fragmentos cerâmicos, obtendo temperaturas entre 600 e $650 \pm 50^{\circ} \mathrm{C}$. A partir desses resultados, é possível inferir que as cerâmicas Guarita de São Paulo II eram queimadas em temperaturas superiores às das cerâmicas Manacapuru e Paredão dos sítios Lago Grande, Osvaldo e Hatahara, e seriam possíveis correlatos de uma mudança tecnológica entre essas fases, pelo menos no que se refere ao processo de queima.

Mais análises de cerâmicas Paredão ainda precisam ser feitas para confrontar os resultados de EPR deste trabalho com a informação, disponível na literatura (Lima, 2008), de que a queima Paredão é uma queima completa, que quase atinge o estado de vitrificação da argila. É sabido que reações de vitrificação exigiriam temperaturas consideravelmente mais altas que as encontradas neste estudo. Por outro lado, as temperaturas de queima encontradas representam uma média para o fragmento cerâmico, a partir do centro de incisão pela broca (ver procedimento para remoção de pó no Capítulo 6). A remoção de pó não contemplou a amostragem das superfícies internas e externas das cerâmicas, que podem atingir temperaturas consideravelmente mais altas durante o processo de queima. A dehidroxilação, ou perda de água quimicamente combinada, é uma reação endotérmica. Assim, o interior da cerâmica é mais frio que as superfícies exteriores, 
em contato direto com as chamas, sendo que a dehidroxilação é completada primeiro nessas superfícies, enquanto o interior ainda continua em processo de expansão. Segundo Maggetti et al. (2011), o gradiente térmico em uma seção transversal específica de um objeto cerâmico pode chegar a até $390^{\circ} \mathrm{C}$.

Observou-se que alguns fragmentos cerâmicos de Lago Grande e Osvaldo apresentam núcleo mais escuro. A oxidação incompleta do carbono durante a queima é responsável pelo aparecimento desse tipo de núcleo, observado na seção transversal de vasos cerâmicos quebrados, queimados a temperaturas relativamente baixas por curtos períodos, ou cerâmica de textura muito fina (Rice, 1987, pág. 88). A condição de baixas temperaturas para a queima obtidas para as amostras de Lago Grande e Osvaldo na Tab. 7.36 corroboram esse fato.

Foram repetidos testes com as amostras CSQN59 e CSQN100 para a verificação da influência do tempo de requeima em laboratório, já que não se sabe ao certo o tempo de queima utilizado pelos ceramistas antigos de Lago Grande e Osvaldo. Contudo, de modo geral, sabe-se que raramente a queima cerâmica atingia a condição de equilíbrio (Rice, 1987, pág. 86), para uma dada temperatura. Os resultados foram reprodutíveis para a amostra CSQN100. Para a amostra CSQN59, estimou-se uma temperatura de queima mais alta, em torno de $725 \pm 25^{\circ} \mathrm{C}$. Contudo, esse último resultado não parece fazer sentido, uma vez que pela manutenção de tempos de requeima maior, esperar-se-iam temperaturas de queima menores, já que haveria mais tempo para que fossem iniciadas mudanças na estrutura cristalina em temperaturas menores que as estimadas por 20 minutos de requeima (Mangueira et al., 2011).

Determinar se um objeto foi queimado ou não é uma tarefa que pode ser feita, frequentemente, com alto grau de certeza por EPR. Por outro lado, já é esperada uma incerteza maior para a interpretação dos detalhes do processo de queima, em virtude da interdependência entre variáveis particulares, como a temperatura, atmosfera e duração da queima. Assim, é recomendado o estudo de EPR com matérias-primas não queimadas, argilas e antiplásticos, por meio de experimentos térmicos varrendo a faixa de temperatura de interesse, para melhor entendimento dos processos pirolíticos que podem afetar os perfis de EPR, obtendo-se informações sobre o maior número possível de espécies que apresentam sinal analítico para essa técnica (Bartoll \& Tani, 1998; Bensimon et al., 1999). 


\subsection{Datação por Luminescência Opticamente Estimulada (OSL)}

Neste trabalho, houve uma tentativa inicial de datação por termoluminescência, porém os resultados foram descartados por apresentarem razão entre pico e radiação de fundo insatisfatória. A explicação encontrada para esse sinal baixo foi a dominância de termoluminescência residual nas curvas de TL (glow curves), adquirida antes de os fragmentos cerâmicos entrarem no contexto deposicional, e que está associada a níveis energéticos que não são facilmente esvaziados, ou seja, seu sinal característico não pode ser reduzido facilmente a aproximadamente zero. Uma vez que o sinal de OSL está associado apenas a armadilhas em níveis energéticos que são de fácil esvaziamento, ou eliminação do sinal, ela foi a técnica mais adequada para as amostras deste trabalho, cujas massas disponíveis para análise eram relativamente baixas (menor que $100 \mathrm{mg}$ ). Para cerâmicas arqueológicas, o “evento zero" tanto para TL como para OSL é a última queima da cerâmica (Aitken, 1998).

Não se conseguiu massa residual suficiente para datação da amostra CSQN379 (R6) após a preparação de amostras para OSL (seção 6.4). A Fig. 7.69 mostra as curvas de decaimento para as amostras "naturais" e as amostras irradiadas com radiação $\beta$, relacionadas na Tab. 6.3, para o cálculo da paleodose. A dose acumulada, ou paleodose, das amostras foi obtida traçando-se uma reta às medidas de respostas às doses utilizadas $(0$, 2 e 4 Gy), utilizando-se a parte inicial do sinal de OSL (máximo da intensidade). Os resultados de paleodose encontram-se na Tab. 7.40.

A radioatividade natural da região onde estão situados os sítios Osvaldo e Lago Grande não foram medidas por meio da instalação de dosímetros termoluminescentes. Assim, as componentes beta e gama da taxa anual de dose foram estimadas pela concentração dos elementos $\mathrm{U}, \mathrm{K}$ e Th nos fragmentos cerâmicos analisados e nos sedimentos próximos aos sítios, por meio de INAA (Adamiec \& Aitken, 1998). Os resultados das determinações desses três elementos químicos para as amostras e argilas coletadas nas proximidades dos sítios são apresentados na Tabela 7.37. O elemento $\mathrm{Rb}$ foi desprezado nos cálculos devido a sua contribuição limitada à taxa anual de dose, quando comparado com os demais elementos (Ikeya \& Miki, 1985). 


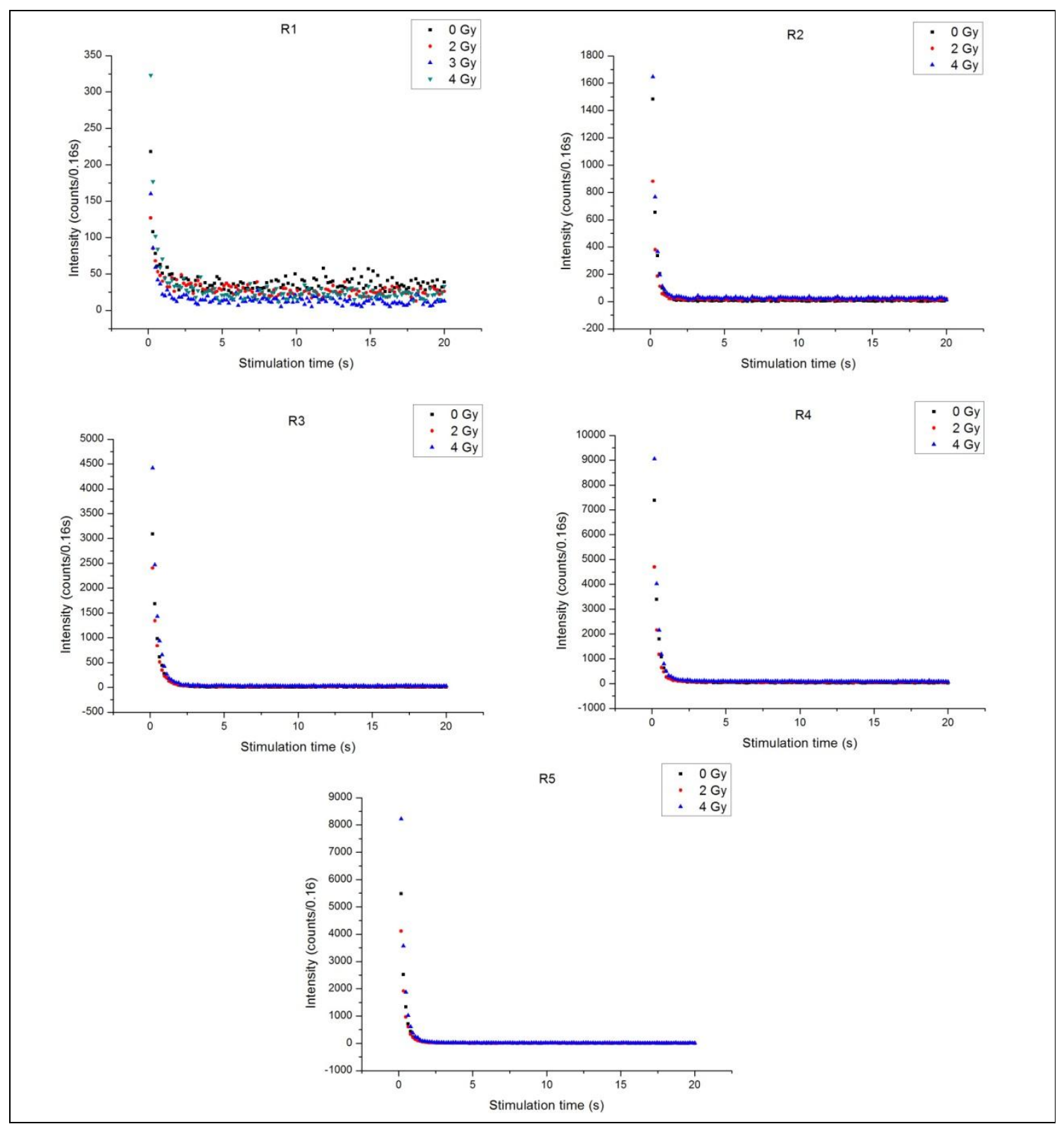

Figura 7.69 - Curvas de crescimento das amostras de Lago Grande e Osvaldo para datação por OSL. 
Tabela 7.37 - Concentrações dos elementos químicos U, Th e $\mathrm{K}$ nos fragmentos cerâmicos e argilas próximas aos sítios Lago Grande e Osvaldo, para cálculo das componentes beta e gama da taxa de dose anual.

\begin{tabular}{cccc}
\hline Amostra & $\mathbf{U}\left(\boldsymbol{\mu g} \cdot \mathbf{g}^{-\mathbf{1}}\right)$ & ${ }^{\mathbf{2 3 2}} \mathbf{T h}\left(\boldsymbol{\mu g} \cdot \mathbf{g}^{-\mathbf{1}}\right)$ & $\mathbf{K}\left(\mathbf{m g} \cdot \mathbf{g}^{-\mathbf{1}}\right)$ \\
\hline R1 & $4,4 \pm 0,6$ & $16,1 \pm 0,9$ & $12,6 \pm 1,3$ \\
R2 & $4,7 \pm 0,7$ & $10,9 \pm 0,6$ & 10,1 (estimado*) \\
R3 & $4,1 \pm 0,4$ & $15,7 \pm 0,9$ & $9,8 \pm 1,2$ \\
R4 & $3,0 \pm 0,7$ & $17,1 \pm 1,0$ & $14,3 \pm 2,7$ \\
R5 & $3,1 \pm 0,5$ & $13,4 \pm 0,8$ & $7,9 \pm 0,8$ \\
Argila LG & $4,2 \pm 0,2$ & $19,5 \pm 0,7$ & $24,3 \pm 1,2$ \\
Argila O & $4,4 \pm 0,4$ & $16,3 \pm 0,7$ & $17,6 \pm 1,5$ \\
\hline
\end{tabular}

LG $=$ Lago Grande. $\mathrm{O}=$ Osvaldo.

*Média para 36 amostras de Osvaldo.

Considerando os grãos de quartzo nos fragmentos cerâmicos como amostra finita, a taxa anual de radiação gama incidente nas amostras foi calculada a partir da concentração dos radioisótopos de interesse presentes nos sedimentos adjacentes, em vez da dose gama interna do material (Ikeya \& Miki, 1985). Para isso, as concentrações de ${ }^{238} \mathrm{U},{ }^{232} \mathrm{Th}$ and ${ }^{40} \mathrm{~K}$ nos sedimentos foram aproximadas pelas concentrações dos mesmos em amostras de argilas nas proximidades de Osvaldo e Lago Grande (Tab. 7.37). Para a dose interna beta, por sua vez, foram utilizadas as concentrações desses elementos nos fragmentos cerâmicos.

O efeito da umidade nos locais de escavação deve ser considerado nos cálculos de OSL, pois podem ter uma influência considerável na estimativa das idades. Segundo Bruno et al. (2006), os solos de floresta tropical amazônica podem apresentar umidade entre $0,38 \mathrm{e} 0,53 \mathrm{~m}^{3} \mathrm{~m}^{-3}$, considerando as estações seca e chuvosa, e para profundidades até $10 \mathrm{~m}$. A média desses valores foi utilizada na estimativa de $W_{s}$ na Eq. 4.18. Para a estimativa do conteúdo de água nas amostras, $W_{p}$, relacionada à porosidade e capilaridade, as massas de 15 fragmentos cerâmicos de ambos os sítios foram medidas em três condições (Zink et al., 2012):

a. Antes da secagem, em condições laboratoriais;

b. Após secagem em mufla a $110^{\circ} \mathrm{C}$ por $24 \mathrm{~h}$; e

c. Após imersão dos fragmentos em béqueres contendo água comum. 
Para o valor final de $W_{p}$, foi escolhida a média entre o conteúdo de água das amostras nas condições ambientais do laboratório e nas condições de saturação. $\mathrm{Na}$ Tab. 7.38 estão organizados os resultados para as componentes beta e gama da taxa anual de dose, como expressas pela Eq. 4.18.

Tabela 7.38 - Componentes beta e gama das taxas anuais de dose para os fragmentos cerâmicos de Lago Grande e Osvaldo.

\begin{tabular}{cccccc}
\hline Amostra & Sítio & $\mathbf{W}_{\mathbf{p}}(\boldsymbol{\%})$ & $\mathbf{W}_{\mathbf{s}}(\boldsymbol{\%})$ & $\dot{\boldsymbol{D}}_{\boldsymbol{\beta}}(\mathbf{m G y} / \mathbf{a})$ & $\dot{\boldsymbol{D}}_{\boldsymbol{\gamma}}((\mathbf{m G y} / \mathbf{a})$ \\
\hline R1 & LG & 13,9 & 28,4 & 1,5 & 1,3 \\
R2 & O & 13,9 & 28,4 & 1,3 & 1,1 \\
R3 & LG & 13,9 & 28,4 & 1,3 & 1,3 \\
R4 & O & 13,9 & 28,4 & 1,5 & 1,1 \\
R5 & O & 13,9 & 28,4 & 1,1 & 1,1 \\
\hline
\end{tabular}

LG = Lago Grande. $\mathrm{O}=$ Osvaldo.

O cálculo do último termo da Eq. 4.18, a componente cósmica da taxa anual de dose, foi realizado utilizando-se as Eq. 4.19-4.21. Os resultados estão organizados na Tab. 7.39 .

Tabela 7.39 - Cálculo da taxa anual de radiação cósmica para os sítios Lago Grande e Osvaldo.

\begin{tabular}{ccccccccccc}
\hline Amostra & Sítio & Coord. geo & h (m) & $\begin{array}{c}\text { Prof. } \\
(\mathbf{c m})\end{array}$ & $\dot{\boldsymbol{D}}_{\mathbf{0}}$ & $\boldsymbol{\lambda}$ & $\mathbf{F}$ & $\mathbf{J}$ & $\mathbf{H}(\mathbf{k m})$ & $\begin{array}{c}\dot{\boldsymbol{D}}_{\text {cos }} \\
\left(\mathbf{G y} . \mathbf{k a} \mathbf{-}^{-1}\right)\end{array}$ \\
\hline $\mathrm{R} 1$ & $\mathrm{LG}$ & $3^{\circ} 14^{\prime} \mathrm{S} 50^{\circ} 24^{\prime} \mathrm{W}$ & 92 & 35 & 0,20 & $-0,25$ & 0,4 & 0,52 & 4,38 & 0,19 \\
$\mathrm{R} 2$ & $\mathrm{O}$ & $3^{\circ} 11^{\prime} 15^{\prime \prime} \mathrm{S} 60^{\circ} 20^{\prime} 41^{\prime \prime} \mathrm{W}$ & 60 & 5 & 0,21 & $-0,26$ & 0,4 & 0,52 & 4,38 & 0,19 \\
$\mathrm{R} 3$ & $\mathrm{LG}$ & $3^{\circ} 14^{\prime} \mathrm{S} 50^{\circ} 24^{\prime} \mathrm{W}$ & 92 & 65 & 0,20 & $-0,25$ & 0,4 & 0,52 & 4,38 & 0,18 \\
$\mathrm{R} 4$ & $\mathrm{O}$ & $3^{\circ} 11^{\prime} 15^{\prime \prime} \mathrm{S} 60^{\circ} 20^{\prime} 41^{\prime \prime} \mathrm{W}$ & 60 & 35 & 0,20 & $-0,26$ & 0,4 & 0,52 & 4,38 & 0,19 \\
$\mathrm{R} 5$ & $\mathrm{O}$ & $3^{\circ} 11^{\prime} 15^{\prime \prime} \mathrm{S} 60^{\circ} 20^{\prime} 41^{\prime \prime} \mathrm{W}$ & 60 & 35 & 0,20 & $-0,26$ & 0,4 & 0,52 & 4,38 & 0,19 \\
\hline
\end{tabular}

LG = Lago Grande; $\mathrm{O}=$ Osvaldo.

Na Tab. 7.40 estão organizados os resultados finais de datação por OSL. A paleodose média, assim como as taxas anuais de dose obtidas pela soma das componentes beta, gama e cósmica (Tab. 7.38 e 7.39), na forma expressa na Eq. 4.18, são apresentadas. A Eq. 4.17 foi utilizada no cálculo das idades. Para as incertezas, foi considerado o valor 
mais alto entre um desvio-padrão para as alíquotas das amostras, e a variação das idades supondo valores para $W_{c}$ e $W_{p}$ variando entre as condições laboratoriais e condições de saturação em água, que representaram as variações máximas nas idades para variações extremas desses parâmetros.

Tabela 7.40 - Datações por OSL de fragmentos cerâmicos dos sítios Lago Grande e Osvaldo. As idades de ${ }^{14} \mathrm{C}$ para comparação foram retiradas de Lima (2008).

\begin{tabular}{ccccccc}
\hline Amostra & Sítio & Prof. $(\mathbf{c m})$ & ${ }^{14} \mathbf{C}($ anos d.C. $) *$ & P $(\mathbf{G y})$ & $\dot{\mathbf{D}}(\mathbf{m G y} / \mathbf{a})$ & Idade (anos a.C.) \\
\hline R1 & Lago Grande & $30-40$ & $1040-1170$ & 3,13 & 3,0 & $967 \pm 477$ \\
R2 & Osvaldo & $0-10$ & $>770$ & 2,96 & 2,6 & $867 \pm 101$ \\
R3 & Lago Grande & $60-70$ & $>1110$ & 2,40 & 2,8 & $1154 \pm 62$ \\
R4 & Osvaldo & $30-40$ & $\approx 620-770$ & 3,08 & 2,8 & $906 \pm 81$ \\
R5 & Osvaldo & $30-40$ & $\approx 620-770$ & 2,52 & 2,4 & $938 \pm 77$ \\
\hline
\end{tabular}

Algumas observações podem ser feitas a partir da Tab. 7.40. As idades médias das amostras variaram entre 867 e 1154 a.C., um intervalo de tempo de 287 anos. As incertezas nas idades variaram entre 5\% (para R3) e 49\% (para R1). O valor mais alto para o desvio da amostra R1 deve-se ao seu menor sinal luminescente, quando comparado ao das demais amostras. Em um teste preliminar com irradiação beta, mediram-se 150 contagens para a amostra R1. Para fins de comparação, a amostra R3 foi medida com 8000 contagens, o maior valor entre todas as amostras, fazendo com que sua razão pico/radiação de fundo fosse mais elevada e seu desvio-padrão para as 5 alíquotas dessa amostra fosse o mais baixo (2,6\%). Apesar do valor extremo de dispersão para a amostra R1, todas as demais amostras apresentaram desvios menores que $12 \%$.

De acordo com cálculos da variação das idades obtidas utilizando-se os valores mínimos de umidade nos fragmentos cerâmicos e sedimentos (menores valores para $W_{c} \mathrm{e}$ $W_{s}$ ), e valores máximos supondo saturação em água (valores máximos para $W_{c}$ e $W_{s}$ ), o efeito da umidade pode causar um erro de até $10 \%$ nas idades. Considerando-se as condições ambientais da Amazônia, referentes à alta umidade do ar e solo, o efeito do conteúdo de água nas amostras e sedimentos na datação por OSL não pode ser rejeitado. Cálculos demonstraram que ignorar o conteúdo de água nas amostras e sedimentos adicionaria entre 202 e 262 anos às idades determinadas, fazendo com que os fragmentos 
cerâmicos fossem considerados supostamente mais novos, com idades que não estão de acordo com o esperado pelas datações de ${ }^{14} \mathrm{C}$ na literatura (Lima, 2008).

As datas para os dois fragmentos de Lago Grande estão em concordância com o intervalo de ocupação considerado para o sítio na literatura (Donatti, 2003; Lima, 2008), do século VIII até o século XII d.C. No sítio Osvaldo, duas ocupações humanas foram identificadas no registro arqueológico. Acredita-se que a última, mais densa e associada à terra preta, tenha ocupado o sítio entre os séculos VII e VIII d. C. (Portocarrero, 2006; Lima, 2008). Pelas datas obtidas para os três fragmentos cerâmicos de Osvaldo, observouse que a ocupação do sítio poderia ser estendida até o século $X$ d.C. Contudo, mais amostras precisam ser analisadas para considerações mais conclusivas à respeito da cronologia dos dois sítios, já que os cálculos de dose anual ainda poderiam ser refinados melhorando-se a amostragem de sedimentos na região, para uma medida mais representativa de $\mathrm{U}$, Th e $\mathrm{K}$ no cálculo da componente gama da taxa de dose anual; e pela instalação de dosímetros luminescentes. Na Tab. 7.41 estão organizados os resultados obtidos pela aplicação do teste $t$ para verificação de diferenças estatisticamente significativas entre as idades médias obtidas para cada fragmento cerâmico analisado por OSL.

Tabela 7.41 - Teste $t$ para idades de fragmentos cerâmicos de Lago Grande e Osvaldo obtidas por OSL. Nível de significância $\alpha=0,05$.

\begin{tabular}{ccccc}
\hline Amostras testadas & Sítio & $p$ & $\mathrm{H}_{0}$ & status \\
\hline R1, R3 & LG vs. LG & 0,27 & aceita & Idades iguais \\
R3, R2 & LG vs. Osv & 0,001 & rejeitada & Idades diferentes \\
R3, R4 & LG vs. Osv & 0,0008 & rejeitada & Idades diferentes \\
R3, R5 & LG vs. Osv & 0,001 & rejeitada & Idades diferentes \\
\hline
\end{tabular}

$\mathrm{LG}=$ Lago Grande. Osv = Osvaldo.

Pelo teste de hipóteses para as médias da Tab. 7.41, com nível de significância de 5\%, verificou-se, como esperado, que não é possível rejeitar a hipótese nula referente à igualdade das duas idades obtidas para os fragmentos cerâmicos do sítio Lago Grande (R1, R3). Esse resultado era esperado, pois o desvio na idade da amostra R1 é maior que o intervalo de tempo compreendendo todas as amostras determinadas por OSL (287 anos). Assim, não é possível rejeitar a possibilidade de contemporaneidade das amostras, apesar 330 
da diferença entre seus níveis estratigráficos. Comparando-se a amostra R3 de Lago Grande, com as amostras R2, R4 e R5 de Osvaldo, o teste de hipóteses para a igualdade das médias indicou que é possível rejeitar a hipótese nula de igualdade entre as idades, ou seja, as amostras de Osvaldo são mais antigas que a amostra R3 de Lago Grande. Considerando-se que a ocupação humana de Lago Grande durou mais tempo (até o século XII d.C.), quando comparada à de Osvaldo, esses resultados seriam esperados ao se amostrar as camadas mais superficiais de ambos os sítios, embora um período de contemporaneidade também seja assumido para os mesmos (Portocarrero, 2006; Lima, 2008; Mongeló, 2011).

Pela comparação das datas radiocarbônicas presentes na literatura (Lima, 2008) com as datas por OSL na Tab. 7.40, observou-se que as amostras R4 e R5 apresentaram os maiores desvios em relação ao resultado esperado por ${ }^{14} \mathrm{C}$. Contudo, essas datas esperadas não devem ser tomadas como absolutas, uma vez que foram estimadas a partir da literatura, pela comparação das estratigrafias das amostras datadas por ${ }^{14} \mathrm{C}$ e das amostradas para OSL neste trabalho. Essa comparação estratigráfica é frequentemente inexata, pois o fenômeno de bioturbação é frequente na região (Donatti, 2003; Lima, 2008), além da possibilidade de inversão estratigráfica em montículos. Em geral, os resultados corroboraram o intervalo cronológico médio assumido para a ocupação de Lago Grande encontrado na literatura (Donatti, 2003; Portocarrero, 2006; Lima, 2008). Por outro lado, as datas obtidas para as amostras de Osvaldo são mais recentes que o esperado.

A quantidade de amostras analisadas neste trabalho foi limitada pela disponibilidade de fragmentos cerâmicos, pois muitos deles não tinham um tamanho adequado para datação por OSL, ou não poderiam ser destruídos, devido ao seu caráter diagnóstico. Para trabalhos futuros, recomenda-se a análise de mais amostras dos dois sítios, procurando amostrar de forma mais sistemática diferentes estratigrafias e unidades de escavação, para considerações mais conclusivas acerca da cronologia de ocupação de Osvaldo e Lago Grande e comparação com datações por ${ }^{14} \mathrm{C}$. Além disso, como já foi sugerido, seria conveniente analisar mais amostras de sedimentos das proximidades dos sítios para melhorar a estimativa das concentrações de $\mathrm{U}$, Th e $\mathrm{K}$ nos cálculos da componente gama de dose anual. Finalmente, a instalação de dosímetros na região poderia gerar dados para estimativa de dose anual visando à comparação com as doses obtidas neste trabalho, a partir das concentrações dos radioisótopos ${ }^{40} \mathrm{~K},{ }^{238} \mathrm{U}$ e ${ }^{232} \mathrm{Th}$. 


\section{CAPÍTULO 8}

\section{CONCLUSÃO}

Realizou-se um estudo interdisciplinar envolvendo a aplicação de quatro técnicas analíticas físicas ao estudo de fragmentos cerâmicos arqueológicos dos sítios Lago Grande e Osvaldo, na Amazônia Central. Por ter sido encontrado material cerâmico exógeno e contemporâneo de fases cerâmicas distintas às dominantes nos dois antigos assentamentos, procurou-se testar se a potencial definição e comparação de grupos químicos de cerâmicas desses dois sítios de grandes dimensões, assim como características tecnológicas evidenciadas em sua microestrutura e temperatura de queima, poderiam indicar a existência de uma rede de trocas entre os antigos habitantes de Lago Grande e Osvaldo.

A principal técnica utilizada para responder à hipótese testada foi a análise por ativação neutrônica instrumental (INAA). A qualidade analítica dos resultados obtidos por essa técnica foi estudada pela análise do material de referência IAEA-Soil-7, pela qual foram aprovados 15 elementos químicos, dentre os 24 medidos: As, K, La, Lu, Na, Yb, Ce, $\mathrm{Co}, \mathrm{Cr}, \mathrm{Cs}, \mathrm{Eu}, \mathrm{Fe}, \mathrm{Hf}, \mathrm{Sc}$ e Th.

Foram identificadas alterações potenciais nos perfis geoquímicos de $\mathrm{Na}, \mathrm{K}$, Cs, As e Hf, que poderiam obscurecer padrões que reflitissem aspectos geoquímicos naturais e culturais dos dados para interpretação arqueológica. Pelas medidas de INAA de cauixi, verificou-se que essas alterações não poderiam ter ocorrido devido ao enriquecimento preferencial de algum elemento químico presente nesse antiplástico. A hipótese levantada para o enriquecimento e variabilidade de $\mathrm{Na}$ nas amostras cerâmicas foi a combinação de intemperismo de feldspatos e disponibilidade de cloreto de sódio de águas pluviais na região de confluência dos rios Negro e Solimões. De maneira análoga, a hipótese de intemperismo de feldspatos potássicos foi sugerida para explicar o enriquecimento e variabilidade de $\mathrm{K}$ nas amostras.

Dessa forma, foram definidos cinco cenários variando o grupo de elementos químicos utilizados nas análises multivariadas, e também a transformação de dados. Os cenários considerados adequados para comparação, para a avaliação do efeito da adição de 
elementos antiplásticos às pastas cerâmicas e interpretação arqueológica foram os correspondentes à utilização de um grupo de nove elementos químicos $(\mathrm{Ce}, \mathrm{Cr}, \mathrm{Eu}, \mathrm{Fe}, \mathrm{La}$, $\mathrm{Lu}, \mathrm{Sc}$, Th e Yb) com transformação logarítmica decimal (Cenário 3) e logarítmica racional aditiva, utilizando o elemento escândio como divisor (Cenário 5).

Foram definidos dois grupos químicos elementares de cerâmicas para cada sítio arqueológico, nos dois cenários, a partir da análise de agrupamento e componentes principais. Os mesmos padrões foram identificados em análise discriminante e mapas autoorganizáveis, sendo que essa última técnica, um tipo de rede neural, não depende de hipóteses acerca da normalidade dos dados e homogeneidade das matrizes de covariância, como a análise discriminante. Os dois grupos químicos de cada sítio apresentaram superposições pareadas com grupos do outro sítio nos dois cenários estudados, indicando uma semelhança geoquímica entre as amostras de Lago Grande e Osvaldo, possível correlato de mecanismos de troca cultural ou contexto geoquímico similar das fontes de matérias-primas utilizadas por antigos ceramistas dos dois sítios.

A significância estatística dos grupos formados foi testada indiretamente pela comparação com tendências estatisticamente observáveis em estudos de caracterização química de cerâmicas arqueológicas realizados em todo o mundo. $\mathrm{O}$ teste direto foi realizado por uma análise multivariada de variância, pela qual foi observado que a existência de pelo menos dois grupos químicos, com diferenças estatisticamente significativas entre seus vetores de concentrações médias, podem ser definidos para Lago Grande e Osvaldo, independentemente da transformação de dados utilizada.

Os grupos químicos definidos neste trabalho provavelmente não estão representando apenas uma pasta cerâmica ou fonte de argila, mas podem ser correlatos de um aglomerado de grupos de diferentes pastas e combinações de fontes argilosas, cuja identificação seria possível, provavelmente, pelo aumento do número de amostras analisadas, dos elementos determinados por INAA e precisão analítica dos resultados. Dessa forma, aumentar-se-ia a resolução geoquímica da região estudada, buscando a caracterização de um número maior de grupos químicos potencialmente contidos nos grupos A e B de cada sítio, definidos nesta tese. Uma definição em mais grupos químicos foi testada preliminarmente, porém, devido a questões de amostragem e falta de correlações arqueológicas evidentes, decidiu-se não aprofundar a resolução geoquímica e trabalhar com dois grupos químicos por sítio arqueológico. 
$\mathrm{Na}$ correlação arqueológica dos grupos químicos com a fase cerâmica, observou-se que as cerâmicas Manacapuru apresentaram os padrões mais homogêneos entre os sítios Lago Grande e Osvaldo, e pela mudança na transformação de dados, indicando que o efeito de adição de antiplásticos foi menos crítico para cerâmicas dessa fase cultural. Para as cerâmicas Paredão, foram observadas diferenças nos padrões pela mudança de sítio e transformação dos dados. Para explicar as diferenças entre a distribuição dessa fase cerâmica por grupo químico entre os sítios, foram levantadas as hipóteses de Osvaldo ter participado de relações de troca com outros sítios que não apenas Lago Grande, ou diferenciação de produção cerâmica para os objetos que teriam como destino a troca comercial.

A maior variabilidade geoquímica observada para as cerâmicas Paredão poderia estar associada a uma maior variação na escolha de matérias-primas por parte dos produtores dessa indústria cerâmica, devido à sazonalidade na oferta de fontes argilosas e outras matérias-primas nos períodos de cheia e de seca. Durante o pico demográfico na Amazônia Central, associado à fase Paredão, mais cerâmica utilitária deve ter sido produzida, fazendo com que fosse impraticável esperar para produzir cerâmica apenas em períodos de seca, nos quais outras matérias-primas, potencialmente preferenciais, estivessem disponíveis.

Não foi possível, com os resultados de caracterização química das cerâmicas arqueológicas por INAA, definir inequivocamente se as amostras Paredão analisadas de Osvaldo seriam provenientes de Lago Grande, assim como as Manacapuru de Lago Grande seriam provenientes de Osvaldo. Contudo, há indícios na literatura arqueológica que reforçam que a troca entre esses dois sítios tenha ocorrido, embora provavelmente não tenham sido as únicas.

Mongeló (2011) relatou que há outros 15 sítios Manacapuru e outros 14 sítios Paredão que devem ter sido contemporâneos a Lago Grande e Osvaldo na Amazônia Central, indicando que as relações de troca entre esses dois sítios não seriam casos isolados, dificultando a interpretação dos grupos químicos de cerâmica como correlatos diretos de interação entre Lago Grande e Osvaldo. A análise comparativa com mais sítios arqueológicos da região poderia responder a essa questão de maneira mais eficiente. De fato, foi sugerido pela análise logarítmica racional aditiva dos dados que parte da maior variabilidade geoquímica das cerâmicas Manacapuru de Lago Grande, concentradas em seu grupo A, indicaria que elas estariam entrando no sítio por relações de troca não apenas 
com o sítio Osvaldo, mas também com outros sítios habitados por grupos produtores de cerâmica Manacapuru. Se confirmada em estudos futuros, essa hipótese corroboraria a existência de um sistema regional de interação, no qual etnias diferentes compartilhariam uma ideologia e uma cultura comuns através de extensas redes de troca, casamentos exogâmicos e alianças intercomunitárias. Esses sistemas foram indicados arqueologicamente nas áreas periféricas da Amazônia, mas ainda foram pouco estudados na região da Amazônia Central.

De maneira geral, a hipótese mais provável a partir dos dados deste trabalho é que, durante um determinado período, os antigos ceramistas de Lago Grande e Osvaldo utilizaram fontes de argila comuns para produção de suas cerâmicas características, devido a algum grau de integração territorial, já que as amostras dos dois sítios não são caracterizadas por apenas um perfil distinto de concentrações químicas elementares; e ainda praticaram trocas comerciais, evidenciadas na semelhança regular no padrão de distribuição de cerâmicas Manacapuru nos grupos químicos de Lago Grande e Osvaldo.

Foi realizada uma comparação preliminar de PCA das amostras de Lago Grande e Osvaldo com amostras dos sítios Hatahara e Açutuba, também na Amazônia Central. A partir dos resultados, foi inferido um quadro de pouca variabilidade geoquímica das amostras entre esses quatro sítios arqueológicos. Uma das interpretações sugeridas para esse contexto foi que essa sobreposição geoquímica seria outro indicativo de uma rede extensa de trocas operante na região, que faria com que amostras com padrões geoquímicos similares pudessem ser encontradas nesses quatro sítios. Contudo, o aprofundamento desse estudo comparativo precisa ser realizado para interpretações mais assertivas, e verificar se esses padrões refletem essa rede mais extensa de trocas, a variabilidade geoquímica da região, ou outros fatores redutores dessa variabilidade, como a inserção de cacos moídos. Esse é um estímulo a trabalhos futuros que tragam novas informações arqueométricas.

De qualquer forma, por Lago Grande e Osvaldo representarem um microcosmo da Amazônia Central, os dados deste trabalho corroboram a hipótese de redes de troca atuantes entre povos habitantes da região estudada, indo ao encontro de teorias que questionam o determinismo ambiental como vetor para o entendimento dos processos de ocupação da Amazônia Central pré-colonial. 
Não foram encontradas correlações evidentes dos grupos químicos com a estratigrafia, unidade de proveniência dentro dos sítios e tipo de objeto cerâmico, a partir dos resultados deste trabalho.

Nas análises de difração de raios $X$, foi constatado que os minerais caulinita, ilita e smectita podem ser esperados nos sedimentos da região da Amazônia Central, em concordância com trabalhos na literatura. $\mathrm{Na}$ análise de cauixi, foi identificado um pico largo entre $15^{\circ}$ e $30^{\circ}$, característico de sílica amorfa, a constituinte principal das espículas biogênicas dessa esponja de água doce. Para os dois sítios estudados, não se verificou nenhuma correlação evidente dos grupos químicos aos quais os fragmentos pertencem e a presença de algum mineral específico, pelos dois cenários de interesse. Desvios na correlação entre a presença de feldspatos e as concentrações de sódio e potássio foram interpretados como indícios adicionais de que mecanismos de enriquecimento estejam ocorrendo para esses dois elementos químicos.

Pela ausência de caulinita, presença de ilita-muscovita, e pela ausência de minerais formados em queima a altas temperaturas nos difratogramas de cerâmicas de Lago Grande e Osvaldo, concluiu-se que as temperaturas de queima das cerâmicas analisadas estão dentro da faixa $500-900{ }^{\circ} \mathrm{C}$. As temperaturas de queima determinadas por ressonância paramagnética eletrônica estão dentro desse intervalo, mais próximas de seu limite inferior, compreendendo temperaturas menores que $600{ }^{\circ} \mathrm{C}$ para todos os fragmentos, com exceção de uma amostra de Lago Grande, proveniente de nível estratigráfico profundo $(120-130 \mathrm{~cm})$. Não foram encontradas variações nos resultados em relação aos grupos químicos nos quais as amostras foram classificadas. Ainda, esses valores estão na mesma faixa das temperaturas de queima determinadas por Nunes (2009) para o sítio Hatahara. Pelos resultados de EPR, inferiu-se que os antigos ceramistas de Osvaldo e Lago Grande não utilizavam fornos na produção das cerâmicas Manacapuru e Paredão.

Recomenda-se a análise de mais amostras por XRD e outras técnicas que possam identificar minerais que são de difícil determinação por difração de raios X, para melhorar a caracterização da estrutura mineralógica dos fragmentos cerâmicos de Lago Grande e Osvaldo, o que poderia ajudar na discriminação de grupos químicos. Além disso, a determinação de outros minerais poderia auxiliar no refinamento da estimativa de temperaturas de queima, para comparação com a técnica de EPR. 
As idades de cinco fragmentos cerâmicos, três de Osvaldo e dois de Lago Grande, foram estimadas pela técnica de datação por luminescência opticamente estimulada. Verificou-se que ignorar o conteúdo de água nas amostras e sedimentos adicionaria entre 202 e 262 anos às idades determinadas, fazendo com que os fragmentos cerâmicos fossem considerados supostamente mais novos, com idades que não estão de acordo com o esperado segundo datações por ${ }^{14} \mathrm{C}$. As datas para os dois fragmentos de Lago Grande (967 \pm 477 e $1154 \pm 62$ a.C.) estão em concordância com o intervalo de ocupação considerado para o sítio na literatura, do século VIII até o século XII d.C. Já as datas obtidas para os três fragmentos cerâmicos de Osvaldo, são mais recentes que o esperado. Sugeriu-se a ampliação da amostragem, a análise mais sistemática de sedimentos na confluência dos rios Negro e Solimões, e a instalação de dosímetros luminescentes na região, para refinamento na aplicação da técnica, comparação com as datas obtidas neste trabalho e datações por ${ }^{14} \mathrm{C}$ na literatura, e considerações mais conclusivas acerca da cronologia de ocupação de Osvaldo e Lago Grande por OSL.

O objetivo principal deste trabalho foi fornecer material adicional para as discussões arqueológicas por meio de novas informações geradas na análise do registro arqueológico cerâmico de Lago Grande e Osvaldo, considerados como um microcosmo da Amazônia Central. A existência de redes de troca, dentro de um contexto mais amplo de esfera de interações, tem implicações para a discussão da emergência da complexidade social na floresta tropical amazônica, questionando modelos baseados no determinismo ambiental, e relativizando o papel de limitações ambientais inerentes à floresta tropical como fatores limitantes para o aparecimento de sociedades sedentárias e de crescimento demográfico entre as populações ameríndias pré-coloniais (Heckenberger et al., 1999). 


\section{CONSIDERAÇÕES FINAIS}

Em relação aos sítios estudados, há ainda três unidades de escavação em Lago Grande que não foram analisadas do ponto de vista arqueométrico. Essas análises podem ser úteis para revelar novos padrões que, porventura, o universo amostral deste trabalho não tenha evidenciado, embora a amostragem tenha sido adequada para a hipótese testada acerca de redes de troca. Além disso, outros projetos que visem responder a perguntas específicas da arqueologia da região só poderão ser propostos de maneira adequada após a devida caracterização de sedimentos argilosos da Amazônia Central, para estudar a variabilidade geoquímica na região.

A análise de mais sítios escavados no âmbito do Projeto Amazônia Central poderá permitir a análise de relações entre o registro arqueológico dos sítios; novas hipóteses poderão ser testadas; hipóteses recorrentes reiteradas ou refutadas; novos grupos químicos elementares poderão ser criados, caracterizados e discriminados, podendo formar grupos de referência para estudos futuros, contra os quais amostras desconhecidas poderão ser projetadas. Além disso, o aprofundamento de trabalhos arqueométricos na região poderá ser útil para tratar de questões como a existência de redes regionais de interação atuantes na Amazônia Central. Esse estado de conhecimento poderá ser atingido pela integração crescente de projetos de caracterização físico-química de cerâmicas arqueológicas de sítios escavados na região de confluência, como o Hatahara (Nunes, 2009), e Osvaldo e Lago Grande, neste trabalho.

Há uma grande incógnita sobre o futuro da técnica de análise por ativação com nêutrons em longo prazo, devido, principalmente, ao descomissionamento gradual de reatores nucleares (fonte principal de nêutrons para irradiação). Assim, recomenda-se que os dados obtidos por INAA sejam comparados aos dados obtidos por outras técnicas que poderão substituí-la, como a ICP-MS, verificando sua compatibilidade e definindo fatores de intercalibração, de forma que o banco de dados obtidos por trabalhos que utilizem nêutrons para irradiação esteja disponível para futuros pesquisadores que, porventura, utilizem outras técnicas que sejam dominantes em seu tempo (Pollard et al., 2007, pp. 134136). 
APÊNDICE A - Concentrações elementares no material de referência IAEA-Soil-7 por INAA. Concentrações em $\mu \mathrm{g} \cdot \mathrm{g}^{-1}$ quando não indicado.

\begin{tabular}{|c|c|c|c|c|c|}
\hline Irradiação & Mat. Ref. & As & $\mathrm{K}(\mathrm{mg} / \mathrm{g})$ & $\mathbf{L a}$ & Lu (ng/g) \\
\hline $02 / 06 / 2003$ & Briver/FFA & $16,4 \pm 0,7$ & $11,3 \pm 1,5$ & $30,2 \pm 2,1$ & $330 \pm 27$ \\
\hline $25 / 08 / 2003$ & srm1633b & $19,9 \pm 0,7$ & $12,2 \pm 4,0$ & $30,6 \pm 0,3$ & $405 \pm 22$ \\
\hline $09 / 02 / 2004$ & srm $1633 b$ & $14,2 \pm 0,4$ & $10,5 \pm 1,3$ & $31,1 \pm 0,2$ & $352 \pm 17$ \\
\hline $10 / 02 / 2004$ & $\operatorname{srm} 1633 b$ & $14,9 \pm 0,5$ & $14,4 \pm 2,6$ & $30,6 \pm 0,2$ & $419 \pm 18$ \\
\hline 05/07/2004 & $\operatorname{srm} 1633 b$ & $14,9 \pm 0,4$ & $14,2 \pm 1,5$ & $31,4 \pm 0,3$ & $353 \pm 18$ \\
\hline 06/07/2004 & $\operatorname{srm} 1633 b$ & $20,6 \pm 1,0$ & $17,2 \pm 9,1$ & $30,6 \pm 0,4$ & $381 \pm 18$ \\
\hline $12 / 07 / 2004$ & srm1633b & $14,9 \pm 0,4$ & $11,8 \pm 1,6$ & $28,5 \pm 0,2$ & $351 \pm 15$ \\
\hline 02/09/2004 & $\operatorname{srm} 1633 b$ & $15,4 \pm 0,5$ & $13,1 \pm 2,4$ & $30,3 \pm 0,3$ & $343 \pm 19$ \\
\hline $08 / 12 / 2004$ & srm1633b & $20 \pm 0,7$ & $9,9 \pm 8,8$ & $31,9 \pm 0,2$ & $392 \pm 15$ \\
\hline $13 / 12 / 2004$ & srm1633b & $16,1 \pm 0,5$ & $13,5 \pm 2,1$ & $30,2 \pm 0,3$ & $364 \pm 23$ \\
\hline $12 / 01 / 2005$ & $\operatorname{srm} 1633 b$ & $14,8 \pm 0,5$ & $11,2 \pm 1,6$ & $30,1 \pm 0,4$ & $407 \pm 38$ \\
\hline 25/01/2005 & srm $1633 b$ & $11,2 \pm 0,5$ & $10,6 \pm 3,6$ & $30,0 \pm 0,3$ & $350 \pm 23$ \\
\hline $17 / 08 / 2009$ & srm1633b & $14,1 \pm 0,8$ & $11,2 \pm 3,9$ & $29,2 \pm 0,6$ & $451 \pm 67$ \\
\hline 24/08/2009 & srm1633b & $15,6 \pm 0,4$ & $13,1 \pm 0,4$ & $32,3 \pm 0,4$ & $219 \pm 71$ \\
\hline 09/09/2009 & srm1633b & $14,3 \pm 0,5$ & $11,2 \pm 2,3$ & $30,7 \pm 0,3$ & $256 \pm 17$ \\
\hline $23 / 11 / 2009$ & $\operatorname{srm} 1633 b$ & $13,4 \pm 0,6$ & $7,9 \pm 2,8$ & $27,2 \pm 0,3$ & $358 \pm 16$ \\
\hline $07 / 12 / 2009$ & srm1633b & $15,0 \pm 0,5$ & $13,6 \pm 2,3$ & $32,3 \pm 0,3$ & $428 \pm 37$ \\
\hline $09 / 12 / 2009$ & srm1633b & $16,0 \pm 0,5$ & $15,6 \pm 3,3$ & $32,5 \pm 0,3$ & $363 \pm 30$ \\
\hline $02 / 03 / 2010$ & srm1633b & $13,3 \pm 0,4$ & $12,0 \pm 1,1$ & $28,0 \pm 0,2$ & $335 \pm 12$ \\
\hline 06/10/2010 & srm1633b & $15,0 \pm 0,5$ & $9,9 \pm 1,5$ & $31,3 \pm 0,5$ & $355 \pm 18$ \\
\hline $13 / 10 / 2010$ & srm1633b & $13,2 \pm 0,4$ & $13,0 \pm 1,9$ & $30,5 \pm 0,5$ & $333 \pm 11$ \\
\hline $18 / 10 / 2010$ & srm1633b & $14,9 \pm 0,4$ & $12,6 \pm 1,3$ & $31,3 \pm 0,4$ & $408 \pm 19$ \\
\hline $20 / 10 / 2010$ & srm1633b & $15,7 \pm 0,5$ & $14,4 \pm 1,7$ & $31,8 \pm 0,4$ & $377 \pm 10$ \\
\hline $01 / 11 / 2010$ & srm $1633 b$ & $14,8 \pm 0,4$ & $13,6 \pm 1,3$ & $30,4 \pm 0,4$ & $408 \pm 19$ \\
\hline $17 / 11 / 2010$ & srm $1633 b$ & $15,7 \pm 0,4$ & $12,9 \pm 0,9$ & $30,7 \pm 0,4$ & $374 \pm 10$ \\
\hline $01 / 11 / 2011$ & srm1633b & $14,6 \pm 0,4$ & $13,1 \pm 1,8$ & $30,2 \pm 0,2$ & $320 \pm 19$ \\
\hline $08 / 11 / 2011$ & srm1633b & $10,9 \pm 0,5$ & - & $31,0 \pm 0,3$ & $369 \pm 24$ \\
\hline $14 / 11 / 2011$ & srm1633b & $15,7 \pm 0,4$ & $12,5 \pm 1,6$ & $32,1 \pm 0,2$ & $365 \pm 23$ \\
\hline $16 / 11 / 2011$ & srm1633b & $14,0 \pm 0,5$ & $11,3 \pm 2,2$ & $30,4 \pm 0,3$ & $359 \pm 25$ \\
\hline 07/02/2012 & srm1633b & $14,7 \pm 0,4$ & $13,9 \pm 0,8$ & $30,7 \pm 0,2$ & $355 \pm 20$ \\
\hline $25 / 04 / 2012$ & srm1633b & $15,0 \pm 0,8$ & - & $29,2 \pm 0,4$ & $343 \pm 31$ \\
\hline $19 / 02 / 2013$ & srm1633b & $14,3 \pm 0,4$ & $13,2 \pm 1,6$ & $29,7 \pm 0,3$ & $374 \pm 18$ \\
\hline 20/02/2013 & srm1633b & $15,8 \pm 0,4$ & $13,9 \pm 0,9$ & $30,8 \pm 0,2$ & $401 \pm 17$ \\
\hline $26 / 02 / 2013$ & srm1633b & $15,3 \pm 0,4$ & $12,9 \pm 0,9$ & $31,5 \pm 0,3$ & $375 \pm 24$ \\
\hline
\end{tabular}




\begin{tabular}{|c|c|c|c|c|c|}
\hline Irradiação & $\mathrm{Na}(\mathrm{mg} / \mathrm{g})$ & Nd & Sb & $\mathrm{Sm}$ & $\mathbf{U}$ \\
\hline 02/06/2003 & $2,17 \pm 0,06$ & $31 \pm 8$ & $1,3 \pm 0,4$ & $12,34 \pm 0,74$ & $2,6 \pm 0,2$ \\
\hline 25/08/2003 & $2,34 \pm 0,08$ & $27 \pm 8$ & $1,9 \pm 0,4$ & $1,93 \pm 0,03$ & $2,3 \pm 0,3$ \\
\hline 09/02/2004 & $2,39 \pm 0,05$ & $30 \pm 7$ & $1,9 \pm 0,6$ & $4,21 \pm 0,01$ & $2,5 \pm 0,3$ \\
\hline $10 / 02 / 2004$ & $2,33 \pm 0,06$ & $27 \pm 9$ & $1,4 \pm 0,6$ & $5,43 \pm 0,07$ & $1,4 \pm 0,7$ \\
\hline 05/07/2004 & $2,48 \pm 0,05$ & $16 \pm 6$ & - & $0,84 \pm 0,01$ & $2,8 \pm 0,5$ \\
\hline 06/07/2004 & $2,59 \pm 0,12$ & - & $1,7 \pm 0,6$ & $4,75 \pm 0,11$ & $2,0 \pm 0,7$ \\
\hline $12 / 07 / 2004$ & $2,20 \pm 0,05$ & $26 \pm 6$ & $1,3 \pm 0,5$ & $9,79 \pm 0,04$ & $2,5 \pm 0,2$ \\
\hline 02/09/2004 & $2,24 \pm 0,05$ & $26 \pm 7$ & $1,9 \pm 0,6$ & $12,47 \pm 0,05$ & $2,2 \pm 0,4$ \\
\hline 08/12/2004 & $2,32 \pm 0,09$ & $21 \pm 5$ & $2,4 \pm 0,4$ & $14,09 \pm 0,1$ & $2,7 \pm 0,4$ \\
\hline $13 / 12 / 2004$ & $2,37 \pm 0,06$ & $20 \pm 6$ & $2,1 \pm 0,6$ & $3,65 \pm 0,02$ & $2,6 \pm 0,4$ \\
\hline $12 / 01 / 2005$ & $2,34 \pm 0,05$ & $19 \pm 10$ & - & $4,05 \pm 0,03$ & $2,6 \pm 0,8$ \\
\hline 25/01/2005 & $2,16 \pm 0,07$ & $26 \pm 10$ & $0,9 \pm 0,5$ & $2,38 \pm 0,04$ & $1,9 \pm 0,6$ \\
\hline $17 / 08 / 2009$ & $2,29 \pm 0,09$ & - & - & $7,93 \pm 0,14$ & $5,0 \pm 2,5$ \\
\hline 24/08/2009 & $2,51 \pm 0,04$ & - & - & $5,80 \pm 0,03$ & $1,3 \pm 1,0$ \\
\hline 09/09/2009 & $2,24 \pm 0,06$ & $25 \pm 12$ & - & $5,61 \pm 0,04$ & $2,1 \pm 0,4$ \\
\hline 23/11/2009 & $2,04 \pm 0,06$ & $18 \pm 7$ & - & $3,96 \pm 0,03$ & $2,7 \pm 0,8$ \\
\hline 07/12/2009 & $2,36 \pm 0,06$ & - & - & $2,47 \pm 0,03$ & $2,2 \pm 0,4$ \\
\hline 09/12/2009 & $2,40 \pm 0,06$ & $25 \pm 9$ & $3,2 \pm 0,9$ & $2,98 \pm 0,03$ & $3,0 \pm 0,5$ \\
\hline 02/03/2010 & $2,11 \pm 0,04$ & $19 \pm 7$ & - & $2,91 \pm 0,02$ & $1,7 \pm 0,4$ \\
\hline 06/10/2010 & $2,39 \pm 0,06$ & $31 \pm 6$ & - & $5,78 \pm 0,03$ & $2,9 \pm 0,4$ \\
\hline $13 / 10 / 2010$ & $2,32 \pm 0,07$ & $30 \pm 5$ & - & $5,20 \pm 0,03$ & $2,8 \pm 0,5$ \\
\hline $18 / 10 / 2010$ & $2,45 \pm 0,06$ & $27 \pm 6$ & - & $5,61 \pm 0,02$ & $2,5 \pm 0,4$ \\
\hline 20/10/2010 & $2,43 \pm 0,06$ & $29 \pm 5$ & - & $5,63 \pm 0,03$ & $2,4 \pm 0,4$ \\
\hline 01/11/2010 & $2,32 \pm 0,06$ & $17 \pm 4$ & - & $5,56 \pm 0,03$ & $1,9 \pm 0,3$ \\
\hline $17 / 11 / 2010$ & $2,44 \pm 0,05$ & $26 \pm 5$ & - & $5,56 \pm 0,02$ & $2,0 \pm 0,3$ \\
\hline 01/11/2011 & $2,30 \pm 0,05$ & $36 \pm 8$ & $1,9 \pm 0,7$ & $6,15 \pm 0,05$ & $2,4 \pm 0,4$ \\
\hline 08/11/2011 & $2,30 \pm 0,09$ & $53 \pm 13$ & $1,7 \pm 0,9$ & $4,64 \pm 0,07$ & $2,8 \pm 0,7$ \\
\hline $14 / 11 / 2011$ & $2,45 \pm 0,05$ & $25 \pm 8$ & - & $4,23 \pm 0,02$ & $2,2 \pm 0,2$ \\
\hline $16 / 11 / 2011$ & $2,34 \pm 0,06$ & $27 \pm 9$ & - & $4,36 \pm 0,07$ & $2,7 \pm 0,3$ \\
\hline 07/02/2012 & $2,35 \pm 0,04$ & $24 \pm 9$ & - & $5,49 \pm 0,05$ & $3,3 \pm 0,3$ \\
\hline 25/04/2012 & $2,26 \pm 0,11$ & $23 \pm 9$ & $2,0 \pm 0,6$ & $2,19 \pm 0,03$ & $2,2 \pm 0,8$ \\
\hline $19 / 02 / 2013$ & $2,40 \pm 0,05$ & $22 \pm 7$ & - & $5,74 \pm 0,02$ & $1,6 \pm 0,4$ \\
\hline 20/02/2013 & $2,55 \pm 0,05$ & $29 \pm 7$ & $3,1 \pm 1,0$ & $6,25 \pm 0,02$ & $2,9 \pm 0,4$ \\
\hline 26/02/2013 & $2,37 \pm 0,04$ & $20 \pm 9$ & - & $5,62 \pm 0,03$ & $3,1 \pm 0,5$ \\
\hline
\end{tabular}




\begin{tabular}{|c|c|c|c|c|c|}
\hline Irradiação & $\mathbf{Y b}$ & $\mathbf{B a}$ & $\mathrm{Ce}$ & Co & $\mathrm{Cr}$ \\
\hline $02 / 06 / 2003$ & $2,32 \pm 0,14$ & - & - & - & - \\
\hline 25/08/2003 & $2,05 \pm 0,08$ & - & - & - & - \\
\hline 09/02/2004 & $2,25 \pm 0,07$ & $182 \pm 98$ & $57 \pm 1$ & $9,1 \pm 0,2$ & $70 \pm 3$ \\
\hline $10 / 02 / 2004$ & $2,39 \pm 0,08$ & - & $57 \pm 1$ & $8,5 \pm 0,3$ & $70 \pm 3$ \\
\hline 05/07/2004 & $2,14 \pm 0,11$ & - & $61 \pm 1$ & $9,4 \pm 0,2$ & $73 \pm 3$ \\
\hline 06/07/2004 & $2,20 \pm 0,13$ & $541 \pm 404$ & $62 \pm 1$ & $9,2 \pm 0,2$ & $70 \pm 3$ \\
\hline $12 / 07 / 2004$ & $2,11 \pm 0,07$ & - & $53 \pm 1$ & $8,5 \pm 0,2$ & $63 \pm 3$ \\
\hline 02/09/2004 & $2,31 \pm 0,09$ & - & $59 \pm 1$ & $9,1 \pm 0,3$ & $69 \pm 3$ \\
\hline $08 / 12 / 2004$ & $2,31 \pm 0,07$ & $207 \pm 73$ & $61 \pm 1$ & $9,3 \pm 0,2$ & $69 \pm 2$ \\
\hline $13 / 12 / 2004$ & $2,23 \pm 0,10$ & - & $57 \pm 1$ & $8,7 \pm 0,2$ & $68 \pm 3$ \\
\hline $12 / 01 / 2005$ & $2,48 \pm 0,17$ & - & $59 \pm 1$ & $9,5 \pm 0,4$ & $68 \pm 4$ \\
\hline 25/01/2005 & $2,11 \pm 0,10$ & - & $57 \pm 1$ & $9,1 \pm 0,4$ & $65 \pm 4$ \\
\hline $17 / 08 / 2009$ & $2,03 \pm 0,27$ & - & $68 \pm 5$ & $8,5 \pm 0,7$ & $60 \pm 9$ \\
\hline 24/08/2009 & $2,80 \pm 0,37$ & - & $61 \pm 3$ & $9,3 \pm 0,7$ & $77 \pm 11$ \\
\hline 09/09/2009 & $2,33 \pm 0,14$ & - & $61 \pm 2$ & $9,1 \pm 0,3$ & $72 \pm 4$ \\
\hline $23 / 11 / 2009$ & $2,35 \pm 0,13$ & - & $74 \pm 2$ & $9,6 \pm 0,4$ & $74 \pm 3$ \\
\hline 07/12/2009 & $2,08 \pm 0,12$ & - & $57 \pm 2$ & $9,6 \pm 0,4$ & $70 \pm 4$ \\
\hline 09/12/2009 & $2,37 \pm 0,11$ & - & $72 \pm 2$ & $10,3 \pm 0,4$ & $81 \pm 4$ \\
\hline 02/03/2010 & $2,22 \pm 0,11$ & - & $106 \pm 4$ & $9,2 \pm 0,3$ & $66 \pm 3$ \\
\hline 06/10/2010 & $2,38 \pm 0,09$ & - & $63 \pm 2$ & $8,8 \pm 0,3$ & $65 \pm 5$ \\
\hline $13 / 10 / 2010$ & $2,32 \pm 0,09$ & - & $55 \pm 1$ & $8,3 \pm 0,5$ & $69 \pm 4$ \\
\hline $18 / 10 / 2010$ & $2,52 \pm 0,08$ & - & $74 \pm 2$ & $9,1 \pm 0,5$ & $73 \pm 3$ \\
\hline 20/10/2010 & $2,52 \pm 0,08$ & - & $61 \pm 2$ & $9,4 \pm 0,5$ & $72 \pm 3$ \\
\hline $01 / 11 / 2010$ & $2,27 \pm 0,08$ & - & $54 \pm 2$ & $8,8 \pm 0,5$ & $72 \pm 3$ \\
\hline $17 / 11 / 2010$ & $2,39 \pm 0,08$ & $91 \pm 47$ & $58 \pm 2$ & $8,6 \pm 0,4$ & $68 \pm 2$ \\
\hline 01/11/2011 & $1,98 \pm 0,10$ & - & - & - & - \\
\hline 08/11/2011 & $2,25 \pm 0,10$ & - & $60 \pm 1$ & $8,6 \pm 0,3$ & $69 \pm 4$ \\
\hline $14 / 11 / 2011$ & $2,54 \pm 0,11$ & - & $62 \pm 1$ & $9,1 \pm 0,3$ & $71 \pm 4$ \\
\hline $16 / 11 / 2011$ & $2,26 \pm 0,11$ & - & $57 \pm 1$ & $8,3 \pm 0,3$ & $66 \pm 4$ \\
\hline 07/02/2012 & $2,36 \pm 0,09$ & $304 \pm 175$ & $60 \pm 1$ & $9,7 \pm 0,3$ & $69 \pm 4$ \\
\hline 25/04/2012 & $2,36 \pm 0,13$ & $172 \pm 304$ & $54 \pm 1$ & $8,5 \pm 0,3$ & $66 \pm 4$ \\
\hline $19 / 02 / 2013$ & $2,27 \pm 0,08$ & - & $56 \pm 2$ & $8,5 \pm 0,3$ & $69 \pm 3$ \\
\hline 20/02/2013 & $2,22 \pm 0,07$ & - & $63 \pm 1$ & $9,0 \pm 0,3$ & $76 \pm 3$ \\
\hline $26 / 02 / 2013$ & $2,27 \pm 0,10$ & - & $68 \pm 2$ & $9,6 \pm 0,4$ & $76 \pm 4$ \\
\hline
\end{tabular}




\begin{tabular}{|c|c|c|c|c|c|}
\hline Irradiação & Cs & $\mathbf{E u}$ & $\mathrm{Fe}(\mathrm{mg} / \mathrm{g})$ & Hf & $\mathbf{R b}$ \\
\hline $02 / 06 / 2003$ & - & - & - & - & - \\
\hline $25 / 08 / 2003$ & - & - & - & - & - \\
\hline 09/02/2004 & $5,9 \pm 0,2$ & $0,96 \pm 0,05$ & $26,7 \pm 0,8$ & $5,4 \pm 0,3$ & $55 \pm 5$ \\
\hline $10 / 02 / 2004$ & $5,6 \pm 0,3$ & $1,09 \pm 0,07$ & $26,4 \pm 0,9$ & $4,8 \pm 0,4$ & $42 \pm 6$ \\
\hline 05/07/2004 & $5,8 \pm 0,2$ & $1,02 \pm 0,05$ & $27,4 \pm 0,9$ & $5,2 \pm 0,3$ & $51 \pm 6$ \\
\hline 06/07/2004 & $5,4 \pm 0,3$ & $1,10 \pm 0,05$ & $26,2 \pm 0,8$ & $5,1 \pm 0,2$ & $48 \pm 3$ \\
\hline $12 / 07 / 2004$ & $4,9 \pm 0,2$ & $0,93 \pm 0,04$ & $24,1 \pm 0,8$ & $5,2 \pm 0,3$ & $36 \pm 5$ \\
\hline 02/09/2004 & $5,1 \pm 0,4$ & $1,06 \pm 0,07$ & $25,0 \pm 0,8$ & $4,3 \pm 0,3$ & $54 \pm 7$ \\
\hline $08 / 12 / 2004$ & $5,7 \pm 0,2$ & $1,05 \pm 0,04$ & $27,2 \pm 0,8$ & $5,0 \pm 0,2$ & $48 \pm 4$ \\
\hline $13 / 12 / 2004$ & $5,1 \pm 0,3$ & $1,14 \pm 0,06$ & $26,3 \pm 0,8$ & $5,0 \pm 0,3$ & $56 \pm 8$ \\
\hline $12 / 01 / 2005$ & $5,7 \pm 0,6$ & $1,17 \pm 0,10$ & $25,5 \pm 0,9$ & $5,2 \pm 0,5$ & $49 \pm 8$ \\
\hline $25 / 01 / 2005$ & $5,4 \pm 0,6$ & $1,06 \pm 0,09$ & $25,0 \pm 0,9$ & $4,7 \pm 0,4$ & $24 \pm 12$ \\
\hline $17 / 08 / 2009$ & $7,3 \pm 2,0$ & $1,01 \pm 0,18$ & $26,2 \pm 1,2$ & $4,7 \pm 0,9$ & - \\
\hline $24 / 08 / 2009$ & $6,6 \pm 1,4$ & $0,88 \pm 0,18$ & $27,7 \pm 1,3$ & $4,2 \pm 0,7$ & - \\
\hline 09/09/2009 & $6,4 \pm 0,8$ & $0,88 \pm 0,08$ & $26,1 \pm 1,0$ & $4,9 \pm 0,7$ & - \\
\hline $23 / 11 / 2009$ & $6,3 \pm 0,8$ & $0,99 \pm 0,09$ & $28,3 \pm 1,0$ & $5,1 \pm 0,6$ & $56 \pm 9$ \\
\hline $07 / 12 / 2009$ & $6,0 \pm 0,8$ & $0,90 \pm 0,09$ & $25 \pm 0,90$ & $4,9 \pm 0,6$ & $58 \pm 37$ \\
\hline 09/12/2009 & $6,8 \pm 0,8$ & $1,21 \pm 0,10$ & $30,4 \pm 1,1$ & $5,9 \pm 0,6$ & $63 \pm 13$ \\
\hline 02/03/2010 & $6,0 \pm 0,7$ & $1,20 \pm 0,09$ & $26,6 \pm 0,9$ & $4,5 \pm 0,5$ & $12 \pm 10$ \\
\hline 06/10/2010 & $5,3 \pm 0,7$ & $1,03 \pm 0,08$ & $26,5 \pm 0,9$ & $4,9 \pm 0,4$ & $52 \pm 8$ \\
\hline $13 / 10 / 2010$ & $5,1 \pm 1,1$ & $1,07 \pm 0,08$ & $24,4 \pm 0,8$ & $5,0 \pm 0,3$ & $43 \pm 5$ \\
\hline $18 / 10 / 2010$ & $6,3 \pm 1,2$ & $1,15 \pm 0,08$ & $26,1 \pm 0,9$ & $5,4 \pm 0,3$ & $58 \pm 6$ \\
\hline 20/10/2010 & $5,9 \pm 0,9$ & $1,23 \pm 0,08$ & $26,6 \pm 0,9$ & $5,1 \pm 0,3$ & $41 \pm 5$ \\
\hline $01 / 11 / 2010$ & $5,9 \pm 1,0$ & $1,10 \pm 0,08$ & $26,3 \pm 0,9$ & $4,6 \pm 0,3$ & $57 \pm 7$ \\
\hline $17 / 11 / 2010$ & $4,6 \pm 0,8$ & $1,07 \pm 0,07$ & $25,7 \pm 0,8$ & $5,0 \pm 0,3$ & $56 \pm 6$ \\
\hline $01 / 11 / 2011$ & - & - & - & - & - \\
\hline $08 / 11 / 2011$ & $5,1 \pm 0,6$ & $1,14 \pm 0,08$ & $26,9 \pm 0,9$ & $5,6 \pm 0,4$ & $51 \pm 7$ \\
\hline $14 / 11 / 2011$ & $5,9 \pm 0,5$ & $1,14 \pm 0,08$ & $27,5 \pm 0,9$ & $5,2 \pm 0,4$ & $58 \pm 7$ \\
\hline $16 / 11 / 2011$ & $5,8 \pm 0,7$ & $0,97 \pm 0,08$ & $25,4 \pm 0,9$ & $4,9 \pm 0,3$ & $52 \pm 7$ \\
\hline $07 / 02 / 2012$ & $5,2 \pm 0,5$ & $1,03 \pm 0,07$ & $26,8 \pm 0,9$ & $4,3 \pm 0,4$ & $48 \pm 7$ \\
\hline $25 / 04 / 2012$ & $5,6 \pm 0,5$ & $1,08 \pm 0,07$ & $25,5 \pm 0,8$ & $5,0 \pm 0,4$ & $80 \pm 18$ \\
\hline $19 / 02 / 2013$ & $4,9 \pm 0,4$ & $0,94 \pm 0,08$ & $25,3 \pm 0,8$ & $4,8 \pm 0,3$ & $50 \pm 10$ \\
\hline $20 / 02 / 2013$ & $5,9 \pm 0,4$ & $1,01 \pm 0,07$ & $26,7 \pm 0,9$ & $5,8 \pm 0,4$ & $64 \pm 9$ \\
\hline $26 / 02 / 2013$ & $5,6 \pm 0,6$ & $1,05 \pm 0,10$ & $26,7 \pm 0,9$ & $5,3 \pm 0,4$ & $65 \pm 13$ \\
\hline
\end{tabular}




\begin{tabular}{|c|c|c|c|c|c|}
\hline Irradiação & Sc & Ta (ng/g) & Tb (ng/g) & Th & $\mathbf{Z n}$ \\
\hline $02 / 06 / 2003$ & - & - & - & - & - \\
\hline $25 / 08 / 2003$ & - & - & - & - & - \\
\hline 09/02/2004 & $8,67 \pm 0,05$ & $763 \pm 88$ & $611 \pm 178$ & $8,1 \pm 0,4$ & $100 \pm 4$ \\
\hline $10 / 02 / 2004$ & $8,47 \pm 0,06$ & $409 \pm 69$ & $579 \pm 187$ & $8,1 \pm 0,5$ & $97 \pm 6$ \\
\hline 05/07/2004 & $8,96 \pm 0,04$ & $726 \pm 73$ & $628 \pm 179$ & $8,3 \pm 0,4$ & $100 \pm 4$ \\
\hline 06/07/2004 & $8,64 \pm 0,04$ & $694 \pm 91$ & $910 \pm 129$ & $8,1 \pm 0,4$ & $102 \pm 4$ \\
\hline $12 / 07 / 2004$ & $7,90 \pm 0,04$ & $628 \pm 80$ & $490 \pm 152$ & $7,6 \pm 0,4$ & $97 \pm 4$ \\
\hline 02/09/2004 & $8,36 \pm 0,06$ & $1189 \pm 195$ & $344 \pm 168$ & $7,7 \pm 0,5$ & $99 \pm 6$ \\
\hline 08/12/2004 & $8,82 \pm 0,04$ & $759 \pm 66$ & $822 \pm 144$ & $8,6 \pm 0,5$ & $97 \pm 3$ \\
\hline $13 / 12 / 2004$ & $8,59 \pm 0,05$ & $910 \pm 165$ & $634 \pm 175$ & $8,3 \pm 0,5$ & $98 \pm 5$ \\
\hline $12 / 01 / 2005$ & $8,72 \pm 0,07$ & $803 \pm 152$ & $450 \pm 296$ & $8,1 \pm 0,5$ & $124 \pm 9$ \\
\hline $25 / 01 / 2005$ & $8,36 \pm 0,07$ & $922 \pm 285$ & $180 \pm 182$ & $8,4 \pm 0,5$ & $121 \pm 9$ \\
\hline 17/08/2009 & $8,64 \pm 0,16$ & - & - & $8,6 \pm 1,0$ & $356 \pm 115$ \\
\hline 24/08/2009 & $8,70 \pm 0,14$ & - & - & $7,7 \pm 1,0$ & $429 \pm 214$ \\
\hline 09/09/2009 & $8,29 \pm 0,07$ & $818 \pm 213$ & $459 \pm 127$ & $8,5 \pm 0,6$ & $91 \pm 7$ \\
\hline $23 / 11 / 2009$ & $9,42 \pm 0,07$ & $870 \pm 323$ & $634 \pm 129$ & $8,1 \pm 0,5$ & - \\
\hline $07 / 12 / 2009$ & $8,43 \pm 0,08$ & $200 \pm 129$ & $535 \pm 279$ & $8,2 \pm 0,6$ & $1238 \pm 540$ \\
\hline 09/12/2009 & $9,82 \pm 0,07$ & $611 \pm 223$ & $859 \pm 129$ & $9,5 \pm 0,6$ & $120 \pm 8$ \\
\hline 02/03/2010 & $8,88 \pm 0,06$ & $695 \pm 114$ & $535 \pm 98$ & $8,2 \pm 0,5$ & - \\
\hline 06/10/2010 & $8,44 \pm 0,06$ & $657 \pm 186$ & $545 \pm 106$ & $7,2 \pm 0,6$ & - \\
\hline $13 / 10 / 2010$ & $8,16 \pm 0,09$ & $546 \pm 152$ & $577 \pm 95$ & $7,6 \pm 0,5$ & $485 \pm 94$ \\
\hline $18 / 10 / 2010$ & $8,96 \pm 0,09$ & $843 \pm 167$ & $924 \pm 120$ & $8,7 \pm 0,5$ & $138 \pm 15$ \\
\hline 20/10/2010 & $8,78 \pm 0,09$ & $766 \pm 158$ & $459 \pm 86$ & $9,3 \pm 0,5$ & $180 \pm 27$ \\
\hline $01 / 11 / 2010$ & $8,50 \pm 0,09$ & $805 \pm 188$ & $650 \pm 100$ & $8,0 \pm 0,5$ & - \\
\hline $17 / 11 / 2010$ & $8,71 \pm 0,08$ & $685 \pm 178$ & $591 \pm 91$ & $10,3 \pm 0,6$ & - \\
\hline $01 / 11 / 2011$ & - & - & - & - & - \\
\hline 08/11/2011 & $8,74 \pm 0,06$ & $811 \pm 155$ & $865 \pm 334$ & $8,5 \pm 0,5$ & $101 \pm 6$ \\
\hline $14 / 11 / 2011$ & $8,93 \pm 0,06$ & $1000 \pm 216$ & $636 \pm 210$ & $8,4 \pm 0,5$ & - \\
\hline $16 / 11 / 2011$ & $8,61 \pm 0,07$ & $499 \pm 156$ & $203 \pm 209$ & $8,1 \pm 0,5$ & $112 \pm 7$ \\
\hline 07/02/2012 & $8,65 \pm 0,06$ & $845 \pm 169$ & $346 \pm 155$ & $7,7 \pm 0,5$ & $109 \pm 6$ \\
\hline 25/04/2012 & $8,24 \pm 0,06$ & $789 \pm 201$ & $868 \pm 321$ & $7,7 \pm 0,5$ & $102 \pm 6$ \\
\hline $19 / 02 / 2013$ & $8,28 \pm 0,06$ & $680 \pm 158$ & $474 \pm 230$ & $7,8 \pm 0,5$ & - \\
\hline 20/02/2013 & $8,98 \pm 0,06$ & $646 \pm 129$ & $762 \pm 215$ & $8,7 \pm 0,5$ & - \\
\hline 26/02/2013 & $9,16 \pm 0,08$ & $942 \pm 300$ & $644 \pm 283$ & $9,1 \pm 0,6$ & - \\
\hline
\end{tabular}


APÊNDICE B - Informações arqueológicas e concentrações elementares nos fragmentos cerâmicos de Lago Grande e Osvaldo por INAA. Concentrações em $\mu \mathrm{g}, \mathrm{g}^{-1}$ quando não indicado.

\begin{tabular}{|c|c|c|c|c|c|c|}
\hline Código & $\begin{array}{l}\text { Código } \\
\text { MAE }\end{array}$ & Sítio & Fase & Unidade & Prof. (cm) & Tipo \\
\hline CSQN58 & $12-55-5$ & Lago Grande & Paredão & 1 & $20-30$ & prato \\
\hline CSQN59 & $12-237$ & Lago Grande & Paredão & 1 & $120-130$ & prato raso \\
\hline CSQN60 & $12-57$ & Lago Grande & Paredão & 1 & $20-30$ & panela \\
\hline CSQN61 & $12-373-2$ & Lago Grande & Paredão & 1 & $0-10$ & panela \\
\hline CSQN62 & $12-80$ & Lago Grande & Paredão & 1 & $50-60$ & cabeça \\
\hline CSQN63 & $12-366$ & Lago Grande & Paredão & 1 & $120-130$ & cabeça \\
\hline CSQN64 & $12-120$ & Lago Grande & Paredão & 1 & $70-80$ & prato raso \\
\hline CSQN65 & $12-250-1$ & Lago Grande & Paredão & 1 & $120-130$ & vaso com pescoço \\
\hline CSQN66 & $12-79$ & Lago Grande & Paredão & 1 & $50-60$ & cesta com alça \\
\hline CSQN67 & $12-85-9$ & Lago Grande & Paredão & 1 & $60-70$ & cuia pintada \\
\hline CSQN68 & $12-370$ & Lago Grande & Paredão & 1 & $20-30$ & cuia pintada \\
\hline CSQN70 & $12-52-14$ & Lago Grande & Paredão & 1 & $10-20$ & prato raso \\
\hline CSQN72 & $12-55-20$ & Lago Grande & Paredão & 1 & $20-30$ & cabeça \\
\hline CSQN73 & $12-62-1$ & Lago Grande & Paredão & 1 & $20-30$ & prato \\
\hline CSQN74 & $12-96$ & Lago Grande & Paredão & 1 & $70-80$ & cuia pintada \\
\hline CSQN75 & $12-228$ & Lago Grande & Paredão & 1 & $110-120$ & vaso com pescoço \\
\hline CSQN76 & $12-55-27$ & Lago Grande & Paredão & 1 & $20-30$ & copo \\
\hline CSQN77 & $12-72-6$ & Lago Grande & Paredão & 1 & $40-50$ & copo \\
\hline CSQN78 & $12-94$ & Lago Grande & Paredão & 1 & $70-80$ & vaso com pescoço \\
\hline CSQN79 & $12-219$ & Lago Grande & Paredão & 1 & $100-110$ & alça \\
\hline CSQN80 & $12-260$ & Lago Grande & Paredão & 1 & $130-140$ & copo \\
\hline CSQN81 & $12-115-1$ & Lago Grande & Paredão & 1 & $70-80$ & prato \\
\hline CSQN82 & $7-202$ & Osvaldo & - & S710 E1966 & $10-20$ & - \\
\hline CSQN83 & $7-205$ & Osvaldo & - & S710 E1966 & $20-30$ & - \\
\hline CSQN84 & $7-219$ & Osvaldo & - & S710 E1966 & $30-40$ & - \\
\hline CSQN85 & $7-358$ & Osvaldo & - & S710 E1966 & $40-50$ & - \\
\hline CSQN86 & $7-394$ & Osvaldo & - & S710 E1966 & $50-60$ & - \\
\hline CSQN87 & $7-431$ & Osvaldo & - & S710 E1966 & $60-70$ & - \\
\hline CSQN88 & $7-454$ & Osvaldo & - & S710 E1966 & $70-80$ & - \\
\hline CSQN89 & $7-471$ & Osvaldo & - & S710 E1966 & $80-90$ & - \\
\hline CSQN90 & - & Osvaldo & Paredão & S710 E1966 & $20-30$ & - \\
\hline CSQN91 & - & Osvaldo & Paredão & S710 E1966 & $30-40$ & - \\
\hline CSQN92 & - & Osvaldo & Paredão & S710 E1966 & $50-60$ & - \\
\hline CSQN93 & - & Osvaldo & Paredão & S710 E1966 & $60-70$ & - \\
\hline CSQN94 & - & Osvaldo & Paredão & S710 E1966 & $70-80$ & - \\
\hline CSQN95 & $7-206$ & Osvaldo & Paredão & S710 E1966 & $20-30$ & base \\
\hline CSQN96 & $7-219$ & Osvaldo & Paredão & S710 E1966 & $30-40$ & - \\
\hline CSQN97 & $7-478$ & Osvaldo & Paredão & S710 E1966 & $40-50$ & - \\
\hline CSQN98 & $7-383$ & Osvaldo & Paredão & S710 E1966 & $50-60$ & - \\
\hline
\end{tabular}




\begin{tabular}{|c|c|c|c|c|c|c|}
\hline Código & $\begin{array}{c}\text { Código } \\
\text { MAE } \\
\end{array}$ & Sítio & Fase & Unidade & Prof, (cm) & Tipo \\
\hline CSQN99 & $7-480$ & Osvaldo & Paredão & S710 E1966 & $60-70$ & - \\
\hline CSQN100 & $7-490$ & Osvaldo & Paredão & S710 E1966 & $60-70$ & - \\
\hline CSQN101 & $7-481$ & Osvaldo & Paredão & S710 E1966 & $80-90$ & - \\
\hline CSQN103 & $12-82$ & Lago Grande & Paredão & 1 & - & cesta \\
\hline CSQN104 & $12-78-1$ & Lago Grande & Paredão & 1 & - & cesta \\
\hline CSQN105 & $12-60$ & Lago Grande & Paredão & 1 & $20-30$ & cesta \\
\hline CSQN106 & $12-77-12$ & Lago Grande & Paredão & 1 & - & cesta \\
\hline CSQN107 & $12-77-7$ & Lago Grande & Paredão & 1 & - & cesta \\
\hline CSQN108 & $12-226$ & Lago Grande & Paredão & 1 & - & urna \\
\hline CSQN109 & $12-369$ & Lago Grande & Paredão & 1 & $110-120$ & urna \\
\hline CSQN110 & $12-360$ & Lago Grande & Paredão & 1 & - & urna \\
\hline CSQN111 & $12-286$ & Lago Grande & Paredão & 1 & $150-160$ & urna \\
\hline CSQN112 & $12-115-2$ & Lago Grande & Paredão & 1 & $70-80$ & prato fundo \\
\hline CSQN113 & $12-78-4$ & Lago Grande & Paredão & 1 & - & prato fundo \\
\hline CSQN114 & $12-51-10$ & Lago Grande & Paredão & 1 & - & panela \\
\hline CSQN115 & $12-341$ & Lago Grande & Paredão & 1 & - & panela \\
\hline CSQN116 & $12-333$ & Lago Grande & Paredão & 1 & $60-70$ & panela \\
\hline CSQN117 & $12-92-2$ & Lago Grande & Paredão & 1 & - & cuia pintada \\
\hline CSQN118 & $12-89-5$ & Lago Grande & Paredão & 1 & $60-70$ & cuia pintada \\
\hline CSQN119 & $12-93-14$ & Lago Grande & Paredão & 1 & - & cuia pintada \\
\hline CSQN120 & $12-55-12$ & Lago Grande & Paredão & 1 & - & cuia pintada \\
\hline CSQN121 & $12-52-15$ & Lago Grande & Paredão & 1 & - & base \\
\hline CSQN122 & $12-371$ & Lago Grande & Paredão & 1 & - & base \\
\hline CSQN123 & $12-224$ & Lago Grande & Paredão & 1 & $110-120$ & base \\
\hline CSQN126 & $12-216-2$ & Lago Grande & Paredão & 1 & $100-110$ & prato fundo \\
\hline CSQN127 & $12-?-038$ & Lago Grande & Paredão & 1 & - & prato fundo \\
\hline CSQN128 & $12-65-15$ & Lago Grande & Paredão & 1 & - & prato fundo \\
\hline CSQN129 & $12-343$ & Lago Grande & Paredão & 1 & $120-130$ & prato fundo \\
\hline CSQN130 & $12-52-21$ & Lago Grande & Paredão & 1 & - & prato fundo \\
\hline CSQN131 & $12-214-1$ & Lago Grande & Paredão & 1 & $120-130$ & vaso com pescoço \\
\hline CSQN132 & $12-154-1$ & Lago Grande & Paredão & 1 & - & vaso com pescoço \\
\hline CSQN133 & $12-365$ & Lago Grande & Paredão & 1 & $130-140$ & vaso com pescoço \\
\hline CSQN351 & $12-350$ & Lago Grande & Manacapuru & 1 & perfil & parede decorada \\
\hline CSQN352 & $12-177-2$ & Lago Grande & Manacapuru & 1 & $100-110$ & - \\
\hline CSQN353 & $12-141$ & Lago Grande & Manacapuru & 1 & $80-90$ & parede decorada \\
\hline CSQN354 & $12-65-91$ & Lago Grande & Manacapuru & 1 & $30-40$ & - \\
\hline CSQN355 & $12-208-12$ & Lago Grande & Manacapuru & 1 & $110-120$ & - \\
\hline CSQN356 & $12-245$ & Lago Grande & Manacapuru & 1 & $120-130$ & borda \\
\hline CSQN357 & $12-117-8$ & Lago Grande & Manacapuru & 1 & $80-90$ & \\
\hline CSQN358 & $12-299$ & Lago Grande & Manacapuru & 1 & $150-160$ & borda \\
\hline CSQN359 & $12-51-4$ & Lago Grande & Manacapuru & 1 & $0-10$ & borda \\
\hline CSQN360 & $12-2-13$ & Lago Grande & Manacapuru & 1 & $100-110$ & borda \\
\hline CSQN361 & $12-362$ & Lago Grande & Manacapuru & 1 & $160-170$ & borda \\
\hline CSQN362 & $12-77-4$ & Lago Grande & Manacapuru & 1 & $50-60$ & borda \\
\hline
\end{tabular}




\begin{tabular}{|c|c|c|c|c|c|c|}
\hline Código & $\begin{array}{c}\text { Código } \\
\text { MAE }\end{array}$ & Sítio & Fase & Unidade & Prof, (cm) & Tipo \\
\hline CSQN363 & $12-235-26$ & Lago Grande & Manacapuru & 1 & $140-150$ & borda \\
\hline CSQN364 & $12-55-28$ & Lago Grande & Manacapuru & 1 & $10-20$ & borda \\
\hline CSQN365 & $12-258$ & Lago Grande & Manacapuru & 1 & $130-140$ & borda \\
\hline CSQN366 & $12-110$ & Lago Grande & Guarita & 1 & $70-80$ & prato \\
\hline CSQN367 & $12-531-2$ & Lago Grande & Açutuba & 3 & $90-100$ & borda \\
\hline CSQN368 & $12-531-1$ & Lago Grande & Açutuba & 3 & $90-100$ & borda \\
\hline CSQN369 & $12-531-4$ & Lago Grande & Açutuba & 3 & $90-100$ & borda \\
\hline CSQN370 & $12-519-3$ & Lago Grande & Açutuba & 3 & $70-80$ & borda \\
\hline CSQN371 & $12-520-4$ & Lago Grande & Açutuba & 3 & $70-80$ & parede decorada \\
\hline CSQN372 & $12-249$ & Lago Grande & Manacapuru & 1 & $120-130$ & borda \\
\hline CSQN373 & $12-236-10$ & Lago Grande & Manacapuru & 1 & $120-130$ & borda \\
\hline CSQN374 & $12-342$ & Lago Grande & Manacapuru & 1 & Limpeza de $p$ leste & borda \\
\hline CSQN375 & $12-295$ & Lago Grande & Manacapuru & 1 & perfil & borda \\
\hline CSQN376 & $12-255-5$ & Lago Grande & Manacapuru & 1 & $130-140$ & borda \\
\hline CSQN377 & $12-281-7$ & Lago Grande & Manacapuru & 1 & $100-110$ & borda \\
\hline CSQN378 & $12-90-2$ & Lago Grande & Manacapuru & 1 & $60-70$ & borda \\
\hline CSQN379 & $12-208-1$ & Lago Grande & Manacapuru & 1 & $110-120$ & borda \\
\hline CSQN380 & $12-512$ & Lago Grande & Paredão & 3 & $40-50$ & borda \\
\hline CSQN381 & $12-503-65$ & Lago Grande & Paredão & 3 & $20-30$ & alça \\
\hline CSQN382 & $12-511-15$ & Lago Grande & Paredão & 3 & $30-40$ & $30-40$ \\
\hline CSQN383 & $12-514-32$ & Lago Grande & Paredão & 3 & $50-60$ & cuia \\
\hline CSQN384 & $12-507-2$ & Lago Grande & Paredão & 3 & $20-30$ & parede decorada \\
\hline CSQN385 & $12-508-1$ & Lago Grande & Paredão & 3 & $20-30$ & base \\
\hline CSQN386 & $12-518-17$ & Lago Grande & Paredão & 3 & $60-70$ & base \\
\hline CSQN387 & $12-511-14$ & Lago Grande & Paredão & 3 & $30-40$ & base \\
\hline CSQN388 & $12-578-1$ & Lago Grande & Paredão & 3 & $60-70$ & base \\
\hline CSQN389 & $12-549-1$ & Lago Grande & Paredão & 3 & $50-60$ & base \\
\hline CSQN390 & $12-558-1$ & Lago Grande & Paredão & 3 & $60-70$ & - \\
\hline CSQN391 & $12-512-2$ & Lago Grande & Paredão & 3 & $40-50$ & base \\
\hline CSQN392 & $12-511-13$ & Lago Grande & Paredão & 3 & $30-40$ & base \\
\hline CSQN393 & $12-558-2$ & Lago Grande & Paredão & 3 & $60-70$ & - \\
\hline CSQN394 & $9-339-12$ & Osvaldo & Manacapuru & Tradagem & $10-20$ & base \\
\hline CSQN395 & $9-339-18$ & Osvaldo & Manacapuru & Tradagem & $10-20$ & borda \\
\hline CSQN396 & $9-339-14$ & Osvaldo & Manacapuru & Tradagem & $10-20$ & borda \\
\hline CSQN397 & $9-339-9$ & Osvaldo & Manacapuru & Tradagem & $10-20$ & borda \\
\hline CSQN398 & $9-339-5$ & Osvaldo & Manacapuru & Tradagem & $10-20$ & borda \\
\hline CSQN399 & $9-339-1$ & Osvaldo & Manacapuru & Tradagem & $10-20$ & borda \\
\hline CSQN400 & $9-339-4$ & Osvaldo & Manacapuru & Tradagem & $10-20$ & borda \\
\hline CSQN401 & $9-339-10$ & Osvaldo & Manacapuru & Tradagem & $10-20$ & borda \\
\hline CSQN402 & $9-339-20$ & Osvaldo & Manacapuru & Tradagem & $10-20$ & borda \\
\hline CSQN403 & $9-320-13$ & Osvaldo & Paredão & Tradagem & $0-10$ & borda \\
\hline CSQN404 & $9-320-5$ & Osvaldo & Paredão & Tradagem & $0-10$ & borda \\
\hline CSQN405 & $9-320-9$ & Osvaldo & Paredão & Tradagem & $0-10$ & borda \\
\hline CSQN406 & $9-320-2$ & Osvaldo & Manacapuru & Tradagem & $0-10$ & borda \\
\hline
\end{tabular}




\begin{tabular}{|c|c|c|c|c|c|c|}
\hline Código & $\begin{array}{l}\text { Código } \\
\text { MAE }\end{array}$ & Sítio & Fase & Unidade & Prof, (cm) & Tipo \\
\hline CSQN407 & $9-320-8$ & Osvaldo & Manacapuru & Tradagem & $0-10$ & borda \\
\hline CSQN408 & $9-320-4$ & Osvaldo & Manacapuru & Tradagem & $0-10$ & borda \\
\hline CSQN409 & $9-320-3$ & Osvaldo & Manacapuru & Tradagem & $0-10$ & borda \\
\hline CSQN410 & $9-320-1$ & Osvaldo & Manacapuru & Tradagem & $0-10$ & borda \\
\hline CSQN411 & $9-320-7$ & Osvaldo & Manacapuru & Tradagem & $0-10$ & borda \\
\hline CSQN412 & $9-320-6$ & Osvaldo & Manacapuru & Tradagem & $0-10$ & borda \\
\hline CSQN413 & $9-344-14$ & Osvaldo & Manacapuru & Tradagem & $20-30$ & borda \\
\hline CSQN414 & $9-223-16$ & Osvaldo & Manacapuru & Tradagem & $30-40$ & borda \\
\hline CSQN415 & $9-223-5$ & Osvaldo & Manacapuru & Tradagem & $30-40$ & borda \\
\hline CSQN416 & $9-223-4$ & Osvaldo & Manacapuru & Tradagem & $30-40$ & borda \\
\hline CSQN417 & $9-223-6$ & Osvaldo & Manacapuru & Tradagem & $30-40$ & borda \\
\hline CSQN418 & $9-223-2$ & Osvaldo & Manacapuru & Tradagem & $30-40$ & borda \\
\hline CSQN419 & $9-223-1$ & Osvaldo & Manacapuru & Tradagem & $30-40$ & borda \\
\hline CSQN420 & $9-223-3$ & Osvaldo & Manacapuru & Tradagem & $30-40$ & borda \\
\hline CSQN421 & $9-223-34$ & Osvaldo & Manacapuru & Tradagem & $30-40$ & borda \\
\hline CSQN422 & $9-223-19$ & Osvaldo & Manacapuru & Tradagem & $30-40$ & borda \\
\hline CSQN423 & 9-223-9 & Osvaldo & Manacapuru & Tradagem & $30-40$ & borda \\
\hline CSQN424 & $7-401$ & Osvaldo & - & S710 E1966 & - & borda externa \\
\hline CSQN424\#2 & $7-401$ & Osvaldo & - & S710 E1966 & - & borda externa \\
\hline CSQN425 & $7-21$ & Osvaldo & - & S710 E1966 & - & borda externa \\
\hline CSQN426 & $9-204-6$ & Osvaldo & - & S710 E1966 & - & borda externa \\
\hline CSQN426\#2 & 9-204-6 & Osvaldo & - & S710 E1966 & - & borda externa \\
\hline CSQN427 & $\begin{array}{c}(?) 7-459- \\
23\end{array}$ & Osvaldo & - & S710 E1966 & - & borda externa \\
\hline CSQN428 & $7-217-13$ & Osvaldo & - & S710 E1966 & - & borda externa \\
\hline CSQN428\#2 & $7-217-13$ & Osvaldo & - & S710 E1966 & - & borda externa \\
\hline CSQN429 & $7-430-9$ & Osvaldo & - & S710 E1966 & - & borda externa \\
\hline CSQN429\#2 & $7-430-9$ & Osvaldo & - & S710 E1966 & - & borda externa \\
\hline CSQN430 & $7-459-34$ & Osvaldo & - & S710 E1966 & - & borda externa \\
\hline CSQN430\#2 & $7-459-34$ & Osvaldo & - & S710 E1966 & - & borda externa \\
\hline CSQN431 & $7-358-3$ & Osvaldo & - & S710 E1966 & - & borda externa \\
\hline CSQN432 & $7-204-10$ & Osvaldo & - & S710 E1966 & - & borda externa \\
\hline CSQN433 & $\begin{array}{c}12-1046- \\
39\end{array}$ & Lago Grande & Paredão & 4 & $30-40$ & parede decorada \\
\hline CSQN434 & $\begin{array}{c}12-1052- \\
32\end{array}$ & Lago Grande & Paredão & 4 & $30-40$ & parede decorada \\
\hline CSQN435 & $12-518-18$ & Lago Grande & - & 3 & $60-70$ & base \\
\hline CSQN436 & $12-65-18$ & Lago Grande & Manacapuru & 4 & $80-90$ & - \\
\hline CSQN437 & $\begin{array}{c}\text { 7-219- } \\
18(?)\end{array}$ & Osvaldo & - & S710 E1966 & - & tigela decorada \\
\hline CSQN438 & $7-243$ & Osvaldo & - & S710 E1966 & - & tigela decorada \\
\hline CSQN439 & $7-459-12$ & Osvaldo & - & S710 E1966 & - & tigela decorada \\
\hline CSQN440 & $7-430-25$ & Osvaldo & - & S710 E1966 & - & tigela decorada \\
\hline CSQN441 & $\begin{array}{c}\text { 7-459- } \\
38(?)\end{array}$ & Osvaldo & - & S710 E1966 & - & tigela decorada \\
\hline CSQN442 & $7-617-6$ & Osvaldo & - & S710 E1966 & - & tigela decorada \\
\hline CSQN443 & 7-459-39 & Osvaldo & - & S710 E1966 & - & tigela decorada \\
\hline
\end{tabular}




\begin{tabular}{|c|c|c|c|c|c|c|}
\hline Código & $\begin{array}{c}\text { Código } \\
\text { MAE }\end{array}$ & Sítio & Fase & Unidade & Prof, (cm) & Tipo \\
\hline CSQN444 & $7-202-18$ & Osvaldo & - & S710 E1966 & - & tigela decorada \\
\hline CSQN445 & $7-458-38$ & Osvaldo & - & S710 E1966 & - & tigela decorada \\
\hline CSQN446 & $7-479-3$ & Osvaldo & - & S710 E1966 & - & tigela decorada \\
\hline CSQN447 & $12-444-31$ & Lago Grande & Manacapuru & 4 & $80-90$ & - \\
\hline CSQN448 & $\begin{array}{c}12-1144- \\
35\end{array}$ & Lago Grande & Manacapuru & 4 & $80-90$ & - \\
\hline CSQN449 & $\begin{array}{c}12-1144- \\
32\end{array}$ & Lago Grande & Manacapuru & 4 & $80-90$ & - \\
\hline CSQN450 & $12-1144-6$ & Lago Grande & - & 4 & $80-90$ & parede decorada \\
\hline CSQN451 & $\begin{array}{c}12-1144- \\
14\end{array}$ & Lago Grande & - & 4 & $80-90$ & parede decorada \\
\hline CSQN453 & $12-1142-8$ & Lago Grande & - & 4 & $80-90$ & parede decorada \\
\hline CSQN454 & $\begin{array}{c}12-1142- \\
16\end{array}$ & Lago Grande & - & 4 & $80-90$ & parede decorada \\
\hline CSQN455 & $12-1142-3$ & Lago Grande & Manacapuru & 4 & $80-90$ & - \\
\hline CSQN456 & $12-1142-2$ & Lago Grande & Manacapuru & 4 & $80-90$ & - \\
\hline CSQN457 & $12-1142-2$ & Lago Grande & Manacapuru & 4 & $80-90$ & - \\
\hline
\end{tabular}




\begin{tabular}{|c|c|c|c|c|c|}
\hline Código & Código MAE & Irradiação & As & $\mathrm{K}(\mathrm{mg} / \mathrm{g})$ & La \\
\hline CSQN58 & $12-55-5$ & - & $6,8 \pm 0,3$ & $10,5 \pm 1,3$ & $31 \pm 2,2$ \\
\hline CSQN59 & $12-237$ & - & $4,1 \pm 0,2$ & $4,3 \pm 0,8$ & $30 \pm 2,1$ \\
\hline CSQN60 & $12-57$ & - & $11,1 \pm 0,5$ & $12,9 \pm 1,7$ & $43 \pm 3$ \\
\hline CSQN61 & $12-373-2$ & - & $5,1 \pm 0,3$ & $11,6 \pm 1,6$ & $38 \pm 2,6$ \\
\hline CSQN62 & $12-80$ & $02 / 09 / 04$ & $10,8 \pm 0,4$ & $9 \pm 1,6$ & $43 \pm 0,3$ \\
\hline CSQN63 & $12-366$ & $02 / 09 / 04$ & $6,3 \pm 0,3$ & $10,6 \pm 2,1$ & $50,2 \pm 0,3$ \\
\hline CSQN64 & $12-120$ & $02 / 09 / 04$ & $6,4 \pm 0,3$ & $6,2 \pm 1,3$ & $30,6 \pm 0,2$ \\
\hline CSQN65 & $12-250-1$ & 02/09/04 & $8,3 \pm 0,4$ & $9,7 \pm 1,9$ & $42,3 \pm 0,3$ \\
\hline CSQN66 & $12-79$ & $02 / 09 / 04$ & $15,7 \pm 0,6$ & $12,8 \pm 2,6$ & $45,6 \pm 0,3$ \\
\hline CSQN67 & $12-85-9$ & $09 / 02 / 04$ & $6,7 \pm 0,2$ & $2,9 \pm 0,5$ & $60 \pm 0,3$ \\
\hline CSQN68 & $12-370$ & 09/02/04 & $6,4 \pm 0,3$ & $9,5 \pm 1$ & $49,1 \pm 0,3$ \\
\hline CSQN70 & $12-52-14$ & $09 / 02 / 04$ & $13,3 \pm 0,4$ & $6,4 \pm 0,7$ & $36,2 \pm 0,2$ \\
\hline CSQN72 & $12-55-20$ & $09 / 02 / 04$ & $10,2 \pm 0,4$ & $10,2 \pm 1,4$ & $46,7 \pm 0,3$ \\
\hline CSQN73 & $12-62-1$ & 09/02/04 & $3,7 \pm 0,2$ & $7,6 \pm 0,8$ & $34,3 \pm 0,2$ \\
\hline CSQN74 & $12-96$ & $09 / 02 / 04$ & $12,6 \pm 0,4$ & $7,4 \pm 0,9$ & $54,2 \pm 0,3$ \\
\hline CSQN75 & $12-228$ & $25 / 08 / 03$ & $12,5 \pm 0,7$ & $7,9 \pm 3,3$ & $45,8 \pm 0,4$ \\
\hline CSQN76 & $12-55-27$ & $25 / 08 / 03$ & $13,4 \pm 0,7$ & $12 \pm 4,3$ & $53,4 \pm 0,4$ \\
\hline CSQN77 & $12-72-6$ & $25 / 08 / 03$ & $5,3 \pm 0,5$ & - & $40 \pm 0,4$ \\
\hline CSQN78 & $12-94$ & $25 / 08 / 03$ & $9,5 \pm 0,6$ & $7,6 \pm 3,5$ & $57,4 \pm 0,4$ \\
\hline CSQN79 & $12-219$ & $25 / 08 / 03$ & $9,1 \pm 0,8$ & $5 \pm 2,9$ & $52,1 \pm 0,4$ \\
\hline CSQN80 & $12-260$ & $25 / 08 / 03$ & $15 \pm 0,9$ & - & $41,3 \pm 0,4$ \\
\hline CSQN81 & $12-115-1$ & $25 / 08 / 03$ & $11,3 \pm 0,7$ & - & $35,5 \pm 0,3$ \\
\hline CSQN82 & 7-202 & 05/07/04 & $10,6 \pm 0,4$ & $8,5 \pm 0,9$ & $82,9 \pm 0,5$ \\
\hline CSQN83 & $7-205$ & 05/07/04 & $7,4 \pm 0,3$ & $7,8 \pm 1$ & $86,9 \pm 0,5$ \\
\hline CSQN84 & $7-219$ & 05/07/04 & $13,6 \pm 0,4$ & $4,1 \pm 0,9$ & $92,1 \pm 0,5$ \\
\hline CSQN85 & $7-358$ & 05/07/04 & $11,2 \pm 0,4$ & $10,9 \pm 1,2$ & $81,3 \pm 0,5$ \\
\hline CSQN86 & $7-394$ & 05/07/04 & $5,8 \pm 0,3$ & $3,7 \pm 0,7$ & $78,9 \pm 0,5$ \\
\hline CSQN87 & $7-431$ & 05/07/04 & $10,8 \pm 0,4$ & $4,1 \pm 0,8$ & $76,3 \pm 0,5$ \\
\hline CSQN88 & $7-454$ & 06/07/04 & $9,3 \pm 0,7$ & - & $80,3 \pm 0,7$ \\
\hline CSQN89 & $7-471$ & 06/07/04 & $10,8 \pm 0,8$ & - & $77,8 \pm 0,7$ \\
\hline CSQN90 & 0 & 06/07/04 & $8,7 \pm 0,9$ & - & $40,2 \pm 0,4$ \\
\hline CSQN91 & 0 & 06/07/04 & $6,1 \pm 0,7$ & - & $21,4 \pm 0,3$ \\
\hline CSQN92 & 0 & $06 / 07 / 04$ & $8,2 \pm 0,9$ & - & $40,5 \pm 0,4$ \\
\hline CSQN93 & 0 & 06/07/04 & $6,2 \pm 0,7$ & - & $44,8 \pm 0,5$ \\
\hline CSQN94 & 0 & 06/07/04 & $8,8 \pm 0,8$ & - & $41,6 \pm 0,5$ \\
\hline CSQN95 & $7-206$ & $12 / 07 / 04$ & $15,2 \pm 0,5$ & $10,2 \pm 1,3$ & $36,9 \pm 0,2$ \\
\hline CSQN96 & $7-219$ & $12 / 07 / 04$ & - & - & - \\
\hline CSQN97 & $7-478$ & $12 / 07 / 04$ & $3,4 \pm 0,3$ & $12,3 \pm 1,6$ & $34,2 \pm 0,2$ \\
\hline CSQN98 & $7-383$ & $12 / 07 / 04$ & $3,5 \pm 0,3$ & $11,2 \pm 1,6$ & $35,2 \pm 0,2$ \\
\hline CSQN99 & $7-480$ & $12 / 07 / 04$ & $4 \pm 0,3$ & $10,5 \pm 1,6$ & $44,7 \pm 0,3$ \\
\hline CSQN100 & $7-490$ & $12 / 07 / 04$ & $2,4 \pm 0,2$ & $21,9 \pm 2,5$ & $86 \pm 0,4$ \\
\hline CSQN101 & $7-481$ & $12 / 07 / 04$ & $5,8 \pm 0,3$ & $13,3 \pm 1,9$ & $42,1 \pm 0,2$ \\
\hline CSQN103 & $12-82$ & $19 / 02 / 13$ & $5,8 \pm 0,3$ & $10,9 \pm 1,6$ & $36,9 \pm 0,3$ \\
\hline CSQN104 & $12-78-1$ & $08 / 12 / 04$ & $7,4 \pm 0,4$ & $19,8 \pm 13,1$ & $37,6 \pm 0,3$ \\
\hline CSQN105 & $12-60$ & $08 / 12 / 04$ & $6,8 \pm 0,4$ & - & $41,3 \pm 0,3$ \\
\hline
\end{tabular}




\begin{tabular}{|c|c|c|c|c|c|}
\hline Código & Código MAE & Irradiação & As & $\mathrm{K}(\mathrm{mg} / \mathrm{g})$ & La \\
\hline CSQN106 & $12-77-12$ & $08 / 12 / 04$ & $9,1 \pm 0,6$ & $13,4 \pm 9,8$ & $41,9 \pm 0,3$ \\
\hline CSQN107 & $12-77-7$ & $08 / 12 / 04$ & $16,1 \pm 0,6$ & $9,1 \pm 8,8$ & $46,4 \pm 0,3$ \\
\hline CSQN108 & $12-226$ & $08 / 12 / 04$ & $5,2 \pm 0,4$ & $21,8 \pm 15,4$ & $41,3 \pm 0,3$ \\
\hline CSQN109 & $12-369$ & $08 / 12 / 04$ & $6,7 \pm 0,5$ & $30,6 \pm 19,7$ & $46,6 \pm 0,3$ \\
\hline CSQN110 & $12-360$ & $08 / 12 / 04$ & $9 \pm 0,5$ & $13,2 \pm 10,2$ & $44,5 \pm 0,3$ \\
\hline CSQN111 & $12-286$ & $08 / 12 / 04$ & $10,4 \pm 0,6$ & $27,8 \pm 17,6$ & $33,5 \pm 0,2$ \\
\hline CSQN112 & $12-115-2$ & $13 / 12 / 04$ & $7 \pm 0,3$ & $9,9 \pm 1,6$ & $37,9 \pm 0,3$ \\
\hline CSQN113 & $12-78-4$ & $13 / 12 / 04$ & $6,3 \pm 0,3$ & $12,2 \pm 1,9$ & $46,3 \pm 0,3$ \\
\hline CSQN114 & $12-51-10$ & $13 / 12 / 04$ & $6,6 \pm 0,3$ & $7,3 \pm 1,2$ & $33,7 \pm 0,3$ \\
\hline CSQN115 & $12-341$ & $13 / 12 / 04$ & $6,9 \pm 0,3$ & $6,5 \pm 1,3$ & $35,5 \pm 0,3$ \\
\hline CSQN116 & $12-333$ & $13 / 12 / 04$ & $2,4 \pm 0,9$ & - & $39,4 \pm 0,4$ \\
\hline CSQN117 & $12-92-2$ & $25 / 01 / 05$ & $7,6 \pm 0,5$ & $7,5 \pm 2,5$ & $55,3 \pm 0,5$ \\
\hline CSQN118 & $12-89-5$ & $25 / 01 / 05$ & $7,8 \pm 0,5$ & $11,5 \pm 3,7$ & $58,5 \pm 0,5$ \\
\hline CSQN119 & $12-93-14$ & $25 / 01 / 05$ & $9,9 \pm 0,4$ & $10,7 \pm 1,7$ & $53,8 \pm 0,4$ \\
\hline CSQN120 & $12-55-12$ & $25 / 01 / 05$ & $6,7 \pm 0,4$ & $8,2 \pm 2,5$ & $53,1 \pm 0,5$ \\
\hline CSQN121 & $12-52-15$ & $13 / 12 / 04$ & $5,7 \pm 0,3$ & $6,2 \pm 1,4$ & $48 \pm 0,3$ \\
\hline CSQN122 & $12-371$ & $13 / 12 / 04$ & $6,6 \pm 0,3$ & $2 \pm 1$ & $59,2 \pm 0,4$ \\
\hline CSQN123 & $12-224$ & $13 / 12 / 04$ & $12,2 \pm 0,5$ & $9 \pm 1,7$ & $44,1 \pm 0,3$ \\
\hline CSQN126 & $12-216-2$ & $25 / 01 / 05$ & $6,7 \pm 0,4$ & - & $24,9 \pm 0,3$ \\
\hline CSQN127 & $12-?-038$ & $12 / 01 / 05$ & $6,3 \pm 0,7$ & - & $54,8 \pm 0,5$ \\
\hline CSQN128 & $12-65-15$ & $12 / 01 / 05$ & $5,2 \pm 0,4$ & $7,7 \pm 1,2$ & $23,4 \pm 0,3$ \\
\hline CSQN129 & $12-343$ & $12 / 01 / 05$ & $7,8 \pm 0,4$ & $6,4 \pm 1,2$ & $33,5 \pm 0,4$ \\
\hline CSQN130 & $12-52-21$ & $12 / 01 / 05$ & $8 \pm 0,5$ & $12,7 \pm 2,2$ & $45,4 \pm 0,5$ \\
\hline CSQN131 & $12-214-1$ & $12 / 01 / 05$ & $15,7 \pm 0,8$ & $5,3 \pm 1,2$ & $35,6 \pm 0,4$ \\
\hline CSQN132 & $12-154-1$ & $12 / 01 / 05$ & $6,3 \pm 0,5$ & $10,9 \pm 1,8$ & $44,6 \pm 0,5$ \\
\hline CSQN133 & $12-365$ & $12 / 01 / 05$ & $7,1 \pm 0,4$ & $8,1 \pm 1,6$ & $42,8 \pm 0,5$ \\
\hline CSQN351 & $12-350$ & $24 / 08 / 09$ & $6,4 \pm 0,3$ & $13,6 \pm 0,5$ & $40,2 \pm 0,4$ \\
\hline CSQN352 & $12-177-2$ & $24 / 08 / 09$ & $9,8 \pm 0,3$ & $3,5 \pm 0,2$ & $47,2 \pm 0,4$ \\
\hline CSQN353 & $12-141$ & $17 / 08 / 09$ & $7,7 \pm 0,9$ & - & $35,4 \pm 0,7$ \\
\hline CSQN354 & $12-65-91$ & $17 / 08 / 09$ & $4,3 \pm 0,8$ & $11,1 \pm 4,3$ & $43 \pm 0,8$ \\
\hline CSQN355 & $12-208-12$ & $24 / 08 / 09$ & $5,9 \pm 0,3$ & $18 \pm 0,6$ & $43,1 \pm 0,4$ \\
\hline CSQN356 & $12-245$ & 17/08/09 & $4,9 \pm 1,9$ & $11 \pm 3,9$ & $38,5 \pm 0,7$ \\
\hline CSQN357 & $12-117-8$ & $24 / 08 / 09$ & $16,5 \pm 0,5$ & $9,8 \pm 0,4$ & $25,1 \pm 0,3$ \\
\hline CSQN358 & $12-299$ & 09/09/09 & $5,4 \pm 0,5$ & $13,2 \pm 2,7$ & $37,1 \pm 0,4$ \\
\hline CSQN359 & $12-51-4$ & $24 / 08 / 09$ & $3,4 \pm 0,2$ & $7,3 \pm 0,3$ & $44,3 \pm 0,4$ \\
\hline CSQN360 & $12-2-13$ & 09/09/09 & $5 \pm 0,5$ & $10,7 \pm 2,5$ & $49,6 \pm 0,5$ \\
\hline CSQN361 & $12-362$ & 09/09/09 & $8,4 \pm 0,5$ & $14,5 \pm 3,1$ & $40,5 \pm 0,4$ \\
\hline CSQN362 & $12-77-4$ & 09/09/09 & $9,4 \pm 0,6$ & $9,8 \pm 2,7$ & $42,7 \pm 0,4$ \\
\hline CSQN363 & $12-235-26$ & 09/09/09 & $2,7 \pm 0,4$ & - & $40,3 \pm 0,4$ \\
\hline CSQN364 & $12-55-28$ & 09/09/09 & $6,4 \pm 0,5$ & $5 \pm 1,9$ & $33,5 \pm 0,4$ \\
\hline CSQN365 & $12-258$ & 09/09/09 & $5,9 \pm 0,5$ & $10,3 \pm 2,8$ & $31,7 \pm 0,4$ \\
\hline CSQN366 & $12-110$ & $07 / 12 / 09$ & $5,8 \pm 0,3$ & - & $35,3 \pm 0,3$ \\
\hline CSQN367 & $12-531-2$ & $07 / 12 / 09$ & $15,7 \pm 0,6$ & $16,8 \pm 2,8$ & $43,5 \pm 0,4$ \\
\hline CSQN368 & $12-531-1$ & 07/12/09 & $11 \pm 0,5$ & $13,6 \pm 2,7$ & $41,4 \pm 0,4$ \\
\hline CSQN369 & $12-531-4$ & $07 / 12 / 09$ & $15,3 \pm 0,6$ & $19,4 \pm 3,5$ & $44,2 \pm 0,4$ \\
\hline
\end{tabular}




\begin{tabular}{|c|c|c|c|c|c|}
\hline Código & Código MAE & Irradiação & As & $\mathrm{K}(\mathrm{mg} / \mathrm{g})$ & La \\
\hline CSQN370 & $12-519-3$ & $07 / 12 / 09$ & $6,6 \pm 0,5$ & $8,6 \pm 2,6$ & $42 \pm 0,4$ \\
\hline CSQN371 & $12-520-4$ & 07/12/09 & $9,2 \pm 0,5$ & $13,2 \pm 3$ & $25,2 \pm 0,3$ \\
\hline CSQN372 & $12-249$ & $23 / 11 / 09$ & $7,8 \pm 0,4$ & $13,1 \pm 1,9$ & $49 \pm 0,4$ \\
\hline CSQN373 & $12-236-10$ & $26 / 02 / 13$ & $11,9 \pm 0,4$ & $10,1 \pm 0,9$ & $30,8 \pm 0,3$ \\
\hline CSQN374 & $12-342$ & $23 / 11 / 09$ & $9,1 \pm 0,4$ & $7,1 \pm 1,6$ & $33,6 \pm 0,3$ \\
\hline CSQN375 & $12-295$ & $23 / 11 / 09$ & $7,1 \pm 0,4$ & - & $27,2 \pm 0,3$ \\
\hline CSQN376 & $12-255-5$ & $23 / 11 / 09$ & $5,5 \pm 0,4$ & $10,1 \pm 2,1$ & $45,5 \pm 0,4$ \\
\hline CSQN377 & $12-281-7$ & $23 / 11 / 09$ & $7,7 \pm 0,4$ & $10,6 \pm 1,9$ & $29,1 \pm 0,3$ \\
\hline CSQN378 & $12-90-2$ & $23 / 11 / 09$ & $5 \pm 0,5$ & $10,7 \pm 3$ & $126,8 \pm 0,8$ \\
\hline CSQN379 & $12-208-1$ & 09/12/09 & $10,8 \pm 0,5$ & $10,3 \pm 2,7$ & $34 \pm 0,3$ \\
\hline CSQN380 & $12-512$ & 09/12/09 & $14,9 \pm 0,6$ & $11,8 \pm 3$ & $46,7 \pm 0,4$ \\
\hline CSQN381 & $12-503-65$ & 09/12/09 & $8,5 \pm 0,6$ & $28,3 \pm 5,8$ & $46,7 \pm 0,4$ \\
\hline CSQN382 & $12-511-15$ & 09/12/09 & $10,9 \pm 0,6$ & $10,4 \pm 3,5$ & $42,5 \pm 0,4$ \\
\hline CSQN383 & $12-514-32$ & 09/12/09 & $4 \pm 0,4$ & - & $31,8 \pm 0,3$ \\
\hline CSQN384 & $12-507-2$ & 09/12/09 & $10,1 \pm 0,5$ & $16,6 \pm 4,7$ & $42,3 \pm 0,4$ \\
\hline CSQN385 & $12-508-1$ & 09/12/09 & $8,3 \pm 0,5$ & - & $46 \pm 0,4$ \\
\hline CSQN386 & $12-518-17$ & $02 / 03 / 10$ & $17,3 \pm 0,5$ & $9 \pm 0,9$ & $37,1 \pm 0,2$ \\
\hline CSQN387 & $12-511-14$ & $02 / 03 / 10$ & $5,2 \pm 0,3$ & $12,6 \pm 1,3$ & $47,7 \pm 0,3$ \\
\hline CSQN388 & $12-578-1$ & $02 / 03 / 10$ & $6,7 \pm 0,4$ & $18,2 \pm 1,7$ & $47,2 \pm 0,3$ \\
\hline CSQN389 & $12-549-1$ & $02 / 03 / 10$ & $9,5 \pm 0,4$ & $12,6 \pm 1,3$ & $41,1 \pm 0,3$ \\
\hline CSQN390 & $12-558-1$ & $02 / 03 / 10$ & $7,4 \pm 0,3$ & $9,8 \pm 1,2$ & $35,6 \pm 0,2$ \\
\hline CSQN391 & $12-512-2$ & $02 / 03 / 10$ & $9,6 \pm 0,4$ & $8,4 \pm 1,4$ & $49,4 \pm 0,3$ \\
\hline CSQN392 & $12-511-13$ & $02 / 03 / 10$ & $7,2 \pm 0,4$ & $9,1 \pm 1,4$ & $41,4 \pm 0,3$ \\
\hline CSQN393 & $12-558-2$ & 06/10/10 & $9,9 \pm 0,4$ & $6,3 \pm 1,3$ & $34,8 \pm 0,5$ \\
\hline CSQN394 & $9-339-12$ & $06 / 10 / 10$ & - & $4,8 \pm 1,3$ & $35,8 \pm 0,5$ \\
\hline CSQN395 & $9-339-18$ & $06 / 10 / 10$ & $7,8 \pm 0,4$ & - & $34,2 \pm 0,5$ \\
\hline CSQN396 & 9-339-14 & 06/10/10 & - & $11,1 \pm 2,1$ & $49,3 \pm 0,7$ \\
\hline CSQN397 & $9-339-9$ & 06/10/10 & - & $3,9 \pm 1,7$ & $29,9 \pm 0,5$ \\
\hline CSQN398 & $9-339-5$ & $06 / 10 / 10$ & $5,8 \pm 0,4$ & $15,1 \pm 2,6$ & $38,8 \pm 0,6$ \\
\hline CSQN399 & $9-339-1$ & $06 / 10 / 10$ & $4,5 \pm 0,3$ & $6,7 \pm 2,1$ & $37,2 \pm 0,6$ \\
\hline CSQN400 & $9-339-4$ & $13 / 10 / 10$ & $7,7 \pm 0,4$ & $10 \pm 1,9$ & $45,1 \pm 0,7$ \\
\hline CSQN401 & $9-339-10$ & $13 / 10 / 10$ & $6,5 \pm 0,3$ & $8,3 \pm 1,6$ & $46,2 \pm 0,7$ \\
\hline CSQN402 & $9-339-20$ & $13 / 10 / 10$ & $3,3 \pm 0,3$ & $15,9 \pm 2,4$ & $39,3 \pm 0,6$ \\
\hline CSQN403 & $9-320-13$ & $13 / 10 / 10$ & $8 \pm 0,4$ & $11,2 \pm 2,1$ & $46,1 \pm 0,7$ \\
\hline CSQN404 & $9-320-5$ & $13 / 10 / 10$ & $5 \pm 0,3$ & $16,2 \pm 2,8$ & $49,2 \pm 0,7$ \\
\hline CSQN405 & $9-320-9$ & $13 / 10 / 10$ & $3,9 \pm 0,3$ & $6 \pm 1,8$ & $34 \pm 0,6$ \\
\hline CSQN406 & $9-320-2$ & $13 / 10 / 10$ & $4,7 \pm 0,3$ & - & $31,8 \pm 0,5$ \\
\hline CSQN407 & $9-320-8$ & $18 / 10 / 10$ & $6,2 \pm 0,3$ & $8,7 \pm 1,9$ & $53,5 \pm 0,7$ \\
\hline CSQN408 & $9-320-4$ & $20 / 10 / 10$ & $2,5 \pm 0,2$ & $10,6 \pm 1,4$ & $38,4 \pm 0,5$ \\
\hline CSQN409 & $9-320-3$ & $20 / 10 / 10$ & $4,7 \pm 0,3$ & $7,2 \pm 1,4$ & $40,8 \pm 0,5$ \\
\hline CSQN410 & $9-320-1$ & $20 / 10 / 10$ & $4,9 \pm 0,3$ & $11,7 \pm 1,9$ & $33,5 \pm 0,5$ \\
\hline CSQN411 & $9-320-7$ & $20 / 10 / 10$ & $5 \pm 0,3$ & $15,7 \pm 2,2$ & $42,5 \pm 0,6$ \\
\hline CSQN412 & $9-320-6$ & $20 / 10 / 10$ & $4,6 \pm 0,3$ & $9 \pm 1,9$ & $55,5 \pm 0,7$ \\
\hline CSQN413 & $9-344-14$ & $20 / 10 / 10$ & $5,5 \pm 0,3$ & $6,8 \pm 2,2$ & $48,6 \pm 0,6$ \\
\hline CSQN414 & 9-223-16 & $20 / 10 / 10$ & $5,3 \pm 0,3$ & $14,3 \pm 2,7$ & $42 \pm 0,6$ \\
\hline
\end{tabular}




\begin{tabular}{|c|c|c|c|c|c|}
\hline Código & Código MAE & Irradiação & As & K (mg/g) & La \\
\hline CSQN415 & $9-223-5$ & $01 / 11 / 10$ & $6,3 \pm 0,3$ & $11,5 \pm 1,8$ & $42,8 \pm 0,6$ \\
\hline CSQN416 & $9-223-4$ & $01 / 11 / 10$ & $5,5 \pm 0,3$ & $7,8 \pm 1,8$ & $41,8 \pm 0,6$ \\
\hline CSQN417 & $9-223-6$ & $17 / 11 / 10$ & $18,6 \pm 0,5$ & $20,2 \pm 1,3$ & $46,9 \pm 0,5$ \\
\hline CSQN418 & $9-223-2$ & $17 / 11 / 10$ & $2,5 \pm 0,2$ & $4,6 \pm 0,7$ & $33,5 \pm 0,4$ \\
\hline CSQN419 & $9-223-1$ & $17 / 11 / 10$ & $3 \pm 0,2$ & $13,8 \pm 1$ & $36,5 \pm 0,4$ \\
\hline CSQN420 & $9-223-3$ & $17 / 11 / 10$ & $4,6 \pm 0,2$ & $7,9 \pm 0,8$ & $31,8 \pm 0,4$ \\
\hline CSQN421 & $9-223-34$ & $17 / 11 / 10$ & $4 \pm 0,2$ & $11,6 \pm 1$ & $39,4 \pm 0,5$ \\
\hline CSQN422 & $9-223-19$ & $17 / 11 / 10$ & $9,6 \pm 0,7$ & $10,8 \pm 2,9$ & $37,6 \pm 0,5$ \\
\hline CSQN423 & $9-223-9$ & $17 / 11 / 10$ & $15,8 \pm 0,9$ & $10,6 \pm 3,1$ & $58,3 \pm 0,7$ \\
\hline CSQN424 & $7-401$ & $01 / 11 / 11$ & $7,7 \pm 0,4$ & $10,1 \pm 1,6$ & $49,7 \pm 0,3$ \\
\hline CSQN424\#2 & $7-401$ & $25 / 04 / 12$ & $7,5 \pm 0,5$ & - & $47,8 \pm 0,4$ \\
\hline CSQN425 & $7-21$ & $25 / 04 / 12$ & $3,3 \pm 0,5$ & - & $39 \pm 0,4$ \\
\hline CSQN426 & $9-204-6$ & $01 / 11 / 11$ & $2,6 \pm 0,3$ & $10 \pm 1,8$ & $37,9 \pm 0,3$ \\
\hline CSQN426\#2 & $9-204-6$ & $25 / 04 / 12$ & - & - & $39,5 \pm 0,4$ \\
\hline CSQN427 & (?)7-459-23 & $25 / 04 / 12$ & $4,4 \pm 0,6$ & - & $49,6 \pm 0,5$ \\
\hline CSQN428 & 7-217-13 & $01 / 11 / 11$ & $5,5 \pm 0,4$ & $5,4 \pm 1,4$ & $38,1 \pm 0,3$ \\
\hline CSQN428\#2 & $7-217-13$ & $25 / 04 / 12$ & $6,9 \pm 0,7$ & - & $40,7 \pm 0,4$ \\
\hline CSQN429 & $7-430-9$ & $01 / 11 / 11$ & $4,7 \pm 0,3$ & $3,2 \pm 1,6$ & $28,4 \pm 0,2$ \\
\hline CSQN429\#2 & $7-430-9$ & $25 / 04 / 12$ & $6,9 \pm 0,6$ & - & $28,2 \pm 0,3$ \\
\hline CSQN430 & $7-459-34$ & $01 / 11 / 11$ & $2,8 \pm 0,3$ & $13,7 \pm 2,5$ & $35,2 \pm 0,3$ \\
\hline CSQN430\#2 & $7-459-34$ & $25 / 04 / 12$ & $2,5 \pm 0,5$ & - & $36,3 \pm 0,4$ \\
\hline CSQN431 & $7-358-3$ & $08 / 11 / 11$ & $4,2 \pm 0,7$ & - & $50,1 \pm 0,5$ \\
\hline CSQN432 & $7-204-10$ & $08 / 11 / 11$ & $4,4 \pm 0,5$ & - & $48,2 \pm 0,4$ \\
\hline CSQN433 & $12-1046-39$ & $08 / 11 / 11$ & $5,2 \pm 0,5$ & - & $43,4 \pm 0,4$ \\
\hline CSQN434 & $12-1052-32$ & $08 / 11 / 11$ & $4 \pm 0,6$ & - & $50,7 \pm 0,5$ \\
\hline CSQN435 & $12-518-18$ & $08 / 11 / 11$ & $5,9 \pm 0,6$ & - & $36,6 \pm 0,4$ \\
\hline CSQN436 & $12-65-18$ & $08 / 11 / 11$ & $6,4 \pm 0,7$ & - & $57,7 \pm 0,5$ \\
\hline CSQN437 & 7-219-18(?) & $08 / 11 / 11$ & - & - & $53,1 \pm 0,5$ \\
\hline CSQN438 & $7-243$ & $14 / 11 / 11$ & $3,1 \pm 0,3$ & $7,6 \pm 1,2$ & $23,1 \pm 0,2$ \\
\hline CSQN439 & $7-459-12$ & $14 / 11 / 11$ & $3,3 \pm 0,2$ & $14,2 \pm 1,7$ & $32,7 \pm 0,2$ \\
\hline CSQN440 & $7-430-25$ & $14 / 11 / 11$ & $2,3 \pm 0,2$ & $7,1 \pm 1,4$ & $34,3 \pm 0,3$ \\
\hline CSQN441 & 7-459-38(?) & $14 / 11 / 11$ & $9 \pm 0,4$ & $4,1 \pm 1,1$ & $40,5 \pm 0,3$ \\
\hline CSQN442 & 7-617-6 & $14 / 11 / 11$ & $9,3 \pm 0,4$ & $9 \pm 1,5$ & $37,1 \pm 0,3$ \\
\hline CSQN443 & $7-459-39$ & $14 / 11 / 11$ & $9 \pm 0,4$ & $4 \pm 1,4$ & $61,2 \pm 0,4$ \\
\hline CSQN444 & $7-202-18$ & $14 / 11 / 11$ & $0,5 \pm 0,3$ & $9,3 \pm 1,8$ & $54,7 \pm 0,4$ \\
\hline CSQN445 & $7-458-38$ & $16 / 11 / 11$ & $3,9 \pm 0,4$ & $5,9 \pm 2,2$ & $68,3 \pm 0,5$ \\
\hline CSQN446 & 7-479-3 & $16 / 11 / 11$ & $3,1 \pm 0,3$ & $5,7 \pm 1,6$ & $36,4 \pm 0,3$ \\
\hline CSQN447 & $12-444-31$ & $16 / 11 / 11$ & $9,2 \pm 0,6$ & - & $30,2 \pm 0,3$ \\
\hline CSQN448 & $12-1144-35$ & $16 / 11 / 11$ & $6 \pm 0,5$ & $16,4 \pm 3,5$ & $35,7 \pm 0,3$ \\
\hline CSQN449 & $12-1144-32$ & $16 / 11 / 11$ & $5,3 \pm 0,5$ & $16,3 \pm 3,6$ & $38 \pm 0,3$ \\
\hline CSQN450 & $12-1144-6$ & $16 / 11 / 11$ & $8,7 \pm 0,5$ & - & $25,5 \pm 0,2$ \\
\hline CSQN451 & $12-1144-14$ & $16 / 11 / 11$ & $8,9 \pm 0,5$ & - & $45,1 \pm 0,4$ \\
\hline CSQN453 & $12-1142-8$ & $07 / 02 / 12$ & $9,2 \pm 0,3$ & $4,3 \pm 0,4$ & $32,4 \pm 0,2$ \\
\hline CSQN454 & $12-1142-16$ & $07 / 02 / 12$ & $5,6 \pm 0,2$ & $16 \pm 1,1$ & $44,4 \pm 0,3$ \\
\hline CSQN455 & $12-1142-3$ & $26 / 02 / 13$ & $6,8 \pm 0,3$ & $11,4 \pm 0,9$ & $36,6 \pm 0,3$ \\
\hline
\end{tabular}




\begin{tabular}{cccccc}
\hline Código & Código MAE & Irradiação & As & K (mg/g) & La \\
\hline CSQN456 & $12-1142-2$ & $26 / 02 / 13$ & $7,8 \pm 0,4$ & $16 \pm 1,2$ & $39,9 \pm 0,4$ \\
CSQN457 & $12-1142-2$ & $26 / 02 / 13$ & $6,4 \pm 0,3$ & $13,9 \pm 1,2$ & $39,7 \pm 0,4$ \\
\hline
\end{tabular}




\begin{tabular}{|c|c|c|c|c|c|}
\hline Código & Lu (ng/g) & $\mathrm{Na}(\mathrm{mg} / \mathrm{g})$ & Nd & Sb & Sm \\
\hline CSQN58 & $329 \pm 28$ & $2,5 \pm 0,07$ & $35 \pm 9$ & - & $4,89 \pm 0,3$ \\
\hline CSQN59 & $256 \pm 23$ & $0,35 \pm 0,01$ & $18 \pm 6$ & - & $4,67 \pm 0,29$ \\
\hline CSQN60 & $428 \pm 36$ & $3,93 \pm 0,1$ & $25 \pm 8$ & - & $8,23 \pm 0,49$ \\
\hline CSQN61 & $415 \pm 35$ & $3,28 \pm 0,09$ & $18 \pm 7$ & - & $7,95 \pm 0,48$ \\
\hline CSQN62 & $446 \pm 26$ & $2,14 \pm 0,05$ & $19 \pm 8$ & - & $6,16 \pm 0,13$ \\
\hline CSQN63 & $617 \pm 29$ & $3,07 \pm 0,07$ & $28 \pm 9$ & - & $11,92 \pm 0,05$ \\
\hline CSQN64 & $381 \pm 24$ & $0,54 \pm 0,02$ & $23 \pm 6$ & $0,9 \pm 0,4$ & $2,58 \pm 0,01$ \\
\hline CSQN65 & $552 \pm 29$ & $1,85 \pm 0,05$ & $38 \pm 10$ & - & $6,81 \pm 0,03$ \\
\hline CSQN66 & $550 \pm 30$ & $4,82 \pm 0,11$ & $36 \pm 10$ & - & $7,12 \pm 0,12$ \\
\hline CSQN67 & $625 \pm 29$ & $1,33 \pm 0,03$ & $52 \pm 11$ & - & $2,6 \pm 0,01$ \\
\hline CSQN68 & $613 \pm 28$ & $1,9 \pm 0,04$ & $50 \pm 10$ & - & $2,45 \pm 0,01$ \\
\hline CSQN70 & $405 \pm 21$ & $0,52 \pm 0,01$ & $17 \pm 6$ & - & $1,23 \pm 0,01$ \\
\hline CSQN72 & $453 \pm 24$ & $3,19 \pm 0,07$ & $36 \pm 11$ & - & $2,76 \pm 0,01$ \\
\hline CSQN73 & $417 \pm 19$ & $1,04 \pm 0,02$ & $41 \pm 10$ & $0,4 \pm 0,5$ & $2,8 \pm 0,01$ \\
\hline CSQN74 & $549 \pm 23$ & $1,74 \pm 0,04$ & $59 \pm 12$ & - & $2,04 \pm 0,01$ \\
\hline CSQN75 & $461 \pm 29$ & $1,27 \pm 0,05$ & $61 \pm 17$ & - & $5,1 \pm 0,05$ \\
\hline CSQN76 & $641 \pm 38$ & $2,1 \pm 0,08$ & $43 \pm 12$ & - & $8,81 \pm 0,2$ \\
\hline CSQN77 & $571 \pm 33$ & $4,55 \pm 0,15$ & $73 \pm 19$ & - & $6,55 \pm 0,15$ \\
\hline CSQN78 & $540 \pm 31$ & $1,44 \pm 0,05$ & $63 \pm 17$ & $1,2 \pm 0,4$ & $8,86 \pm 0,16$ \\
\hline CSQN79 & $728 \pm 37$ & $2,1 \pm 0,08$ & $95 \pm 22$ & - & $8,6 \pm 0,18$ \\
\hline CSQN80 & $627 \pm 40$ & $1,69 \pm 0,07$ & $49 \pm 15$ & - & $6,62 \pm 0,19$ \\
\hline CSQN81 & $468 \pm 33$ & $2,61 \pm 0,09$ & $37 \pm 11$ & - & $2,19 \pm 0,03$ \\
\hline CSQN82 & $923 \pm 55$ & $0,35 \pm 0,01$ & $41 \pm 13$ & - & $2,99 \pm 0,01$ \\
\hline CSQN83 & $703 \pm 49$ & $0,56 \pm 0,02$ & $42 \pm 12$ & - & $1,76 \pm 0,02$ \\
\hline CSQN84 & $905 \pm 58$ & $0,27 \pm 0,01$ & $56 \pm 14$ & $2,4 \pm 1$ & $5,35 \pm 0,09$ \\
\hline CSQN85 & $716 \pm 46$ & $0,84 \pm 0,02$ & $33 \pm 12$ & - & $2,82 \pm 0,01$ \\
\hline CSQN86 & $755 \pm 45$ & $0,38 \pm 0,02$ & $58 \pm 15$ & - & $4,13 \pm 0,06$ \\
\hline CSQN87 & $766 \pm 48$ & $0,42 \pm 14,05$ & $25 \pm 9$ & - & $3,91 \pm 0,06$ \\
\hline CSQN88 & $822 \pm 63$ & $0,46 \pm 0,05$ & $30 \pm 10$ & - & $10,26 \pm 0,25$ \\
\hline CSQN89 & $890 \pm 58$ & $0,64 \pm 0,05$ & $43 \pm 13$ & - & $12,36 \pm 0,15$ \\
\hline CSQN90 & $415 \pm 29$ & $2,58 \pm 0,12$ & $36 \pm 17$ & - & $5,58 \pm 0,07$ \\
\hline CSQN91 & $475 \pm 30$ & $0,39 \pm 0,04$ & - & - & $3,82 \pm 0,06$ \\
\hline CSQN92 & $435 \pm 25$ & $3,45 \pm 0,16$ & $26 \pm 9$ & - & $5,67 \pm 0,19$ \\
\hline CSQN93 & $400 \pm 27$ & $1,8 \pm 0,09$ & $40 \pm 15$ & - & $6,81 \pm 0,2$ \\
\hline CSQN94 & $681 \pm 52$ & $1,3 \pm 0,07$ & $25 \pm 9$ & - & $5,26 \pm 0,07$ \\
\hline CSQN95 & $623 \pm 26$ & $0,96 \pm 0,02$ & $26 \pm 7$ & $0,7 \pm 0,5$ & $3,95 \pm 0,01$ \\
\hline CSQN96 & - & - & - & - & - \\
\hline CSQN97 & $489 \pm 20$ & $2,76 \pm 0,05$ & $28 \pm 7$ & - & $2,38 \pm 0,01$ \\
\hline CSQN98 & $442 \pm 21$ & $2,72 \pm 0,05$ & $32 \pm 7$ & - & $4,23 \pm 0,06$ \\
\hline CSQN99 & $467 \pm 22$ & $2,5 \pm 0,05$ & $30 \pm 7$ & - & $6,4 \pm 0,02$ \\
\hline CSQN100 & $724 \pm 25$ & $0,92 \pm 0,02$ & $86 \pm 12$ & - & $4,92 \pm 0,02$ \\
\hline CSQN101 & $479 \pm 15$ & $2,1 \pm 0,04$ & $31 \pm 7$ & - & $5,09 \pm 0,08$ \\
\hline CSQN103 & $399 \pm 18$ & $2,14 \pm 0,05$ & $38 \pm 9$ & - & $6,51 \pm 0,03$ \\
\hline CSQN104 & $403 \pm 18$ & $1,53 \pm 0,06$ & $31 \pm 6$ & - & $6,36 \pm 0,11$ \\
\hline CSQN105 & $480 \pm 13$ & $0,6 \pm 0,03$ & $33 \pm 6$ & - & $8,09 \pm 0,06$ \\
\hline
\end{tabular}




\begin{tabular}{|c|c|c|c|c|c|}
\hline Código & Lu (ng/g) & $\mathrm{Na}(\mathrm{mg} / \mathrm{g})$ & Nd & $\mathbf{S b}$ & Sm \\
\hline CSQN106 & $460 \pm 13$ & $2,42 \pm 0,09$ & $38 \pm 8$ & $0,3 \pm 0,3$ & $7,29 \pm 0,12$ \\
\hline CSQN107 & $484 \pm 20$ & $2,04 \pm 0,08$ & $38 \pm 7$ & $0,8 \pm 0,3$ & $7,89 \pm 0,12$ \\
\hline CSQN108 & $443 \pm 18$ & $3,08 \pm 0,11$ & $20 \pm 5$ & - & $6,68 \pm 0,12$ \\
\hline CSQN109 & $587 \pm 21$ & $5,82 \pm 0,21$ & $24 \pm 6$ & - & $7,65 \pm 0,12$ \\
\hline CSQN110 & $410 \pm 13$ & $0,49 \pm 0,04$ & $44 \pm 9$ & $0,9 \pm 0,3$ & $0,35 \pm 0,01$ \\
\hline CSQN111 & $414 \pm 18$ & $3,92 \pm 0,14$ & $25 \pm 6$ & $0,2 \pm 0,5$ & $4,78 \pm 0,1$ \\
\hline CSQN112 & $370 \pm 17$ & $3,47 \pm 0,08$ & $20 \pm 7$ & $1 \pm 0,6$ & $2,2 \pm 0,04$ \\
\hline CSQN113 & $447 \pm 22$ & $4,18 \pm 0,09$ & $26 \pm 10$ & - & $3,42 \pm 0,05$ \\
\hline CSQN114 & $337 \pm 24$ & $1,61 \pm 0,04$ & $10 \pm 7$ & - & $2 \pm 0,04$ \\
\hline CSQN115 & $291 \pm 16$ & $0,35 \pm 0,02$ & $20 \pm 8$ & $0,3 \pm 0,3$ & $1,93 \pm 0,01$ \\
\hline CSQN116 & $550 \pm 33$ & $4,19 \pm 0,14$ & - & - & $3,96 \pm 0,03$ \\
\hline CSQN117 & $597 \pm 42$ & $1,1 \pm 0,04$ & $40 \pm 15$ & - & $4,31 \pm 0,08$ \\
\hline CSQN118 & $527 \pm 36$ & $1,61 \pm 0,05$ & $45 \pm 16$ & - & $4,38 \pm 0,1$ \\
\hline CSQN119 & $627 \pm 21$ & $1,7 \pm 0,04$ & $46 \pm 9$ & - & $10,72 \pm 0,03$ \\
\hline CSQN120 & $526 \pm 25$ & $1,11 \pm 0,04$ & $34 \pm 13$ & - & $3,71 \pm 0,08$ \\
\hline CSQN121 & $524 \pm 23$ & $0,79 \pm 0,03$ & $30 \pm 10$ & $1,2 \pm 0,4$ & $1,37 \pm 0,01$ \\
\hline CSQN122 & $650 \pm 35$ & $0,64 \pm 0,02$ & $24 \pm 7$ & - & $2,41 \pm 0,01$ \\
\hline CSQN123 & $501 \pm 32$ & $1,49 \pm 0,04$ & $15 \pm 6$ & - & $2,73 \pm 0,05$ \\
\hline CSQN126 & $420 \pm 21$ & $0,38 \pm 0,02$ & $20 \pm 10$ & - & $1,12 \pm 0,02$ \\
\hline CSQN127 & $498 \pm 31$ & $0,5 \pm 0,02$ & - & - & $4,8 \pm 0,06$ \\
\hline CSQN128 & $151 \pm 40$ & $0,44 \pm 0,02$ & - & - & $0,92 \pm 0,02$ \\
\hline CSQN129 & $453 \pm 33$ & $0,35 \pm 0,02$ & $7 \pm 9$ & - & $3,68 \pm 0,04$ \\
\hline CSQN130 & $636 \pm 53$ & $6,3 \pm 0,13$ & - & - & $5,55 \pm 0,14$ \\
\hline CSQN131 & $420 \pm 34$ & $0,56 \pm 0,02$ & $25 \pm 11$ & $1,4 \pm 1$ & $3,45 \pm 0,13$ \\
\hline CSQN132 & $405 \pm 54$ & $2,47 \pm 0,06$ & $26 \pm 11$ & - & $4,81 \pm 0,04$ \\
\hline CSQN133 & $472 \pm 55$ & $1,11 \pm 0,03$ & - & - & $4,64 \pm 0,15$ \\
\hline CSQN351 & $468 \pm 104$ & $3,95 \pm 0,06$ & - & - & $6,16 \pm 0,04$ \\
\hline CSQN352 & $482 \pm 86$ & $0,47 \pm 0,01$ & - & - & $5,94 \pm 0,02$ \\
\hline CSQN353 & $368 \pm 81$ & $4,17 \pm 0,16$ & - & - & $5,78 \pm 0,09$ \\
\hline CSQN354 & $484 \pm 95$ & $2,82 \pm 0,12$ & - & - & $4,4 \pm 0,09$ \\
\hline CSQN355 & $367 \pm 101$ & $2,17 \pm 0,04$ & - & - & $7,05 \pm 0,04$ \\
\hline CSQN356 & $530 \pm 55$ & $2,08 \pm 0,09$ & - & - & $5,8 \pm 0,09$ \\
\hline CSQN357 & $297 \pm 74$ & $0,66 \pm 0,01$ & - & - & $4,19 \pm 0,03$ \\
\hline CSQN358 & $419 \pm 47$ & $2,6 \pm 0,07$ & - & - & $4,69 \pm 0,03$ \\
\hline CSQN359 & $330 \pm 44$ & $0,41 \pm 0,01$ & - & - & $6,5 \pm 0,03$ \\
\hline CSQN360 & $528 \pm 46$ & $2,84 \pm 0,08$ & $52 \pm 22$ & - & $6,2 \pm 0,03$ \\
\hline CSQN361 & $455 \pm 49$ & $3,22 \pm 0,08$ & - & - & $4,7 \pm 0,04$ \\
\hline CSQN362 & $431 \pm 28$ & $2,84 \pm 0,08$ & - & - & $4,83 \pm 0,03$ \\
\hline CSQN363 & $422 \pm 44$ & $0,84 \pm 0,03$ & - & - & $5,11 \pm 0,03$ \\
\hline CSQN364 & $350 \pm 40$ & $0,45 \pm 0,03$ & - & - & $1,9 \pm 0,03$ \\
\hline CSQN365 & $463 \pm 44$ & $3,18 \pm 0,08$ & - & - & $4,8 \pm 0,15$ \\
\hline CSQN366 & $355 \pm 18$ & $0,4 \pm 0,02$ & - & - & $3,94 \pm 0,04$ \\
\hline CSQN367 & $469 \pm 22$ & $0,82 \pm 0,03$ & - & - & $3,53 \pm 0,04$ \\
\hline CSQN368 & $424 \pm 21$ & $1,04 \pm 0,04$ & $62 \pm 23$ & - & $2,99 \pm 0,04$ \\
\hline CSQN369 & $479 \pm 21$ & $0,87 \pm 0,03$ & $68 \pm 22$ & - & $4,59 \pm 0,05$ \\
\hline
\end{tabular}




\begin{tabular}{|c|c|c|c|c|c|}
\hline Código & Lu (ng/g) & $\mathrm{Na}(\mathrm{mg} / \mathrm{g})$ & Nd & $\mathbf{S b}$ & Sm \\
\hline CSQN370 & $432 \pm 21$ & $1,92 \pm 0,06$ & - & - & $5,24 \pm 0,05$ \\
\hline CSQN371 & $481 \pm 20$ & $0,98 \pm 0,04$ & - & - & $3,04 \pm 0,03$ \\
\hline CSQN372 & $529 \pm 22$ & $2,31 \pm 0,05$ & $50 \pm 14$ & - & $4,11 \pm 0,04$ \\
\hline CSQN373 & $426 \pm 27$ & $3,01 \pm 0,06$ & $23 \pm 10$ & - & $5 \pm 0,03$ \\
\hline CSQN374 & $503 \pm 21$ & $1,4 \pm 0,04$ & - & - & $5,53 \pm 0,03$ \\
\hline CSQN375 & $296 \pm 16$ & $0,36 \pm 0,02$ & - & - & $0,82 \pm 0,03$ \\
\hline CSQN376 & $532 \pm 21$ & $2,12 \pm 0,05$ & $52 \pm 15$ & - & $6,52 \pm 0,04$ \\
\hline CSQN377 & $429 \pm 19$ & $3,14 \pm 0,07$ & - & - & $4,04 \pm 0,04$ \\
\hline CSQN378 & $1303 \pm 37$ & $0,55 \pm 0,04$ & $105 \pm 24$ & - & $9,9 \pm 0,06$ \\
\hline CSQN379 & $416 \pm 18$ & $1,31 \pm 0,04$ & - & - & $5,05 \pm 0,14$ \\
\hline CSQN380 & $481 \pm 19$ & $1,78 \pm 0,05$ & $50 \pm 14$ & - & $6,97 \pm 0,06$ \\
\hline CSQN381 & $543 \pm 20$ & $5,8 \pm 0,14$ & $51 \pm 16$ & - & $4,27 \pm 0,05$ \\
\hline CSQN382 & $486 \pm 19$ & $0,92 \pm 0,04$ & - & - & $6,09 \pm 0,05$ \\
\hline CSQN383 & $342 \pm 15$ & $0,45 \pm 0,03$ & - & - & $4,21 \pm 0,04$ \\
\hline CSQN384 & $479 \pm 18$ & $4,4 \pm 0,11$ & $35 \pm 12$ & - & $4,07 \pm 0,04$ \\
\hline CSQN385 & $505 \pm 18$ & $2,05 \pm 0,07$ & $31 \pm 11$ & - & $7,21 \pm 0,06$ \\
\hline CSQN386 & $505 \pm 16$ & $0,53 \pm 0,01$ & $20 \pm 8$ & - & $1,54 \pm 0,02$ \\
\hline CSQN387 & $547 \pm 17$ & $3,74 \pm 0,07$ & $28 \pm 9$ & - & $8,15 \pm 0,03$ \\
\hline CSQN388 & $497 \pm 16$ & $3,1 \pm 0,06$ & $35 \pm 11$ & - & $3,7 \pm 0,03$ \\
\hline CSQN389 & $472 \pm 15$ & $3,91 \pm 0,07$ & $29 \pm 10$ & - & $3,33 \pm 0,03$ \\
\hline CSQN390 & $445 \pm 15$ & $0,54 \pm 0,02$ & $26 \pm 8$ & - & $4,9 \pm 0,02$ \\
\hline CSQN391 & $508 \pm 16$ & $0,69 \pm 16,76$ & $34 \pm 10$ & - & $6,45 \pm 0,09$ \\
\hline CSQN392 & $330 \pm 13$ & $0,7 \pm 0,02$ & $36 \pm 9$ & - & $5,27 \pm 0,08$ \\
\hline CSQN393 & $426 \pm 13$ & $0,58 \pm 0,03$ & $26 \pm 5$ & - & $5,04 \pm 0,03$ \\
\hline CSQN394 & - & $0,59 \pm 0,03$ & $113 \pm 13$ & - & $5,24 \pm 0,04$ \\
\hline CSQN395 & $309 \pm 15$ & $0,48 \pm 0,03$ & $42 \pm 6$ & - & $4,14 \pm 0,03$ \\
\hline CSQN396 & $563 \pm 22$ & $1,79 \pm 0,06$ & $107 \pm 12$ & - & $7,35 \pm 0,04$ \\
\hline CSQN397 & $396 \pm 21$ & $0,78 \pm 0,04$ & $101 \pm 12$ & - & $4,26 \pm 0,04$ \\
\hline CSQN398 & $454 \pm 13$ & $2,11 \pm 0,07$ & $35 \pm 6$ & - & $7,22 \pm 0,04$ \\
\hline CSQN399 & $408 \pm 13$ & $1,88 \pm 0,06$ & $21 \pm 5$ & - & $6,16 \pm 0,03$ \\
\hline CSQN400 & $584 \pm 17$ & $1,75 \pm 0,06$ & $28 \pm 5$ & - & $6,88 \pm 0,03$ \\
\hline CSQN401 & $511 \pm 16$ & $1,85 \pm 0,06$ & $45 \pm 8$ & - & $6,6 \pm 0,03$ \\
\hline CSQN402 & $502 \pm 14$ & $3,26 \pm 0,09$ & $41 \pm 7$ & - & $6,3 \pm 0,03$ \\
\hline CSQN403 & $595 \pm 16$ & $2,61 \pm 0,08$ & $40 \pm 7$ & - & $7,73 \pm 0,03$ \\
\hline CSQN404 & $574 \pm 16$ & $4,65 \pm 0,13$ & $43 \pm 7$ & - & $8,41 \pm 0,04$ \\
\hline CSQN405 & $426 \pm 14$ & $0,42 \pm 0,03$ & $18 \pm 5$ & - & $3,98 \pm 0,03$ \\
\hline CSQN406 & $472 \pm 14$ & $0,51 \pm 0,03$ & $22 \pm 5$ & - & $4,63 \pm 0,03$ \\
\hline CSQN407 & $609 \pm 16$ & $2,29 \pm 0,06$ & $45 \pm 8$ & - & $8,51 \pm 0,04$ \\
\hline CSQN408 & $410 \pm 12$ & $1,27 \pm 0,04$ & $34 \pm 6$ & - & $5,6 \pm 0,04$ \\
\hline CSQN409 & $524 \pm 13$ & $1,6 \pm 0,05$ & $35 \pm 6$ & - & $6,38 \pm 0,03$ \\
\hline CSQN410 & $510 \pm 13$ & $2,39 \pm 0,07$ & $23 \pm 5$ & - & $6,12 \pm 0,03$ \\
\hline CSQN411 & $492 \pm 13$ & $4,52 \pm 0,11$ & $36 \pm 6$ & - & $6,82 \pm 0,03$ \\
\hline CSQN412 & $600 \pm 14$ & $2,66 \pm 0,08$ & $49 \pm 7$ & - & $8,69 \pm 0,04$ \\
\hline CSQN413 & $519 \pm 14$ & $1,35 \pm 0,05$ & $31 \pm 6$ & - & $7,46 \pm 0,04$ \\
\hline CSQN414 & $444 \pm 13$ & $1,77 \pm 0,06$ & $31 \pm 6$ & - & $6,12 \pm 0,03$ \\
\hline
\end{tabular}




\begin{tabular}{|c|c|c|c|c|c|}
\hline Código & Lu (ng/g) & $\mathrm{Na}(\mathrm{mg} / \mathrm{g})$ & Nd & $\mathbf{S b}$ & Sm \\
\hline CSQN415 & $498 \pm 15$ & $1,9 \pm 0,06$ & $26 \pm 5$ & - & $6,63 \pm 0,03$ \\
\hline CSQN416 & $494 \pm 28$ & $2,92 \pm 0,08$ & $23 \pm 5$ & - & $6,52 \pm 0,03$ \\
\hline CSQN417 & $545 \pm 13$ & $3,14 \pm 0,06$ & $33 \pm 6$ & - & $6,95 \pm 0,02$ \\
\hline CSQN418 & $360 \pm 11$ & $0,86 \pm 0,02$ & $32 \pm 6$ & - & $5,32 \pm 0,02$ \\
\hline CSQN419 & $414 \pm 12$ & $0,36 \pm 0,01$ & $15 \pm 5$ & - & $3,88 \pm 0,02$ \\
\hline CSQN420 & $429 \pm 12$ & $0,41 \pm 0,01$ & $21 \pm 5$ & - & $4,28 \pm 0,02$ \\
\hline CSQN421 & $468 \pm 12$ & $1,66 \pm 0,04$ & $29 \pm 5$ & - & $7,11 \pm 0,03$ \\
\hline CSQN422 & $604 \pm 21$ & $0,69 \pm 0,04$ & $35 \pm 10$ & - & $9,39 \pm 0,05$ \\
\hline CSQN423 & $884 \pm 29$ & $0,93 \pm 0,05$ & $68 \pm 15$ & - & $12,17 \pm 0,07$ \\
\hline CSQN424 & $547 \pm 36$ & $2,43 \pm 0,05$ & $40 \pm 9$ & - & $9,34 \pm 0,07$ \\
\hline CSQN424\#2 & $513 \pm 40$ & $2,34 \pm 0,1$ & $31 \pm 12$ & - & $7,62 \pm 0,04$ \\
\hline CSQN425 & $462 \pm 39$ & $3,36 \pm 0,14$ & $32 \pm 11$ & - & $5,88 \pm 0,23$ \\
\hline CSQN426 & $477 \pm 30$ & $1,7 \pm 0,04$ & $11 \pm 6$ & - & $6,6 \pm 0,05$ \\
\hline CSQN426\#2 & $489 \pm 35$ & $1,62 \pm 0,08$ & $33 \pm 13$ & - & $6,3 \pm 0,15$ \\
\hline CSQN427 & $522 \pm 44$ & $1,58 \pm 0,08$ & $38 \pm 16$ & - & $3,63 \pm 0,04$ \\
\hline CSQN428 & $581 \pm 34$ & $0,51 \pm 0,02$ & $29 \pm 8$ & - & $4,31 \pm 0,19$ \\
\hline CSQN428\#2 & $579 \pm 38$ & $0,53 \pm 0,05$ & $34 \pm 11$ & $1,2 \pm 0,6$ & $1,85 \pm 0,03$ \\
\hline CSQN429 & $390 \pm 26$ & $0,35 \pm 0,02$ & $25 \pm 9$ & - & $2,7 \pm 0,04$ \\
\hline CSQN429\#2 & $432 \pm 34$ & $0,38 \pm 0,05$ & - & - & $3,73 \pm 0,16$ \\
\hline CSQN430 & $408 \pm 28$ & $3,65 \pm 0,07$ & $18 \pm 6$ & - & $5 \pm 0,12$ \\
\hline CSQN430\#2 & $434 \pm 39$ & $3,76 \pm 0,17$ & $18 \pm 9$ & - & $6,66 \pm 0,06$ \\
\hline CSQN431 & $564 \pm 48$ & $1,56 \pm 0,08$ & $57 \pm 20$ & - & $6,63 \pm 0,18$ \\
\hline CSQN432 & $594 \pm 42$ & $1,13 \pm 0,06$ & $22 \pm 10$ & - & $7,82 \pm 0,04$ \\
\hline CSQN433 & $515 \pm 40$ & $2,75 \pm 0,11$ & $41 \pm 13$ & - & $5,3 \pm 0,15$ \\
\hline CSQN434 & $600 \pm 42$ & $1,81 \pm 0,09$ & $44 \pm 15$ & - & $3,92 \pm 0,04$ \\
\hline CSQN435 & $472 \pm 39$ & $1,59 \pm 0,08$ & $27 \pm 10$ & - & $3,88 \pm 0,04$ \\
\hline CSQN436 & $607 \pm 49$ & $3,19 \pm 0,13$ & $51 \pm 17$ & - & $4,27 \pm 0,04$ \\
\hline CSQN437 & $503 \pm 41$ & $4,96 \pm 0,21$ & $35 \pm 17$ & - & $2,61 \pm 0,04$ \\
\hline CSQN438 & $284 \pm 18$ & $0,44 \pm 0,01$ & - & - & $3,08 \pm 0,11$ \\
\hline CSQN439 & $394 \pm 19$ & $2,53 \pm 0,05$ & $20 \pm 10$ & - & $3,88 \pm 0,1$ \\
\hline CSQN440 & $418 \pm 26$ & $1,47 \pm 0,03$ & $7 \pm 7$ & - & $2,47 \pm 0,15$ \\
\hline CSQN441 & $477 \pm 31$ & $0,43 \pm 0,02$ & $17 \pm 11$ & - & $6,63 \pm 0,03$ \\
\hline CSQN442 & $460 \pm 30$ & $1,63 \pm 0,04$ & $35 \pm 10$ & - & $4,05 \pm 0,03$ \\
\hline CSQN443 & $745 \pm 40$ & $0,63 \pm 0,02$ & $68 \pm 16$ & - & $9,25 \pm 0,03$ \\
\hline CSQN444 & $455 \pm 29$ & $2,7 \pm 0,06$ & $43 \pm 11$ & - & $5,28 \pm 0,01$ \\
\hline CSQN445 & $571 \pm 34$ & $2,45 \pm 0,06$ & $50 \pm 14$ & - & $8,08 \pm 0,19$ \\
\hline CSQN446 & $354 \pm 25$ & $0,46 \pm 0,02$ & $34 \pm 11$ & - & $2,41 \pm 0,02$ \\
\hline CSQN447 & $572 \pm 43$ & $0,39 \pm 0,02$ & - & - & $4,13 \pm 0,03$ \\
\hline CSQN448 & $454 \pm 36$ & $3,75 \pm 0,09$ & $44 \pm 13$ & - & $5,36 \pm 0,03$ \\
\hline CSQN449 & $465 \pm 39$ & $3,76 \pm 0,09$ & $71 \pm 19$ & - & $4,67 \pm 0,13$ \\
\hline CSQN450 & $337 \pm 35$ & $0,28 \pm 0,02$ & - & - & $2,37 \pm 0,11$ \\
\hline CSQN451 & $687 \pm 40$ & $0,59 \pm 0,03$ & $40 \pm 12$ & - & $4,64 \pm 0,03$ \\
\hline CSQN453 & $610 \pm 35$ & $0,48 \pm 0,01$ & $32 \pm 10$ & $1,2 \pm 0,5$ & $4,28 \pm 0,09$ \\
\hline CSQN454 & $541 \pm 35$ & $3,89 \pm 0,06$ & $38 \pm 13$ & - & $4,21 \pm 0,02$ \\
\hline CSQN455 & $452 \pm 27$ & $3,46 \pm 0,06$ & $27 \pm 10$ & - & $5,51 \pm 0,03$ \\
\hline
\end{tabular}




\begin{tabular}{cccccc}
\hline Código & Lu (ng/g) & Na (mg/g) & Nd & Sb & Sm \\
\hline CSQN456 & $494 \pm 29$ & $4,4 \pm 0,08$ & $24 \pm 10$ & - & $6,11 \pm 0,03$ \\
CSQN457 & $547 \pm 30$ & $5,86 \pm 0,1$ & $21 \pm 10$ & - & $5,72 \pm 0,03$ \\
\hline
\end{tabular}




\begin{tabular}{|c|c|c|c|c|c|}
\hline Código & $\mathbf{U}$ & $\mathbf{Y b}$ & $\mathbf{B a}$ & $\mathrm{Ce}$ & Co \\
\hline CSQN58 & $2,4 \pm 0,2$ & $2,02 \pm 0,13$ & $592 \pm 136$ & $58 \pm 4$ & $11,1 \pm 0,5$ \\
\hline CSQN59 & $2,8 \pm 0,4$ & $2,2 \pm 0,14$ & $267 \pm 75$ & $58 \pm 4$ & $2,7 \pm 0,2$ \\
\hline CSQN60 & $3,8 \pm 0,3$ & $3,1 \pm 0,18$ & $588 \pm 136$ & $79 \pm 5$ & $9,9 \pm 0,5$ \\
\hline CSQN61 & $2,6 \pm 0,2$ & $2,83 \pm 0,17$ & $402 \pm 104$ & $74 \pm 5$ & $12,7 \pm 0,6$ \\
\hline CSQN62 & $4,4 \pm 0,5$ & $2,71 \pm 0,11$ & $385 \pm 141$ & $83 \pm 2$ & $12,3 \pm 0,3$ \\
\hline CSQN63 & $3,9 \pm 0,4$ & $3,76 \pm 0,13$ & $230 \pm 244$ & $98 \pm 2$ & $17,1 \pm 0,4$ \\
\hline CSQN64 & $2,7 \pm 0,5$ & $2 \pm 0,1$ & $318 \pm 141$ & $54 \pm 1$ & $5 \pm 0,2$ \\
\hline CSQN65 & $3 \pm 0,4$ & $3,31 \pm 0,11$ & $550 \pm 185$ & $81 \pm 1$ & $8,4 \pm 0,3$ \\
\hline CSQN66 & $4,4 \pm 0,6$ & $3,45 \pm 0,13$ & $550 \pm 210$ & $87 \pm 1$ & $11,4 \pm 0,3$ \\
\hline CSQN67 & $3,6 \pm 0,4$ & $3,75 \pm 0,11$ & $548 \pm 182$ & $113 \pm 1$ & $10,1 \pm 0,2$ \\
\hline CSQN68 & $3,8 \pm 0,4$ & $3,77 \pm 0,12$ & $689 \pm 211$ & $92 \pm 1$ & $9,6 \pm 0,2$ \\
\hline CSQN70 & $3,2 \pm 0,4$ & $2,38 \pm 0,09$ & $243 \pm 137$ & $64 \pm 1$ & $4,4 \pm 0,1$ \\
\hline CSQN72 & $3,4 \pm 0,6$ & $3,23 \pm 0,12$ & $618 \pm 183$ & $89 \pm 1$ & $13,3 \pm 0,3$ \\
\hline CSQN73 & $3,1 \pm 0,3$ & $2,59 \pm 0,09$ & $412 \pm 136$ & $61 \pm 1$ & $5,6 \pm 0,2$ \\
\hline CSQN74 & $3,4 \pm 0,3$ & $3,57 \pm 0,11$ & $276 \pm 155$ & $104 \pm 1$ & $9,5 \pm 0,2$ \\
\hline CSQN75 & $3,9 \pm 0,4$ & $3,21 \pm 0,13$ & $612 \pm 334$ & $82 \pm 2$ & $14,4 \pm 0,6$ \\
\hline CSQN76 & $4,7 \pm 0,4$ & $3,99 \pm 0,14$ & $551 \pm 260$ & $97 \pm 2$ & $12,6 \pm 0,3$ \\
\hline CSQN77 & $3,8 \pm 0,3$ & $3,1 \pm 0,14$ & $344 \pm 218$ & $70 \pm 2$ & $18,3 \pm 0,6$ \\
\hline CSQN78 & $3,7 \pm 0,3$ & $3,78 \pm 0,15$ & $793 \pm 357$ & $114 \pm 2$ & $27,5 \pm 0,5$ \\
\hline CSQN79 & $5,6 \pm 0,4$ & $4,58 \pm 0,16$ & $761 \pm 319$ & $77 \pm 1$ & $5,5 \pm 0,2$ \\
\hline CSQN80 & $4,7 \pm 0,4$ & $3,51 \pm 0,15$ & $758 \pm 320$ & $77 \pm 2$ & $7,8 \pm 0,3$ \\
\hline CSQN81 & $3,5 \pm 0,3$ & $2,81 \pm 0,13$ & $547 \pm 240$ & $65 \pm 1$ & $10 \pm 0,3$ \\
\hline CSQN82 & $6,9 \pm 1$ & $5,53 \pm 0,2$ & - & $155 \pm 2$ & $3 \pm 0,1$ \\
\hline CSQN83 & $6,8 \pm 0,8$ & $4,63 \pm 0,18$ & - & $161 \pm 2$ & $2,4 \pm 0,1$ \\
\hline CSQN84 & $7 \pm 1,1$ & $5,93 \pm 0,2$ & - & $91 \pm 1$ & $2,4 \pm 0,1$ \\
\hline CSQN85 & $7 \pm 0,8$ & $4,85 \pm 0,18$ & - & $154 \pm 2$ & $4,2 \pm 0,1$ \\
\hline CSQN86 & $6,4 \pm 0,8$ & $4,58 \pm 0,17$ & - & $146 \pm 2$ & $2,9 \pm 0,1$ \\
\hline CSQN87 & $6,2 \pm 0,7$ & $4,55 \pm 0,17$ & - & $143 \pm 2$ & $1,9 \pm 0,1$ \\
\hline CSQN88 & $5,5 \pm 0,9$ & $4,79 \pm 0,23$ & $2051 \pm 1322$ & $148 \pm 2$ & $1,7 \pm 0,1$ \\
\hline CSQN89 & $6,8 \pm 1,1$ & $5,71 \pm 0,25$ & $1146 \pm 773$ & $149 \pm 2$ & $3,4 \pm 0,1$ \\
\hline CSQN90 & $5,4 \pm 1,6$ & $2,68 \pm 0,22$ & $1259 \pm 835$ & $78 \pm 1$ & $17,2 \pm 0,3$ \\
\hline CSQN91 & $7,4 \pm 1,8$ & $2,27 \pm 0,19$ & $1500 \pm 980$ & $42 \pm 1$ & $7,4 \pm 0,2$ \\
\hline CSQN92 & $4,6 \pm 0,8$ & $3,01 \pm 0,18$ & $2158 \pm 1401$ & $77 \pm 1$ & $14,8 \pm 0,3$ \\
\hline CSQN93 & $4,5 \pm 0,9$ & $3,11 \pm 0,25$ & $2022 \pm 1314$ & $87 \pm 1$ & $10,5 \pm 0,2$ \\
\hline CSQN94 & $4 \pm 0,7$ & $3,41 \pm 0,21$ & $1292 \pm 850$ & $78 \pm 1$ & $9,6 \pm 0,2$ \\
\hline CSQN95 & $3,9 \pm 0,3$ & $3,44 \pm 0,09$ & $1111 \pm 700$ & $65 \pm 1$ & $8,3 \pm 0,2$ \\
\hline CSQN96 & $0 \pm 0$ & $0 \pm 0$ & $492 \pm 364$ & $49 \pm 1$ & $40 \pm 0,5$ \\
\hline CSQN97 & $3,2 \pm 0,4$ & $2,65 \pm 0,09$ & $1266 \pm 793$ & $62 \pm 1$ & $8,4 \pm 0,2$ \\
\hline CSQN98 & $2,9 \pm 0,2$ & $2,51 \pm 0,08$ & $1650 \pm 1005$ & $63 \pm 1$ & $5,5 \pm 0,2$ \\
\hline CSQN99 & $2,9 \pm 0,2$ & $2,78 \pm 0,09$ & $1226 \pm 753$ & $87 \pm 1$ & $9,1 \pm 0,2$ \\
\hline CSQN100 & $3,7 \pm 0,3$ & $4,69 \pm 0,11$ & $1010 \pm 627$ & $148 \pm 1$ & $11 \pm 0,2$ \\
\hline CSQN101 & $3,5 \pm 0,3$ & $2,88 \pm 0,09$ & $1653 \pm 1017$ & $77 \pm 1$ & $7,1 \pm 0,2$ \\
\hline CSQN103 & $3,6 \pm 0,6$ & $2,61 \pm 0,1$ & $654 \pm 228$ & $76 \pm 2$ & $11,6 \pm 0,4$ \\
\hline CSQN104 & $3,4 \pm 0,4$ & $2,67 \pm 0,09$ & $518 \pm 112$ & $70 \pm 1$ & $13,8 \pm 0,2$ \\
\hline CSQN105 & $4 \pm 0,5$ & $2,79 \pm 0,1$ & $239 \pm 92$ & $77 \pm 1$ & $8,8 \pm 0,2$ \\
\hline
\end{tabular}




\begin{tabular}{|c|c|c|c|c|c|}
\hline Código & $\mathbf{U}$ & $\mathbf{Y b}$ & $\mathbf{B a}$ & $\mathrm{Ce}$ & Co \\
\hline CSQN106 & $4,2 \pm 0,7$ & $2,81 \pm 0,09$ & $556 \pm 131$ & $80 \pm 1$ & $10,8 \pm 0,2$ \\
\hline CSQN107 & $4,8 \pm 0,5$ & $3,42 \pm 0,11$ & $655 \pm 128$ & $88 \pm 1$ & $13,4 \pm 0,2$ \\
\hline CSQN108 & $3,7 \pm 0,4$ & $2,95 \pm 0,09$ & $806 \pm 160$ & $79 \pm 1$ & $10,3 \pm 0,2$ \\
\hline CSQN109 & $4,8 \pm 0,5$ & $3,69 \pm 0,11$ & $913 \pm 167$ & $112 \pm 1$ & $10,6 \pm 0,2$ \\
\hline CSQN110 & $4,5 \pm 0,7$ & $2,64 \pm 0,1$ & $600 \pm 131$ & $79 \pm 1$ & $33,8 \pm 0,4$ \\
\hline CSQN111 & $3,4 \pm 0,4$ & $2,59 \pm 0,08$ & $766 \pm 142$ & $63 \pm 1$ & $9,8 \pm 0,2$ \\
\hline CSQN112 & $3,3 \pm 0,5$ & $2,4 \pm 0,11$ & $323 \pm 87$ & $72 \pm 1$ & $15,4 \pm 0,3$ \\
\hline CSQN113 & $3,6 \pm 0,7$ & $2,58 \pm 0,16$ & $553 \pm 137$ & $91 \pm 1$ & $14,1 \pm 0,3$ \\
\hline CSQN114 & $2,6 \pm 0,3$ & $2,36 \pm 0,11$ & $537 \pm 125$ & $71 \pm 1$ & $10,5 \pm 0,3$ \\
\hline CSQN115 & $2,7 \pm 0,3$ & $1,52 \pm 0,1$ & $354 \pm 100$ & $62 \pm 1$ & $6,1 \pm 0,2$ \\
\hline CSQN116 & $4,8 \pm 1,7$ & $3,34 \pm 0,35$ & $605 \pm 266$ & $77 \pm 2$ & $46,8 \pm 1$ \\
\hline CSQN117 & $3,8 \pm 0,8$ & $3,8 \pm 0,16$ & - & $108 \pm 2$ & $10,4 \pm 0,4$ \\
\hline CSQN118 & $5,2 \pm 0,9$ & $3,63 \pm 0,16$ & $470 \pm 255$ & $110 \pm 2$ & $8,9 \pm 0,4$ \\
\hline CSQN119 & $3,4 \pm 0,6$ & $3,67 \pm 0,11$ & $771 \pm 254$ & $113 \pm 2$ & $11 \pm 0,3$ \\
\hline CSQN120 & $3,3 \pm 0,9$ & $3,18 \pm 0,15$ & $114 \pm 126$ & $96 \pm 2$ & $9,6 \pm 0,4$ \\
\hline CSQN121 & $5,3 \pm 0,9$ & $3,13 \pm 0,14$ & $402 \pm 110$ & $120 \pm 1$ & $13,1 \pm 0,3$ \\
\hline CSQN122 & $4 \pm 0,6$ & $4,04 \pm 0,15$ & $277 \pm 100$ & $112 \pm 1$ & $11,9 \pm 0,3$ \\
\hline CSQN123 & $4,3 \pm 0,6$ & $3,13 \pm 0,12$ & $337 \pm 115$ & $87 \pm 1$ & $11,8 \pm 0,3$ \\
\hline CSQN126 & $2,8 \pm 0,4$ & $2,56 \pm 0,14$ & - & $48 \pm 1$ & $6,1 \pm 0,3$ \\
\hline CSQN127 & - & $2,72 \pm 0,47$ & $360 \pm 171$ & $81 \pm 2$ & $27,3 \pm 0,7$ \\
\hline CSQN128 & $2 \pm 0,8$ & $1,35 \pm 0,12$ & $163 \pm 136$ & $48 \pm 1$ & $5,2 \pm 0,3$ \\
\hline CSQN129 & $3 \pm 0,9$ & $2,73 \pm 0,22$ & $652 \pm 239$ & $57 \pm 1$ & $3,9 \pm 0,2$ \\
\hline CSQN130 & $2,8 \pm 1$ & $3,78 \pm 0,24$ & $582 \pm 233$ & $86 \pm 2$ & $13,9 \pm 0,4$ \\
\hline CSQN131 & $3,5 \pm 1$ & $2,15 \pm 0,16$ & $221 \pm 155$ & $65 \pm 2$ & $10,6 \pm 0,4$ \\
\hline CSQN132 & $5,6 \pm 1,3$ & $3,22 \pm 0,22$ & $503 \pm 210$ & $83 \pm 2$ & $13,9 \pm 0,4$ \\
\hline CSQN133 & $4,1 \pm 1,4$ & $3,4 \pm 0,22$ & $498 \pm 218$ & $79 \pm 2$ & $9,3 \pm 0,4$ \\
\hline CSQN351 & $4,4 \pm 1,7$ & $2,85 \pm 0,48$ & - & $74 \pm 4$ & $7,7 \pm 0,8$ \\
\hline CSQN352 & $2,5 \pm 1,1$ & $3,94 \pm 0,44$ & - & $87 \pm 5$ & $7,8 \pm 0,7$ \\
\hline CSQN353 & $6,4 \pm 3,5$ & $2,62 \pm 0,42$ & - & $80 \pm 5$ & $9,8 \pm 1,8$ \\
\hline CSQN354 & $10,6 \pm 5,2$ & $2,09 \pm 0,37$ & $593 \pm 271$ & $90 \pm 8$ & $8,4 \pm 1,5$ \\
\hline CSQN355 & $4,2 \pm 1,3$ & $4,49 \pm 0,52$ & - & $81 \pm 8$ & $9,5 \pm 0,8$ \\
\hline CSQN356 & $7 \pm 3,7$ & $2,83 \pm 0,33$ & $797 \pm 307$ & $77 \pm 4$ & $11,8 \pm 1,3$ \\
\hline CSQN357 & $4 \pm 1,2$ & $3,1 \pm 0,41$ & - & $51 \pm 8$ & $3,6 \pm 0,6$ \\
\hline CSQN358 & $5,5 \pm 1,4$ & $2,66 \pm 0,22$ & - & $72 \pm 3$ & $7,5 \pm 0,3$ \\
\hline CSQN359 & $1,9 \pm 0,9$ & $2,75 \pm 0,39$ & - & $87 \pm 8$ & $3,7 \pm 0,6$ \\
\hline CSQN360 & $4 \pm 1,2$ & $3,35 \pm 0,22$ & - & $89 \pm 3$ & $11,2 \pm 0,4$ \\
\hline CSQN361 & $4,6 \pm 1,2$ & $2,65 \pm 0,18$ & - & $76 \pm 3$ & $8,4 \pm 0,3$ \\
\hline CSQN362 & $2,6 \pm 0,8$ & $2,84 \pm 0,21$ & - & $92 \pm 3$ & $11,9 \pm 0,4$ \\
\hline CSQN363 & $3 \pm 1,1$ & $3,12 \pm 0,21$ & - & $90 \pm 3$ & $9,9 \pm 0,4$ \\
\hline CSQN364 & $4,2 \pm 1,4$ & $2,25 \pm 0,2$ & - & $75 \pm 3$ & $4,8 \pm 0,3$ \\
\hline CSQN365 & $3,4 \pm 1$ & $2,38 \pm 0,16$ & - & $73 \pm 2$ & $6 \pm 0,3$ \\
\hline CSQN366 & $4,5 \pm 0,9$ & $2,1 \pm 0,13$ & - & $65 \pm 2$ & $5,5 \pm 0,3$ \\
\hline CSQN367 & $3,8 \pm 0,8$ & $2,86 \pm 0,17$ & - & $81 \pm 3$ & $10 \pm 0,4$ \\
\hline CSQN368 & $3,4 \pm 0,9$ & $2,54 \pm 0,16$ & - & $110 \pm 3$ & $15,3 \pm 0,5$ \\
\hline CSQN369 & $2 \pm 0,6$ & $2,68 \pm 0,15$ & - & $78 \pm 2$ & $8,6 \pm 0,3$ \\
\hline
\end{tabular}




\begin{tabular}{|c|c|c|c|c|c|}
\hline Código & $\mathbf{U}$ & $\mathbf{Y b}$ & Ba & $\mathrm{Ce}$ & Co \\
\hline CSQN370 & $2,4 \pm 0,7$ & $2,45 \pm 0,15$ & - & $71 \pm 2$ & $5,4 \pm 0,3$ \\
\hline CSQN371 & $4,1 \pm 1$ & $2,73 \pm 0,15$ & - & $42 \pm 2$ & $5,3 \pm 0,3$ \\
\hline CSQN372 & $3,5 \pm 0,8$ & $3,08 \pm 0,16$ & $584 \pm 218$ & $122 \pm 3$ & $9,2 \pm 0,4$ \\
\hline CSQN373 & $3,4 \pm 0,6$ & $2,4 \pm 0,11$ & $524 \pm 200$ & $69 \pm 2$ & $6,9 \pm 0,3$ \\
\hline CSQN374 & $3 \pm 0,7$ & $3,14 \pm 0,17$ & $317 \pm 139$ & $75 \pm 2$ & $6,5 \pm 0,3$ \\
\hline CSQN375 & $3,3 \pm 0,8$ & $2,06 \pm 0,13$ & $348 \pm 145$ & $43 \pm 2$ & $2,1 \pm 0,2$ \\
\hline CSQN376 & $4,2 \pm 0,8$ & $3,22 \pm 0,15$ & $604 \pm 207$ & $89 \pm 2$ & $7,3 \pm 0,3$ \\
\hline CSQN377 & $3,3 \pm 0,8$ & $2,27 \pm 0,15$ & $529 \pm 194$ & $65 \pm 2$ & $8,1 \pm 0,3$ \\
\hline CSQN378 & $4,8 \pm 1$ & $8,13 \pm 0,29$ & $811 \pm 283$ & $298 \pm 5$ & $8,5 \pm 0,4$ \\
\hline CSQN379 & $5,2 \pm 1,3$ & $2,67 \pm 0,15$ & - & $65 \pm 2$ & $9,1 \pm 0,3$ \\
\hline CSQN380 & $6,5 \pm 1,3$ & $3,07 \pm 0,16$ & - & $100 \pm 3$ & $11,6 \pm 0,4$ \\
\hline CSQN381 & $4,5 \pm 1,4$ & $3,54 \pm 0,17$ & - & $99 \pm 3$ & $11,8 \pm 0,4$ \\
\hline CSQN382 & $0,8 \pm 0,8$ & $2,86 \pm 0,15$ & - & $92 \pm 2$ & $9,7 \pm 0,4$ \\
\hline CSQN383 & $3,7 \pm 1,1$ & $2,31 \pm 0,14$ & - & $69 \pm 2$ & $4 \pm 0,2$ \\
\hline CSQN384 & $5,8 \pm 1,4$ & $2,97 \pm 0,15$ & - & $96 \pm 2$ & $10,1 \pm 0,3$ \\
\hline CSQN385 & $2,2 \pm 1$ & $3,04 \pm 0,15$ & - & $104 \pm 3$ & $8,7 \pm 0,3$ \\
\hline CSQN386 & $3,2 \pm 0,3$ & $2,83 \pm 0,13$ & $280 \pm 102$ & $125 \pm 5$ & $3,6 \pm 0,2$ \\
\hline CSQN387 & $4,4 \pm 0,6$ & $3,84 \pm 0,15$ & - & $175 \pm 6$ & $17,4 \pm 0,4$ \\
\hline CSQN388 & $4 \pm 0,7$ & $3,05 \pm 0,14$ & $291 \pm 80$ & $161 \pm 6$ & $16,7 \pm 0,4$ \\
\hline CSQN389 & $4,1 \pm 0,7$ & $3,42 \pm 0,15$ & $292 \pm 98$ & $206 \pm 8$ & $10,7 \pm 0,3$ \\
\hline CSQN390 & $4,1 \pm 0,4$ & $2,72 \pm 0,13$ & $296 \pm 104$ & $136 \pm 5$ & $4,5 \pm 0,2$ \\
\hline CSQN391 & $4 \pm 0,4$ & $3,35 \pm 0,15$ & - & $171 \pm 6$ & $4,9 \pm 0,2$ \\
\hline CSQN392 & $3,6 \pm 0,6$ & $2,36 \pm 0,12$ & $276 \pm 90$ & $149 \pm 5$ & $6 \pm 0,2$ \\
\hline CSQN393 & $4,5 \pm 0,7$ & $2,71 \pm 0,1$ & - & $67 \pm 2$ & $5,5 \pm 0,2$ \\
\hline CSQN394 & $3,8 \pm 1,2$ & $2,93 \pm 0,19$ & - & $94 \pm 2$ & $13 \pm 0,4$ \\
\hline CSQN395 & $4,4 \pm 0,9$ & $2,05 \pm 0,12$ & - & $86 \pm 2$ & $8,3 \pm 0,3$ \\
\hline CSQN396 & $3,6 \pm 1$ & $3,6 \pm 0,18$ & - & $144 \pm 3$ & $20,8 \pm 0,5$ \\
\hline CSQN397 & $3,9 \pm 1,4$ & $2,39 \pm 0,17$ & - & $150 \pm 3$ & $20,6 \pm 0,5$ \\
\hline CSQN398 & $4,3 \pm 0,7$ & $2,79 \pm 0,1$ & - & $83 \pm 2$ & $21,7 \pm 0,5$ \\
\hline CSQN399 & $3,5 \pm 0,6$ & $2,63 \pm 0,1$ & - & $83 \pm 2$ & $11,5 \pm 0,3$ \\
\hline CSQN400 & $4,6 \pm 0,7$ & $3,3 \pm 0,12$ & $663 \pm 180$ & $88 \pm 2$ & $7,5 \pm 0,5$ \\
\hline CSQN401 & $4,9 \pm 0,8$ & $3,07 \pm 0,12$ & $636 \pm 179$ & $85 \pm 2$ & $10,6 \pm 0,6$ \\
\hline CSQN402 & $3,7 \pm 0,6$ & $2,99 \pm 0,11$ & $592 \pm 150$ & $82 \pm 3$ & $11,2 \pm 0,5$ \\
\hline CSQN403 & $4,8 \pm 0,7$ & $3,54 \pm 0,12$ & $628 \pm 177$ & $90 \pm 2$ & $11,8 \pm 0,6$ \\
\hline CSQN404 & $3,6 \pm 0,6$ & $3,37 \pm 0,12$ & $783 \pm 196$ & $97 \pm 2$ & $16,2 \pm 0,7$ \\
\hline CSQN405 & $3,9 \pm 0,8$ & $2,77 \pm 0,11$ & $594 \pm 162$ & $73 \pm 3$ & $4,2 \pm 0,4$ \\
\hline CSQN406 & $4,7 \pm 0,7$ & $2,91 \pm 0,11$ & $749 \pm 181$ & $56 \pm 1$ & $5,4 \pm 0,4$ \\
\hline CSQN407 & $5,8 \pm 0,8$ & $4,02 \pm 0,12$ & $561 \pm 129$ & $111 \pm 3$ & $9,8 \pm 0,5$ \\
\hline CSQN408 & $3,3 \pm 0,6$ & $2,75 \pm 0,09$ & $704 \pm 176$ & $70 \pm 2$ & $6,6 \pm 0,4$ \\
\hline CSQN409 & $4,2 \pm 0,6$ & $3,07 \pm 0,1$ & $954 \pm 234$ & $71 \pm 2$ & $6,7 \pm 0,4$ \\
\hline CSQN410 & $4,4 \pm 0,6$ & $3,15 \pm 0,1$ & $1179 \pm 278$ & $69 \pm 3$ & $6,6 \pm 0,4$ \\
\hline CSQN411 & $4 \pm 0,6$ & $2,94 \pm 0,1$ & $1331 \pm 306$ & $78 \pm 2$ & $10,1 \pm 0,5$ \\
\hline CSQN412 & $4,5 \pm 0,7$ & $3,78 \pm 0,11$ & $1279 \pm 300$ & $105 \pm 3$ & $9,6 \pm 0,5$ \\
\hline CSQN413 & $5,6 \pm 0,8$ & $3,33 \pm 0,11$ & $652 \pm 181$ & $96 \pm 3$ & $9,9 \pm 0,5$ \\
\hline CSQN414 & $3 \pm 0,7$ & $2,86 \pm 0,1$ & $743 \pm 196$ & $73 \pm 3$ & $6,1 \pm 0,4$ \\
\hline
\end{tabular}




\begin{tabular}{|c|c|c|c|c|c|}
\hline Código & $\mathbf{U}$ & $\mathbf{Y b}$ & $\mathbf{B a}$ & $\mathrm{Ce}$ & Co \\
\hline CSQN415 & $3,5 \pm 0,6$ & $3,24 \pm 0,11$ & $352 \pm 163$ & $161 \pm 4$ & $28,2 \pm 0,9$ \\
\hline CSQN416 & $3,4 \pm 0,5$ & $2,71 \pm 0,1$ & $996 \pm 293$ & $78 \pm 2$ & $10,7 \pm 0,5$ \\
\hline CSQN417 & $4,5 \pm 0,6$ & $3,55 \pm 0,11$ & $766 \pm 168$ & $30 \pm 1$ & $4 \pm 0,3$ \\
\hline CSQN418 & $1,9 \pm 0,5$ & $2,23 \pm 0,08$ & $343 \pm 99$ & $57 \pm 2$ & $20,8 \pm 0,8$ \\
\hline CSQN419 & $3,5 \pm 0,5$ & $2,31 \pm 0,09$ & $573 \pm 138$ & $56 \pm 2$ & $6,7 \pm 0,4$ \\
\hline CSQN420 & $3,1 \pm 0,5$ & $2,8 \pm 0,08$ & $628 \pm 142$ & $49 \pm 1$ & $3,3 \pm 0,3$ \\
\hline CSQN421 & $4,3 \pm 0,6$ & $3,06 \pm 0,09$ & $679 \pm 150$ & $74 \pm 2$ & $9,1 \pm 0,5$ \\
\hline CSQN422 & $3,6 \pm 0,9$ & $4,12 \pm 0,18$ & $455 \pm 107$ & $65 \pm 3$ & $5,5 \pm 0,4$ \\
\hline CSQN423 & $4,5 \pm 1$ & $5,9 \pm 0,23$ & $1364 \pm 0$ & $51 \pm 2$ & $5 \pm 0,4$ \\
\hline CSQN424 & $4,6 \pm 0,9$ & $3,45 \pm 0,15$ & - & - & - \\
\hline CSQN424\#2 & $4,2 \pm 0,9$ & $3,37 \pm 0,17$ & $1205 \pm 787$ & $94 \pm 2$ & $8,3 \pm 0,3$ \\
\hline CSQN425 & $1,8 \pm 0,7$ & $2,95 \pm 0,16$ & $1591 \pm 1004$ & $70 \pm 2$ & $7,9 \pm 0,3$ \\
\hline CSQN426 & $3,1 \pm 0,7$ & $2,8 \pm 0,11$ & - & - & - \\
\hline CSQN426\#2 & $3,8 \pm 0,9$ & $2,9 \pm 0,16$ & $2435 \pm 1456$ & $76 \pm 2$ & $6,2 \pm 0,2$ \\
\hline CSQN427 & $5,1 \pm 1,1$ & $3,21 \pm 0,18$ & $1397 \pm 882$ & $95 \pm 2$ & $9,4 \pm 0,3$ \\
\hline CSQN428 & $5,2 \pm 0,7$ & $3,23 \pm 0,13$ & - & - & - \\
\hline CSQN428\#2 & $3,5 \pm 1$ & $3,77 \pm 0,18$ & $2369 \pm 1433$ & $67 \pm 1$ & $4 \pm 0,2$ \\
\hline CSQN429 & $3,7 \pm 0,8$ & $2,55 \pm 0,12$ & - & - & - \\
\hline CSQN429\#2 & $5,1 \pm 1$ & $2,51 \pm 0,1$ & $2059 \pm 1260$ & $46 \pm 1$ & $3,5 \pm 0,2$ \\
\hline CSQN430 & $3,2 \pm 0,5$ & $2,6 \pm 0,13$ & - & - & - \\
\hline CSQN430\#2 & $2,5 \pm 0,9$ & $2,57 \pm 0,16$ & $2241 \pm 1367$ & $71 \pm 1$ & $6,5 \pm 0,2$ \\
\hline CSQN431 & $3,1 \pm 1,1$ & $3,33 \pm 0,2$ & $949 \pm 426$ & $95 \pm 2$ & $9,9 \pm 0,3$ \\
\hline CSQN432 & $5,5 \pm 1,2$ & $3,43 \pm 0,16$ & $1044 \pm 451$ & $91 \pm 2$ & $5,5 \pm 0,2$ \\
\hline CSQN433 & $6 \pm 1,2$ & $2,82 \pm 0,16$ & $916 \pm 415$ & $83 \pm 2$ & $11,2 \pm 0,4$ \\
\hline CSQN434 & $5,1 \pm 1,4$ & $3,9 \pm 0,21$ & $612 \pm 331$ & $100 \pm 2$ & $7,3 \pm 0,3$ \\
\hline CSQN435 & $2,9 \pm 1$ & $2,87 \pm 0,18$ & $498 \pm 271$ & $70 \pm 2$ & $8,6 \pm 0,3$ \\
\hline CSQN436 & $3,8 \pm 0,7$ & $3,93 \pm 0,21$ & $265 \pm 243$ & $108 \pm 2$ & $7,6 \pm 0,3$ \\
\hline CSQN437 & $4,4 \pm 1,3$ & $3,5 \pm 0,19$ & $1341 \pm 577$ & $99 \pm 2$ & $10,2 \pm 0,3$ \\
\hline CSQN438 & $3,6 \pm 0,5$ & $2,26 \pm 0,16$ & $261 \pm 139$ & $41 \pm 1$ & $121 \pm 1,7$ \\
\hline CSQN439 & $5,1 \pm 0,7$ & $2,75 \pm 0,14$ & $896 \pm 347$ & $62 \pm 1$ & $8,9 \pm 0,3$ \\
\hline CSQN440 & $3,6 \pm 0,6$ & $2,8 \pm 0,13$ & $758 \pm 286$ & $71 \pm 1$ & $12,9 \pm 0,3$ \\
\hline CSQN441 & $3,1 \pm 0,7$ & $3,31 \pm 0,15$ & $540 \pm 235$ & $106 \pm 2$ & $9,1 \pm 0,3$ \\
\hline CSQN442 & $3,9 \pm 0,7$ & $3,08 \pm 0,13$ & $547 \pm 217$ & $73 \pm 1$ & $8,4 \pm 0,3$ \\
\hline CSQN443 & $5,1 \pm 0,4$ & $4,41 \pm 0,17$ & $663 \pm 279$ & $118 \pm 2$ & $7,1 \pm 0,3$ \\
\hline CSQN444 & $2,4 \pm 0,6$ & $3,16 \pm 0,14$ & $767 \pm 299$ & $109 \pm 2$ & $7,6 \pm 0,3$ \\
\hline CSQN445 & $4 \pm 0,7$ & $3,9 \pm 0,17$ & $741 \pm 313$ & $115 \pm 2$ & $12,1 \pm 0,4$ \\
\hline CSQN446 & $1,5 \pm 0,6$ & $2,48 \pm 0,13$ & $565 \pm 253$ & $69 \pm 1$ & $5,4 \pm 0,2$ \\
\hline CSQN447 & $3,9 \pm 0,4$ & $3,12 \pm 0,19$ & $447 \pm 244$ & $59 \pm 2$ & $5,5 \pm 0,3$ \\
\hline CSQN448 & $2,7 \pm 0,8$ & $2,79 \pm 0,15$ & - & $69 \pm 2$ & $8,5 \pm 0,3$ \\
\hline CSQN449 & $3,6 \pm 0,7$ & $2,99 \pm 0,19$ & $228 \pm 244$ & $77 \pm 2$ & $9,5 \pm 0,3$ \\
\hline CSQN450 & $3,9 \pm 0,8$ & $2,19 \pm 0,15$ & $373 \pm 210$ & $46 \pm 1$ & $1,8 \pm 0,2$ \\
\hline CSQN451 & $5,6 \pm 1$ & $3,87 \pm 0,18$ & - & $86 \pm 2$ & $8,6 \pm 0,3$ \\
\hline CSQN453 & $4,8 \pm 0,7$ & $3,27 \pm 0,14$ & - & $62 \pm 2$ & $16,4 \pm 0,4$ \\
\hline CSQN454 & $3,1 \pm 0,6$ & $3,06 \pm 0,13$ & $972 \pm 420$ & $88 \pm 2$ & $20,5 \pm 0,5$ \\
\hline CSQN455 & $4 \pm 0,6$ & $2,46 \pm 0,11$ & $486 \pm 192$ & $76 \pm 2$ & $6,6 \pm 0,3$ \\
\hline
\end{tabular}




\begin{tabular}{cccccc}
\hline Código & $\mathbf{U}$ & $\mathbf{Y b}$ & $\mathbf{B a}$ & $\mathbf{C e}$ & Co \\
\hline CSQN456 & $3,4 \pm 0,6$ & $2,84 \pm 0,1$ & $653 \pm 228$ & $85 \pm 2$ & $9,1 \pm 0,4$ \\
CSQN457 & $3 \pm 0,6$ & $3,06 \pm 0,12$ & $748 \pm 248$ & $76 \pm 2$ & $7,9 \pm 0,4$ \\
\hline
\end{tabular}




\begin{tabular}{|c|c|c|c|c|c|}
\hline Código & $\mathrm{Cr}$ & Cs & Eu & $\mathrm{Fe}(\mathrm{mg} / \mathrm{g})$ & Hf \\
\hline CSQN58 & $52 \pm 3$ & $9,3 \pm 0,6$ & $0,98 \pm 0,06$ & $31,1 \pm 0,8$ & $3,4 \pm 0,3$ \\
\hline CSQN59 & $39 \pm 3$ & $6,8 \pm 0,5$ & $0,84 \pm 0,04$ & $22,1 \pm 0,6$ & $4 \pm 0,3$ \\
\hline CSQN60 & $69 \pm 4$ & $8 \pm 0,5$ & $1,41 \pm 0,09$ & $38,9 \pm 1$ & $5,2 \pm 0,4$ \\
\hline CSQN61 & $57 \pm 3$ & $8 \pm 0,5$ & $1,38 \pm 0,09$ & $33,9 \pm 0,9$ & $3,9 \pm 0,3$ \\
\hline CSQN62 & $66 \pm 4$ & $3,9 \pm 0,3$ & $1,27 \pm 0,08$ & $46,5 \pm 1,5$ & $4,7 \pm 0,4$ \\
\hline CSQN63 & $74 \pm 4$ & $1,3 \pm 0,4$ & $1,72 \pm 0,1$ & $44,8 \pm 1,4$ & $5,7 \pm 0,5$ \\
\hline CSQN64 & $49 \pm 3$ & $13,1 \pm 0,5$ & $0,77 \pm 0,06$ & $21,9 \pm 0,7$ & $4,1 \pm 0,3$ \\
\hline CSQN65 & $70 \pm 4$ & $9,1 \pm 0,4$ & $1,26 \pm 0,08$ & $37,6 \pm 1,2$ & $7,2 \pm 0,5$ \\
\hline CSQN66 & $65 \pm 4$ & $8,5 \pm 0,5$ & $1,59 \pm 0,09$ & $35,5 \pm 1,2$ & $5,8 \pm 0,4$ \\
\hline CSQN67 & $81 \pm 4$ & $1,5 \pm 0,4$ & $1,97 \pm 0,08$ & $40,6 \pm 1,3$ & $7,1 \pm 0,4$ \\
\hline CSQN68 & $73 \pm 3$ & $9,9 \pm 0,4$ & $1,43 \pm 0,07$ & $48,5 \pm 1,5$ & $9 \pm 0,5$ \\
\hline CSQN70 & $59 \pm 3$ & $13,7 \pm 0,5$ & $0,84 \pm 0,04$ & $41,9 \pm 1,3$ & $9 \pm 0,5$ \\
\hline CSQN72 & $72 \pm 3$ & $7 \pm 0,3$ & $1,48 \pm 0,07$ & $38,5 \pm 1,2$ & $4,8 \pm 0,3$ \\
\hline CSQN73 & $54 \pm 3$ & $6,7 \pm 0,3$ & $1,07 \pm 0,06$ & $28 \pm 0,9$ & $7,4 \pm 0,4$ \\
\hline CSQN74 & $71 \pm 3$ & $9,9 \pm 0,4$ & $1,68 \pm 0,07$ & $39,4 \pm 1,2$ & $7,5 \pm 0,4$ \\
\hline CSQN75 & $64 \pm 6$ & $9,5 \pm 0,7$ & $1,39 \pm 0,16$ & $33,8 \pm 1,3$ & $4,5 \pm 0,6$ \\
\hline CSQN76 & $85 \pm 5$ & $16,2 \pm 0,7$ & $1,57 \pm 0,09$ & $46,8 \pm 1,5$ & $11,2 \pm 0$ \\
\hline CSQN77 & $59 \pm 5$ & $4,2 \pm 0,7$ & $1,34 \pm 0,13$ & $46,5 \pm 1,6$ & $6,8 \pm 0,6$ \\
\hline CSQN78 & $88 \pm 4$ & $4,6 \pm 0,6$ & $1,8 \pm 0,1$ & $39,2 \pm 1,3$ & $6,4 \pm 0,5$ \\
\hline CSQN79 & $60 \pm 3$ & $12,2 \pm 0,5$ & $0,91 \pm 0,06$ & $27,7 \pm 0,9$ & $9,3 \pm 0,6$ \\
\hline CSQN80 & $70 \pm 4$ & $7,6 \pm 0,6$ & $1,28 \pm 0,09$ & $41,5 \pm 1,3$ & $8 \pm 0,6$ \\
\hline CSQN81 & $58 \pm 4$ & $12,3 \pm 0,5$ & $1,02 \pm 0,07$ & $28,8 \pm 0,9$ & $9,1 \pm 0,6$ \\
\hline CSQN82 & $126 \pm 5$ & $12,1 \pm 0,4$ & $2,1 \pm 0,07$ & $64,3 \pm 2$ & $24,9 \pm 1,3$ \\
\hline CSQN83 & $108 \pm 5$ & $9,8 \pm 0,3$ & $2,11 \pm 0,07$ & $58,9 \pm 1,8$ & $22 \pm 1,2$ \\
\hline CSQN84 & $58 \pm 2$ & $8,4 \pm 0,3$ & $2,28 \pm 0,07$ & $38,3 \pm 1,2$ & $15,9 \pm 0,9$ \\
\hline CSQN85 & $107 \pm 5$ & $16,5 \pm 0,5$ & $2,17 \pm 0,07$ & $52,8 \pm 1,6$ & $19,2 \pm 1$ \\
\hline CSQN86 & $95 \pm 4$ & $8,5 \pm 0,3$ & $2,03 \pm 0,07$ & $48,1 \pm 1,5$ & $21,9 \pm 1,2$ \\
\hline CSQN87 & $91 \pm 4$ & $13,3 \pm 0,4$ & $1,81 \pm 0,06$ & $44,9 \pm 1,4$ & $24,1 \pm 1,3$ \\
\hline CSQN88 & $98 \pm 4$ & $8,7 \pm 0,3$ & $2,25 \pm 0,08$ & $53,5 \pm 1,6$ & $22,5 \pm 1,1$ \\
\hline CSQN89 & $99 \pm 4$ & $8,7 \pm 0,4$ & $2,41 \pm 0,09$ & $37,8 \pm 1,2$ & $22 \pm 1,1$ \\
\hline CSQN90 & $63 \pm 3$ & $10 \pm 0,3$ & $1,3 \pm 0,05$ & $37,8 \pm 1,2$ & $4,9 \pm 0,3$ \\
\hline CSQN91 & $62 \pm 3$ & $8,8 \pm 0,3$ & $0,61 \pm 0,04$ & $36,9 \pm 1,1$ & $8,2 \pm 0,5$ \\
\hline CSQN92 & $66 \pm 3$ & $11,3 \pm 0,4$ & $1,3 \pm 0,05$ & $39,5 \pm 1,2$ & $5,2 \pm 0,3$ \\
\hline CSQN93 & $64 \pm 3$ & $8,6 \pm 0,3$ & $1,45 \pm 0,06$ & $34,3 \pm 1,1$ & $5,9 \pm 0,4$ \\
\hline CSQN94 & $66 \pm 3$ & $7,5 \pm 0,3$ & $1,19 \pm 0,06$ & $37,1 \pm 1,2$ & $9,8 \pm 0,5$ \\
\hline CSQN95 & $62 \pm 3$ & $11,1 \pm 0,3$ & $1,04 \pm 0,05$ & $40,3 \pm 1,3$ & $12,5 \pm 0,6$ \\
\hline CSQN96 & $56 \pm 3$ & $12 \pm 0,4$ & $0,79 \pm 0,04$ & $29,4 \pm 0,9$ & $5,8 \pm 0,3$ \\
\hline CSQN97 & $58 \pm 3$ & $11,1 \pm 0,3$ & $1,03 \pm 0,05$ & $32,2 \pm 1$ & $6,4 \pm 0,4$ \\
\hline CSQN98 & $59 \pm 3$ & $8,3 \pm 0,3$ & $1,13 \pm 0,05$ & $33,7 \pm 1,1$ & $5,6 \pm 0,3$ \\
\hline CSQN99 & $57 \pm 3$ & $11 \pm 0,3$ & $1,23 \pm 0,05$ & $26,2 \pm 0,8$ & $6,3 \pm 0,3$ \\
\hline CSQN100 & $33 \pm 2$ & $3,5 \pm 0,3$ & $2,8 \pm 0,09$ & $26,8 \pm 0,8$ & $13 \pm 0,7$ \\
\hline CSQN101 & $63 \pm 3$ & $6,1 \pm 0,2$ & $1,35 \pm 0,06$ & $34,9 \pm 1,1$ & $6,4 \pm 0,4$ \\
\hline CSQN103 & $58 \pm 3$ & $11,5 \pm 0,7$ & $1,17 \pm 0,08$ & $39,3 \pm 1,3$ & $6,3 \pm 0,4$ \\
\hline CSQN104 & $55 \pm 2$ & $12,1 \pm 0,3$ & $1,25 \pm 0,04$ & $35,4 \pm 1,1$ & $3,4 \pm 0,1$ \\
\hline CSQN105 & $68 \pm 3$ & $12,6 \pm 0,3$ & $1,02 \pm 0,04$ & $32,1 \pm 1$ & $8,9 \pm 0,3$ \\
\hline
\end{tabular}




\begin{tabular}{|c|c|c|c|c|c|}
\hline Código & $\mathrm{Cr}$ & Cs & $\mathbf{E u}$ & $\mathrm{Fe}(\mathrm{mg} / \mathrm{g})$ & Hf \\
\hline CSQN106 & $61 \pm 2$ & $6 \pm 0,2$ & $1,48 \pm 0,05$ & $32,8 \pm 1$ & $3,9 \pm 0,2$ \\
\hline CSQN107 & $65 \pm 3$ & $11,2 \pm 0,3$ & $1,56 \pm 0,06$ & $44,7 \pm 1,4$ & $6 \pm 0,3$ \\
\hline CSQN108 & $68 \pm 2$ & $5,2 \pm 0,2$ & $1,34 \pm 0,05$ & $31,5 \pm 1$ & $5 \pm 0,2$ \\
\hline CSQN109 & $77 \pm 3$ & $11 \pm 0,3$ & $1,47 \pm 0,05$ & $36,3 \pm 1,1$ & $6,8 \pm 0,3$ \\
\hline CSQN110 & $63 \pm 2$ & $11,6 \pm 0,3$ & $1,02 \pm 0,04$ & $28,8 \pm 0,9$ & $6,7 \pm 0,2$ \\
\hline CSQN111 & $68 \pm 2$ & $6,1 \pm 0,2$ & $0,93 \pm 0,04$ & $46 \pm 1,4$ & $5,6 \pm 0,2$ \\
\hline CSQN112 & $54 \pm 3$ & $13,7 \pm 0,5$ & $1,17 \pm 0,06$ & $28,7 \pm 0,9$ & $4,5 \pm 0,3$ \\
\hline CSQN113 & $69 \pm 3$ & $13,5 \pm 0,5$ & $1,54 \pm 0,08$ & $33 \pm 1$ & $5,2 \pm 0,3$ \\
\hline CSQN114 & $47 \pm 2$ & $11 \pm 0,4$ & $1,01 \pm 0,06$ & $30,8 \pm 1$ & $4,9 \pm 0,3$ \\
\hline CSQN115 & $53 \pm 3$ & $12,9 \pm 0,5$ & $0,83 \pm 0,06$ & $21,6 \pm 0,7$ & $5 \pm 0,3$ \\
\hline CSQN116 & $73 \pm 5$ & $9,5 \pm 1$ & $1,58 \pm 0,12$ & $31,5 \pm 1,1$ & $10,8 \pm 0,9$ \\
\hline CSQN117 & $72 \pm 5$ & $9,1 \pm 1,1$ & $1,84 \pm 0,13$ & $36,9 \pm 1,2$ & $5,4 \pm 0,5$ \\
\hline CSQN118 & $83 \pm 6$ & $12,3 \pm 1,3$ & $1,98 \pm 0,13$ & $41,4 \pm 1,4$ & $5,2 \pm 0,5$ \\
\hline CSQN119 & $73 \pm 3$ & $9,2 \pm 0,6$ & $1,99 \pm 0,11$ & $39,8 \pm 1,3$ & $6 \pm 0,4$ \\
\hline CSQN120 & $71 \pm 5$ & $9,2 \pm 1,1$ & $1,67 \pm 0,12$ & $35,5 \pm 1,2$ & $6,3 \pm 0,6$ \\
\hline CSQN121 & $61 \pm 3$ & $9,6 \pm 0,4$ & $1,28 \pm 0,07$ & $18,8 \pm 0,6$ & $11,1 \pm 0,6$ \\
\hline CSQN122 & $90 \pm 4$ & $2,9 \pm 0,4$ & $1,8 \pm 0,09$ & $60,4 \pm 1,9$ & $9,1 \pm 0,5$ \\
\hline CSQN123 & $70 \pm 3$ & $10,7 \pm 0,4$ & $1,43 \pm 0,07$ & $38,1 \pm 1,2$ & $7,7 \pm 0,4$ \\
\hline CSQN126 & $36 \pm 3$ & $6,8 \pm 0,8$ & $0,69 \pm 0,07$ & $13,2 \pm 0,5$ & $17,3 \pm 1,3$ \\
\hline CSQN127 & $56 \pm 3$ & $7,8 \pm 0,8$ & $1,59 \pm 0,12$ & $31 \pm 1$ & $9,7 \pm 0,8$ \\
\hline CSQN128 & $40 \pm 3$ & $9,4 \pm 0,8$ & $0,57 \pm 68,37$ & $21,5 \pm 0,8$ & $2,9 \pm 0,3$ \\
\hline CSQN129 & $51 \pm 4$ & $8 \pm 0,8$ & $0,86 \pm 0,08$ & $28 \pm 0,9$ & $9,6 \pm 0,8$ \\
\hline CSQN130 & $64 \pm 4$ & $13,7 \pm 1,2$ & $1,67 \pm 0,13$ & $48,1 \pm 1,6$ & $7 \pm 0,6$ \\
\hline CSQN131 & $60 \pm 4$ & $16 \pm 1,3$ & $0,79 \pm 0,09$ & $19 \pm 0,7$ & $11,9 \pm 1$ \\
\hline CSQN132 & $65 \pm 4$ & $7,9 \pm 0,7$ & $1,3 \pm 0,12$ & $28,1 \pm 1$ & $5 \pm 0,5$ \\
\hline CSQN133 & $73 \pm 5$ & $10,9 \pm 1$ & $1,42 \pm 0,12$ & $41,4 \pm 1,4$ & $8,4 \pm 0,7$ \\
\hline CSQN351 & $68 \pm 12$ & $8,2 \pm 1,8$ & $1,33 \pm 0,24$ & $43,6 \pm 1,9$ & $3,7 \pm 0,7$ \\
\hline CSQN352 & $109 \pm 17$ & - & $1,38 \pm 0,24$ & $49,9 \pm 2,1$ & $8,4 \pm 1,3$ \\
\hline CSQN353 & $56 \pm 10$ & $9,1 \pm 2,3$ & $1,59 \pm 0,52$ & $36,8 \pm 1,6$ & $5,1 \pm 0,5$ \\
\hline CSQN354 & $62 \pm 5$ & $6,2 \pm 1,8$ & $1,49 \pm 0,58$ & $29 \pm 1,4$ & $4,9 \pm 0,5$ \\
\hline CSQN355 & $85 \pm 14$ & $12,3 \pm 2,4$ & $1,3 \pm 0,23$ & $43,4 \pm 1,9$ & $5,6 \pm 1$ \\
\hline CSQN356 & $68 \pm 5$ & $12 \pm 2,6$ & - & $40,2 \pm 1,7$ & $5 \pm 0,5$ \\
\hline CSQN357 & $90 \pm 16$ & $12,2 \pm 2,3$ & $0,78 \pm 0,22$ & $48,3 \pm 2$ & $4,4 \pm 0,8$ \\
\hline CSQN358 & $63 \pm 4$ & $7,6 \pm 0,9$ & $1,04 \pm 0,09$ & $34,6 \pm 1,2$ & $7,8 \pm 1$ \\
\hline CSQN359 & $48 \pm 13$ & $8,2 \pm 1,7$ & $1,26 \pm 0,22$ & $19,5 \pm 1$ & $5 \pm 0,9$ \\
\hline CSQN360 & $76 \pm 5$ & $2,2 \pm 0,6$ & $1,45 \pm 0,1$ & $39 \pm 1,4$ & $5,3 \pm 0,8$ \\
\hline CSQN361 & $77 \pm 10$ & $10,6 \pm 1,1$ & $1,1 \pm 0,09$ & $48,8 \pm 1,7$ & $5,3 \pm 0,8$ \\
\hline CSQN362 & $66 \pm 5$ & $19,1 \pm 1,9$ & $1,13 \pm 0,11$ & $39,6 \pm 1,4$ & $5,2 \pm 0,8$ \\
\hline CSQN363 & $68 \pm 5$ & - & $1,28 \pm 0,1$ & $39,3 \pm 1,4$ & $6,5 \pm 0,9$ \\
\hline CSQN364 & $74 \pm 5$ & $15,1 \pm 1,4$ & $0,8 \pm 0,08$ & $39,3 \pm 1,4$ & $6,8 \pm 0,9$ \\
\hline CSQN365 & $62 \pm 4$ & $10,4 \pm 1,1$ & $1,03 \pm 0,09$ & $37,4 \pm 1,3$ & $10,1 \pm 1,3$ \\
\hline CSQN366 & $44 \pm 3$ & $13,2 \pm 1,2$ & $0,64 \pm 0,08$ & $15,9 \pm 0,6$ & $8,7 \pm 0,9$ \\
\hline CSQN367 & $74 \pm 4$ & $2,4 \pm 0,6$ & $1,14 \pm 0,09$ & $36,2 \pm 1,2$ & $4,5 \pm 0,6$ \\
\hline CSQN368 & $103 \pm 6$ & $5,3 \pm 0,9$ & $1,63 \pm 0,12$ & $53,9 \pm 1,8$ & $7,3 \pm 1$ \\
\hline CSQN369 & $70 \pm 4$ & $4,5 \pm 0,7$ & $0,95 \pm 0,09$ & $33,4 \pm 1,2$ & $4,8 \pm 0,7$ \\
\hline
\end{tabular}




\begin{tabular}{|c|c|c|c|c|c|}
\hline Código & $\mathrm{Cr}$ & Cs & $\mathbf{E u}$ & $\mathrm{Fe}(\mathrm{mg} / \mathrm{g})$ & Hf \\
\hline CSQN370 & $61 \pm 4$ & $8,7 \pm 1$ & $0,93 \pm 0,09$ & $31,2 \pm 1,1$ & $4,7 \pm 0,7$ \\
\hline CSQN371 & $66 \pm 4$ & $8,2 \pm 0,9$ & $0,64 \pm 0,07$ & $40 \pm 1,4$ & $9,2 \pm 1$ \\
\hline CSQN372 & $77 \pm 3$ & $10,4 \pm 1,1$ & $1,49 \pm 0,12$ & $45,2 \pm 1,5$ & $5,9 \pm 0,7$ \\
\hline CSQN373 & $72 \pm 4$ & $9,5 \pm 0,8$ & $0,97 \pm 0,1$ & $49,8 \pm 1,6$ & $5,8 \pm 0,5$ \\
\hline CSQN374 & $79 \pm 3$ & $10,6 \pm 1,2$ & $1,09 \pm 0,09$ & $43,1 \pm 1,4$ & $8,8 \pm 1$ \\
\hline CSQN375 & $50 \pm 5$ & $6,7 \pm 0,8$ & $0,36 \pm 0,06$ & $22,3 \pm 0,8$ & $5 \pm 0,6$ \\
\hline CSQN376 & $53 \pm 3$ & $5 \pm 0,7$ & $1,46 \pm 0,11$ & $28,5 \pm 1$ & $5,5 \pm 0,6$ \\
\hline CSQN377 & $69 \pm 3$ & $12,7 \pm 1,3$ & $1,11 \pm 0,1$ & $40,2 \pm 1,3$ & $4,6 \pm 0,6$ \\
\hline CSQN378 & $56 \pm 3$ & $3 \pm 0,6$ & $3,39 \pm 0,19$ & $53,5 \pm 1,8$ & $7,8 \pm 0,9$ \\
\hline CSQN379 & $86 \pm 5$ & $9 \pm 1$ & $1,17 \pm 0,1$ & $51,1 \pm 1,7$ & $7,1 \pm 0,7$ \\
\hline CSQN380 & $79 \pm 4$ & $14 \pm 1,4$ & $1,5 \pm 0,11$ & $47,1 \pm 1,6$ & $7,8 \pm 0,8$ \\
\hline CSQN381 & $73 \pm 4$ & $8,9 \pm 0,9$ & $1,76 \pm 0,12$ & $45 \pm 1,5$ & $7,5 \pm 0,7$ \\
\hline CSQN382 & $78 \pm 4$ & $14 \pm 1,3$ & $1,45 \pm 0,12$ & $47,1 \pm 1,6$ & $8 \pm 0,8$ \\
\hline CSQN383 & $68 \pm 4$ & $8,3 \pm 0,9$ & $0,91 \pm 0,09$ & $38,4 \pm 1,3$ & $5,1 \pm 0,5$ \\
\hline CSQN384 & $82 \pm 4$ & $13,2 \pm 1,2$ & $1,8 \pm 0,12$ & $46,4 \pm 1,6$ & $5,8 \pm 0,7$ \\
\hline CSQN385 & $90 \pm 5$ & $15,1 \pm 1,4$ & $1,62 \pm 0,12$ & $44,4 \pm 1,5$ & $7,5 \pm 0,7$ \\
\hline CSQN386 & $79 \pm 3$ & $10,9 \pm 1,2$ & $0,95 \pm 0,08$ & $38,1 \pm 1,2$ & $5,6 \pm 0,6$ \\
\hline CSQN387 & $81 \pm 3$ & $6,5 \pm 0,9$ & $1,87 \pm 0,12$ & $59,6 \pm 1,9$ & $8,4 \pm 0,8$ \\
\hline CSQN388 & $76 \pm 3$ & $11,8 \pm 1,2$ & $1,51 \pm 0,1$ & $44 \pm 1,4$ & $6,8 \pm 0,7$ \\
\hline CSQN389 & $84 \pm 3$ & $14,9 \pm 1,4$ & $1,28 \pm 0,09$ & $51,2 \pm 1,6$ & $6,4 \pm 0,6$ \\
\hline CSQN390 & $75 \pm 3$ & $8,2 \pm 1$ & $1,05 \pm 0,08$ & $36,7 \pm 1,2$ & $7,2 \pm 0,7$ \\
\hline CSQN391 & $79 \pm 3$ & $10 \pm 1,1$ & $1,25 \pm 0,1$ & $38,1 \pm 1,2$ & $8 \pm 0,8$ \\
\hline CSQN392 & $65 \pm 3$ & $10,6 \pm 1,1$ & $1,01 \pm 0,08$ & $34,5 \pm 1,1$ & $4,2 \pm 0,4$ \\
\hline CSQN393 & $74 \pm 6$ & $7 \pm 0,8$ & $0,96 \pm 0,08$ & $36,9 \pm 1,2$ & $5,7 \pm 0,5$ \\
\hline CSQN394 & $92 \pm 7$ & $10,4 \pm 1,1$ & $1,41 \pm 0,1$ & $48,6 \pm 1,6$ & $9,9 \pm 0,8$ \\
\hline CSQN395 & $87 \pm 5$ & $9,2 \pm 1$ & $1,1 \pm 0,08$ & $47,5 \pm 1,5$ & $8,7 \pm 0,8$ \\
\hline CSQN396 & $79 \pm 6$ & $9,3 \pm 1$ & $1,36 \pm 0,1$ & $38,3 \pm 1,2$ & $9 \pm 0,8$ \\
\hline CSQN397 & $76 \pm 6$ & $8,3 \pm 1$ & $1,6 \pm 0,11$ & $39,5 \pm 1,3$ & $9,9 \pm 0,8$ \\
\hline CSQN398 & $51 \pm 5$ & $10 \pm 1$ & $0,72 \pm 0,07$ & $28 \pm 0,9$ & $8,3 \pm 0,7$ \\
\hline CSQN399 & $59 \pm 5$ & $12,2 \pm 1,2$ & $1,37 \pm 0,09$ & $46,5 \pm 1,5$ & $4,1 \pm 0,5$ \\
\hline CSQN400 & $71 \pm 4$ & $15,9 \pm 2,5$ & $1,28 \pm 0,1$ & $39,9 \pm 1,3$ & $8,6 \pm 0,5$ \\
\hline CSQN401 & $75 \pm 3$ & $10,8 \pm 1,8$ & $1,35 \pm 0,1$ & $34,4 \pm 1,1$ & $6,9 \pm 0,5$ \\
\hline CSQN402 & $62 \pm 4$ & $8,3 \pm 1,4$ & $1,18 \pm 0,08$ & $32,3 \pm 1$ & $8,8 \pm 0,5$ \\
\hline CSQN403 & $69 \pm 3$ & $8,1 \pm 1,6$ & $1,58 \pm 0,1$ & $42,4 \pm 1,4$ & $7,8 \pm 0,5$ \\
\hline CSQN404 & $72 \pm 3$ & $6,4 \pm 1,3$ & $1,64 \pm 0,11$ & $41,6 \pm 1,3$ & $5,1 \pm 0,4$ \\
\hline CSQN405 & $67 \pm 4$ & $5,7 \pm 1,1$ & $0,84 \pm 0,08$ & $33,4 \pm 1,1$ & $9 \pm 0,5$ \\
\hline CSQN406 & $53 \pm 2$ & $4,6 \pm 1$ & $0,97 \pm 0,08$ & $25,1 \pm 0,8$ & $8,4 \pm 0,5$ \\
\hline CSQN407 & $74 \pm 3$ & $10,5 \pm 1,7$ & $1,76 \pm 0,1$ & $38,3 \pm 1,2$ & $10,4 \pm 0,6$ \\
\hline CSQN408 & $50 \pm 2$ & $6,2 \pm 1$ & $1,1 \pm 0,09$ & $30,8 \pm 1$ & $7,4 \pm 0,4$ \\
\hline CSQN409 & $73 \pm 3$ & $9,3 \pm 1,2$ & $1,23 \pm 0,08$ & $33,9 \pm 1,1$ & $6,9 \pm 0,3$ \\
\hline CSQN410 & $66 \pm 4$ & $9,5 \pm 1,3$ & $1,39 \pm 0,1$ & $37,2 \pm 1,2$ & $5,3 \pm 0,3$ \\
\hline CSQN411 & $66 \pm 3$ & $10 \pm 1,3$ & $1,41 \pm 0,09$ & $43,4 \pm 1,4$ & $5,9 \pm 0,3$ \\
\hline CSQN412 & $78 \pm 4$ & $12,4 \pm 1,6$ & $1,85 \pm 0,1$ & $43,2 \pm 1,4$ & $10,2 \pm 0,5$ \\
\hline CSQN413 & $65 \pm 4$ & $5,9 \pm 1$ & $1,42 \pm 0,1$ & $38,2 \pm 1,2$ & $9,6 \pm 0,5$ \\
\hline CSQN414 & $62 \pm 4$ & $5,7 \pm 1$ & $1,41 \pm 0,09$ & $37,3 \pm 1,2$ & $6,7 \pm 0,4$ \\
\hline
\end{tabular}




\begin{tabular}{|c|c|c|c|c|c|}
\hline Código & $\mathrm{Cr}$ & Cs & $\mathbf{E u}$ & $\mathrm{Fe}(\mathrm{mg} / \mathrm{g})$ & Hf \\
\hline CSQN415 & $100 \pm 5$ & $6,6 \pm 1,2$ & $1,6 \pm 0,1$ & $38,5 \pm 1,3$ & $14,6 \pm 0,8$ \\
\hline CSQN416 & $70 \pm 5$ & $17,6 \pm 2,3$ & $1,29 \pm 0,09$ & $41 \pm 1,3$ & $6 \pm 0,4$ \\
\hline CSQN417 & $58 \pm 2$ & $6,2 \pm 1$ & $0,39 \pm 0,05$ & $35,9 \pm 1,2$ & $5,7 \pm 0,3$ \\
\hline CSQN418 & $52 \pm 2$ & $3,2 \pm 0,8$ & $1,13 \pm 0,08$ & $34,6 \pm 1,1$ & $3 \pm 0,3$ \\
\hline CSQN419 & $59 \pm 2$ & $6,7 \pm 1$ & $0,6 \pm 0,06$ & $33,9 \pm 1,1$ & $9,2 \pm 0,5$ \\
\hline CSQN420 & $43 \pm 2$ & $3,8 \pm 0,7$ & $0,8 \pm 0,06$ & $23,6 \pm 0,8$ & $7,7 \pm 0,4$ \\
\hline CSQN421 & $62 \pm 2$ & $12,6 \pm 1,5$ & $1,34 \pm 0,08$ & $33,2 \pm 1,1$ & $3,9 \pm 0,3$ \\
\hline CSQN422 & $54 \pm 2$ & $5,7 \pm 0,9$ & $0,88 \pm 0,07$ & $28,3 \pm 0,9$ & $4,9 \pm 0,3$ \\
\hline CSQN423 & $65 \pm 3$ & $6,9 \pm 1$ & $0,83 \pm 0,07$ & $34 \pm 1,1$ & $18,7 \pm 0,9$ \\
\hline CSQN424 & - & - & - & - & - \\
\hline CSQN424\#2 & $67 \pm 5$ & $8,1 \pm 0,6$ & $1,43 \pm 0,08$ & $30,9 \pm 1$ & $7,1 \pm 0,5$ \\
\hline CSQN425 & $55 \pm 4$ & $6,3 \pm 0,7$ & $1,08 \pm 0,08$ & $25,7 \pm 0,8$ & $7,6 \pm 0,6$ \\
\hline CSQN426 & - & - & - & - & - \\
\hline CSQN426\#2 & $60 \pm 4$ & $9,3 \pm 0,7$ & $1,16 \pm 0,08$ & $31,5 \pm 1$ & $6,6 \pm 0,5$ \\
\hline CSQN427 & $70 \pm 5$ & $15,5 \pm 1,1$ & $1,43 \pm 0,08$ & $33,6 \pm 1,1$ & $4,5 \pm 0,4$ \\
\hline CSQN428 & - & - & - & - & - \\
\hline CSQN428\#2 & $61 \pm 4$ & $10,3 \pm 0,9$ & $1,08 \pm 0,08$ & $23,4 \pm 0,8$ & $14,6 \pm 0,9$ \\
\hline CSQN429 & - & - & - & - & - \\
\hline CSQN429\#2 & $51 \pm 4$ & $5,7 \pm 0,6$ & $0,79 \pm 0,06$ & $30,5 \pm 1$ & $7,8 \pm 0,5$ \\
\hline CSQN430 & - & - & - & - & - \\
\hline CSQN430\#2 & $58 \pm 4$ & $9,3 \pm 0,7$ & $1,16 \pm 0,08$ & $25,5 \pm 0,8$ & $5,8 \pm 0,5$ \\
\hline CSQN431 & $67 \pm 6$ & $15,9 \pm 1,2$ & $1,58 \pm 0,11$ & $36,4 \pm 1,2$ & $4,1 \pm 0,6$ \\
\hline CSQN432 & $70 \pm 5$ & $12,3 \pm 1$ & $1,57 \pm 0,1$ & $36,3 \pm 1,2$ & $9,4 \pm 0,7$ \\
\hline CSQN433 & $63 \pm 5$ & $8 \pm 0,9$ & $1,36 \pm 0,09$ & $35,3 \pm 1,2$ & $5,2 \pm 0,5$ \\
\hline CSQN434 & $78 \pm 6$ & $12,1 \pm 1,2$ & $1,65 \pm 0,11$ & $36,6 \pm 1,2$ & $10,4 \pm 0,8$ \\
\hline CSQN435 & $60 \pm 5$ & $11,4 \pm 1$ & $1,12 \pm 0,08$ & $35,4 \pm 1,2$ & $7,3 \pm 0,6$ \\
\hline CSQN436 & $78 \pm 5$ & $9,6 \pm 1$ & $1,72 \pm 0,11$ & $41,1 \pm 1,3$ & $7,3 \pm 0,6$ \\
\hline CSQN437 & $69 \pm 6$ & $11,7 \pm 1,1$ & $1,5 \pm 0,1$ & $38,3 \pm 1,3$ & $7,2 \pm 0,6$ \\
\hline CSQN438 & $53 \pm 3$ & $6,7 \pm 0,8$ & $0,6 \pm 0,08$ & $28,6 \pm 1$ & $5,2 \pm 0,5$ \\
\hline CSQN439 & $61 \pm 4$ & $7,5 \pm 0,8$ & $0,99 \pm 0,08$ & $29,9 \pm 1$ & $5,3 \pm 0,5$ \\
\hline CSQN440 & $44 \pm 3$ & $11,1 \pm 0,9$ & $1,06 \pm 0,08$ & $25,4 \pm 0,8$ & $7,4 \pm 0,6$ \\
\hline CSQN441 & $57 \pm 4$ & $10,6 \pm 0,9$ & $1,55 \pm 0,1$ & $28,2 \pm 0,9$ & $7,2 \pm 0,6$ \\
\hline CSQN442 & $66 \pm 4$ & $11,2 \pm 1$ & $1,29 \pm 0,09$ & $36,4 \pm 1,2$ & $7,7 \pm 0,7$ \\
\hline CSQN443 & $84 \pm 5$ & $6,9 \pm 0,7$ & $1,86 \pm 0,11$ & $25,8 \pm 0,8$ & $18,8 \pm 1,5$ \\
\hline CSQN444 & $64 \pm 4$ & $9,6 \pm 0,9$ & $1,57 \pm 0,1$ & $30,3 \pm 1$ & $7,4 \pm 0,6$ \\
\hline CSQN445 & $49 \pm 4$ & $5,6 \pm 0,8$ & $1,81 \pm 0,11$ & $24,6 \pm 0,8$ & $8,4 \pm 0,5$ \\
\hline CSQN446 & $41 \pm 3$ & $5,1 \pm 0,6$ & $0,99 \pm 0,07$ & $24,3 \pm 0,8$ & $6,4 \pm 0,4$ \\
\hline CSQN447 & $54 \pm 5$ & $9,8 \pm 0,9$ & $0,87 \pm 0,07$ & $28,4 \pm 1$ & $13,6 \pm 0,7$ \\
\hline CSQN448 & $59 \pm 5$ & $9 \pm 1$ & $0,95 \pm 0,08$ & $48 \pm 1,6$ & $5,4 \pm 0,5$ \\
\hline CSQN449 & $64 \pm 5$ & $9,2 \pm 1$ & $1,13 \pm 0,09$ & $50,1 \pm 1,6$ & $6,3 \pm 0,5$ \\
\hline CSQN450 & $62 \pm 5$ & $7,7 \pm 0,9$ & $0,54 \pm 0,06$ & $33,9 \pm 1,1$ & $6,6 \pm 0,5$ \\
\hline CSQN451 & $79 \pm 5$ & $2 \pm 0,7$ & $1,22 \pm 0,1$ & $44,7 \pm 1,4$ & $13,5 \pm 0,7$ \\
\hline CSQN453 & $58 \pm 4$ & $6,4 \pm 0,6$ & $0,64 \pm 0,06$ & $26,6 \pm 0,9$ & $9,6 \pm 0,7$ \\
\hline CSQN454 & $65 \pm 4$ & $7,1 \pm 0,8$ & $1,29 \pm 0,09$ & $37,2 \pm 1,2$ & $3,8 \pm 0,4$ \\
\hline CSQN455 & $62 \pm 4$ & $7 \pm 0,7$ & $1 \pm 0,1$ & $45,3 \pm 1,5$ & $5,2 \pm 0,4$ \\
\hline
\end{tabular}




\begin{tabular}{cccccc}
\hline Código & Cr & Cs & Eu & $\mathbf{F e}(\mathbf{m g} / \mathbf{g})$ & Hf \\
\hline CSQN456 & $70 \pm 4$ & $8,3 \pm 0,7$ & $1,06 \pm 0,11$ & $57,1 \pm 1,9$ & $7,1 \pm 0,5$ \\
CSQN457 & $72 \pm 4$ & $9,9 \pm 0,8$ & $1,08 \pm 0,1$ & $44,5 \pm 1,5$ & $6,5 \pm 0,5$ \\
\hline
\end{tabular}




\begin{tabular}{|c|c|c|c|c|c|c|}
\hline Código & $\mathbf{R b}$ & Sc & Ta & Tb (ng/g) & Th & Zn \\
\hline CSQN58 & $101 \pm 7$ & $11,82 \pm 0,08$ & $1,1 \pm 0,1$ & $0,9 \pm 0,3$ & $9,4 \pm 0,2$ & $159 \pm 7$ \\
\hline CSQN59 & $55 \pm 5$ & $9,48 \pm 0,07$ & $1,0 \pm 0,1$ & $0,6 \pm 0,2$ & $7,6 \pm 0,2$ & $85 \pm 5$ \\
\hline CSQN60 & $77 \pm 6$ & $16,78 \pm 0,1$ & $1,6 \pm 0,2$ & $1,2 \pm 0,3$ & $13,1 \pm 0,3$ & $136 \pm 6$ \\
\hline CSQN61 & $73 \pm 6$ & $14,5 \pm 0,09$ & $1,4 \pm 0,2$ & $0,9 \pm 0,3$ & $12,0 \pm 0,2$ & $132 \pm 6$ \\
\hline CSQN62 & $50 \pm 7$ & $17,08 \pm 0,09$ & $1,7 \pm 0,3$ & $1,2 \pm 0,3$ & $13,5 \pm 0,8$ & $151 \pm 8$ \\
\hline CSQN63 & $18 \pm 6$ & $18,97 \pm 0,1$ & $1,4 \pm 0,2$ & $0,6 \pm 0,2$ & $15,5 \pm 0,8$ & $169 \pm 9$ \\
\hline CSQN64 & $135 \pm 15$ & $11,41 \pm 0,07$ & $0,8 \pm 0,1$ & - & $11,2 \pm 0,6$ & $130 \pm 7$ \\
\hline CSQN65 & $125 \pm 13$ & $16,23 \pm 0,09$ & $1,8 \pm 0,3$ & $0,4 \pm 0,2$ & $14,9 \pm 0,8$ & $123 \pm 7$ \\
\hline CSQN66 & $111 \pm 11$ & $16,62 \pm 0,09$ & $1,5 \pm 0,2$ & $0,9 \pm 0,2$ & $14,4 \pm 0,8$ & $146 \pm 8$ \\
\hline CSQN67 & $36 \pm 11$ & $17,77 \pm 0,07$ & $1,7 \pm 0,2$ & $1,1 \pm 0,3$ & $16,7 \pm 0,9$ & $142 \pm 6$ \\
\hline CSQN68 & $116 \pm 8$ & $17,95 \pm 0,07$ & $1,7 \pm 0,2$ & $0,8 \pm 0,2$ & $15,7 \pm 0,8$ & $158 \pm 6$ \\
\hline CSQN70 & $128 \pm 9$ & $13,61 \pm 0,06$ & $1,1 \pm 0,1$ & $0,3 \pm 0,2$ & $14,2 \pm 0,7$ & $147 \pm 5$ \\
\hline CSQN72 & $76 \pm 6$ & $17,58 \pm 0,07$ & $2,1 \pm 0,2$ & $1,1 \pm 0,2$ & $14,3 \pm 0,8$ & $149 \pm 6$ \\
\hline CSQN73 & $64 \pm 6$ & $11,66 \pm 0,05$ & $1,0 \pm 0,1$ & $0,9 \pm 0,2$ & $11,8 \pm 0,6$ & $109 \pm 5$ \\
\hline CSQN74 & $78 \pm 7$ & $16,99 \pm 0,07$ & $1,8 \pm 0,2$ & $1,2 \pm 0,3$ & $15,1 \pm 0,8$ & $104 \pm 5$ \\
\hline CSQN75 & $116 \pm 24$ & $14,41 \pm 0,14$ & $3,7 \pm 0,4$ & - & $11,5 \pm 0,9$ & $123 \pm 11016$ \\
\hline CSQN76 & $116 \pm 12$ & $18,32 \pm 0,09$ & $1,1 \pm 0,2$ & $1,1 \pm 0,3$ & $18,6 \pm 1,1$ & $168 \pm 8$ \\
\hline CSQN77 & $32 \pm 20$ & $15,42 \pm 0,12$ & $1,2 \pm 0,2$ & $1,2 \pm 0,4$ & $12,4 \pm 0,7$ & $195 \pm 11$ \\
\hline CSQN78 & $29 \pm 11$ & $19,84 \pm 0,1$ & $3,6 \pm 0,3$ & $0,9 \pm 0,3$ & $16,7 \pm 0,9$ & $156 \pm 8$ \\
\hline CSQN79 & $93 \pm 9$ & $12,81 \pm 0,07$ & $0,9 \pm 0,1$ & $0,7 \pm 0,2$ & $12,9 \pm 0,7$ & $127 \pm 7$ \\
\hline CSQN80 & $81 \pm 10$ & $15,57 \pm 0,09$ & $1,3 \pm 0,2$ & $0,8 \pm 0,3$ & $14,4 \pm 0,8$ & $133 \pm 8$ \\
\hline CSQN81 & $112 \pm 11$ & $12,92 \pm 0,08$ & $2 \pm 0,2$ & $0,7 \pm 0,3$ & $12,3 \pm 0,7$ & $128 \pm 7$ \\
\hline CSQN82 & $97 \pm 10$ & $19,46 \pm 0,07$ & $3,1 \pm 0,2$ & $1,6 \pm 0,3$ & $36,2 \pm 1,9$ & $261 \pm 8$ \\
\hline CSQN83 & $71 \pm 9$ & $19,66 \pm 0,07$ & $3,1 \pm 0,2$ & $1,3 \pm 0,2$ & $35,9 \pm 1,9$ & $192 \pm 6$ \\
\hline CSQN84 & $16 \pm 2$ & $14,55 \pm 0,05$ & $3 \pm 0,2$ & $1,4 \pm 0,2$ & $18 \pm 0,9$ & $155 \pm 5$ \\
\hline CSQN85 & $100 \pm 11$ & $19,83 \pm 0,07$ & $2,4 \pm 0,2$ & $1,6 \pm 0,2$ & $30,4 \pm 1,6$ & $221 \pm 7$ \\
\hline CSQN86 & $71 \pm 9$ & $16,07 \pm 0,06$ & $2,7 \pm 0,2$ & $1,7 \pm 0,3$ & $30,9 \pm 1,6$ & $224 \pm 7$ \\
\hline CSQN87 & $61 \pm 6$ & $15,47 \pm 0,06$ & $2,7 \pm 0,2$ & $1 \pm 0,2$ & $31,4 \pm 1,6$ & $254 \pm 8$ \\
\hline CSQN88 & $60 \pm 7$ & $16,83 \pm 0,06$ & $3,1 \pm 0,2$ & $1,1 \pm 0,2$ & $32,5 \pm 1,7$ & $205 \pm 7$ \\
\hline CSQN89 & $74 \pm 7$ & $19,71 \pm 0,07$ & $2,7 \pm 0,2$ & $1,3 \pm 0,2$ & $30,5 \pm 1,6$ & $134 \pm 5$ \\
\hline CSQN90 & $90 \pm 8$ & $15,44 \pm 0,06$ & $3,3 \pm 0,3$ & $1 \pm 0,2$ & $13,8 \pm 0,7$ & $160 \pm 6$ \\
\hline CSQN91 & $66 \pm 7$ & $11,77 \pm 0,05$ & $16,7 \pm 1,1$ & $0,4 \pm 0,2$ & $11,9 \pm 0,6$ & $98 \pm 4$ \\
\hline CSQN92 & $98 \pm 9$ & $15,28 \pm 0,06$ & $5,8 \pm 0,4$ & $0,5 \pm 0,2$ & $13,5 \pm 0,7$ & $153 \pm 6$ \\
\hline CSQN93 & $83 \pm 8$ & $15,18 \pm 0,06$ & $7,1 \pm 0,5$ & $0,9 \pm 0,2$ & $14,1 \pm 0,7$ & $135 \pm 5$ \\
\hline CSQN94 & $94 \pm 12$ & $14,41 \pm 0,06$ & $3,4 \pm 0,2$ & $0,7 \pm 0,1$ & $15,4 \pm 0,8$ & $123 \pm 5$ \\
\hline CSQN95 & $105 \pm 7$ & $13,5 \pm 0,05$ & $1,5 \pm 0,1$ & $0,8 \pm 0,3$ & $15,1 \pm 0,8$ & $102 \pm 4$ \\
\hline CSQN96 & $72 \pm 7$ & $10,73 \pm 0,05$ & $1,2 \pm 0,1$ & $0,6 \pm 0,2$ & $10,3 \pm 0,6$ & $95 \pm 4$ \\
\hline CSQN97 & $91 \pm 8$ & $13,45 \pm 0,06$ & $0,9 \pm 0,1$ & $0,8 \pm 0,2$ & $12,2 \pm 0,7$ & $131 \pm 5$ \\
\hline CSQN98 & $59 \pm 6$ & $12,92 \pm 0,05$ & $0,9 \pm 0,1$ & $0,5 \pm 0,2$ & $12,3 \pm 0,7$ & $111 \pm 4$ \\
\hline CSQN99 & $85 \pm 7$ & $11,98 \pm 0,05$ & $1,4 \pm 0,1$ & $0,8 \pm 0,2$ & $11,3 \pm 0,6$ & $122 \pm 5$ \\
\hline CSQN100 & $76 \pm 7$ & $10,54 \pm 0,05$ & $1,8 \pm 0,1$ & $1,4 \pm 0,3$ & $20,2 \pm 1,1$ & $50 \pm 3$ \\
\hline CSQN101 & $44 \pm 5$ & $14,64 \pm 0,06$ & $1,3 \pm 0,1$ & $0,6 \pm 0,2$ & $13,8 \pm 0,7$ & $104 \pm 4$ \\
\hline CSQN103 & $130 \pm 18$ & $15,16 \pm 0,08$ & $0,9 \pm 0,2$ & $0,8 \pm 0,3$ & $12,9 \pm 0,7$ & - \\
\hline CSQN104 & $107 \pm 6$ & $14 \pm 0,05$ & $0,8 \pm 0,1$ & $0,5 \pm 0,1$ & $12,1 \pm 0,6$ & $182 \pm 5$ \\
\hline CSQN105 & $96 \pm 6$ & $15,03 \pm 0,05$ & $1,4 \pm 0,1$ & $0,5 \pm 0,1$ & $14,2 \pm 0,7$ & $161 \pm 5$ \\
\hline
\end{tabular}




\begin{tabular}{|c|c|c|c|c|c|c|}
\hline Código & $\mathbf{R b}$ & Sc & $\mathbf{T a}$ & Tb (ng/g) & Th & $\mathbf{Z n}$ \\
\hline CSQN106 & $77 \pm 5$ & $14,52 \pm 0,05$ & $1 \pm 0,1$ & $1,1 \pm 0,2$ & $12,5 \pm 0,7$ & $119 \pm 4$ \\
\hline CSQN107 & $121 \pm 7$ & $15,79 \pm 0,05$ & $1 \pm 0,1$ & $0,9 \pm 0,2$ & $15,4 \pm 0,8$ & $148 \pm 5$ \\
\hline CSQN108 & $73 \pm 5$ & $15,07 \pm 0,05$ & $1,1 \pm 0,1$ & $0,7 \pm 0,2$ & $13,1 \pm 0,7$ & $124 \pm 4$ \\
\hline CSQN109 & $139 \pm 6$ & $18,17 \pm 0,05$ & $1,6 \pm 0,1$ & $0,8 \pm 0,2$ & $15,5 \pm 0,8$ & $177 \pm 5$ \\
\hline CSQN110 & $103 \pm 6$ & $13,71 \pm 0,05$ & $1 \pm 0,1$ & $0,5 \pm 0,1$ & $15 \pm 0,8$ & $144 \pm 5$ \\
\hline CSQN111 & $71 \pm 5$ & $14,69 \pm 0,05$ & $1,2 \pm 0,1$ & $0,5 \pm 0,1$ & $12,1 \pm 0,6$ & $115 \pm 4$ \\
\hline CSQN112 & $139 \pm 10$ & $13,67 \pm 0,06$ & $1,3 \pm 0,2$ & $0,8 \pm 0,2$ & $12,1 \pm 0,7$ & $117 \pm 5$ \\
\hline CSQN113 & $131 \pm 10$ & $16,9 \pm 0,07$ & $1,5 \pm 0,2$ & $0,9 \pm 0,2$ & $14,4 \pm 0,8$ & $197 \pm 8$ \\
\hline CSQN114 & $92 \pm 8$ & $12,18 \pm 0,06$ & $1,3 \pm 0,2$ & $0,3 \pm 0,2$ & $11,3 \pm 0,6$ & $138 \pm 6$ \\
\hline CSQN115 & $129 \pm 9$ & $12,49 \pm 0,06$ & $1,5 \pm 0,2$ & $0,4 \pm 0,2$ & $14 \pm 0,8$ & $102 \pm 5$ \\
\hline CSQN116 & $78 \pm 12$ & $14,34 \pm 0,1$ & $1,8 \pm 0,5$ & $0,9 \pm 0,3$ & $13,4 \pm 0,8$ & $116 \pm 9$ \\
\hline CSQN117 & $45 \pm 9$ & $16,65 \pm 0,11$ & $1,6 \pm 0,5$ & $0,7 \pm 0,3$ & $14 \pm 0,8$ & $119 \pm 9$ \\
\hline CSQN118 & $44 \pm 18$ & $17,42 \pm 0,12$ & $1,7 \pm 0,4$ & $0,6 \pm 0,3$ & $14,9 \pm 0,8$ & $143 \pm 10$ \\
\hline CSQN119 & $72 \pm 13$ & $17,28 \pm 0,09$ & $1,2 \pm 0,2$ & $1,3 \pm 0,3$ & $14,9 \pm 0,8$ & - \\
\hline CSQN120 & $113 \pm 15$ & $16,64 \pm 0,11$ & $1,7 \pm 0,5$ & $0,5 \pm 0,3$ & $15,1 \pm 0,9$ & $154 \pm 11$ \\
\hline CSQN121 & $93 \pm 7$ & $11,77 \pm 0,06$ & $2,1 \pm 0,3$ & $1,2 \pm 0,2$ & $14,1 \pm 0,7$ & $82 \pm 4$ \\
\hline CSQN122 & $20 \pm 7$ & $21,31 \pm 0,09$ & $2,8 \pm 0,4$ & $1,1 \pm 0,3$ & $17,3 \pm 0,9$ & $180 \pm 7$ \\
\hline CSQN123 & $112 \pm 9$ & $15,76 \pm 0,07$ & $2 \pm 0,3$ & $1 \pm 0,3$ & $15,5 \pm 0,8$ & $144 \pm 6$ \\
\hline CSQN126 & $59 \pm 9$ & $7,62 \pm 0,07$ & $1,7 \pm 0,4$ & $0,3 \pm 0,2$ & $15,1 \pm 0,9$ & $79 \pm 7$ \\
\hline CSQN127 & $65 \pm 10$ & $11,05 \pm 0,08$ & $1,5 \pm 0,3$ & $0,8 \pm 0,3$ & $14,6 \pm 0,8$ & $63 \pm 7$ \\
\hline CSQN128 & $106 \pm 13$ & $10,39 \pm 0,08$ & $1 \pm 0,2$ & - & $9,1 \pm 0,6$ & $127 \pm 9$ \\
\hline CSQN129 & $84 \pm 15$ & $10,22 \pm 0,08$ & $1,9 \pm 0,3$ & $0,4 \pm 0,2$ & $15 \pm 0,8$ & $96 \pm 8$ \\
\hline CSQN130 & $138 \pm 16$ & $16,14 \pm 0,1$ & $1,2 \pm 0,2$ & $0,9 \pm 0,3$ & $14,7 \pm 0,8$ & $207 \pm 13$ \\
\hline CSQN131 & $147 \pm 17$ & $12,17 \pm 0,09$ & $1,5 \pm 0,2$ & $0,4 \pm 0,2$ & $15,4 \pm 0,9$ & $119 \pm 9$ \\
\hline CSQN132 & $74 \pm 14$ & $16,27 \pm 0,1$ & $0,4 \pm 0,4$ & - & $14,6 \pm 0,8$ & $154 \pm 11$ \\
\hline CSQN133 & $88 \pm 12$ & $15,46 \pm 0,1$ & $1,2 \pm 0,2$ & $0,8 \pm 0,3$ & $14,4 \pm 0,8$ & $186 \pm 12$ \\
\hline CSQN351 & $152 \pm 45$ & $14,58 \pm 0,21$ & - & - & $13,5 \pm 1,5$ & $301 \pm 170$ \\
\hline CSQN352 & - & $18,77 \pm 0,25$ & - & - & $18,2 \pm 1,9$ & $458 \pm 237$ \\
\hline CSQN353 & $108 \pm 27$ & $13,41 \pm 0,19$ & - & - & $12,5 \pm 1,3$ & - \\
\hline CSQN354 & - & $15,65 \pm 0,21$ & - & - & $14,4 \pm 1$ & - \\
\hline CSQN355 & $134 \pm 45$ & $16,83 \pm 0,23$ & - & - & $13,7 \pm 1,7$ & $1463 \pm 666$ \\
\hline CSQN356 & $153 \pm 23$ & $14,72 \pm 0,18$ & - & - & $13,8 \pm 0,9$ & - \\
\hline CSQN357 & $129 \pm 38$ & $15,78 \pm 0,22$ & - & - & $14,9 \pm 1,7$ & $322 \pm 173$ \\
\hline CSQN358 & $195 \pm 82$ & $14,31 \pm 0,11$ & $1,4 \pm 0,3$ & - & $13,5 \pm 0,9$ & $73 \pm 8$ \\
\hline CSQN359 & $89 \pm 30$ & $11,75 \pm 0,18$ & - & - & $13,4 \pm 1,5$ & $345 \pm 184$ \\
\hline CSQN360 & - & $18,56 \pm 0,12$ & $1,4 \pm 0,3$ & $1 \pm 0,2$ & $15,2 \pm 1$ & - \\
\hline CSQN361 & $244 \pm 101$ & $15,58 \pm 0,12$ & $1,2 \pm 0,3$ & - & $15,8 \pm 1,3$ & - \\
\hline CSQN362 & $274 \pm 111$ & $16,05 \pm 0,11$ & $1,1 \pm 0,3$ & $0,6 \pm 0,2$ & $13,8 \pm 0,9$ & - \\
\hline CSQN363 & - & $15,67 \pm 0,11$ & $1,2 \pm 0,3$ & $0,5 \pm 0,3$ & $13,6 \pm 0,9$ & - \\
\hline CSQN364 & - & $16,84 \pm 0,11$ & $1,2 \pm 0,3$ & $0,8 \pm 0,2$ & $15,2 \pm 1$ & $75 \pm 8$ \\
\hline CSQN365 & $280 \pm 113$ & $14,52 \pm 0,1$ & $1 \pm 0,3$ & $0,8 \pm 0,2$ & $15 \pm 1$ & - \\
\hline CSQN366 & $99 \pm 34$ & $11,74 \pm 0,09$ & $0,9 \pm 0,2$ & - & $16,7 \pm 1$ & $497 \pm 224$ \\
\hline CSQN367 & $86 \pm 32$ & $18,05 \pm 0,12$ & $0,6 \pm 0,2$ & $0,2 \pm 0,3$ & $15,2 \pm 0,9$ & - \\
\hline CSQN368 & $166 \pm 56$ & $26,39 \pm 0,16$ & $1,5 \pm 0,3$ & $0,7 \pm 0,5$ & $23,1 \pm 1,4$ & $2419 \pm 1051$ \\
\hline CSQN369 & - & $16,22 \pm 0,11$ & $0,7 \pm 0,1$ & - & $15,3 \pm 0,9$ & $775 \pm 344$ \\
\hline
\end{tabular}




\begin{tabular}{|c|c|c|c|c|c|c|}
\hline Código & $\mathbf{R b}$ & Sc & Ta & Tb (ng/g) & Th & $\mathbf{Z n}$ \\
\hline CSQN370 & $40 \pm 28$ & $13,52 \pm 0,11$ & $0,6 \pm 0,2$ & $0,4 \pm 0,3$ & $12,1 \pm 0,8$ & - \\
\hline CSQN371 & $271 \pm 93$ & $14,53 \pm 0,11$ & $0,8 \pm 0,2$ & - & $12,4 \pm 0,8$ & - \\
\hline CSQN372 & $102 \pm 13$ & $18,64 \pm 0,11$ & $1,5 \pm 0,4$ & $1 \pm 0,2$ & $16,1 \pm 0,9$ & - \\
\hline CSQN373 & $98 \pm 18$ & $15,36 \pm 0,11$ & $0,9 \pm 0,3$ & $0,8 \pm 0,3$ & $13,8 \pm 0,8$ & - \\
\hline CSQN374 & $79 \pm 11$ & $16,23 \pm 0,1$ & $1,3 \pm 0,3$ & $0,7 \pm 0,2$ & $14,8 \pm 0,8$ & $2589 \pm 1573$ \\
\hline CSQN375 & $71 \pm 12$ & $9,88 \pm 0,07$ & $1,1 \pm 0,3$ & $0,5 \pm 0,1$ & $10,3 \pm 0,7$ & - \\
\hline CSQN376 & $57 \pm 9$ & $12,59 \pm 0,09$ & $0,7 \pm 0,3$ & $0,8 \pm 0,1$ & $10,7 \pm 0,6$ & $1373 \pm 861$ \\
\hline CSQN377 & $139 \pm 16$ & $14,62 \pm 0,09$ & $1,5 \pm 0,4$ & $0,5 \pm 0,1$ & $12,1 \pm 0,7$ & $6510 \pm 3909$ \\
\hline CSQN378 & $119 \pm 14$ & $15,44 \pm 0,1$ & $1,9 \pm 0,5$ & $2 \pm 0,2$ & $23,7 \pm 1,3$ & $5846 \pm 3512$ \\
\hline CSQN379 & $71 \pm 35$ & $19,09 \pm 0,12$ & $1,1 \pm 0,2$ & - & $17,1 \pm 1$ & $134 \pm 10$ \\
\hline CSQN380 & $157 \pm 25$ & $19,47 \pm 0,12$ & $1,3 \pm 0,3$ & $0,4 \pm 0,3$ & $18 \pm 1,1$ & $237 \pm 13$ \\
\hline CSQN381 & $72 \pm 16$ & $19,39 \pm 0,12$ & $1,2 \pm 0,3$ & $1,1 \pm 0,2$ & $16,8 \pm 1$ & $163 \pm 11$ \\
\hline CSQN382 & $39 \pm 28$ & $19,89 \pm 0,13$ & $1,9 \pm 0,4$ & $0,7 \pm 0,3$ & $18,3 \pm 1,1$ & $130 \pm 10$ \\
\hline CSQN383 & $77 \pm 16$ & $15,42 \pm 0,1$ & $1,2 \pm 0,2$ & - & $15 \pm 0,9$ & - \\
\hline CSQN384 & $116 \pm 20$ & $20,05 \pm 0,11$ & $1,4 \pm 0,3$ & $0,9 \pm 0,2$ & $17,3 \pm 1$ & $115 \pm 9$ \\
\hline CSQN385 & $173 \pm 27$ & $20,72 \pm 0,12$ & $1,7 \pm 0,3$ & $0,4 \pm 0,3$ & $20,7 \pm 1,2$ & - \\
\hline CSQN386 & $87 \pm 11$ & $19,13 \pm 0,1$ & $1,2 \pm 0,2$ & $0,6 \pm 0,1$ & $16,5 \pm 0,9$ & - \\
\hline CSQN387 & $69 \pm 10$ & $18,25 \pm 0,09$ & $1,1 \pm 0,2$ & $1 \pm 0,1$ & $16,1 \pm 0,9$ & - \\
\hline CSQN388 & $127 \pm 13$ & $19,11 \pm 0,09$ & $0,8 \pm 0,1$ & $0,6 \pm 0,1$ & $16,6 \pm 0,9$ & - \\
\hline CSQN389 & $134 \pm 14$ & $17,91 \pm 0,09$ & $1,1 \pm 0,2$ & $0,6 \pm 0,1$ & $16 \pm 0,9$ & - \\
\hline CSQN390 & $56 \pm 9$ & $16,3 \pm 0,09$ & $1 \pm 0,1$ & $0,7 \pm 0,1$ & $15,7 \pm 0,9$ & - \\
\hline CSQN391 & $83 \pm 10$ & $17,87 \pm 0,09$ & $0,9 \pm 0,1$ & $0,4 \pm 0,1$ & $17,3 \pm 1$ & - \\
\hline CSQN392 & $93 \pm 11$ & $14,65 \pm 0,08$ & $0,9 \pm 0,1$ & $0,5 \pm 0,1$ & $13,2 \pm 0,7$ & - \\
\hline CSQN393 & $92 \pm 12$ & $15,5 \pm 0,08$ & $1,2 \pm 0,2$ & $0,4 \pm 0,1$ & $14,7 \pm 1$ & - \\
\hline CSQN394 & $110 \pm 13$ & $21,14 \pm 0,11$ & $3,1 \pm 0,4$ & - & $20,1 \pm 1,3$ & - \\
\hline CSQN395 & $93 \pm 12$ & $21,62 \pm 0,11$ & $2,1 \pm 0,3$ & - & $18,3 \pm 1,1$ & - \\
\hline CSQN396 & $102 \pm 13$ & $19,51 \pm 0,1$ & $4,4 \pm 0,5$ & - & $19,1 \pm 1,3$ & - \\
\hline CSQN397 & $104 \pm 13$ & $19,93 \pm 0,11$ & $4 \pm 0,5$ & - & $19,3 \pm 1,3$ & - \\
\hline CSQN398 & $100 \pm 12$ & $10,93 \pm 0,07$ & $4,3 \pm 0,5$ & $0,6 \pm 0,1$ & $12,4 \pm 0,9$ & - \\
\hline CSQN399 & $146 \pm 16$ & $15,7 \pm 0,08$ & $0,7 \pm 0,2$ & $0,8 \pm 0,1$ & $14,6 \pm 1$ & - \\
\hline CSQN400 & $94 \pm 8$ & $16,93 \pm 0,15$ & $1,2 \pm 0,2$ & $0,9 \pm 0$ & $16,8 \pm 0,9$ & $1423 \pm 270$ \\
\hline CSQN401 & $111 \pm 9$ & $18 \pm 0,16$ & $0,8 \pm 0,2$ & - & $14,5 \pm 0,8$ & $786 \pm 151$ \\
\hline CSQN402 & $75 \pm 7$ & $13,51 \pm 0,12$ & $0,8 \pm 0,2$ & $0,7 \pm 0,1$ & $12,8 \pm 0,7$ & - \\
\hline CSQN403 & $98 \pm 8$ & $16,16 \pm 0,14$ & $0,8 \pm 0,2$ & $1 \pm 0,1$ & $16,2 \pm 0,9$ & $892 \pm 170$ \\
\hline CSQN404 & $82 \pm 8$ & $19,71 \pm 0,16$ & $1 \pm 0,2$ & $0,5 \pm 0,2$ & $12,6 \pm 0,7$ & - \\
\hline CSQN405 & $72 \pm 7$ & $14,38 \pm 0,14$ & $1,2 \pm 0,2$ & - & $13,2 \pm 0,8$ & $563 \pm 110$ \\
\hline CSQN406 & $42 \pm 5$ & $10,3 \pm 0,11$ & $1,1 \pm 0,2$ & $1 \pm 0,1$ & $10,9 \pm 0,6$ & $246 \pm 52$ \\
\hline CSQN407 & $98 \pm 9$ & $17,81 \pm 0,14$ & $1,6 \pm 0,3$ & $1 \pm 0,1$ & $15,8 \pm 0,9$ & - \\
\hline CSQN408 & $59 \pm 6$ & $12,12 \pm 0,11$ & $1 \pm 0,2$ & $0,8 \pm 0,1$ & $11,6 \pm 0,6$ & $388 \pm 50$ \\
\hline CSQN409 & $134 \pm 10$ & $16,8 \pm 0,13$ & $1,5 \pm 0,2$ & $0,6 \pm 0,1$ & $13,9 \pm 0,8$ & - \\
\hline CSQN410 & $91 \pm 8$ & $17,06 \pm 0,15$ & $0,8 \pm 0,2$ & - & $15,5 \pm 0,9$ & - \\
\hline CSQN411 & $109 \pm 8$ & $16,63 \pm 0,13$ & $1,3 \pm 0,2$ & $0,9 \pm 0,1$ & $17,2 \pm 0,9$ & $632 \pm 78$ \\
\hline CSQN412 & $191 \pm 12$ & $20,01 \pm 0,15$ & $1,4 \pm 0,2$ & $0,8 \pm 0,1$ & $21,4 \pm 1,1$ & $460 \pm 59$ \\
\hline CSQN413 & $73 \pm 7$ & $18,27 \pm 0,15$ & $1,5 \pm 0,2$ & $0,4 \pm 0,2$ & $17,6 \pm 0,9$ & $163 \pm 27$ \\
\hline CSQN414 & $65 \pm 6$ & $16,93 \pm 0,14$ & $1 \pm 0,2$ & $0,8 \pm 0,1$ & $17,1 \pm 1$ & - \\
\hline
\end{tabular}




\begin{tabular}{|c|c|c|c|c|c|c|}
\hline Código & $\mathbf{R b}$ & Sc & $\mathbf{T a}$ & Tb (ng/g) & Th & Zn \\
\hline CSQN415 & $66 \pm 9$ & $24,89 \pm 0,18$ & $2,6 \pm 0,4$ & $1,3 \pm 0,2$ & $19,5 \pm 1,1$ & $548 \pm 101$ \\
\hline CSQN416 & $115 \pm 12$ & $15,72 \pm 0,14$ & $0,9 \pm 0,2$ & $0,9 \pm 0,1$ & $14,5 \pm 0,9$ & $482 \pm 91$ \\
\hline CSQN417 & $86 \pm 12$ & $15,08 \pm 0,13$ & $1,4 \pm 0,3$ & - & $16,8 \pm 0,9$ & $356 \pm 45$ \\
\hline CSQN418 & $35 \pm 6$ & $13,4 \pm 0,13$ & $0,5 \pm 0,2$ & $0,6 \pm 0,2$ & $12,9 \pm 0,7$ & - \\
\hline CSQN419 & $108 \pm 10$ & $14,28 \pm 0,12$ & $1,6 \pm 0,3$ & $0,8 \pm 0,1$ & $17,9 \pm 1$ & - \\
\hline CSQN420 & $56 \pm 6$ & $10,06 \pm 0,09$ & $1,3 \pm 0,3$ & $0,7 \pm 0,1$ & $13,4 \pm 0,8$ & $161 \pm 24$ \\
\hline CSQN421 & $167 \pm 13$ & $16,04 \pm 0,12$ & $1,1 \pm 0,3$ & $0,7 \pm 0,1$ & $18,1 \pm 1$ & $377 \pm 49$ \\
\hline CSQN422 & $93 \pm 9$ & $13,93 \pm 0,12$ & $1,4 \pm 0,3$ & $0,6 \pm 0,1$ & $15,9 \pm 0,9$ & - \\
\hline CSQN423 & $101 \pm 9$ & $14,05 \pm 0,13$ & $2 \pm 0,4$ & - & $20,7 \pm 1,1$ & - \\
\hline CSQN424 & - & - & - & - & - & - \\
\hline CSQN424\#2 & $94 \pm 20$ & $15,27 \pm 0,08$ & $1,6 \pm 0,3$ & $1,1 \pm 0,4$ & $15,5 \pm 0,9$ & $114 \pm 6$ \\
\hline CSQN425 & $115 \pm 21$ & $12,96 \pm 0,07$ & $1,1 \pm 0,2$ & $0,3 \pm 0,3$ & $12 \pm 0,7$ & $90 \pm 6$ \\
\hline CSQN426 & - & - & - & - & - & - \\
\hline CSQN426\#2 & $157 \pm 25$ & $14,04 \pm 0,08$ & $1,2 \pm 0,2$ & $0,9 \pm 0,4$ & $13,8 \pm 0,8$ & $124 \pm 7$ \\
\hline CSQN427 & $130 \pm 25$ & $16,88 \pm 0,09$ & $1,6 \pm 0,3$ & $0,9 \pm 0,3$ & $15,6 \pm 0,9$ & - \\
\hline CSQN428 & - & - & - & - & - & - \\
\hline CSQN428\#2 & $98 \pm 20$ & $11,7 \pm 0,07$ & $1,5 \pm 0,2$ & $0,9 \pm 0,2$ & $15,8 \pm 0,9$ & $112 \pm 6$ \\
\hline CSQN429 & - & - & - & - & - & - \\
\hline CSQN429\#2 & $67 \pm 16$ & $11,97 \pm 0,07$ & $1,1 \pm 0,2$ & $0,4 \pm 0,3$ & $11 \pm 0,7$ & $91 \pm 5$ \\
\hline CSQN430 & - & - & - & - & - & - \\
\hline CSQN430\#2 & $113 \pm 22$ & $13,07 \pm 0,07$ & $1,4 \pm 0,2$ & $0,6 \pm 0,3$ & $11,9 \pm 0,7$ & $135 \pm 7$ \\
\hline CSQN431 & $116 \pm 13$ & $18,7 \pm 0,11$ & $1,2 \pm 0,2$ & $1,1 \pm 0,4$ & $16 \pm 1$ & $167 \pm 9$ \\
\hline CSQN432 & $96 \pm 10$ & $15,63 \pm 0,09$ & $1,7 \pm 0,2$ & $1,3 \pm 0,4$ & $17,9 \pm 1$ & $128 \pm 7$ \\
\hline CSQN433 & $79 \pm 15$ & $15,86 \pm 0,09$ & $0,9 \pm 0,2$ & $1 \pm 0,4$ & $13,6 \pm 0,8$ & $109 \pm 7$ \\
\hline CSQN434 & $86 \pm 10$ & $16,77 \pm 0,1$ & $2,2 \pm 0,3$ & $1,7 \pm 0,6$ & $15,7 \pm 1$ & $120 \pm 7$ \\
\hline CSQN435 & $74 \pm 9$ & $13,31 \pm 0,08$ & $0,8 \pm 0,1$ & $0,7 \pm 0,4$ & $13,6 \pm 0,8$ & $118 \pm 7$ \\
\hline CSQN436 & $90 \pm 11$ & $18,79 \pm 0,11$ & $1,5 \pm 0,2$ & $1,2 \pm 0,5$ & $16,9 \pm 1$ & $138 \pm 8$ \\
\hline CSQN437 & $131 \pm 13$ & $17,11 \pm 0,1$ & $1,4 \pm 0,2$ & $0,9 \pm 0,4$ & $15,6 \pm 1$ & $132 \pm 8$ \\
\hline CSQN438 & $65 \pm 20$ & $12,91 \pm 0,08$ & $11 \pm 1,7$ & $0,8 \pm 0,3$ & $12,1 \pm 0,8$ & $73 \pm 7$ \\
\hline CSQN439 & $84 \pm 9$ & $14,82 \pm 0,08$ & $1,8 \pm 0,3$ & $0,5 \pm 0,2$ & $12,2 \pm 0,7$ & - \\
\hline CSQN440 & $83 \pm 8$ & $11,51 \pm 0,07$ & $1,1 \pm 0,2$ & $0,3 \pm 0,2$ & $13 \pm 0,8$ & - \\
\hline CSQN441 & $47 \pm 15$ & $14,5 \pm 0,08$ & $1,5 \pm 0,3$ & $0,8 \pm 0,3$ & $16,2 \pm 0,9$ & - \\
\hline CSQN442 & $97 \pm 10$ & $15,82 \pm 0,09$ & $1,3 \pm 0,2$ & $0,6 \pm 0,2$ & $15,7 \pm 0,9$ & $118 \pm 7$ \\
\hline CSQN443 & $67 \pm 8$ & $16,26 \pm 0,09$ & $2,1 \pm 0,4$ & $1,2 \pm 0,3$ & $24,1 \pm 1,4$ & $100 \pm 6$ \\
\hline CSQN444 & $115 \pm 12$ & $13 \pm 0,07$ & $1,5 \pm 0,3$ & $0,7 \pm 0,2$ & $13,1 \pm 0,7$ & $140 \pm 7$ \\
\hline CSQN445 & $56 \pm 8$ & $12,52 \pm 0,08$ & $1,4 \pm 0,3$ & $1,3 \pm 0,4$ & $13,5 \pm 0,8$ & - \\
\hline CSQN446 & $53 \pm 8$ & $9,83 \pm 0,07$ & $0,8 \pm 0,2$ & $0,4 \pm 0,2$ & $8,6 \pm 0,6$ & $76 \pm 6$ \\
\hline CSQN447 & $93 \pm 11$ & $10,35 \pm 0,08$ & $1,4 \pm 0,3$ & $0,3 \pm 0,2$ & $11,6 \pm 0,8$ & $81 \pm 6$ \\
\hline CSQN448 & $127 \pm 14$ & $15,01 \pm 0,1$ & $1,2 \pm 0,3$ & $0,3 \pm 0,2$ & $13 \pm 0,8$ & $147 \pm 9$ \\
\hline CSQN449 & $123 \pm 14$ & $16,15 \pm 0,1$ & $1,4 \pm 0,2$ & $0,8 \pm 0,4$ & $13,3 \pm 0,9$ & $147 \pm 9$ \\
\hline CSQN450 & $65 \pm 9$ & $11,7 \pm 0,08$ & $0,9 \pm 0,2$ & - & $13,3 \pm 0,9$ & $107 \pm 7$ \\
\hline CSQN451 & $27 \pm 6$ & $18,64 \pm 0,11$ & $1,8 \pm 0,3$ & $0,5 \pm 0,3$ & $16,9 \pm 1$ & $172 \pm 10$ \\
\hline CSQN453 & $44 \pm 7$ & $11,52 \pm 0,07$ & $1,6 \pm 0,3$ & $0,3 \pm 0,2$ & $14,8 \pm 0,9$ & $67 \pm 5$ \\
\hline CSQN454 & $63 \pm 9$ & $16,44 \pm 0,09$ & $1 \pm 0,2$ & $1 \pm 0,3$ & $12,7 \pm 0,8$ & $136 \pm 7$ \\
\hline CSQN455 & $104 \pm 17$ & $14,62 \pm 0,1$ & $1,2 \pm 0,3$ & $0,8 \pm 0,3$ & $12,8 \pm 0,8$ & - \\
\hline
\end{tabular}




\begin{tabular}{ccccccc}
\hline Código & Rb & Sc & Ta & Tb (ng/g) & Th & Zn \\
\hline CSQN456 & $87 \pm 16$ & $16,46 \pm 0,11$ & $1,8 \pm 0,4$ & $0,5 \pm 0,3$ & $15,7 \pm 0,9$ & - \\
CSQN457 & $91 \pm 17$ & $15,78 \pm 0,11$ & $1,7 \pm 0,4$ & - & $14,7 \pm 0,9$ & - \\
\hline
\end{tabular}


APÊNDICE C - Cartas de Controle para o material de referência IAEA-Soil-7.
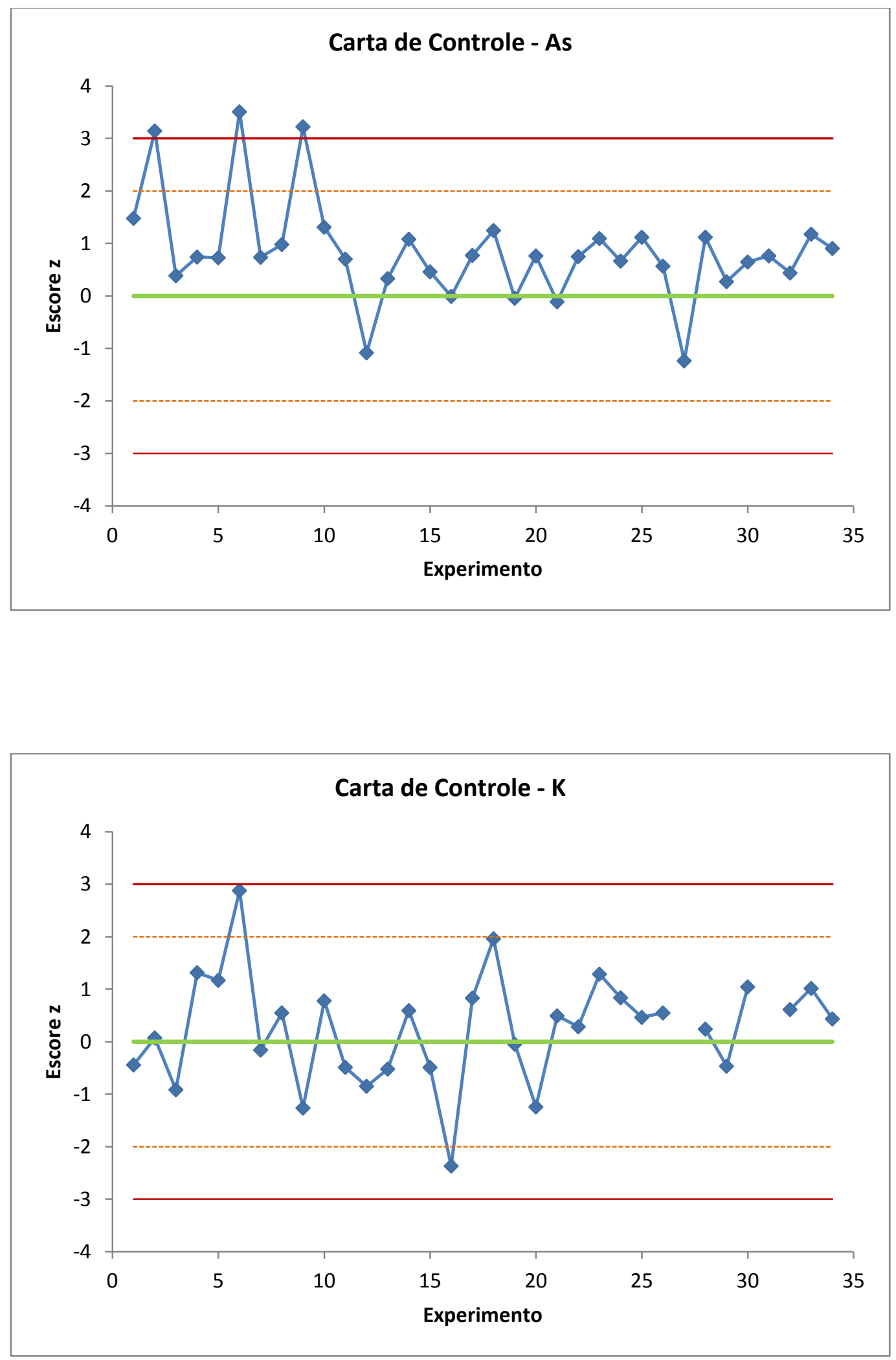

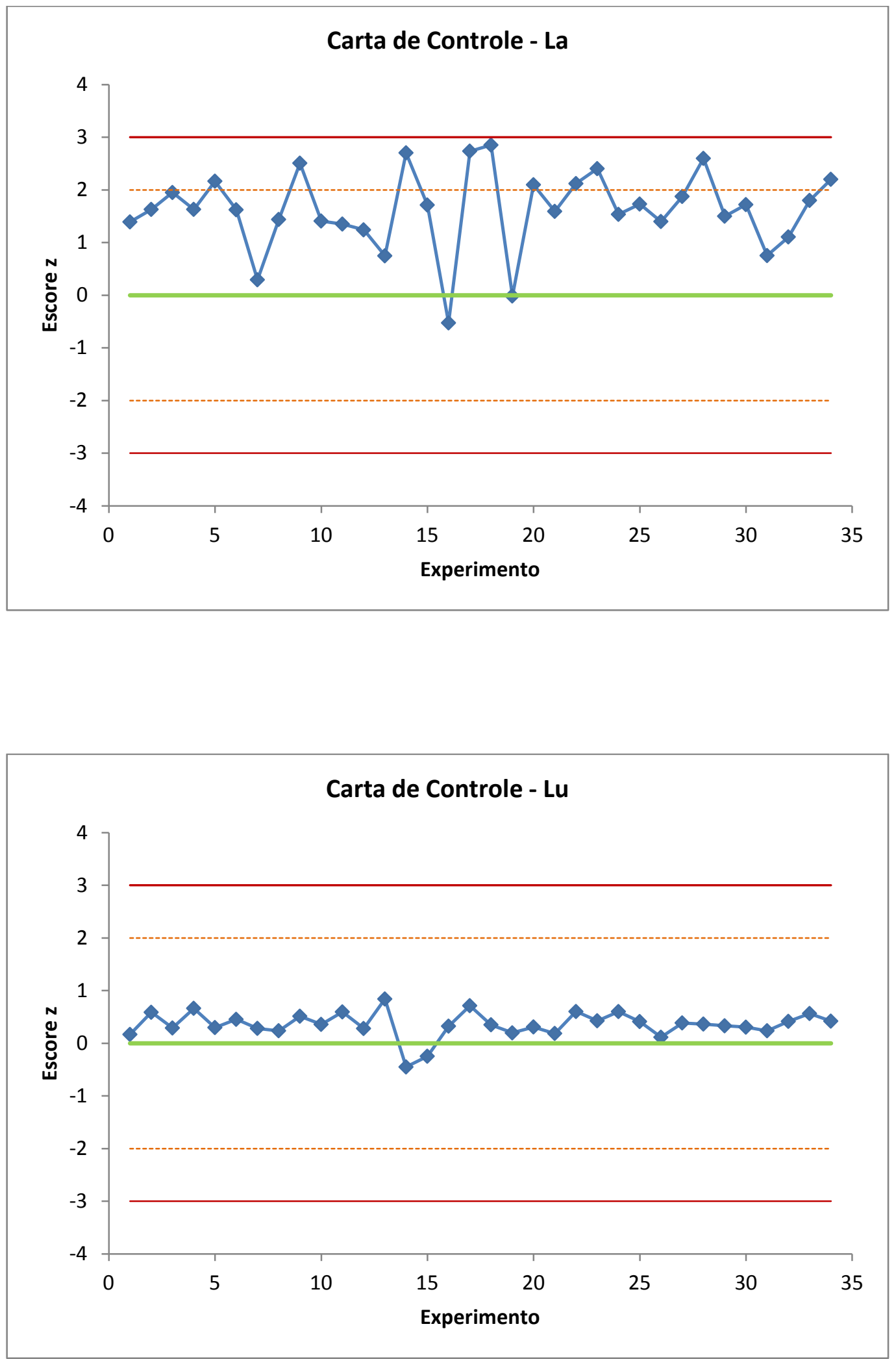

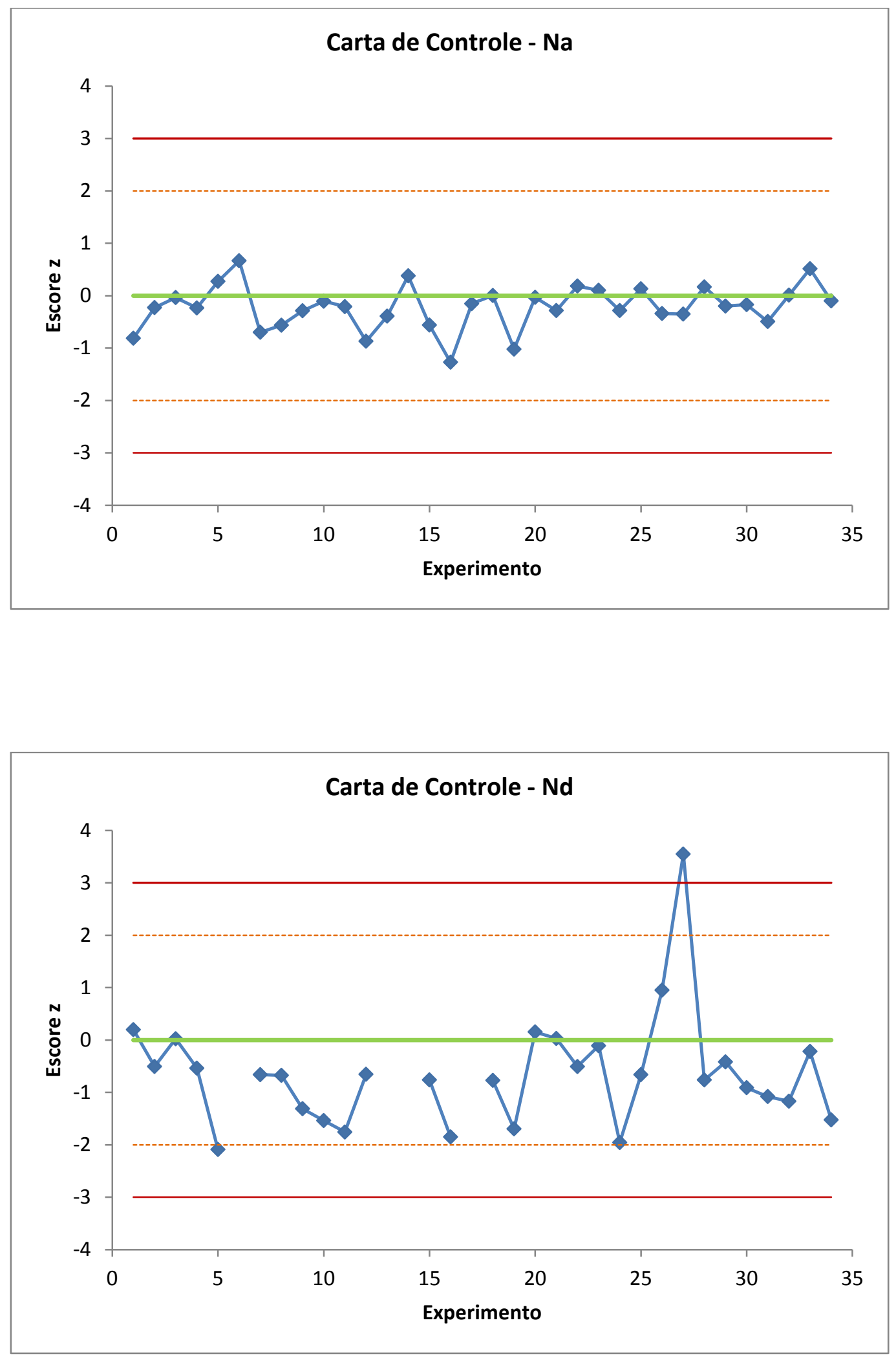

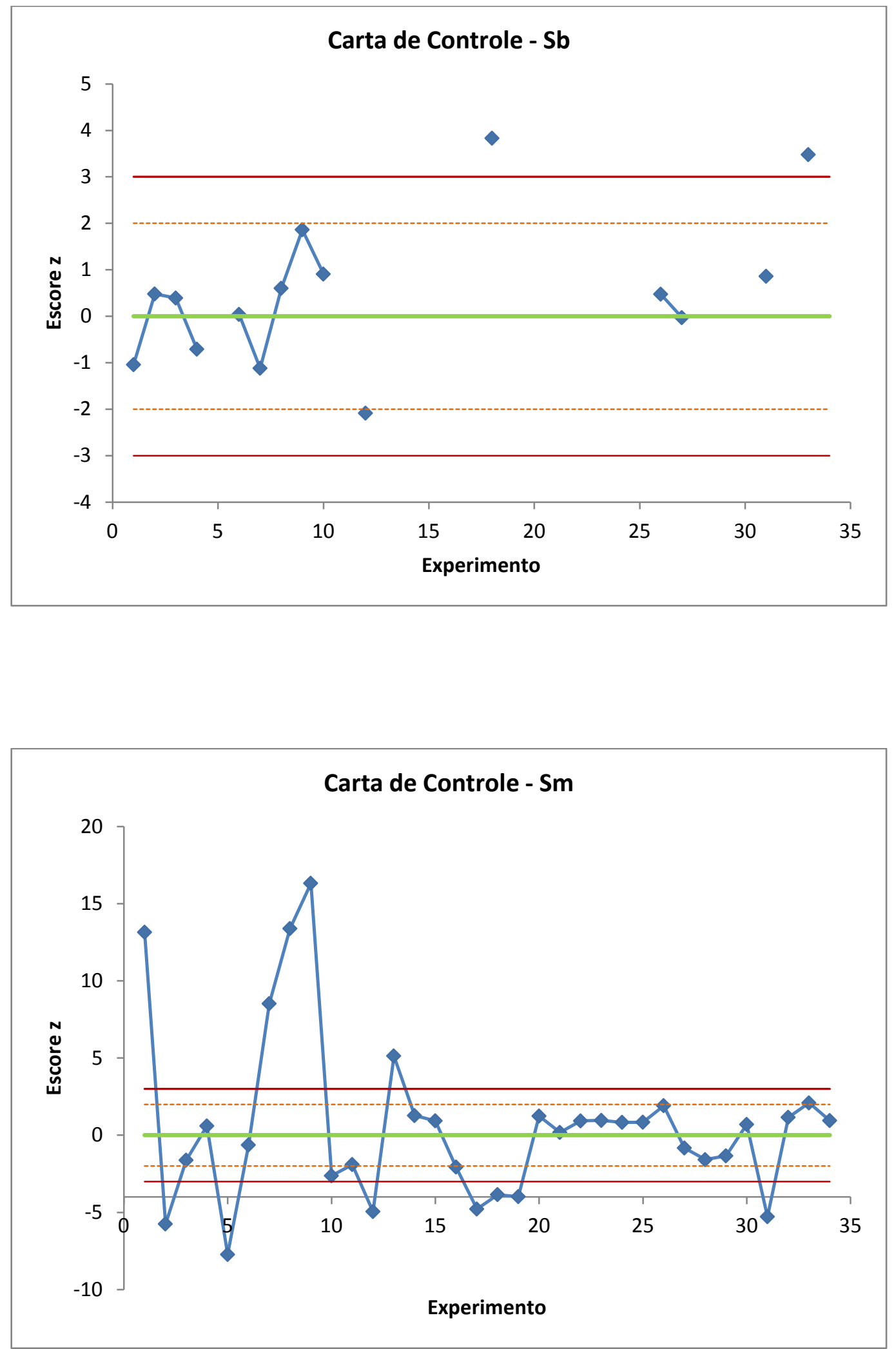

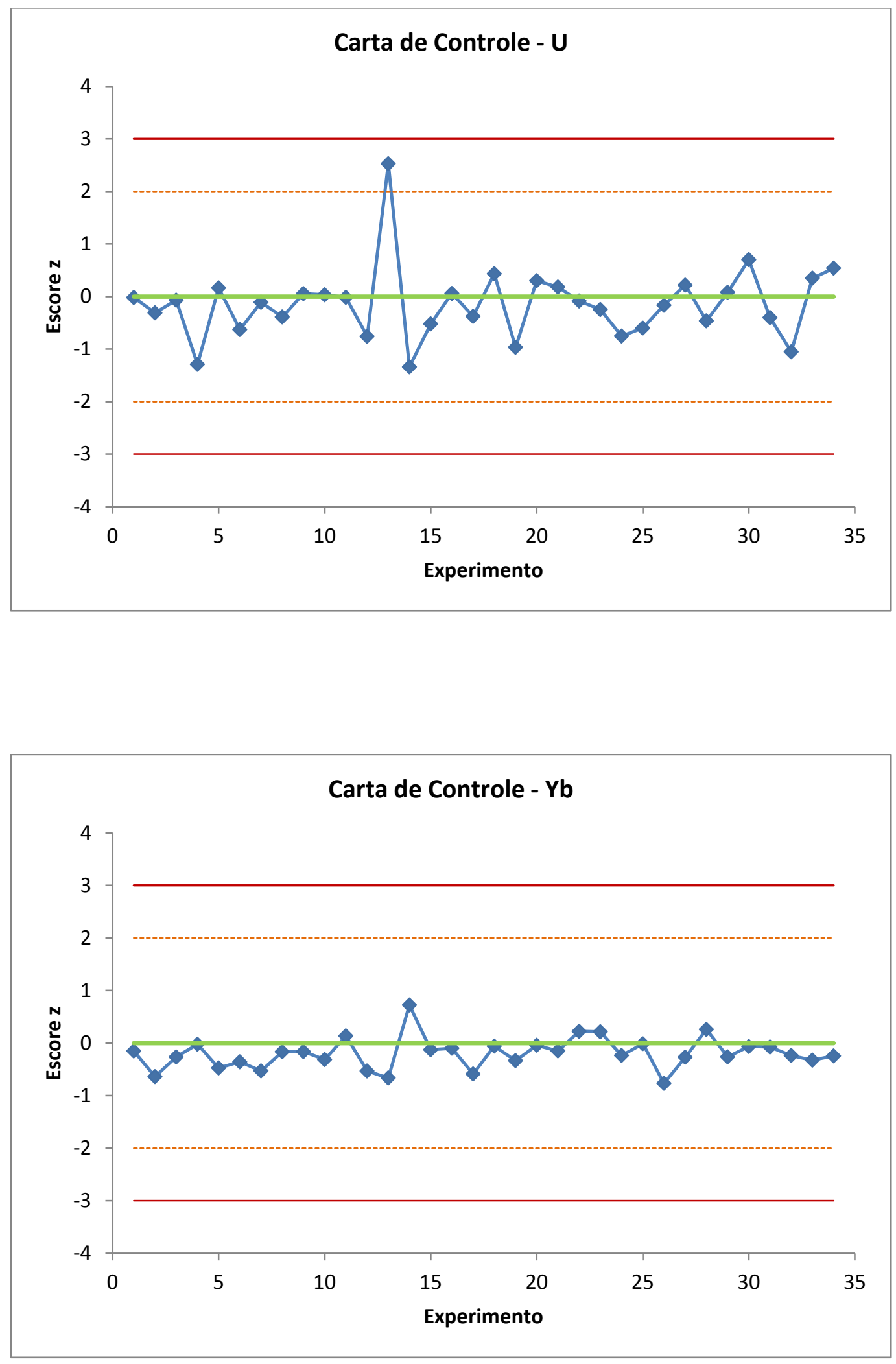

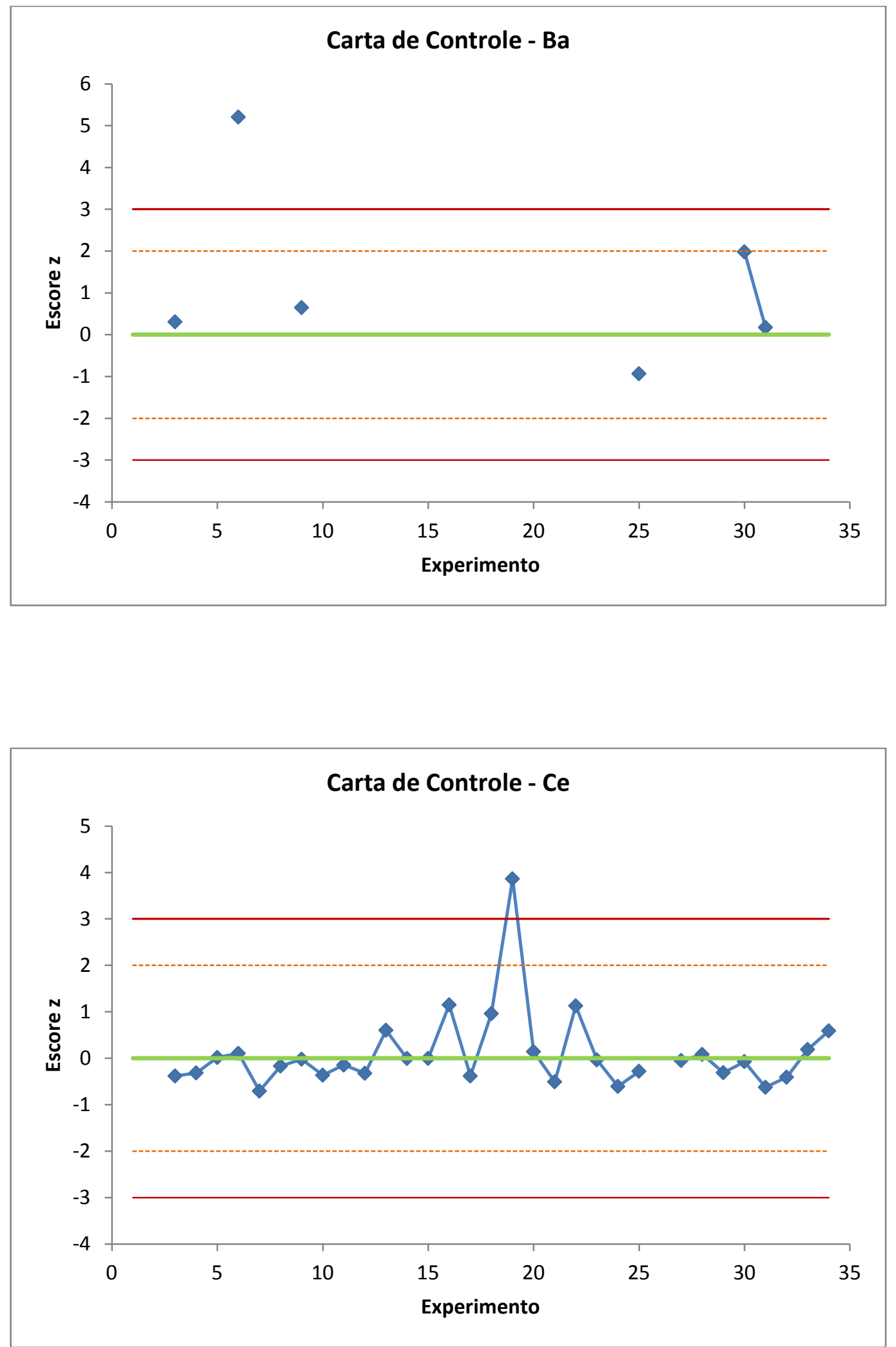

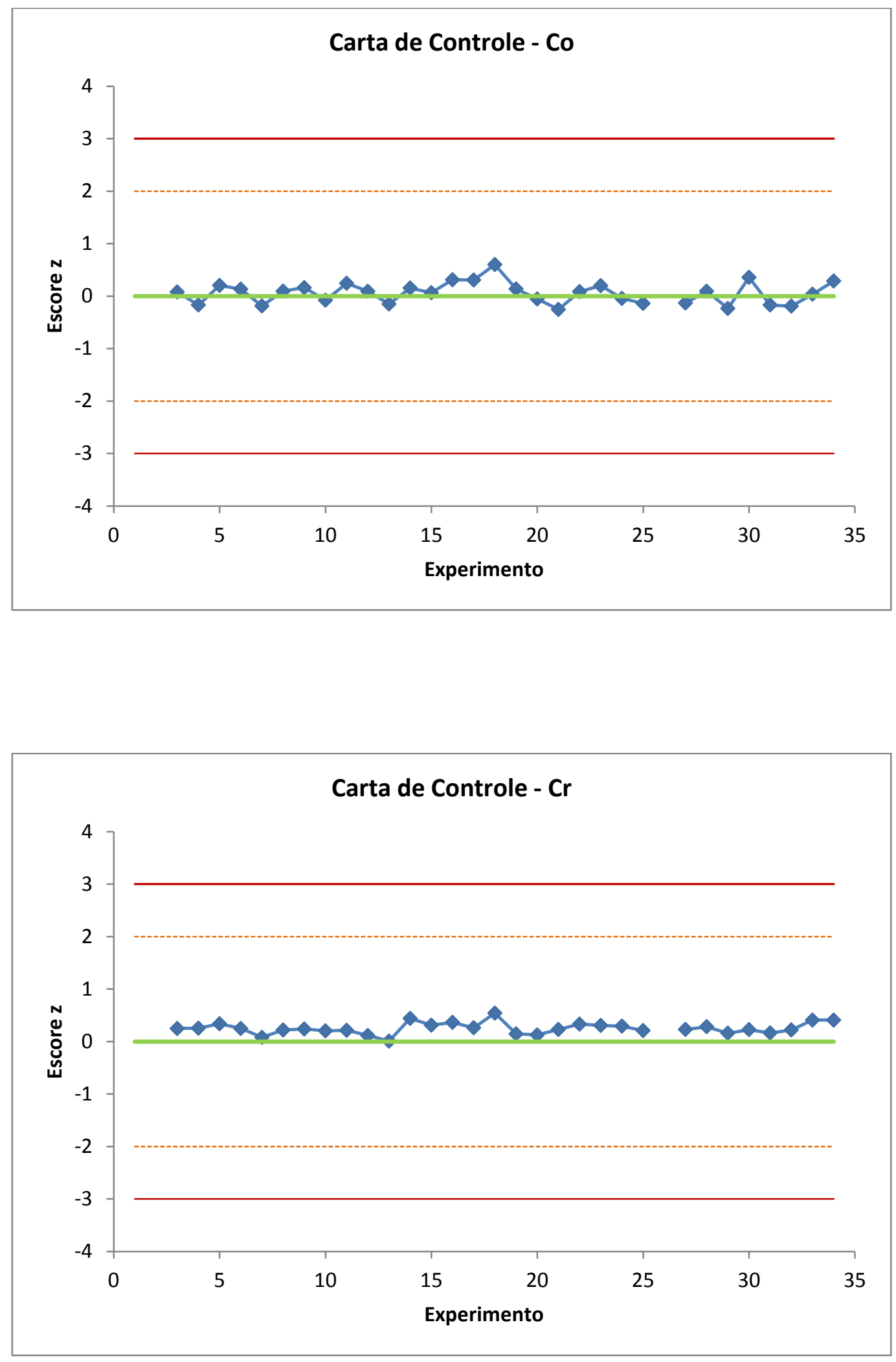

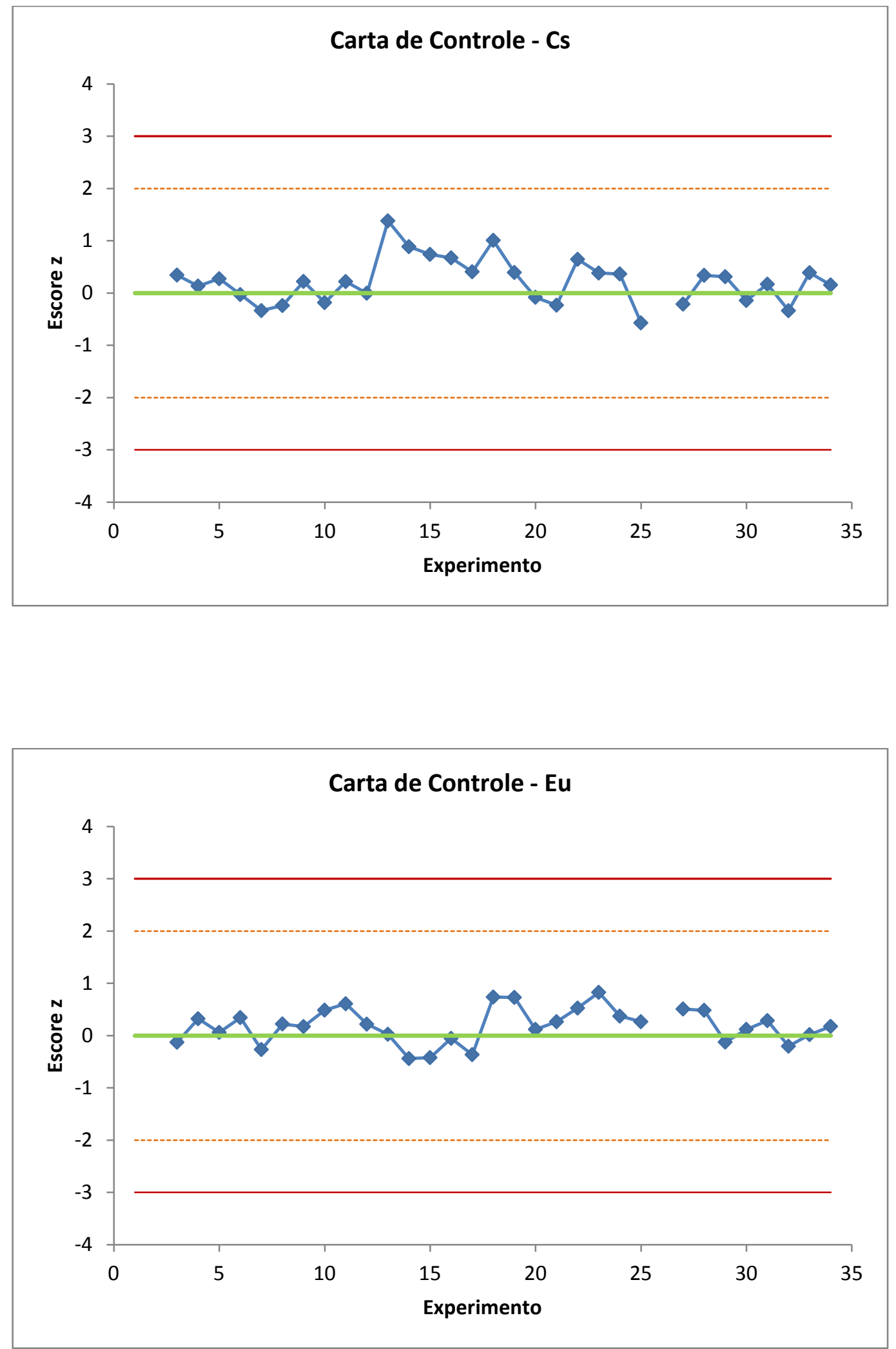

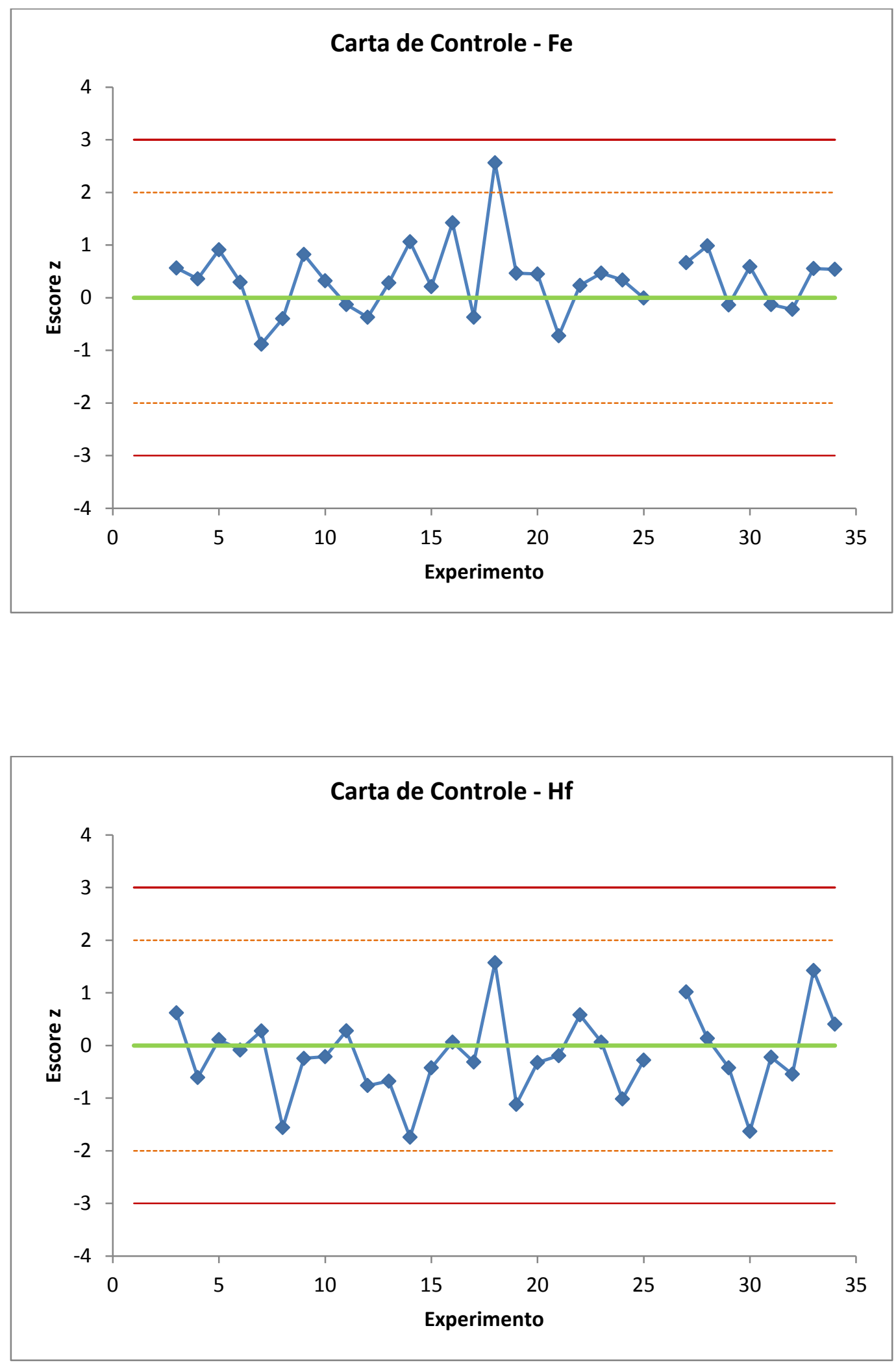

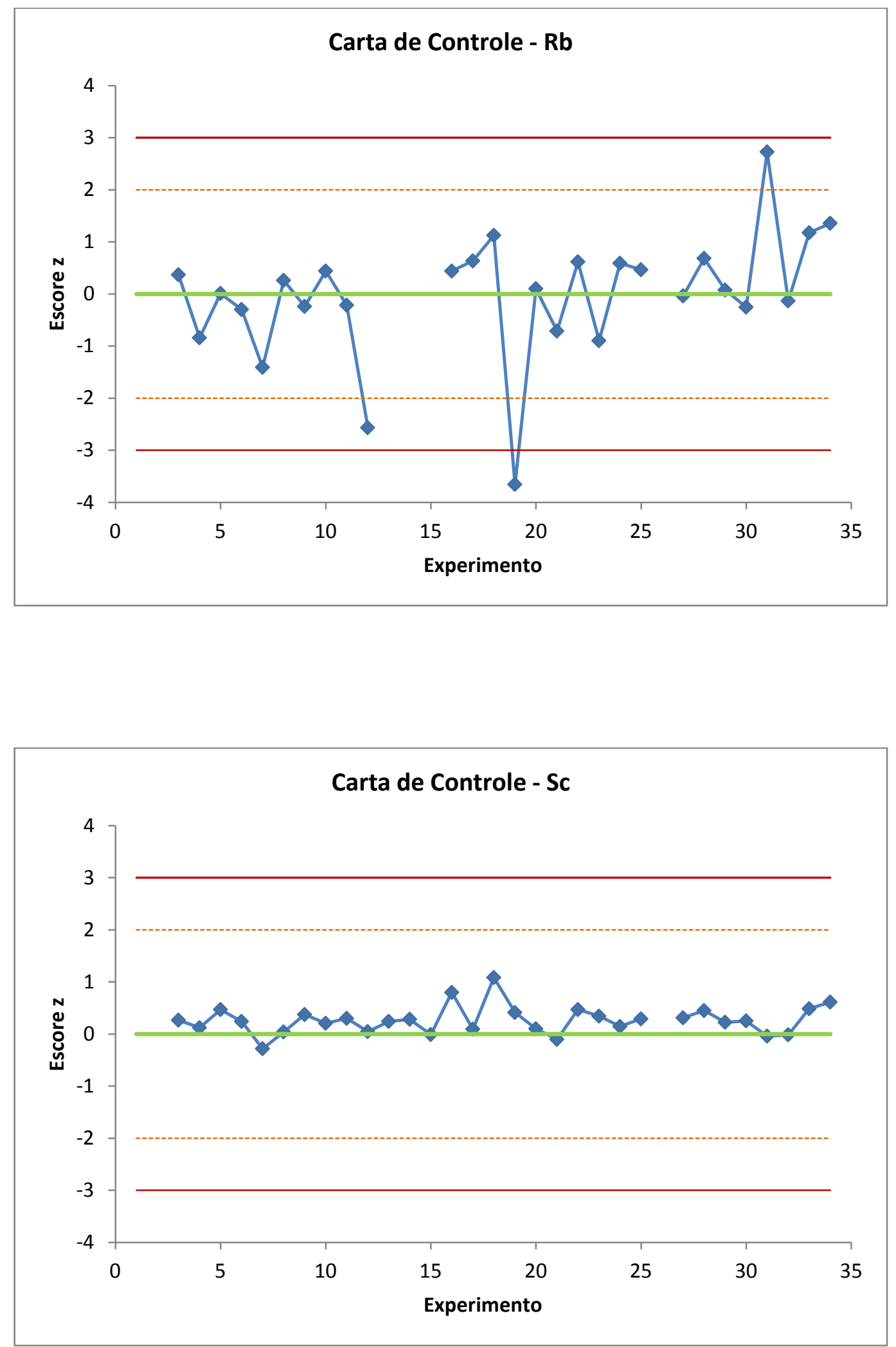

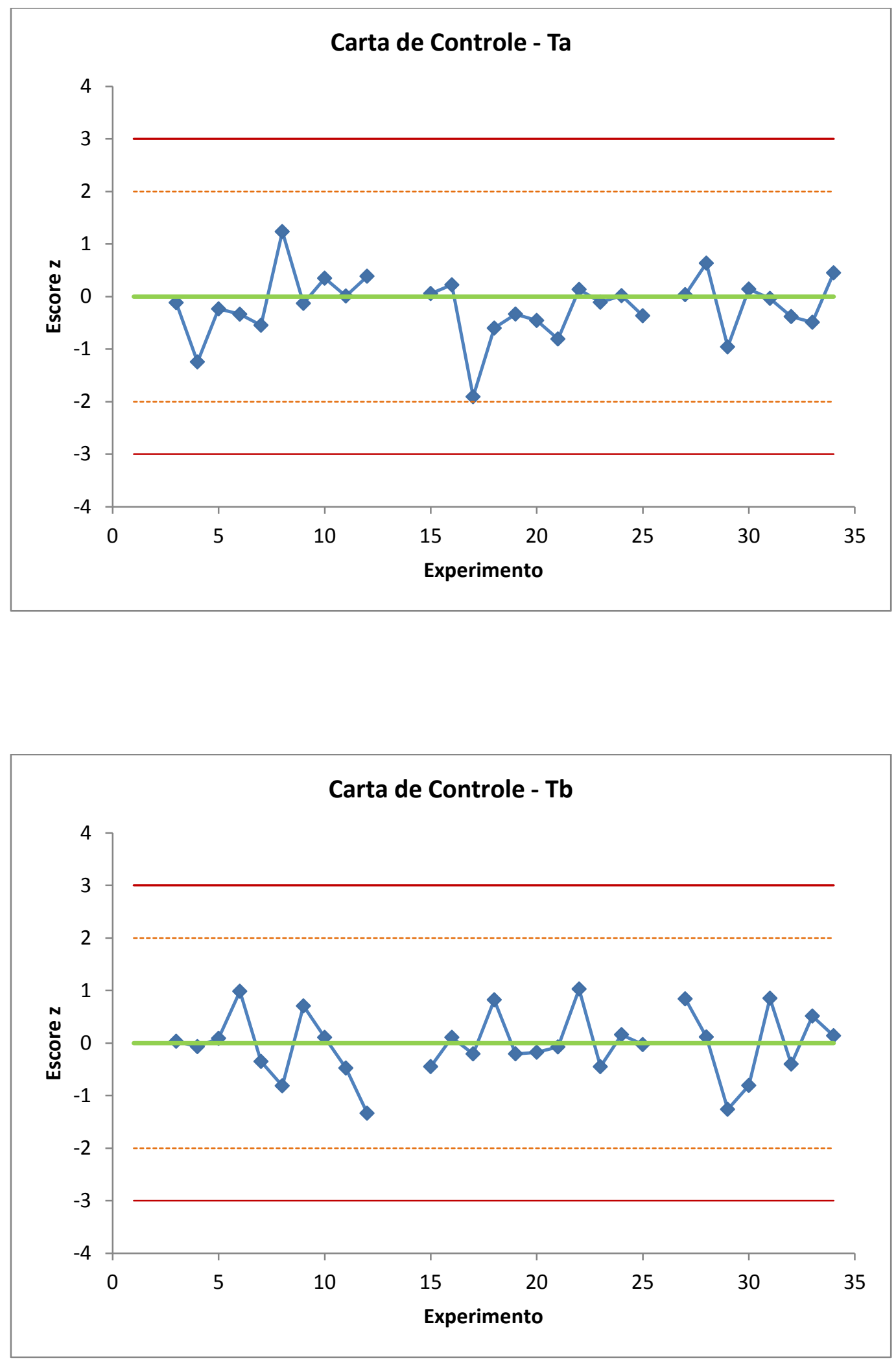

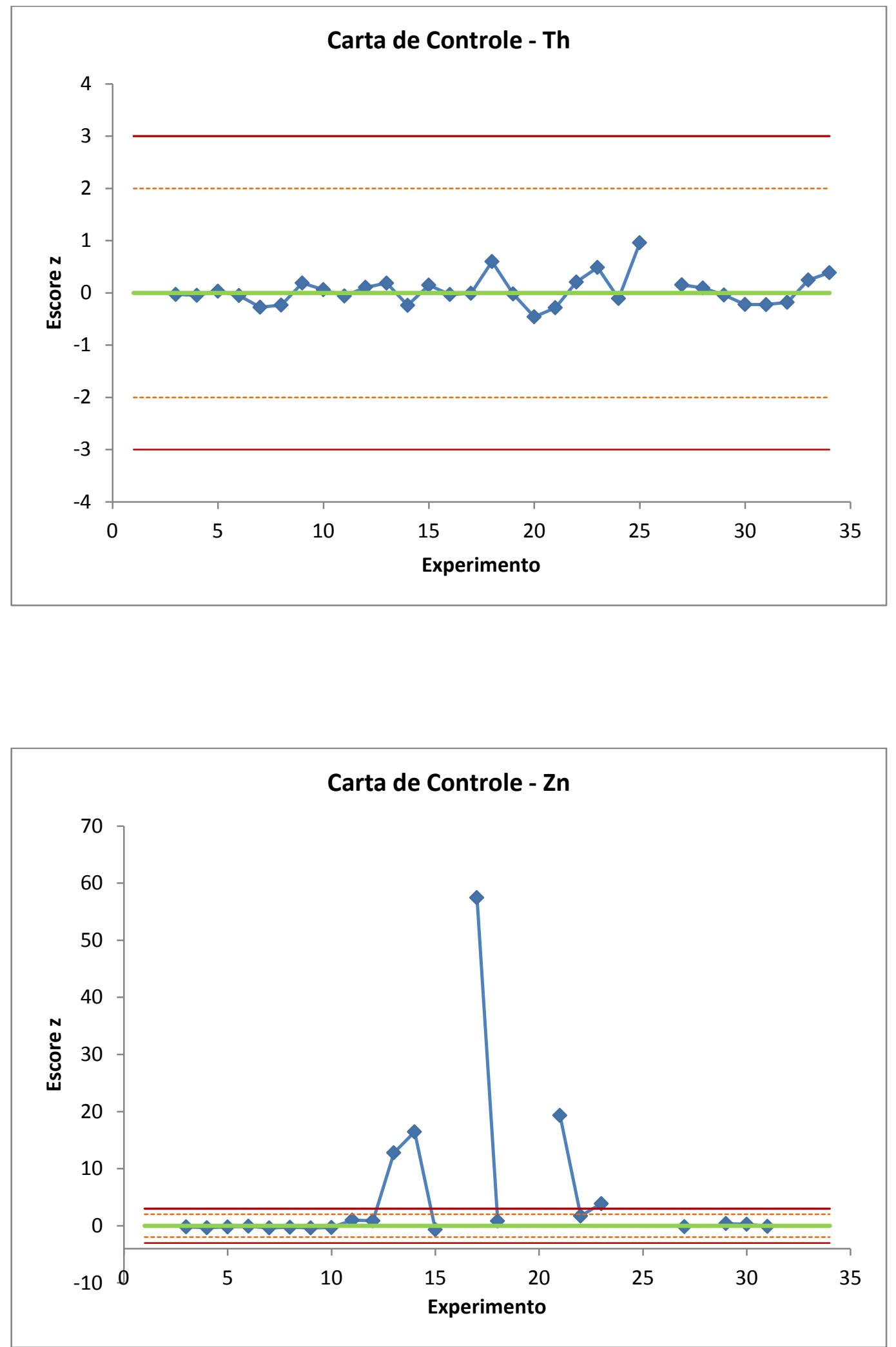
APÊNDICE D - Controle de qualidade analítico pelo teste de proficiência adaptado da IAEA-Seibersdorf.

\begin{tabular}{|c|c|c|c|c|c|c|c|c|c|c|c|c|c|c|c|c|c|}
\hline \multirow{3}{*}{ Element } & \multicolumn{3}{|c|}{ Target } & \multicolumn{3}{|c|}{ Laboratory Results } & \multicolumn{5}{|c|}{ Performance Coefficients } & \multicolumn{5}{|c|}{ Acceptance criteria } & \multirow{3}{*}{ Final score } \\
\hline & \multirow{2}{*}{$\begin{array}{c}\text { Conc } \\
{[\mu \mathrm{g} / \mathrm{g}]}\end{array}$} & \multicolumn{2}{|c|}{ Uncertainty } & \multirow{2}{*}{$\begin{array}{c}\text { Conc } \\
{[\mu \mathrm{g} / \mathrm{g}]}\end{array}$} & \multicolumn{2}{|c|}{ Uncertainty } & \multirow{2}{*}{ Tendência (\%) } & \multirow{2}{*}{ z-score } & \multirow{2}{*}{ z-score evaluation } & \multirow{2}{*}{ u-score } & \multirow{2}{*}{ Lab/Target } & \multicolumn{3}{|c|}{ Trueness } & \multicolumn{2}{|r|}{ Precision } & \\
\hline & & {$[\mu \mathrm{g} / \mathrm{g}]$} & $\%$ & & {$[\mu \mathrm{g} / \mathrm{g}]$} & $\%$ & & & & & & A1 & A2 & Score & $\mathbf{P}$ & Score & \\
\hline As & 13.40 & 2.06 & 15.367237 & 14.90 & 0.83 & 5.6 & 11.2 & 1.12 & satisfactory & 0.67 & 1.11 & 1.50 & 5.73 & Acceptable & 16.3 & Acceptable & Acceptable \\
\hline $\mathrm{K}(\mathrm{mg} / \mathrm{g})$ & 12.10 & 1.77 & 14.624157 & 12.55 & 1.81 & 14.4 & 3.7 & 0.37 & satisfactory & 0.18 & 1.04 & 0.45 & 6.54 & Acceptable & 20.6 & Acceptable & Acceptable \\
\hline $\mathrm{La}$ & 28.00 & 1.57 & 5.6210245 & 30.66 & 1.04 & 3.4 & 9.5 & 0.95 & satisfactory & 1.41 & 1.10 & 2.66 & 4.87 & Acceptable & 6.6 & Acceptable & Acceptable \\
\hline $\mathrm{Lu}(\mathrm{ng} / \mathrm{g})$ & 300.00 & 179.42 & 59.807116 & 369.34 & 27.81 & 7.5 & 23.1 & 2.31 & questionable & 0.38 & 1.23 & 69.34 & 468.44 & Acceptable & 60.3 & Not Acceptable & Not Acceptable \\
\hline $\mathrm{Na}(\mathrm{mg} / \mathrm{g})$ & 2.40 & 0.28 & 11.75084 & 2.34 & 0.12 & 5.1 & 2.5 & -0.25 & satisfactory & 0.20 & 0.97 & 0.06 & 0.79 & Acceptable & 12.8 & Acceptable & Acceptable \\
\hline $\mathrm{Nd}$ & 30.00 & 6.49 & 21.625228 & 24.91 & 4.75 & 19.1 & 17.0 & -1.70 & satisfactory & 0.63 & 0.83 & 5.09 & 20.74 & Acceptable & 28.8 & Acceptable & Acceptable \\
\hline $\mathrm{Sb}$ & 1.70 & 0.40 & 23.657717 & 1.79 & 0.35 & 19.4 & 5.4 & 0.54 & satisfactory & 0.17 & 1.05 & 0.09 & 1.37 & Acceptable & 30.6 & Not Acceptable & Not Acceptable \\
\hline $\mathrm{Sm}$ & 5.10 & 0.55 & 10.801184 & 4.73 & 1.81 & 38.3 & 7.2 & -0.72 & satisfactory & 0.19 & 0.93 & 0.37 & 4.89 & Acceptable & 39.8 & Not Acceptable & Not Acceptable \\
\hline $\mathrm{U}$ & 2.60 & 0.95 & 36.637471 & 2.39 & 0.48 & 20.2 & 8.3 & -0.83 & satisfactory & 0.20 & 0.92 & 0.21 & 2.75 & Acceptable & 41.8 & Not Acceptable & Not Acceptable \\
\hline $\mathrm{Yb}$ & 2.40 & 0.55 & 22.952517 & 2.28 & 0.14 & 6.2 & 5.1 & -0.51 & satisfactory & 0.22 & 0.95 & 0.12 & 1.47 & Acceptable & 23.8 & Acceptable & Acceptable \\
\hline $\mathrm{Ba}$ & 159.00 & 73.30 & 46.101481 & 190.90 & 76.87 & 40.3 & 20.1 & 2.01 & questionable & 0.30 & 1.20 & 31.90 & 274.05 & Acceptable & 61.2 & Not Acceptable & Not Acceptable \\
\hline $\mathrm{Ce}$ & 61.00 & 11.74 & 19.241771 & 60.71 & 5.70 & 9.4 & 0.5 & -0.05 & satisfactory & 0.02 & 1.00 & 0.29 & 33.66 & Acceptable & 21.4 & Acceptable & Acceptable \\
\hline Co & 8.90 & 2.36 & 26.489718 & 9.04 & 0.48 & 5.3 & 1.6 & 0.16 & satisfactory & 0.06 & 1.02 & 0.14 & 6.21 & Acceptable & 27.0 & Acceptable & Acceptable \\
\hline $\mathrm{Cr}$ & 60.00 & 39.60 & 66.003685 & 69.99 & 4.37 & 6.2 & 16.6 & 1.66 & satisfactory & 0.25 & 1.17 & 9.99 & 102.79 & Acceptable & 66.3 & Not Acceptable & Not Acceptable \\
\hline Cs & 5.40 & 1.41 & 26.064683 & 5.72 & 0.61 & 10.6 & 5.9 & 0.59 & satisfactory & 0.21 & 1.06 & 0.32 & 3.96 & Acceptable & 28.2 & Acceptable & Acceptable \\
\hline $\mathrm{Eu}$ & 1.00 & 0.28 & 27.958072 & 1.05 & 0.09 & 9.0 & 5.3 & 0.53 & satisfactory & 0.18 & 1.05 & 0.05 & 0.76 & Acceptable & 29.4 & Acceptable & Acceptable \\
\hline $\mathrm{Fe}(\mathrm{mg} / \mathrm{g})$ & 25.70 & 1.85 & 7.2065388 & 26.20 & 0.99 & 3.8 & 2.0 & 0.20 & satisfactory & 0.24 & 1.02 & 0.50 & 5.41 & Acceptable & 8.1 & Acceptable & Acceptable \\
\hline $\mathrm{Hf}$ & 5.10 & 0.52 & 10.21532 & 5.00 & 0.41 & 8.2 & 1.9 & -0.19 & satisfactory & 0.15 & 0.98 & 0.10 & 1.71 & Acceptable & 13.1 & Acceptable & Acceptable \\
\hline $\mathrm{Rb}$ & 51.00 & 10.66 & 20.895816 & 52.41 & 7.13 & 13.6 & 2.8 & 0.28 & satisfactory & 0.11 & 1.03 & 1.41 & 33.09 & Acceptable & 24.9 & Acceptable & Acceptable \\
\hline $\mathrm{Sc}$ & 8.30 & 2.37 & 28.532501 & 8.63 & 0.32 & 3.7 & 4.0 & 0.40 & satisfactory & 0.14 & 1.04 & 0.33 & 6.16 & Acceptable & 28.8 & Acceptable & Acceptable \\
\hline $\mathrm{Ta}(\mathrm{ng} / \mathrm{g})$ & 800.00 & 314.78 & 39.347171 & 761.03 & 159.04 & 20.9 & 4.9 & -0.49 & satisfactory & 0.11 & 0.95 & 38.97 & 909.90 & Acceptable & 44.6 & Not Acceptable & Not Acceptable \\
\hline $\mathrm{Tb}(\mathrm{ng} / \mathrm{g})$ & 600.00 & 314.78 & 52.462895 & 593.52 & 194.62 & 32.8 & 1.1 & -0.11 & satisfactory & 0.02 & 0.99 & 6.48 & 954.82 & Acceptable & 61.9 & Not Acceptable & Not Acceptable \\
\hline Th & 8.20 & 2.21 & 26.975568 & 8.23 & 0.52 & 6.4 & 0.4 & 0.04 & satisfactory & 0.01 & 1.00 & 0.03 & 5.86 & Acceptable & 27.7 & Acceptable & Acceptable \\
\hline $\mathrm{Zn}$ & 104.00 & 19.74 & 18.975998 & 101.79 & 7.44 & 7.3 & 2.1 & -0.21 & satisfactory & 0.10 & 0.98 & 2.21 & 54.41 & Acceptable & 20.3 & Acceptable & Acceptable \\
\hline
\end{tabular}


APÊNDICE E - Microscopia óptica ilustrando a presença de espículas biogênicas da esponja de água doce cauixi. Aumento: 100x.

CSQN73

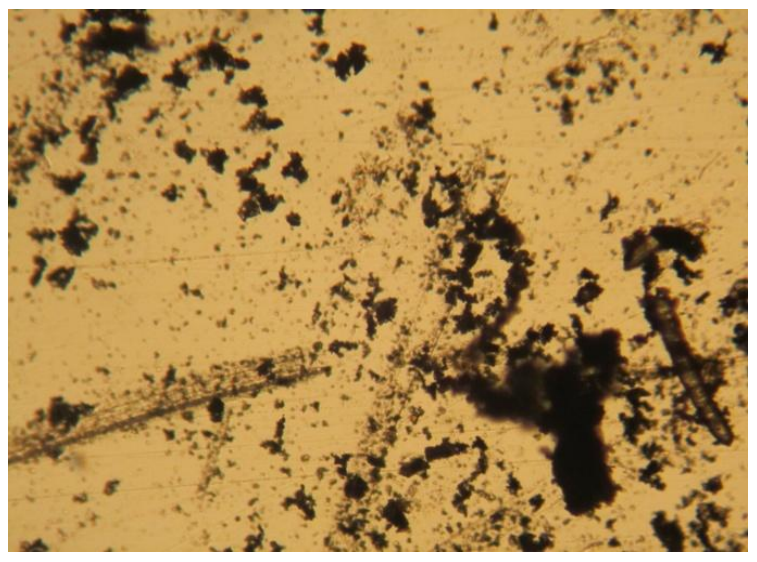

CSQN85

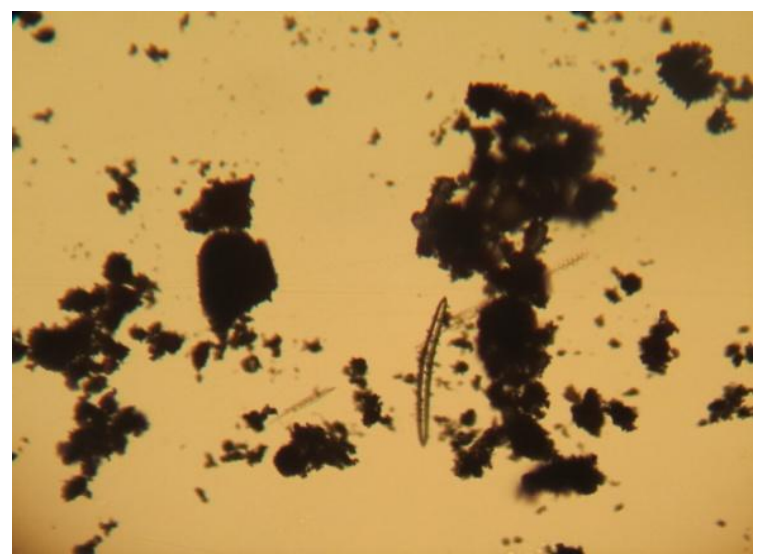

CSQN109

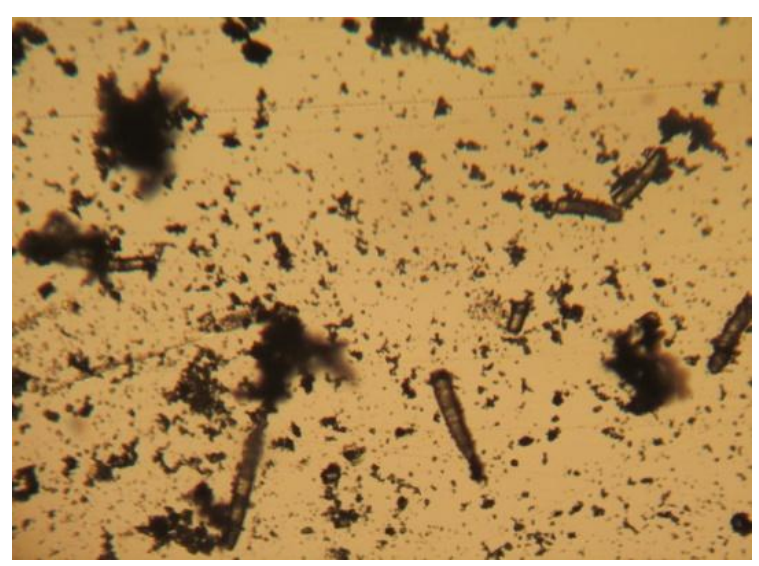

CSQN83

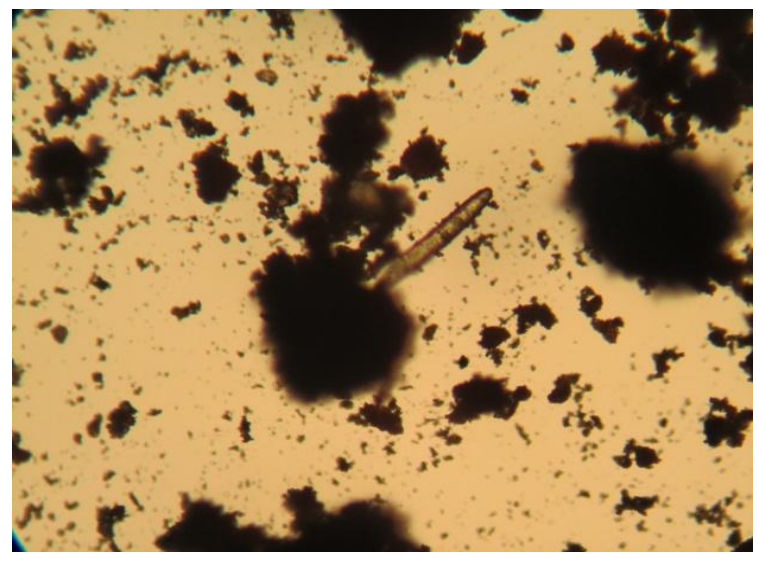

CSQN88

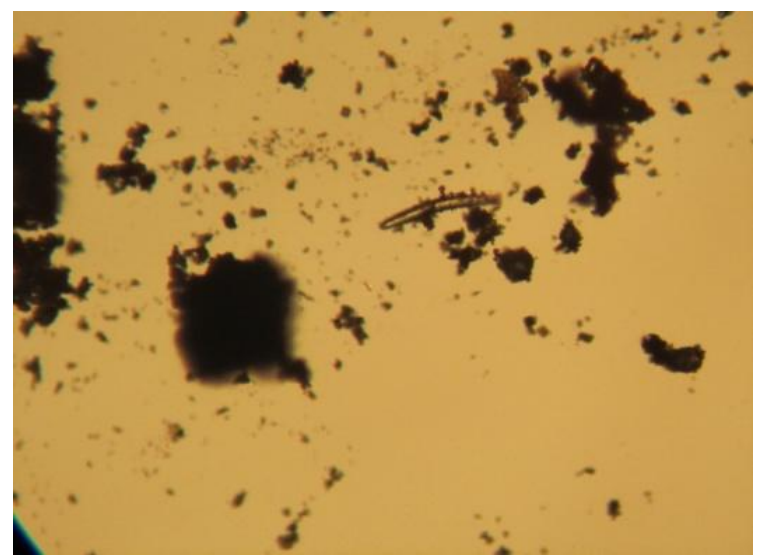

CSQN118

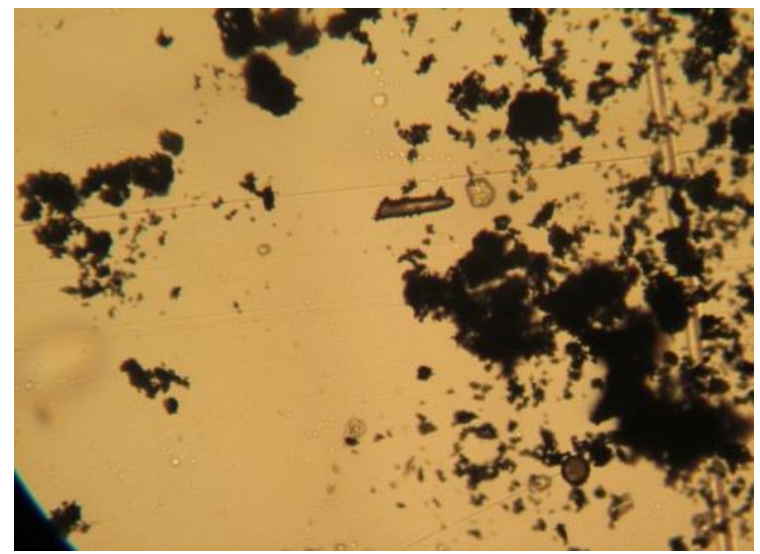


CSQN130

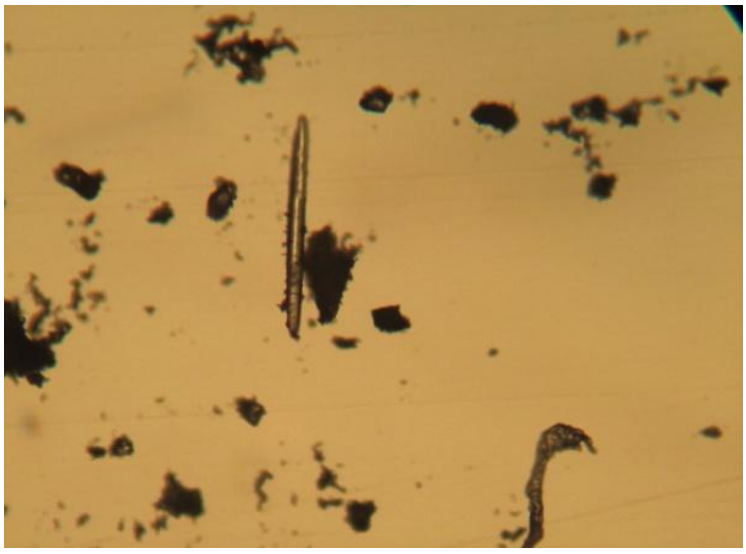

CSQN353

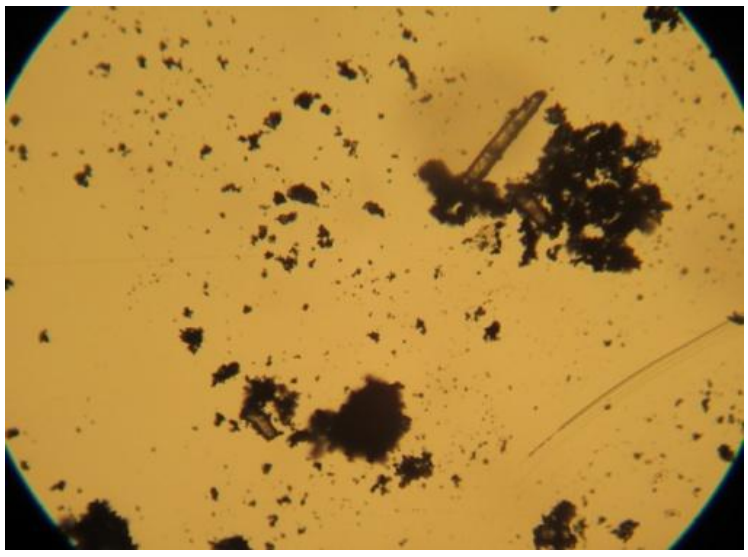

CSQN370

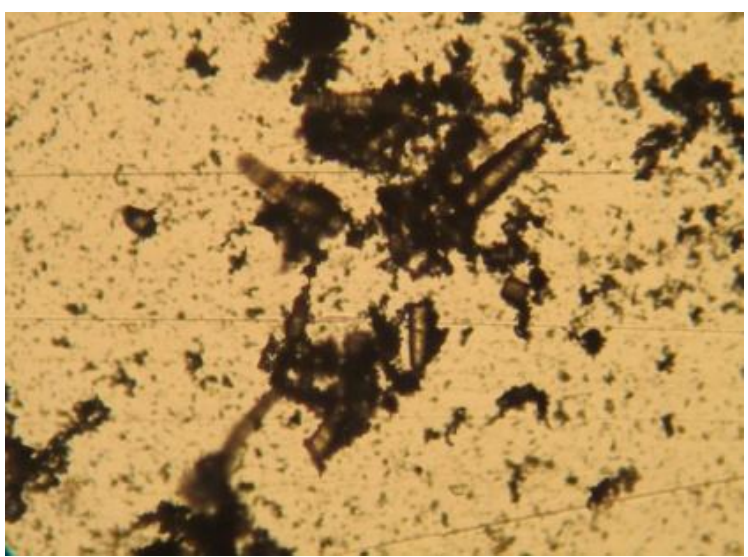

CSQN352

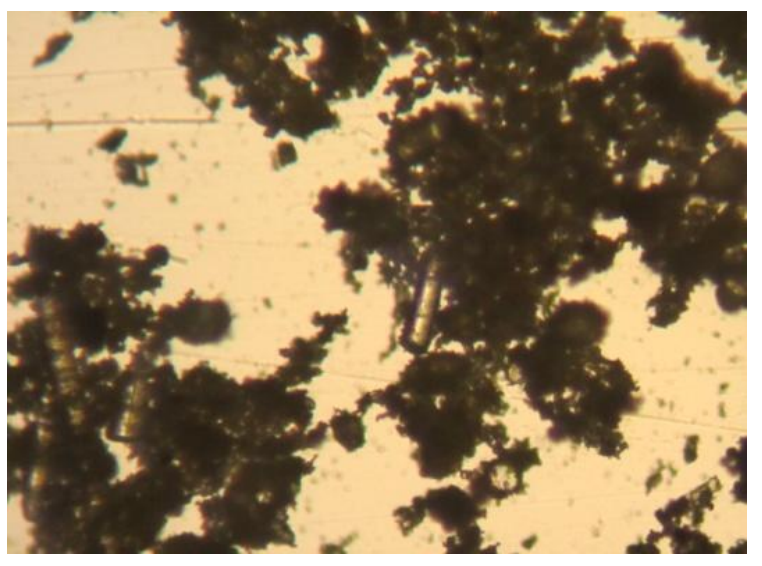

CSQN366

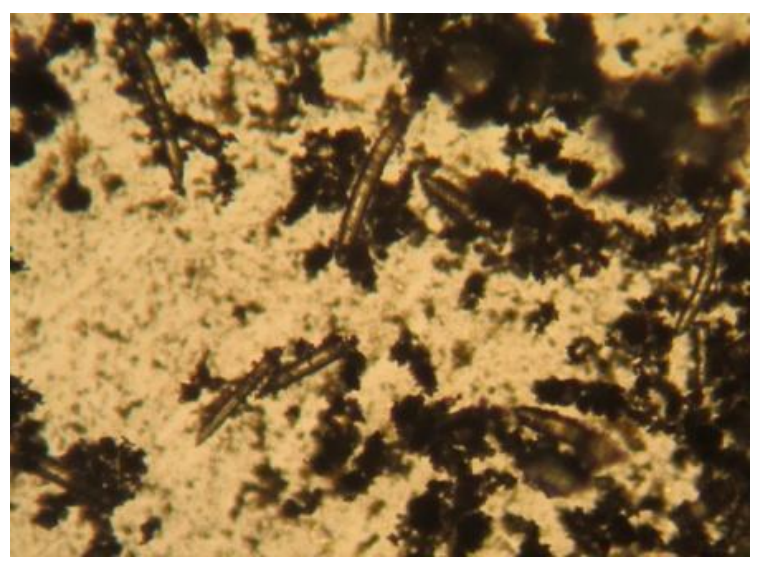

CSQN379

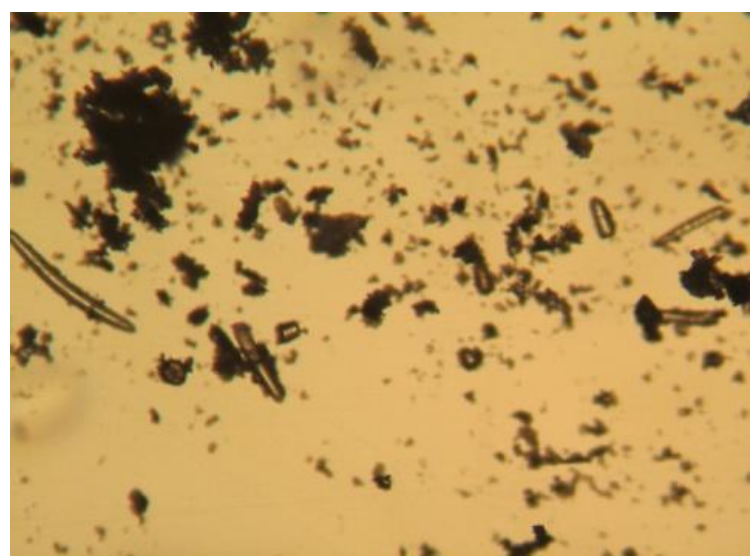


CSQN386

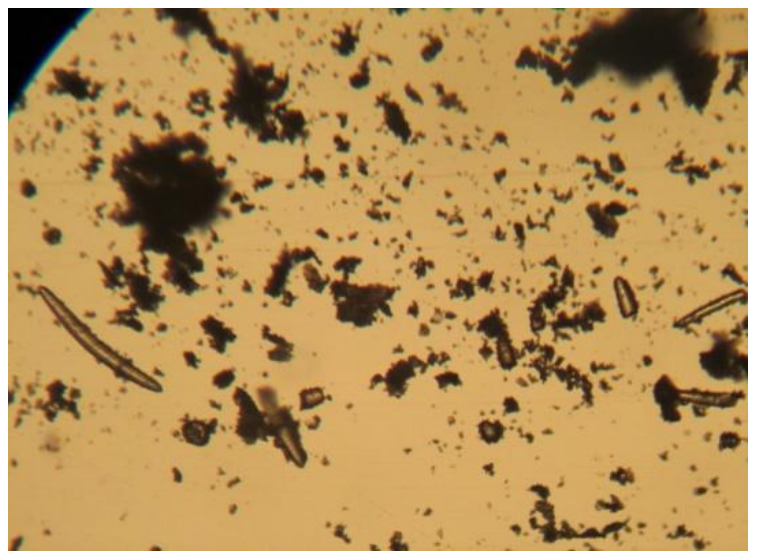

CSQN405

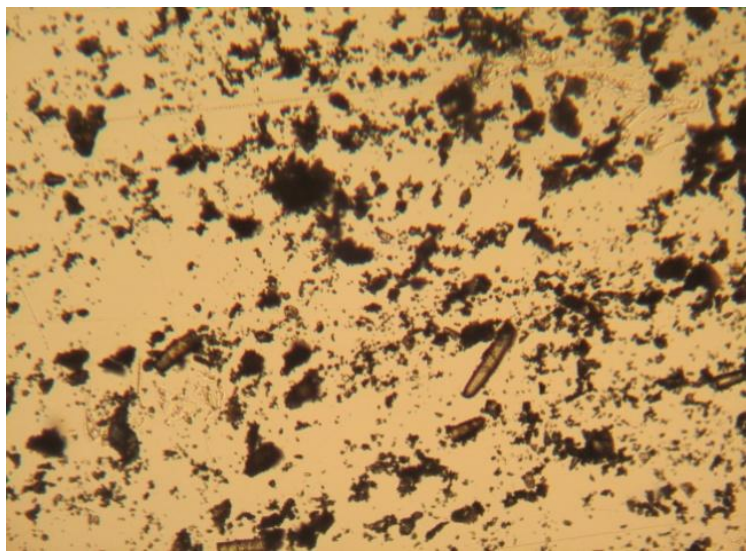

CSQN421

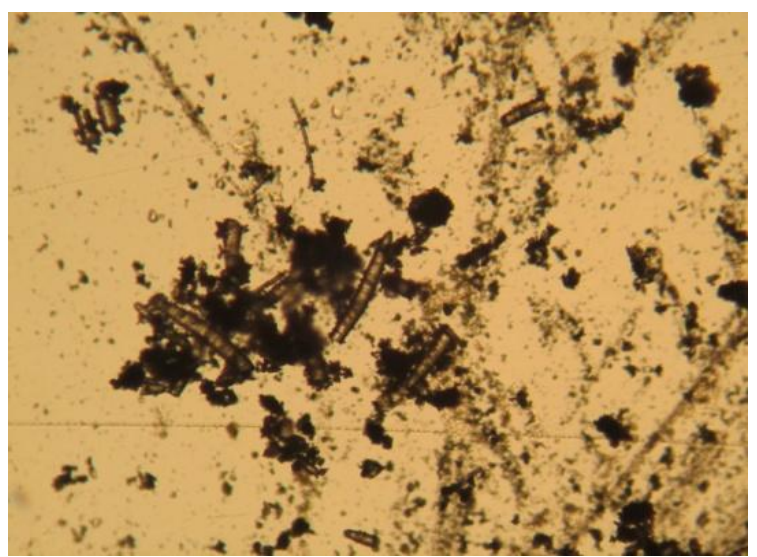

CSQN404

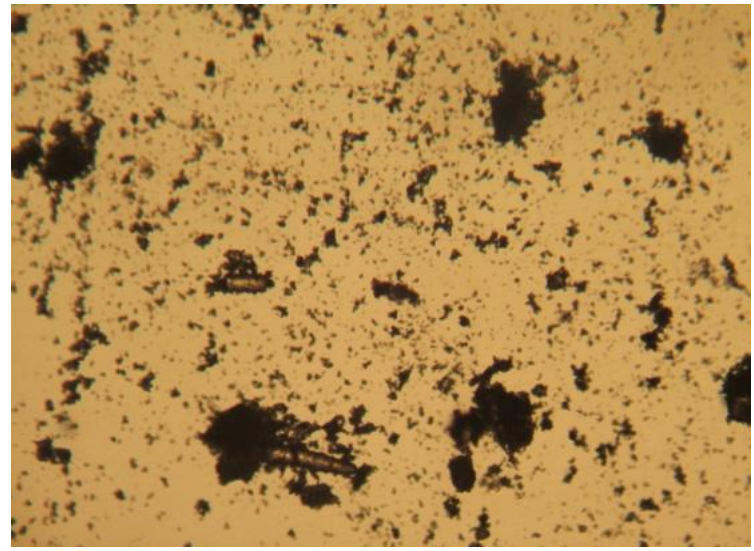

CSQN413

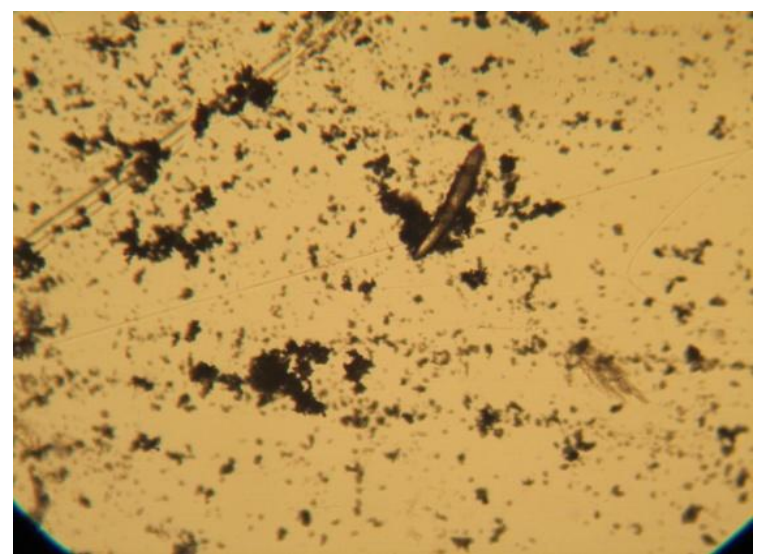

CSQN436

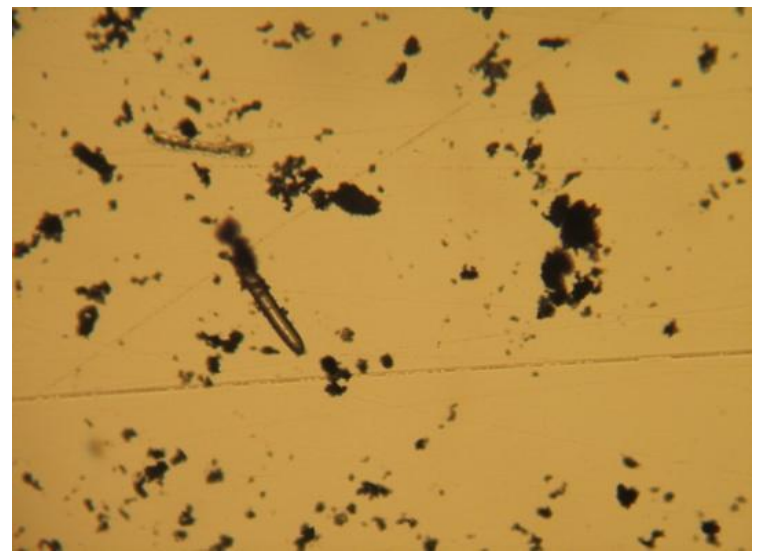




\section{APÊENDICE F - Dendrogramas das análises de agrupamento.}

Cenário 1: Os 14 elementos As, K, La, Lu, Na, Yb, Ce, Cr, Cs, Eu, Fe, Hf, Sc e Th com transformação logarítmica $\left(\log _{10}\right)$. Dados combinados de Lago Grande e Osvaldo. Para reprodução do dendrograma total, fotocopiar as páginas do cluster (1-3) e colá-las. 


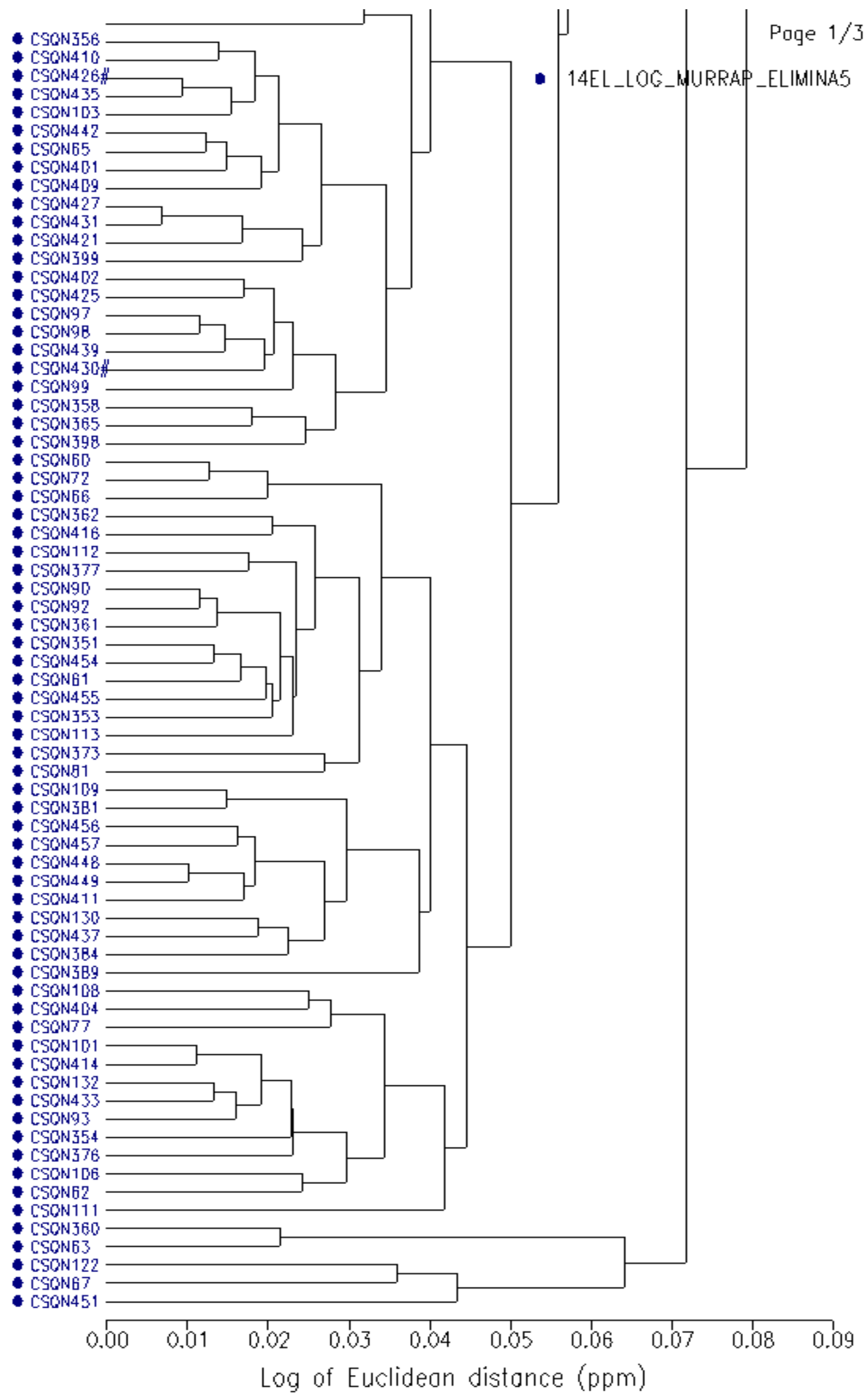




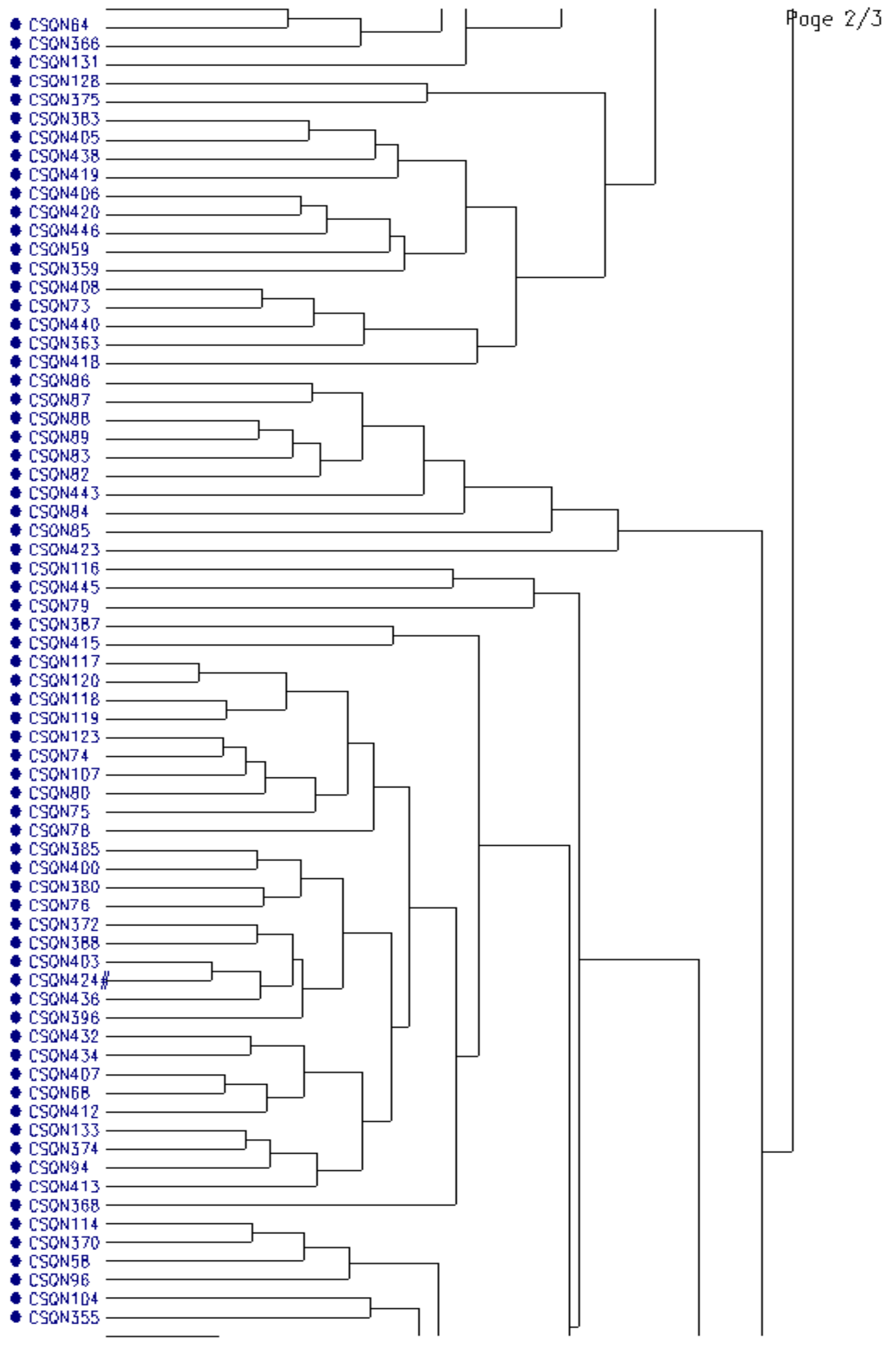


Poge $3 / 3$

- $\operatorname{cson} 367$

CSON369

CSON 422

CSON300

CSON39 1

Cson392

$\operatorname{cson} 110$

Csonj8

$\operatorname{cson} 379$

CSON382

CSON95

CSON37

CSON357

CSON12

CSON441

CSON121

CSON428

CSON352

CSON394

CSON105

CSON3E4

CSON70

CSON393

CSON395

CSON397

CSON 447

CSON453

CSON129

CSON429

CSON91

CSON450

CSON115
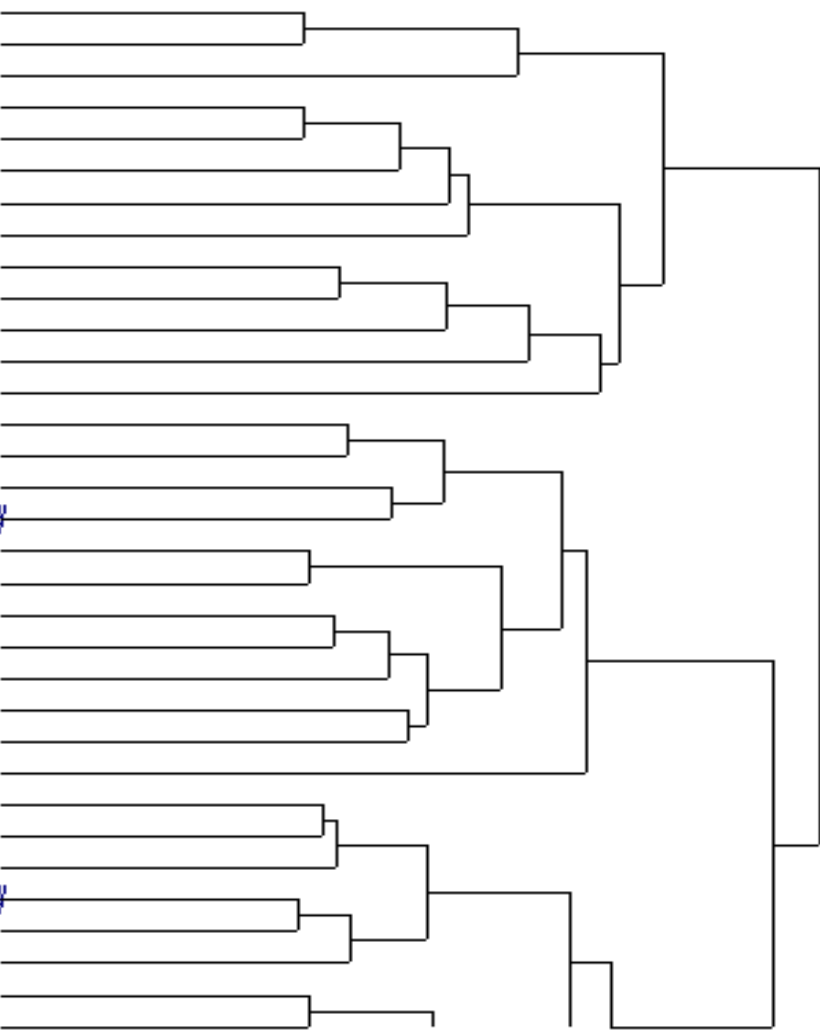
Cenário 2: Os 12 elementos As, La, Lu, Yb, Ce, Cr, Cs, Eu, Fe, Hf, Sc e Th com transformação logarítmica $\log _{10}$. Dados combinados de Lago Grande e Osvaldo. Para reprodução do dendrograma total, fotocopiar as páginas do cluster (1-3) e colá-las. 


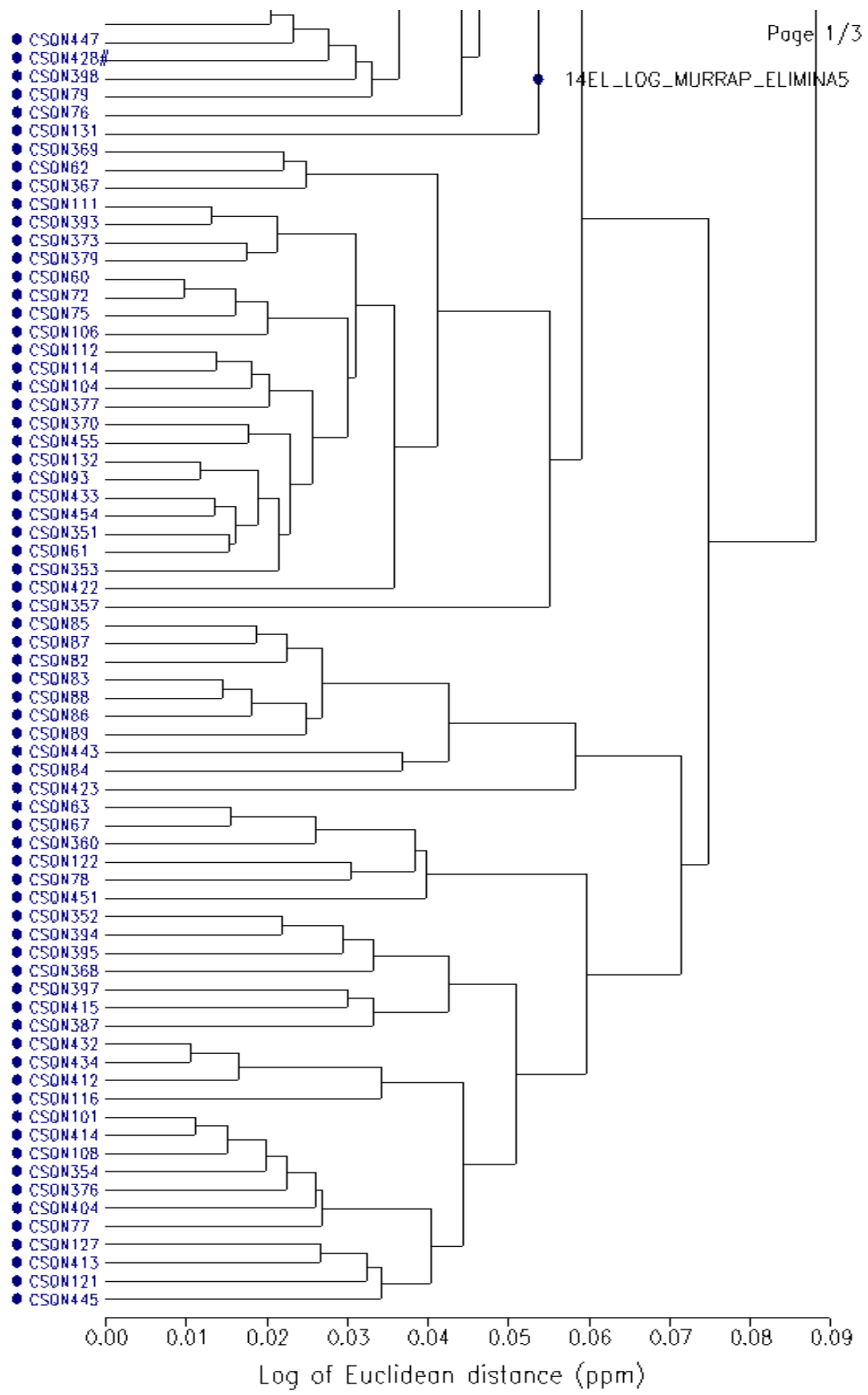




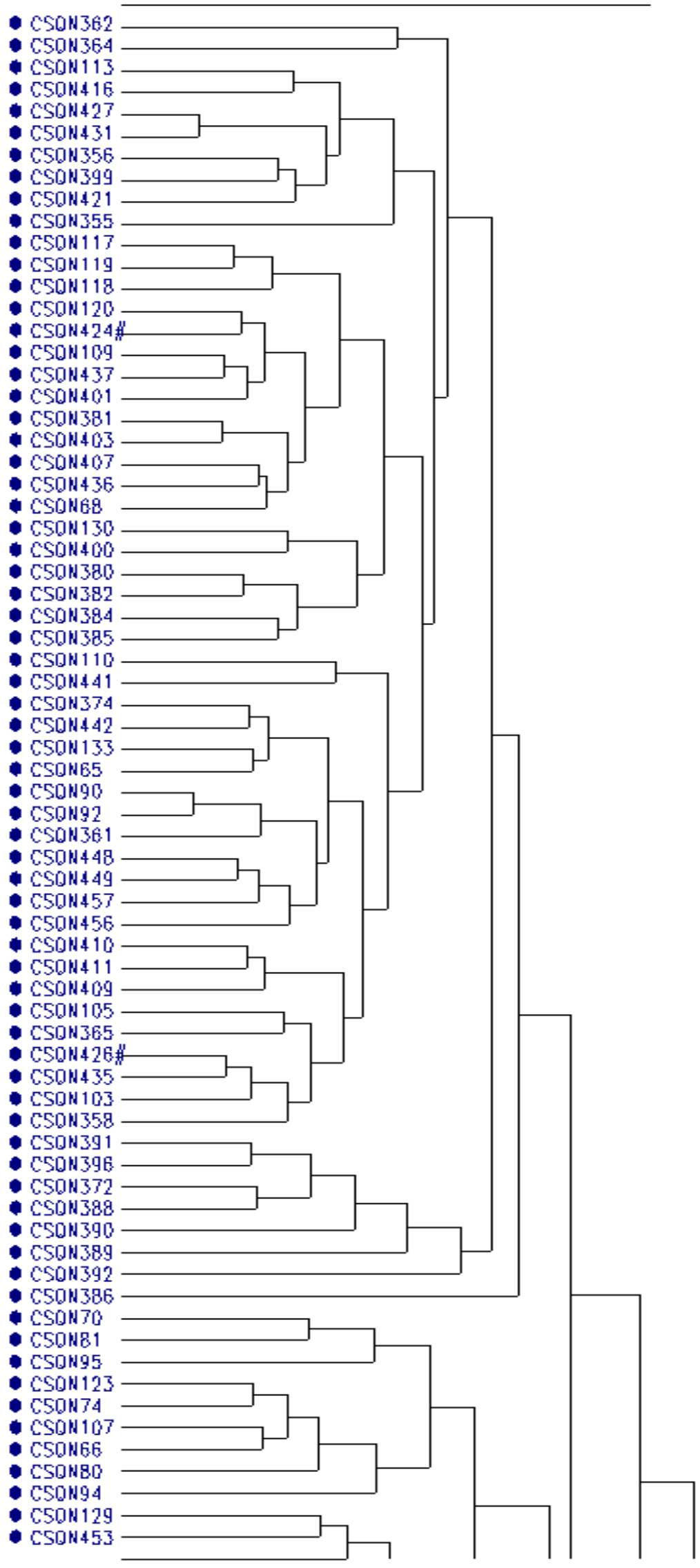

Poge| 2/3

c50n 416

Soln 427

c50nz5

Son39g

- c50nze

CSON 117

C50n 120

CSON424

-

csonto

- csontas

- $\operatorname{cson} 407$

- conter

C50N 130

c5on3ar

C50N385

cson374

- CSONES

csong

C50n 48

$50 N 456$

cson 400

- $50 n 105$

- c50nat

C50N435

csoniza

csonsas

c5onsa

- conzo

c50n38

$\operatorname{cson} 70$

csongs

$\operatorname{cson} 12$

- $\operatorname{con} 105$

c50n6.

csong

- $50 n 12$

cSOn 45 
Poge 3/3

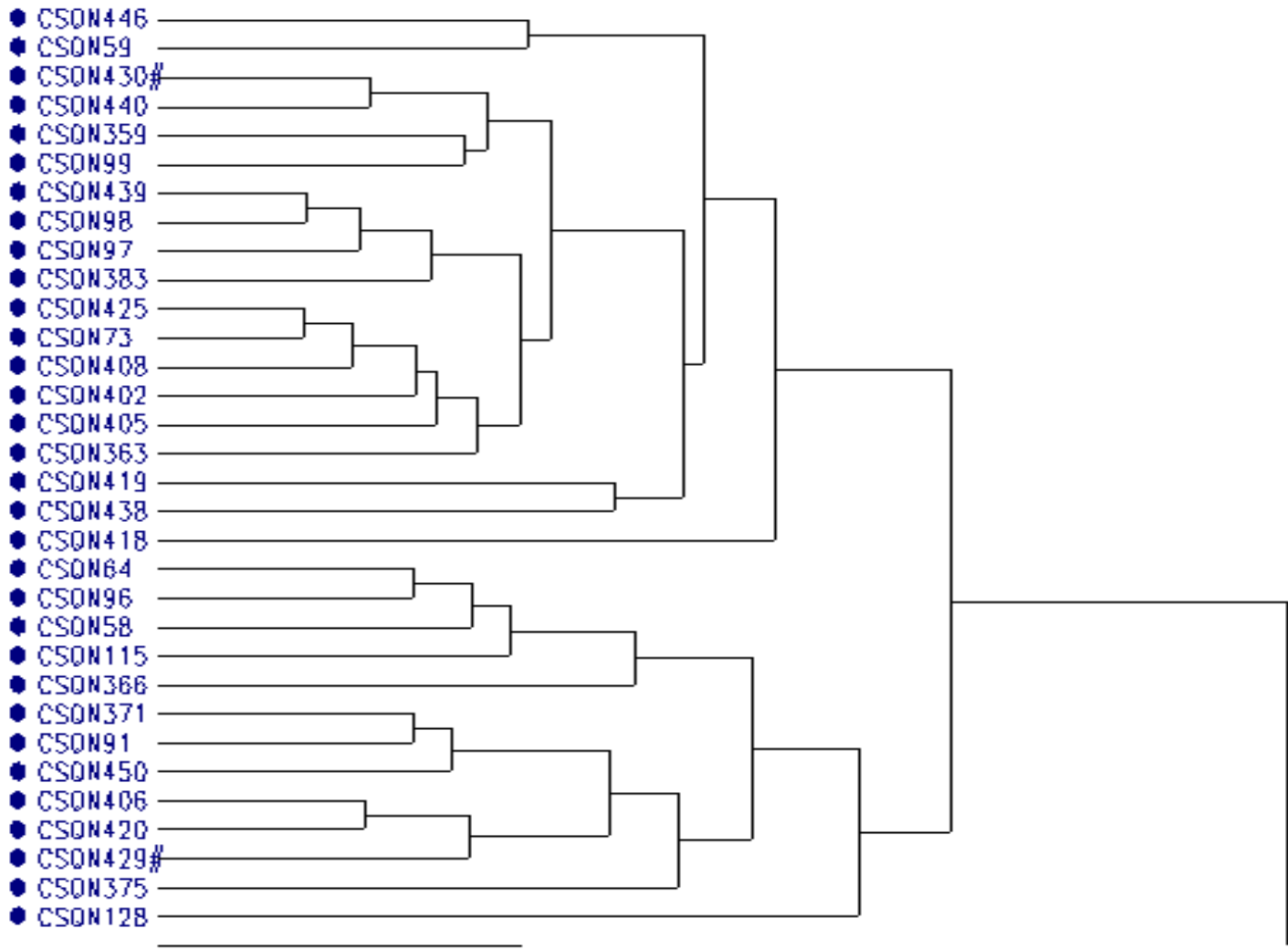


Cenário 3: Os 9 elementos $\mathrm{La}, \mathrm{Lu}, \mathrm{Yb}, \mathrm{Ce}, \mathrm{Cr}, \mathrm{Eu}, \mathrm{Fe}, \mathrm{Sc}$ e Th com transformação logarítmica $\log _{10}$. Dados combinados de Lago Grande e Osvaldo. Para reprodução do dendrograma total, fotocopiar as páginas do cluster (1-3) e colá-las. 


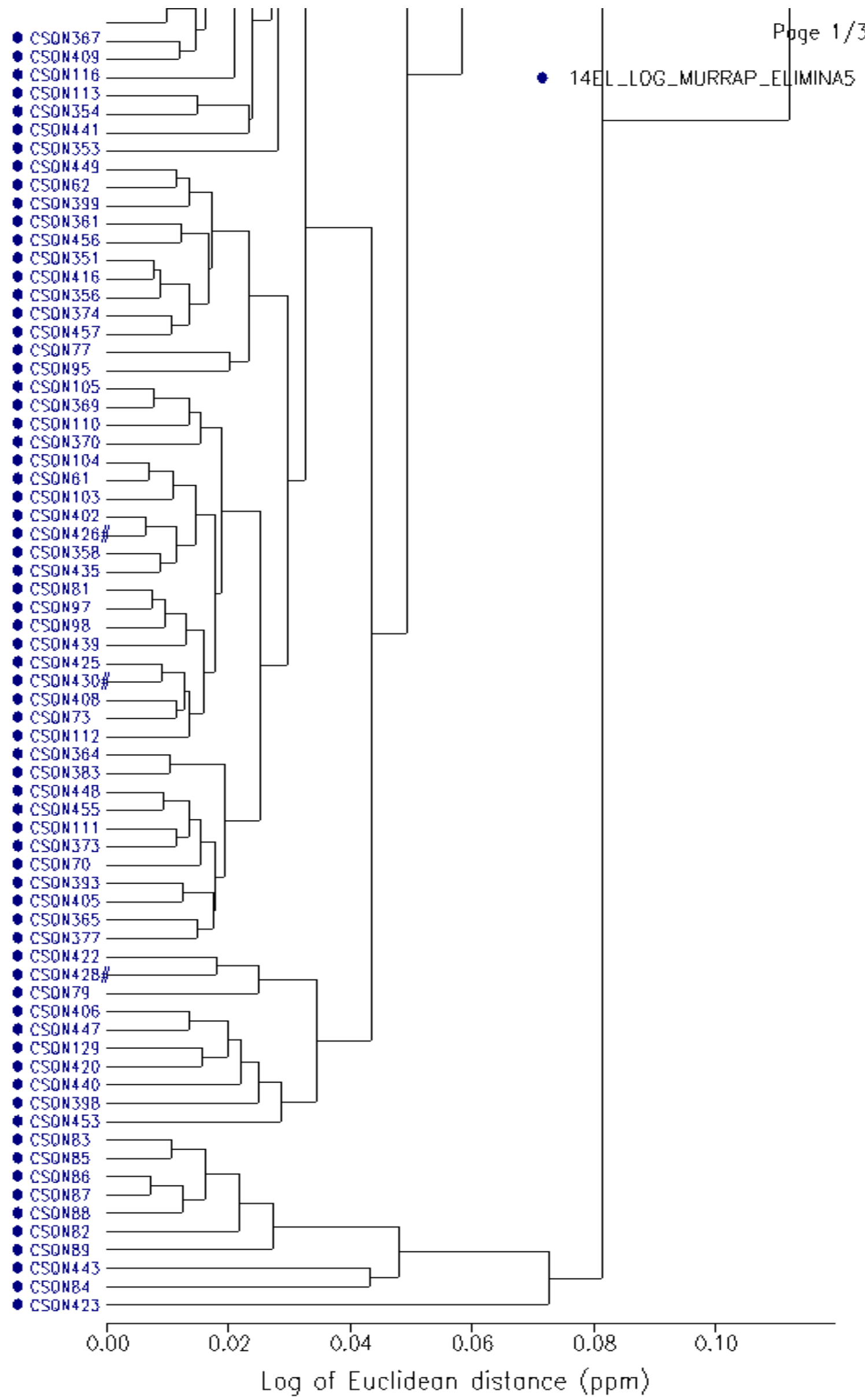




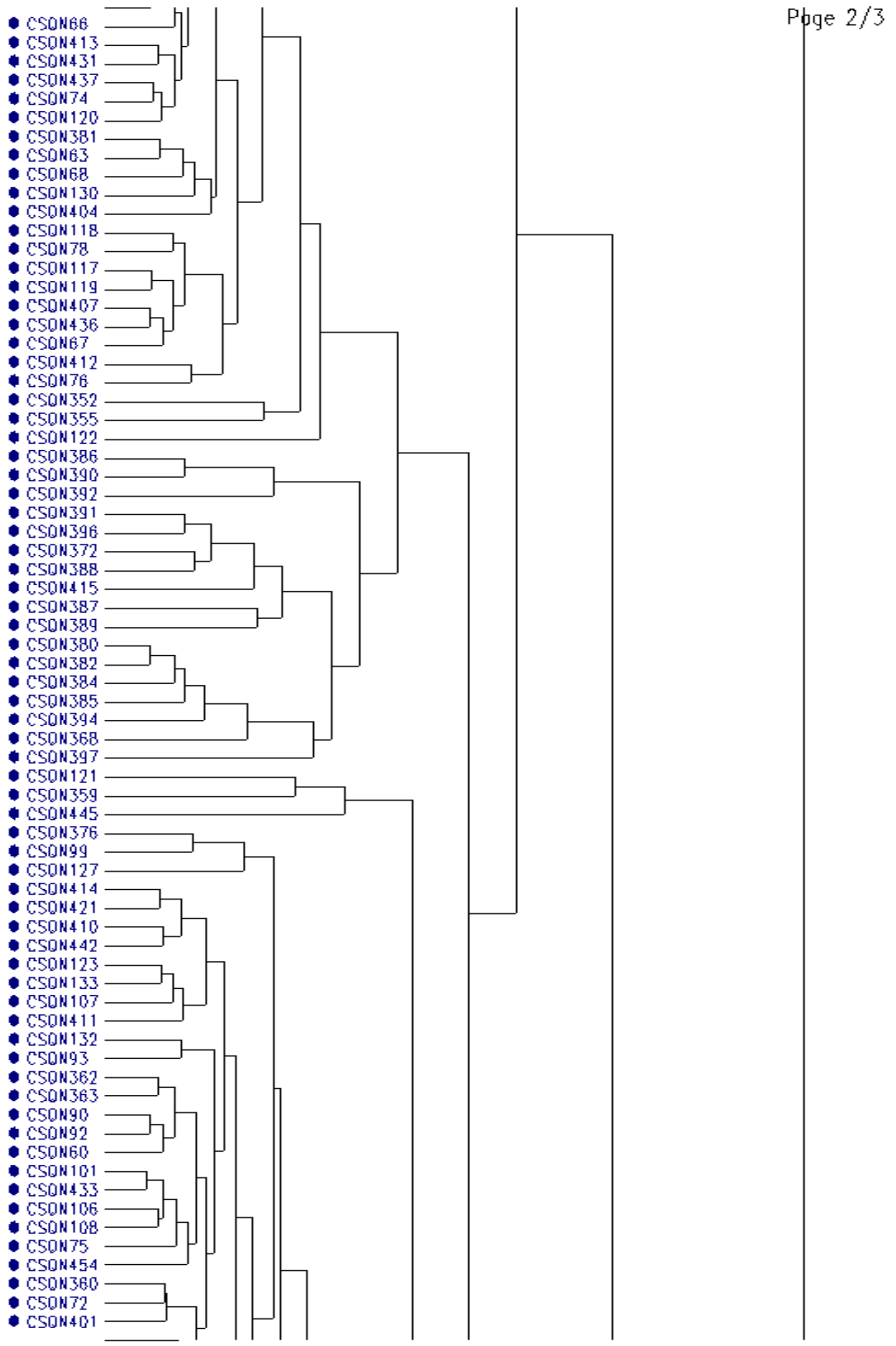


Poge 3/3

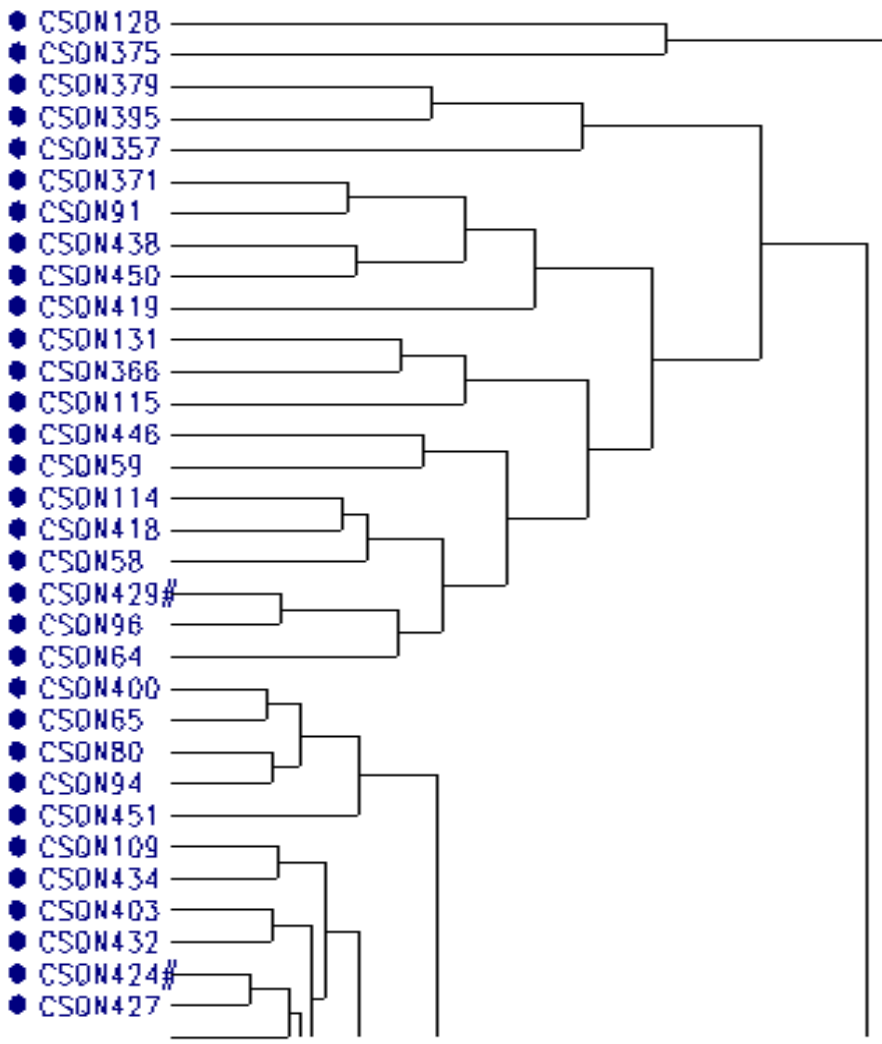


Cenário 4: Os 12 elementos As, La, Lu, Yb, Ce, Cr, Cs, Eu, Fe, Hf, Sc e Th com transformação em razão logarítmica aditiva (alr). Dados combinados de Lago Grande e Osvaldo. Para reprodução do dendrograma total, fotocopiar as páginas do cluster (1-3) e colá-las. 


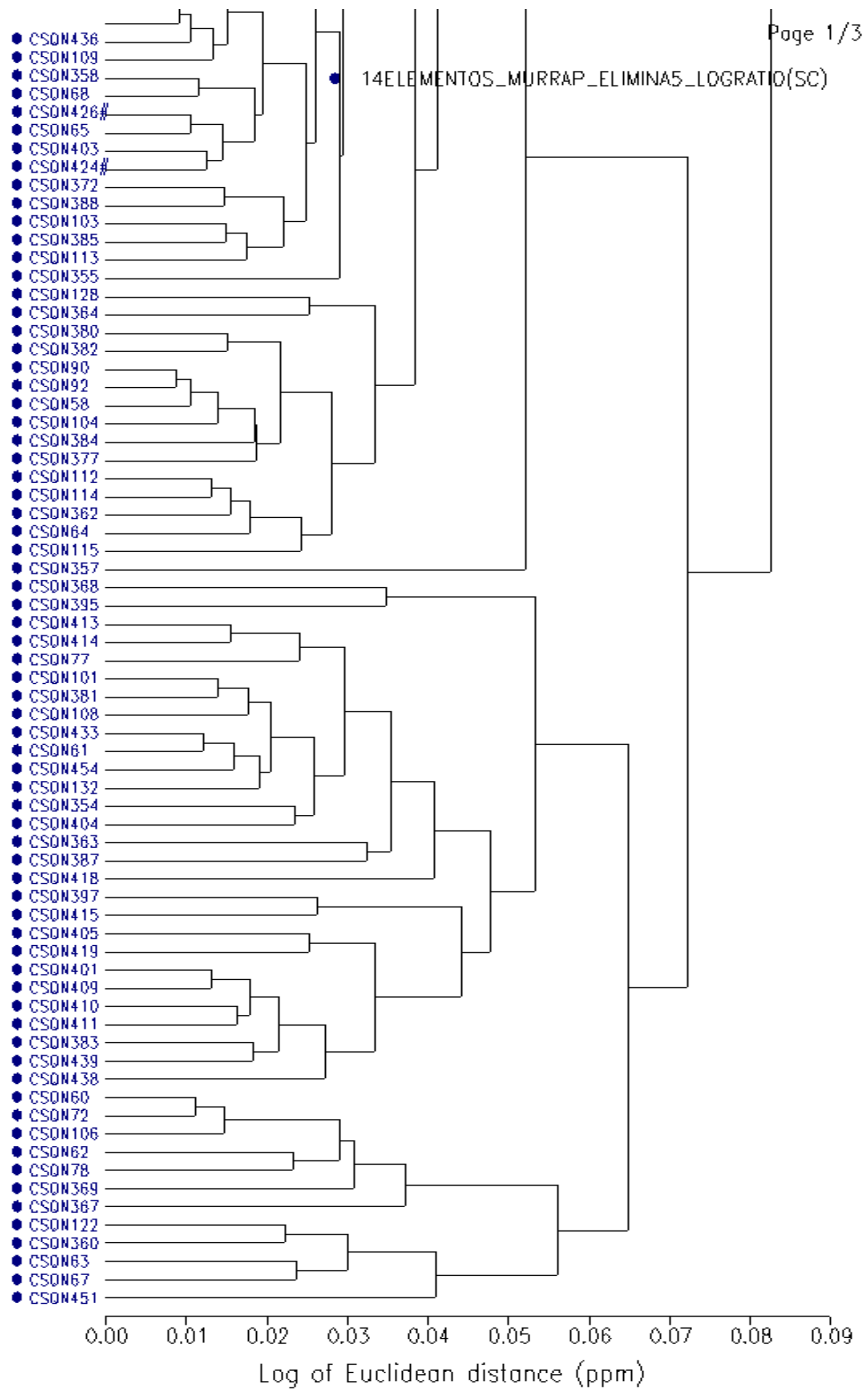




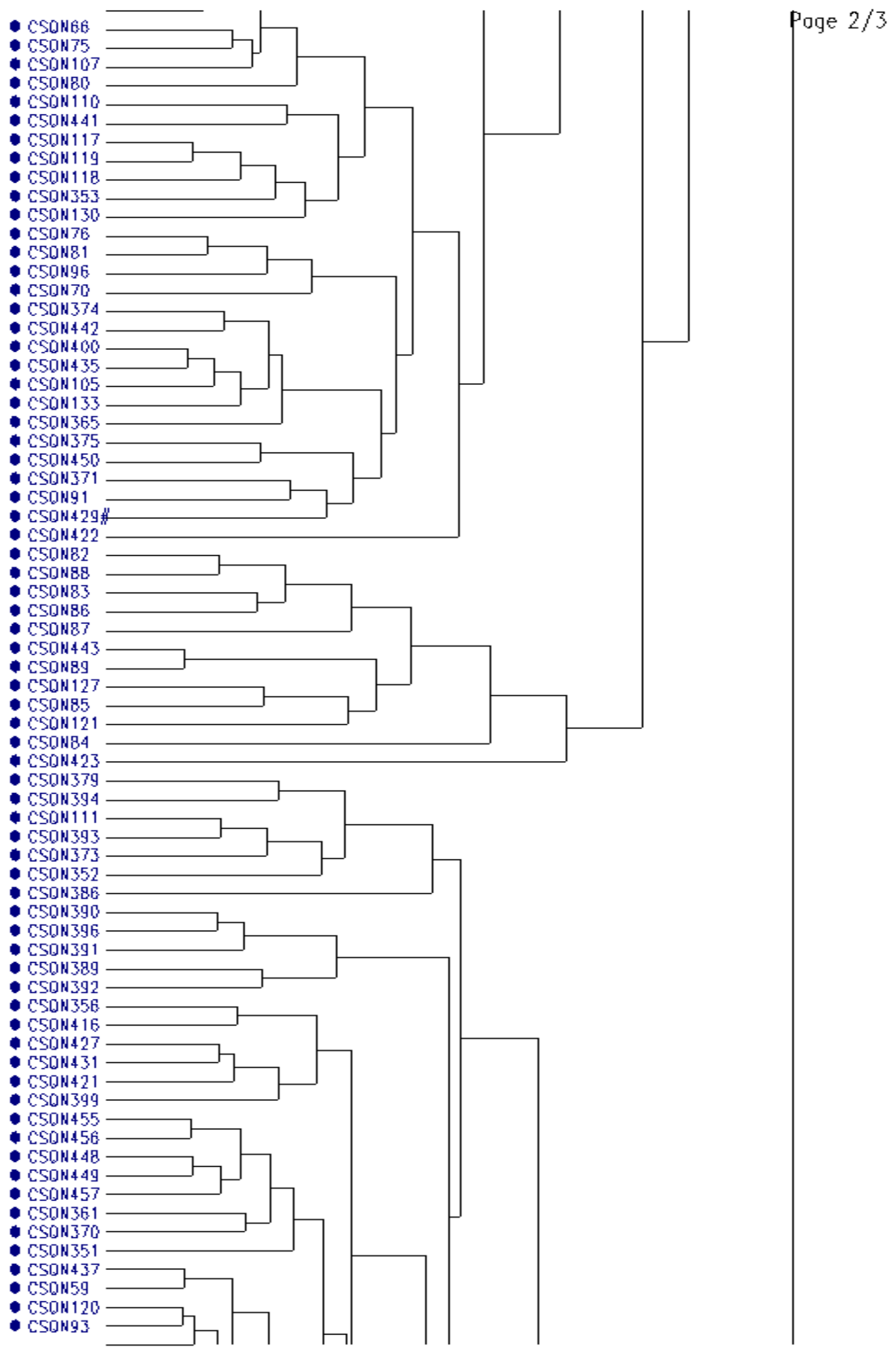


Poge $3 / 3$

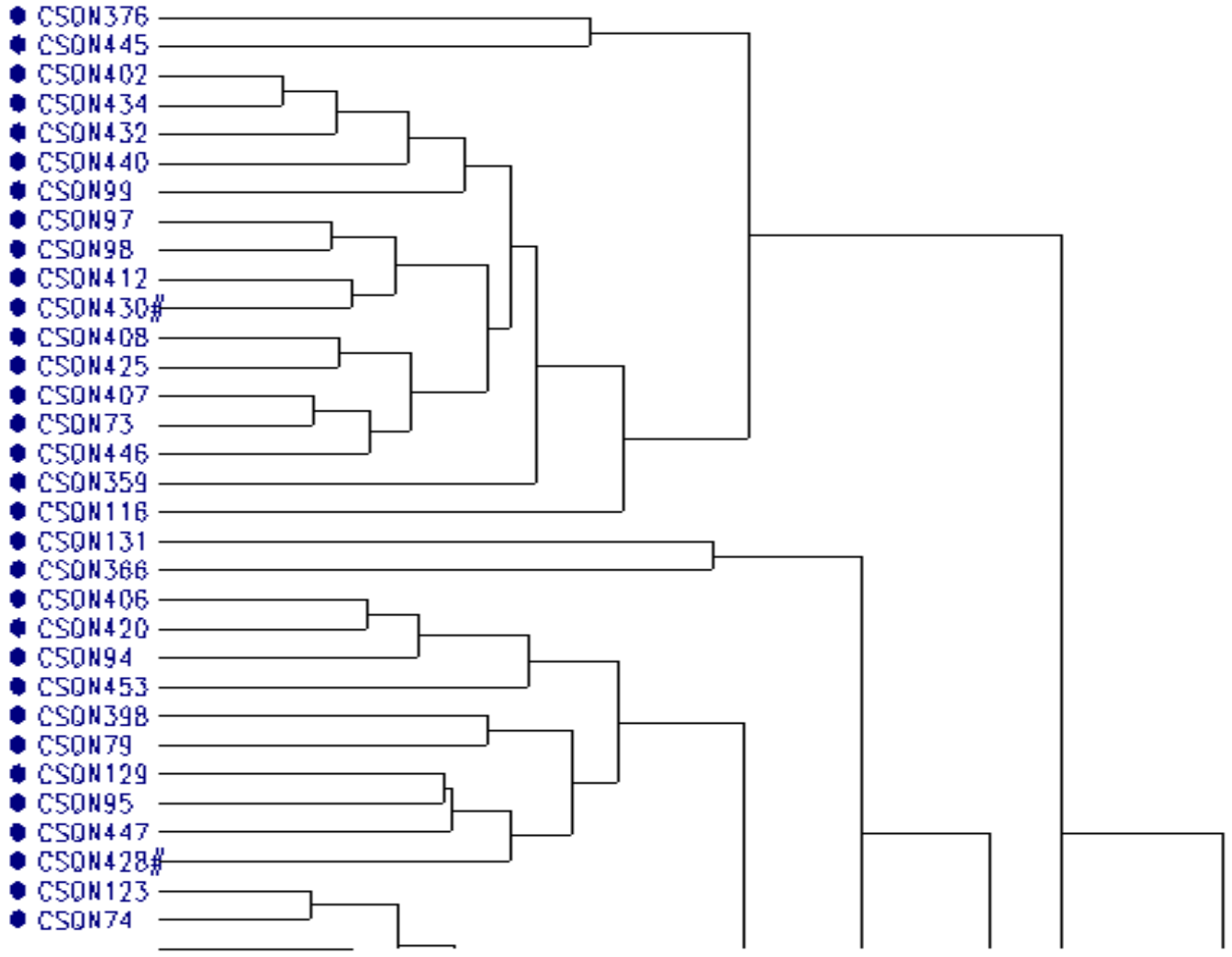


Cenário 5: Os 9 elementos $\mathrm{La}, \mathrm{Lu}, \mathrm{Yb}, \mathrm{Ce}, \mathrm{Cr}, \mathrm{Eu}, \mathrm{Fe}, \mathrm{Sc}$ e Th com transformação em razão logarítmica aditiva (alr). Dados combinados de Lago Grande e Osvaldo. Para reprodução do dendrograma total, fotocopiar as páginas do cluster (1-3) e colá-las. 


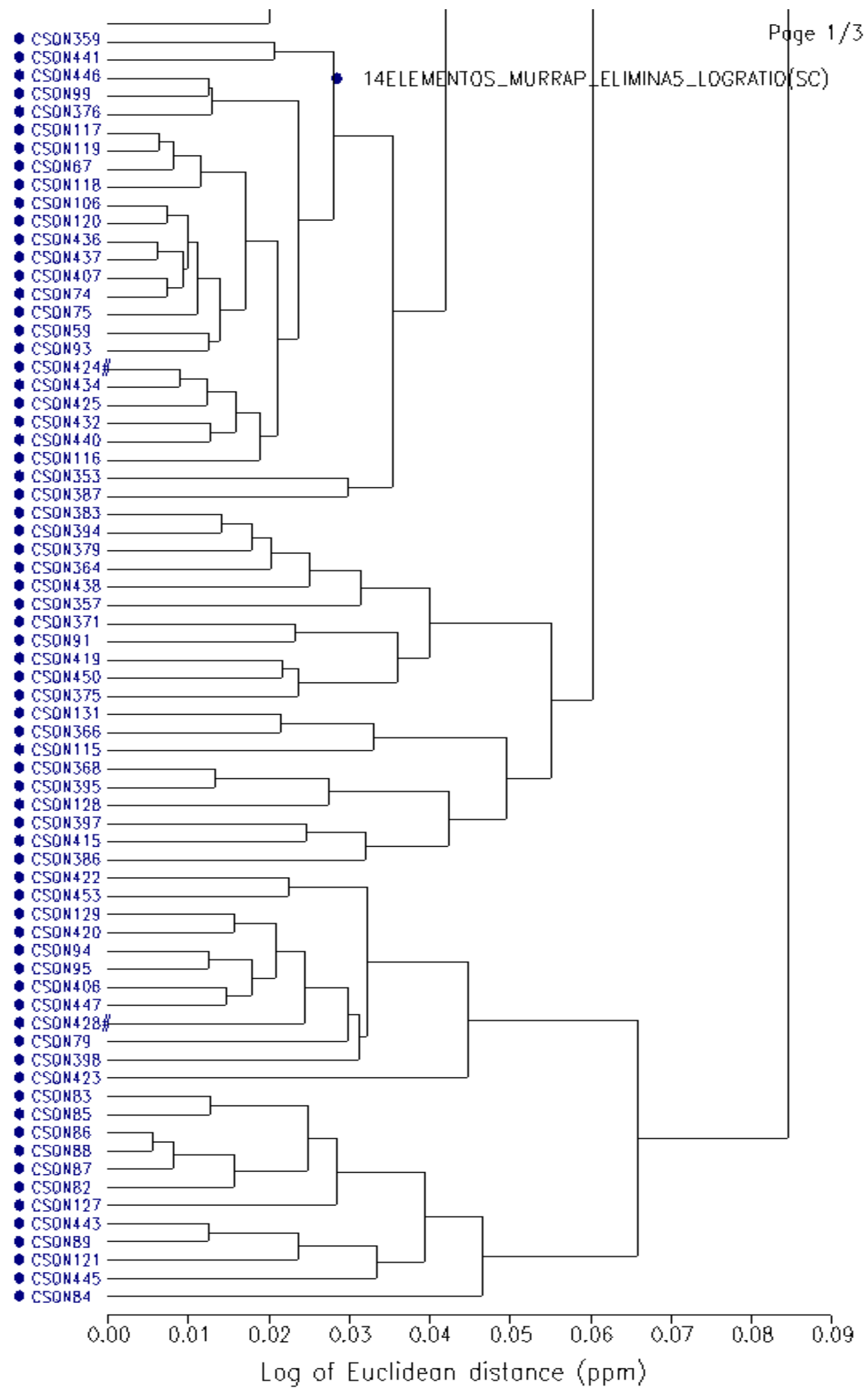




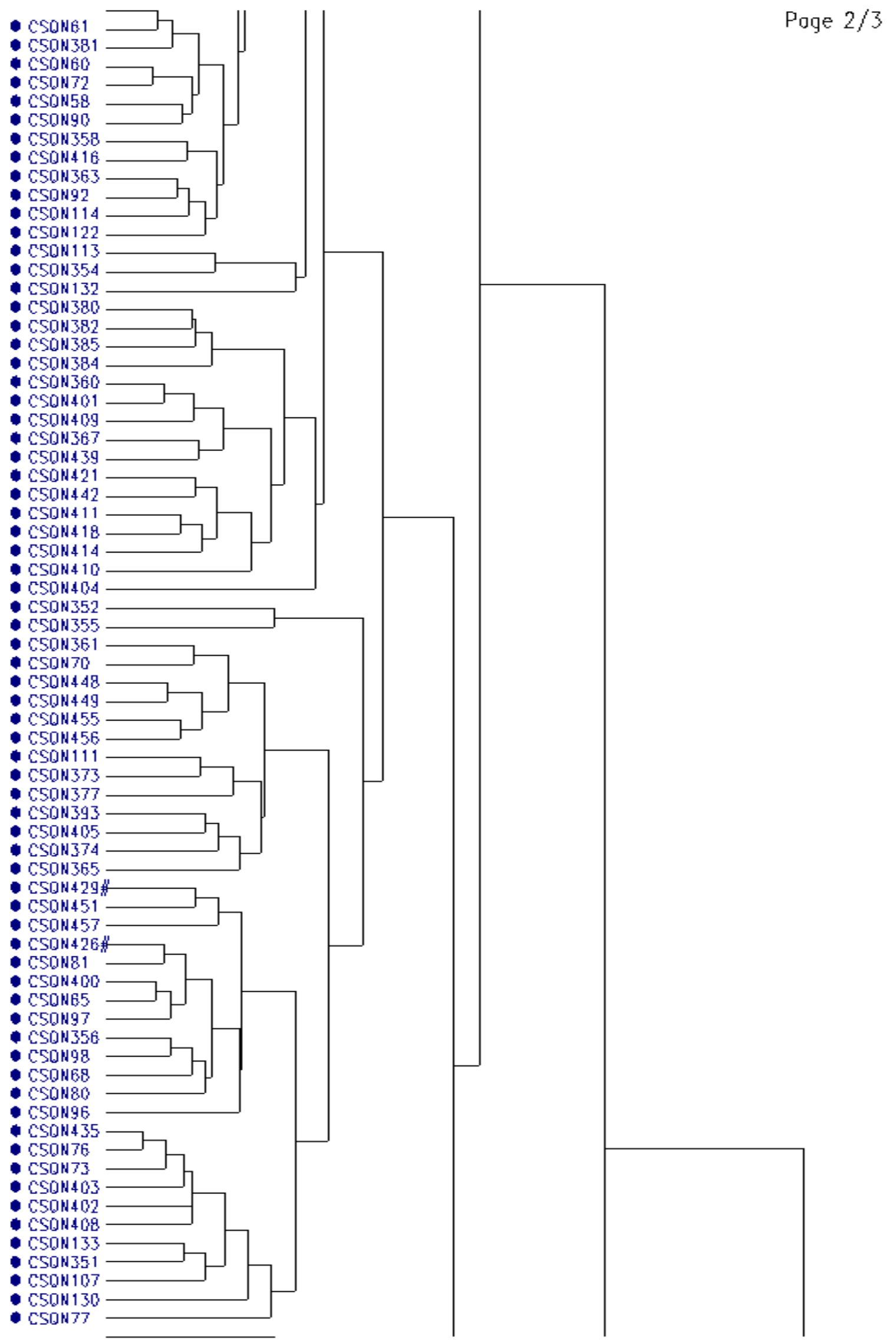


Poge 3/3

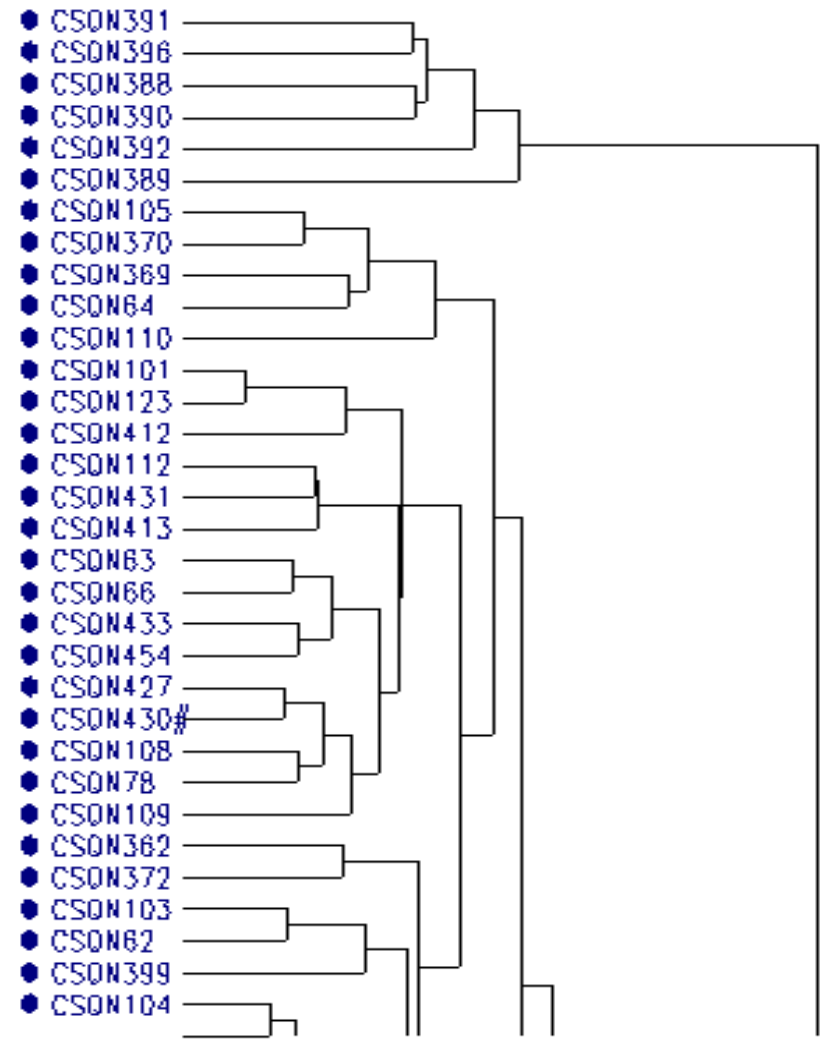


Cenário 3: Os 9 elementos $\mathrm{La}, \mathrm{Lu}, \mathrm{Yb}, \mathrm{Ce}, \mathrm{Cr}, \mathrm{Eu}, \mathrm{Fe}, \mathrm{Sc}$ e Th com transformação logarítmica $\log _{10}$. Dados de Lago Grande. Para reprodução do dendrograma total, fotocopiar as páginas do cluster (1-2) e colá-las. 


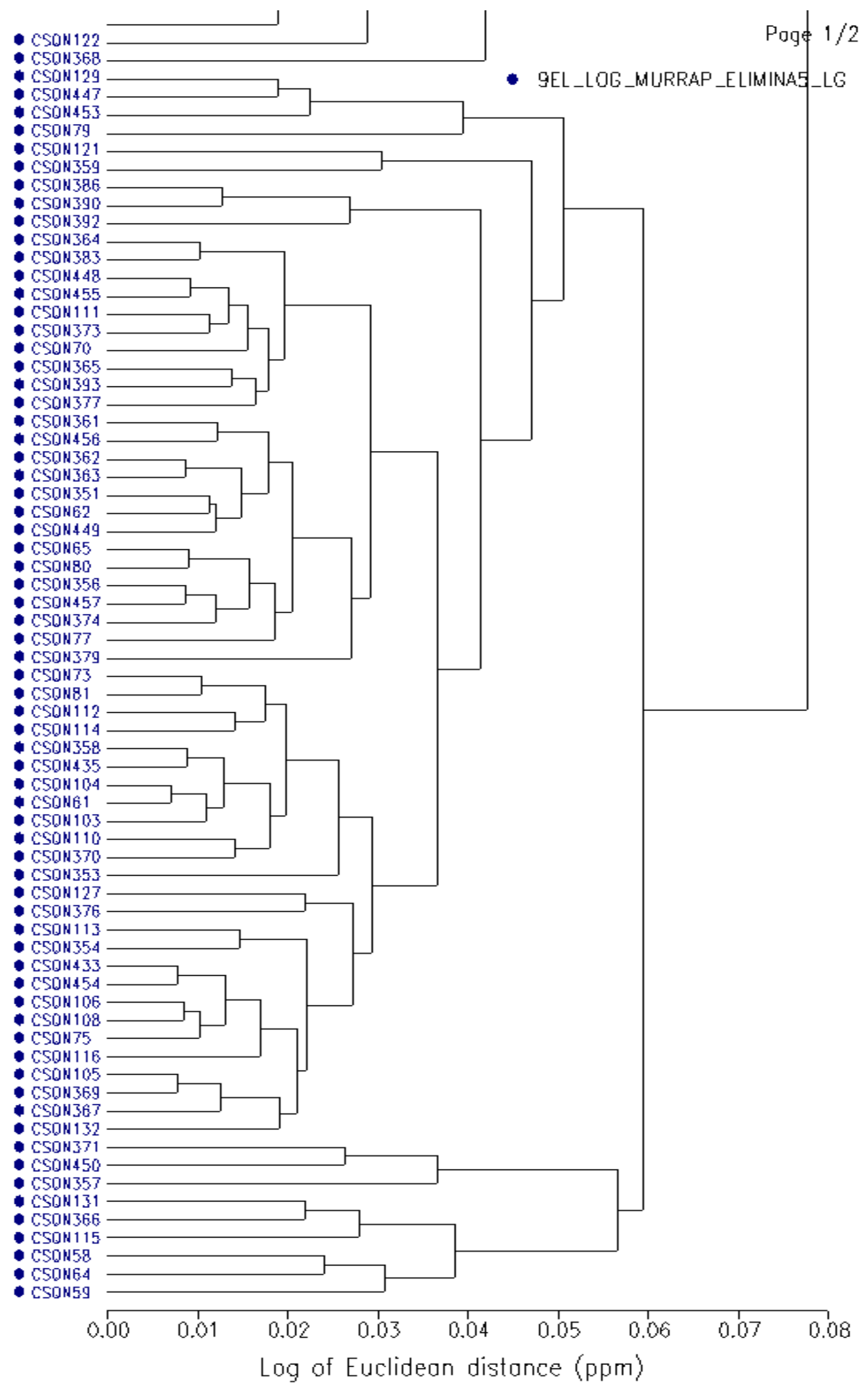


Poge 2/2

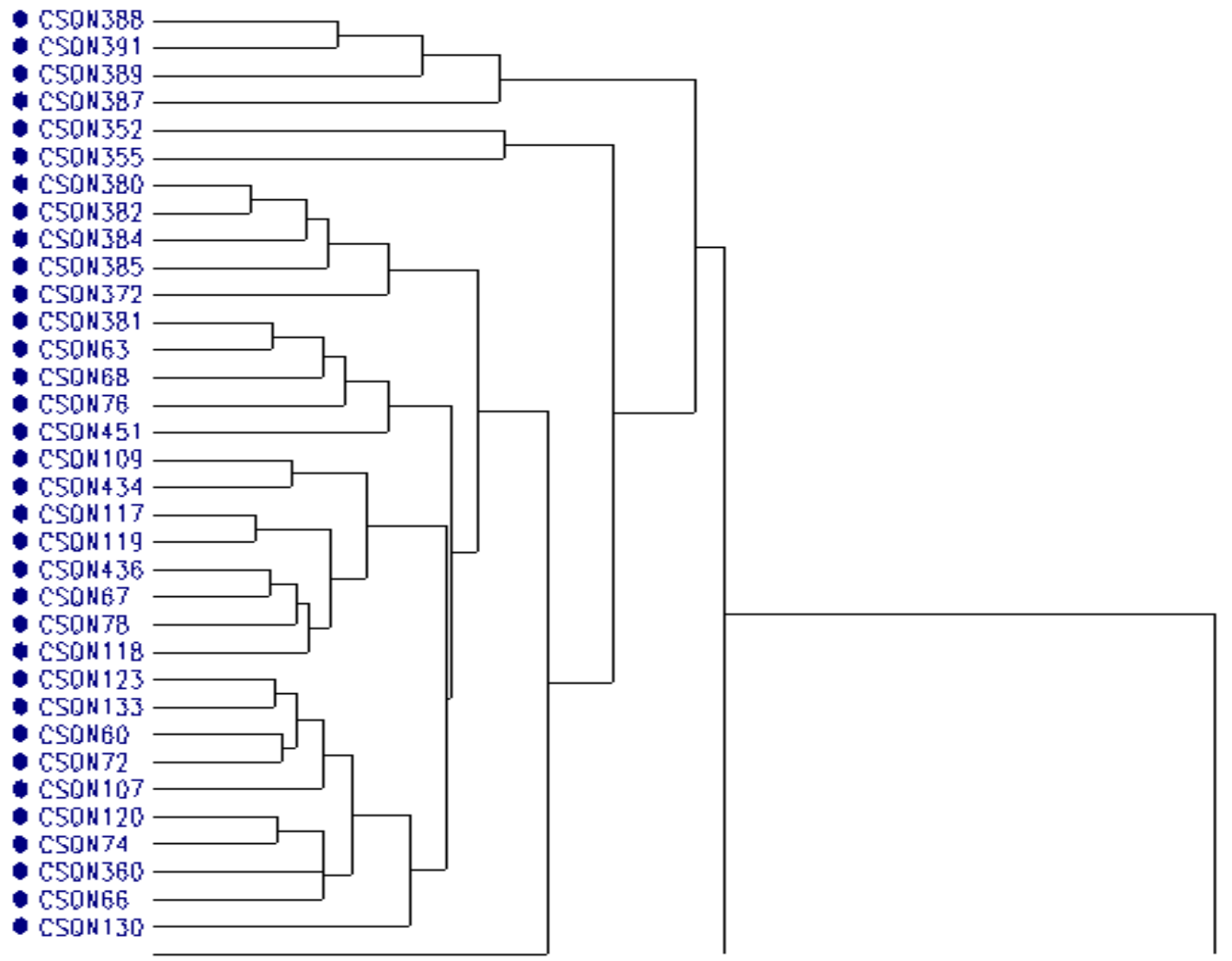


Cenário 3: Os 9 elementos $\mathrm{La}, \mathrm{Lu}, \mathrm{Yb}, \mathrm{Ce}, \mathrm{Cr}, \mathrm{Eu}, \mathrm{Fe}, \mathrm{Sc}$ e Th com transformação logarítmica $\log _{10}$. Dados de Osvaldo.

Poge 1/1

- 9EL_LOG_MURRAP_ELIMINAS_OSV SEM ARG

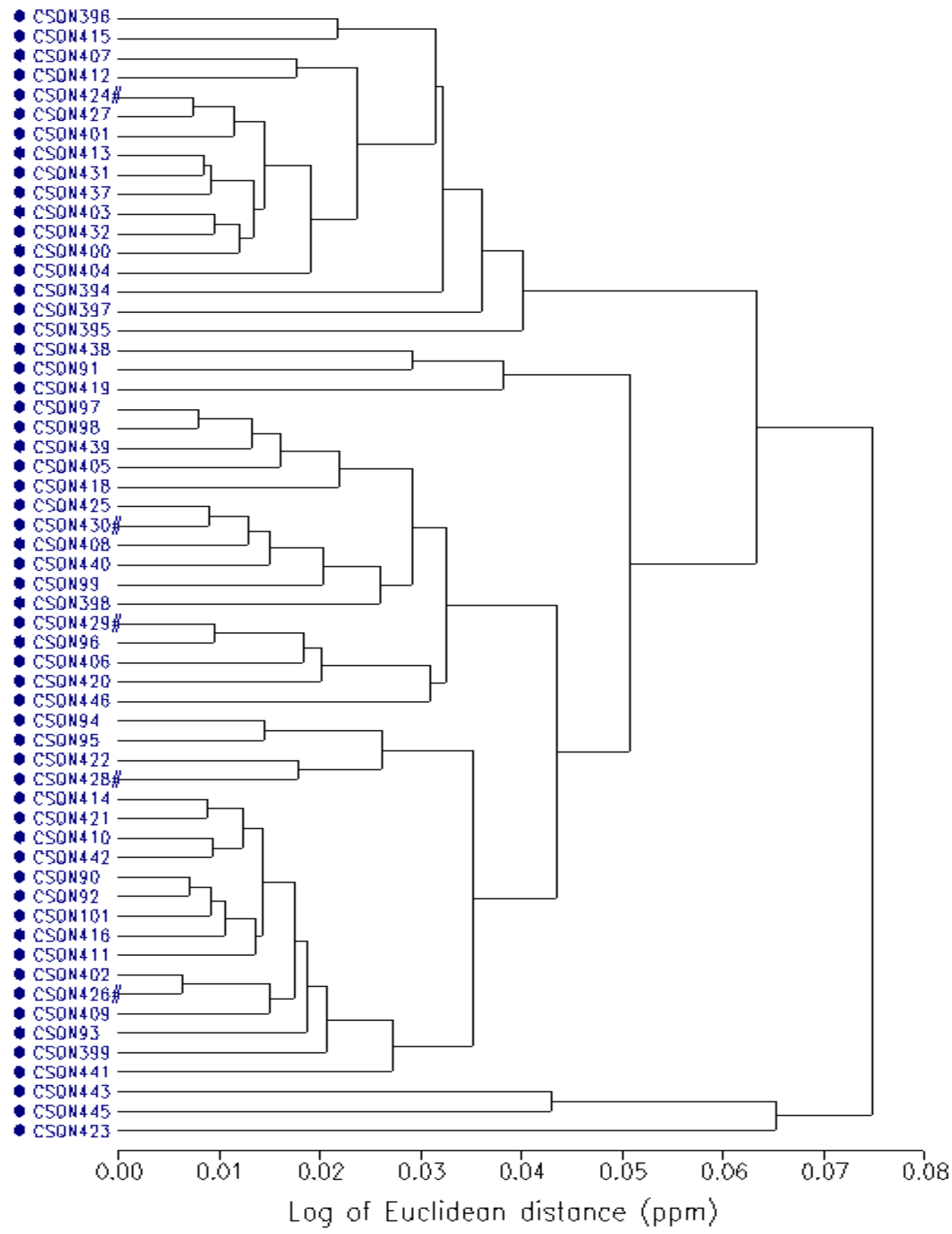


Cenário 5: Os 9 elementos $\mathrm{La}, \mathrm{Lu}, \mathrm{Yb}, \mathrm{Ce}, \mathrm{Cr}, \mathrm{Eu}, \mathrm{Fe}, \mathrm{Sc}$ e Th com transformação em razão logarítmica aditiva (alr). Dados de Lago Grande. Para reprodução do dendrograma total, fotocopiar as páginas do cluster (1-2) e colá-las. 


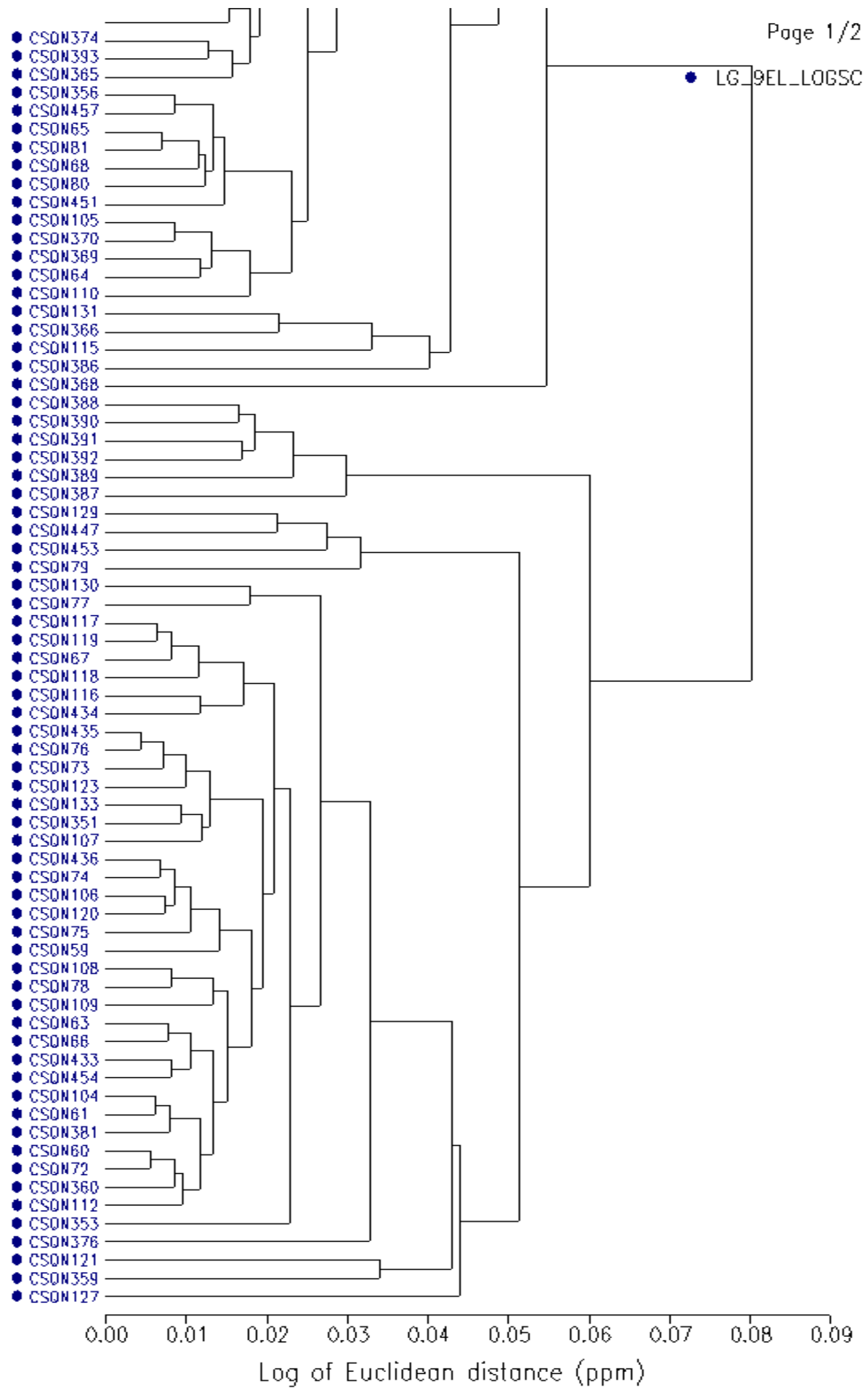


Poge 2/2

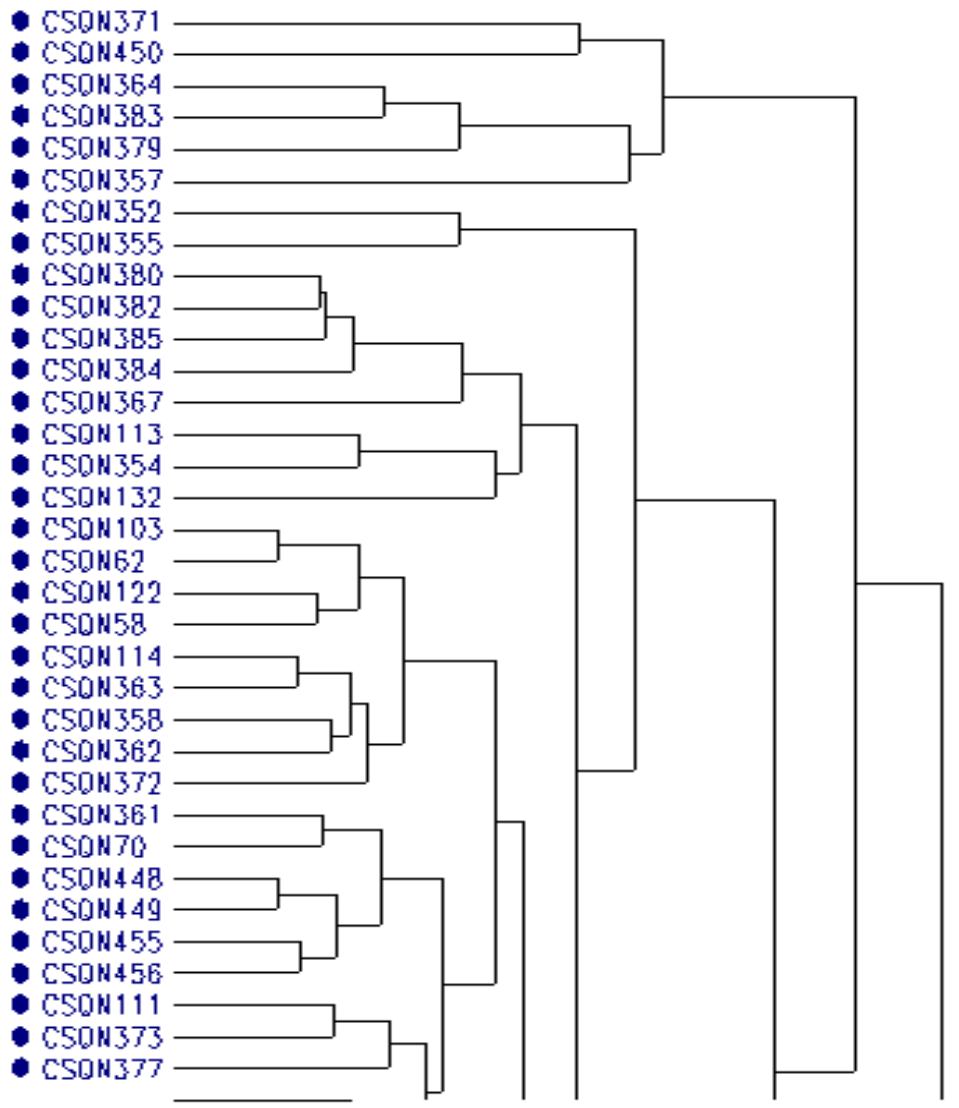


Cenário 5: Os 9 elementos $\mathrm{La}, \mathrm{Lu}, \mathrm{Yb}, \mathrm{Ce}, \mathrm{Cr}, \mathrm{Eu}, \mathrm{Fe}, \mathrm{Sc}$ e Th com transformação em razão logarítmica aditiva (alr). Dados de Osvaldo.

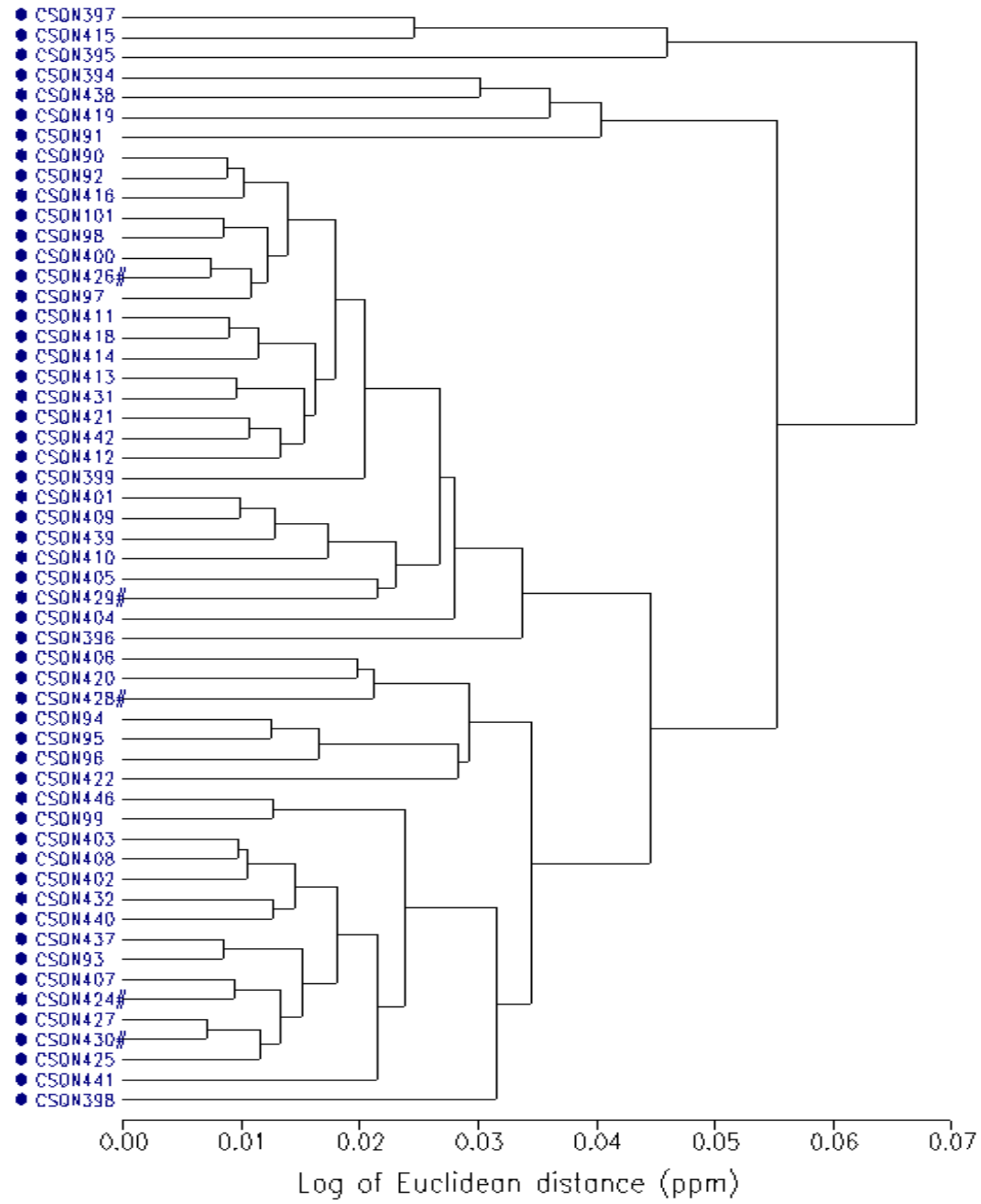


APÊNDICE G - Rotina para teste de Shenton-Bowman para normalidade multivariada em Scilab.

//Baseado no artigo "An Omnibus Test for Univariate and Multivariate Normality - Jurgen A. Doornik (Nuffield College) e Henrik Hansen (University of Copenhagen), 2008.

//Teste de normalidade multivariável baseado em Shenton \& Bowman (1977)

//condição: $\mathrm{b} 2>1+\mathrm{b} 1$

//Hipótese: b2 apresente distribuição gama

//condição: $\mathrm{n}>=7$

//ATENÇÃO: Parâmetros são estimadores -> divisões por n-1 em vez de n.

$\operatorname{mode}(-1)$

X=fscanfMat ("teste_14el_log_g12.sce") //base de dados

$[\mathrm{nlin}, \mathrm{ncol}]=\operatorname{size}(\mathrm{X})$

//Teste de condição de tamanho mínimo da amostra

printf("O tamanho da amostra deve ser $\mathrm{n}>7$. Para o presente caso, $\mathrm{n}="+\operatorname{string}(\mathrm{nlin}))$

write(\%io(2),"")

write(\%io(2),"')

//Cálculo do vetor de médias

for $\mathrm{i}=1$ :ncol

media $(1, \mathrm{i})=$ mean $(\mathrm{X}(:, \mathrm{i}))$ //é vetor linha para facilitar próximo cálculo

end

//Cálculo alternativo da matriz de covariância

$/ /$ function $[\mathrm{Va}]=\operatorname{cov}(\mathrm{M})$

//for $\mathrm{i}=1:$ ncol

$/ / \mathrm{M}(:, \mathrm{i})=\mathrm{M}(:, \mathrm{i})-\operatorname{media}(1, \mathrm{i})$

//end

$/ / \mathrm{Va}=\left(\mathrm{M}^{\prime} * \mathrm{M}\right) /($ nlin-1) $/ /$ confirmar se é $\mathrm{n}$ ou $\mathrm{n}-1$

//endfunction

$/ / \mathrm{S}=\operatorname{cov}(\mathrm{X})$

//Matriz de desvios relativos

for $\mathrm{i}=1$ :nlin

$\operatorname{Xrel}(\mathrm{i},:)=\mathrm{X}(\mathrm{i},:)-$ media

end 
//Matriz de covariância $S$ alternativa

$\mathrm{S}=\left(\mathrm{Xrel}^{\prime} * \mathrm{Xrel}\right) /($ nlin-1) $/ /$ no artigo é $\mathrm{n} ! ! !$

//Matriz diagonal V

for $\mathrm{i}=1$ :ncol

$$
\mathrm{V}(\mathrm{i}, \mathrm{i})=1 / \operatorname{sqrt}(\mathrm{S}(\mathrm{i}, \mathrm{i}))
$$

end

//Matriz de correlação

$\mathrm{C}=\mathrm{V} * \mathrm{~S} * \mathrm{~V}$

$\operatorname{rankc}=\operatorname{rank}(\mathrm{C}) / /$ Deve ser igual a $\mathrm{p}$

printf("O rank de C é : " + string(rankc) + "; deve ser igual a p = " + string(ncol))

write(\%io(2),"")

write(\%io(2),"")

//Cálculo de autovetores e autovalores da matriz X

//Lambda é uma matriz diagonal com os autovalores e H é uma matriz modal cujas colunas são os autovetores

$[\mathrm{H}, \mathrm{Lambda}]=\operatorname{spec}\left(\mathrm{C}+\% \mathrm{i}^{*} 0\right)$

//Matriz de observações tranformadas

$[$ H2,Lambda2 $]=\operatorname{spec}\left(\right.$ Lambda $\left.+\% i^{*} 0\right)$

$/ /$ Fazer $\mathrm{A}^{\wedge} \mathrm{p}=\mathrm{V} * \mathrm{D} \cdot{ }^{\wedge} \mathrm{p} / \mathrm{V}$ para $\operatorname{Lambda}^{\wedge}(-1 / 2)$

$/ /$ Rtrans $=\mathrm{H}^{*} \operatorname{inv}\left(\left(\right.\right.$ Lambda2 $* \mathrm{H} 2 .^{\wedge}(1 / 2) /$ Lambda2 $\left.)\right) * \mathrm{H}^{\prime} * \mathrm{~V} *$ Xrel' //confirmar

//Utilizado o teorema de decomposição espectral para matrizes simétricas (Jordan): $A^{\wedge}$ alfa $=\mathrm{P}^{*}\left(\right.$ lambda ${ }^{\wedge}$ alfa $) * \mathrm{P}^{\wedge} \mathrm{T}$

Rtrans $=\mathrm{H}^{*}\left(\mathrm{H} 2 * \operatorname{Lambda}^{\wedge}(-1 / 2) * \mathrm{H} 2^{\prime}\right) * \mathrm{H}^{\prime *} \mathrm{~V}^{*}$ Xrel' //Lambda é simétrica $->$ Teorema da Decomposição Espectral

$\mathrm{R}=$ Rtrans'

//Cálculo do vetor de médias de $\mathrm{R}$

for $\mathrm{i}=1$ :ncol

mediaR $(1, \mathrm{i})=$ mean $(\mathrm{R}(:, \mathrm{i})) / /$ aqui usa $\mathrm{n}-1$, mas rever artigo

end

//ATENÇÃO: Utilizando-se parâmetros populacionais, uma distribuição normal multivariada pode ser transformada em normais padronizadas independentes; utizando-se estimadores esse procedimento é apenas aproximadamente válido. 


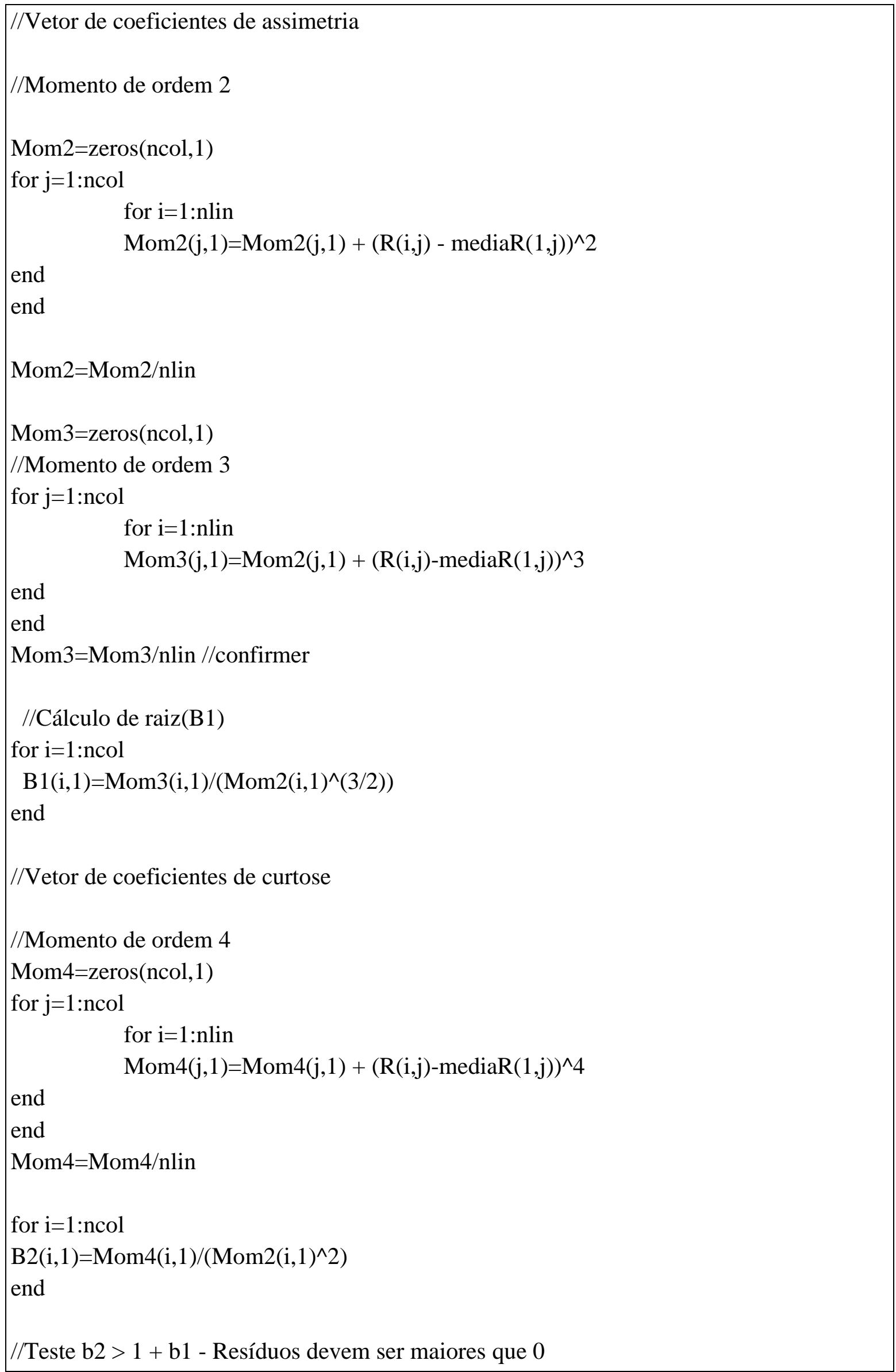




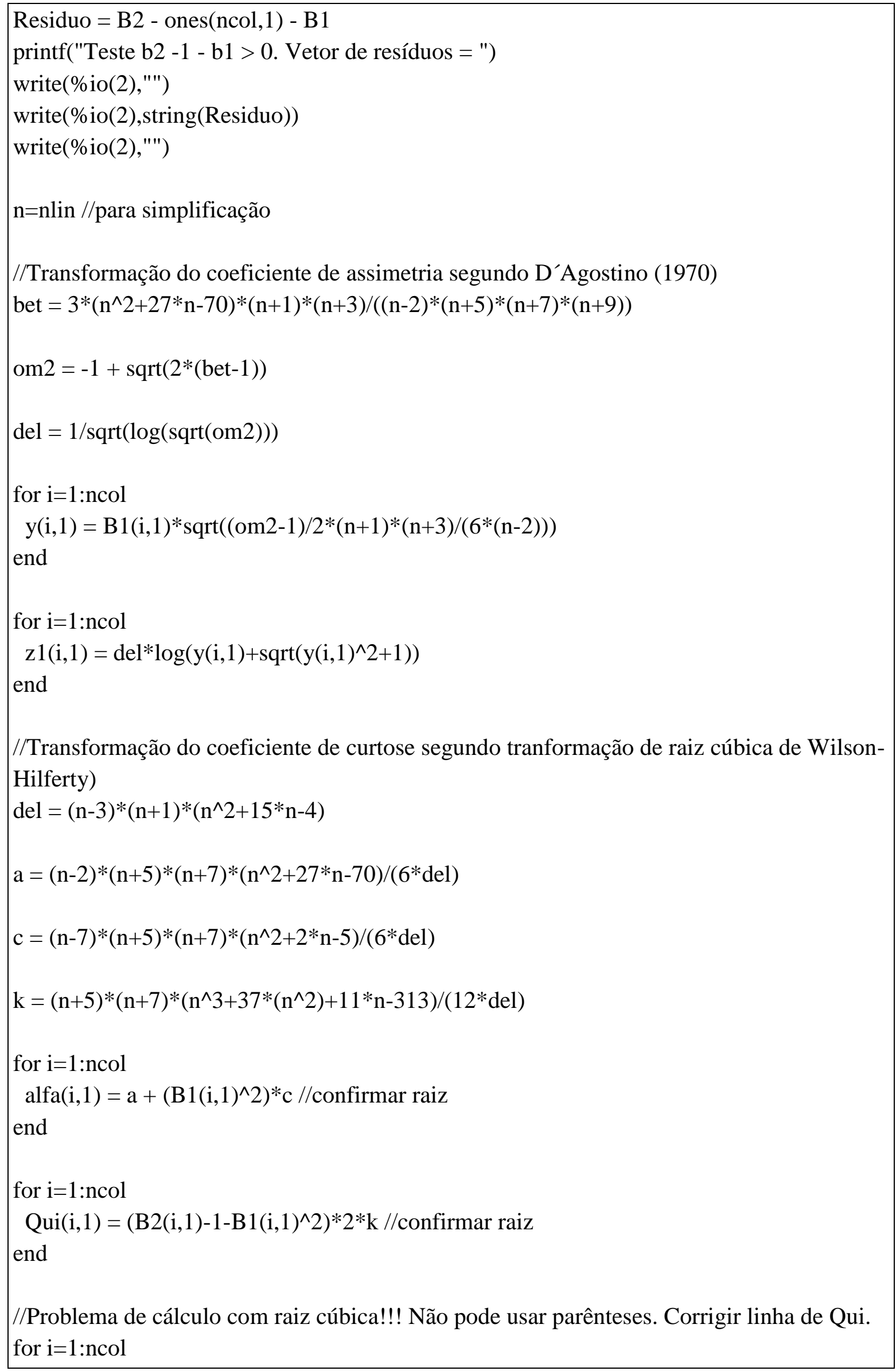




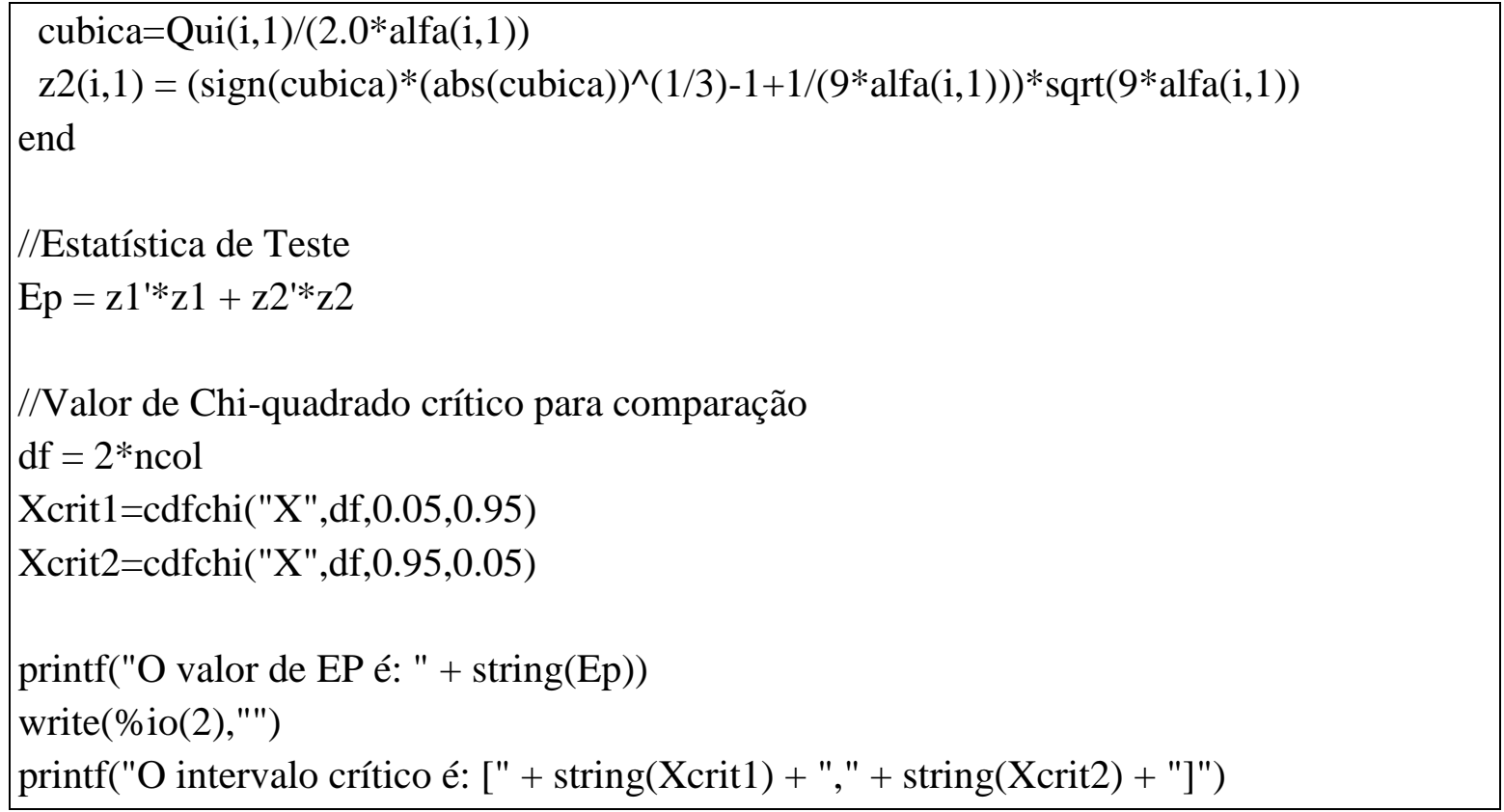


APÊNDICE H - Comparação PCA preliminar entre os sítios arqueológicos Lago Grande, Osvaldo, Açutuba e Hatahara.

Cenário 3: Os 9 elementos $\mathrm{La}, \mathrm{Lu}, \mathrm{Yb}, \mathrm{Ce}, \mathrm{Cr}, \mathrm{Eu}, \mathrm{Fe}, \mathrm{Sc}$ e Th com transformação logarítmica $\log _{10}$.
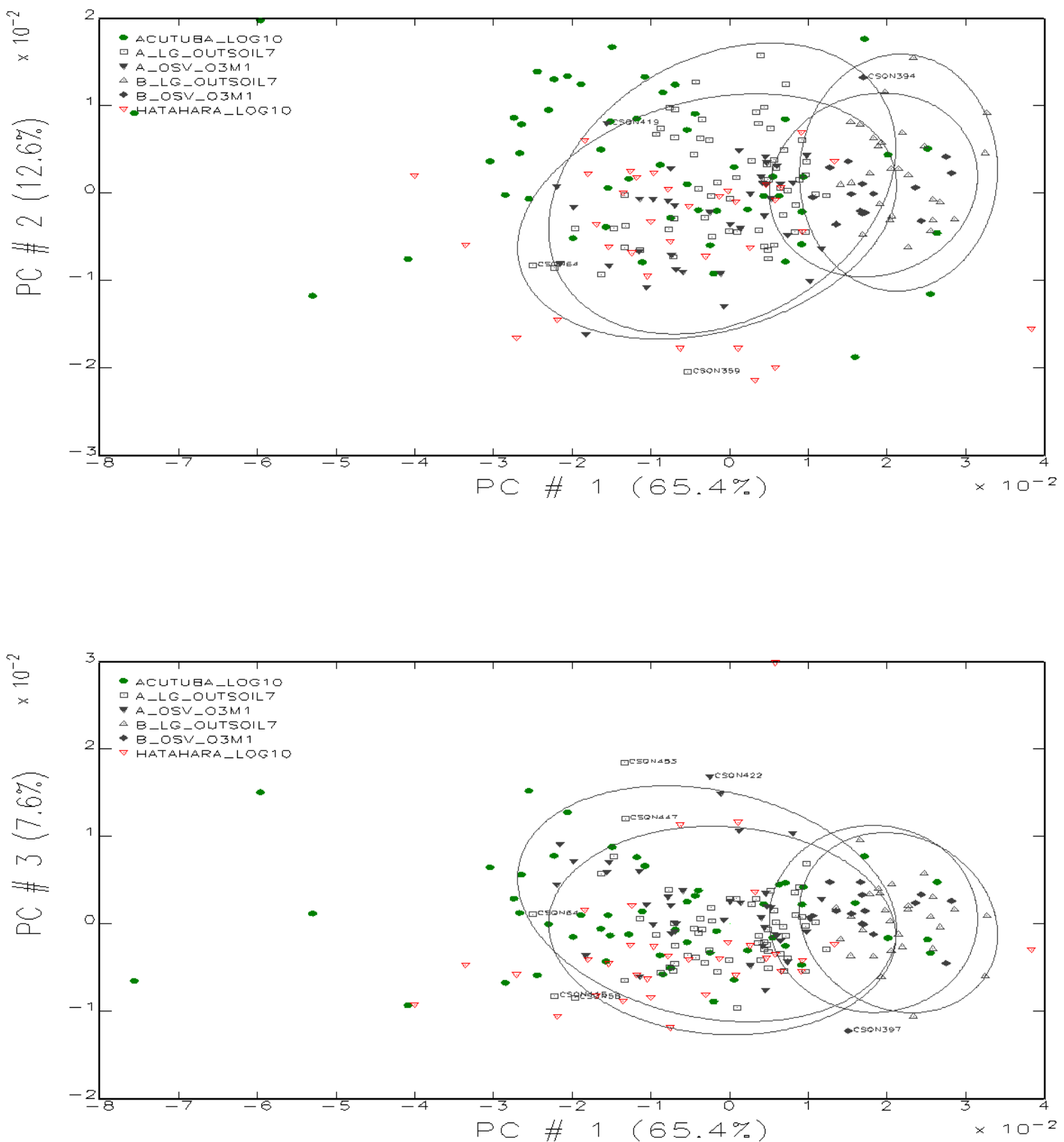
Cenário 5: Os 9 elementos $\mathrm{La}, \mathrm{Lu}, \mathrm{Yb}, \mathrm{Ce}, \mathrm{Cr}, \mathrm{Eu}, \mathrm{Fe}, \mathrm{Sc}$ e Th com transformação em razão logarítmica aditiva (alr).
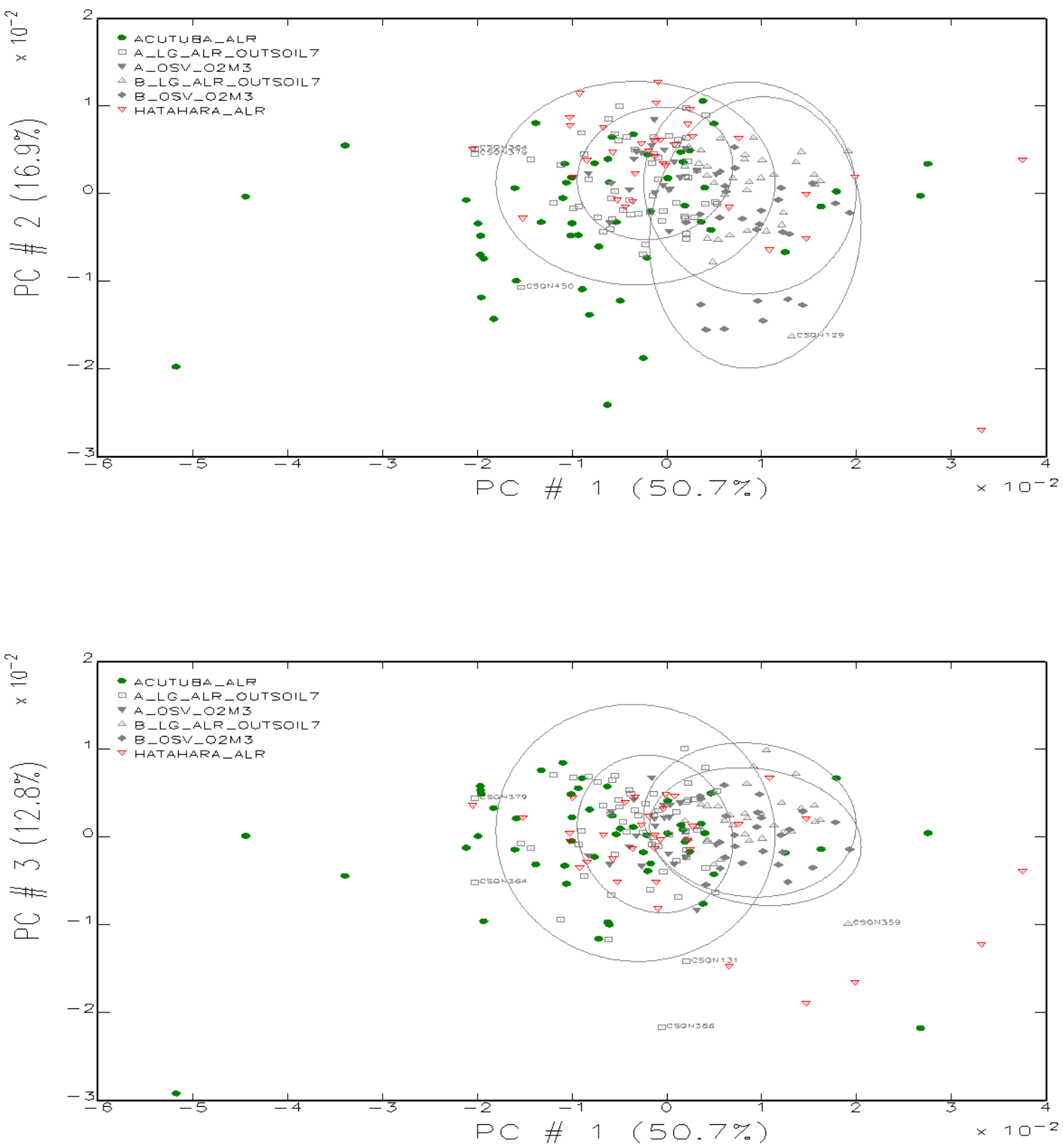
APÊNDICE I - Curvas de EPR para determinação da temperatura de queima.
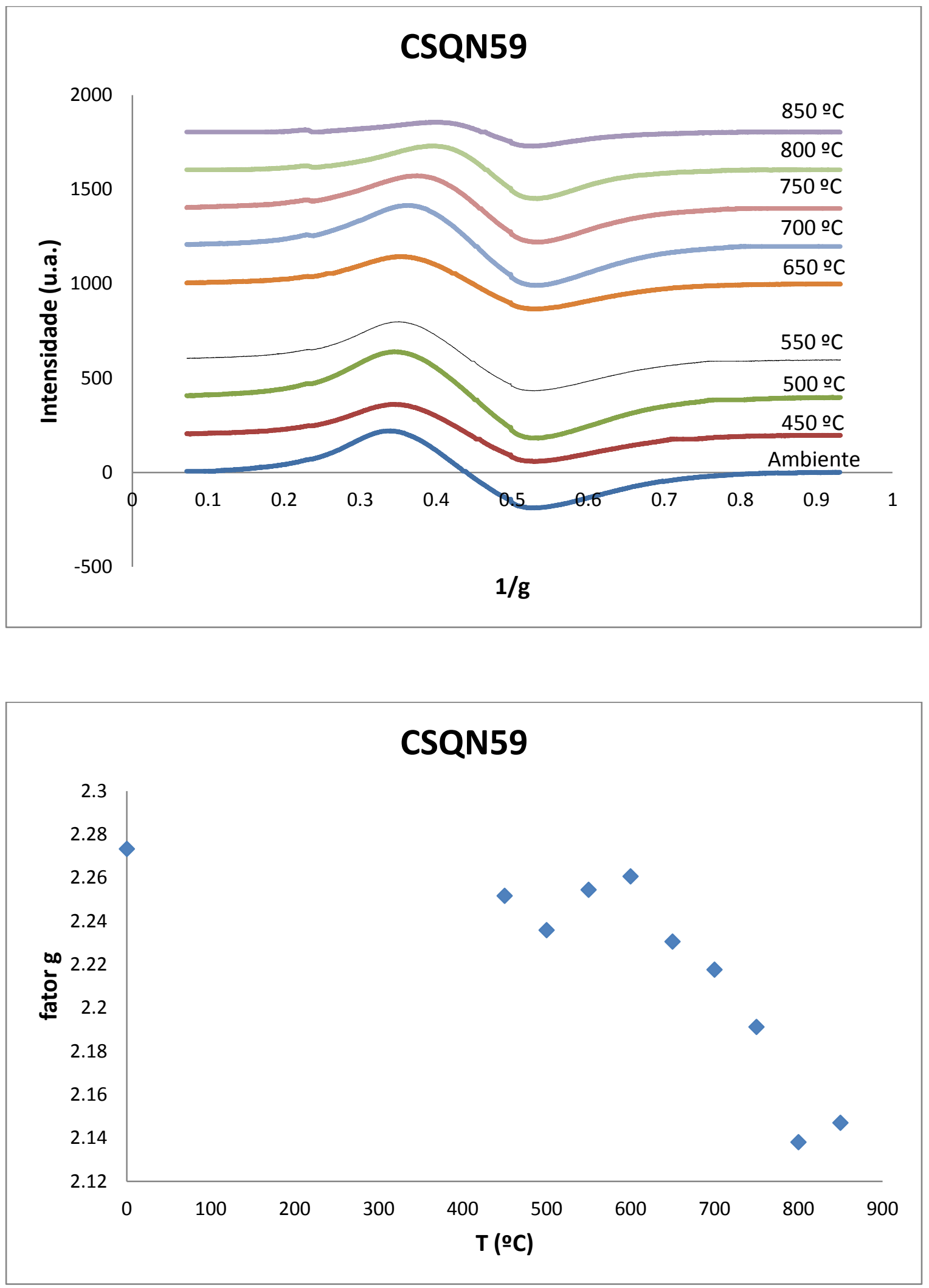

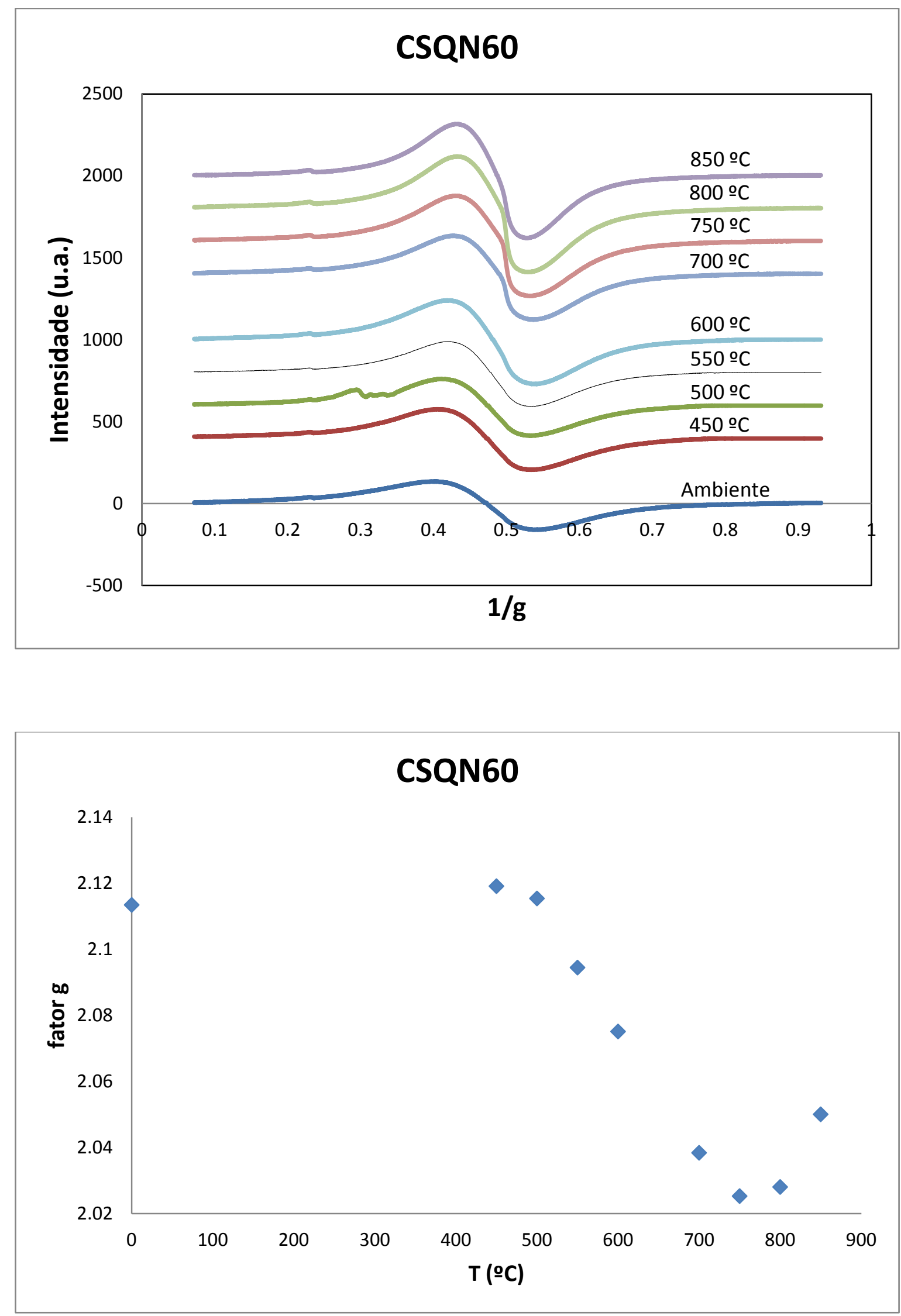

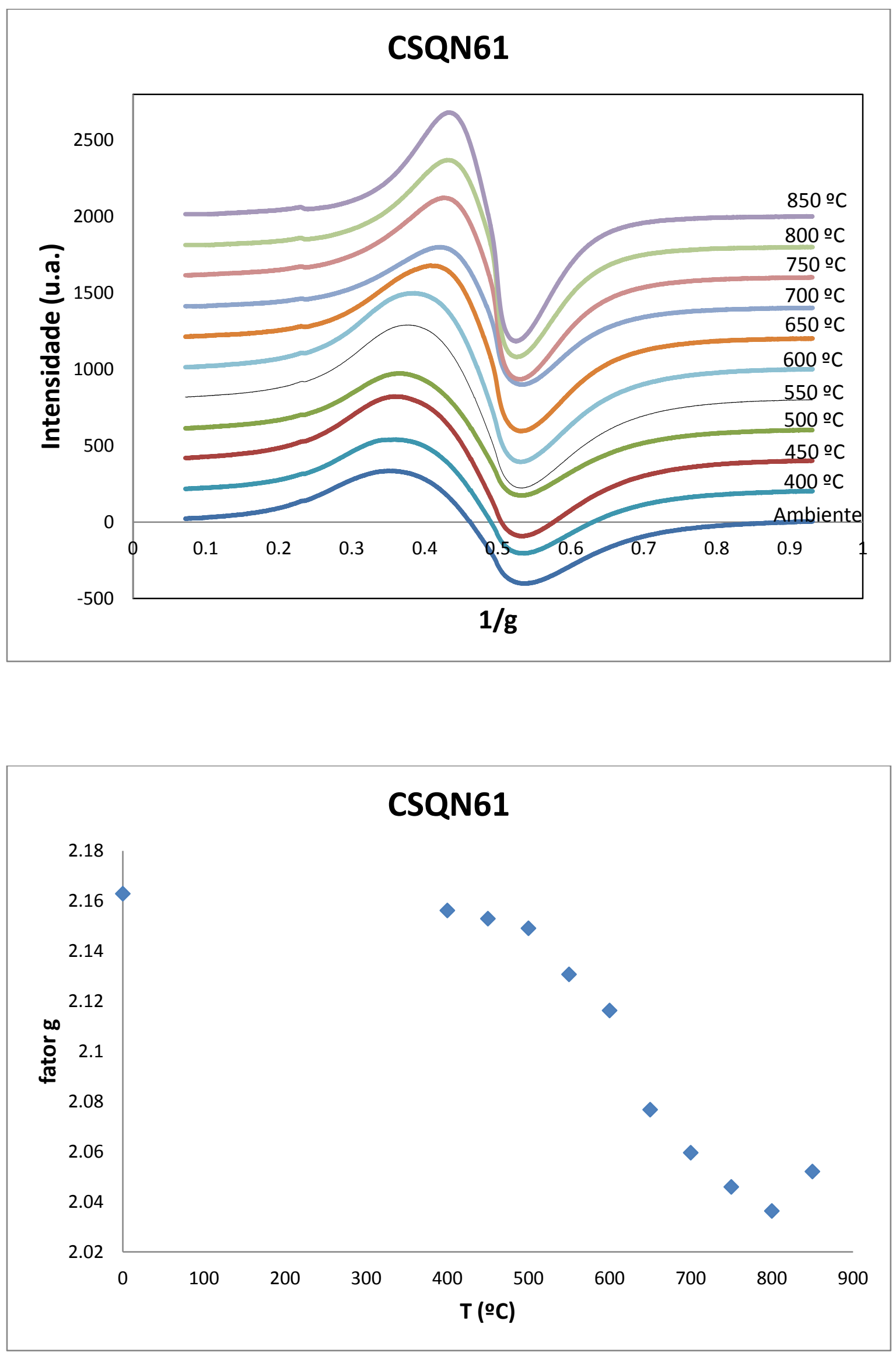

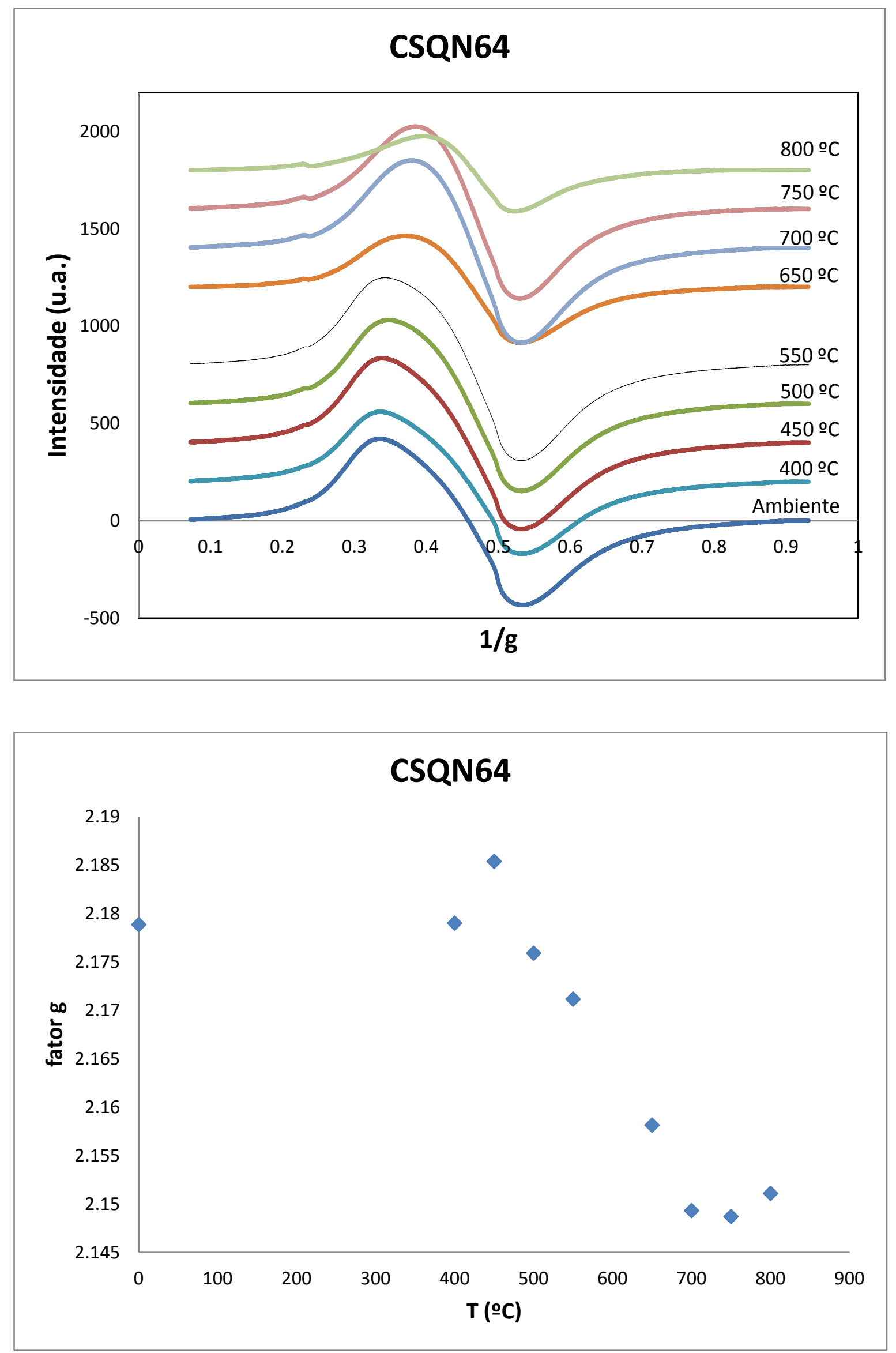

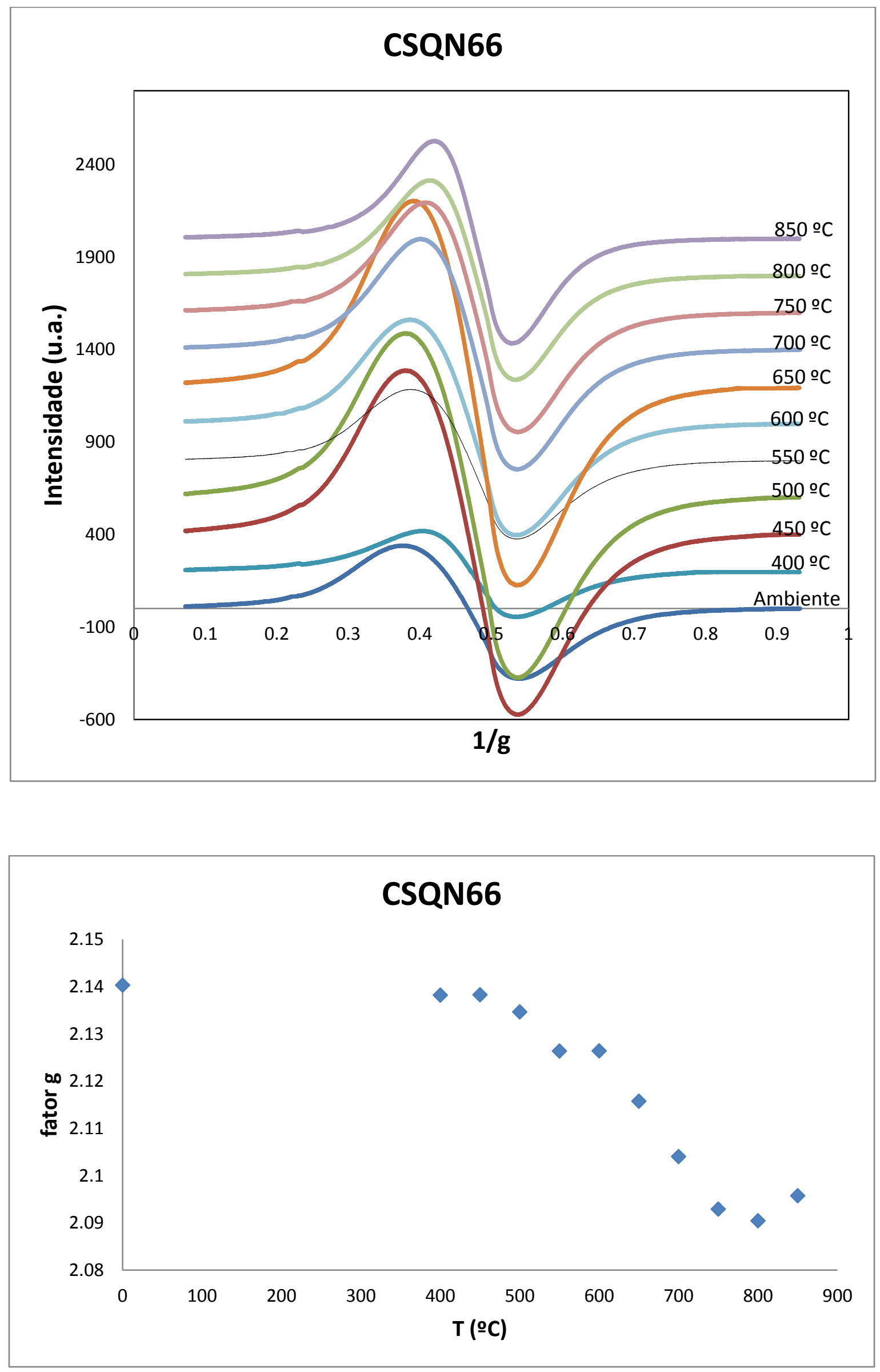

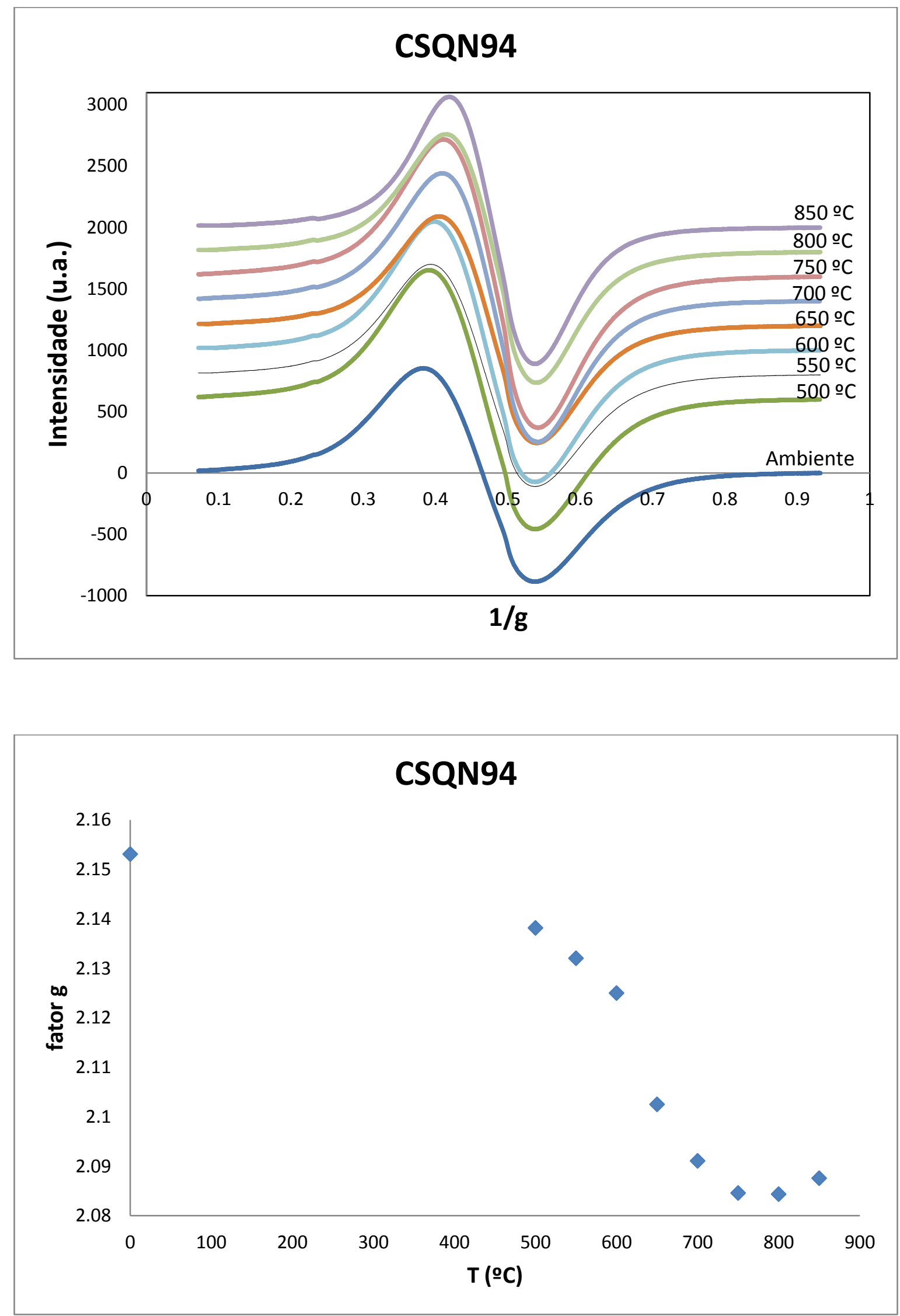

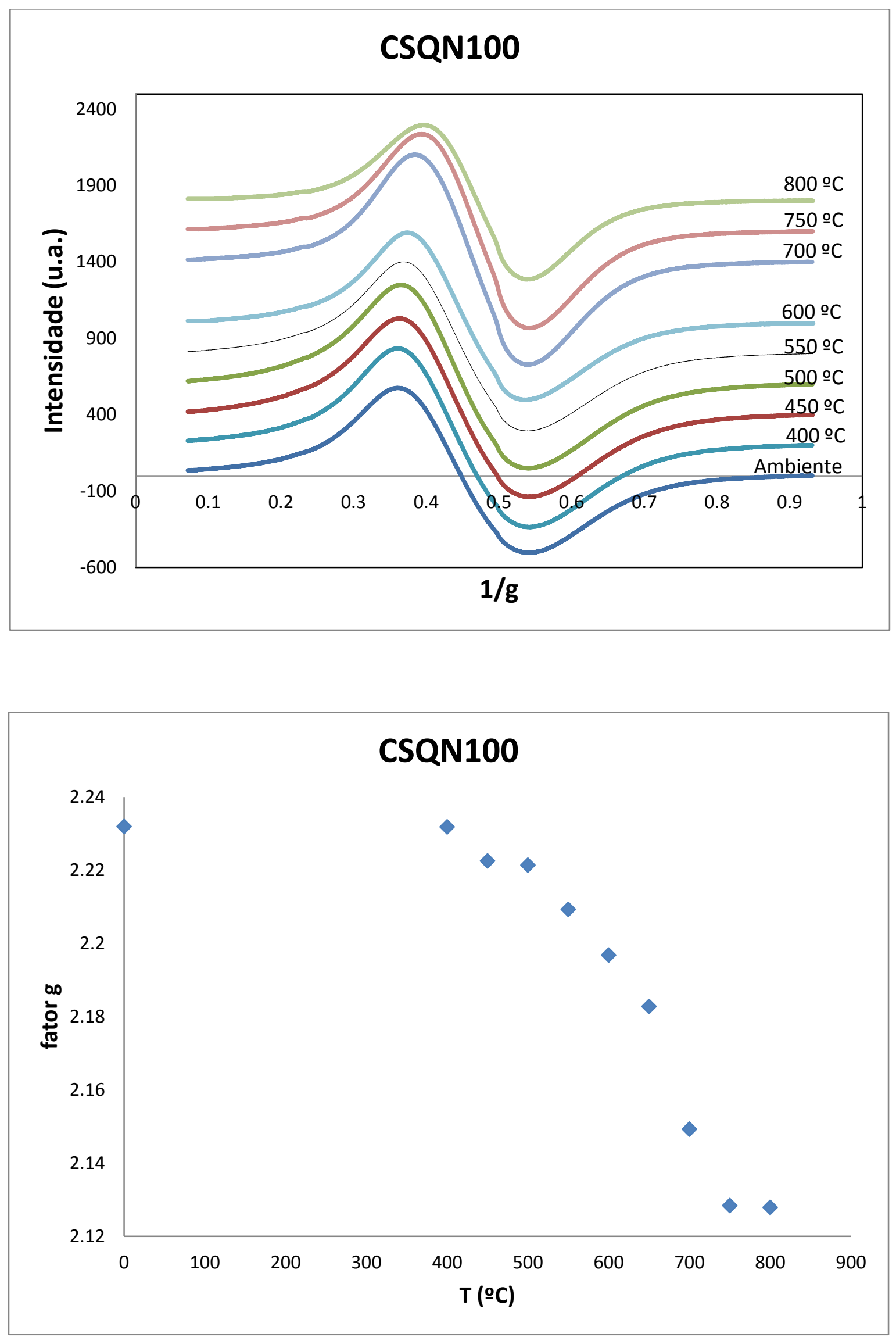

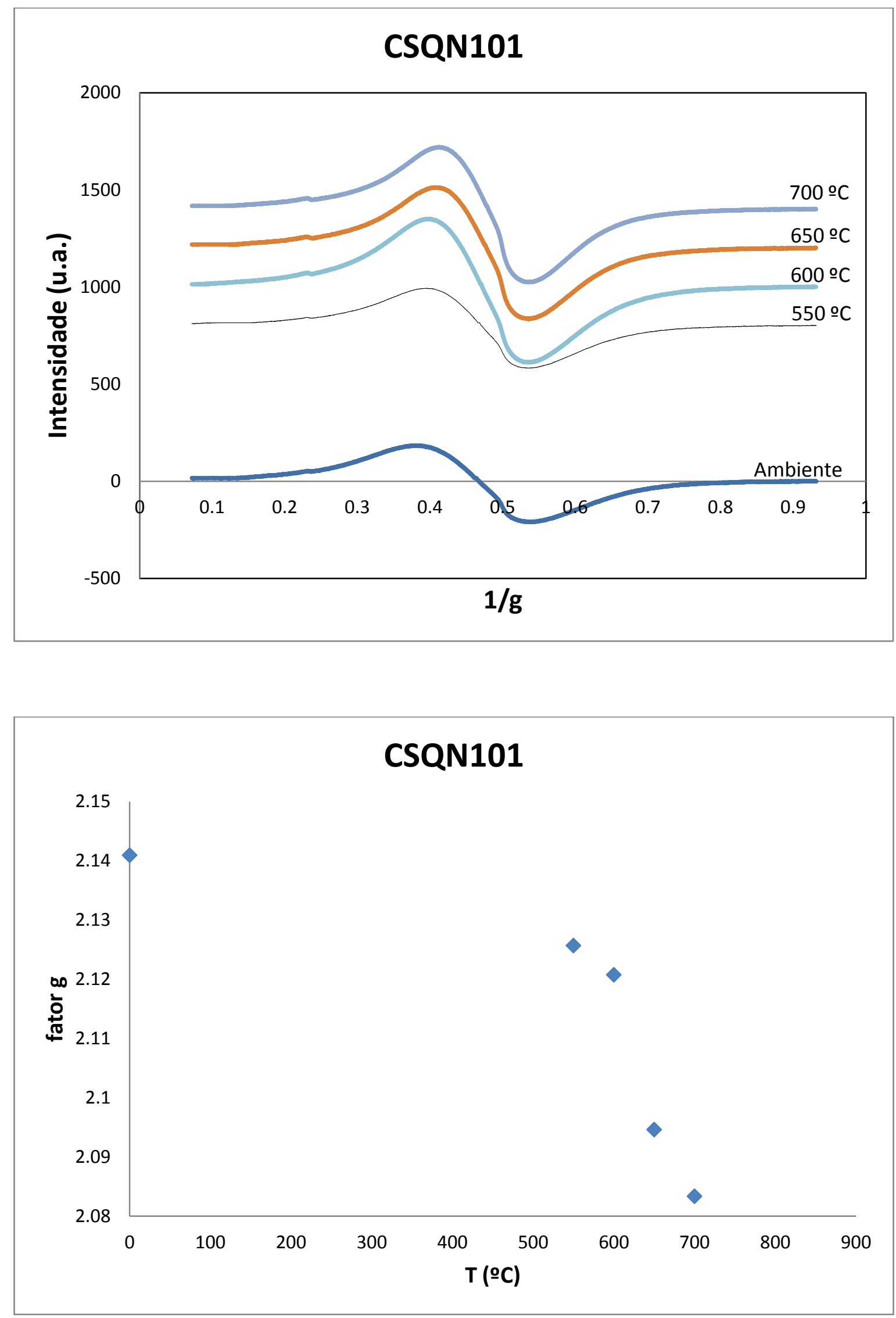

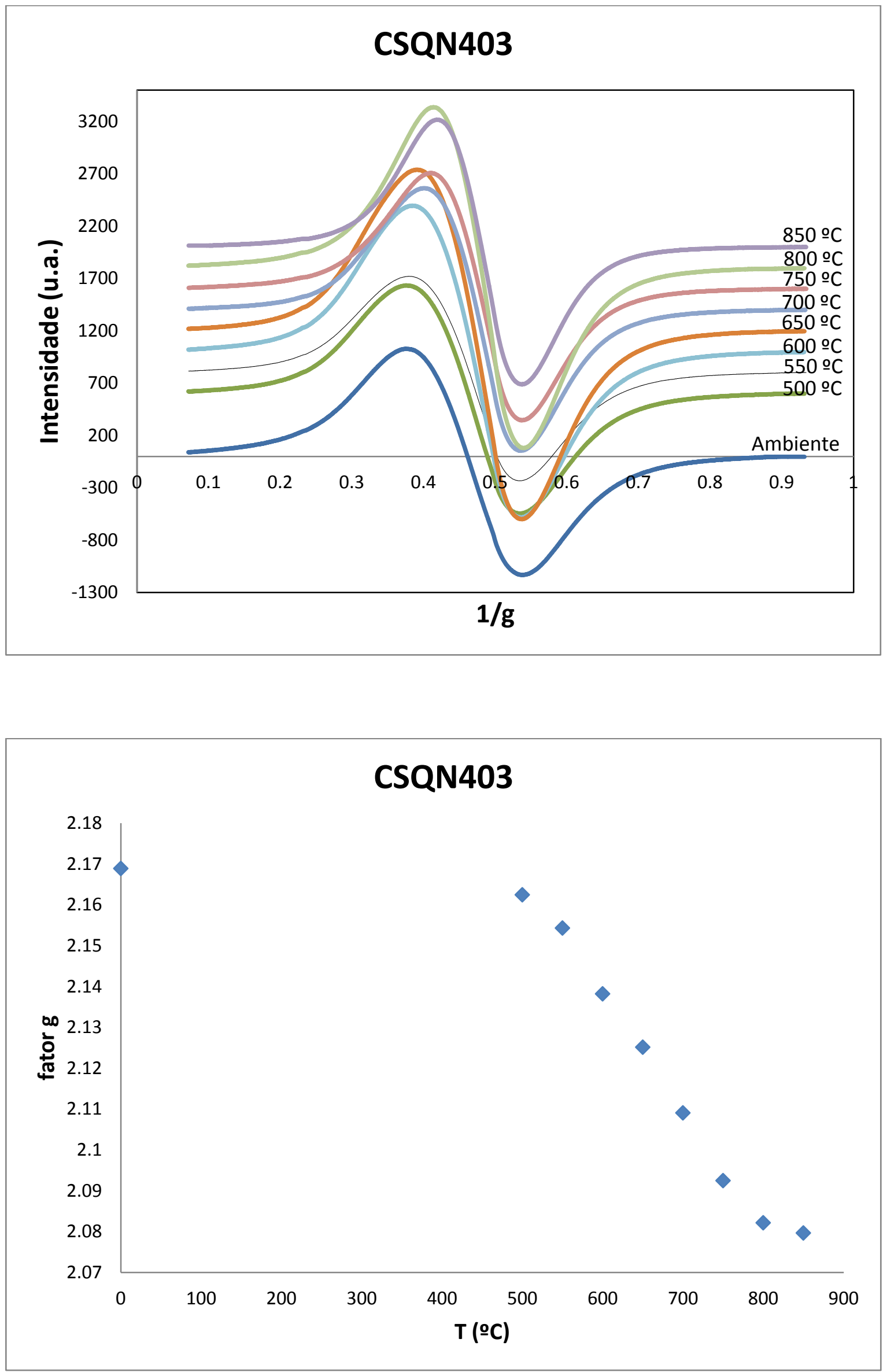

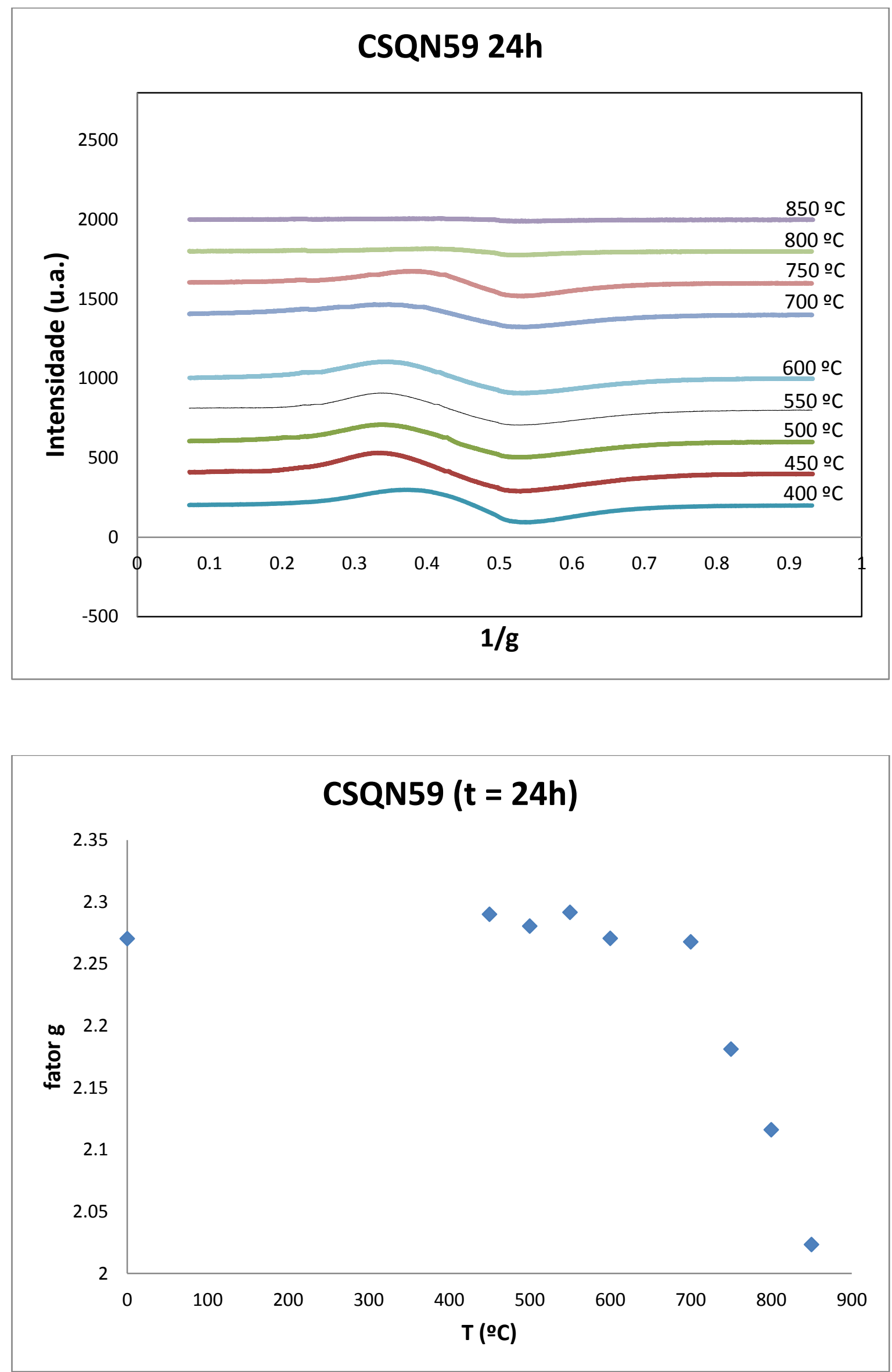

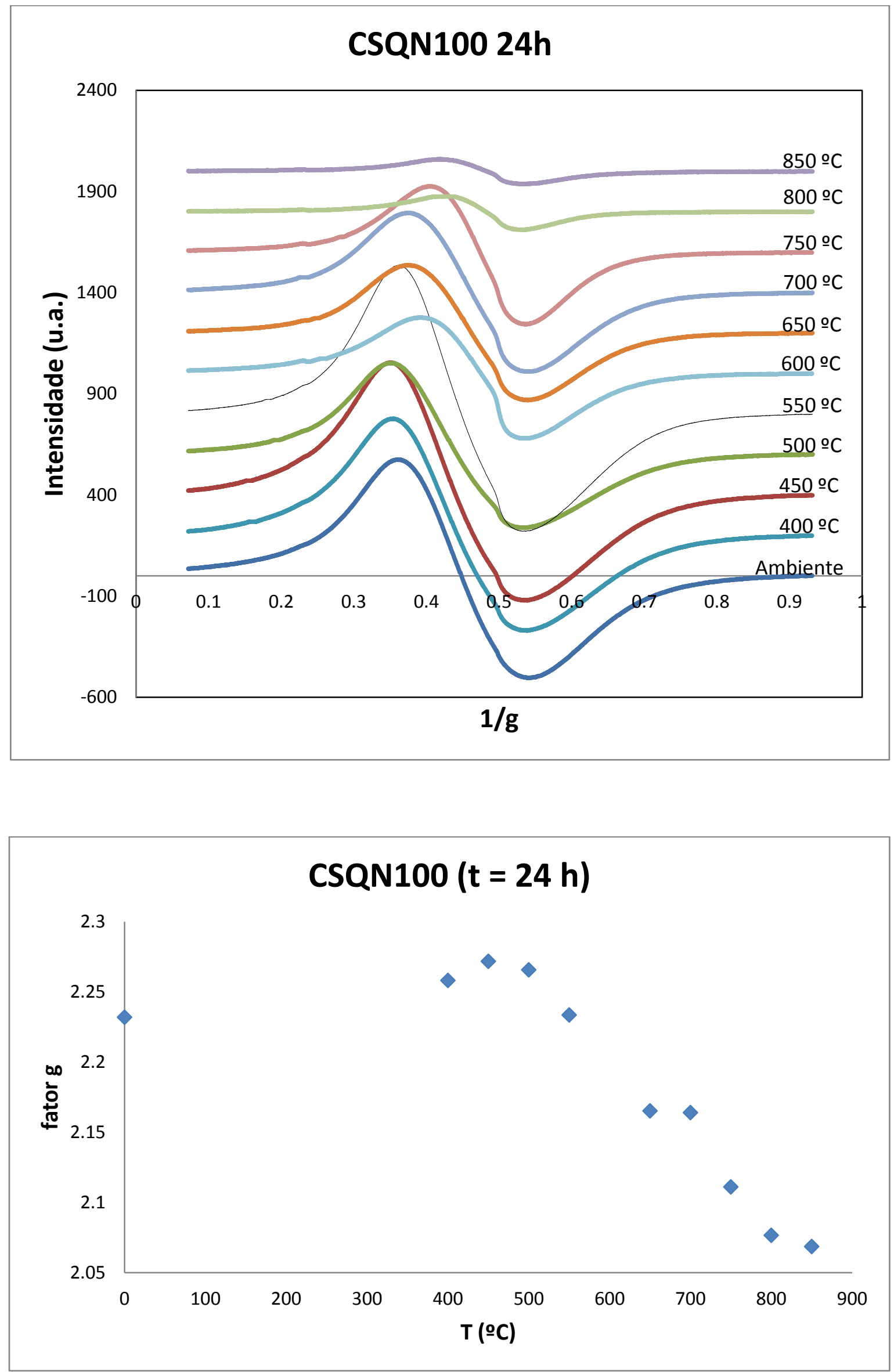


\section{REFERÊNCIAS BIBLIOGRÁFICAS}

ADAMIEC, G.; AITKEN, M. J. Dose-rate conversion factors: update, Ancient TL, 16, pp. 37-50, 1998.

AITCHISON, J. The statistical analysis of compositional data. Chapman and Hall, London, 1986.

AITCHISON, J.; BARCELÓ-VIDAL, C.; PAWLOWSKY-GLAHN, V. Some comments on compositional data analysis in archaeometry, in particular the fallacies in Tangri and Wright's dismissal of logratio analysis. Archaeometry, 44(2), pp. 295-304, 2002.

AITKEN, M. J. An Introduction to Optical Dating, Oxford University Press, New York, USA, 267 p., 1998.

ALBERS, A. P. F.; MELCHIADES, F. G.; MACHADO, R.. BALDO, J. B.; BOSCHI, A. O. Um método simples de caracterização de argilominerais por difração de raios $\mathrm{X}$. Cerâmica, 48(305), pp. 34-37, 2002.

ANDRADE, J. M.; GÓMEZ-CARRACEDO, M. P.; KRZANOWSKI, W.; KUBISTA, M. Procrustes rotation in analytical chemistry, a tutorial. Chemometrics and Intelligent Laboratory Systems, 72, pp.123-132, 2004.

ARTIOLI, G. Scientific Methods and Cultural Heritage - An introduction to the application of materials science to archaeometry and conservation science. Oxford University Press, 536 p, 2010.

ATTAS, M.; FOSSEY, J. M.; YAFFE, L. Corrections for Drill-bit Contamination in Sampling Ancient Pottery for Neutron Activation Analysis. Archaeometry, 26(1), pp 104107, 1984.

BALLABIO, D.; CONSONNI, V.; TODESCHINI, R. The Kohonen and CP-ANN toolbox: a collection of MATLAB modules for Self Organizing Maps and Counterpropagation Artificial Neural Networks. Chemometrics and Intelligent Laboratory Systems, 98, pp. 115-122, 2009.

BARROSO, L. P.; ARTES, R. Minicurso Análise Multivariada, Lavras, 2003.

BARSOUM, M. W. Fundamentals of Ceramics. Taylor \& Francis, 603 p., 2003.

BARTOLL, J.; TANI, A. Thermal History of Archaeological Objects, Studied by Electron Spin Resonance. Naturwissenschaften, 85, pp. 474-481, 1998. 
BARTOLL, J.; TANI, A.; IKEYA, M.; INADA, T. ESR Investigations of Burnt Soil. Applied Magnetic Resonance, 11, pp. 577-586, 1996.

BAXTER, M. J. Exploratory Multivariate Analysis in Archaeology. Edinburgh Univesity Press, 1994.

BAXTER, M. J. Testing Multivariate Normality, with Applications to Lead Isotope Data Analysis in Archaeology. CAA Conference, 1997. Disponível em: $<$ http://citeseerx.ist.psu.edu/viewdoc/summary?doi=10.1.1.51.107> Acesso em: 19/01/2011.

BAXTER, M. J. Variable Selection in Artefact Compositional Studies, Archaeometry, 43, pp. 253-268, 2001.

BAXTER, M. J. Distance and Transformation in the multivariate analysis of archaeometric data. In: Physics Methods in Archaeometry - Proceedings of the Internation School of Physics Enrico Fermi, 2004.

BAXTER, M. J. Archaeological Data Analysis and Fuzzy Clustering, Archaeometry, 51(6), pp. 1035-1054, 2009.

BAXTER, M. J.; BUCK, C. E. Data Handling and Statistical Analysis. In: Modern Analytical Methods in Art and Archaeology, ch. 20, editado por Enrico Ciliberto e Giuseppe Spoto, Chemical analysis Series, 155, 2000.

BAXTER, M. J.; FREESTONE, I. C. Log-ratio Compositional Data Analysis in Archaeometry. Archaeometry, 48(3), pp. 511-531, 2006.

BAXTER, M. J.; BEARDAH, C.C.; COOL, H.E.M; JACKSON, C.M. Compositional data analysis in archaeometry. In: CoDaWork03: Compositional Data Analysis Workshop, Girona, Spain, 2003.

BAXTER, M. J.; BEARDAH, C.C.; PAPAGEORGIOU, I.; CAU, M.A.; DAY, P.M.; KILIKOGLOU, V. On statistical approaches to the study of ceramic artefacts using geochemical and petrographic data. Archaeometry, 50 (1), pp. 142-157, 2008.

BECKMAN, R. J.; COOK, R.D. Outlier. Technometrics, 25, pp. 119-163, 1983.

BEIER, T.; Mommsen, H. Modified Mahalanobis filters for grouping pottery by chemical composition. Archaeometry, 36(2), pp. 287-306, 1994. 
BELL, S.; CROSON, C. Artificial Neural Networks as a Tool for Archaeological Data Analysis, Archaeometry, 40(1), pp. 139-151, 1998.

BENSIMON, Y.; DEROIDE, B.; CLAVEL, S.; ZANCHETTA, J. Electron spin resonance and dilatometric studies of ancient ceramics applied to the determination of firing temperature. Japanese Journal of Applied Physics, 37, pp. 4367-4372, 1998.

BENSIMON, Y.; DEROIDE, B.; ZANCHETTA, J. V. Comparison between the electron paramagnetic resonance spectra obtained in X-and W-bands on fired clay: a preliminary study. Journal of Physics and Chemistry of Solids, 60, pp. 813-818, 1999.

BETTIS III, E. A. Soil Morphologic Properties and Weathering Zone Characteristics as Age Indicators in Holocene Alluvium in the Upper Midwest. In: Soils in Archaeology: Landscape Evolution and Human Occupation, editado por E. Athur Bettis III, Smithsonian Institution, 1992.

BINFORD, L. R. Behavioral Archaeology and the "Pompeii Premise". Journal of Anthropological Research, 37(3), pp. 195-208, 1981.

BISHOP, R. L. Instrumental Neutron Activation Analysis of Archaeological Ceramics: Progress and Challenges. In: IAEA-TRS416 - Nuclear Analytical Techniques in Archaeological Investigations, Vienna, cap. 2, pp. 35-44, 2003.

BISHOP, R. L.; CANOUTS, V.; DE ATLEY, S. P.; QÖYAWAYMA, A.; AIKINS, C. W. The Formation of Ceramic Analytical Groups: Hopi Pottery Production and Exchange, A.C. 1300-1600. Journal of Field Archaeology, 15(3), pp. 317-337, 1988.

BISHOP, R. L.; HARBOTTLE, G.; SAYRE, E. V. Chemical and Mathematical Procedures Employed in the Mayan Fine Paste Ceramics Project. In: Sabloff, J. A. (ed.). Excavations at Saibal - Analyses of Fine Paste Ceramics, BNL-28105, 1982. doi: $10.2172 / 5258886$.

BLACKMAN, M. J.; BISHOP, R. L. The Smithsonian-NIST Partnership: The Application of Instrumental Neutron Activation Analysis to Archaeology. Archaeometry, 49(2), pp. 321-341, 2007.

BOCH, P.; NIÈPCE, J.C. Ceramic Materials - Processes, Properties and Applications. ISTE, 573 p., 2007.

BODE, P. Instrumental and Organizational Aspects of a Neutron Activation Analysis Laboratory. Delft: Interfacultair Reactor Instituut, 250 p., 1996. 
BODE, P.; van DIJK, C. P. Operational management of results in INAA utilizing a versatile system of control charts. Journal of Radioanalytical and Nuclear Chemistry, 215(1), pp. 87-94, 1997.

BROOKHAVEN NATIONAL LABORATORY. History of Research Reactor at Brookhaven. Disponível em: <http://www.bnl.gov/bnlweb/stewardship/reactors.asp> . Acesso em: 07/03/2014.

BRUNO, R. D.; ROCHA, H. R.; FREITAS, H. C.; GOULDEN, M. L.; MILLER, S. D. Soil moisture dynamics in an eastern Amazonian tropical forest, Hydrological Processes, 20, pp. 2477-2489, 2006.

BUXEDA I GARRIGÓS, J. Alteration and Contamination of Archaeological Ceramics: The Perturbation Problem. Journal of Archaeological Science, 26, pp. 295-313, 1999.

BUXEDA I GARRIGÓS, J.; KILIKOGLOU, V.; DAY, P. M. Chemical and Mineralogical Alteration of Ceramics from a Late Bronze Age Kiln at Kommos, Crete: The Effect on the Formation of a Reference Group. Archaeometry, 43(3), pp. 349-371, 2001.

BUXEDA I GARRIGÓS, J.; MOMMSEN, H.; TSOLAKIDOU, A. Alterations of Na-, K-, and $\mathrm{Rb}$ - concentrations in Mycenaean pottery and a proposed explanation using $\mathrm{X}$-ray diffraction. Archaeometry, 44(2), pp. 187-198, 2002.

CALLISTER, W. D. Materials science and engineering: an introduction. John Wiley \& Sons, 7 ed., 2007.

CANTELMO, N. F.; FERREIRA, D. F. Desempenho de Testes de Normalidade Multivariados Analisados por Simulação Monte Carlo. Ciência e Agrotecnologia, 31 (6), pp.1630-1636, 2007.

CARPENTER, J. M. Neutron Production, Moderation and Characterization of Sources. 2004. Disponível em <http://www.neutron.anl.gov>. Acesso em: 12/05/2011

CARTER, C. B.; NORTON, M. G. Ceramic Materials - Science and Engineering. Springer, 715 p., 2007.

CARTER, E. A.; SARAH, J. K.; KONONENKO, N.; TORRENCE, R. Raman Spectroscopic Studies of Obsidian. In: Analytical Archaeometry - Selected Topics, editado por H. G. M. Edwards e P. Vandenabeele, The Royal Society of Chemistry, Cambridge, 2012.

CHI, Y. Multivariate Methods. WIREs Computational Statistics, 4, pp. 35-47, 2012. doi: 10.1002/wics.185. 
COSTA, L. M.; SANTOS, R. F.; SCHAEFER, C. E. G. R.; MOREAU, A. M. S. S.; MOREAU, M. S. Ocorrência de corpos silicosos em horizontes superficiais de solos de diferentes ecossistemas. Revista Brasileira de Ciência do Solo, 34, pp. 871-879, 2010.

COSTA, M. L.; KERN, D. C.; PINTO, A. H. E.; SOUZA, J. R. T. The ceramic artifacts in archaeological black earth (terra preta) from lower Amazon region, Brazil: Mineralogy. Acta Amazonica, 34(2), pp. 165-178, 2004.

DEL CASTILLO, H. C.; STRIVAY, D. X-ray methods. In: Analytical Archaeometry Selected Topics, editado por H. G. M. Edwards e P. Vandenabeele, The Royal Society of Chemistry, Cambridge, 2012.

DEMASTER, D. J. The diagenesis of biogenic silica: Chemical transformations occurring in the water column, seabed, and crust. In: Treatise of Geochemistry, v. 7, editado por F.T. Mackenzie, pp. 87-98, 2005.

DIAS M. I.; PRUDÊNCIO M. I. Neutron activation analysis of archaeological materials: An overview of ITN NAA laboratory, Portugal. Archaeometry, 49(2), pp. 383-393, 2007.

DIAS, M. I.; PRUDÊNCIO, M. I. On the importance of using Scandium to normalize geochemical data preceding multivariate analyses applied to archaeometric pottery studies. Microchemical Journal, 88, pp. 136-141, 2008.

DONATTI, P. B. A ocupação pré-colonial da área do Lago Grande, Iranduba, AM. Dissertação (Mestrado em Arqueologia) - Museu de Arqueologia e Etnologia, Universidade de São Paulo, 2003.

DOORNIK, J. A.; HANSEN, H. An Omnibus Test For Univariate and Multivariate Normality. Oxford Bulletin of Economics and Statistics, 70(1), pp. 927-939, 2008.

DUNNEL, R. C. Why Archaeologists Don't Care about Archaeometry. Archeomaterials, 7, pp. 161-165, 1993.

EHMANN, W. D.; VANCE, D. E. Radiochemistry and Nuclear Methods of Analysis. Wiley-Interscience, 1 ed., 560 p., 1991.

EVERITT, B. S. Cluster Analysis, 2 ed., Heinemann Educational Books, London, 1980.

FAUSTO, C. Entre o Passado e o Presente: Mil Anos de História Indígena no Alto Xingu. Revista de Estudos e Pesquisas, 2(2), pp. 9-51, 2005. 
FELICISSIMO, M. P.; PEIXOTO, J. L.; BITTENCOURT, C.; TOMASI, R.; HOUSSIAU, L.; PIREAUX, J.; RODRIGUES-FILHO, U. P. SEM, EPR and ToF-SIMS Analyses Applied to Unravel the Technology Employed for Pottery-Making by Pre-colonial Indian Tribes from Pantanal, Brazil. Journal of Archaeological Science, 37(9), pp. 2179-2187, 2010 .

FERREIRA, D. F. Estatística Multivariada. Editora UFLA, 662 p., 2008

FREESTONE, I. C.; MIDDLETON, A. P. Mineralogical applications of the analytical SEM in archaeology. Mineralogical Magazine, 51, pp. 21-31, 1987.

GAILlARDET, J.; DUPRÉ, B.; ALLÈGRE, C. J.; NÉGREL, P. Chemical and physical denudation in the Amazon River Basin. Chemical Geology, 142, pp. 141-173, 1997.

GAUDETTE, H. E.; GRIM, R. E.; METZGER, C. F. Illite: A model based on the sorption behavior of Cesium. The American Mineralogist, 51, pp. 1649-1656, 1966.

GENGA, A.; SICILIANO, M.; TEPORE, A.; MANGONE, A.; TRAINI, A.; LAGANARA, A. An archaeometric approach about the study of medieval glass from Siponto (Foggia, Italy). Microchemical Journal, 90(1), pp. 56-62, 2008.

GLASCOCK, M. D. Characterization of Archaeological Ceramics at MURR by Neutron Activation Analysis and Multivariate Statistics. In: Chemical Characterization of Ceramic Pastes in Archaeology, edited by H. Neff, pp. 11-26, Pre-History Press, Madison, 1992.

GLASCOCK, M. D.; NEFF, H. Neutron activation analysis and provenance research in archaeology. Measurement Science and Technology, 14, pp. 1516-1526, 2003.

GLASCOCK, M. D.; NEFF, H.; VAUGH, K. J. Instrumental Neutron Activation Analysis and Multivariate Statistics for Pottery Provenance. Hyperfine Interactions, 154, pp. 95$105,2004$.

GOEBEL, F. Ueber den Einfluss der Chemie auf die Ermittelung der Volker der Vorzeit oder Resultate der chemischen Untersuchung metallischer Alterthumer insbesondere der in den Ostseegouvernements vorkommenden Behufs der Ermittelung der Volker von welchen sie abstammem. Erlangen, 38 p., 1842.

GOLITKO, M.; DUDGEON, J. V.; NEFF, H.; TERRELL, J. E. Identification of postdepositional chemical alteration of ceramics from the North coast of Papua New Guinea (Sanduan Province) by time-of-flight-laser ablation-inductively-coupled plasma-mass spectrometry (TOF-LA-ICP-MS). Archaeometry, 54(1), pp. 80-100, 2012. 
GUINN, V. P.; LUKENS, H. R. Nuclear Methods. In: Trace Analysis - Physical Methods. Cap. 9 , pp. 325-376, 1965

GUYOT, J. L.; JOUANNEAU, J. M.; SOARES, L.; BOAVENTURA, G. R.; MAILLET, N.; LAGANE, C. Clay mineral composition of river sediments in the Amazon Basin. Catena, 71, pp. 340-356, 2007.

HAIR, J. F. JR.; ANDERSON, R. E.; TATHAM, R. L.; BLACK, W. C. Multivariate Data Analysis, 5 ed., New Jersey, Prentice Hall, 1998.

HARBOTLE, G. Activation Analysis in Archaeology. In Radiochemistry, v. 3, editado por G. W. A. Newton, pp. 33-72, The Chemical Society, Londres, 1976.

HARBOTTLE, G. Chemical characterization in Archaeology. In: Contexts for Prehistoric Exchange, editado por J. E. Ericson e T. K. Earle, Academic Press, New York, pp. 13-51, 1982a.

HARBOTTLE, G. Provenance studies using neutron activation analysis: the role of standardization. In: Olin, J. S., and Franklin, A. D. (eds.). Archaeological Ceramics, pp. 67-77, Washington, D.C., Smithsonian Institution Press, 1982b.

HARBOTTLE, G.; HOLMES, L. The history of Brookhaven National Laboratory project in archaeological chemistry, and applying nuclear methods to the fine arts. Archaeometry, 49(2), pp. 185-199, 2007.

HÄUSLER, W. Firing of Clays Studied by X-ray Diffraction and Mössbauer Spectroscopy. Hyperfine Interactions, 154, pp. 121-141, 2004.

HECKENBERGER, M. J.; NEVES, E. G. Amazonian Archaeology. Annual Review of Anthropology, 38, pp. 251-266, 2009.

HECKENBERGER, M. J.; PETERSEN, J. B.; NEVES, E. G. Village Size and Permanence in Amazonia: Two Archaeological Examples from Brazil. Latin American Antiquity, 10(4), pp. 353-376, 1999.

HEIMANN, R. B. Classic and Advanced Ceramics - From Fundamentals to Applications. Wiley-VCG, Weinheim, 553 p., 2010.

HOLLIDAY, V. T. Soil Formation, Time, and Archaeology. In: Soils in Archaeology: Landscape Evolution and Human Occupation. Smithsonian Institution, 1992.

IAEA-TRS416. Nuclear Analytical Techniques in Archaeological Investigations. Viena, 2003. 
IAEA-CU-2006-02. Proficiency Test on the Determination of ${ }^{137} \mathrm{Cs}$ and ${ }^{210} \mathrm{~Pb}$ in Spiked Soil. Viena, 2006.

IAEA-CU-2008-03. Worldwide Proficiency Test: Determination of Naturally Occurring Radionuclides in Phosphogypsum and Water. Viena, 2010.

IGLEWICZ, B.; HOAGLIN, D. How to detect and handle outliers. ASQC Quality Press, 1993.

IKEYA, M. New Applications of Electron Spin Resonance - Dating, Dosimetry and Microscopy. World Scientific Publishing, Singapore, 501 p., 1993.

IKEYA, M.; MIKI, T. ESR Dating and Dosimetry. Ionics Publishing Company, 1985.

INMETRO. Vocabulário Internacional de Metrologia (VIM), 1 ed. luso-brasileira, 2012.

IPEN - CNEN/SP, Reator IEA-R1. Disponível em: < https://www.ipen.br/sitio/index.php?idm=251>, 2011. Acesso em: 09/03/2014.

JENSEN, M.; KEDING, R.; HÖCHE, T.; YUE,Y. Biologically Formed Mesoporous Amorphous Silica. Journal of the American Chemical Society, 131(7). pp. 1112-1118, 2009.

JENSEN, M.; KEDING, R.; YUE, Y. Microscopic Features of Biologically Formed Amorphous Silica. In: Biomimetics, editado por Lilyana D. Pramatarova, 2011. doi: $10.5772 / 24951$.

JOLLIFFE, I. T. Discarding Variables in a Principal Component Analysis. I: Artificial Data, Journal of the Royal Statistical Society, 21, pp.160-173, 1972.

JOLLIFFE, I. T.; JONES, B. B.; MORGAN, J. T. Identifying influential observations in hierarchical cluster analysis. Journal of Applied Statistics, 22(1), pp. 61-80, 1995.

JONES, A. Archaeometry and materiality: materials-based analysis in theory and practice. Archaeometry, 46(3), pp. 327-338, 2004.

KEDING, R.; JENSEN, M.; YUE, Y. Characterization of the mesoporous amorphous silica in the fresh water sponge Cauxi. In: Innovative Processing and Manufacturing of Advanced Ceramics and Composites, editado por Munir, Z. A.; Ohji, T.; e Hotta, Y., pp.115-129, 2010. 
KLIGMANN, D. M.; CALDERARI, M. Diatoms and ceramics provenance: a cautionary tale. Archaeometry, 54(1), pp. 129-143, 2012.

KOCH, G. S.; LINK, R. F. Statistical Analysis of Geological Data. New York: Courier Dove Publications, 2002.

KONIECZKA, P.; NAMIESNIK, J. Quality Assurance and Quality Control in the Analytical Chemical Laboratory - A Practical Approach. CRC Press, Boca Raton, 233 p., 2009.

KOUlOUMPI, E.; MOUTSATSOU, A. P.; TERLIXI, AV. Canvas and Panel Paintings: Techniques and Analyses. In: Analytical Archaeometry - Selected Topics, editado por H. G. M. Edwards e P. Vandenabeele. The Royal Society of Chemistry, Cambridge, 2012.

KRANE, K. S. Introductory Nuclear Physics. Wiley, 845 p, 1988.

KRZANOWSKI, W. J. A stopping rule for structure-preserving variable selection, Statistics and Computing, 6, pp. 51-56, 1996.

LANDIM, P. M. B. Introdução à análise estatística de dados geológicos multivariados. DGA, IGCE, UNESP/Rio Claro, Tex to Didático 15, 229 p., 2010.

LAYARD, A. H. Discoveries Among the Ruins of Nineveh and Babylon, 762 p., 1853. Disponível pelo acervo virtual da Harvard College Library em <http://ia600300.us.archive.org/23/items/discoveriesinru00layagoog/discoveriesinru00laya goog.pdf>. Acesso em: 29/04/2013.

LESIGYARSKI, D.; SMIT, Z.; ZLATEVA-RANGELOVA, B.; KOSEVA, K.; KULEFF, I. Characterization of the chemical composition or archaeological glass finds from SouthEastern Bulgaria using PIXE, PIGE and ICP-AES. Journal of Radioanalytical and Nuclear Chemistry, 295, pp. 1605-1619, 2013.

LEUTE. U. Archaeometry: an introduction to physical methods in archaeology and the history of art. 176 p., 1987.

LIMA, H. História das Caretas: A Tradição Borda Incisa na Amazônia Central. Tese (Doutorado em Arqueologia), Museu de Arqueologia e Etnologia, Universidade de São Paulo, 2008.

LIMA, H. N.; SCHAEFER, C. E. R.; MELLO, J. W. V.; GILKES, R. J.; KER, J. C. Pedogenesis and pre-Colombian land use of "Terra Preta Anthrosols" ("Indian black earth") of Western Amazonia. Geoderma, 110, pp. 1-17, 2002. 
LOPEZ-MOLINERO, A.; CASTRO, A.; PINO, J.; PEREZ-ARANTEGUI, J.; CASTILLO, J. R. Classification of ancient Roman glazed ceramics using the neural network of Self-Organizing Maps. Fresenius' Journal of Analytical Chemistry, 367, pp. 586-589, 2000.

LUTGENS, F. K.; TARBUCK, E. J. Essentials of Geology. 7 ed., Prentice Hall, 2000.

MACHADO, J. S. Dos artefatos às aldeias: os vestígios arqueológicos no entendimento das formas de organização social da Amazônia. Revista de Antropologia, 49(2), 2006.

MAGGETTI, M.; NEURURER, CH.; RAMSEYER, D. Temperature evolution inside a pot during experimental surface (bonfire) firing. Applied Clay Science, 53(3), pp. 500-508, 2011. doi: 0.1016/j. clay.2010.09.013.

MALAINEY, M. E. A Consumer's Guide to Archaeological Science. Springer, 603 p., 2011.

MANGUEIRA, G. M.; TOLEDO, R.; TEIXEIRA, S.; FRANCO, R. W. A. A study of the firing temperature of archaeological pottery by X-ray diffraction and electron paramagnetic resonance. Journal of Physics and Chemistry of Solids, 72, pp. 90-96, 2011.

MARTINELLI, L. A.; VICTORIA, R. L.; DEMATTE, J. L. I.; RICHEY, J. E.; DEVOL, A. H. Chemical and mineralogical composition of Amazon River floodplain sediments, Brazil. Applied Geochemistry, 8, pp. 391-402, 1993.

MARTINI, M. Physics Methods in Archaeometry. In: Proceedings of the International School of Physics "Enrico Fermi". Villa Monastero, 2003.

MAZZOCCHIN, G.; DEL FAVERO, M.; TASCA, G. Analysis of Pigments from Roman Wall Paintings Found in the Agro Centuriato of Julia Concordia (Italy). Annali di Chimica, 97(9), pp. 905-913, 2007.

MEGGERS, B. J. Amazonia - Man and Culture in a Counterfeit Paradise, 2 ed., 214 p., 1996.

MERDUN, H. Self-organizing map artificial neural network application in multidimensional soil data analysis. Neural Computing and Applications, 20, pp. 12951303, 2011. Doi: 10.1007/s00521-010-0425-1.

MEYERS, L. S.; GAMST, G.; GUARINO, A. J. Applied Multivariate Research - Design and Interpretation. Sage Publications, Thousand Oaks, 722 p., 2006. 
MICHELAKI, K.; HANCOCK, R. G. V. Chemistry versus Data Dispersion: Is There a Better Way to Assess and Interpret Archaeometric Data? Archaeometry, 53(6), pp. 12591279, 2011.

MOMMSEN, H. Short note: Provenancing of pottery - the need for an integrated approach? Archaeometry, 46(2), pp. 267-271, 2004.

MOMMSEN, H.; KREUSER, A.; WEBER, J. A Method for Grouping Pottery by Chemical Composition. Archaeometry, 30(1), pp. 47-57, 1988.

MOMMSEN, H.; SJÖBERG, B. L. The importance of "best relative fit factor" when evaluating elemental concentration data of pottery demonstrated with Mycenaean sherds from Sinda, Cyprus. Archaeometry, 49(2), pp. 359-371, 2007.

MONGELÓ, G. Z. Processos de interação entre os sítios Lago Grande e Oswaldo (AM) baseados no material cerâmico. Revista do Museu de Arqueologia e Etnologia, 11, pp. 109-114, 2011.

MORAES, C. P. Arqueologia na Amazônia Central Vista de Uma Perspectiva da Região do Lago do Limão. Dissertação (Mestrado em Arqueologia), Museu de Arqueologia e Etnologia, Universidade de São Paulo, 2006.

MOSQUERA, D. F.; SÁNCHEZ, J. S. A Simple Method to Separate Quartz and Feldspar and its Application to TL/OSL Methods. Geochronometria, 30, pp. 41-47, 2008.

MUNITA, C. S. Contribuição da análise por ativação com nêutrons a estudos arqueométricos: estudo de caso. Canindé, 6, pp. 159-181, 2005.

MUNITA, C. S.; BARROSO, L. P.; OLIVEIRA, P. M. S. Variable selection using Procrustes analysis with stopping rule in archaeometric studies. In: Proceeding of the $38^{\text {th }}$ International Symposium on Archaeometry, Tampa, Florida, 10-15 maio, 2010.

MUNITA, C. S.; NASCIMENTO, A.; SCHREIBER, S. B.; LUNA, S.; OLIVEIRA, P. M. S. Chemical Study of Some Ceramics from Brazilian Northeast. Journal of Radioanalytical and Nuclear Chemistry, 259(2), pp. 305-309, 2004.

MUNITA, C. S.; PAIVA, R. P.; ALVES, M. A.; MOMOSE, E. F. Chemical characterization by INAA of Brazilian ceramics and cultural implications. Journal of Radioanalytical and Nuclear Chemistry, 244(3), pp. 575-578, 2000.

MUNITA, C. S.; PAIVA, R. P.; ALVES, M. A.; OlIVEIRA, P. M. S.; MOMOSE, E. F. Provenance study of archaeological ceramics. Journal of Trace Microprobe Techniques, 21, pp. 697-706, 2003. 
MUNITA, C. S.; PAIVA, R. P.; MOMOSE, E. F.; OLIVEIRA, P. M. S. Chemical characterization of Brazilian prehistoric ceramics by INAA. Nuclear Analytical Techniques in Archaeological Investigations, Technical Report Series, 416, Chapter 5, pp. 89-97, 2003.

MYERS, T. P. Agricultural limitations of Amazon in Theory and Practice. World Archaeology, 24(1), pp. 82-97, 1992.

NATIONAL INSTITUTE OF STANDARDS AND TECHNOLOGY. Certificate of Analysis: Standard Reference Material 1633 (Constituent Elements in Coal Fly Ash). 2004.

NEFF, H. RQ-mode Principal Components Analysis of Ceramic Compositional Data. Archaeometry, 36(1), pp. 115-130, 1994.

NEFF, H. Comment: Chemical and mineralogical approaches to ceramic provenance determination. Archaeometry, 54(2), pp. 244-249, 2012.

NEFF, H.; BISHOP, R. L.; SAYRE, E. V. More Observations on the Problem of Tempering in Compositional Studies of Archaeological Ceramics. Journal of Archaeological Science, 16, pp. 57-69, 1989.

NEVES, E. G. Changing Perspectives in Amazonian Archaeology. In: Archaeology in Latin America, editado por B. Alberti, pp. 216-243, London, Routledge, 1999.

NEVES, E. G. Arqueologia da Amazônia. Rio de Janeiro, Jorge Zahar Ed., 2006.

NEVES, E. G. Ecology, Ceramic Chronology and Distribution, Long-term History, and Political Change in the Amazonian Floodplain. In: Handbook of South American Archaeology, editado por H. Silverman e W. H. Isbell, pp. 359-379, New York, Springer, 2008.

NUNES, K. P. Estudos Arqueométricos do Sítio Arqueológico Hatahara. Dissertação (Mestrado em Tecnologia Nuclear - Aplicações), Instituto de Pesquisas Energéticas e Nucleares, Universidade de São Paulo, 2009.

OLIVEIRA, P. M. S. Influência do Valor Crítico na Detecção de Valores Discrepantes em Arqueometria. In: Anais do 10 $^{\circ}$ SEAGRO, Lavras, 7-11 julho, 2003.

PAVIA, S. The determination of brick provenance and technology using analytical techniques from the physical sciences. Archaeometry, 48(2), pp. 201-218, 2006. 
PAWLOWSKY-GLAHN, V.; EGOZCUE, J. J.; TOLOSANA-DELGADO, R. Lecture Notes on Compositional Data Analysis, 87 p., 2007.

POLIKRETI, K.; MANIATIS, Y.; BASSIAKOS, Y.; KOUROU, N.; KARAGEORGHIS, V. Provenance of archaeological limestone with EPR spectroscopy: the case of the Cypriote-type statuettes. Journal of Archaeological Science, 31(7), pp. 1015-1028, 2004.

POLLARD, A. M. Archaeometry $50^{\text {th }}$ Anniversary Issue Editorial. Archaeometry, 50(2), pp. 191-193, 2008.

POLlARD, M.; BATT, C.; STERN, B.; YOUNG, S. M. M. Analytical Chemistry in Archaeology. University Press, Cambridge, 404 p., 2007.

POLLARD, M.; HERON, C. Archaeological Chemistry. The Royal Society of Chemistry, 375 p., 1996.

POPELKA-FILCOFF, R. Applications of Elemental Analysis for Archaeometric Studies: Analytical and Statistical Methods for Understanding Geochemical Trends in Ceramics, Ochre and Obsidian. Tese (Doutorado em Química), University of Missouri, Columbia, 2006.

PORTOCARRERO, R. C. A variabilidade espacial no sítio Osvaldo. Estudo de um assentamento da tradição barrancóide na Amazônia central. Dissertação (Mestrado em Arqueologia), Museu de Arqueologia e Etnologia, Universidade de São Paulo, 2006.

PRESCOTT, J. R.; HUTTON, J. T. Cosmic ray contributions to dose rates for luminescence and ESR dating: Large depths and long-term time variations. Radiation Measurements, 23, pp. 497-500, 1994.

PRICE, T. D.; BURTON, J. H. An Introduction to Archaeological Chemistry. Springer Science, 311 p., 2012.

RAHAMAN, M. N. Ceramic Processing and Sintering. Marcel Dekker, 2 ed., 875 p., 2003.

RAVISANKAR, R.; RAJA ANNAMALAI, G.; NASEERUTHEEN, A.; CHANDRASEKARAN, A. Application of a Multi-Analytical Toolset to Characterize the Ancient Pottery from Kottapalayam, Tamilnadu, India Using Spectroscopic Techniques. International Research Journal of Pure \& Applied Chemistry, 3(3), pp. 210-219, 2013.

REHREN, T.; PERNICKA, E. Coins, artefacts and Isotopes - Archaeometalurgy and Archaeometry. Archaeometry, 50(2), pp. 232-248, 2008. 
RENCHER, A. C. Methods of Multivariate Analysis. 2 ed., John Wiley and Sons, 2002.

RENFREW, C.; BAHN, P. Archaeology Essentials: Theories, Methods and Practice. New York, Thames e Hudson, pp. 42-56, 2007.

RHODES, E. J. Optically Stimulated Luminescence Dating of Sediments over the Past 200,000 Years. Annual Review of Earth and Planetary Sciences, 39, pp. 461-488, 2011.

RIBEIRO, R. B. Caracterização Físico-Química da Cerâmica do Sítio Arqueológico São Paulo II. Dissertação de Mestrado, Instituto de Pesquisas Energéticas e Nucleares, Universidade de São Paulo, 2013.

RICE, P. M. Pottery Analysis: A Sourcebook. University of Chicago Press, 1987, 559 p.

RIPLEY, B. D. Pattern Recognition and Neural Networks. Cambridge University Press, 2007.

ROBINET, L.; EREMIN, K. Glass. In: Analytical Archaeometry - Selected Topics, editado por H. G. M. Edwards e P. Vandenabeele, Cap. 9, The Royal Society of Chemistry, Cambridge, 2012.

ROPP, R. C. Solid State Chemistry. Elsevier Science, 447 p., 2003.

SAYRE, E. V. Brookhaven Procedures for Statistical Analyses of Multivariate Archaeometric Data. Brookhaven National Laboratory Report BNL-21693, New York, 1975.

SAYRE, E. V.; DODSON, R. W. Neutron activation studies of Mediterranean Potsherds. American Journal of Archaeology, 61(1), pp. 35-41, 1957.

SBF (Sociedade Brasileira de Física). Espectro Eletromagnético. Disponível em: <http://www.sbfisica.org.br/v1/pion/index.php/publicacoes/imagens/130-espectroeletromagnetico>. Acesso em: 23/09/2013.

SCHIFFER, M. B. Archaeological context and systemic context. American Antiquity. 37(2), pp. 156-165, 1972.

SCHIFFER, M. B. The Nature of Archaeological Evidence. In: Formation Processes of the Archaeological Record, pp. 3-11, 1987a

SCHIFFER, M. B. (ed.) The dimensions of Artifact Variability. Formation Processes of the Archaeological Record, pp. 13-27, 1987b. 
SCHLOMER, G. L.; BAUMAN, S.; CARD, N. A. Best Practices for Missing Data Management in Counseling Psychology. Journal of Counseling Psychology, 57(1), pp. 1$10,2010$.

SCHWEDT, A.; MOMMSEN, H. On the influence of drying and firing of clay on the formation of trace element concentration profiles within pottery. Archaeometry, 49(3), pp. 495-509, 2007.

SCHWEDT, A.; MOMMSEN, H.; ZACHARIAS, N. Post-depositional elemental alterations in pottery: neutron activation analysis of surface and core samples. Archaeometry, 46(1), pp. 85-101, 2004.

SEO, S. A Review and Comparison of Methods for Detecting Outliers in Univariate Data Sets. Dissertação (Mestrado em Ciências), University of Pittsburgh, 2006.

SHENTON, L. R.; BOWMAN, K. O. A. Bivariate Model for the Distribution of $\sqrt{ }_{1}$ and $\mathrm{b}_{2}$. Journal of the American Statistical Association, 72(357), pp. 206-211, 1977.

SILVA, F. A. A etnoarqueologia na Amazônia: contribuições e perspectivas. Boletim do Museu Paraense Emílio Goeldi, 4(1), pp. 27-37, 2009.

SITHOLE, M. M. Variable Selection in Principal Component Analysis: Using Measures of Multivariate Association, Tese (Master of Science in Mathematics), School of Mathematics and Statistics, Curtin University of Technology, 1992.

SKIBO, J. M. Pottery function: A Use-Alteration Perspective. New York, Plenum Press, 1992.

SOARES, E. A. A.; HAZENFRATZ, R.; VERCEZE, R. C.; MUNITA, C. S.; GONÇALVES JÚNIOR, E. S. Chemical analyses of the Quaternary fluvial terraces at Careiro-Castanho and Autazes, Central Amazonia. Trabalho apresentado no $\boldsymbol{8}^{\text {th }}$ International Conference on the Analysis of Geological and Environmental Materials, Geoanalysis 2012, 16 - 20 de setembro, Búzios/RJ, 2012.

SPEAKMAN, R. J.; GLASCOCK M. D. Acknowledging fifty years of neutron activation analysis in Archaeology. Archaeometry, 49(2), pp. 179-183, 2007.

STANJEK, H.; HÄUSLER, W. Basics of X-ray Diffraction. Hyperfine Interactions, 154, pp. 107-119, 2004.

SZAKMÁNY, G.; STARNINI, E. Archaeometric Research on the First Pottery Production in the Carpathian Basin: Manufacturing Traditions of the Early Neolithic, Körös Culture Ceramics, Archeometriai Mühely, 2, pp. 5-19, 2007. 
TANEVSKA, V.; KUZMANOVSKI, I.; GRUPČE, O. Provenance determination of Vinica terra cotta icons using self-organizing maps. Annali di Chimica, 97, pp. 541-552, 2007.

TERREMOTO, L. A. A. Fundamentos de Tecnologia Nuclear - Reatores. Apostila da disciplina TNR5764, 2004.

THOMPSON, M. Recent trends in inter-laboratory precision at ppb and sub-ppb concentrations in relation to fitness for purpose criteria in proficiency testing. Analyst Communication, 125, pp. 385-386, 2000.

THOMPSON, M. Limitations of the application of the Horwitz Equation: A rebuttal. Trends in Analytical Chemistry, 26(7), pp. 659-661, 2007

TITE, M. S. Ceramic production, provenance and use - a review. Archaeometry, 50(2), pp. 216-231, 2008.

TITE, M. S. Mastering Materials. Oxford Handbook of Archaeology, 2009.

TOYOTA, R. G. Caracterização Química da Cerâmica Marajoara. Dissertação (Mestrado em Tecnologia Nuclear - Aplicações), Universidade de São Paulo, 2009.

TOYOTA, R. G.; MUNITA, C. S.; BOSCARIOLI, C.; HERNANDEZ, E. D. M.; NEVES, E. G.; DERMATINI, C. Neural Network Applied to Elemental Archaeological Marajoara Ceramic Compositions. In: Anais de International Nuclear Atlantic Conference (INAC 2009), 27 set-02 out, 2009.

VAN VLACK, L. H. Princípios de Ciências dos Materiais. Edgar Blücher, 427 p., 1970 (reimpressão 2010).

VANDENABEELE, P. Archaeometry, an interdisciplinary approach. Analytical and Bioanalytical Chemistry, editorial, 2007.

VANDENABEELE, P.; EDWARDS, G. M. Pigments and dyes. In: Analytical Archaeometry - Selected Topics, editado por H. G. M. Edwards e P. Vandenabeele. The Royal Society of Chemistry, Cambridge, 2012.

VANDENABEELE, P.; GARCIA-MORENOB, R.; MATHISB, F.; LETERMEA, K.; ELSLANDEC, E. VON; HOCQUETB, F.; RAKKAAB, S.; LABOURYB, D.; MOENSD, L.; STRIVAYB, D.; HARTWIGE, M. Multi-disciplinary investigation of the tomb of Menna (TT69), Theban Necropolis, Egypt. Spectrochimica Acta Part A-molecular and Biomolecular Spectroscopy, 73(3), pp. 546-552, 2008. 
VELDE, B.; DRUC, I. C. Archaeological ceramic materials: origin and utilization. Berlin, Springer, 1999.

VERMA, H. R. Atomic and Nuclear Analytical Methods: XRF, Mössbauer, XPS, NAA and ion-beam spectroscopic techniques. Springer, 375 p., 2007.

VIERS, J.; BARROUX, G.; PINELli, M.; SEYLER, P.; OLIVA, P.; DUPRÉ, B.; BOAVENTURA, G. R. The influence of the Amazonian floodplain ecosystems on the trace element dynamics of the Amazon River mainstem (Brazil). Science of the Total Environment, 339, pp. 219-232, 2005.

VITAL, H.; STATTEGGER, K. Major and trace elements of stream sediments from the lowermost Amazon River. Chemical Geology, 168, pp. 151-168, 2000.

WARNER, R. Applied Statistics - From Bivariate Through Multivariate Techniques. 2 ed., 1172 p., 2013.

WEIGAND, P. C.; HARBOTTLE, G.; SAYRE, E. V. Turquoise sources and source analysis: Mesoamerica and the Southwestern U.S.A.. In: (T.K. Earle \& J.E. Ericson, eds.) Exchange systems in prehistory. Academic Press Inc., New York \& London, pp. 15-34, 1977.

WELLS, E. C. Investigating Activity Patterns In Prehispanic Plazas: Weak AcidExtraction ICP-AES Analysis of Anthrosols at Classic Period El Coyote, Northwestern Honduras. Archaeometry, 46(1), pp. 67-84, 2004.

WINTLE, A. G. Fifty years of luminescence dating. Archaeometry, 50(2), pp. 276-312, 2008.

WOODS, W. I.; MCCANN, J. M. The Anthropogenic Origin and Persistence of Amazonian Dark Earths. In: Yearbook - Conference of Latin Americanist Geographers, 25, pp. 7-14, 1999.

WORONOW, A.; LOVE, K. M. Quantifying and Testing Differences Among Means of Compositional Data Suites. Mathematical Geology, 22(7), pp. 837-852, 1990.

YONEKURAA, A.; SUZUKIC, T. Microhardness analysis and characterization of Palaeolithic stone tool materials for understanding primary material selections and utilizations. Materials Characterization, 60(4), pp. 282-291, 2009.

YOUNG, H. D.; FREEDMAN, R. A. Sears e Zemansky Física IV: Ótica e Física Moderna. São Paulo, Addison Wesley, 2004. 
ZACHARIAS, N.; BUXEDA I GARRIGÓS, J.; MOMMSEN, H.; SCHWEDT, A.; KILIKOGLOU, V. The effect of post burial alterations of ceramics on the Tl/Osl dating, In: Proceedings of the $6^{\text {th }}$ European Meeting on Ancient Ceramics, Fribourg, Switzerland, 36 outubro, pp. 335-343, 2001.

ZHANG, B.; LIU, Y. L.; GAO, Z. Y.; ZHAO, W. J.; LI, G. X.; CHENG, H. S. Mössbauer Spectroscopy, NAA and PIXE Study on Some Archeological Problems of Ancient Chinese Ru Celadon. Hyperfine Interactions, 163, pp. 1-12, 2005.

ZINK, A. J. C.; SUSINO, G. J.; PORTO, E.; HUFFMAN, T. N. Direct OSL dating of Iron Age pottery from South Africa - Preliminary dosimetry investigations. Quaternary Geochronology, 8, pp. 1-9, 2012. 